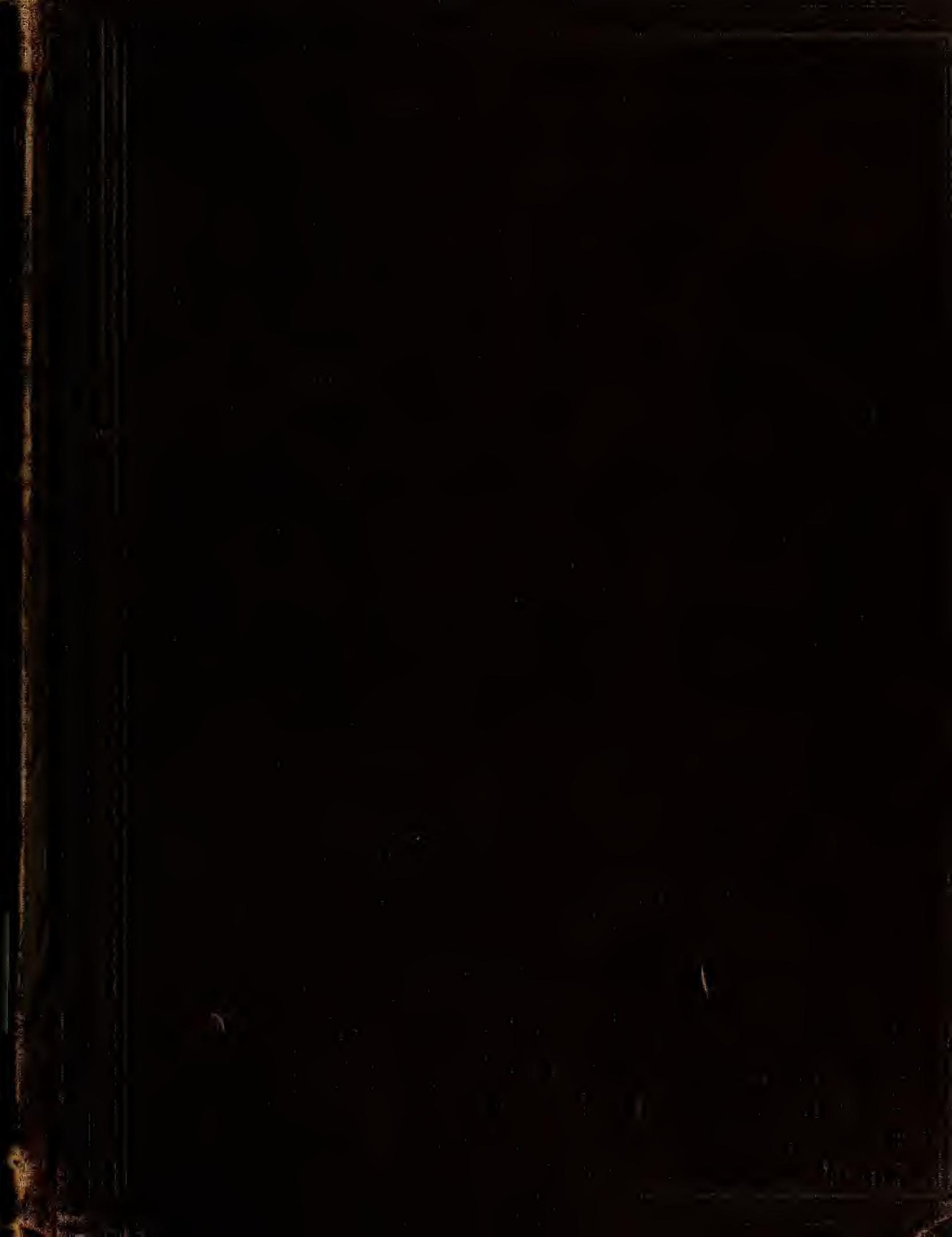








\section{LIBRARY CATAIAGUE SLIPS.}

United States. Department of the interior. (U. S. geologioal survey). Department of the interior | - | Monographs | of the ! United States geological survey | Volume XV-text [plates] | [Seal of the department] |

Washington | government printing office | 1889

Sccond titlc: United States geological survey | J. W. Powell, director | - | The Potomae | or | Younger Mesozoic flora | by | William Morris Fontaine | [Vignette] |

Washingtou | government printing office | 1889

$4^{\circ} .2$ v. text xiv, $377 \mathrm{pp}$; plates x pp. $180 \mathrm{pl}$.

Fontaine (William Morris).

United States geological survey | J. W. Powell, director $\mid-1$

The Potomac | or | Younger Mesozoic flora | by | William Morris

Fontaine | [Viguette] |

Wushington | government printing office | 1839

$4^{\circ} .2$ v. text xiv, $377 \mathrm{pp}$; plates x pp. $180 \mathrm{pl}$.

[United States. Department of the interior. (U. S. geological survey). Monograph XV].

United States geological survey | J. W. Powell, director | - | The Potomae | or | Younger Mesozoic flora | by | William Morris Fontaine | [Viguette] |

Washington | government printing office | 1889

$4^{\circ} .2$ v. text xiv, $377 \mathrm{pp}$; plates $\mathrm{x}$ pp. $180 \mathrm{pl}$.

[UNITED States. Department of the interior. (U. S. geological survey). Monograph XV]. 
Digitized by the Internet Archive in 2009 with funding from

Boston Library Consortium Member Libraries

http://www.archive.org/details/potomacoryounger00font 


\title{
ADVERTISEMENT.
}

\author{
[Monograph XV.]
}

The publications of the United States Geological Survey are issued in aceordance with the statute approved March 3, 1879, which declares that-

"The publieations of the Geologieal Survey shall eonsist of the annual report of operations, geological and economic maps illustratmg the resources and classifieation of the lands, and reports ipon aeneral and economic geology and palenntology. The anunal report of operations of the Geological Survey shall accompany the annual report of the Secretary of the Interior. All special memoirs and reports of said Survey shall be issued in nniform quarto series if deened necessary by the Director, but otherwise in ordinary nctavos. Three thonsand copies of each shall be publisbed for scientific exchanges and for sale at the price of publication; and all literary and eartographic materials received in exchange shall be the property of the United States and form a part of the libraty of the organization: And the money resulting from the sale of such publications shall be covered into the Treasury of the United States."

On July 7, 18\&:, the following joint resolution, referring to all Government publications, was passed by Congress:

"That whenever any docment or report shall be ordered printed br Congress, there sball be printed, in addition to the number in each ease stated, the 'usual number' $(1,900)$ of eopies for biuding and distribntion amoug those euritled to receive them."

Except in those cases in which an extra number of any publication bas been snpplied to the Survey hy special resolntion of Congress or has heen ordered by the Secretary of the Interior, this ofice has no copies for gratuitous distribution.

\section{ANNUAL REPORTS.}

I. First Annual Report of the United States Geological Survey, by Clarence King. 1880. $8^{\circ}$. 79 pp. 1 map.-A preliminary report deseribing plan of organization and publications.

II. Second Annual Report of the United States Geological Survey, 1880-'81, by J. W. Powell.

1882. 8. lv, $588 \mathrm{pp} .61 \mathrm{pl}, 1$ map.

Iir. Third Annual Report of the United States Geological Survey, 1881-'82, by J. Wr. Puwell.

1883. $8^{\circ}$. xviii, 564 jp. 67 pl. and maps.

IV. Fourth Annual Report of the United States Geological Survey, 188:-'83, by J. W. Powell.

1884. $8^{\circ}$. xxxii, $473 \mathrm{pl}$. $85 \mathrm{pl}$. and maps.

V. Fifth Ammal Report of the United States Geologieal Survay, 1898-'s4, by J. W. Powell.

1885. $8^{\circ}$. xxxvi, $469 \mathrm{pp} .58 \mathrm{pl}$. and mans.

VI. Sixth Amual Report of the United States Geological Survey, 1884-85, bJ J. W. Powell.

1886. $8^{\circ}$. xxix, $570 \mathrm{pl}$. $65 \mathrm{pl}$. and maps.

VII. Seventh Annual Report of the United States Geological Survey, 1885-'86, by J. W. Powell.

1888. $8^{\circ}$. xx, $656 \mathrm{pp}$. $72 \mathrm{pl}$. and maps.

The Eighth and Ninth Annual Reports are in press.

\section{MONOGRAPHS.}

Monograph I is not yet published.

II. Tertiary History of the Grand Cañon District, with atlas, by Clarence E. Dutton, Capt., U. S. A

1882. 4. xiv, $264 \mathrm{pp}$. $42 \mathrm{pl}$, and atlas of 24 sheets folio. Price $\$ 10.12$.

III. Geology of the Comstock Lode and the Washoe Distriet, with atlas, by George F. Bceker.

1882. $4^{\circ} . \mathrm{xv}, 42 \% \mathrm{pp} .7 \mathrm{pl}$, and atlas of 21 sheets folio. Price $\$ 11$.

IV. Comstock Mining and Miners, by Eliot Lord. 188:3. 40. xiv, 451 pp. 3 pl. Price $\$ 1.50$.

V. The Copper-Bearing Rocks of Lake Superior, by Rolaud Duer Inving. 1883. 4. xvi, 464 pp.

15 1. 29 pl. and maps. Price $\$ 1.85$.

VI. Contribntions to the Fnowledge of the Older Mesozoie Flora of Virginia, hy William Morris

Fontaine. 1883. 4\% xi, $144 \mathrm{pl} .541 .54 \mathrm{pl}$. Price $\$ 1.05$.

VII. Silver-Lead Deposits of Eureka, Nevada, by Joseph Story Curtis. 1884. 4․ xiii, $200 \mathrm{pp}$. 16 pl. Price $\$ 1.20$.

24 1. $24 \mathrm{pl}$. Price $\$ 1.10$. 
IX. Brachiopoda and Lamellibranchiata of the Raritan Clays and Greensand Marls of New Jersey, by Robert P. Whitfield. 18ะ5. 4 . $\mathrm{xx}, 338 \mathrm{pl}$. $35 \mathrm{pl}$. I mal. Price $\$ 1.15$.

X. Dinocerata. A Monograph of an Extinct Order of Gigantic Mammals, by Othuiel Charles Marsh. 1806. 4\%. xviii, 243 pp. 56 l. $56 \mathrm{pl}$. Price $\$ 2.70$.

XI. Geological History of Lake Lahontan, a Quateruary Lake of Northwesteru Nevada, by Israel Cook Rnssell. 1085. 40. Xi 288 pp. 46 pl. and maps. Price $\$ 1.75$.

XII. Geology and jliniug Iudnstry of Leadville, Colorado, with atlas, by Samuel Franklin Emmons. 1886. 40. xxix, $770 \mathrm{pp}, 45 \mathrm{pl}$. aod atlas of 35 sheets folio. Price $\$ 8.40$.

XIII. Geology of the Quicksilver Deposits of the Paeitic Slope, with atlas, by George F. Becker. 1888. 40. xix, $486 \mathrm{pp} .7 \mathrm{pt}$. and atlas of 14 sheets folio. Price $\$ 2.0 \mathrm{v}$.

XIV. Fossil Fishes and Fossil Plants of the Triassic Rocks of New Jerses and the Connecticnt Valley, hy John S. Newberry. 1888. $4^{\circ}$. xir, $152 \mathrm{pp} .26^{\circ} \mathrm{pl}$. Price $\$ 1.00$.

XV. The Potomac or Yomger Mesozoic Flora, by Willian Merris Fontaiue. 1889. $4^{\circ}$. xiv, $377 \mathrm{pp}$. $\quad 180 \mathrm{pl}$. Text and plates bound separately. Price, \$3.25.

In press:

I. Lake Benneville, by G. K. Gilbert.

Xiv. Paleozoic Fishes of North America, by J. S. Newberry.

In preparation :

-Description of New Fessil Plants from the Daketa Group, by Leo Lesqnerenx.

- Gasteropoda of the New Jerses Cretaceous and Eoceue Marls, by R. P. Whittield.

-Geology of the Eureka Mliniug District, Nevada, with atlas, by Arnold Hague.

- Sauropoda, by O. C. Marsh.

-Stecosauria, by O. C. Marsh.

-Broutotheridix, by O. C. Mlarsh.

-The Penokee-Gogebic Iron-Bearing Series of North Wiscousin and Michigan, by Reland D. Irving.

- Report ou the Denver Coal Basiu, by S. F. Emmous.

-Report on Silver Clifi aud Ten-Mile Nlining District, Colorado, by S. F. Emmoas.

-Flora of the Dakota Group, by J. S. Newberry.

-The Glacial Lake Agassiz, by Warren Uplaw.

- Geology of the Potomac Formation in Virgiuiil, by W. M. Fontaiue.

\section{BULLETINS,}

Each of the Bunlletins is complete in itself, but in order that they may be bound in volumes of cenrenient size, each Bulletin has two paginations, oue proper te itself aud another which belongs to it as part of the volume. Numbers 1 to 6 form Volume 1; Numbers 7 to 14, Volume I1; Numbers 15 to 23, Volume IlI; Numbers 24 te 30, Volnme IV; Numbers 31 to 36, Volume V; Numbers 37 to 41, Volume VI; Numbers 42 to 46, Volume V1I; Numbers 47 to 54 , Volume VIII.

1. Oo Hsprersthene-Andesite and un Trielinie Pyroxene in Angitic Rocks, by Whitman Cross, with a Geological Sketeh of Buffialo Peaks, Colorado, by S. F. Emmons. 1883. 8०. 42 pp. 2 pl. Price 10 cents.

2. Gold and Silver Conversion Tables, giving the coining valucs of troy ounces of fine metal, etc., compnted by Albert Williams, jr. 1883. $80.8 \mathrm{pp}$. Price 5 cents.

3. On the Fossil Fannas of the Upper Devonian, aloug the meridian of $76^{\circ} 30^{\prime}$, from Tompkins County, N. Y., to Bradford County, Pa., by Henry S. Williams. 1884. 8०. 36 pp. Price 5 cents.

4. On Ḿesozoic Fossils, by Charles A. White. 1884. 8. $36 \mathrm{pp} .9 \mathrm{pl}$. Prico 5 cents.

5. A Dietionary of Altitudes in the United States, compiled by Henry Gaunctt. $1884.88^{\circ} .325 \mathrm{pp}$.

Price 20 cents.

6. Elevations in the Dominion of Canada, by J. W. Spencer. 1884. 80.43 pp. Price 5 ceuts.

7. Hapoteca Geologica Americana. A Catalogue of Geological Maps of America (Nortl and Sontl),

1752-1851, in geographic and chronologic order, by Jules Mareou aud John Belkuap Marcou. 1884.

8०. Ist pp. Price 10 cents.

8. On Secondary Eulargements of Mineral Fragments in Certain Rocks, by R. D. Irving aud C. R.

Van Hise. 1884. 8? $56 \mathrm{pp}, 6 \mathrm{pl}$. Price 10 cents.

9. A Report of work done in the Washiugton Lahoratory duriog the fiseal year 1883-'84. F. W.

Clarke, chief chemist; T. M. Chatard, assistant ehemist. $1884.8^{\circ} .40$ pp. Price 5 cents.

10. On the Cambrian Fannas of Nortl America. Preliminary studies, by Cbarles Doolittle Wal-

cett. $1884.80 .74 \mathrm{pp}$. $10 \mathrm{pl}$. Price 5 cents.

11. On the Quateruary and Recent Mollusca of the Great Basin; with Descriptions of New Forms, by R. EIlsworth Call. Introdneed by a sketch of the Quateruary Lakes of the Great Basin, by G. K. Gilbert. $1 \times 84.8^{\circ} .66 \mathrm{pp} .6 \mathrm{pl}$. Price 5 cents.

12. A Crystallographic Study of the Thinolite of Lake Lahontan, by Edward S. Dana. 1884. $8^{\circ}$.

$34 \mathrm{pp} .3 \mathrm{pl}$. Price 5 cents.

13. Bonndaries of the United States and of the several States and Territories, $\pi$ ith a Historical Sketch of the Territorial Changes, by Henrs Gannett. I845, 80. $135 \mathrm{pp}$. Price 10 cents.

14. The Electrical aud Narnetic Properties of the Iron-Carburets, by Carl Barus aud Vincent Stroubal. 1885. $80.238 \mathrm{pp}$. Price 15 cents.

15. On the Mesozoie and Cenozoic Paleontology of California, by Charles A. White. 1885. $8^{\circ}$. $33 \mathrm{pp}$. Price 5 cents.

16. On the Higher Devonian Faunas of Outario Ceunty, New York, bø John M. Clarke, 1885. $8^{\circ}$. $86 \mathrm{pp} .3 \mathrm{pl}$. Price 5 cents. 
17. On the Development of Crystallization in the Igneous Rocks of Washoe, Nevada, with Notes on the Geology of the District, by Arnold Hague ad Joseph P. Iddings. 1885. 80. 44 pp. Price 5 ceuts.

18. On Marine Eocene, Fresh-Water Miocene, and other Fossil Mollusca of Westeru North America, by Charles A. White. 1885. 8०, $26 \mathrm{pp}, 3 \mathrm{pl}$. Price 5 cents.

19. Notes on the Stratigraphy of California, by George F. Becker. 1885. $8^{\circ}$. $28 \mathrm{pp}$. Price 5 cents. 20. Contributions to the Mineralogy of the Rocky Monntains, by Whitman Cross and W. F. Hillebraud. 1885. $8^{\circ} .114 \mathrm{pp} .1 \mathrm{pl}$. Price 10 cents.

21. The Liguites of the Great Sionx Reservation. A Report on the Region between the Grand and Moreau Rivers, Dakota, by Bailey Willis. 1835. 8०. $16 \mathrm{pp} .5 \mathrm{pl}$. Price 5 cents.

22. On New Cretaceons Fossils from California, by Charles A. White. 1835. 80. 25 pp. 5 pl. Price 5 cents.

23. Observations on the Junction between the Eastern Sandstone aud the Keweenaw Series on Keweenaw Point, Lake Superior, by R. D. Irving and. T. C. Chamberliu. 1835. 80.124 pp. 17 pl, Price 15 cents.

24. List of Marine Mollusca, comprising the Quateruary fossils and recent forms from American Localities between Cape Hatteras and Cape Roque, including tho Berıudas, by William Healey Dall.

1885. $80^{\circ} .336 \mathrm{pp}$. Price 25 ceuts.

25. The Present Technical Condition of the Steel Industry of the United States, by Phineas Barnes.

1885. 80. $85 \mathrm{pp}$. Price 10 cents.

26. Copper Smelting, by Heury M. Howe. 18s5. 8०. 107 pp. Price 10 cents.

27. Report of work done in the Division of Chemistry and Plysies, mainly during the fiscal year

1884-85. 18-6. 8. $80 \mathrm{pp}$. Price 10 cents.

28. The Gabbros and Associated Horublende Rocks oceurring in the Neighborhood of Baltimore,

Md., by George Huntington Williams. 1886 . yo. $78 \mathrm{pp} .4 \mathrm{pl}$. Price i0 cents.

29. On the Fresh-water Invertebrates of the North American Jurassic, by Charles A. White. 1886.

80. 41 pp. 4 pl. Price 5 cents.

30. Second Contribution to the Studies on the Cambrian Fannas of North America, by Charles

Doolittle Walcott. 1N86, 80. 369 pp. 33 pl. Price 25 cents.

31. Systematic Review of our Present Knowledge of Fossil Insects, inclnding Myriapods and Arachnids, by Samuel Hubbard Seudder. 1886: 8०. $128 \mathrm{pp}$. Price 15 eents.

32. Lists and Analyses of the Mineral Springs of the United States; a Preliminary Study, by

Albert C. Peale. 1886. $8 \circ .235$ pp. Price 20 cents.

33. Notes on the Geology of Northern California, by J.S. Diller. 1886. 8०. 23 pp. Price 5 cents. 34. On the relation of the Laramie Molluscan Fanna to that of the succeediog Fresi-water Eocene and other gromps, by Charles A. White. $1886.80 .54 \mathrm{pp} .5 \mathrm{pl}$. Price 10 cents.

35. Phssical Properties of the 1ron-Carburets, by Carl Barus and Vincent Stronhal. 1886. $8^{\circ}$. 62 pp. Price 10 cents.

36. Subsidence of Fine Solid Particles in Liquids, by Carl Barus. 1886. $8^{\circ} .58$ pp. Price 10 ceuts. 37. Types of the Laramie Flora, by Lester F. Waril. $18 \times 7 . \quad 8.354$ pp. 57 pl. Price 25 ceuts. 38. Periclotite of Elliott County, Kentucks, by J S. Diller. 1857. $8^{\circ}$. 31 pp. 1 pl. Price 5 cents. 39. The Upper Beaches and Deltas of the Glacial Lake Agassiz, by Warren Upham. 18s7. $8^{\circ}$. 84 pp. 1 pl. Price 10 cents.

40. Changes in River Courses in Washington Territory due to Glaciation, by Bailes Willis. 1887. 80. $10 \mathrm{pp} .4 \mathrm{pl}$. Price 5 ceuts.

41. On the Fossil Fiunas of the Upper Devonian-the Genesee Section, New York, by Henry S.

Williams. $1807.8 \% .121 \mathrm{pp}, 4 \mathrm{pl}$. Price 15 cents.

42. Report of work done in the Division of Chemistry aud Physies, mainly during the fiscal jear 1885-86. F. W. Clarke, chief' chemist. 1887. 80. $152 \mathrm{pp}, 1 \mathrm{pl}$. Price 15 ceuts.

43. Tertiary and Cretaceous Strata of the Tiscaloosa, Toubigbee, and Alabama Rivers, by Engene

A. Smith and Lawrence C. Johnson. 1837. 80. $189 \mathrm{pp} .21 \mathrm{pl}$. Price 15 cents.

44. Bibliography of North American Geology for 1886, by Nelson H. Dartov. 1887. 80.35 pp. Price 5 cents.

45. The Present Coudition of Kuowledge of the Gcology of Texas, by Robert T. Hill. 1887. $8^{\circ}$.

94 pp. Price 10 cents.

46. Nature and Origin of Deposits of Phosphate of Lime, by R. A. F. Penrose, jr., with an Tutrodnction by N. S. Shaler. $1888.8^{\circ} .143 \mathrm{pp}$. Price 15 cents

47. Analyses of Waters of the Yellowstone National Park, with an Acconnt of the Methods of Analysis employed, by Frauk Austin Gooch aud James Edward Whitfield. 1838. $8^{\circ}$. 84 pp. Price 10 cents.

48. On the Form and Position of the Sea Level, by Robert Simpsou Woodward. 1888. $8^{\circ}$. 88

pp. Price 10 cents.

49. Latitudes and Longitudes of Certain Points in Missouri, Kansas, and New Mexico, by Robert

Simpson Woodward. 1889. 8०. 133 pp. Price 15 cents.

50. Formulas and Tables to facilitate the Construction and Use of Maps, by Robert Simpson

Woodward. 1889. 8. $124 \mathrm{pp}$. Price 15 eents.

51. On Invertebrate Fossils from the Pacific Coast, by Charles Abiathar White. $1889.8^{\circ} .102$

Fp. 14 pl. Prize 15 cents.

52. Snbaërial Decay of Rocks and Origin of the Red Color of Certain Formations, by Israel Cook

Russell. $1889.8^{\circ}$. $65 \mathrm{pp} .5 \mathrm{pl}$. Price 10 ceuts. 10 cents.

53. The Goology of Nantucket, by Nathaniel Sonthgate Shaler. $1889.8^{\circ} .55 \mathrm{pp} . \quad 10 \mathrm{pl}$. Price 
In press :

54. A Report on the Thermo-Electrical Measmrement of High Temperatures, by Carl Barus. $1886-87$

55. Report of work done in the Division of Chenistry and Physics, mainly during the fiseal year

56. Fossil Woods and Liguites of the Potomac Formation, by F. H. linuwlton.

57. Notes on the Geology of Southwesteru Kansas, by Robert Hay.

58. On the Glac.al Boundary, by G.F. Wright.

In preparation:

- The Gabbros and Associated Roeks in Delaware, by F. D. Chester.

- Mineralogy of the Pacifie Coast, by W. H. Melville and Waldemar Lindgren.

- The Greenstone Schist Areas of the Mlenominee and Miripuette Regions of Michigan, by George H. Williams; with an introdnetion by R. D. Irving.

- Bibliography of the Paleozoic Crnstacea, by A. WV. Vogiles.

- The Viscosit $y$ of Solids, by Carl Barns.

- Ou a Gronly of Voleanio Rocks from the Tewan Mountains, New Mexico, and on the oecnrence of Primary Quartz in certain Basilts, by J.P. Illlings.

- On the relations of the Traps of the Jura-Trias of New Jersey, by N. H. Darton.

- Altitudes between Lake Superior and the Rocky Mountains, by Warren Upham.

- Mesozoic Fossils in the Pernian of Texas, by C. A. Wlitite.

- Natural Gas Districts in Indiana, by Arthur John Phinnes.

-A Late Volcanic Eruption in Northern California aud its peculiar lava, by J. S. Diller

-A General Acconnt of the Fresh-Water Morasses of the United States, with a description of the Dismal Swamp District of Virginia, by N. S. Shaler.

\section{STATISTICAL PAPERS.}

Mineral Resourees of the United States [1882], by Albert Williams, jr. 1883. $8 \circ$. xvii, 813 pp. Price 50 cents.

Ilineral Resonrces of the United States, 1383 aud 1884, by Albert Williams, jr. 1885. $8^{\circ}$. xiv, 1016 pl). Price 60 cents.

Mineral Resonrees of the United States, 1885. Division of Mining Statistics and Techuology. 1886. 8. vii, $576 \mathrm{pp}$. Price 40 cents. 50 ceots.

Mineral Resonrces of the Uuiterl States, 1886, by Davil T. Day. 188\%. 8०. viii, 813 pp. Prico 50 cents.

Mineral Resourees of the United States, 1887, by David T. Day. 1888. 8०. vii, 832 pn. Price

In preparation:

Mineral Resources of the United States, 1888, by David T. Day.

The money received from the sale of these publications is deposited in the Treasury, and tho Seeretary of that Departinent fleclines to receive bank cheeks, dratts, or postace stamps; all remittances, therefore, nust be by POSTAL NOTE or MONEY ORDER, made payable to the Librarian of the U. S. Geological Survey, or in CURRiscy for the exact amount. Correspondenee relating to the publications of the Survey should be addressed

To TIE DIRECTOR OF THE

Uxited States Geological Survey,

Wasurgaton, D. C., September 1, 1889.

IVASHINGTON, D. C. 
DEPARTMENT OF THE INTERIOR

\section{MONOGRAPHS}

OF THE

$\checkmark$

\section{United States Geological Survey}

VOLUME XV-TEXT

W A SH I NGTON

GOVERNMENT PRINTING OFFICE 1889 

UNITED STATES GEOLOGICAL SURVEY

J. W. POWELL, DIRECTOR

\section{THE POTOMAC}

OR

\section{YOUNGER MESOZOIC FLORA}

BY

WILLIAM MORRIS FONTAINE

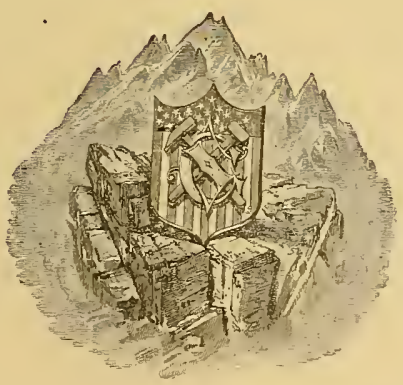

WA SH I NGTON GOVERNMENT PRINTING OFFICE 1889 



\section{CONTENTS}

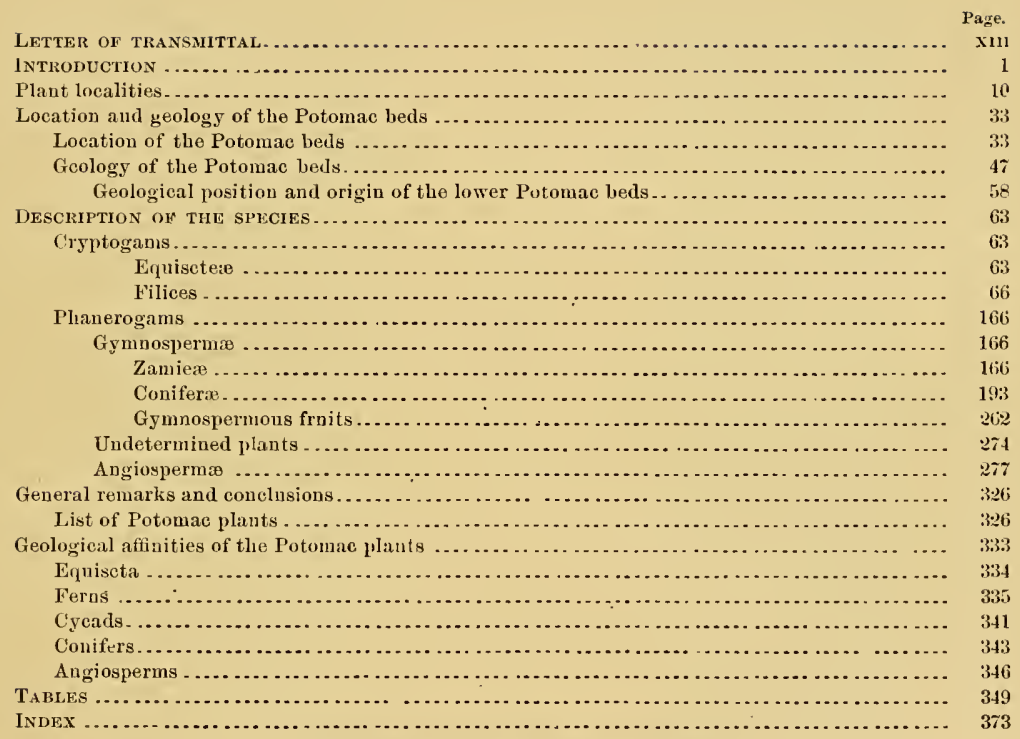

[The plates are bound in a separate volume.] 



\section{LLUSTRATIONS.}

Plate I. Figs, 1-6,8. Equisetum Virginicum. Fig. 7. Equisetum Lyelli.

II. Fige, 1-3, 6, 7, 9. Equisetum Virginionm Figs. 4, 5. Equisetum Lyelli.

Fig, 8. Rhizome of Equisetum, sp. undet. Fig. 10. Equisetum Marylandicum. Fig. 11. CladophIebis constricta

III. Fig. 1. Cladophlebis latifolia. Fig. 2. Cladophlebis constrieta. Figs. 3-8. Cladophlebis Virginiensis.

IV. Figs. 1, 3-6. Cladophlebis V irriniensis. Fig. 2. Cladopblebis denticulata. Fig. 7. Cladophlebis parva. Fig. 8. Cladopblebis falcata.

. Figs. 1-6. Cladopblebis falcata. Fig. 7. Cladopblebis acuta,

I. Figs, 1-3. Cladophlebis parra. Fig. 4. Cladophlebis latifolia. Figs. 5, 6.8-14. Cladopblebis constricta. Fig. 7. Cladophlebis falcata,

VII. Figs. 1,2. Cladophlebis falcata. Figs. 3-5. Cladophlteis oblongifolia. Fig. 6. Claciopblebis acuta. Fig. 7. Cladophltbis dentienlata. Figs. 8-11. Angiopteridium auriculatum.

YIII. Figs. 1-7. Prcopteris Virginiensis.

IX. Figs. 1-6. Pecopteris Virginiensis. Figs. 7-9 Claduphlebis crenata.

T. Figs. 1, 2. Cladopblebis crenata. Figs. 3, 4. Cladophlebis inclinata. Figs. 5, 8. Cladopulebis, sp. undet. Figs. 6, 7. Cladopblebis aenta. Fig. 9. Asplenium dubium.

XI. Figs, 1-6. Aspidium Fredericksbnrgense. Figs. 7, 8. Cladopblebis acuta.

XII. Fige. 1-6. Aspidium Fredericksburgense.

XIII. Figs, 1-3. Cladophebis crenata. Figs, 4,5. Claclophlobis distans. Figs, 6-8. Pecopteris strictinervis. Figs. 9, 10. A spidium ellipticum.

X1V. Figs. 1-5. Aspidium beteropbyllum.

XV. Figs. 1-5. Aspidium beteropbylum.

Fig. 6. Cladophlovis, sp. undet. Fig. 7. Aspidium Virginieum. Fig. 8. Pecopteris ovatodentata.

XVI. Figs, 1, 3, 8. Aspidium angustipinnatum. Fig. 2. Aspidium cystopteroides. Figs. 4, 5. Polypodium fad yenioides. Fig. 6. Aspleniopteris adiantifolia. Fig. 7. Acrosticbum crassifulium. Fig. 9. Aspidium Fredericksburgense.
PLATE XVIL. Fig. 1. Aspidinm angustipinnatum. Fig. 2. Aspidium nacrocarpum. Figs. 3-7. Thinnfeldia variabilis. XVIII. Figs. 1-6. Thinofeldia variabilis

XIX. Fig. 1. Cladophlebis crenata. Fig. 2. Cladopblebis, sp. nodet. Fig. 3. Cladopblebis, sp. undet.

Fig. 4. Aspidium Oerstedi?. Fig. 5. Cladophlebis alata. Figs. 6, 7. Aspidium Frellericksburgense.

Fig. 8. Pecopteris microdonta. Fig. 9. Pecopteris strictinervis. Fig. 10, Aspidjum angustipionatum.

XX. Figs. 1,2,4. Pecopteris cunstricta. Fig. 3. Pecopteris strictinervis. Figs. 5, 11. Pecopteris microdonta. Fig. 6. Cladophlobis crenata. Fig. 7. Cladophlebis, sp. undet. Fig. 8. Ciadopluebis inclinata. Figs. 9, 10. Cladopllebis rotundata.

XXI. Figs. 1-3. Pecopteris brevipeonis. Fig. 4. Cladopulebis sphenopteroides. Fig. 5. Aspidium oblongifolium. Fig.6. Aspidium parvifolium. Fig. 7. Pecopteris socialis. Fig. 8. Stenopteris Virginica. Firs. 9, 13. Clatopblebis constricta. Fig. 10. Pecopteris augustipennis. Fig. 11. Gleichenia Nordenskioldi. Fig. 12. Undetermined fern. Fig. 14. Aspidinm Virginicum. Fig. 15. Aspidium pisnatifidum.

XxIJ. Figs, 1-3,6,7. Aspleniopieris pinnatifida. Figs. 1, 5. Polspodium dentatnm. Fig. 8. Cladopblebis petiolata. Fig. 9. Aspidinm Dunkeri. Figs. 10, 11. Pecopteris Browuiasa. Fig. 12. Peconteris ovatodentata. Fin. 13. Pecopteris otrictinervis.

XXIII. Fig. 1. Pecopteris ovatedentata. Figs. 2-7. Pecopteris Browniana.

XXIV. Fig. 1. Thyrsopteris Virginica. Fig. 2. Pecoptrris Virginiensis. Fig. 3. Thyrsopteris elliptica. Figs. 4,6, 7, 9. Thyrsopteris dentata. Figs 5,10 . Thyrsonteris brevifolia. Fig. 8, Aspidium parvifolium.

XXV. Firs. 1, 2. Thyrsopteris dentata Fig.3. Sphenopteris thyrsopteroides. Figs. $4,5,16$. Thyrsopteris gervosa. Figs. 6, 7, 14, 15. Aspidium dentatum. 
Plate XXV. Fig. 8. Cladophlebis inzegniloba. Fig. 9. Cladophlebis pachyphylla. Fig. 10. Aspidinm parrifolium. Figs. 11, 12. Aspidium Dunkeri. Fig. 13. Osmunda sphezopteroides.

xXVI. Figs. 1, 14,16,17. Aspidinm parsifolinm. Figs. 2, 8, 9, 18. Aspidinm Dunkeri. Figs. 3, 13. Pecopteris Browniana. Figs, 4, 5. Pecopteris pachsphylla. Figs. 6, 7. Tusrsopteris ratinervis. Figs. 10-12. Thinnfeldia granulata. Fig. 15. Cladophlebis, sp, undet.

XXII Figs. 1-5, 8. Thinnfeldia granulata. Figs, 6, 7. Thinufeldia rotnndiloba. Fig. 10. Sagenopteris latifolia. Figs, 9,11-17. Sagenopteris ellipticn.

XXV1II. Fig. 1, Angiopteridium auricnlatum. Figs 2, 4, 6. Seleropteris elliptica. Figs.3, 5. Scleropteris Tirginica. Fig. 7. Scleropteris elliptica, var. longifolia.

XIIX. Fig.1. Scleropteris elliptica.

Fig. 2. Angiopteridium nerrosum. Fig. 3. Angiopteridium ellipticum. Fig, 4. Angiopteridium densinerro. Fig. 5. Angiopteridium paebyphyllum. Figs. 6, 7. Angiopteridium ovatun. Figs. 8, 9. Angiopteridium strictinerve.

XXX. Figs. 1, 5. Angiopteridium strictiverve, var: latifulium.

Figs. 2, 3. Anomozamites angustifolius. Fig. 4. Anomozamites Virginicus. Figo, 6, 7. Angiopteridinm ientatnm. Fig. 8. Platspterigiuru densinerre.

XXXI. Figs. 1,4. Platy pterigium densinerre. Fig. 2. Platypterigium Rogersinnnm. Fic. 3. A nomozamites Virginicus.

xxxir. Figs. 1, 2, Platylteriginm densinerve.

xxxı11. Fig. 1. Platypteriginm densiuerve. Fig, 2. Platypterigium Rogersianum.

xxxIV. Fig. 1. Platypterigium densinerve. Fig. 2. Platypterigium Eogersianmm. Fig. 3. Thrrsopteris brevipennis. Fig. 4. Sphenopteris acrodentata.

xxxV. Figs.1,2. PJatypterigium densinerse. Figs. 3-5. Sphenopteris Jatiloba.

XXXiI. Fig. 1. Cladophlebis brevipennis. Fig. 2. Thyrsopteris brevipennis. Fig. 3. Thyrsopteris alata. Figs. 4-9. Sphenopteris latiloba.

XXXVII. Fig. 1. Sphenopteris latiloba. Figs. 2, 4. Thyrsopteris nervosa. Figs. 3,9. Thyrsopteris breripennis. Figs. 5-8. Thyrsopteris divaricata.

XXxviII. Fig. 1. Thyrsopteris brovipennis. Figs, 2-4, 8. Thyrsopteris Meek iana. Figs. 5-7, 9. Thrrsepterís Meekiana, var. angustiloba.

TxXIX, Figs. 1, 2. Thrrsopteris erenata. Fig. 3. Thyrsopteris densifolia. Fig. 4. Thyrsopteris insignis. Fig. 5. Thyrsopteris nervosa.

SL. Fig. 1. Tly̧rsopteris insignis. Figs. 2-5. Thyrsopteris densifolia. Fig. ô. Thrrsopteris nervosa.

XLI. Figs. J-3. Thyrsopteris erassinerris. Fig.4. Tluyrsopteris brevipenzis. Fig. 5. Osmunda Dicksonioides.
PLATE XLI. Fig. 6. Thyrsopteris insignis.

XL1I, Figs, 1, 2,4, Thyrsopteris insignis.

Fig. 3. Thjrsoptoris insignis, var. angustipennis.

XLIII. Figs. 1, 3. Thyrsopteris insignis.

Fig. 2. Thyrsopteris insignis, var, augustipen. nis.

Figs. 4-6. Thytsopteris manervis.

Fig. 7. Thyrsopteris decurrens.

Fig. 8. Thyrsopteris Mleekiana, var, :uırustiloba.

XLIV. Figs, 1, 2, 5. Thyrsopteris rarinervis.

Fig. 3. Thyrsopteris Meekiana, var. angustiloba.

Fig. 4. Thyrsopteris angustifolia.

XLV. Figs. 1, 2, 4, 5. Thyrsopteris mierophylla. Fig. 3, Thyrsopteris angustifolia.

XLV r. Fig. 1، Thyrsopteris elliptica.

Figs. 2, 4. Thyrsepteris decurrons. Figs. 3, 5. Thyrsopteris pachyrachis.

XIVII. Figs, 1, 2. Thrrsopteris pachyrachis. Fjg. 3. Thyrsopteris distans.

Fig. 4. Thyrsopteris Meekiana, var. angustiJoba.

X1TIII. Fig. 1. Thjrsopteris Meekiana, var. augusti. loba.

Fig. 2. Thyrsopteris angustifolia. Figs. 3-5, Thyrgopteris augustiloba.

XLIX. Fig. I. Thyrsopteris paclyy rachis. Fig. 2. Thrrapteris rarinervis. Figs. 3, 4. Thyrsopteris angustifolia. Figs. 5-7. Thyrsopteris decurrens.

L. Figs. 1, 2, Sphenopteris Mantelli. Fig. 3. Thyrsepteris pachyphylla. Fig.4. Sphenopteris spatulata. Fig. 5. Sphenopteris pacbyphylla. Figs, 6, 9. Thyrsopteris elliptica. Figs. 7, 8. Thyrsopteris Meokiann.

LI. Fig. 1. Thsrsopteris pecopteroides. I'ig. 2. Thyrsopteris pinnatifida. Fig. 3. 1 hyrsopteris Meekiana. Figs. 4, 6, 7. Thyrsopteris elliptica. Fig. 5. Thyrsopteris densifolia.

LII. Fig. 1. Thyrsopteris heteromorpha. Figs. E-4. Thyrsopteris varians. Fig. 5. Thyrsopteris rbombifolia.

LIII. Hjßs, I-3. Thyrsopteria varians, Fig. 4. Thyrsopteris heteroloba. Fig. 5. Thyrsopteris bella.

LIV. Fig. 1. Thrrsopteris rhombifolia. Figs. 2, 11. Thyrsopteris Meekiana, var. angustijoba.

Figs. 3, 9. Aspidinm Dnnkeri.

Figs. 4, 5, 7. Thyrsopteris pinnatifida.

Fig. 6. Thyrsopteris elliptiea.

F,g. 8. Thyrsopteris distans.

Fig. 10. Thyrsopteris varians.

LV. Fig. 1. Thyrsopteris Meekiana, var. angreti. loba.

Fig. 2. Thyrsopteris angustifolia.

Fig, 3. Thyrsopteris angustiloba.

Fig. 4. Thyrsopteris olliptica.

Fig. 5. Thyrsopteris microloha, var. alata.

Figs, 6, 7. Thyrsapteris bella.

LVI. Figs, 1, 3. Thyrsopteris Meekiana, var. 2agnstiloba.

Figs, 2.5. Thyrsopteris bel]a. 


\section{ILLUSTRATIONS.}

Plate LVI. Figs. 4, 8. Thyrsopteris nana. Figs. 6, 7. Thyrsopteris elliptica.

LVII. Figs. 1, 5. Thyrsopteris bella. Fig. 2. Thyrsopteris varians. Figs. 3, 8. Thyrsopteris inequipinnata. Fig. 4. Thyrsopteris microloba. Fig. 6. Thsrsopteris elliptica. Fig. 7. Thyrsopteris pinmatifida.

LVIII. Fig. 1. Thyrsopteris microlola, var. alata. Fig. 2. Thyrsopteris elliptica.

Fig. 3. Thyropteris heterophylla. Fig. 4. Thyrsopteris bella.

Fig. 5. Sphenopteris thyisopteroides Fig. 6. Thisrsopteris sphenopteroides. Figs. 7, 10. Thyrsopteris outusiloba. Fig. 8. Thyrsopteris angustifolia. Fig. 9. Osuunda Dicksouioides.

LIX. Figs. 1, 4, 8,9, 11. Osmnnda Dicksovioides. Figs. 2, 12. Aspidium nierocarpum. Fig. 3. Thyrsopteris squarrosa. Fig. 5. Fern frond in ci cinate verpation. Figs, 6, 7. Thyrsopteris rhombiloba. Fig. 10. Thyrsopteris retusa.

LX. Figs. 1, 3. Osmunda Dicksoninides, var. latipennis.

Figs. 2,4,5,9. Osmunda Dicksonioides. Figs. 6, 7. Aspidium microcarpum. Fig. 8. Thyrsopteris rhombiloba.

LXI. Figs. 1,2. Osmunda Dicksonioiles. Fig. 3. Osmunda Dicksonioides, var. latipennis. Figs. 4, 5. Ctenopteris insignis. Fig. 6. Undetermined plant.

Fig. 7. Zamiopsis pimuatifida.

Fig. 8. Zamiopsis longipennis.

LXII. Fig. 1. Ctenopteris insignis.

Fig. 2. Ctenopteris integrifolia. Fig. 3. Zamiopsis insignis.

Fig. 4. Ctenopteris Virginiensis.

Fig. 5. Zauuiopsis pinnatifida.

LXIII. Figs. 1, 2. Ctenopteris insiguis. Figs. 3,4 . Scleropteris dentata.

LXIV. Figs. 1, 3. Zamiopsis insiguis. Fig. 2. Zamiopsis pinuatifida.

LXV. Fig. 1. Ctenopteris Virginiensis.

Fig. 2. Ctenopteris angustifolia. Fig. 3. Ctenopteris integrifalia. Figs. 4-6. Zamiopsis iosignis.

LXVI. Figs. 1,5-8. Zamiopsis laciniata. Fig. 2. Zamiopsis insignis. Fig. 3. Zamiopsis petiolata. Fig. 4. C enopteris Virginiensis.

LXVII. Fig. 1. Zamites tenninervis. Fig. 2. Zamiopsis pinnatifida. Fig. 3. Ctenopteris minor. Fig. 4. Ctenopteris angustifolia.

Fig. 5. Ctenopteris longifolia.

Fig. 6. Dioönites Buchiasıs, var. angustifolìs. Fig. 7. \%amiopsis insignis.

LXVIIJ. Fig. 1. Dioönites Buchianus. Figs. 2, 3. Ctenophyllum latifolium. Fig. 4. Dioönites Buchianus, var. angratifolius Fig. 5. Glossozamites distaus. Fig. 6. Podozamites subfalcatns.

LXIX. Figs. 1, 3. Dioönites Buchianus. Fig. 2. Zamites tenuinervis.

LXIX. Fig.4. Zamites crassinervis.
Plate LXX. Fig. 1. Zamites tenninervis. Figs. 2, 3. Dioönitey Buchianus. Fig. 4. Encephalartopsis nervosa.

LXXI. Fig. 1. Dioönites Buchianus. Fig. 2. Dioönites Buchianus, var. angustifolius.

Figs. 3, 4. Encephalartopsis vervosa.

IXXIr. Figs. 1,2. Dioönites Buchianns. Figś. 3, 4. Ene pylıalartopsis nerrosa.

Lxxırf, Fins. 1-3. Diönites Buehianns.

LXXIV. Figs, 1-3. Dioönites Buchianns.

LXXV. Fig. 1. Nageiopsis longifolia. Fig. 2. Nageiopsis recurrata. Fig. 3. Zamites tenuinerris.

LXXVI. Fig. 1. Podozamites pedicellatus. Figs. 2-6. Nageiopsis longifolia. Fig. 7. Zamites tenuinerris.

LXXVIL. Figs. 1, 2, Nageiopsis longifolia. Fig. 3. Nageiopsis decrescens. Fig. 4. Nageiopsis orata.

LXXVIII. Fig. I-5. Nageiopsis loy gifolia. Fig. 6. Zamites tenninervis. Fig. 7. Podozamites pedicellatus.

LXXIX. Figs. 1,3. Nageiopsis zamioideg. Figs. 2, 6. Nageiopsis crassicaulis. Fig. 4. Nageiopsis recurrata. Fig. 5. Podozanites distantinervis. Fig. 7. Nageiopsis longifolia.

LXXX. Figs. 1, 2,4. Nageiopsis zamioides. Fig. 3. Nageiopsis reenrvata. Fig. 5. Nageiopsis ovata. Fig. 6. Podozamites acutifolius.

LXXXI. Figs. 1-6. Nageiopsis zamiuides.

LХХХU. Fig.1. Nageiopsis crassicaulis. Fig. 2. Podozamites grandifoliug. Fig. 3. Nageiopsis latifolia. Fig. 4. Podozamites distantinervis. Fig. 5. Podnzamites pedicellatus.

LXXXIII. Figs. 1, 2,6,7. Podozamites distantinervis. Fig. 3. Zamites erassinervis. Fig. 4. Zamites distantinervis. Fig. 5. Podozamites grandifolius.

LIXXIV. Figs. 1, 2, 8, 10,14, 15. Podozamites distantinervis.

Figs. 3,9 , 11. Nageiopsis crassicaulis.

Fig. 4. Nageiopsis heteropliylla.

Fig. 5. Phylloclarlopsis heteropbslla. Fig. 6. Nageiopsis mierophylla.

Fig. 7. Zamites tenuinervis.

Fig. 12. Zamites ? sp. nndet.

Fig. 13. Zamites subfalcatus.

LXXXV. Figs. 1, 2, 8,9. Nageiopsis lougifolia. Fig. 3. Zamites snbfalcatus. Fig. 4. Zamites ovalis.

Fig. 5. Feilueniopsis crassinervis. Fig. 6. Nageiopsis in equilateralis. Fig. 7. Nageiopsis obtusifolia.

Figs. 10, 15. Podozamites acntifolins. Fig. 11. Nageiopsis acuminata. Figs, 12, 16. Podozamites distantipervis. Fig. 13. A rancaria obtusifolia. Fig. 14. Nageiopsis mieropbylla.

LXXXVI. Figs. 1-3, 5, Nageiopsis microphylla. Fig. 4. Arnucaria podocarpoides. Figs. 6, 7. Nageiopsis heterophylla. Figs. 8, 9. Nageiopsis angustifolia. 
Prate LTRTVII. Fig. 1. Podozamites acutifolius. Figs. 2-6. Nageiopsis augustifolia.

LXXXVIII. Figs. 1,3,4,6-8. Nageiopsis angustifolia. Figs. 2, 5. Nageiopsis heterophylla.

LXXX1X. Figs, 1, 3. Baieropsis expansa. Fig. 2. Nageiopsis aognstifolia. Fig 4. Baieropsis pluripartita.

XC. Fig. 1. Baieropsis expansa. Figs. 2-5. Baieropsis pluripartita. Fig. 6. Baieropsis macrophylla.

XCI. Figs. 1,3,4,7. Baieropsis pluripartita. Fig. 2. Baicropsis expansa.

Fig. 5. Baieropsis pluripartita, var. minor.

Fig. 6. Baieropsis loogifolia.

XCII. Figs. 1,2,6. Baieropsis pluripartita. Figs. 3,4 . Baieropsis piuripatita, var. minor.

Fig. 5. Baieronsis expansa

Fig. i. Baierupsis denticulata, var. augustifolia.

Figs. 8, 9. Baieropsis atiantifolia.

XCIII. Figs. 1-3. Baieropsis adiantifolia.

Figs. 4-6. Bieropsis foliosa.

Fig. 7. Baieropsis denticulata.

XCIV. Fig. 1. Baieropsis adiantifolia, var. minor.

Figs. 2, 3. Baieropsis alliantifolia.

Fig. 4. Acrostichopteris densifolia.

Figs. 5, 9, 10, 12. Acrostichopteris yarvifolia.

Figs, 6, 7, 11, 14. Acrostichopteris parce. lobata.

Fig. 8. Acrostichopter is eyclopteroides. Fig. 13. Baiera multifolia.

XCV. Figs. 1-5. Frenelopsis ramosissima.

XCVI. Figs. 1-3. Fredelopsis ramosissima.

XCVII, Figs, 1-6. Fredelopsis yamosissima.

XCVIII. Figs, 1-6. Frenelopsis ramosissima.

XCIS. Figs. 1-4. Frenelopsis runosissima.

C. Figs, 1-3. Frenelopsis ramosissimn Fig. 4. Brachyphylluw erassicaule.

c1. Fig. 1. Frenelopsis ramesissima. Figs. 2, 3. Leptostrobus lougifolins. Fig. 4. Leptostrobus foliosus.

CII. Tigs. 1-4. Leptostrobus longifolins. Figs. 5, 6. Laricopsis brevifolia Figs, 7,8. Laricopsis longifolia. Figs, 9, 10. Laricopsis angustifolia.

CIII. Figs, 1, 4. Laricopsis angustifolia. Figs. 2, 3, Laricopsis longifolia. Fig. 5. Leptostrobus foliosits. Figs. 6-12. Leptostrobus longifolius.

CIV. Fig. 1. Leptostrobus foliosns. Figs. 2, 3. Cephalotaxopsis ramosns. Figs. 4, 5. Cephalotaxopsis magnifolia. Fig. 6. Leptostrobus loogifolins.

CV. Figs. 1, 2, 4. Cephalotaxopsis magoifolia. Fig. 3. Cephalotaxopsis brevifolia.

CVI. Figs. 1, 3. Cephalotaxopsis magnifolia. Figs. 2, 4. Cephalotaxopsis ramosa. Fig. 5. Cephalotaxopsis brevifolia.

CVII. Figs. 1, 2,4. Cepbalotaxopsis magnifolia. Fig. 3. Cephalotaxopsis ramosi. Fig. 5. Cephatotaxopsis brevifolia.

CVIII. Figs. 1, 3, 4. Cephalotaxopsis inagaifolia. Fig.2. Cephalotaxopsis ranosa.
Plate CVIII. Fig. 5. Cephalotaxopsis microphylla.

CIX. Figs. 1-7. Brachyphyllum crassicanle. Fig. 8. Torroya Virginica. Figr. 9. Cephalotaxopsis microphy lla.

CX. Figs. 1-3. Brachyphylum erassicaule. Fig. 4. Brathylihyllin parceramosum.

CXI. Fits. 1-5. Frouelopsis parceramosa. Figs. 6, 7. Brachyph, llnm crassicanle.

CXII, Figs. 1-5. Frenelopsis parceramosa. Figs. 6-8. Brachyphyllum crassicaule. Figs.9-11. Sequoia cycalopsis.

CXIII. Figs. 1-3. Sequoia cycadopsis. Fis. 4. Torreya falcata. Figs. 5, 6. Athrotaxopsis expansa.

CXIV. Figs. 1-3. A throtaxopsis graudis. Figs. 4, 5. Athrotaxopsis tenuicanlis.

CX V. Figs. 1, 3. Athrotaxopsis paclyphylla. Fig. 2. Athrotaxopsis expansa. Fig. 4. Athrotaxopsis tenuicanlis.

CXVI. Figs. 1-4. Athrotaxopsis grandis. Fig. 5. Athrotaxopsis oxpansa.

Fig. 6. Athrotaxopsis tenticanlis. Fig 7. Sequoia, sp, nulet.

CXVII. Figg. 1.3-5. A throtaxopsis pachyphylla. Fig. 2. Athrotaxopsis tenuicaulis. Fig. 6. Athrotaxopsis expansa.

Fig. 7. Sequoia subnlata.

Fig. 8. Sequoin Teichenbachi, var. longifolia.

CXVIII. Figs. 1,4. Sequoia Reichenbachi.

Fig. 2. Sequoia ambigua.

Fig. 3. Sequoia rigida.

Figs. 5, 6. Sequoia subulata.

Fig. 7. Sphenolepidinm Sterobergianum, var. densifolina.

CXIS. Figs. 1-5. Sequoia Reichenbachi.

CXX. Figs. 1-6. Sequoia ambigut. Figs. 7, 8. Segnoia Reichenbachi. Fig. 9. Sequoia, sp. undet.

CXXI. Fig. 1. Araucaria zamioides. Fig. 2. Sequoia rigida.

Fig. 3. Seguoia delicatula.

Fig. 4. Seqnoia deasifinlit.

Figs, 5, 7, 9. Sphenolepidium Sternbergianom, var. densifolium.

Fig. 6. Taxodium (Glyptostrohns) Virginicum.

Figs, 8, 10, 11. Sphenolepidium Sternbergiannu.

CXxII. Fig. 1. Taxodium (Glyptostrobus) Brookense. Fig. 2. Sequoia Fieichenbachi.

CXXIII. Fig.1. Taxodiam (Glyptostrobms) expansum. Figs. 2, 3. Taxodizm (Glyptostrobus) ramo. som.

CXXIV. Fig. 1. Taxorlinn (Glsptostrobns) deaticnlatum.

Fig. 2. Taxodiun (Glyptostrobus) ramosum. Figs. 3-9. Taxodium (Glyptostrobus) Drook. ense.

CXXV. Figs. 1, 3. Taxolinm (Glyptostrobus) fastigi atum.

Fis. 2. Sphevolepidinm Sterohergianum, var. densifolinm. Fig. 4. Splenolepidinm Virginicum.

CXKVI. Figs. 1, 5, 6. Sphenolepidium Linrı janum, Fig. 2. Sequoia rigida. Figs. 3, 4. Sequoia gracilis.

CXXVII. Fig. 1. Taxodium (Glsptostrohus) ramosum. 
Plate CXXVII. Fig. 2, Splenolepidiun recurrifolium. Figs. 3, 4. Spheuole pidium destifolium. Fig. 5, Secquoiz ambigua.

CXXVIII. Figs. 1, 7. Splienolepidiun Knrrianum. Figs. 2-6. Splenolepidiam dentifolium.

Cxxix. Figs. 1, 2, 4, 6, 8. Spbeoolepidium Kurriapum.

Fig. 3. Sphenolepidium Sterabergianum, rar. densifoliun.

Fig. 5. Spleselepidinm deatifolium.

Fig. 7. Spheuolepidium parceramosum.

Cxxx. Fig. 1. Spbeuolepidinm Sterabergianmm, rar. deasifolium

Figs. 2, 7. Sphenolepidium recurvifolium. Fig. 3. Sequoia rigida.

Figs. 46, 10. Sphenolepidinm deatifoliuos. Fig. 8. Spleoolepidium parceramosnm. Fig. 9. Spheuolepidiun Sternbergiaoum. Fig. 11. Sphenolepidiumn Kuтrianuas.

CXXXI. Figs. 1,3. Sphenolepidiun Sternhergianum, var, densifoliam.

Fig. 2. Spluenolepidiam parceramosum.

Fig. 4. Sphenolepidium Kurrianuı.

Fig. 5. Taxodium (Glyptostrobus) Brookense.

Figs. 6, 7. Sphenolepidium pachsphyllum.

CXxXII. Fig. 1. Tasodiam (Glsptostrobus) ramo. sum.

Figs. 2, 5, 6. Sequoia, sp. uadet

F'ig. 3. Sequoia ambigua.

Fig. 4. Spheoolepidiua Sternbergiasum, var. densifolium.

Fig. 7. A bietites macrocarpos.

Figs. 8, 9. A bietites ellipticus.

Fig. 10. Sequoia, sp, uadet.

CxxxII. Fig.1. Abietites angusticarpns.

Figs. 2-4. A bietites ellipticus.

Figs. 5-7. Williausonin Virginiensis.

Figs. 8-12. Arancarites Aquieosis.

CXXXIV. Fig. 1. Carpolithas fasciculatus.

Figs, 2-4, 6, 8. Carpolituns teroatos.

Fig. 5. Carpolithus agglomeratus.

Fig. 7. A raucarites Virginicns.

Fig. 9. Carpoli thus conjugatus.

Fig. 10. Carpolithus geminatus.

Figs. 11-14. Carpolithus Virginiensis.

CXXXV. Figs.1,5. Carpolitus Virginzensis.

Figs. 2, 4, Carpolithus Brookensis.

Fig. 3. Carpolith is latos.

Fig. 6. Leptostrobus, sp, undet.

Fig. 7. A ujent of coeifer.

Fig. 8. Brachyplyllum, sp. nadet.

Fig. 9. Brachsphyllum, sp. uodet.

Fjg. 10. Athrotasopsis graodis.

Figs. 11.21. Cyeadeospermum spatulatum.

Fig. 12. Cycadeospermum acntum.

Fig. 13. C'ycalcospermum oboratum.

Fig. 14. Capsules, sp, uadet.

Figs. 15, 18, 22. A throtaxoysis expansa.

Fig. 16. dment of angiosperm?

Fig. 17. Carpolithus curvatus.

Fig. 19. Cycadeospermum ellipticn@.

Fig. 20. Cycadeospermum angusturn.

cxXXVI. Fig. 1. Macrospores, sp. nadet.

Figs. 2-5, 8. A prents of couifers, sp. undet

Fig. 6. Carpolithns Brookensis.

Fig. 7. Pollen sacs, sp. ondet.
Plate CX:XXVI. Fig, 9. Carpolituus sessilis. Fig. 10, 11. Leptostrobus, sp. nodet. Fig. 12, Cycadeosperounu rotuadatum. Firs. 13, 14. Tudeterwined plants. Fig. 15. Carpolithns mueronatus.

CXXXГII. Figs. 1-5. Uadetermiged piants. Fig. 6. Acacirphsllum longifulium.

CxxxviII. Figs. I-3. Acaciaplusllum lou gifolium. Figs. 4, 6-9. Acacix phyllum spatulatum. Fig. 5. Acacirephyllum microplytlum. Figs. 10-12. Ctenis inubricata. Fig. 13. SageLopteris Virgioieosis. Fig. 14. Conospermites elliptiens.

CX5xIx. Fiq. 1. Sagenopteris Virgiaicusis. Fig. 2. Protexphyllum, sp. uadet. Fig.3. Protezplyllura reoiforme. rig. 4. I'roterephyllum orbiculare. Fig. 5. Proterephillum oblougifoliuro. Fig. 6. Rogersia longifolia. Fig. 7 . Sassarras parrifolium.

CXL. Figs. 1. 2. Proterephyllum oblongifolium. Fis. 3. Ficophrllnm tenuinerre.

CXLI. Fig. 1. Proterephyllum ovatum. Fig. 2. Ficophyllum teduinerve.

CXLII. Figs. 1,2. Proterephyllum ellipticum.

CXLIII. Figs. 1,3. Ficus Virginiensis. Fig. 2. Rogersia aogustifolia.

CXLIV. Fig. 1. Ficus Virginieosis. Fig. 2. Rogersia loogifolia. Fig. 3. Ficopusllum crassinerre.

CXLV. Figs, 1,4. Ficophslium tenniaerve. Fig. 2. Ficophyllun serratom. Fig. 3. Ficophyllum crassioerve.

CXLVI. Fig. 1. Ficophyllam crassiaerve. Figs. 2,4. Salicipbyllum ellipticum. Fig. 3. Celastropluyllum arciatrre. Fig. 5. Celastrophyllam proteoides.

CXLVII. Fig. 1. Sapiadopsis cordata. Fig. 2. Ficophyllam teoujoerve. Fig. 3. Sapiadopsis elliptica. Fig. 4. Ficophyllum crassioerve.

CXLVIII. Figs. 1,2,4. Ficophyllnm erassinerre. Figs. 3, 5. Ficns Fredericksburgeosis

C.LIX. Figs. 1, 3, 5. Ficophyllum tenuinerve. Fig. 2. Phyllites pachyphsllus. Figs. 4, 8. Rogersia angustifolia. Figs. 6, 7. Quercopliyllum tenuigerve. Fig. 9. Ficophrllum serratum.

CL. Fiq. 1. Rogersia longifolia. Figs. 2-7. Rogersia angustifolia. Fjg. 8. Saliciphyllun elliptic um.

Figs. 9, 10. Vitiphyllum (Cissites) crassifolium.

Fig. 11. Mrxica Brookensis.

Fig. 12. Saliciphyllum longifolian. Fig. 13. Proterphyluan tenuinerre.

CLI. Fiæ. I. Sapindopsis rariahilis. Figs, 2,3. Sapiodopsis magnifolia. Fig. 4. Bombax Virginieusis.

CLII. Figs. 1,4. Sapiodopsis variabilis. Figs, 2, 3. Sapiadopsis maguifolia. Fig. 5. Sassatras eretaceum, var, heterolobum.

CLIII. Fig. I. Sapiodopsis tenuinervis Fig. 2. Sapindopsis magoifolia.

Fig. 3. Sajundopsis variabilis. Fig.4. Sapipdopsis brerifolia. 
Plate CLIV. Figs. 1,5. Sapindopsis magoifolia. Figs. 2-4. Sapindopsis rariabilis. Fig. 6. Sapiodopsis parrifolia.

CLV. Figs. 1, 7. Sapindopsis brerifolia. Figs. 2-5. Sapiudopsis rariabilis. Fig. 6. Sapindupsis magnifolia. Fig. 8. Uimiphyllum Brookense. Fig. 9. Populophyllum reniforme.

CLVI. Fig. 1. Ficopbyllnm tenuinerre. Fig. 2. Proterphyllum tenuiverre. Fig. 3. Popalophyllnin reoiforme. Fig. 4. Proterephyllnm reviforme. Fig. 5. Celastropbyllnm obtusideus. Fig. 6. MIrracepbylinm dentatum. Fig. 7. Protexphyllum dentatum. Fig. 8. Celastrophyllow acutideus. Fig. 9. Quercophyllum grossedeatatum. Fig. 10. Myrica Brookensis. Fig. 11. Araliæphyllnm aceroides. Fio 12. Sassafrns bilobatum. Fig. 13. Sapindopsis obtusifolia.

CLVIr. Figs. 1, 7. Aralia dubia.

Fig. 2. Sterculia elegaus. Figs. 3, 5, 6. . Iuglaodiphslluta iategrifolium. Fig. 4. Ficophyllum crassinerve.

CLVIII Ftg. 1. Clmiph rllum tenuiuerre. Figs. 2, 3. Sterculia elegans. Fig. 4. Populoph pllam crassinerve. Fig. 5. Platanophsllam crassiuerre, Figs. 6, 7. Dlmiphyllum crassinerre. Fig, 8. Celastrophrllna Brookenso.

CLIX. Figg. 1, 2. Rogersia lougifolia. Figs. 3-6. Sapiodopsis obtusifolia. Fig. 7. Celastrophyllnm Brookense. Fig. 8. Sassafras cretaceum, var, heterolobum. Figs. 9. 10. Araliepbsllum magnifolium.

CLX. Figs. 1, 2. Proterephyllum reaiforide. Figy. 3-6. Aristolocbirepbyllum crassiverve.

CLXI. Figs. 1, 2. Menispermites Virguaieasis.

CLXII. Fig. 1. Hederæphyllum angnlitum. Fig. 2. Aralixepbrilum aceroides. Fig. 3. Hedersphyllum crenulatum. Hig. 4. Encalsptopbyllum oblougifolium.

CLXIII. Eigs. 1,4. Aralirephyllum obtusilobum. Fig. 2. Aralixpbyllum acutilobum. Fig. 3. Sapindopsis brevifolia. Fig. 5. Saliciphyllum ellipticum. Fig. 6. Hymentea Virginiensis. Fig. 7. Ulmiph fllum Brookense. Fig. 8. Aceriphyllum aralioides.

CLXIV. Figs. 1, 2. Ficophyllum euealyptoides. Fig. 3. A raliæplysllum obtusilobum. Fig. 4. Sassafras bilobatum. Fig. 5. Sassafras cretaceum, var. heterolobum. CLXV. Figs. 1-3. Taxodium (Gljptostrobus) Brookense.

Fig. 4. Laricopsis lougifolia.

Fig. 5. Willamsonia Virginieusis. Fig. 6. Leptostrohns multifiorus.

CLIVI. Fig. 1. Taxodium (Gljptostrobus) ramosum. Fig. 2. Saliciphyllnm ellipticum. Fig. 3. Populophyllum hederæforme. Figs. 4,7. Taxodium (Glyptostrobus) Brookense.
PLATE CLNVI. Fig. 5. Cladophlebis acuta.

Fig. 6. Sphenolepicium Virgiuicum.

CLXVII. Fig. 1. Taxodium (Glyptostrobus) Brookense, var. angustifnlizm.

Fig. 2. Spheuvepidium Kurrianum.

Fig. 3. Taxodiuru (Glyptostrobus) Brook. ense.

Fig. 4. Phyllodadopsis beteropbylla.

Fig. 5. Sequoia Rescheubachi.

Fig. 6. Carpolithus Brookeusis.

CLXVII. Fig. 1. Frenelopsis pareeramosa.

Fig. 2. Brachsplusllum, sp. undet.

Fig. 3. Dioöoites Buchianus, var. obtusifolius.

Fig. 4. Nageiopsis subfalcata.

Figs. 5, 6. Laricopsis lnagifolia.

Fig. 7. Carpolithus Virginiensis.

Fig. 8. Abietites ellipticus.

Fig. 9. Brachyphyllum crassicaulo.

CLXIX. Fig.1. Thinnfelủia grauulata.

Fig. 2. Cladophlebis constricta.

Fig. 3. Pecopteris Virginieasis.

Figs. 4, 5, 9. Uudetermined stems.

Figs, 6, 7. Thyrsupteris rurinervis.

Fig. 8. Callitris, sp. undet.

Fig. 10. Celastrophyllum denticulatum.

CLXX. Fig. 1. Thyr'soptoris divarieata.

Fig. 2. Podozamites acntifolius.

Fig. 3. Zamites ovalı.

Fig. 4. Pinus, sp. uadet.

Figs. 5,6. Pecopteris strictinervis

Fig. 7. Aeaciephyllum variabile.

Fig. 8. Rlizome of Equisetum, sp. undet.

Fig. 9. Podozanites subfalcatus.

Fig. 10. Acrostichopteris longipenois.

Fig. 11. Acrosticbopteris densifolia.

CLXXI. Figs. 1, 5, 7. A crostichopteris loogipes ais. Figs. 2.6. Acrosticbopteris donsifolia. Figs. 3, 4. Acrostichopteris parvifolia.

CLXXII. Figs. 1,4. Proterephyllum dentatum. Fig. 2. Celastrophyllum tentioerve. Figs, 3, 6, C. lastrophyll um latifolinm. Fig. 5. Saliciphsllum parvifolinu. Fig. 7. Celastrophyllum denticulatum. Fig. 8. Menispermites temuinervis. Figs. 9, 10. Celastrophyllum obovatum. Figs. 11, 12. Vitiphyllum (Cissites) parrifo. lium.

Fig. 13. Acrosticbopteris densifolia.

Fig. 14. Acrostiehopteris parrifolia.

CLXXIIl. Figs. 1-9. Vitiphyllum (Cissites) roultifidum.

CLXXII Fig. 10. Ficophyllum crassinerve.

Fig. 11. Uadetermined plast.

Figs. 12, 14. Protexpbjllum destatun.

Fig. 13. Celastrophyllum latifolinm.

CLXXIV. Tysonia Marylandica.

CLXXV. Tysosia Marylandica.

CLXXVI. Tysonia Marylandica.

CLXXVIJ. Tysonia Marslandica.

cLXXVIII. Tysooia Marylandica.

CLXXIS. Tysonia Marylandica.

CLxxx. Tysonia Marylaudica. 


\title{
LETTER OF TRANSMITTAL.
}

\author{
Department of the Interior, \\ U. S. Geological Surver, \\ University of Virginia, Virginia, January 10, 1889.
}

Sir: I transmit with this the manuscript and plates describing and illustrating the flora of the Potomac or Younger Mesozoic formation of Virginia.

Almost all of the material described in this memoir was obtained in the State of Virginia. A small portion was collected in Maryland, at Baltimore.

The work of collection occupied several years. A large number of localities, extending over the belt between Baltimore, Md., and Petersburg, Va., were carefully examined, and all significant specimens were selected from a very large amount of material. A number of the localities were visited several times and new collections made.

The extent of ground over which the fossiliferous exposures occur and the thorough examination made entitle us to believe that the fossils described in this monograph give a fair idea of the unique and interesting vegetation existing in Potomac times. This flora is unique, for it apparently contains the oldest known angiosperms, and exhibits them in considerable numbers associated with numerons Jurassic types, a conjunction not hitherto known.

Accompanying my manuscript is a series of tables, comparing the Potomac plants with previously described fossil floras. These tables were 
prepared by Prof. Lester F. Ward for his own use, but he has kindly consented to permit their publication as an appendix to this memoir. Their preparation involved an inmense amount of research and comparison, and their comprehensiveness and accuracy will add greatly to the value of my work.

$$
\text { Respectfully submitted, }
$$

Wm. M. Fontaine.

Hon. J. W. Powell,

Director U. S. Geological Survey. 


\title{
THE POTOMAC OR YOUNGER MESOZOIC FLORA.
}

\author{
By W. M. Fontaine.
}

INTRODUCTION.

The plants described in this memoir, with very few exceptions, were collected personally by me.

The formation from which the plants were obtained was for a $10 \mathrm{ng}$ time and by most writers included in the so-called Trias of the Atlantic slope. Prof. William B. Rogers, however, in his earliest publications on the geology of Virginia, recognized the difference between this group of strata and most of the Mesozoic of that State. In his first publications he called the beds Upper Secondary, and expressed the opinion that they are of about the age of the English Purbeck. Later ${ }^{1}$ he asserts the possibility that they may form a group of passage beds, comparable to the Wealden. In his more recent writings he calls the formation Jurasso-Cretaceous.

Mr. IV J McGee, of the U. S. Geological Survey, has proposed the name "Potomac" for the group, and this name will be nsed by me.

Nearly all the plants described in this work come from the Potomac formation in Virginia. The few exceptions were found in Maryland, and these embrace all the plants not collected by myself. They will be more particularly noticed further on.

With the exception of the Maryland fossils, all the plants which form the subject of this work were not only collected by me, but were packed, 
shipped, unpacked, and worked out of the rough material with my own hands. The specimens have in consequence never passed from under my direct supervision. The plants were collected at intervals, and repeated visits were paid to the more important localities in order to secure new material which might throw light on imperfect specimens previously obtained. This method of collection canses delay and imposes much additional labor, but it has many advantages.

In the first place, the exact locality and geological horizon of a specimen can be fixed, a matter of great importance in determining the diffusion of species, and in the discovery of comnecting links between the local floras. In the Potomac formation, owing to the peculiar facies of some of these floras, connecting links are of unusual importance.

A much greater adrantage is obtained in the increased number of significant parts of plants selected and in the greater opportunity afforded for the detection of new species.

When the material is collected by the person who will describe it special attention is paid to the significant portions of fossils. In the case of plantfossils, parts with the greatest structural significance are often not as conspicuons as those with less meaning. They may also be poorly preserved. They would be rejected in such cases by a collector unacquainted with the science they illustrate, especially if the amount of material were large.

The circumstances attending my collection of these plant-fussils were most farorable for thoroughness of exploration and selection. The search for these impressions extended over several years. During the summer material was obtained from different localities, and in autumn and winter this was worked over, studied, and drawn, the drawings in all cases being made by myself.

It often happened in this study that a number of fragments unlike the rest were found which were too imperfect to be made out, and this led me in several cases to make repeated visits to the same locality, in the hope of obtaining more complete specimens of the undetermined species. The renerved search often met with success. It will be easily seen that a collection made under such circumstances has a completeness and value not otherwise attainable. 
The distance apart of the most remote plant localities and the number of intervening spots affording specimens give reason to think that the fossils obtained enable us to form a fair notion of the vegetation of that period. This is especially fortunate, for the hitherto known floria of the oldest Cretaceous is exceedingly scanty.

One feature of the Potomac flora at once attracts attention. This is the large number of plants confined to single localities. In many cases this number is so great as to give the local floras a peculiar facies, which, were it not for the connecting links, wonld induce one to believe that they differ considerably in age. This localization is perhaps chiefly dne to differences in the conditions attending the entombment and preservation of the plants. At any rate this feature attests the richness of the flora. The variety within certain limits and the abundance of the vegetation nust have been great.

The distance from Deep Bottom on James River to White House Bluff on the Potonac is more than 90 miles. If we include the Maryland localities, 50 miles must be added. The number and location of the intervening stations will appear in the account of them presently to be given.

When fossils have been collected at given localities it may easily happen that natural or artificial changes so alter the exposures that the spot yielding the impressions is soon concealed. The Potomac beds, owing to their want of coherence and the poverty of exposures in them, are especially liable to have fossiliferous portions hidden. Then, too, plant-impressions occur in them with exceeding irregularity, at best sparingly, and in very thin layers. It seems, then, desirable to describe with some minuteness the spots where plant-fossils were found.

Before beginning these deseriptions it is proper to give some account of what was formerly known of plant-fossils from this formation. The belief, before referred to, in the Triassic age of the strata now in question was due in part to the apparent absence of all fossils that could throw light on the subject and call for a separation of the Potomac from the older Mesozoic. So far as is known to me, only two persons have published anything concerning the occurrence of fossil plants in the Potomac beds of Virginia. 
Prof. William B. Rogers, in his annual reports on the geology of Virginia, ${ }^{1}$ made more than forty years ago, mentions the finding of certain plant-fossils in the vicinity of Fredericksburg. He does not describe any of them, but considers them as indicating for the Mesozoic strata at that town an age not far from that of the Purbeck of England.

Mr. R. C. Taylor" gives an account of "certain fossil dicotyledonous plants in the secondary strata of Fredericksburg." He speaks briefly of some of the features of the Potomac formation in the vicinity of that town, and mentions rather vaguely the location of the plants. He says that at his request some of the impressions were furnished to the geological society by Mr. F. Shepherd. These seem to have been few in number and poorly preserved. Mr. Taylor gives in his article some figures and imperfect descriptions of these fossils. The delineations are so vagne that little can be learner from an inspection of them. No dicotyledons are indicated. Certain long stems of succulent plants are mentioned as appearing in the form of hollow casts. These may be the Frenelopsis ramosissima, so abundant at Fredericksburg. Some coniferous twigs with acicular leaves and some ferns are figured, but they can not be specifically determined. His figure 3 is without doubt a Scleropteris, different from the one (S. elliptica) found by me, being a smaller form. I have seen none of the plants mentioned by Professor Rogers and none of those described by Mr. Taylor, and, notwithstanding persistent search, I liave failed to find the locality mentioned by the latter gentleman. It seems, from what he says, to be different from the one which yielded me so many fossils.

The mention by Professor Rogers of the discovery of plant-fossils in the Fredericksburg beds and the account given by Mr. Taylor seem to have attracted very little attention.

Mr. F. B. Meek many years ago made a search for fossils in the clays lying on the line of the Baltimore and Ohio Railroad between Washington and Baltimore. He succeeded in finding at Baltimore a few well-preserved impressions, which are mostly those of ferns. These were subsequently placed in the collections of Columbia College, New York, where they now are. Dr. J. S. Newberry kindly loaned them to me for description. An

${ }^{1}$ A reprint of Annual Reports on the Geology of the Virginias, 1884, pp. 7, 712.

${ }^{2}$ Trans. Geol. Soc. Pennsylvania, vol. 1, 1835, pl'. 314-325, Pl. XVIII, XIX. 
account of them will be given in the proper place, and they will be noted as belonging to Meek's collection of Baltimore plants. So far as I know the only mention made hitherto of these fossils is an incidental reference made by Dr. Newberry in his article on the Chinese Mesozoic plants collected by Pumpelly.

Mr. P. Tyson, while State geologist of Maryland, obtained in 1859 two cycad trunks. They were found in the above-mentioned clays extending from Washington to Baltimore. One of them was found near Contee's Station, a point on the Baltimore and Ohio Railroad two miles southwest of the town of Laurel, and the other near Beltsville, a station on the same rail'nad a few miles nearer Washington. These trunks, now in the Museum of the Maryland Academy of Sciences at Baltimore, are described in this memoir. I think no previous description has been published. They were photographed by Mr. Tyson, and copies of the photographs were furnished by him to a number of his correspondents. Various writers have made reference from time to time to these trunks. Mr. Tyson, Professor Rogers, and Prof. P. R. Uhler, of Baltimore, lave regarded them as indicating the Wealden age of the clays which afforded them. Professor Uhler first found the plant locality at Fredericksburg from which I collected. He says that when he discovered the spot he collected several boxes of specimens and sent then to Prof. Lonis Agassiz, at the Museum of Comparative Zoölogy, Cambridge, Mass. According to Professor Uhler these impressions were finer than any found since at this place. I can well believe this, for I have observed in collecting at the Fredericksburg locality that the plant-impressions became poorer and fewer as the stratum was followed in from the outcrop. I have not been able to learn what became of these specimens.

Professor Uhler placed a number of the plants collected here in the Museum of the Maryland Academy of Sciences, where they were subsequently seen by me. They were the first that I ever saw coming from the Potomac formation. Professor Uhler found at Baltimore also a number of plantimpressions. They came mainly from Federal Hill. Unfortunately both these and his Fredericksburg collections have been lost. Owing to a mis-

${ }^{1}$ Smithsonian Contributions to linowledge, vol. XV, No. 202, 1867, pp. 119-123, Pl. $1 X$. 
take, in the absence of the professor, all these specimens were sent to the World's Exposition at New Orleans. Nothing has been heard of them since. As the material was very fragile, and probably was badly packed, it was no donbt ground to powder before reaching its destination.

It is much to be regretted that these impressions were lost before they had been carefully studied and described. My recollection of them is not very distinet, but it is sufficient to enable me to say that the Baltimore fossils were chiefly rather delicately incised ferns, with a sphenopterid facies, not unlike the most important plants collected by Meek.

The plants found by Professor Uhler at Fredericksburg contained certain portions of some species that I have never been able to find myself. I especially remember an impression of the smmmit of a large leaf, which then seemed to me to be a Macrotaniopteris. From my own discoveries since, I am now sure that it was the tip of a large Anomozamites. I have never succeeded in finding a single specimen showing the termination of the leares of this plant. As Professor Uhler was kind enongl to offer to place these specimens in my hands for description, I looked forward with much pleasure to their examination. The cases above mentioned embrace, so far as I know, all the discoverjes of fossil plants hitherto made in the Potomac formation.

When I first began to seararch for fossils in the Potomac beds I knew of no discoreries of plant-impressions in them except those mentioned by Professor Rogers. Judging from the lithology and the stratigraphy of these beds, I was convinced that Professor Rogers was right in supposing that they differed in age from most of the Mesozoic of Virginia. His mention of the existence of plants in the formation induced me to undertake a systematic search for plant localities. In the course of my first reconnaissance I paid a visit to Baltimore, and having learned from Professor Uhler of the existence of Tyson's cyead trunks and of his own collections obtained at Baltimore, I made with him a hasty examination of these fossils at the Museum of the Maryland Academy of Sciences.

Professor Uhler had not told me of his discovery of plant-impressions at Fredericksburg, but while at the museum my attention was attracted by a small collection of fossil plants unlike any that I had ever seen. Professor Uhler informed me that he had collected them at Fredericksburg, and 
he was kind enough to promise to show me the spot. Under his guidance I visited this plant locality and found the exposure in the form of a small ledge of rock, showing an ontcrop only a few feet in length. Here I made my first collection from the Potomac strata. Among the specimens found were some that appeared to be certainly dicotyledons. These plants, and many others new and of great interest found there, induced me to make thorough search of the spot. The experience gained at Fredericksburg tanght me how to look for fossils in this formation. In the course of several years, during which examinations were made, the number of plant localities found and the amount of material obtained proved to be unexpectedly great.

The mode of occurrence of the plants in the Potomac formation deserves a brief general description. There is nowhere any continuons stratum affording plant-impressions. When found at any locality and on a given horizon it rarely happens that even in the immediate vicinity any trace of the plant-bearing bed can be found. One can depend upon nothing except what is seen on the spot to contain plants. Even this material as a rule, when followed in working, soon gives out, often suddenly and unexpectedly. In the sandy portions of the formation we find little besides silicified wood, and even this is very rare.

Lignite is abundant, but it always occur's enveloped in clay. This, when damp, is, with hardly an exception, dark gray to black. All the determinable portions of plants occur in clay, which, as a rule, is but little indurated. It is ustrally quite plastic and tenacious. In rare cases the material is somewhat indurated, so as to approach in nature a shale. Two colors are common in the clay; one is pale reddish brown or chocolate; the other when damp is dark lead-gray to nearly black. The first is more commonly the carrier of identifiable plants, but even this clay is by no means usually fossiliferous. In many cases it is without a trace of vegetable matter, and in others it contains nothing but small diffused bits of plants. The gray clay sometimes contains good impressions, but more commonly only lignite.

Both kinds of clay occur in tro forms: (1) They are fonnd undisturbed and as originally deposited; (2) they appear disturbed, that is, torn up from 
the original bed and redeposited in an irregular manner. The undisturbed clay often possesses a somewhat regular structure. It is then either laminated or cleavable, especially if plants are present. This form of the clays gives almost all of the well-preserved specimens. These undisturbed clays occur in more or less extended lenticular sheets that finally thin out and disappear, showing in their course many irregnlarities. Often they are found in pockets of limited extent.

The clays are commonly found disturbed. They then appear in the form of masses or small particles that have been torn up from some preexisting clay layer, transported to a greater or less distance, and deposited either singly enveloped in the sands, or together in irregular pockets and lnyers mixed with some sand. If abundant, the redeposited clay particles, when cemented together by pressure, form layers, at first sight not unlike the undisturbed clay beds. It is easy to detect these deposits on attempt ing to work" out plant impressions occurring in them. They lack the laminated structure and cleavage of the undisturbed material. The clay is much mixed with sand, and is confusedly heaped together, contorted, and affected by slickensides. The contained fossils are very fragmentary, and lie at any angle in the material, so that it is rarely possible to extricate them without destroying the specimens.

In some cases the redeposited masses are large enough to retain the original comparatively regular structure, especially if they have not been transported far. In such cases good impressions may be obtained. In some cases a remnant of the original bed may be found covered by the disturbed clay. There is no essential difference between the plants in the original beds and those in the redeposited clays, and hence no very long period of time had elapsed between the deposition of the original bed and that of the disturbed material. These confused and disturbed clays may occur at any horizon in the Potomac, and they are common at and near its top. They are often mixed with coarse sand, and they even contain pebbles, sometimes of large size. It is not unusual to find one of these disturbed clays resting on a cobblestone layer.

A common mode of occurrence for the clay of both colors is in the form of isolated masses and particles imbedded in the sand. In some cases 
these particles are small, and are intimately mixed with sand; in others they take the shape of rolled masses or balls of considerable size. These have been seen five or six feet in diameter, but more commonly they are only a foot or less. The balls rarely contain good impressions, for they have generally been much crushed and contorted. They are often associated with large cobbles. The presence of these balls, and of the disturbed clays, may be taken as indicating that some change has occurred which increased the agitation of the waters and caused erosion to take place for a short time. Hence they indicate erosion-horizons. It is clear that the normal deposit of the Potomac of Virginia was sand, and that the clay layers were formed only in eddies and still portions of the waters. Any renewal of the more violent movement, continuing the transport and deposition of sand, might erode the lately deposited clay.

Lignite is very abundant in the Potomac formation, and its mode of occurence is worthy of notice. As stated before, it occurs always imbedded in dark gray clay. The usual form in which this material is found is that of single logs and limbs, or aggregations of these. The single logs, and some of the aggregations, were plainly drift material. It is quite a common thing to find imbedded in the sand, and surrounded immediately by a patch of clay, logs of lignite which now lie where they quietly settled to the bottom after floating about for a period. These represent entire trees, and the lignite does not occur in the fragmentary condition in which it is always found in the so-called "iron-ore clays." The logs occasionally have great length. In the cutting of the Dutch Gap Canal there was removed, as I am informed, a lignite $\log$ forty feet long. An end of this log may still be seen in the bank of the canal, indicating a tree of the diameter of ten inches. At least twenty feet in addition to the forty feet have been removed from it.

In several localities we find aggregations of lignite logs which appear to have been formed by the prostration of forests, the trees falling where they grew. In these cases the lignite logs occur lying one over the other and nearly all having the same direction.

No plants that can be identified lave been found south of James River. In the banks of the Appomattox clay occurs that seems favorable for the preservation of plant-impressions; only small fragments, however, have 
been seen in it. The fossils found in the Petersburg area were all obtained from the banks of the James River below Richmond.

\section{PLANT LOCALITIES.}

Deep Bottom is the locality farthest down the James River where plant-impressions have been found, and here the Potomac disappears from view. The spot is about four miles below the Dutch Gap Canal, being located in a sharp bend of the river near a group of luts A small creek enter's here after having cut a deep ravine through all the formations down to the top of the Potomac. At this spot the river bank is composed of Quaternary, Eocene marl, and Potomac. In places the Quaternary rests on the Potomac, but usually the Eocene bed intervenes. Just below the mouth of the small stream above mentioned a thick mass of Quaternary is seen resting on a confused mixture of materials that have the character of the Potomac.

The greater portion of the exposure of this latter is of a rather argillaceous gray sand, that shows all the features so common in the disturberl clay commonly found in the upper part of the Potomac. This material barely rises above high-tide level. The argillaceous sand seems to be derived from the erosion of some stratum which has been torn up and had its fragments confusedly redeposited. It is a structureless mass, made up of particles of various sizes cemented together by pressure. Embedded in this sandy matter we may find some particles more argillaceous than the main mass, which retain to some extent the structure and cleavage of the original stratum. These furnish occasionally fragments of dicotyledons and other plants of the same sort as those found elsewhere in the Potomac. The gray masses in which the plants are found are of the same general character as the debris in which they are embedded, being simply more argillaceons. Associated with these, and inclosed in the confused matrix, we find large rounded masses three or four feet in diameter, of a dark chocolate tenacious clay, which is entirely different from the surrounding sandy matter. This clay has the character of the chocolate clay so common elservhere in the Potomac formation. Its masses contain plant-impressions similar to those of the gray argillaceons sand, but they are more perfectly preserved. 
A little farther down the river the top of the Potomac formation shows itself undisturbed, rising two or three feet above low tide. It is a dark tenacious clay, full of small fragments of plants. The Eocene greensand marl rests upon it. About two hundred yards distant, in the bottom of the ravine cut by the creek, the Potomac shows itself again undisturbed, but here only sand appear's The spot affording the plant-impressions seems to be one of the erosion horizons so common in the top of the Potomac. This locality will be referred to as "Deep Bottom."

The next plant-bearing locality met with in ascending the river is at the lower entrance of Trent's Reach. Trent's Reach is the great bend in the James River to avoid which the Dutch Gap Canal was cut. The exposures of the Potomac strata in this reach are extensive, but none of them are noteworthy as yielding plants, except a bluff in the river bank diagonally opposite the lower end of the canal, and on the sonth side of the river. The spot may be located by its showing the first high bank seen on entering Trent's Reach. At this place a spring branch enters the river near the ruins of a small wharf. The bank immediately at and below the wharf contains ten to fifteen feet of the chocolate Potomac clay, but this material, thongh highly favorable for the preservation of plant-impressions, revealed none.

The high bank extends thirty or forty yards above the month of the branch, but the material composing it changes considerably, becoming an irregular mixture of sand and clay. This portion of the bank has such sudden and irregular changes of structure and material as to defy description. Most of the impressions were found about fifteen yards above the mouth of the branch. They occur at different horizons in the bluff and so irregnlarly that no description can serve as a guide for finding them. They may be looked for in the highest part of the Potomac, which shows about fifteen feet of material, and is capped by Quaternary.

The upper portion for the thickness of three or four feet shows occasionally good impressions. The uppermost portion is quite argillaceons, in a layer four to six inches thick. This has a brownish color and contains an immense number of fragments of plants, with now and theur good impressions. The fragments seem originally to have made up a large part of the 
material of the layer, but now many of them have weatliered out, so that the clay is very porous and is full of the carities left by them. Most of these fragments are coniferous, and many belong to the species of Frenelopsis which is found only lere. This stratum has yielded a number of interesting plants. We find in it the following, among other less noteworthy forms: Baieropsis (B. pluripartita minor), Williamsonia, Dioönites, Pachyphyllum, and Frenelopsis parceramosa.

Some portions of the material under this layer show a tendency to lamination; and here occurs a different group of plants, but they are scattered so irregularly that one can never tell where they may be found. Here is the largest form of Baieropsis seen at Dutch Gap, viz., B.pluripartita, and various coniferous twigs and cones, as well as several fernis. In one part of the bluff a log was seen silicified in one portion and clianged to lignite in another. The locality will be referred to in the description of species as "Entrance of Trent's Reach."

Plant-impressions occur in both banks of Dutch Gap Canal. This canal is only about one hundred yards long. The banks are layers of sand and clay irregularly intermixed, and varying much in thickness. The clay is in both forms, the disturbed and the undisturbed; the latter containing most of the impressions. It has both of the characteristic colors, the gray and the reddish. In most of the bank the clay occurs in masses and pockets of variable thickness, apparently replacing portions of the sand. In one portion of the right bank thin layers of dark gray clay and sand are interstratified. These clay layers sometimes contain very large impressions of Dioonites Buchianus, which are over a foot in length, indicating that the leaf must have been in some cases a yard long. This material is so fragile that it was impossible to get out specimens nearly as large as they showed themselves to be as they lay in the clay. When Dioönites Buchiames is abundant, as it is here in places, very few other plants are found. The plants occur irregularly in the sides of the canal and apparently in small pockets in the clay. The greater portion of the material is entirely free from them. Dioönites Buchiamus and a few ferns, with some conifers, especially of the Sphenolepidium and Sequoia types, are the most common forms in the general mass of the clay. 
On the right bank of the canal and in the thin interstratified layers of sand and clay a curions mode of occurrence of plants was discovered. In examining here the clay layers, to procure as large specimens of Dioönites as possible, a small mass of pale reddish plastic clay was found embedded in the interstratified sand and dark gray clay. This reddish clay seemed to be a ball inclosed in the stratified material. It was withont bedding, and was somewhat contorted and affected with slickensides. From this it will be seen that its lithologic character differed totally from that of the matrix in which it was inclosed. The fossils found in it showed still greater differences, for the large impressions of Dioönites Buchianus were lacking, and instead there was a great variety of plants, some of which have not been fonnd anywhere else. A number of the species occuring in this homogeneous clay seem to have been delicate, finely incised ferns, some of which were beautifully preserved. This mass seems to have been a fragment torn off from some bed of clay exceptionally rich in plants, which was subsequently embedded in the interstratified sand and clay. The number and beauty of the impressions found in it make special reference to it desirable. It will be referred to as "Red clay ball, Dutch Gap Canal." This clay mass was five to six feet in diameter. The locality in general will be characterized as "Dutch Gap Canal." By this will be meant that the plants thus referred were found in the banks of the canal, but not in the red clay ball.

Above the canal there is a reach of river about one and a balf miles long. The left bank for this distance is mostly high, and conposed of Quaternary resting on Potomac. Host of the Potomac material is a gray, coarse, current-bedded sand, with here and there pebbles and large clay balls. In places in the sand, nearly at high-tide level, are lenticular layers, interrupted patches, and irregular masses of both dark gray and reddish clay, the former predominating. These are undisturbed. Plants are found in severai places, mostly in the lenticular layers and interrupted patches of gray clay. The clay is very tenacious and plastic, with indistinet cleavage. It is difficult to work ont good specimens from it, notrvithstanding the undisturbed condition of the material. 'The plants, however, are preserved in it very perfectly. 
The most important locality in this reach, and the one which has yielded the most numerous and best preserved specimens found at Dutch Gap, is situated a few yards above a spot used by fishermen as a landing place for their reel nets, where a small shanty is located. Where the plants are obtained two layers of dark gray clay oceur in the base of the bluff, a foot or so above high tide. These layers are mululating in their course and tend to run together. Where most distant from each other, they are separated by eighteen inches of sand. Plants occur irregularly in both layers, but in the lower seam there is a portion, only two to three inches thick, that contains plant-impressions for a considerable distance.

This fossiliferous seam is usually found near the center of the clay layer, but it rises and falls in its course, so that it is sometimes near the top and sometimes near the bottom. The clay layers are each about twelve inclies thick, but they vary a good deal. The lower layer is much the richer in impressions. The best specimens of Equisetum found in the Potomac formation occur at this spot, also very fine specimens of Jioönites. Many conifers, especially long-leaved Sequitas, a number of ferns, good impressions of Baieropsis pluripurtita minor, and a number of other plants may here be obtained. The locality will be referred to as "Fishing hut aloove Dntch Gap Canal."

About two hundred yards above this spot there is a pocket of dark clay in the sand, which stands at so low a level as to be covered by high tide. This is full of leaves of Dioüniles quite well preserved, but, as is nsually the case when the Dioönites is abundant, only fer other species ocenr. About one and a half miles above the canal a very large spring discharges into the river, at a place called Sailor's Tavern. The clays and sand found farther down the stream still continue to show themselves for about four hundred yards above the spring in the form of an irregular bluff. About two hundred and fifty yards above the spring a pocket of gray clay, irregularly mixed with sandy matter, occurs at about lightide level. This material, when it was first found, was carefully examined, and the impression of the posterior part of a fish was obtained from it. Above this point on the river no good plant-impressions were found. 
These localities embrace all that are worthy of mention in the vicinity of Dutch Gap. The narrow neck of land throngh which the canal is cut, and which is known as Dutelı Gap, is by river 17 miles below Richmond; by country roads, 12 miles.

In the interval between Richmond and Fredericksburg no plant-impressions have been found, and in the immediate vicinity of the latter town only one place has yielded any notable amount of fossils. As was stated before, this spot was discovered by Professor Uhler.

The plant-bearing layer at Fredericksburg, on being followed in from the outcrop, proved to be very limited in horizontal extent. The space from which impressions were obtained was only about fifteen feet square, and the fossiliferous material seemed to be a lenticular pocket, apparently formed in an eddy in the waters. On the outcrop the impressions were more numerous and better preserved than farther in. The particular layer that most abounded in vegetable matter served as a water-rvay, and the long-continned seepage of water through it destroyed much good material.

The locality now in question is situated just below Mr. Phillips's warehouse and near the boat-house of the Fredericksburg boating club, on the right-hand side of the road descending to the steamboat landing. When first seen by me the fossiliferous material was exposed in the form of a small ledge of rock close to the road. The ledge was mainly composed of a gray, highly argillaceous, and very fine-grained sandstone, graduating into sandy shale. About four feet of the material contained vegetable matter. The upper portion for about three feet contained few recognizable parts of plants, while it had in a layer of considerable thickness so much comminuted plant-matter that it was colored brown and rendered thinly fissile. Nearly all the good impressions occurred towards the bottom of the mass, near its junction with a bed of cobble-stones, on which the fossiliferous stratum rested.

Distinct impressions were found mostly in a layer here three to five inches in thickness. This cobble-stone bed is one of the most curious features of the locality. It thickened up so as to cut out in all directions the plant-bearing material. The cobbles are composed of Azoic rock, such as occurs several miles to the west of the spot, mixed with some rounded 
stones of the typical Potomac sand, here having the consistency of a sandstone. The cobble-stone bed itself is very local, and is nothing but a pocket representing a local erosive horizon. Many of the stones are three to fire inches in diameter and some as much as eight to ten inches. Over the fossiliferous stratum Quaternary deposits come, having large, partly rounded Azoic masses in their base. On working the plant deposit and following it in and along the onterop it was found to thin ont to the west and north, while to the south the material continned withont essential lithologic cliange, but lost entirely its fossils.

I made repeated visits to this place and collected largely from it. I was induced to do this because the study of each collection made known to me fragments that were not otherwise identifiable, while they were clearly different from the better-preserved imprints. Unfortmnately the town anthorities availed themselves of the excavation I had made to get material for mending roads, so that no doubt a large amount of good fossiliferous matter was wasted. The quarrying operations carried on by myself and the town finally exhausted the deposit, and the place now appears as a rectangular recess, showing in the walls little besides the Quaternary and the cobble-stone bed. From its present aspect no one would think that any plant impressions had ever been found there. This locality will be referred to in the descriptions of species as "Fredericksburg."

I have made repeated and careful search for other plant localities in the vicinity of this spot, but with no success. I found that on the same horizon with these fossil impressions, in the immediate vicinity, the material was totally different. The changes of rock material on the same horizon were so many and so sudden, that it soon became evident that there was nothing here like an extensive fossiliferous horizon. Here and there, very locally and on different horizons, a few obscure impressions might be found, but they in no case ever extended over more than a foot or so of space taken horizontally, while in thickness the material would be a mere film.

North of Fredericksburg, however, other localities yield plants. It may be said here that in searching for plant-impressions in the Potomac formation there is no guide except the presence of undisturbed clay. Any layer of this kind may contain impressions, and hence before one can say 
that no fossiliferous localities exist in a given region, he must have examined every clay layer in it. As these occur generally in small patches which in the poverty of exposures must be often hidden, it will be easily seen that many fossiliferous spots may exist where none have been found.

Going north, the next plant locality that has been seen is on the farm of Mr. Powhatan Moncure and in its vicinity. The spot may be best located as follows: The Telegraph road crosses Potomac Run about seven miles north of Fredericksburg, at the farm of Mr. Moncure. Near the run, and just south of it, a rather steep hill descends, and here the road is much washed, producing a deep gully on the right-hand side. The gully exposes at the foot of the hill an interrupted stratum of gray clay, which rests upon a gravel bed. The clay is mixed with sand, and was eviclently torn up from some pre-existing layer, the particles being deposited confusedly, sometimes in masses of considerable size. Owing to the mixed character of the material and the very limited amount of it, it was difficult, except when the fragments were large, to get out good specimens. All the clay visible was worked out. The spot is interesting for yielding one of the two species of Sagenopteris found in the Potomac beds and for the occurrence of several well-marked plants found also at Dutch Gap and Fredericksburg. This locality may be designated as "Road-side near Potomac Run."

It may be noted here that the tidal portions of the streams entering the Potomac River from Virginia are known as "creeks," while from the head of tide up the streams are called "ruus."

At the point on the Telegraph road above mentioned an obscure farm road diverges to enter a field. At a distance of about two hundred and fifty yards this road deflects to approach a wooded hill. Where the road passes first along the base of the lill another fossiliferons stratum occurs. 'This is found a few yards up the hill and within the woods. This stratum is composed of gray shale intercalated in the sand. The material is more indurated than we usually find the clays to be, and it is well laminated. Lithologically it is strikingly like the fossiliferous gray shale of the Potomac found at Federal Hill, on Covington street, in Baltimore, which will be noticed further on. The stratum is from two to three feet thick, and has apparently considerable horizontal extent, although no traces of it appear MON $\mathrm{XV}-2$ 
on the Telegraph road. It is one of the most favorable materials knowu to me in the Potomac formation for the preservation of good fossils.

It is of course composed of undisturbed matter, unlike that found on the road. The impressions in it are numerous and well preserved, but I was disappointed to find that they all belonged to a few species only. The plants are nearly all ferms and conifers. The ferns show close affinity to the most abundant of those collected by Meek at Baltimore, thus confirming the indications of the lithology. These plants illustrate the curious localization so common in the Potomac plants. Hardly a single species found here occurs in the spot on the Telegraph road, the nearest affinity being with certain Baltimore ferns and Dutch Gap conifers. This spot will bo referred to as "IIill-side near Potomac Run."

In the woods that contain the last-described locality an interesting" occurrence of lignite is met with. The lignite is situated on a small stream about one-fourth of a mile to the sonthwest of the plant-locality on the Telegraph road. The stream exposes in its ehamel the lignite logs embedded in dark gray clay. This clay is a local deposit in the usual Potomac sand. The lignite clearly was caused by the prostration of a forest in the place where the trees grew. The trees may be seen for more than one hundred yards along the bed of the run, lying at different levels, and mostly turned in the same direction. The logs are much flattened, so that a crosssection presents the form of a much elongated ellipse. Some of the trunks. appear to have been originally fully two feet in diameter.

This lignite, like all that found in the lower Potomac, seems to lave originated from coniferous wood, and at this place one species of conifer appears to have furnished most if not all of the material. If we may judge from the macroseopic character of the lignite, this tree grew in forests over all of the Potomac terrane; for most of the lignite thronghont the Potomate of Virginia and much of that found in Maryland came from the same species of tree. It seems to have liad a wood of uniform and compact grain, with numerous thin, closely-placed rings of amnual growth.

This lignite shows peculiar features that are characteristic of nearly all found in the Yirginia Potomac. When dry, if it be split longitudinally, the structure of the wood is beautifully shown; but if a cross-fracture be 
made, it presents the features of a true jet. The fracture is conchoidal, resinous, and deep black in color The only leaf-impression seen in the clay containing this lignite was a well-marked imprint of Scleropteris ellipticu.

The next locality yielding plant-impressions found in going north is in the vicinity of Brooke station. The localities on Potomac Run are near the western edge of the Potomac area. Brooke station is on the eastern edge. The area in this region is abont four miles wide. Brooke station is on the Atlantic Coast Line Railroad, nine miles north of Fredericksburg. In the vicinity of Brooke the contact of the Eocene with the Potomac may be seen. The cuttings for the railroad give the exposures liere of the plant-bearing beds. Two localities in this vicinity, a short distance apart, have been found to yield plant-impressions. One of these occurs in a cut on the railroad at the $72 \mathrm{~d}$ mile-post from Richmond, and the other abont one-fourth of a mile farther north and near the railioad crossing over Acquia Creek. The Potomac formation exposed at these two places shows marked lithologic differences, and a diversity in the plants is also found.

The cut on the railroad which exposes the fossiliferous material begins at the mile-post and extends for some distance down the railroad to the north. The Potomac here has resting upon it a thin layer of Eocene, which in two places thickens up by dipping and cutting out the Potomac below the level of the track. This thickening takes place in two narow bands, which represent two pre-Eocene ravines cut ont of the Potomac. They r'un in a northwest and sontheast direction, very nearly in accordance with the direction of the present minor streams of the region. The Potomac material is very irregular in structure and composition. It is composed in the main of sand, with the usual varying character and current-bedded structure, in which is found clay irregularly arranged. The clay that contains plant-impressions is mostly disturbed and deposited in pockets and rude layer's which have no definite course, and in which the clay is much mixed with sand, affected with slickensides, and confusedly cemented together by pressure. Most of the plants seem to have been canght between the particles of clay as they were pressed together, hence it is difficult to get out good specimens; but in one portion of the side of the cut, on the left facing north, a thin irregular stratum was formed by the deposition of fine 
clay. This possessed some regularity of structure and was cleavable. It afforded a number of interesting plants beautifully preserved. Unfortunately the amount was very linited and the stratum was worked out. As most of the clay here is lnmpy and confusedly tlurown together in particles of some size, the plants, althongh quite numerous in species, are generally very fragnentary. The specimens occur mostly a few yards north of the mile-post, the best being obtained on the left hand looking north.

This locality is remarkable for the large number of species of dicotyledons and conifers found, and also for the number of plants occurring nowhere else. Most of the conifers and dicotyledons have apparently a more recent character than the predominant plants found at the more southern localities; but the identity in mode of occurrence, and the number of connecting links seen in the plants here, indicate that the flora of this locality is not essentially different in age from that of the rest of the Potomac. This spot will be designated as "72d mile-post," near Brooke. The fossils at this place give us another illustration of the localization of many of the Potomac plants.

As stated, the number of species occurring here is large, and several of these are very abundant. Nearly all are wanting at the locality presently to be described, while some of the most common of the species at the latter are wanting near the mile-post.

Going down the railroad about one-fourth of a mile in a northerly direction, on the right hand side where a creek crosses the road, we find a considerable area from which the earth has been removed to make a "fill." This has caused an abrupt bank to be left about fifty yards from the railroad. Most of this bank is composed of the current-bedded Potomac sand, but in the top of the bank is a stratum of gray shale about eight feet thick. This is undisturbed material, and shows distinct stratification. Portions of it are sandy and coarse, but a number of thin layers are composed of fine clay, and abound in plant-impressions; which, however, all belong to a very few species. ILost of the impressions occur near the top. By far the most abundant of the impressions are those of Sapindopsis, which also abound at the 72d mile-post The locality has been very thoronghly explored, and 
very few other species have been found. A small Baieropsis occurs next in abundance. It is not found at the mile-post, but has most resemblance to a plant occurring at Federal Hill, in Battimore. The great number of impressions of Sapindopsis is surprising, as is also the fact that so many of the imprints show the preservation of the same portions; i. e., the terminal part of the pimnate leaf.

Two or three imprints of bivalve shells were found. These appear to be small Unios, and they resemble some of the Wealden Unios figured in Dunker's "Monograph of the Wealden." This spot will be referred to as "Bank near Brooke." The clay carrying the fossils seems to be a remnant of an original stratum of considerable extent. It is comparable to the lower Potomac clay over the sand in Baltimore.

Going north, the next plant locality was seen at Mr. Kankey's farm, on Neabsco Run. It lies three-fourths of a mile west of the Telegraph road and nearly opposite the place where the road crosses the run at Mr. Kankey's louse. This is near the western margin of the Potomac area. Only six or eight feet of Potomac sand and clay can be seen, and the floor of Azoic slate is visible in several places. The sand is of the nsual kind. The clay that carries the fossils is dark gray and very tenacious, and it is undisturbed; but it lies in irregular patches of limited extent. Very ferv species occur here. Dioönites Buchianus is the only plant of importance. Great numbers of its leaves occur in some portions of the clay, so that they are matted together. Here, as at Dutch Gap, this plant, when very abundant in a clay, seems to exclude other species. It is noteworthy that in going north from Dutch Gap this is the first locality where any trace of this plant oceurs, and the great number of the specimens seen at its reappearance is remarkable.

This locality deserves especial notice for the lignite found there. It occurs precisely as at Potomac Run, evidently originating in the same way; i. e., by the prostration of a forest of coniferous trees and their subsequent change to lignite in the place where they grew. The lignite is exposed along the channel of a small stream for some thirty or forty yards. The stream has very feeble erosive power, and the deposit of lignite is probably not fully shown.

${ }^{1}$ These have been since determined by Dr. White to be Estheria. 
This lignite exhibits exactly the same physical character as that on Potomac Run, having the curious mingling of features of jet and true lignite with woody structure. Some of the trees, which appear to have been three feet in diameter, are much flattened, having evidently been subjected to great pressure. As only a few feet of material now covers these trunks, the Potomac here must have lost largely by erosion. The locality will be referred to as "Kankey's on Neabsco Run."

Where the Coast Line Railroad crosses Occoquan River a long cut of considerable deptl has been made to form the approach on the south side to the bridge. This cut shows Potomac sand, with fossiliferous reddish and gray clay in small irregular patches. In some places the floor of Azoic slate is shown, so that here, as well as at Kankey's, the base of the Potomac is all that remains. The only fossil worth mentioning that occurs here is Dioönites Buclianus. It is by no means so abundant as at Kankey's, and in general the plants are very rare and fragmentary. No collection was made.

The next locality which has afforded specimens is a little sonth of Telegraph Station. This station is on the Coast Line Railroad, three miles north of the crossing over Occoquan River. A series of cuts made in the Potomac sand and clay are found between the station and the river. The only spot in this region at which plant-impressions have been found is in a cut about one and a half miles south of the station, and towards the river. The material exposed is Azoic slate, with Potomac sand and clay resting on it. The clay containing plants is mostly disturbed and colored gray. This las poor impressions, but in the left-hand side of the cut looking north is a pocket of rather sandy, laminated, and reddish clay, which has afforded a number of well-preserved impressions. The most important of the plants here is Dioonites Buchianus. This is the farthest point north at which good specimens of this fossil liave been obtained. Fragments of it occur at Fort Washington and also at Baltimore, but they are few and small. A number of ferms, conifers, etc., occur here, giving a group of plants much like those found at Dutch Gap. The locality will be referred to as "Near Telegraph Station."

White House Bluff is the end of a point which terminates on the Potomac about two miles below Mount Vernon. The bluff begins just below 
White House wharf, and extends several hundred yards down the river: The material composing it is almost wholly Potomac, of which it shows fully eighty feet. This is capped by about fifteen feet of Quaternary. The lowest portion of the bluff, for fifteen to twenty feet, is a coarse sand, nearly white in color, and consolidated to a pretty firm rock. Higher the sandy matter is yellowish gray, or brownish yellow, from oxidation and from the admixture of some colored clay. Clay layers, balls, and pockets oceur on both horizons. About sixty feet above water level is a pretty woll defined layer two to four fect thick of mixed sand and disturbed clay. This seems to be almost pure clay in some places, and may be detected by the water that issues from the face of the bluff. In a number of places it contains a good many bits of plants, among which some undeterminable conifers and small fragments of Dioünites Buchianus may be seen.

At only one place have well-preserved impressions been found, about seventy-five yards below the old wharf. Here a large amonnt of talus forms a steep slope up to the foot of a perpendicular bank about twenty feet high. In the base of this bank the bed above described ocenrs The material is difficult of access and collecting is dangerous, since the bank above threatens to come down upon one working at its base. The clay presents the usual structural features of the disturbed clays; but its mineral character is unusual, and not found in many of the exposures of the layer in the bluff. It has a light buff color, and is very fine in texture and plastic; the lumps and masses are so mixed with sand in redeposition and so much contorted that it is not easy to obtain good specimens. 'The impressions of leaves are numerous, but the species of plants are ferv. The dicotyledon Sapindopsis variabilis, with pinnate leaves, so common at the two localities near Brooke, gives nearly all the imprints. The state of preservation of these leaves is similar to that of those seen near Brooke, the parts of the leaf most commonly found there being most numerous here also. This locality will be referred to as "White House Bluff."

Fragments of plants with some determinable parts occur at Hount Vernon, on the Potomac River, two miles above White House, and also at Fort Washington, on the Maryland shore, about three miles east of Hount 
Vernon. No prolonged search has been made at either of these places for plant-impressions, and it is quite possible that good fossils may be found at both. M Lount Vernon is noteworthy for showing on the sand of the lower Potomae a gray laminated argillaceons material similar to that seen in Federal Hill, Baltimore. The Fort Washington bluff shows at its base lower Potomac, consisting of sand with pockets of disturbed clay. Over this comes upper Potomac, composed of the Variegated Clay, or so-called "iron-ore clay;" so conspicuous in portions of Maryland. Next above we have Encene with impressions of marine shells; and over all, Quaternary. The disturbed clay in the top of the lower Potomac shows masses and particles of various sizes embedded in the sand. Some of the larger particles retain their original lamination, and in these fragments several species of plants may be found. The most important of these are Frenelopsis ramosissima, Dioönites Buchianus, and an uniletermined dicotyledon.

The lower part of the Potomac formation appears at Washington with the features characterizing it in Virginia. In the clays exposed in the excavation for the reservoir a few obscure fragments of leaves occur, being found in pale reddish clay. In the dark-gray clay, which forms pockets in the sand composing the greater part of the formation here, a good deal of lignite is found. This seems to be formed by the alteration of drift-wood which has accumulated in certain places.

In Virginia the Potomac formation is composed of only one group of beds, the lower one, which is mostly sand or sandstone, with here and there sandy clay. In these materials come irregularly subordinate strata of more or less pure clay, containing the plants found in this formation. In Maryland the case is different, for here we find a series of beds overlying the lower or sandstone menber, and underlying the Eocene, which as yet cannot be separated from the sandstone or sand member by any clearly defined universally present features. For this reason this group is retained in the Potomac formation, forming its upper member.

The Potomac formation extends from Washington to Baltimore, a distance of forty miles. In this space the lower or sand member is rarely seen, for it is too deeply buried under the upper member to be visible, except in the lowest natural depressions and the deepest artificial excava- 
tions. It possesses in Maryland the features which nsually distinguish it in Virginia, except that, so far as seen in Maryland, it is never cemented together and indurated sufficiently to be called a sandstone. It is an incoherent sand of varying character, which has a current-bedded structure, clay locally replacing the sand in various ways.

In the city of Baltimore, on Covington and Belt streets and in other places, several feet of laminated gray shale and clay occur, interbedded with argillaceous sand. This naterial shows on Covington street, at the base of Federal Hill, a thickness for the whole mass varying from six to twelve feet. 'This small group of strata, which on the whole is decidedly argillaceous, rests on the typical sand of the lower Potomac, and forms a member of this lower formation, which, although probably once generally present, is now in most places removed by erosion. This argillaceous portion of the lower Potomac in several places in the city, and notably on Covington and Belt streets, has afforded some interesting plants.

On this plant-bearing material, or, in its absence, on the typical sandy material of the lower Potomac, we find resting everywhere in Maryland the thick mass of clay and sandy clay above mentioned, which has been called by Mr. Tyson and Professor Rogers "the Variegated Clays." Orving to the common occurrence of iron ore in this group of strata, it is very commonly called the "Iron-ore Clay." As stated above, this formation, at least for the present, must be regarded as forming the upper member of the Potomac formation. It will in this memoir be called the "Variegated Clay Group."

This group has not been identifier in Virginia, but it may possibly be feebly represented at Mount Vernon and near Alexandria. The sonthern limit so far as made ont is Fort Washington. It shows itself in great force in the vicinity of Baltimore, and has been traced by $\mathrm{Mr}$. IV J McGee as far as the head of Chesapeake Bay, where extensive exposures are shown.

How far it extends into Delaware and New Jersey and what relations it bears to the plastic clays of the latter State remain to be determined. It is separated from the lower Potomac below by an erosion horizon, and it is composed certainly in part of the ruins of this gronp. From the Eocene also above it is separated by an erosion horizon. So far as the 
evidence goes, the indications are that the variegated clay gronp is of the same age as the plastic clays of New Jersey.

While showing considerable variations in mineral character and physieal properties, this group, when unweathered, is mainly composed of an ash-gray to dark lead-gray plastic elay, often mixed with more or less sand. Quite commonly much of it is a pure highly plastic clay. In the upper, and especially the exposed portions, the iron diffused in the clay las become irregularly oxidized, so that spots, patches, streaks, etc, of red and yellow colors are mingled with the normal gray. From this feature the names "Variegated Clays" and "Mottled Clays" have been taken.

This group during a very long period has been worked locally for the iron present in it. The elay is without bedding or regular structure of any kind. It is much affected by slickensides, and, in short, has many of the features seen in the disturbed clays of the lower Potomac formation. It has a great deal of disseninated lignite, mostly in the form of small fragments. Sometimes the lignite is intimately mixed with the clay, and if the particles are very small the clay is made black by them. The lignite, unlike most of that of the lower Potomac, does not seem to have been formed from the alteration of trees buried during the accumulation of the clay, but appears to have been already in the form of lignite when introduced into the clay. When we consider that the amount of lignite in the lower Potomac is very large, and note that the Variegated Clay rests on it and is certainly partly at least made np of the rnins of that formation, the idea is strongly suggested that the comminuted lignite of these clays comes from the fragments of the lignite logs so common in the lower Potomac

What has been said above belongs more properly to the geological portion of this memoir, but it is necessary to anticipate to this extent in order to render intelligible what will be said about the probable horizon of the Baltimore and other Maryland plants, whose exact geologic position has been left doubtful by their discoverers. Owing to the depth at which the lower Potomac of Maryland usually occurs, the exposures, so far as found, are few and limited in extent. Detailed search has not been made in it for plant-impressions and but few have been found. 
Between Washington and Baltimore lignite is the most important substance of organic origin found in it. The amount of this seems to be large, and it occurs, as in Virginia, in the form of logs changed to lignite in places where the trees were entombed. The characteristic mode of occurrence in such cases is the appearance of the material in the form of entire trunks, which have lain nudisturbed until the present time. This is very different from the condition in which we find the lignite of the Variegated Clays. The lignite logs, as in Virginia, are embedded in gray clay. They occur sometimes scattered in the sand, but each $\log$ has its patch of clay surrounding it. 'The difference between the mode of occurrence of the lignite of the lower Potomac and that of the Variegated Clays is well shown near Hanover, a station on the Baltimore and Ohio Railroad about fifteen miles soutll of Baltimore.

Near Hanover a thick mass of the Variegated Clay covers the lower Potomac. It formis the hills around the station, while the latter is barely exposed in the beds of the largest creeks. Carbonate of iron here, and in many other places, has for a long time been undergoing concentration in the Variegated Clay, owing to concretionary processes. The result has been the formation of nodules and crusts of iron, which for nearly one hundred years have been obtained by open cuts. Around IIanover these pits are numerous and extensive, disclosing well the character and structure of the clay. None of them seem to have penetrated through the clay to the lower Potomac sand below. This clay has all the irregular features of disturbed clay, that is, the material looks as if it were made up of the confusedly deposited debris formed by the erosion of older clay beds. The lignite, which is abundant in some places, occurs as fragments, large and small, mixed with the clay. No entire logs remaining in the position in which the trees were originally entombed have been seen. The material was probably lignite and not wood when it was buried in the clay.

Near the station there is a considerable creek, which has cut its channel below the base of the Variegated Clays. In one place the stream has just cut down to the top of the lower Potomac sand, so as to expose a few feet of it. The Variegated Clay is seen to rest on the eroded top of this. A number of isolated $\operatorname{logs}$ of lignite are found here also, much flattened by 
pressure and embedded in clay. It is evident that these logs represent trunks of trees that settled to the bottom in eddies or reaches of water that remained quiescent just long enough to permit the deposition of a small amount of clay aronud the trunks. One of these logs was seen surrounded by a crust of marcasite about an inch thick, which was partially changed to limonite. This was interesting as suggesting one way in which the form of portions of plants may be retained in limonite. The wood from which the lignite was produced seems to have been coniferous. Two kinds of wood may be detected here even by a hasty inspection. One kind is that which has given rise to nearly all the lignite of the Virginia Potomac; the other was seen here for the first time. This has a coarse grain and open texture. The rings of annual growth are thick and dense; they stand out prominently and are more durable than the material between them. The lignite from this kind of wood is the most common form at Hanover.

A recent visit to Baltiniore enabled me to examine the Potomac formation there under favorable conditions. The gray shale of the lower Potomac, which at Federal Hill shows a thickpess of two or three feet resting on the sand, was found to contain a number of plant-impressions. These in some cases are specifically identical with plants from the Virginia Potomac; in others they are nearly allied to Virginia plants, and in general character this flora seems to be similar to that of the lower Potomac of Virginia.

Professor Uhler assisted me in collecting plants from this locality, and he informed me that several of them are specifically identical with some of those formerly collected by him at Baltimore which were sent to New Orleans. He informed me also that among the fossils sent to the last-named city were a number that he had collected at Federal Hill, near the locality now in question, but at a higher level, and that they all differed from the species obtained by us jointly. This indicates that there are in the vicinity of Federal Hill at least two fossiliferous horizons.

Unfortunately my investigations in Baltimore do not fix the horizon of the plants collected by $\mathrm{Mr}$. Meek. None of the recently obtained species are identical with his, with probably one exception. The rock material of Meek's specimens differs so mucl from the shale which furnishes the specimens on Belt and Covington streets as to indicate a difference in horizon. 
It is quite probable that Meek's specimens come from that higher horizon which yielded fossils to Professor Uhler, from whose description it would appear that they belong to the lower Potomac flora, as is the ease with Meek's plants.

It is probable, then, that all the plant-impressions found at Baltimore belong to the lower member of the Potomac formation, none coming from the upper one, or the Variegated Clay.

The spot where I obtained the plants belongs to the sontheast slope of Federal Hill, and is situated on Covington street, east side, seventy-five feet north of Cross street.

Since my visit additional collections have been made by Professor Uhler and Prof. Lester F. Ward at the Covington-street locality and on Belt street. They have been placed in my hands for study, and form a portion of the plants described further on.

The Belt-street locality is on tlat street, next to and directly north of Ellicott's iron furnace. It is situated two squares southeast of the Covington-street locality. The fossils at both spots occnr in the clay layers immediately above the sand of the lower Potomac, the lowest rock visible. At the Belt-street locality Professor Uhler obtained the best specimens of Celastrophyllum and Achrostichopteris that were found.

The doubt that exists as to the true horizon of the plants formerly found in Maryland arises from the fact that no one who collected them was aware of the existence of the lower Potomac under the Variegated Clays and of the existence of gray clay in the top of the former, or else, if this fact was known, the difference in the age of the two was not perceived.

All the gray clay along the Baltimore and Ohio Railroad between Washington and Baltimore and at the latter place was supposed to belong to the Variegated Clay group. The base of this group seems to be formed of material derived from the erosion of the argillaceous upper portion of the lower Potomac. There is, then, no marked difference in the composition of the uppermost of the lower Potomac and the lowest of the Variegated Clay system. It follows, then, that fossils attributed by former collectors to the lower portion of the Variegated Clay may really come from the top of the lower Potomac. 
A great deal of excavation has been carried on in and around Baltimore, and by this means the character of the formations there has been well disclosed. Lignite is abundant, showing two very distinet modes of occurrence. At all horizons in the Tariegated Clays, exeept at what has been generally supposed to be its base, this material occurs, as at Hanover station, in fragments mixed irregularly with the clay. But at. several places near the supposed base of the Tariegated Clays it has been found in entire logs, either isolated or aggregated in masses. The material seems to have been undisturbed since the change of the trees to lignite. I have not seen these lignites, and hence can not undertake to deternine positively the formation in which they are found; but from what I have seen of the mode of occurrence of the lignite in the lower Potomac and in the Variegated Clays, I feel sure that the undisturbed logs occur only in the former.

After this discussion, which is largely an anticipation of matter more proper for the geologic description of the formation, but which is necessary on account of the donbt attending the true horizon of the first discovered Naryland plants, we may notice the occurrence of Tyson's cycad trunks.

Mr. Tyson has fortunately left in his mupnblished notes some record of the finding of his eycad trunks. By Mr. Tyson and by all others they have been attributed to the Variegated Clays, but this reference is probably not correct. He says that on May 5, 1859, he went to Latchford's ore mine (near Contee's) and got fragments of Saurian bones just exhumed. They occurred, according to him, near a lignite tree about sixty feet long. From what was said above this would seem to show that the Saurian bones were found in the lower Potomac clay and not in the Variegated Clay. He also states that he went to Dr. Jenkins's place and noted the position of the cycad trmks to be at or near the base of the lead-colored clays. This statement is of importance, for the portion called by him "lead-colored clays" forms the base of the Variegated Clays. This position makes it quite probable that the horizon of the trunks is really the upper part of the lower Potomac.

It should be noted that the trunks are thoroughly silicified, and it is possible that they may have been silicified in the lower Potomac sand, and then on the erosion of this, during the deposition of the clay containing 
them, they may have been introduced into the somewhat later material. I call attention to this possibility because of the almost universal change of wood to lignite in the lower Potomac clay. Silicified wood is rare in the Potomac and occurs almost withont exception in sandy matter.

Aceording to Mr. Tyson's notes, one of the trunks, but which it is impossible to say, was obtained from Dr. Jenkins's mine near Contee's station, and the other from Mr. Emack. The latter was obtained from his farm near Beltsville. It does not appear whether this was obtained from an iron mine or was picked up on the surface. Presumably it was found oceuring like the one obtained from Dr. Jenkins. The use of the plural by Mr. Tyson seems to imply this, for while both trunks were sent to him by Dr. Jenkins, only one was found in his mine. The location of Contee's station and that of Beltsville are given in the previous mention of these trunks.

In the excavation of the clay for iron varions animal fossils have been found. The ore-pits in the vicinity of Contee's appear to liave yielded more of these than any others, and they wonld seem worthy of the notice of collectors. Unfortmately little attention has been paid to the collection and preservation of these fossils. Host of the specimens have been lost, and in the case of the few that have been preserved nothing is known of the pits yielding them or of the horizon on which they were found. Some of these fossils are preserved in the Museum of the Maryland Academy of Sciences. In the main they lave not been examined by scientific experts, and hence, if proved to come from the Variegated Clays, they can not be used in determining its age. The fact noted by Tyson that some of them occurred near a large undisturbed lignite tree makes it not altogether certain that they all occur in the true Variegated Clays. ${ }^{1}$

'The anomnt of material obtained from the different plant localities and worked over is very cousiderable. The area over which these localities are distributed is large enough to yield a fair representation of the flora

${ }^{1}$ Since this was written Protessor Marsh bas obtained a large number of Dinosaurian bones from this Variegated Clay group in Maryland. He thinks they belong to Jurassic types. His cliscoveries make it plain that the first discovered animal fossils come from the Variegated Clays. 
of the time of the deposition of the Potomac material. The peculiar localization of the plant-remains causes the aggregate of different species collected at the various places to be mexpectedly large.

It is perhaps proper to say something concerning the plan I have adopted in depicting these plants, for all the drawings were made by myself. The principal figures have been male of natural size, and portions have been given enlarged to show details of nervation and other significant points. In almost every case the enlargement is two diameters; in a very few cases, where the parts of the plant were very minute, three diameter's were required. Owing to the great saving in time and labor I have drawn the principal figures simply in outline, the details onitted being shown in the enlarged parts. As a rule, I have not attempted to give a fac-simile of all the accilental defects and distortions shown in the specimens figured, but at the same time care has been taken not to introduce anything hypothetical.

It has sometimes happened that in removing fossils from the rock in quarrying, impressions were exposed that could not be taken up without breaking them and diminisling the perfection of the specimen. Then again, in transporting the material and in attempting to split up the rock and work ont the fossil, parts would be broken off or otherwise destroyed. This was especially liable to happen in friable and tender material, which at the same time had little or no regular lamination and structure. These facts justify a partial restoration in drawing some of the impressions, for. the existing specimens do not in all cases fairly represent what has been seen. In some cases, then, missing portions have been supplied in the drawings where they have been at one time seen, or where it is clear from the parts still remaining what was the character of the missing ones. These figures I designate as slightly restored.

In a few cases, by talking different portions of the same plant, it has been possible to give a restoration of the entire leaf, which would show what were its probable shape and dimensions. This lias been done in the case of some of the dicotyledons found at Fredericksburg. These were found mostly in a very fragmentary condition, but the fragments were sometimes numerous enough to show partially all portions of the leaf. 
These are given simply as restorations of the probable original character of the leaf.

Many of the ferns of the Potomac formation have features that cause them to resemble one another, and yet there are differences not easy to give in words. These differences are perhaps too slight to justify their separation into distinct species, and yet they are constant and give a facies to the plants that appears to be worthy of delineation. I have for this reason thought it best to give figures of these, although it increases the number of illustrations. The somewhat peculiar grouping of the plants of some localities, if the connecting links were neglected, would cause certain local floras to appear to be different from the normal Potomac vegetation. It seems best in such cases to gire figures of some at least of the widely diffused plants which occur with the peculiar ones, even when they may have been figured from other places.

My tlanks are due to Prof. Lester F. Ward for valuable assistance in collecting the fossils, in the identification of them, and in facilitating the preparation of this memoir. I am under obligations to Dr. J. S. Newberry for the loan of the fossils collected by Mr. Meek at Baltimore, and for permission to describe them. Prof P. R. Uhler has aided me much, facilitating my examinations in Maryland, and affording me the opportunity to describe Tyson's cycad trunks. To him I am indebted for the discovery of the plant locality at Fredericksburg, which is the most important one in the Potomac area.

\section{LOCATION AND GEOLOGY OF THE POTOMAC BEDS.}

In order to make clearer the occurrence and geologic relations of the plants described in this work, it is necessary to give some account of the location and the general geology of the Potomac beds. In this place only so much will be said as is required for this purpose. A detailed account of the geology of the formation will be found in a monograph of the U.S. Geological Survey, shortly to be published.

\section{LOCATION OF THE POTOMAC BEDS.}

In Virginia, the Potomac or Younger Mesozoic forms the greater portion of those beds called by Prof. Irilliam B. Rogers, in his annual reMox $\mathrm{xV}-3$ 
ports on the geology of Virginia, the "Upper Secondary." But Professor liogers under this designation inclnded the strata extending in Hanover Comuty from the North Anna River to the Chickahominy. This series belongs almost wholly to the Older Mesozoic, or Rhxtic formation. It is true that in the vicinity of Hanover Jnuction the Potomac appears in some places, but it is inconspicuons.

It is to be understood that in Virginia the Variegated Clays, or upper member of the Potomac formation, has not been recognized. The Potomac of this State is the lower member. Only when we cross the Potomac River going north is a distinction to be made between lower and upper Potomac.

The Potomac strata show themselves in discomnected areas along a narrow belt which extends from the Nottoway River twenty miles south of Petersburg in a northerly direction past the cities of Petersburg, Richmond, Fredericksburg, and Alexandria. This formation contintes from Virginia into the District of Colımbia and Maryland, including Baltimore. The direction of this belt is almost due north and sonth until Fredericksburg is passed. Then it curves around so as to take a northeast course by Alexandria and Washington to Baltimore. Beyond Baltimore the lower member has not been identified witl certainty, but judging from the character of the material seen at its last exposmes it is not probable that it ends at that city. The name Potomac was selected for the formation by Mr. MeGee on account of its comparatively great development and its typical character along the Potomac River below Washington.

The belt in which the Potomac areas lie is sitnated just ontside or east of the terrane of erystalline rocks. This, in Virginia and Maryland, extends to the head of tide in the principal rivers. The Potomac was buried deeply beneath the more recent deposits which form the coastal and tidewater region of the Atlantic slope, and hence it appear's only where these have been removed by erosion. We accordingly find the exposures of this formation near the junction of the post-Potomac formations with the crystalline rocks, and for the most part near the head of tide in the largest rivers.

The exposures of the formation in the belt above mentioned are so arranged as to indicate the existence of at least four disconnected areas, all 
of small width. There is, however, good reason to think that this isolation of the areas is rather apparent than real, and that the formation extends far to the east and seaward under the later deposits.

A general accomt only can be given here of the location and dimensions of the several Potomac areas. In this account I will begin at the north and proceed southward.

My examination of the distribution of the formation north of the Potomac River in Maryland and the District of Columbia has not been sufficiently detailed to enable me to do more than indicate approximately the location of the area in which exposures are found.

I have not made any search for Potomae strata north of Baltimore, but Mr. MeGee has found the upper member, or the Variegated Clays, as stated before, in force near the head of Chesapeake Bay.

Prof. William B. Roger's ${ }^{1}$ speaks of the Variegated Clays which occur between Washington and Baltimore as extending to Wilmington in Delaware, stating that toward Delaware, from the preponderance of ferruginons coloring, they lave been called by Professor. Booth the "red clay formation." How fir they extend in that direction, and what relation these incoherent beds bear to the plastic clays of New Jersey, are points that remain to be determined.

The upper member, the Variegated Clay, is shomn greatly developed at Baltimore and all along the lines of the Baltimore and Ohio and Baltimore and Potomac Railroads. The eastern limit is to be found several miles east of these railroads, the formation being covered in that quarter by a varying thickness of the Tertiary, by the Quaternary, or by the ruins of these formations.

The western limit lies some miles west of the above-mentioned railroads. The farthest point south at which the Variegated Clay member has been certainly identified is Fort Washington. Possibly it may form a portion of the hills at Mount Vernon, but this member is certainly absent beyond this point.

As stated before, the lower Potomac has not been identified north of Baltimore. Between Baltimore and Washington it is evidently generally 
present under the Variegated Clays, but in most cases it is too deeply buried under the latter to be seen, except in a few spots, where erosion has been carried deep enough to reach it.

At Baltimore the only exposures seen are within the city limits. Baltimore is evidently near the original shore line of the Potomac waters, for at this place the Potomac abuts against hills composed of crystalline rock, and the latter sends tongues into the Potomac terrane.

The Potomac at Baltinore has suffered much and unequally from erosion. In places the Qnaternary alone is found above, resting immediately on the sands of the lower member. In other places the Variegated Clay forms the surface, resting on this sand; and in still others, the typical sand of the lower nember has interposed between it and the Yariegated Clays, fossiliferous, argillaceous sand and laminated clay belonging to the lower member.

Going south towards Washington, the lower Potomac is covered by a thick mass of the Variegated Clays. It is exposed at Relay Station, nine miles from Baltimore. At Relay' Station also the Potomac must be near its original western limit, for we find a high bluff of crystalline rock abutting against and rising much above it. The hills of crystalline rock at Relay Station appear never to have been covered by the Potomac.

From Relay Station to Washington the Baltimore and Washington turnpike runs parallel to the Baltimore and Ohio Railroad and a mile or more west of it. No exposures of the lower Potomac were seen on this pike, for this portion is covered by the Variegated Clays. The margin mnst lie to the west of this road. That it is present under this clay is shown by its occurrence at Hanover, abont six miles soutl of Relay Station. This point is some distance east of the western limit of the formation. These are the only points between Baltimore and Washington where exposures of the lower Potomac have been seen. No detailed search, however, for exposures in this interval has been made.

At Washington, both in the city and near it, the lower nember may be seen in a number of places We may, for the sake of distinction, call the belt from Batimore to Washington the Baltimore area. It is, however, continuous with the Fredericksburg area of Virginia. In the 
vicinity of Washington the lower Potomac is covered by the same formations as at Baltimore. Apparently nowhere north of the Potomac River does the lower Potomac constitute the surface rock; but it is buried more or less deeply under later formations.

The case is different in Virginia. Here, in a belt extending from Washington to Frederickslurg, it occupies the surface, being in the vicinity of the Potomac River alone, covered by Quaternary deposits. This indicates that in going north of the Potomac River the lower member lies at a lower level, or else it has lost more from erosion.

Passing from the District of Columbia into Virginia, we find a connected area of lower Potomac rock, which forms the surface in a narrow belt that extends to a point five miles south of Fredericksburg, where the Massaponax River enters the Rappahannock. This may be called the Fredericksburg area. It is the only region in which the lower Potomac comes to the surface over an area of considerable extent. It forms a belt on an average three or four miles wide, having its western margin near the Telegraph road and its eastern near the Potomac River. The Telegraph road is a dirt road, which runs from Alexandria to Fredericksburg and beyond, crossing the principal streams which flow into the Potomac River: near the head of tide in then. The margin of the lower Potonac keeps, for the most part, about a mile west of this road after Alexandria is left.

Since the upper or Variegated Clay member of the formation is absent in Virginia, the prefix lower may be omitted in giving an account of the formation in this State; Potomac formation being here equivalent to lower Potomac.

Along the Potomac River the principal exposures of the Potomac formation are to be seen on the Virginia shore and in the high points that make down to the river between the creeks. Thus we find extensive exposures at Mount Vernon, White House Point, Freestone Point, Shipping Point, Cockpit Point, and near the mouth of Acquia Creek. In many places, however, along the Potomac River, where we would expect to find the formation in question, erosion prior to the deposition of the Quaternary has cut it away to below water level, so that we find the banks of the river 
composed of Quatemary material. In some places this is wholly composed of the ruins of the Potomac beds, deposited with but little sorting and modification In these places it is sometimes difficult to distinguish the Quateruary from the Potomac. This is the case in High Point, near the mouth of Oecoquan River, where for a long distance the banks of the Potomae River are formed of Quaternary. Professor Rogers, in lis amnual reports, makes this material Potomac.

The exposures of Potomac beds on the Maryland shore are much fewer than on the Virginia side. This shore, lying farther east in the direetion of the declination of the beds, contains them at lower level. The formation may be seen barely exposed at Fort Washington, while farther down the river, at Indian Iead, diagonally above High Point and on the opposite side of the river, a thickness of fully eighty feet is shown.

Along the Potomac River on both sides, as everywhere else, the formation has lost greatly by erosion, and the amount thus lost is very unequal in different plaees. It is impossible to say when this erosion took place, but it is clear that inuch of it occurred prior to the deposition of the Focene. The result has been to leave the formation with an exceedingly irregular surface, and to remove it entirely from considerable areas.

Perhaps the greatest thickness of Potomac exposed at a single locality is to be found on Acquia Creek, about two miles above the point where the Atlantie Coast Line Railroad crosses it. Here a high hill shows the formation rising to the height of one hundred and forty feet above the water. The character of the material is well exposed by quarries It is mostly a coarse gritty sand of light eolor, which is generally eonsolidated to a pretty firm sandstone. In some places we find a good many pebbles, and sometimes a curions mixture of these and clay balls with coarse sand. Little intercalated clay is found here. From Acquia Creek to near Quantieo the Potomac, althongh occurring a little back from the river, is mostly wanting in its banks, Quaternary taking its place. At Quantico and Shipping Point only abont twenty feet is to be seen. Cockpit Point, about two miles north of this last, shows fully sixty feet of very varying material.

At Freestone Point there is a long deep railroad cut, which shows that here the Potonac is over one hundred feet thick, composed of heteroge- 
nous matter. Indian Head, a few miles above Indian Point, shows much the greatest exposure of the Potomac seen on the Maryland side. The rock here has the same irregular structure and mixture of materials as is to bo seen in the cut at Freestone, but the proportion of light colored sand is much smaller. It is covered here by Eocene, and the Variegated Chay is wanting. Indeed, as stated before, this group lias not been seen anywhere south of Fort Washington. Gunsen's Creek is the estuary of the united creeks Pohick and Accotink. On its south and north shores near its mouth are extensive exposures of the Potomac.

On the south side, near Gunsen's Landing, fully seventy-five feet of sand and clay appear, having the same general character as in Indian Head. We see here a graduation of the normal sand of the Potomac into a greenish sandy clay, which is sometimes mottled with red. The same thing in a more striking form is seen at Cockpit Point. Some fragments of lignite, but no impressions of plants, were seen at Indian Head and near Gunsen's Landing.

On the north shore of Gunsen's Creek, White House Point forms a high bluff, called White House Bluff, immediately on the river. Here we may see fully eighty feet of Potomac sand and clay, capped loy some ten feet of Quaternary. This material is sufficiently described in the notice of the occurrence of the plants at this place. It is strikingly different from the Potomac shown on the south side of the creek only a short distance away. We find here a good illustration of the unequal erosion to which the formation has been subjected.

At the upper and lower ends of the exposure of the Potomac, points not a half a mile apart, the Quaternary forms the river bank to below water level. It may be seen rising towards the central portion of the bluff until fully eighty feet of Potomac is exposed beneath it. As no Variegated Clay or Eocene can be detected in this bluff, it would appear that it was not subnerged until Quaternary times, or else these formations lave been removed by erosion.

Two miles above White House the Potomac again appears in the high shore on which the Mount Vernon mansion is situated. It shows here six to eight feet of the light-colored grit which forms the lower portion of White 
House Bluff. Over this lies about twenty feet of laminated sandy gray shale, which appear's to correspond to the similarly placed material at Federal Hill, Baltimore, which has been mentioned as containing plantfossils.

Between White House and Mount Vernon the Quaternary ocetpies the river bank for most of the way. Fort Washington, on the Maryland shore, is a little north of east from Jount Vermon and about four miles distant. This place is interesting as showing in the same vertical exposure all the formations associated with the Potomac. For a very limited space the Lower Potomac sand with its included clays may be seen, showing only a fer feet in thickness. Resting upon this, in the order ascending, we have the Variegated Clay, the Eocene, and the Quaternary. From this point to Washington, about fourteen miles, the Potomac is mostly cut away, and the Quaternary is along the stream the principal visible rock.

It will be seen from this account that the most easterly exposures of the formation in question are confined to the immediate vicinity of the Potomac River. It is not to be supposed that the easteru limit of these beds is to be found anywhere near this river. The character of the material shown in the most eastern localities where the formation is exposed would lead us to suppose that at these places we are still far from the true eastern margin of the formation. Strangely enough, we find in some of the most eastern exposures the maximum thickness of the formation, the greatest amount of coarse material, and the most irregular structure. Indeed, if we were to judge from the lithologic and structural features alone, we would be inclined to think that the material came from the east and not from the west.

In this area, as in all others, no strikes and dips can be made ont for the Potomac beds. It is clear that the formation as a whole declines to the southeast. As from Washington to the mouth of Acquia Creek the general course of the Potomac River is southwest, the declination of the formation is nearly at right angles to its direction, and on the Maryland side it would be soon carried beneath the plane of erosion. Near the month of Acquia Creek the Potomac River bends due east and enters more and more deeply the Tertiary terrane. Hence the last exposures of the Potomac formation on it occur rear the mouth of that creek. 
It is not necessary to give descriptions of the Potomac formation as exposed in the central and western portions of the area The account given of the strata at the several plant localities will give an idea of its variable character. It nay be stated generally that along the western margin there is a larger proportion of argillaceous matter than in the eastern outcrops. The clayey matter shows also a greater tendency to assume various colors, due to oxide of iron, and much of it is mottled. These features are seen more especially in the upper portions of the formation.

At Fredericksburg the western margin is found abont two miles west of the town. It bends around so as to strike the Rappahammock near the month of the Massaponax River. Here the Eocene lies above it, and this is the southern termination of exposures in the Fredericksburg area.

From the mouth of the Massaponax to the vicinity of Hanover Junction no Potomac has been seen. Hanover Junction is the point of crossing of the Atlantic Coast Line, and the Chesapeake and Ohio Railroads. It is situated in the triangle formed by the North Anna and the South Anna Rivers, near their junction. The material exposed in this interval is mainly a thick mass of sands and sandy clays, very variable in composition and color. The name Appomattox is proposed for it, from its great derelopment in typical form in the vicinity of the Appomattox River. It is younger than the Miocene, for it rests on the eroded surface of this, but being without fossils, its exact age can not be fixed. It is probable that no exposures of the Potomac can be found between the points mentioned above, because the erosive power of the streams in the belt where outcrops may be looked for is not sufficient to remove the thick covering of superjacent material. The only streams of any size are the upper waters of the Mattapony. None of these cnt through the Eocene.

In the vicinity of Hanover Junction the Potomac shows in several places a few feet of strata. It has evidently lost much by erosion. In the cuts on the Atlantic Coast Line Railroad, between the Junction and North Anna River, a thin remnant nay be seen of the usual character, resting on the eroded surface of the older Mesozoic (Rhretic), and capped by Quaternary and Appomattox. On the North Anna River; a short distance above its junction with the South Anna, the Potomac sand may be seen 
showing four or five feet under the Eocene. Here, as is commonly the case in Virginia where the Eocene marine strata rest inmediately on the Potomac sand, a layer of large cobbles is found in the top of the latter. The area of Potomac here shown may be called the Hanover area.

Between the South Anna River and Richmond is another gap in the exposures, none being found until Richmond is reached.

Near Ashland, however, on the surface, there is a large quantity of cobblestone, which seems to be the debris from eroded Potomac. A recent well-boring in Ashland disclosed under the Appomattox, and over the older Mesozoic, fifty-six feet of material that may belong to the Potomac. It is highly probable that the formation underlies this interval, but too deeply buried to be reached by the slight excavating power of the streams.

At Richmond, owing to the deep erosion of James River, the Potomac is shown again. It is, however, barely exposed away from the immediate bank of the river, being covered by the Tertiary, both Eocene and Miocene lying above it. Immediately on the river all the Tertiary has been cut away as far down as Deep Bottom, where it makes its first appearance in the river bank. At Richmond, and down the James to Deep Bottom, Qnaternary alone is found in the river banks above the Potomac. The same is true along the Appomattox to near Petersburg, where the Appomattox formation, with the Tertiary underlying it, comes above the Potomac. Away from these rivers, in the triangular area between them and between Richmond and Petersburg, where we may expect to find the Potomac, the surface is mostly composed of the Appomattox formation, showing in a few places small patches of Tertiary exposed beneath it. This area of Potomac may be called the Petersburg area. Its west margin may be taken as approximately determined by the Atlantic Coast Line Railroad, which runs between Richmond and Petersburg. Along this margin the Potomac is mostly hidden under its own ruins and the thick covering of Appomattox material. It is to be seen exposed only along the James and Apjomattox Rivers, and from what may be seen on these streams the formation is continnous at least as far south as Petersburg, twenty miles from Richmond. 
Along the James from Richmond to Deep Bottom, twenty-one miles by river below that city, the Potomac formation shows itself in the base of most of the bluffs and high banks, rising to varions heights and capped by Quaternary. Considering the variability of the material, it is here surprisingly like that found in the Frederickshurg and Baltimore areas. On the James its greatest thickness is attained in Drury's Bluff, eight miles below Richmond. Here abont sixty feet of it can be seen. In Chafin's Bluff, a little below Drury's Bluff, for a long distance it shows a thickness of ten to twenty feet. In the vicinity of Dutch Gap it is exposed for several miles, reaching its maximum thickness in Trent's Reach, where forty feet may be seen.

On the Appomattox it may be found at many places up to Petersburg. Its greatest thickness on this stream is found at Point of Rocks. This is four miles above City Point, where the James and the Appomattox unite. Mere fully eighty feet may be seen. It is noteworthy for the coarseness of the sand which makes up most of the formation, and for the large size and abundance of the pebbles and cobble-stones found in it. Some of the latter, composed of Potsdam quartzite, attain the dimensions of ten or twelve inches. This point, although one of the most eastern exposures, shows the formation in the Petersburg area at its maximum of thickness and of coarseness, which, as on the Potomac River, indicates that the eastern margin of the formation is still far distant. The eastern limit of exposures in this area may be fixed by a line drawn from a point on the Appomattox three miles above City Point, in a direction a little east of nortli, to Deep Bottom, on the James. Although exposures do not occur east of this line, there is good reason to think that the formation extends far eastward under the Tertiary terrane.

In 1869 an artesian well was sunk at Fortress Monroe to the depth of 907 feet. This well passed through the Miocene and Eocene strata, and at the depth of 835 feet entered a material which differed totally from the Tertiary, but possessed the peculiar features of the Potomac formation. The boring was still in this formation when it was stopped, so that at least seventy-two feet of this may be found here. Professor Rogers had an opportunity to study the material from different clepths in this well and he 
gives a description of it. ${ }^{1}$ It is surprising to find here, so far to the east, the heterogeneous composition, coarse character, and indications of the action of agitated waters so characteristic of the Potomac formation in its exposures far to the west. Professor Roger's speaks of a conglomerate of clay, sand, and pebbles, which reminds us of the features seen in the erosion horizons of the Potomac He mentions coarse sandy clay with brownish or reddish blotches, clay and sand with some coarse pebbles, reddisl mottled clay with quartz pebbles, and other features common in the Potomac, but found in no other formation under the Eocene of the Atlantic slope.

Fortress Monroe, at the mouth of James River, is on an air line in the direction of the declination of the strata, sixty miles distant from the last exposures seen on the James and the Apponattox. The average declination of the surface of the Potomac formation is from these data about fourteen feet to the mile. The strata in this, as in the Fredericksburg area, sink in a sontheast direction. As no regular dip can be determined, we can note only the depression of the surface of the formation taken as a whole.

South of Petersburg no detailed examination has been made in search of Potomac onterops, and hence too much stress should not be laid on the apparent absence of them in given places. South of this town, along the eastern margin of the Azoic rocks, no Potomac has been seen until the Nottoway River, twenty miles distant, is reached. In this interval the Potomac, if present, is buried under a thick mass of the Appomattox formation, and there is no stream capable of cutting down through it. The country or dirt road from Petersburg to Weldon, in North Carolina, runs near the nargin of the crystalline terrane, and hence ontcrops of Potomac, if they exist, would appear near this road. As stated, none are seen for twenty miles. When we reach the Nottoway the formation again appears.

At Bolling's Bridge, where the road above mentioned crosses this stream, a few feet of typical Potomac sand with clay balls may be seen in the base of the bank. This is capped by a thin stratum of Eocene with obscure impressions of marine shells. This exposure was apparently not 
seen by Professor Rogers. About four miles higher up the river there is another onterop of a few feet of Potomac in the base of the river bank. This was seen by Professor Rogers. In both places the material is a coarse sand of brownish-gray color, which contains many pebbles, some of which are three inches in diameter. At the bridge occur balls of dark gray clay of a foot or more in diameter, which, as in the areas farther north, are embedded in the pebbly sand. The two exposures considered alone indicate here an area only four miles long; but the coarse pebbly character of the sand, taken with the fact that only the top is shown, seems to show that this, which may be called the Nottoway area, is much more extensive. The river in cutting down has evidently barely reached the top of the formation.

As the Potomac of the Nottoway area in the most important points possesses exactly the same features as those of the more northern areas, there can be little doubt that, if we could trace each of the areas eastward, we should find them uniting to form one continuous terrane extending from north of Baltimore to the Nottoway. South of the Nottoway unequivocal Potomac has not been seen. In portions of Greenville County some of the Appomattox beds are strikingly like the pebbly sand of the Potomac, and indeed seem to be composed of the debris of Potontac strata but little modified. 'This may explain the ammouncement of the existence of the formation in this part of Virginia made by Professor Rogers in his earliest reports, but not repeated in his later ones.

Until the Roanoke at Weldon is reached the streams do not seem to have cut down through the Tertiary, and hence they do not reach the horizon of the Potomac. The Roanoke, however, at Weldou, in North Carolina, has cut down to the Azoic rock, but it is difficult to find exposures at the level where the Potonac may be looked for. The river in flood deposits a large amount of mud on its banks and in the channels of the creeks emptying into it, and this lides everything. Except immediately on the river a thick covering of the Appomattox formation here, as everywhere south of the Nottoway, conceals even the Eocene and Miocene beds. At Weldon, near the north end of the railroad bridge, a small stream, a mere spring branch, flows at a low level into the Roanoke. Over 
a very small space it has stripped the floor of gneiss of the covering which conceals it. In contact with the gneiss a layer a few inches thick is found, consisting of coarse sand and gravel, showing some of the characteristic features of the Potonac. It looks like a mere remmant of what was a formation of some extent, but which in this place has been almost entirely removed by erosion, and it suggests the idea that the Potomac may be found as far south as this place. The exposure, however, is too slight to be taken as anything more than suggestive of probabilities.

If we take the lower Potomac as ending in the vicinity of the Nottoway, and extending east only as far as Fortress Monroe, it will still rank among the more extensive formations of the Atlantic coast region. Stretching from Baltimore to the Nottoway, its length would be about two humdred miles. This, with an arerage width of sixty miles, would give twelve thousand square miles as the approximate space occupied by the Potoniac.

There is good reason to think that the present westernmost exposures of the Potomac do not determine the original extension of the formation in that direction. It seems at one time to have been present considerably farther west than any of the outcrops now visible. The formation at various horizons contains deposits of pebbles and coblble-stones. 'These are chiefly composed of quartz, but in some portions rounded stones of various kinds of crystalline Azoic rocks occur. In the vicinity of Washington some cobbles and pebbles of Potsdam quartzite may be seen. In the Petersburg area, especially along the James and Appomattox Rivers, the Potsdam material is noteworthy for its abundance and the large size of the stones.

On the weathered surface of the lower Potomac and on that of the formations adjacent to its outerops a large amount of gravel and cobblestones occurs of the same nature as the material found in the Potomac. It would seem that the original home of this surface material was the lower. Potomac, and that the stones were liberated on the erosion of that formation. Except along the streams which cross from the Potomac into the Tertiary terrane, these gravels do not pass far into the region occupied by the Tertiary and later formations. On the rivers they are found forming the basal portion of the Quatemary, and as this often rests 
directly on the Potomac, it is not always easy to distinguish the Potomac gravels from the later ones. In this material the Potsdam cobbles are the most significant, and they are usually easily identified. The Potsdam gravel is not seen north of Washington, and south of that city it is not traced farther than Pohick Church, near White House Point. This distribution indicates that these stones were brought down the Potomac River, which crosses for the last time outcrops of the Potsdam a little west of Harper's Ferry. The Potsdam cobbles may be seen throughout the Petersburg area near the outcrops of the Potomac, and they are found, as near Washington, over a belt of country extending considerably to the west of it and within the Azoic terrane. They may be followed also all along to the west of the Hanover area, and five or six miles to the. north of its termination. Much rounded quartz material is found with these stones. In the Azoic terrane they are often found inclosed in Appomattox clays and sands.

The distribution of this coarse, loose material indicates that the Potomac once extended west of its present exposures orer a belt varying from ten to twenty miles in width.

THE GEOLOGY OF THE POTOMAC BEDS.

So much has been said in the preceding pages concerning the geolugy of the formation, that the remarks under this head may be much abbreviated. It is very difficult in any brief general account to give a clear idea of the character of this formation. The want of regular structure and the continual, often abrupt, changes in mineral character and physical features make it necessary to give a separate description of each locality. sections at the same locality, taken at intervals of a few yards or even feet, vary generally in most of their features. It is impossible to take the dip and strike, and no single bed can be traced over any large area. This arises from the fact that the characteristic mode of arrangement of the materials is in irregular pockets, or more commonly in interlocking lenticular layers. The layers may each continne throughout, containing the same kind of material, dovetailing between layers of a very different kind. A layer, on being traced horizontally or vertically, may pass 
graduaily or abruptly into something quite different. The individual layers may be varionsly constituted, and show in their parts on a minor scale the variable features discerned in the composition and the gronping of the layers taken as a whole. Then on various horizons matter previously deposited seems to have been torn up, transported to varying distances, and deposited in a confused manner. These last-named features mark what, for the sake of distinction, I call erosion horizons. They add much to the irregularity of the formation. When one has before him any

- considerable exposure of the lower Potomac he may well hesitate to attempt an accurate description of it, feeling that this would require an examination of each yard of the material.

The layers of sand are often marked by undulating lines across the direction of their length, forming a marked current bedding. This feature is conspicuons in the cuts on the narrow-gange railroad west of Fredericksburg. We may often find gravel, coarse sand, and clay pellets confusedly mixed together. This is to be seen at the top of the quarry on Acquia Creek on a large scale. While no regular dip could be made out from the tracing of individual strata, the formation as a whole sinks gently to the southeast.

Two principal kinds of material make up the lower Potomac beds; namely, sand and clay. The sand is by far the most abuudant. It is the typical material, while clay occurs in limited local layers, either inclosed in the sand or replacing portions of it, owing to the graduation of the sand into it.

The sand may be loose, or cemented into a pretty firm sandstone, which has been used as a building stone. This is its nature to a considerable extent on Acquia Creek and around Stafford Court Honse. It is more generally friable and incoherent, especially in outcrops. All the material near the Potomac River and north of it has this character, but the larger portion of the sand of all the areas does not form a coherent rock. The indurated sand or sandstone generally forms irregular masses, inclosed in the more friable material, or some irregnlar portion of a friable stratum may show this induration. The crumbling sandstone or sand is often quite fine in texture, and has more or less of a light-colored to white 
clay, which serves as a cementing matter, in which the grains of sand are embedded. There seems to be some connection between the presence of this clay and the incoherence of the material, but we find loose sand with little or none of this clay. This is the material which Professor Rogers has called "feldspathic sand." I have seen no feldspar, fresh or decayed, in this material, and the clay, althongh often quite white and pure, is rarely the direct product of the decay of feldspar. This argillaceous sand generally has a white or light gray color.

In some places the amount of the clay thus intimately mixed with the sand makes up a large proportion of the material, forming from one-fourth to one-third or more of the bulk. This sort of sand is common around Fredericksburg, and may also be found in the lower part of the bluff at White House, as well as in many other places. Strange to say, we may find this dispersed clay mixed with coarse sand and even with pebbles. This is the case at White House, for example, and at Point of Rocks near City Point. The base of the bluff at White House Point to the height of fifteen or twenty feet is composed of a very coarse white indurated sand, containing a large amount of diffused white clay, and in places many quartz pebbles. These are half an inch in diameter and under, and they are irregularly seattered through the mass of the rock. At Point of Rocks, on the Appomattox, seventy feet and more of this material is exposed. It contains pockets and irregular courses of large cobbles, most of them of Potsdam quartzite, some of them attaining the diameter of ten to twelve inches. Here we find, in one place at least, several masses of the pale reddish Potomac clay embedded in this coarse mixtmre. One of these blocks was two and one-half feet long and subangular-prismatic in shape. There is a large amount of this irregularly mixed coarse material and white clay in Trent's Reach. In one layer here the cobbles of Potsdam and other material abound, and many of them are eight to ten inches in diameter.

These characters in the sand indicate that it was laid down in agitated and probably shallow waters, in which there was little or no sorting of the materials.

Mica is comparatively rare in all parts of the formation, and is hardly ever seen in any of the beds of the Fredericksburg area. It is more comMON $x \nabla-4$ 
mon in some of the gray clays of the Petersburg area, but it is not there abundant. This is not what we would expect if we attribute the origin of the material to the crystalline rocks lying to the west of the Potomac. In most of these mica forms a large proportion of the rock, as in the granite, gneiss, mica-schist, hormblende-schist, etc. The sandy matter of the Potomac is by most persons called a sandstone, but it is more properly a sand in most cases. The gradation in the fineness of the material and the change in the proportion of clay and sand, as has already been stated, are not what we shonld expect if the sediment came from the west, the materials being coarser and having more sand in the exposures farthest east.

The color of the sand, especially of the lower beds, when they contain much diffused clay, is light gray or white; but this material, owing apparently to the oxidation of diffused pyrite, is sometimes colored yellowish, reddish-brown, etc., the color's being in irregular patches and seams. This coloration often follows, and makes much more distinct the planes of current-bedding:

Towards the upper part of the formation there is a considerable admixture of colored and impure clays with the sand, which then tends to assume brownish-gray, yellowish-gray, and other kindred colors. The colors are in such cases often arranged so as to produce a motiling on a small scale of gray with other colors, or a blotching on a large scale. Towards the western margin of the Fredericksburg area, and especially between Acquia Creek and Occoquan, there is a large proportion of sandy clays of various colors-gray, reddish, yellowish, etc. The colors here are often arranged irregularly, producing mottling and blotching. These colored impure clays are in considerable force along the route of the Atlantic Coast Line Railroad between Alexandria and Telegraph Station. Possibly some of the Variegated Clay members may be found with these clays.

Pebbles and cobbles, as will appear from what has already been said, are not uncommon in the. lower Potomac. They occur at different horizons within the beds and are common towards the top. Very generally in Virginia, where the Eocene rests on the Potomac sand, the upper portion of the latter is a layer of cobbles packed in sand. This is the case at Rich- 
mond, where a well dug through the Eocene to the top of the Potomac disclosed a layer of large cobbles, many of them composed of Potsdam quartzite, and some ten inches in diameter. The same thing may be seen at Ileep Bottom and near Hanover Junction. Indeed, so common is this feature, that Professor Rogers, in his earliest publications on the geology of Virginia, called attention to the trenched and eroded character of the lower Potomac surface upon which the Eocene rested, and to the accumulation of large stones in places on this surface.

These stones are to be found also generally where the Quaternary rests on the Potomac, and then they attain their maximum in abundance and size, deserving sometimes to be called bowlders, since some of the Potsdam stones are two feet in diameter, while the Azoic masses are occasionally much larger.

The stones within the Potomac beds are generally small, being two to three inches and under in diameter, but sometimes they attain the diameter of five to six inches and more. They occur sometimes aggregated into irregnlar beds and pockets, then attaining their largest size. The smaller pebbles are often very abundant, scattered through the general mass of the rock, and showing no particular relation to the inclosing material. This may be sand, coarse or fine, or it nay be clay. This shows that there was little sorting action in the waters.

As stated before, Potsdam material is not seen in the northern areas except in the vicinity of Washington, for in the areas north of Fredericksburg the inclosed stoues are usually quartz or Azoic. In the Petersburg area, as before stated, these are accompanied by an abundance of Potsdam cobbles. No Potsdam stones were seen in the Nottoway area. The Nottoway River does not cross the Blue Ridge and touch the Potsdam terrane, as do the James and the Potomac. The Potsdam quartzite is found in place on the western flanks of the Blue Ridge, but not east of it.

We find these stones in the top of the lower Potomac where the Variegated Clays rest on the sand, but sufficient exposures of this contact have not been seen to enable one to say what is generally the case at such a junction. It is not an uncommon thing to find plant-impressions in the 
disturbed clay which is frequently associated with these deposits of stones. The rich plant-layer at Fredericksburg rested on a mass of cobbles. The plants found on the Telegraph road near Potomac Run, and those on the railroad near Brooke, as well as the richest deposit of clay at Dutch Gap, are all associated with pebbles.

It is worthy of mention that Professor Rogers, noticing the abundance and large size of the Potsdam cobbles at Point of Rocks, and knowing that they must have been brought from the Blue Ridge, speaks of them as marking a diluvial era of ancient times. At that period many geologists, and Professor Rogers among them, were disposed to explain the phenomena of the drift of the glacial period by assuming the existence of a diluvial rush of water's.

The clays found in the lower Potomac are, as has already been stated, merely subordinate masses occurring occasionally in the sand. They are important simply from the fact that they contain all the plantimpressions and nearly all of the undisturbed lignite. Their character and mode of occurrence have already been given. The original isolated pure clay layers are usually thin, being one or two feet thick, but they may suddenly swell up to considerable dimensions, as at the lower entrance of Trent's Reacls. They may split up and be lost in the sand, and they generally disappear by thinning out and dovetailing between sand layers.

The sandy mottled clays formed by the graduation horizontally of a sand into clay are more considerable in amount. This material may be greenish or grayish in color, and when traced horizontally it may assume reddish colors in large masses; or, again, the colors may be intermixed so as to resemble mottled castile soap. In the vicinity of Fredericksburg this kind of material replaces large portions of the normal sands, and it sometimes extends over considerable areas, but without any regularity of occurrence. As illustrating its occurrence, we may take the condition of things seen at Cockpit Point. Here the lowest exposed material is a greenish, gray argillaceous sand. If we follow it, we see it in places becoming more nearly a pure clay, but it then soon becomes again sandy, and is now marked in huge blotches with a brilliant red color. In places 
the entire mass is red. Still farther on it changes to a light gray sand, which is totally unlike the material in other places. This sort of change is common in the Fredericksburg area, but was not seen in the Petersburg district.

A beantifully white, pure, plastic clay is sometimes found in the form of balls, embedded in the sand. It was seen, for example, in the lower part of White House Bluff. It has never been seen in the original or undisturbed beds.

The layers of isolated plastic clay in their original position sometimes show peculiar features in their arrangement, and illustrate the in regularity of the lower Potomac formation. Sometimes, as at Dutch Gap, we may see in the same vertical exposure several of these layer's. They may be formd in the sand inclined at different angles to one another, and in one case several were seen diverging from a common point like the outspread fingers of a hand. Of course snch layers must be deposited upon a shifting surface. These layers are sometimes cut off at one end by coarse sand and gravel. When partially ent away they are frequently associated with clay balls which have been torn from them.

The isolated clay balls and masses often show peculiar features. They occasionally are seen where no trace is left of the bed which furnished them. Some clay masses, fonr or five feet in dianeter, embedded in coarse sand, may be seen at the plant locality on the railroad near Aequia Creek, the dark gray clay contrasting strongly with the light colored sand. In Trent's Reach, where considerable cliff's of nearly white sand occur, we may see a number of large balls of gray elay embedded in the sand, and displayed on the same horizon for a considerable distance in the face of the bluff.

The embedding of clay balls in coarse sand is one of the most constant and characteristic features of the lower Potomac. Clay balls thus inclosed may be seen at all exposures of the formation from Baltimore to the Nottorvay River, and the clay is strikingly similar in all cases. Clay balls and irregular deposits of disturbed elay are common in the top of the lower Potomac sand, associated with the pebbles and cobbles of that horizon. This clay seems to point to the former existence of an 
argillaceons member in the top of the lower Potomac, like that seen at Federal Hill, Baltimore, resting on the sand and apparently extending over a wide area. As this member, from its position, was the portion of the lower Potomac most exposed to erosion, and as it was soft and easily destroyed, we might expect to find it preserved less commonly than the underlying sand. If the lower Potomac has lost much from erosion, this member, if it existed, would suffer most. There is good renson to think that in the long period of time that has elapsed since the deposition of the lower Potomac it has lost much of its thickness. Allusion has already been made to the trenched and eroded condition of its surface where, as in Virginia, it is covered by the Eocene. In Virginia the outcrops of the Potomac occur at very different altitudes, so that it may in some places stand much higher than the Eocene and younger formations, even when found in the immediate vicinity. An example of this may be seen at Point of Rocks, on the Appomattox. Here the Eocene occurs only a mile away. It is exposed in a ravine much below the level of the surface of the Potomac at that point. The two pre-Eocene ravines near Brooke have been mentioned. They gire another example of a worn surface. In Maryland, between Relay and Baltimore, where the Variegated Clay rests on the lower Potomac, much irregularity is shown in the height of the top of the latter formation. Of course, where the Quaternary rests on the lower Potomac the greatest variation is shown in the height of its surface. A striking case is at White House Bluff, where eighty feet of the formation seen in the point shows on each side Quaternary to the level of the water. Many other localities on the Potomac River and elsewhere might be mentioned where the lower Potomac rises high above the surrounding Quaternary.

While from this extensive erosion of the lower Potomac we would expect to find the former uppermost portions of it generally missing, we find in some places remnants which appear to represent it. These have been already mentioned, being the clay bed near the railroad in the vicinity of Brooke, the upper argillaceous portion of the lower Potomac at Mount. Vernon, and the plant-bearing argillaceons material occurring in the top of the formation at Federal Hill. This latter may, I think, be 
considered typical of this portion of the lower Potomac, and for this reason the section at Baltimore will be given further on. We may, then, with some probability conclude that the original uppermost portion of the lower Potomac in most of the areas was more argillaceous than the typical sand now representing most commonly the formation.

I am thus particular in speaking of this possible uppermost member for several reasons. It seems that, if we can assume its existence, it may explain the difference seen in the facies of the flora found at certain points It las already been stated that the most noteworthy plants found in the embedded bowlders at Deep Bottom, also those in the disturbed clay at the $72 \mathrm{~d}$ mile-post near Brooke, and in the bank near the railroad in the vicinity of the last locality, are dicotyledons; and that these in many cases have a younger aspect than the plants found elsewhere, as at Fredericksburg and at Dutch Gap.

At the same time, in the places first named, the dicotyledons ontnumber the ferns, cycads, and conifers, which is not the case at most of the Potomac plant localities. The material at Deep Bottom containing these plants, as well as that at the $72 \mathrm{~d}$ mile-post, looks as if it were the ruins of this argillaceous upper member. The clay layer in the bank near the mile-post, but farther down the railroad, looks like an uneroded remnant of such a member, and this is true of the plant-layer at Baltimore. This latter contains some dicotyledons similar to some of those found near Brooke. It might, then, be supposed that the younger aspect of the dicotyledonous plants at these places is due to the fact that they belong to a flora distinct from that typical of the lower Potomac, and that this occurs in an independent younger group of beds.

But there are many difficulties in the way of this supposition. The connecting links are too numerous. Too many plants found in the local floras having an older facies occur with these. The stratum in White House Bluff, which contains numerous dicotyledons like those occurring near Brooke, is not found so placed that we can admit tlat it belongs to a group of beds distinct from and younger than the normal lower Potomac sand. It has twenty to thirty feet of this coarse sandy matter above it, and it is clearly a member of the typical lower Potomac. In all the 
other cases it is impossible to separate the material carrying these dicotyledonous plants from that containing the seemingly older ones. There is no break between the beds, and the general greological features are the same in all. An attempt will be made in another connection to give the significance of these apparently younger elements. If any more argillaceous upper member was ever generally present in the lower Potomac it is synchronous with it, and the two form one unbroken series

A good type of the upper member, whose probable wirle extent lias been noticerl above, may be found in the southeast slope of Federal Hill, Baltimore. The spot is located on Corington street, near Ellicott's iron furnace. The exposures seen at the time of my visit (Augnst, 1886) were necessarily temporary, as they were made in the grading of a street and in slight excavations formed for the purpose of obtaining sand from the sandy member of the lower Potomac. Professor Uhler writes that the aspect of the place has since been totally elanged. The hill has been dug away and the pits have been filled up.

I was informed by intelligent persons who had much experience in excavating the Potomac beds at Baltimore, and whose business compeller them to make a close study of the different kinds of rocks found there, that the features seen in the section given below might be seen at a number of other points in and near the city. In the descending order we have:

(4) Variegated Clay to the top of the hill.............. Upper Potomac.

(3) Interbedded argillaceous sand and plastic lead-gras clay 6

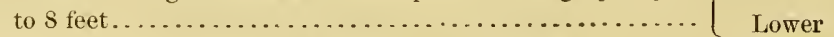

(2) Layer of ferruginou sand and ocher 4 to 6 inches .........

(1) Current-bedled sand, maximum thickness shown 8 feet.... J

The Variegated Clay (No. 4) has already been described in its general character. It descends from the top of the hill to near its base. It is mostly a tenacious gray clay, quite plastic towards the base, and when obtained from that horizon it is used for making tiles, etc. It has no bedding and no cleavage, is much contorted and affected with slickensides, contrasting strongly in these points with the clay of No. 3. While gray is the normal color, it is in places variegated in large blotches with red 
and other colors, due to iron oxide. Irregular masses of it are sometimes sandy. It has often small bits of plants and fragments of lignite, but no lignitic entire trunks were seen. The bottom of this clay is easily distinguished from the top of No. 3 by its peculiar structure. At the same time the clay of No. 3 is rather more sandy.

No. 3 consists of alternations of gray clay and argillaceous sand, showing a distinctly berlded arrangement, but nunch inegularity in the thickness and other features of the constitnent beds. The lower portion has a predominance of sandy matter, but the clay increases as we ascend, and in the top it exceeds the sand in amount. The sandy layers of No. 3 are gray in color and more argillaceons than No. 1. They have many blotehes and streaks of yellowish-brown and reddish colors mingled with the dingy gray, which is the principal color, and the layers swell up and thin away in the most irregular manner. At the base of No. 3 and resting. on No. 2 we find in several places two or three feet of a tender ash-gray shale, with patches and irregnlar lenticular thin partings of fine sandy matter. This is the portion that contains the recognizable plant-impressions. This portion, and indeed all the clay of No. 3, is easily distinguished from the Variegated Clay by most of the workers in the Baltimore clays, and the plant-bearing part is called "shelly or slaty clay."

No. 2 seems to be simply the upper part of No. 1, which has been impregnated with iron. It is not universally present, being generally wanting when formations younger than the Variegated Clay rest on No. 1.

No. 1, at Federal Hill, has clay balls with some pebbles, and it is stained reddish in some irregularly shaped portions by iron oxide. It is here very friable, appearing as an incoherent sand. It lias very little diffused white clay or so-called kaolin. It is sought for on account of the comparatively pure sand that it yields.

The Variegated Clay seems to be a northern formation. As stated before, the point farthest south at which it has been seen with its characteristic features is Fort Washington. Here it is much thinner than between Washington and Baltimore. If it appears in Virginia, it occurs without the features which are so conspicuous farther north. It has not been recognized in that State. 
This group of clays appears to be greatly developed northeast of Baltimore, and from the statement of Professor Rogers, previously quoted, it extends into Delaware.

Mr. McGee has found in this clay formation at the head of Chesapeake Bay some poorly preserved plant-impressions, which are nearly all dicotyledons. These impressions are too few in number and too imperfect to throw any clear light on the question of the age of the formation. In the absence of any evidence that shows the Variegated Clay group to be distinet from and decidedly younger than the lower Potomac formation, its close association with the latter and the difficulty of separating the two make it necessary to group them together as forming one series of beds.

As the Variegated Clay group furnishes none of the plants described in this memoir, no further description of it is called for.

\section{GEOLOGICAL POSITION AND ORIGIN OF THE LOWER POTOMAC BEDS.}

In what will be said under this head the evidence of the fossil plants will not be used, but the horizon of the lower Potomac will be fixed so far as it can be done on evidence independent of them.

Throughout most of the area ocenpied by the lower Potomac the base when seen has been found to be composed of the crystalline rocks, whose age must be placed so far back that they give us no aid in determining the lower limit of the horizon of the Potomac. But in the vicinity of Hanover Junction this formation may be seen resting on the eroded surface of the older Mesozoic, with evidence of a decided break between them. This older Mesozoic in this part of Virginia, as I have shown in Monograph U. S. Geological Survey, No. VI, ${ }^{1}$ is Rhætic in age; at least the plant-bearing portion of it. If the strata of this formation overlying the plant-bearing part differ from the rest in age, they are of course younger.

The striking differences generally found in the lithologic and structural features of the two formations indicate that the difference in their ages is considerable, the Potomac being decidedly the younger: Time 
enough must have elapsed to permit an almost total change in the geologic conditions under which the two formations were laid down. The inland bodies of water, in which the older Mesozoic was for the most part deposited, lad been drained off, so that deposition in Potomac times took place only outside of the crystalline terrane, within which nearly all of the older Mesozoic is to be found. The older Mesozoic areas and the crystalline rocks adjoining them are cut by numerons trap dikes. Not a trace of these traps can be found in the Potomac beck. The period of igneous activity which has left so many traces, probably at the end of the Older Mesozoic time, must have then been over when the Potomac sediments were accumulating. These facts do not enable us to fix the lower linit of the Potomac horizon very definitely, but at least we can say that the formation is considerably younger than the Rhrtic.

The upper limit in age can be fixed more nearly. The marine Cretaceous of New Jersey and Maryland is wanting in Virginia, as is the Variegated Clay formation. In this State the oldest formation which rests upon the Potomac, and whose age is fixed, is the Eocene. Well-exposed contacts of the Eocene with the older formation may be seen in a number of places. The greensand marl bed is the oldest portion of the Eocene that contains any considerable number of fossils. This bed contains, among others, such shells as Ostrea, Turritella, Pecten, Cytherea, Cucullea. This bed in all of the area south of Fredericksburg, and at this place also, rests directly upon the typical sand of the lower Potomac. This latter, in all such cases, gives evidence of having lost much from erosion, and its uppermost portion nearly always contains large cobbles. Towards the northerm part of the State we find under the greensand bed, it is true, a variable thickness, amounting in some cases to from seventy to ninety feet, of nonfossiliferous sandy matter. This, however, from the glauconite that it contains and other features, belongs to the Eocene formation. Under it the lower Potomae still shows marks of great erosion.

The Eocene is a true marine fornation, laid down under very different conditions from those attending the deposition of the lower Potomac. The eastern margin of the continent must have become depressed enough to permit the sea to occupy portions that in lower Potomac times showed 
only shallow agitated waters, and an abundant marine fauna flourished where hitherto no trace of marine organisms has been found.

Judging, then, from the condition of things in Virginia, we must conclude that the Potomac is considerably older than the oldest Tertiary. In the District of Columbia and in Maryland we have the Variegated Clays superposed on the lower Potomac. At Relay Station, where the clays rest on the lower Potomac sands, these last show the same marks of erosion and the same pebble-bed as in Virginia, where the marine Eocene occupies a similar place. At Federal Hill, where we find the Variegated Clays resting on an argillaceous member interposed between them and the sands, the indications of a lost interval are not so decided, but still they may be seen. We may then conclude with some degree of assurance that these Variegated Clays are younger than the lower Potomac, although not yet clearly separable as a distinct formation. So far as the evidence goes, it indicates that the Variegated Clays probably are of the same age as the plant-bearing Sonth Amboy clays of New Jersey. These have been held to be nearly of the age of the Cenomanian of Europe. If this is correct, then from the stratigraphy and general geologic features the lower Potomac beds must be regarded as considerably younger than the Rhrtic and somewhat older than the Cenomanian. There is, at least in the evidence above given, nothing which opposes the assmmption that the age of these beds is Neocomian.

It is proper, in this connection to say something as to the origin of the lower Potomac beds, or the conditions under which they were laid down; because, as it happens, they appear to be similar to those attending the accumulation of a formation which in Europe has a number of plants closely allied to those of the lower Potomac. In order that the reader may appreciate the peculiarly irregular character of this formation, it may be well to repeat in a summary the leading fertures that may be seen in it. If the exposure of the beds at any locality is considerable, all of these features might be seen there.

The lower Potomac is usually a mass of sandy matter of varying coärseness, generally incoherent, and liaving some light-colored interstitial clay. It has usually a light gray to white color, but this is very often 
marked irregularly with colors due to oxide of iron. No regular bedding or structure is found, but we have a series of interlocking leuticular layers, showing extreme variableness in composition, texture, and structure. The arrangement shows mostly current-bedding, and not uncommonly beachstructure. Disperser pebbles and clay balls, also nests and pockets of pebbles and cobbles and disturbed clay, are frequent. Lenticular sheets, occasionally partially cut away and sometimes containing plant-remains, are often met with. These are intercalated in the sand in the most irregular manner, and oceur at no fixed liorizon, lying sometimes inclined to one another, as if deposited on a shifting surface.

These features mark the lower Potomac at all its exposures from the Nottoway River to Baltimore, and, so far as they can be shown in borings, they appear to be present as far east as Fortress Monroe. Such characters could be produced only in deposits accumulating in unquiet and comparatively shallow shore waters, or in the estuary of a great river.

The entire absence of all marine life shows that the waters must have been fresh, or at most brackish.

That the deposits accumulated near land, and probably in part at least in estuary waters, is strongly indicated by the nature and distribution of the plant-remains. The great quantity of dispersed lignite in the form of isolated logs and limbs seems to show that the amount of drift timber must have been large. These trees were probably floated down in the larger' streams.

The areas showing thickly placed logs of lignite, appearing to be formed out of trees which fell where they grew, seem to point to portions of the shore or to islands in the estuary which were suddenly submerged. The delicate ferns and other plants, often preserved in great perfection, could not have been drifted far or floated long in the agitated waters without being destroyed. 'They probably grew on islands.

It seems probable that the James and Potomac River's had their representatives in lower Potomac times in two streams, which in their course may not have differed essentially from the present rivers.

If we ale permitted to assume that at the time of the accumulation of the lower Potomac sediment two such rivers existed, and, further, that 
they were much larger than their representatives and united to form a great estnary whose waters extended at least from Petersburg to Baltimore, we could explain the origin of many of the features of the formation now in question.

The character and distribution of these beds seem to indicate that the margin of the continent covered by these estuary waters was subjected to oscillations of level, so that the shore-line retreated and advanced. If we assume that this margin was first rapidly depressed and then elevated without pause, unquiet conditions would prevail throughout the epoch, and marine life could not be established in the area affected.

The tendency of the action of the waves and river currents would be to work over deposits recently made and to produce the peculiar effects due to alternating erosion and sedimentation which are so conspicuous in the lower Potomac beds. The tendency would also be to work the leposited matter seawards and to give in that quarter thicker accumulations than those found on the western margin, for this would be submerged only temporarily.

If these assumptions be correct, there would be a noteworthy similarity in the conditions attending the formation of the lower Potomac strata and those of the Wealden of Emrope, and it is interesting to note that in the plant remains of the lower Potomac there is an important element which finds its nearest relations in that formation. 


\section{DESCRIPTION OF THE SPECIES.}

\section{CRYPTOGAMS.}

\section{EQUISETE $A$.}

\section{EQUISETUM L.}

None of the Equisetece except Equisetum have been found in the flora of the lower Potomac. Neither of the species of Schizoneura, which occur in the flora of the older Mesozoic, or Rhætic of the Richmond Coal Field, appears. As compared with the species of Equisetum of the older Mesozoic, those of the Potomac formation show a marked change. In the older Mesozoic the variety of forms, it is true, is small, but the number of individuals of Equisetum Rogersi is very great, and the specimens are often to be found filling certain strata in such numbers as to show that the plants must have grown thickly over large areas, and must have formed the greater part of the vegetation of the marsh. The great size attained by all of these individuals and the rarity of their branching show that they belong to the Triassic and older Jurassic type.

The species of the Potomac strata show decidedly more modern aspects, and clearly belong in type to the younger Jurassic and Wealden, showing marked affinity with the species of these periods, especially the latter. Specimens are rare, and they occur singly, scattered very sparingly in certain strata. The plants were small and mostly much branched. In these points they resemble living forms.

\section{Equisetum Virginicum, sp. nov.}

Plate I, Figs. 1-6, 8; Plate II, Figs. 1-3, 6, 7, 9.

Stems and branches branch copiously; the diameter ranges from $3^{\mathrm{mm}}$ to $8^{\mathrm{mm}}$, the average being $4^{\mathrm{mm}}$; length of internodes, $8^{\mathrm{mm}}$ to $22^{\mathrm{mm}}$; sheaths 
closely appressed, $5^{\mathrm{mm}}$ to $10^{\mathrm{mm}}$ long; teeth visible on the upper surface of stems and branches, 5 to 6 . They are usually linear, lanceolate, acute, rarely somewhat obtuse, and approximate.

Locality: Fishing hut above Dutch Gap Canal.

This pretty little Equisetum has not been found anywhere except at the single lucality given above. At this place it is rare. This species in general appearance much more nearly approaches living forms than $E$. Rogersi, which is its last predecessor in this region. It is very close to E. Burcharlti Schimper, from the Wealden of Germany, and perhaps should be identified with that species. It does not, however, show the swollen sheaths and the wide divergence of the teeth seen in the Wealden species. Still, something of both of these features may sometimes be seen.

The most noterortly features of the Potomac species are the copious branching and the slight diminution in the size of the sucessively formed branches. In many cases there is little or no difference in the size of the stem and the branch which it sends off. The mode of branching seems to be quite often dichotomous, but this may possibly be the effect of compression. The specimens are often partially or wholly decorticated so as to show no teeth, and in most of the specimens the teeth appear, from maceration, to be narrower and farther apart than they were originally.

The unusual forms shown in Pl. II, Figs. 1-3, appear to be portions of the main stem, or at least of the primary branches They show six teeth, while the smaller and much more common forms show five. The enlarged portion, Pl. I, Fig. $1^{a}$, gives what seems to be the normal original form of the teeth. They are closely approximate, and have a short acute tip. Pl. I, Fig. 1 $1^{\text {b }}$ shows a slightly different form of teeth. They are blunter and farther apart at the tips. This is perhaps due to distortion from pressure and partial maceration.

This plant must have attained a considerable height. It las much resemblance to the genus Casuarina in the mode of branching, its copiousness, the great length of the branches, and their woody character. 


\section{Equisetum Lyelli Mantell. \\ Plate 1, Fig. 7; Plate 1I, Figs. 4, 5.}

Schenk ${ }^{1}$ says of $E$. Lyelli, from the Wealden of England: "It has a branching stem, with internodes $2^{\text {ow }} \mathrm{long}$, and is $10^{\mathrm{mm}}$ to $13^{\mathrm{mm}}$ in diameter. The branches are $5^{\mathrm{mm}}$ in diameter. The sheaths are $1^{\mathrm{cm}} \mathrm{long}$, and the teeth are linear and acuminate."

The Potomac plant in most of these features agrees closely with $E$. Lyelli. The form given in Pl. II, Fig. 4, and the smaller stem in Fig. 5 of the same plate, are probably branches. The resemblance is especially close in the long, narrow, and remotely placed teeth. This plant has also a marked likeness to E. Lusitanicum Heer, from the Jurassic of Portugal. ${ }^{2}$

Localities: The form given in Pl. I, Fig. 7, comes from Fredericksburg, and the others from the fishing hut above Dutch Gap Canal.

\section{Rhizome of Equisetum, sp.?}

Plate II, Fig. 8.

Plate II, Fig. 8, depicts a fossil which appears to be the rhizome of an equisetum. It shows no sheaths, is jointed at mnequal intervals, and has on the upper surface three or four narrow prominent ridges. It seems to be decorticated, and is probably the rhizome of $E$. Lyelli.

Locality: Fredericksburg; only one specimen was found.

Equisetum Marylandicum, sp. nov.

Plate 11, Fig. 10.

Stems branching copiously; branches long and slender; surface smooth; branches $1.5^{\mathrm{mm}}$ and less in diameter; internodes $15^{\mathrm{mm}}$ or a little more in length; sheaths slightly swollen, $2^{\text {mm }}$ long; teeth visible on the branches, three to fon in number, very short, oval in shape, and terminating in short acute tips.

Localities: Not rare on Belt and Covington streets, Baltimore.

Specimens of this little Equisetum may be found occasionally in the shale, especially of Covington street. They are mostly in the form of

${ }^{1}$ Die foss. Flor. d. nordwestdentseh. Wealdenformation, Cassel, 1871, p. 5.

Commare Heer's Contrib. Fl. Foss. Portugal, Lisbonne, 1881, Pl. VIII, Figs. 1-6. IION XV- 5 
slender decorticated branches, often attached to stems but slightly larger than the branches, in such a manner as to indicate that the branching was copious; in this respect reminding one of $E$. Virginicum. The branches average in diameter $1^{\text {mom }}$ and under. Considering their slenderness, they have a remarkably rigid and woody aspect. The length that many of these impressions attain and their stiff character remind one of Casuarina.

\section{Rhizome of Equisetum, sp.?}

Plate CLXX, Fig. 8.

Pl. CLXX, Fig. 8, gives a specimen found at Covington street, Baltimore. It seems to be the decorticated rhizome of some Equisetum, showing two tubercles. Only one specimen was found. As E. Marylandicum occurs at this spot, it is probable that this rhizome belongss to it.

\section{FILICES.}

The ferns form a very important element in the Potomac flora. Notwithstanding the great variety of forms, with very few exceptions specimens of ferus are rare at all the localities. This comparative scarcity of individual preserved fossils is no doubt due to the conditions attending the fossilization, which farored the preservation of other plants in larger proportion. The large number of species, althongh represented by comparatively few individuals, shows that ferns abounded. There is a curious mingling of older and more recent aspects in the fern-flora. Taken as a whole, Jurassic and Wealden types decidedly predominate. The very large proportion of species belonging to the Cladophlebis and Thyrsopteris forms gives a marked Jurassic facies to the flora. Many forms are closely allied to Sphenopteris Mantelli and other Wealden species, so that the IVealden element is a large one. But the numerous species of Aspidium give modern features a strong representation.

In the ferns, as in most of the other plants of the Potomac, we find much isolation of the species, forms occurring at a given locality being commonly restricted to it. In some of the species of Cladophlebis we find some of the closest approximations made by Potomac forms to those of the older Mesozoic or Rhætic flora of the Richmond Coal Felds. This latter 
flora is in the Potomac terrane, the one which came next to the Potomac flora among its predecessor's.

Cladophlebis Brong., ex parte.

Saporta first defined the character of the genus Cladophlebis. $\mathrm{He}$ gives the following description: "Frond pinnately divided; pinnules separate from one another, or slightly mited, attached to the rachis by the entire base." Schimper ${ }^{2}$ gives a much fuller analysis of the generic character: He says: "Fronds pinnately divided; pinnæe spreading; lobes or pimules attached by the entire base, sometimes confluent, rarely slightly auriculate, acuminate, or obtuse, occasionally dentate, especially at the apex, not rarely subfalcately curved upwards; midnerves pretty strong; secondary nerves departing at a more or less acute angle, dichotomous a little above the base, and repeatedly dichotomous: slender to very slender:"

In his later work, however, for Zittel's Handbuch der Palæontologie, he makes no mention of this genus. If we modify Schimper's description so as to make it read, midnerve strong at base, and towards the summit dissolving into branches, we have a very accurate description of a group of ferns that is strongly characteristic of the Jurassic, and which is fully as much entitled to be called a genus as is Sphenopteris or Pecopteris. In my opinion it is necessary to retain the name Cladophlebis for all fossil plants with the above-described character, and which have no fructification by which they can be placed in other genera. It does not seem proper, as some have done, to group under this specific name all the Jurassic plants of the Cladophlebis type, which have more or less resemblance to the Pecopteris Whithiensis of Lindley and Hutton and the different plant given the same name by Brongniart. Pecopteris Whittiensis, used by Heer as a specific name for plants widely diffused over the world in the Jurassic period, is nearly equivalent to the generic name Cladophlebis. Again, becanse certain Jurassic plants of the Cladophlebis type have in their foliage some of the features of ferns possessing the fructification of Asplenium, Dicksonia, etc., it does not seem proper to group

'Pal, Frauc., 2d series, Végétaux, PI, Jurass., vol, 1, pp. 293, 299. "Traité de Pal. Vég., vol. 3, p. 503. 
them as Asplenium, Dicksonia, etc., when they have no fructification and are found in countries far remote from the supposed fructified forms. For the reasons given above, the generic name Cladopllebis is retained for Mesozoic fossil ferns which possess the character given by Schimper, amended as suggesterl.

\section{Cladophlebis constricta, sp. nov.}

PlateII, Fig. 11; PlateIII, Fig. 2; Plate VI, Figs. 5, 6, ४-14; PlateXXI, Figs. 9, 13; Plate CLXIX, Fig. 2.

Frond bipinnate or tripinnate, arborescent; principal rachis slender; primary pinne remotely placed, very rapidly becoming shorter in ascending; ultimate pinnie very remotely placed, alternate, in the lower part of the frond pinnately lobed; in ascending on the frond abruptly passing first into pimnules with undulate margins and then into those with entire unargins; pinnules mostly very remotely placed, thick and leathery, alternate, at their tips subacute or obtusely rounded, often constricted at base; in shape oblong to ovate; the midnerves of the pinnules towards their summits split up into branches. The lower lateral nerves are once or twice forked, the upper ones once forked.

Localities: Fredericksburg; 72d mile-post, near Brooke: Deep Bottom; Covington street, Baltimore. In all these places rare.

I have united in this species a number of forms which differ somewhat in facies, but not enough to form the basis of specific separation. In Pl. XXI, Figs. 9, 13, are given two small fragments coming from Deep Bottom, being the only specimens found there. They are thick and leathery in character, and differ considerably from the fine specimen given in Pl. II, Fig. 11, which comes from Fredericksburg. The small fragment depicted in Pl. CLXIX, Fig. 2, comes from Covington street, Baltimore. This also is leathery in character, and is much smaller than most of the normal forms. The forms given in Pl. VI, Figs. 3, 12-14, come from the 72d mile-post, near Brooke. Their textme is very leathery and thick, and the general character of the pinnules is not exactly that of the type form, which may be considered as given in Pl. II, Fig. 11. Pl. VI, Fig. 9, gives a small fragment from Fredericksburg which in facies is much like a Gleichenia, and is quite aberrant. 
The smaller forms of this species are somewlat like Pecopteris boreatis Brong., which, as Heer has shown, oceurs in Kome, Greenland. Pecopteris liberata Heer in the Jurassic flora of Cape Boheman, ${ }^{1}$ has the pinnules constricted at base, and is a good deal like some of those fonnd in this species. But neither one of these species is near enough to the Potomac plant to be identified withont hesitation with it.

The leaf substance of all the specimens of this plant must have been thick and leathery, for the pinnules and lobes make deep impressions in the shale, and some of the rounded small pinnules and lobes leave round pits. The epidermis of the pinnules seems to have been thick and durable, for the specimens often have a dark brown shining surface. I have, with a good deal of hesitation, placed in this species some of the specimens given in the figures named

Among described fossils, Schenk's Alethopteris cycarlina stands nearest to the plant now in question. The resemblance is considerable between the form given in Pl. VI, Fig. 2, and Schenk's Foss. Flor. d. nordwestdeutsch. Wealdenformation, Pl, X, Fig. 2.

\section{Cladophlebis latifolia, sp. nov. \\ Plate III, Fig. 1; Plate VI, Fig. 4.}

Frond bipimate or tripinnate; principal rachis slender, with a keel in the middle; pinne quite remotely placed; pinnules broad, ver'y obtuse, with mndnlate margins; alternate, subauriculate, and rounded off at base, attached by the middle of the base, separate and rather remote; midnerve, as in the genns generally, strong at base, and towards the summit splitting up into veins; lower lateral nerves forming copionsly branched groups; those higher are bifurcate, and simply forked, slender, but very distinctly defined; leaf-substance thin.

Locality: Fredericksburg.

This beantiful species was found only at Fredericksburg, and but two specimens were obtained.

The dimensions and character shown indicate that the plant was probably arborescent. It is nearly allied to no fossil known to me. It is more

${ }^{1}$ Flor. Foss. Arctica, vol. 4, Ziirieh, I877, No. 1, p. 30, Pl. VI, Fig. 2. 
like Pecopteris Haibumensis, L. and H., from the Oolitic formation of Haiburn Wyke, Yorkshire, England, than any other previonsly described plant, but is quite distinct from this. It has some resemblance to Neuropteris undulata, L. and H., Foss. Flor,, vol. 2, Pl. LXXXIII.

\section{Cladophlebis Virginiensis, sp. nov.}

Plate III, Figs. 3-8 ; Plate IV, Fig. 1, 3-6.

Frond bipimate or tripinnate, arborescent; principal rachis very stout and woody; rachises of the penultimate and nltimate pinnæ stont, rigid, on the under side rounded and prominent, on the mpper side ridged on each margin; ultimate pinne very long, rather remote, subopposite; pinnules alternate to subopposite, at the tips varying from acute to obtuse, with margins usually very entire, rarely crenulate to subdentate, in shape ovate to lanceolate and subfalcate, attached by the greatly -widened base, mostly separate to the base; midnerve stout at base, but soon becoming attenuated, and some distance below the summit splitting up into veins; lateral nerves at the base of the pinnules branched several times, in some cases forming nerve-bundles, in ascending towards the tips of the pinnules less and less subdivided, finally simply furcate and unbranched.

Locality: Fredericksburg.

This splendid plant is perhaps the most common fern at Fredericksburg, but it is not abundant there. The specimens are usually quite fragmentary, as if they had been transported some distance. From the size of the rachis shown in Pl. III, Fig. 3, the plant must have been arborescent. The rachis of the pinnæ in all the specimens is strong and rigid. The under side of the rachis is usually rounded and prominent. On its upper surface a strong ridge is often seen on each margin, and to this the pinnæ and pinnules are attached. The pimules of Pl. III, Fig. 3, may be taken as typical for form and dimensions. Sometimes, however, pimnles may be seen which are quite obtuse at their tips, and in some cases they occur with margins showing incipient lobing. These come probably from lower portions of the frond. Possibly in Pl. IV, Figs. 1, 3, may be denoted a smaller species of this type. 
This plant is plainly Jurassic in type, and may be regarded as a survivor of the Jurassic flora. It is so much like the sterile forms of the plant from the older Mesozoic or Rhetic flora of Virginia, first made known by Bunbury and described by me in Contributions to the Knowledge of the Older Mesozoic Flora of Virginia, ${ }^{1}$ under the name Acrostichides linncecefolius, that one is tempted to consider it as a descendant of the latter. Comparison may be made with Pl. VII, Fig. 1, and Pl. VIII, Fig. 1, of the work cited. It is also in some points nuch like Acrostichides rhombifolius, described in the same monograph.

The Potomac plant is strikingly like Brongniart's Pecopteris Whitbiensis, and $P$. tenuis, and one may well hesitate to separate them. Heer, in Flor. Foss. Aretica, vol. 4, under the name Asplenium, has described some forms that are very close to the plant now in question. It does not, however, seem proper to make the Potomae plant an Asplenium so long as it shows no fructification.

\section{Cladophlebis denticulata, sp. nov.}

\section{Plate IV, Fig. 2; Plate VII, Fig. 7.}

Frond bipinnate or tripinnate; rachis of the pinne rather slender; pinnules opposite to alternate, attached by the entire base, oblong to lanceolate, subfalcate, minutely dentate toward their tips, those in the upper part of the frond entire; midnerve as in the genus; lateral nerves bifurcate or simply forked, and rather slender.

Localities: Fredericksburg; road-side near Potomac Run; very rare.

I have with much hesitation nnited the plant given in Pl. IV, Fig. 2, which comes from Fredericksbarg, and that depicted in Pl. VII, Fig. 7 , which was found on the road-side near Potomac Run. The latter differs from the former in having the pinnules more erect, oblong in shape, and separate to the base. 'Then, too, they have their nerves simply forked, and more Pecopteris-like. The very fragmentary nature of the specimens does not permit the true nature of the species to be fully made out.

The form given in Pl. VII, Fig. 7, may be compared with Pecopteris denticulata, Heer, as given in Flor. Foss. Aretica, vol. 3, Die Kreideflora 
des Aretischen Zone, Pl. XX̣VI, Fig. 7. The Potomac plant resembles this a good deal. The form from Fredericksburg given in Pl. IV, Fig. 2, is much like Neuropteris ligata, ${ }^{2}$ L. and $H$., but the nerves are more copionsly branched and the pinnules are broader. The Potomac plant is no doubt nearer this latter than any other described form.

\section{Cladophlebis falcata, sp. nov.}

Plate IV, Fig. 8; Plate V, Figs. I-6; Plate VI, Fig. 7 ; Plate VII, Figs. I, 2.

Frond bipinnate or tripinnate, arborescent; rachis of the primary pinnæ or of the frond stout and rigid; pimme opposite, with a moderately strong rigid rachis; pinnules mostly opposite, sometimes alternate, falcate, acnte to obtuse, separate to the base, and slightly rounded off on the upper side, with margins mostly entire, rarely slightly lobed, attached by the whole of the broad base, varying in size according to position on the frond. The pinnæ of ultimate order, in ascending on the frond, pass throngh pinnules that are long and falcate with slightly lobed margins, into those of smaller size with entire margins; midnerve rigid and continued to near the summit, with comparatively little diminution in size. The lateral nerves are bifurcate and go off at an acute angle, and curve ontwards to meet the margin.

Locality: Fredericksburg; not very rare.

This fine plant is one of the most common ferns at Fredericksburg. It has, more than is usual in the Cladophlebids, the aspect of an Alethopteris, and although a good deal larger, is something like the Pecopteris Trhitbiensis of Lindley and Hutton. The Jurassic ferns that have some resemblance to this species are numerons, and it is hardly worth while to refer to all of them, as none of them can with much probability be identified with it. The forms with larger pinnules may be compared with Pecopteris insignis, $\mathrm{L}$. and $\mathrm{H},{ }^{2}$ but, besides other points of difference, the nervation is essentially distinct.

Heer's Asplenium spectabile, Flor. Foss. Arctica, Jura. Flor. Ost. Sib., vol. 4, Pl. XXI, Figs. 1, 2, has the nervation of this plant. The Potomac specimens, with smaller pinnules, resemble more or less a number of 
Jurassic ferns from widely separated portions of the globe. Among these we have Neuropteris recentior, L. and H., Foss. Flor. of Great Britain, PI. LXVIII, and several of the fossils united by Heer with Asplenium Whithiensis, in his article on the Jura. Flor. Ost. Sib., Flor. Foss. Aretica, vol. 4, No. 2, p. 94, Pecopteris Indica of Oldham and Morris, and Nathorst's figures of Cladoplubbis nebbensis from the Rhretic of Swerlen, resemble in some points the smaller forms of the Potomac plant. Some of the pinnules of C. nebbensis show a fine toothing similar to that found on Cladopllebis denticulata.

I have with some hesitation grouper under the species $C$. falcata several forms that do not resemble in all respects the more common and typical specimens of that species, which may be taken as represented in Pl. V, Figs. 1, 2. The bhuntly terninated pinnules in Pl. V, Figs. 3, 5, also the very slightly falcate pimnules and the nerves of Pl. VII, Fig. 2, show a cleparture from the normal form.

\section{Cladophlebis parva, sp. nov.}

Plate IV, Fig. 7; Plate VI, Figs. 1-3.

Frond bipinnate or tripinnate; principal rachis proportionally very stout and rigid; pinne short, alternate to subopposite; pinnules alternate, ovate, subfalcate, acute, except in the upper part of the frond, separate to the base; midnerve as in the genus; lateral nerves mostly once forker; leaf-substance thick.

Locality: Fredericksburg; rare.

In the shape of its pinnules it belongs to the same type as $C$. Virginiensis, but the nerves are not so copionsly branched towards the base of the pinnules, and do not diminish in the number of branches so rapidly towards the summit of the pinnules. It is much like Cladophlebis pseudowhitbiensis, ${ }^{1}$ but is a smaller plant. It resembles also the upper part of Pecopteris dentata, given by Lindley and Ilutton in Foss. Flor. of Great Britain, Pl. CLXIX. The nerves, however, do not agree with those of that plant. This small fern is probably another survivor of the Jurassic, or rather Rhetic, flora of Virginia.

${ }^{1}$ Contributions to the Knowledge of the Olier Mesozoic Flora of Virginia: U. S. Geol. Survey, Mon. No. 6, 1883, p. 52, Pl. XXVII, Fig. 4. 
Cladophlebis acuta, sp. nov.

Plate V, Fig. 7; Plate VII, Fig. 6; Plate X, Figs. 6, 7 ; Plate XI, Figs. 7,8; Plate CLxVI, Fig. 5.

Frond bipinnate or tripinuate, arborescent; principal rachis stout and rigid; pinne with stont rigid rachises go off at an angle of $45^{\circ}$ and curve upwards; pinnules alternate, united at base, falcate, ovate to oblong, acuminate; midnerve rather stout and rigicl, prolonged to near the summit of the pinnules; lateral nerves furcate, with branches subparallel.

Localities: Hill-side near Potomac Run, rather common; rare at fishing hut above Dutch Gap Canal.

This plant has some of the features of the Pecopteris type combined with those of Cladophlebis. The pinnules show sometimes an inclination forward along the rachis. In the typical forms, snch as PI. XI, Fig. 8, the pinmules are nnited at base and decidedly falcate. Pl. XI, Fig. 7, and Pl. V, Fig. 7, give forms with unusually long and slender pinnules. They probably represent ultimate pinne changed in the npper part of the frond to pinnules. Pl. X, Fig. 6, differ's from the normal forms a good deal, and hesitatingly I unite it with the species now in question.

Cladophlebis acuta is more like Dunker's Neuropteris Albertsii from the Wealden of Germany than any other previously described fossil, and is no doubt quite near the Wealden species. Schenk, in Foss. Flor. nordwestdentsch. Wealdenformation, Pl. VI, Fig. 4, gives a form with the name Alethopteris Albertsii, which resembles our plant more than do the figures of Dunker. Heer, in Flor. Foss. Arctica, vol. 6, Pt. 2, Pls. XVI, XXVIII, XLVI, has given a number of figures of a plant which he identifies with Dunker's species, but which he calls Pteris Albertsii, making it a Pteris without any evidence from fructification. The Potomac fossil is rery close in form to the figure he gives from Unter Atanekerdluk, Pl. XVI, Fig. 6.

\section{Cladophlebis oblongifolia, sp. nov.}

Plate VII, Figs. 3-5.

Frond bipinnate or tripinnate; arborescent; ultimate pinne long and linear, with rigid and comparatively stout rachises; pinnules alternate, oblong, very slightly falcate, in the npper part of the frond with entire 
margins, in the lower portions of the plant with crenate margins; midnerve pecopteris-like, rigid, and prolonged to near the summit of the pinnules; lateral nerves very regularly once forked, with branches subparallel; leaf-substance thick and leathery.

Localities: Fredericksburg, very rare; more common but still rare at fishing hut above Dutch Gap Canal; found also in the banks of Dutch Gap Canal, and in the red clay ball occurring in these banks.

This plant is rare at all the localities where it occurs. It is found in fragments that are too small to give a good idea of the character of the frond. That represented in Fig. 5 was found in the red clay ball which oceurs in the right-hand bank of Duteh Gap Canal. To judge from the size of the rachis in Fig. 5 the plant must have attained very considerable dimensions. This -specimen shows a ridge on each side of the rachis. This is one of the forms that possess some of the features of Pecopteris and Alethopteris. It does not bear much resemblance to any previously described fossil known to me. It seems to be nearest to Pecopteris Whitbiensis of Lindley and Hutton. It appears also to be like Cladophlebis Virginiensis of this work, but can not be sunited with it by transitional forms.

\section{Cladophlebis crenata, sp. nov.}

Plate IX, Figs. 7-9; Plate X, Figs. 1, 2; Plate XIII, Figs. 1-3; Plate XIX, Fig. 1; Plate XX, Fig.6.

Frond bipinnate or tripinnate; rachis of the primary and secondary pinne strong and rigid; pinnæ mostly alternate, rarely opposite, going off at an angle of $45^{\circ}$, and closely placed; pinnules alternate, obliquely rounded at base above, and slightly decurrent on the lower side; in shape ovate-acuminate and falcate; margins with distinct crenate toothing; midnerve as in genus; lateral nerves of the basal lobes of the pinnules fasciculate and palmately diverging, those of the upper lobes once or twice forked.

Localities: Fredericksburg, most common; 72d mile-post, near Brooke; hill-side near Potomac Run; rare.

The crenate lobing of the pimnules seenis to be a constant feature, and there does not appear to be any tendency to pass into entire piunules. 
Most of the specimens figured come from Fredericksburg. Pl. IX, Fig. 2, a form with opposite pinnæ, comes from the $72 \mathrm{~d}$ mile-post, near Brooke. Pl. XIII, Fig. 3, comes from the lill-side near Potomac Run. It has the lobes more rounded than nsual. The pinnules are often decurrent some distance on the rachis.

This plant is not very near any described fossil known to me. It may be compared with Cyathea Tchihatchewi, Schmalhausen, ${ }^{1}$ but shows obvious differences. In the shape of the pinnules the species is nearest to Pecopteris borealis, Brong., as figured by Heer, ${ }^{2}$ from the Kome beds, but this latter has the nerves single.

Cladophlebis, sp.? sp. nov.

Plate X, Figs. 5, 8; Plate XX, Fig. 7.

Nature of frond and pinna unknown; pinnules alternate, oblong, acnte, slightly falcate, attached by a widened base moder a large angle; midnerve ranishing before attaining the tip of the pinnule; lateral nerves not seen; leaf-substance thick.

Localities: Fredericksburg; hill-side near Potomac Run; at both places very rare.

\section{Cladophlebis inclinata, sp. nov.}

Plate X, Figs. 3, 4; Plate XX, Fig. 8.

Frond bipinnate or tripinnate, arborescent(?); pinnæ of ultimate order, opposite, short; pinnules, ovate-lanceolate, acnte, inclined forward, alternate, attached by the whole of the widened base, separate to the base, slightly falcate; midnerve of pinnules slender above the base, but continned to near the apex of the pinnules; lateral nerves once forked.

Locality: Near Telegraph Station; not uncommon.

This plant is a good deal like some of the forms of $C$. acuta, as given in Pl. X, Fig. 6, but the pinnules are smaller and not united at the base, and none of the lateral nerves are more than once forked. It is so much like Pteris Albertsii ${ }^{3}$ Heer, found in the flora of the Atané beds, that it is

${ }^{1}$ Beitr. Jura Flora Russland's, PI. III, Fig.3. St. Petersburgh, 1879

${ }^{2}$ Flor. Foss. Are., vol. 6, Pt. 2, P1. II, Figs. 9c, 10.

Ibid., Pl. XVI, Figs. 5, 6; Pl. XXVIII, Figs. 1-3; Pl. XLVI, Figs. 22-24. 
with much hesitation that I separate them. Heer thinks that this plant is Dunker's Neuropteris Albertsii, but it seems to be quite different from the forms figured by either Dunker or Schenk.

Cladophlebis distans, sp. nov.

Plate XIII, Figs. 4,5.

Frond bipinnate or tripimate; principal rachis stont and rigid; pinnæ alternate, linear elongate, with rigid strong rachises; pinnules oblong or ovate, very obtuse, distant; leaf-substance thick and leathery, slightly falcate, alternate, attached by the entire base; midnerve pecopteris-like; lateral nerves once forked and strong.

Locality: Not very rare in the banks of Dutch Gap Canal; rare at fishing hut above the canal.

This small fern seems to be quite restricted in its distribution. It is well characterized by its pinnules, which are small in size, of leathery texture, and remotely placed.

$$
\begin{aligned}
& \text { CladophlebIs, sp.? sp. nov. } \\
& \text { Plate XV, Fig. 6; Plate XIX, Fig. } 3 .
\end{aligned}
$$

Frond and pinne unknown; pinnules subopposite, ovate to ovateoblong, obtuse, united at the widened base, going off nearly at a right angle; midnerve as in the genus; lateral nerves once forked, or with one branch of the basal pair forking again.

Localities: Hill-side near Potomac Run; bank near Brooke; very rare at both places.

This plant is too rare and found in fragments too small to permit its character to be made out. It seems, however, to be quite distinct from any other fern described coming from the Potomac formation.

Cladophlebis alata, sp. nov.

Plate XIX, Fig. 5.

Frond tripimatifid, arborescent; principal rachis stont and rigid; pimne alternate, curving upwards, with strong rigid rachises; pinnules with thick leaf-substance, opposite or subopposite, in shape linear-lance- 
olate, acute, and falcate, narrowed at the base and decurrent, forming a strong wing on the rachis, margins ent more or less deeply into ovateacute teeth; midnerve slender, prolonged to near the summit of the pinnules; lateral nerves fasciculate in each tooth or lobe, forming nervebundles, with mostly four branches.

Locality: Fredericksburg; very rare.

This fine, well characterized plant is very rare, and, so far as known, occurs only at Fredericksburg. It seems to have been a fern of large size, and was probably arborescent. Some of the Potomac ferns elsewhere described, such as Cludophlebis crenata and Aspidium Fvedericksburgense, look a good deal like this plant, but the decided narrowing of the pinnules on both sides at the base and the distinct wing in Cladophlebis alata serve to distingnish it.

Geyler gives a figure ${ }^{1}$ of his Pecopteris exiliformis, which in general form looks something like the Potomac species, but the differences are marked.

\section{Cladophlebis, sp.? sp. nov. \\ Plate XIX, Fig. 2.}

Frond and pinne unknown; pinnules linear-lanceolate, acute, with margins cut into ovate-acnte lobes and teeth; midnerve as in the genus; lateral nerves in each lobe or tooth having a midnerve, which sends off on each side alternately branches that are mostly single, and curve upwards towards the summit of the tooth.

Locality: Near Telegraph Station.

This plant is too fragmentary to make out its character. It may be merely a portion of the upper part of the frond of some of the species described under another name. The so-called pinnules look like pinnæ reduced to pinnules.

Cladophlebis rotundata, sp. nov.

Plate XX, Figs. 9, 10.

Frond bipinnate or tripinnate, arborescent (?); principal rachis stout, rounded, and prominent; pimæ short, with a strong rigid rachis; ultimate

${ }^{1}$ Foss. Pflanzen Juraformation Japans, Paleontographica, vol. 24, 1877, Pl. XXX, Fig. 1. 
pinnæ, from the lower part of the frond, with alternate, short, broadly ovate, very obtuse, round-lobed pinnules, those of the upper part of the frond having the lowest pinnules distinct and more or less round-lobed, and towards the summit with pinnules passing through such forms as rotundate, subrhombic, and decurrent to entire and rounded, the latter having the tips round-lobed and very obtuse; nerves varying according to the pasition and shape of the pinnules, those of the round-lobed pinnules and of the pinnæ rednced to pinnules flabellately diverging in each lobe, the branches being either forked or simple. The nerves of the subrhombic pinnules have a midnerve, which sends off alternately on each side forked or simple branches. All the nerves are very strongly marked and stont. The leaf-substance is thick and leathery.

Locality: Fredericksburg; rare.

This plant is well characterized by its very strong prominent nerves and by the varying pinnules, which show some of the features of Sphenopteris, of. Thyrsopteris; and of Cladophlebis, respectively. It seems to be unique.

\section{Cladophlebis sphenopteroides, sp. nov.}

Plate XXI, Fig. 4.

Frond bipinnatifid or tripimnatifid; pimunles or uppermost pinnæ ovate-lanceolate, obtuse, narrowed much at base and attacher by the narrowly winged base of the rachis or midnerve, lower ones deeply and obliquely cut into oblong lobes, which are very obtuse and rounded at their tips, upper ones cut less deeply and into ferver lobes, at the summit united and forming a termination similar to the lower pinnules or pinne; nerves flabellately diverging in each lobe, branching several times, very fine and closely placed, but very distinct.

Locality: Fishing hut above Dutch Gap Canal; very rare.

This plant, although found in small fragments only and very rarely, is still evidently a distinct species. It should, perhaps, be placed rather in the Sphenopteris than in the Cladophlebis group of ferns. It is something like Thyrsopteris prisca, ${ }^{1}$ Eichw., as figured by Heer, but the nerves are

${ }^{1}$ Flor. Foss. Aretica, vol. 4, No. 2, Beiträge zur Flor. Ost. Sib., Pl. XVIII, Fig. 8. 
more numeronsly divided and much finer, and the pinnules are longer and proportionately more slender in the Potomac plant.

\section{Cladophlebis petiolata, sp. nov.}

Plate XXII, Fig. 8.

Frond bipinnate or tripimnate; rachis of primary pinne comparatively stout and rigid; pinnules, or reduced ultimate pimne, alternate, oblong, acute, somewhat falcate, narrowed to the base into a winged petiole, cut into ovate subacute teeth; lateral nerves in each tooth composed of a slender midnerve, which sends out alternately on each side simple nerves.

Locality: Red clay ball in the banks of Dutch Gap Canal; very rare.

This plant is in form a good deal like Thinnfeldia variabilis, from the 72d mile-post, near Brooke. The nerves, however, are fewer, coarser, and more remote. It seems to be a distinct new species.

\section{Cladophlebis inđquiloba, sp. nov.}

Plate XXY, Fig. 8.

Frond bipinnate or tripinnate; primary rachis slender; pinnules or reduced pinnæ petiolate, lanceolate-acute, alternate; leaf-substance thick; basal lobe on the upper side of the pinnules or pinnæ ovate-obtuse, erect, and much larger than the other lobes or teeth; the other lobes or teetl of the pinmules ovate-acute, and directed towards the tip of the pinnules; pinnules towards the summit of the primary pinnæ sparingly and acutely toothed; nerves of the lobes and teeth not seen.

Locality: Fredericksburg; very rare.

This small plant seems to show the upper portion of a primary pimna in which the ultimate pinne are reduced to lobes and teeth. It seems to be a distinct species.

\section{Cladophlebis pachyphylla, sp. nov.}

Plate $\mathrm{XXV}$, Fig. 9.

Ultimate pinne linear, with a comparatively stout rachis; pinnules subopposite, with a dense leathery leaf-substance, ovate-falcate, acute, remotely placed, separate to the base, free on the upper side, and cut 
away to form a sort of petiole, attached only by the lower portion of the base; midnerves strong; lateral nerves not seen.

Locality: Fredericksburg; very rare.

This seems to be a very distinct species. It belongs to the Jurassic type of Cladophlebis. It is something like Pecopteris Williamsoni, Brong., but is a much smaller form.

\section{Chajophlebis, species? sp. nov.}

Plate XXVI, Fig. 15.

Pinnules subfalcate, thick and leathery, separate to the base, attached by the whole of the widened base; in shape ovate-acute; nerves not seen.

Locality: Fredericksburg.

The small specimen figured was the only one found. It seems to be a distinct species.

Cladophlebis brevipennis, sp. nov.

Plate XxxvI, Fig. 1.

Frond, ? ultimate pinme very short, subopposite, cut to varying depths into rounded, oval, or elliptical pinnules and lobes; pinnules rounded at base; nerves strong, rather distant, composed of a midnerve dissolved a short distance above its base into branches, which are once or twice forked, and curve strongly outwards to meet the margin of the pinnules and lobes ; leaf-substance thick.

Locality: Fishing hut above Dutch Gap Canal; very rare.

This plant is something like Cladophlebis constricta; the nerves, however, curve outward more strongly, and are more copiously branched, and the ultimate pinnæe are much shorter. It is also something like Dunker's Pecopteris Murchisoni, but the pinnules are rounded and narrowed at base, and the nerves are more flabellate and spreading.

\section{PECOPTERIS, Brong:}

Fronds once or several times pinnate; pinnules mostly entire, attached by the whole of the base, which is rarely narrowed; midnerves extending to the tips of the pinnules; lateral nerves going off on each side HON $\mathrm{xV}-6$ 
of the midnerve in a pinnate mamner, and at a varying angle, simple, or several times forked, not anistomosing.

The genus I'ecopteris, based mainly on the nervation and probably containing many species of distinct ferns, serves simply as a convenient grouping of plants having a particular facies, and whose generic character can not be otherwise fixed. There are a number of forms in the Potomac flora which have the character given above for Pecopteris, and which is taken from Schimper's description of the genus. The number of ferns, however, found in the Potomac flora which could be placed in the genus Pecopteris is far less than that of those which possess the characters of Cladophlebis and Thyrsopteris. This type is rather feebly represented in the Potomac flora.

\section{Pecopteris Virginiensis, sp. nov.}

PIate VIII, Figs.1-7 ; Plate IX, Figs. 1-6 ; Plate XXIV, Fig. 2; Plate CLXIX, Fig. 3.

Frond bipinnate or tripinnate, arborescent; pinnæ alternate, very long; leaf-substance thick and durable; the principal rachis and that of the ultimate pinnæ stout, rigid, with the margins on the upper face raised in the form of a cord; pinnules elongate-oblong to narrowly linear, opposite to alternate, much narrowed at the base and separate to the base, cut away obliquely on the upper side and decurrent slightly on the lower one, or else united at base to form a wing along the rachis of the pinnæ; margins denticulate to distinctly dentate, straight or more commonly slightly falcate; midnerve prolonged to near the tips of the pinnules, often rather slender but distinct; lateral nerves once forked, one of tî́e branches usually ending in the tip of the tooth on the margin.

Localities: Red clay ball in the banks of Dutch Gap Canal; fishing Lut above Dutch Gap Canal; Fredericksburg; road-side near Potomac Rim; 72d mile-post, near Brooke; near Telegraplı Station; Covington street, Baltimore.

This is perhaps the most widely diffused of the Potomac plants. At the locality on the road-side near Potomac Run the fragments are among the most common. They occur in such a way in the irregularly deposited clay as to suggest that the dimensions attained by this fern were great. The clay was of such a nature at this locality as to render it impossible 
to take out the specimens without reducing their size very considerably. In Pl. VIII, Fig. 2, is shown a fragment of what was formerly a portion of the frond a foot wide and more than a foot long. At all the other localities it is rare. It is a singular fact that not a trace of this plant is found at the locality on the hill-side, which is not more than one hundred and fifty yards distant from that on the road-side. This is true, although ferns are the most common fossils at the first-named place.

This fern is so well characterized, that there is no difficulty in identifying it. Indeed it can usually be detected at a glance. The plant shows some variation. Some of the pinnules, especially in those specimens found at the fishing hut above Dutch Gap Canal and at Baltimore, are very narrow, elongate, and slightly toothed. We may take Pl. VIII, Fig. 6, as a typical specimen, the teeth being ácute; but in Fig. 1 of the same plate we have a plant from Fredericksburg which has the teeth less deeply cut and more obtuse. This form somewhat resembles Clatophlebis oblonga.

In most cases, and in typical forms, the pinnules are narrowed at base, strongly decurrent, and united to form a wing, as in Pl. VIII, Fig. 4, from Fredericksburg, and Figs. 2, 6,7 of the same plate, coming from the road-side near Potomac Run. In such forms, however, as PI. VIII, Fig. 3; Pl. IX, Fig. 1, from Fredericksburg, and Fig. 5 of the same plate, from the 72d mile-post, as well as Pl. IX, Fig. 2, from the fishing hut above Dutch Gap Canal, the pinnules are separate, not decurrent at base, less linear, and narrow in form, and less inclined forward. These points may be due to the fact that the parts which show them come from a portion of the frond different from that affording the normal forms, or they may be of sufficient importance to denote a variety of the species.

The form, Pl. VIII, Fig. 5, from the locality at the $72 \mathrm{~d}$ mile-post, is the only specimen which gives the summit of a compound pinna. The corded margins of the rachis appear only on the upper surface, as in Pl. VIII, Fig. 2, while the lower face is rounded and prominent, as in Figs. 1, 4, 6 of the same plate. The lateral nerves are typically once forked only, as in Pl. VIII, Figs. $2^{a}, 2^{\text {b }}$, but in Pl. VIII, Fig. 3, and Pl. IX, Fig. 1, they in the lower teeth form nerve-groups, composed of lateral nerves which go off alternately from a midnerve. 
This plant is more like Pecopteris denticulata,${ }^{1}$ Brong., than any other. The only difference is found in the more slender and elongated pinnules of the Potomac fossil and in their greater thimness. Pteris frigida, ${ }^{2}$ Heer, from the Atané beds, resembles the Potomac plant, but it lacks the distinct toothing found in the latter.

\section{Pecopteris Śtrictinervis, sp. nov.}

Plate XIII, Figs. 6-8; Plate XIX, Fig. 9; PlateXX, Fig. 3; PlateXXII, Fig. 13; Plate CLXX, Figs. $5,6$.

Frond bipinnatifid or tripinnatifid; rachises slender; pinnæ subopposite to alternate, linear; pinnules mited for a considerable distance above their bases, oblong, usually obtnse and inclined forward, slightly falcate, those of the lower part of the frond denticulate, of the upper part entire; leaf-substance thick and obscuring the nerves, which are slender and immersed in it; lateral nerves of the lower pinnules furcate, with the lower branch ending in the teeth; lateral nerves of the upper pinnules mostly forked only in the basal ones, most of them simple, all usually parallel and straight, or nearly so.

Localities: Fredericksburg; Covington street, Baltimore; rare.

This elegant little plant occurs more abundantly at Fredericksburg than at Baltimore. All the specimens figured, except Pl. CLXX, Figs. 5, 6 , come from the former place. Still it is not an abuudant plant even there. Pl. XIII, Fig. 6, seems to be an abnormal form, which has the pinnules united higher up than usual and the lateral nerves more commonly forked and more curving than is usual in the pinnules of this fern, which have entire margins. Perhaps it would be better to separate this as a variety with the name var. unita. Pl. XIII, Fig. 7, gives a normal form for the pinnx and pinnules coming from the middle part of the frond. Fig. 8 of the same plate seens to come from down lower on the frond, where the toothing is more distinct and the nervation is all forked. Pl. XIX, Fig. 9, is a normal form for the parts belonging to the upper portion. of the frond.

This plant is very much like Pecopteris Browniana, Dunker, of the Wealden of Germany, as figured by Schenk in Foss. Flor. Nordw. Weald- 
enformation, Plate V, Fig. 2. The Potomac plant is, however, a stronger form, and the nerves are more conmonly single, straight, and parallel than in the Wealden fern.

Pecopteris Ovatodentata, sp. nov.

Plate XV, Fig. 8; Plate XXII, Fig. 12; Plate XXIII, Fig. 1.

Frond bipinnate or tripinnate, arborescent; pinnules or reduced pinnæ subopposite, linear acute, separate to the narrowed base, slightly decurrent, margins cut distinctly into ovate-subacute teeth; midnerve continued to the summit of the pinnules or pinnæ; lateral nerves furcate.

Localities: Fredericksburg; entrance to Trent's Reach; fishing hut above Dutch Gap Canal; rare at all localities.

This plant is more common at the Dutch Gap localities than at Fredericksburg, but is nowhere abundant. This fossil is found in fragments too small, and occurs too rarely to permit its true character to be made out. It is not close to any previously described fossil known to me.

\section{Pecopteris Microdonta, sp. nov.}

Plate XIX, Fig. 8; Plate XX, Figs. 5, 11.

Frond bipinnate or tripinnate, arborescent?; principal rachis strong and woody; pinnæ of the nltimate order opposite, with a rigid rachis; pinmules lanceolate-acute, somewhat falcate, slightly narrowed and decurrent at base, attached by the lower portion of the base; distinct, with margins cut into small ovate-acute teeth; midnerve strong at base, lateral nerves in each tooth simply forked, or in the lowest teeth with the upper branch again forked.

Localities: Fredericksburg; entrance to Trent's Reach; near Dutch Gap Canal; at each place rare.

The specimen from the Dutch Gap locality, Pl. XX, Fig. 11, has a somewhat different facies from the Fredericksburg form, Pl. XIX, Fig. 8, the pinnules being longer and proportionally narrower. The specimens found indicate that the plant was large and probably arborescent. 
Pecopteris constricta, sp. nov.

Plate Xx, Figs. $1,2, \therefore$

Frond bipinnate or tripinnate, arborescent ?; rachis of the primary pinnæ or of the frond stout and rigid; pimae alternate, with comparatively stout and straight rachises; pinnules with a thick and durable leaf-substance, opposite to altemate, narrowed at the base, and attached by the central portions, those of the lower part of the frond cut deeply into ovate acute lobes that are directed slightly forward, subfalcate, those of the middle portion of the frond oblong, acnte, subfalcate, with ovate acute teeth, the basal lower one being inserted in the angle between the main and secondary rachises; midnerve distinct but slender, extending to the summit of the pinnules; upper pinnæ narrowly linear, with ovate subfalcate pinnules united more or less at base; lateral nerres in each lobe or tooth composed of a midnerve, which sends off alternately on each side branches, the lowest one of which on each side is forked; the others are simple. All the lateral nerves are very strong and prominent.

Locality: Fredericksburg; not uncommon.

This handsome fern is very much like Dunker's Pecopteris Browniana, and it is even more like Pecoptcris strictinervis, it being so close to the latter that I have hesitated to separate them. The specimen shown in Fig. 4 seems to be a portion of a compound pimna which comes from the upper part of a frond where the pinnæe have become greatly reduced, and the large pinnules shown in Fig. 1, coming from the lower portion of the frond, and in Fig. 2 from the middle part, are reduced to small ovate pinnules united at the base, and to ovate teeth. The lateral nerves in the pinnules and lobes of this specimen are so distinct, that they look like threads on the surface of the plant.

\section{Pecopteris brevipennis, sp. nov.}

Plate XXI, Figs. 1-3.

Frond bipinnate or tripinnate, arborescent?; principal rachis stout and rigid : pinnules, or pinnæ reduced to pinuules, subopposite to alternate, oblong, acute to obtuse at the tips, short, very uniform in length, cut into 
ovate or rounded oblong teeth which are subacute to very obtuse; nerves in each lobe or tooth composed of a midnerve which sends off on each side alternately branehes which are single and arch upwards towards the the summits of the lobes.

Loealities: Hill-side near Potomae Run ; fishing hut, above Duteh Gap Canal ; rare at both localities.

As this plant is found only rarely and in fragments, it is possible that it may be identical with some other of the species described from the Potomae formation.

\section{Pecopteris socialis, Heer.}

Plate XXI,/Fig. 7.

Leaf-substance thick and leathery; principal rachis strong; pinnules, or pinnæe reduced to pinnules, subopposite to alternate, narrowed at the base, and eut more or less deeply into ovate-acnte to obtuse teeth; miclnerve of the pinnules, or reduced pinnæ, distinet; no lateral nerves in the lobes and teeth visible, only a midnerve.

Locality: Bank near Brooke; rare.

This plant is found rarely and in small fragments. Fig. 7 gives the largest specimen found. The detached ultimate pinnæ given in this figure agree quite well with the form given by Heer. ${ }^{1}$ The only differenee is the fact that in Heer's plant the pinnules, or redueed pinne, are opposite. This may well be the case with the Potomae plant, for the specimens found belong to the uppermost and variable portions of the frond, which often differ from the normal forms.

\section{Pecopteris angustipennis, sp. nov.}

Plate XXI, Fig. 10.

Frond and primary pinnæ unknown; pinnules, or redneed pinnæ, narrowly linear acute, eut obliquely into oblong or ovate-obtuse lobes or pinnules; the pinnules or lobes containing each a midnerve, sending off on each side alternately straight, simple branches.

Locality: Fishing hut above Duteh Gap Canal; very rare. 
The true character of this plant can not be made out until more and better specimens are found. It has some resemblance to Pecopteris ovatodentata, and may possibly be the same with that fern.

Pecopteris Browniana, Dunker.

Plate XXII, Figs. 10, 11; Plate XXII, Figs. 2-7; Plate XXVI, Figs. 3, 13.

Pecopteris Browniana, Dunker, Monograph, Pl. VIII, Fig. 7.

Alethopteris Brouniana, Schimper, Traité, III, p. 503.

Pecopteris Browniana, Schenk, Foss. Flor. Nordw. Weald., PI. V, Figs. 2, $2^{n}$.

Alethopteris Browniana, Schenk, Foss. Flor. Nordw. Weald., PI. XXVI, Figs. 3-5.

Frond tripinnate, arborescent; the rachises of different orders are comparatively stout and rigid; ultimate pinnæ short, subopposite or opposite, linear, acute; pinnules varying considerably in different parts of the frond, usually quite small, in shape oblong-obtuse to subacute; separate at base in the lower portions of the frond, mited slightly in the upper portions, generally separate; in the upper part of the frond the pinnæ reduced to pinnules, either toothed or with entire margins, the former much narrowed at base, forming a sort of petiole.

Localities: Fredericksburg; Baltimore, among the plants collected by Meek, and at Covington street; red clay ball in the banks of Dutch Gap Canal; hill-side near Potomac River; 72d mile-post, near Brooke.

This elegant little plant is one of the most widely diffused ferns of the Potomac formation. It is at the same time quite well preserved in the specimens found, hence the different parts can be made ont pretty well. It being thus fully represented, some of the specimens differ somewhat from the European forms of the Wealden. The drawing, Pl. XXII, Fig. 11, is from a specimen collected by Mr. Meek. The nerves of this species, although not strong, are very distinct.

\section{Pecopteris pachyphyla, sp. nov.}

Plate XXVI, Figs. 4,5 .

Frond bipinnate or tripinnate; rachis in pinnæe of all orders, comparatively stont and rigid; nltimate pinnæ in the lower part of the frond linear, in the upper part oblong-lanceolate; all alternate; pinnules very small, oblong, very obtuse, subopposite, slightly falcate, united at base to 
form a wing, with margins undulate or crenate; leaf-substance very thick and leathery; nerves composed in each pinnule of a midrib, which extends to the tip, and sends off alternately on each side into the teeth simple branches, all sharply defined.

Locality: Fredericksburg; not uncommon.

This little fern, although found only in small fragments, seems to be very well characterized. It has some of the features of a Thyrsopteris, and perhaps should be placed in that genus rather than in Pecopteris. It is not closely allied to any described plant known to me.

\section{SPHENOPTERIS, Brongn.}

Herbaceons plants, with fronds ranging from pinnate to tripinnatifid; pinnules cumeate or lobed, lobes dentate or subdivided; primary nerve slender, towards the summit often bifid or dissolved into branches; secondary nerves diverging towards their extremities, or prolonged into the lobes or teeth.

This genus is another of the heterogeneous groups which serve to collect together ferns which may belong to quite distinct genera and species, but which have in common certain features not dependent upon the fructification, and are not otherwise characterized. The number of ferns of the Sphenopteris type found in the Potomac flora is small. I place provisionally in this genus a small number of forms. There are a number of plants in the Potomac flora, especially those of the type of Sphenopteris Mantelli Brongn., which have predominantly the character of Thyrsopteris. These I have placed under this ldtter genns.

SPHENOPTERIS THYRSOPTEROIDES, sp. nov.

Plate XXY, Fig. 3; Plate LVIII, Fig. 5.

Frond unknown; rachis of the principal pinnæ winged, nltimate pinnæ opposite or alternate, short, and terminating in incised and lobed segments with acute tips, broadly wingerl; pinnules narrowed at the base, incised into oblong acutely dentate lobes, or cut into oblong acute teeth; leaf-substance thin ; nerves few and distinct; nerves in each pinnnle com- 
posed of a midnerve, which sends off very obliquely alternate forked or simple nerves that go into the lobes and teeth. In each segment there are several nerves, which diverge flabellately into the teeth.

Localities: Fredericksburg; fishing hut above Dutch Gap Canal; rare.

This small plant has a well-marked Sphenopteris facies. It is something like Sphenopteris Williamsonis Brongn. and also resembles somewhat S. denticulata Brongn., of the Oolite of England, but seems to be distinct from both of these and a well marked new species.

\section{Sphenopteris aCrodentata, sp. nov. Plate Xxxiv, Fig. 4.}

Frond tripinnatifid; secondary pimn opposite, very short, terminating in a round-lobed segment which is cuneate at base; ultimate pinne or pinnules subopposite, the lower ones cut obliquely in broadly elliptical lobes or pimnules nearly down to the midrib, lobes and pinnules narrowed towards their bases, the upper ones reduced to pinnules which are first lobed and then simple; pinnules and lobes at their summits rounder, very obtuse, and furnished with very minute teeth; nerves of the rounded lower pinnules and of the lobes, several times forked and diverging flabellately, the ultimate branches ending in the teeth.

Localities: Fishing hut above Dntel Gap Canal ; Baltimore, on Covington street; very rare at both localities.

The specimens figured come from the Dutch Gap locality. The plant is more common here than at Baltimore. A small fragment only was found at the latter place.

\section{Sphenopteris latiloba, sp. nov. \\ Plate XXXV, Figs. 3-5; Plate XXXVI, Figs. 4-9; Plate XXXVII, Fig. 1.}

Frond tripinnate, arborescent; principal rachis very stnut; leaf-substance thick and coriaceons ; primary pinnæ opposite, and having a stont, rigid rachis, which is often somewhat flexuous; ultimate pinnæ remotely placed, very short, passing towards the summit of the principal pinna or of the frond through lobed pinnules into entire ones; pinnules remotely 
placed, cuneate at base, those in the lower part of the frond cut more or less deeply into oblong acnte to obtuse lobes, passing towards the tips of the ultimate pinnæ into lobed pinnules like those of the upper part of the frond, and at the tips into ovate or oblong lobes and teeth. In the upper part of the frond they are elliptical, three lobed, or entire; all the pinnules and segments are broad. The ultimate pinne and the pinnules of the lower part of the frond usnally terminate in three lobed segments or in broad elliptical pinnules. The nerves are copiously branched, diverge flabellately into the lobes and teeth, and are very distinct and strong.

Localities: Fishing hut above Dutch Gap Canal, rather common; Fredericksburg; Deep Bottom; near Telegraph Station; at all except the first rare.

This is the most common fern at the fishing hut above Dutch Gap Canal, and a number of good specimens were found there, although none of them are of large size. Pl. XXXV, Fig. 4, is somewhat different from the normal forms in showing a keeled principal rachis, and in the narrower segments of the pinnules. It resembles Pl. XXXVII, Fig. 1, the only specimen fonnd at Deep Bottom. In Pl. XXXVI, Figs. 5-8, are given the normal forms which are most common at the fishing hut locality. None of the specimens show apparently anything more than fragments of a compound pinna, which, in the case of the stontest forms, may be a primary pinna. The rachises of the compound penultimate pinnæ are sometimes swollen at the insertion of the ultimate pinne. The plant is a very well characterized one, and can nsually be distinguished at a glance. It is one of the more widely diffused ferns of the Potomac flora. It is not nearly allied to any previously described plant known to me.

\section{Sphenopteris Mantelli Brongn.}

Plate L, Figs. 1,2.

Frond bipinnate or tripinnate; primary pinnæ in ontline ovate-lanceolate, acuminate; secondary pinnæ alternate, approximate, erect, fastigiate; pinnules alternate and opposite, straight, linear, or linear-cuneate, at base adnate and decurrent, at the apex acuminate, very entire, the lower ones often dentate or pinnatifid. 
This is Heer's ${ }^{1}$ description. To this he adds that the upper pinnules lave only a midnerve, while the lower ones have from one to three secondary nerves, which detach themselves at a very acute angle.

The species S. Mantelli seems to be quite polymorphous, and different authorities on fossil plants have mited with this species a large number of plants which vary considerably and come from widely separated regions. There is quite a large number of closely allied plants in the Potomac flora which have more or less of the characters of S. MIantelli. These may be noted as belonging to the type of this species, but it does not seem advisable to combine them under one species. Most of them have the characters of Thyrsopteris, and I have described them as belonging to that genns. It is a fact worthy of mention that there are in the Potomac flora several types which resemble described fossils, and under which a number of allied species may be grouped. Thus we find the type of Sphenopteris MIantelli, of Neuropteris Albertsii Dunkr., of Pecopteris Browniana, of Cladophlebis (Pecopteris) Whitbiensis, ete.

In using the name Sphenopteris MLantelli, I have restricted its application to the forms given on Pl. L, Figs. 1, 2, which have clearly the character of the original species. These specimens come from Baltimore, and are found among the specimens collected by Meek at that place. These specimens do not have their locality fixed exactly, but it appears probable that they were obtained from Federal Hill near or on Covington street. The fragments supposed to be S. MIantelli have the principal rachis comparatively very stout, with alternate pinnules, which are cut into narrow linear incurved lobes and teeth, each having a simple slender nerve. Among Meek's specimens there is one form given in Fig. 2, which is smaller than the normal one represented in Fig. 1. In this smaller form the principal pinnæ are opposite, and the lobes of the pinuules much more minute than in the fossil depicted in Fig 1. Probably this plant, with the more slender pinnules and lobes, simply represents a different part of the frond from that given in Fig. 1, and hence the difference in dimensions. The plant is evidently rare at Baltimore, at least on the horizon of the beds yielding the specimens found on Belt and Covington streets, for no spec- 
imens liave been found at these localities. It is probable that Meek's specimens come from a higher level, as the horizon of the Belt and Covington streets plants is not often exposed, and is shown only in excavations made near the level of these streets.

\section{Sphenopteris spatulata, sp. nov.}

Plate L, Fig. 4.

Frond unknown; pinnæ small, short, alternate, terminated with a denticnlate segment like the uppermost lobes or pinnules; pinnules minnte, lower ones spatulate and triple-toothed, upper ones spatulate and obscurely toothed; leaf-substance thick and leathery, nerves not seen.

Locality: Entrance to Trent's Reach; very rare.

The plant is so rare and fragmentary, that its full character can not be made ont. It seems to be a new species, characterized by its thick leafsubstance and very minute size.

SPHENOPTERIS PACHYPHYLLA, sp. nov.

Plate L, Fig. 5.

Frond unkuown; rachis of the penultimate pinnæ very thick in proportion to the other dimensions, apparen tly succulent; ultimate pinne or pinnules very short; pinuules or lobes broadly elliptical in ontline, cut obliquely into oblong minutely dentate lobes; leaf-substance thick and leathery; nerves not seen.

Locality: Entrance to Trent's Reach; very rare.

Although this plant is very rare and fragmentary, it differs from all others known to me in the very thick main rachis and the very small segments into which the pinnules are cut.

\section{ASPIDIUH, Swartz.}

The genns Aspidium seems to be lingely represented in the Potomac flora. The number of species is considerable, and the large number of individuals belonging to each species seems to indicate that ferns of this group were among the most common ones. The plants are quite commonly frnctified, the frnctification being often very well preserved. The large 
development of this genus introduces a strong modern element into the flora, and it is a noteworthy feature that so many well-characterized species of this genus occur with numerous forms belonging in type to the Jurassic flori.

The tribe of the Aspidiere is represented in the Potomac flora by forms that belong to the generic types of both Aspidium proper and Didymochlana. As with these imperfect specimens the identification can not be certainly made with the one genus or the other, it seems best to place them all provisionally under the principal genus Aspidium. It should be noted, however, that some of these species may belong not to the tribe of Aspidiea, but to that of the Davalliece.

Aspidium Frederichsburgense, sp. nov.

Plate XI, Figs. 1-6; Plate X1I, Figs. 1-6; Plate XVI, Fig. 9 ; Plate XIX, Figs. 6, 7.

Frond bipinnate or tripinnate, arborescent; rachis of the penultimate pimm very stout and rigid; pinnæ of the ultimate order mostly alternate, rarely opposite or subopposite, with rigid and proportionally rather slender rachises, very long, linear; pinnules alternate, oblong or ovate, obtuse, slightly falcate, and usually somewhat rounded and narrowed at the attachment to the rachis, separate, those of the lower pinnæ with crenate margins, those of the upper ones entire, passing in the middle part of the frond through pinnules with undulate margins; leaf-substance thick and leathery; midnerve similar to that of Cladopllelis, that is, strong at base and dissolving into branches at the summit; lateral nerves of the crenate and undulate pinnules in groups in each tooth, composed of a midnerve which sends off alternate simple branches, or else of forked nerves with one of the branches forking again; those of the pinnules with entire margins usually once forked, all quite distinct; sori very large, reniform in shape, and distributed in two rows, one on each side of the midnerve, attached to the summit of the upper branch of a furcate nerve.

Localities: Fredericksburg; and near Telegraph Station.

This plant is one of the most common ferns at Fredericksburg. All the specimens figured come from this place, except that in Pl. XI, Fig. 1, which comes from near Telegraph Station, where the plant is not rare. 
Its relative abundance at Fredericksburg may be due to the fitness of the plant for preservation, since it has a leathery durable leaf-substance. To judge from the specimen given in Pl. XII, Fig. 1, the plant must have attained a very large size, for this specimen is probably nerely a compound pinna not of prinary rank. Fig. 3 of the same plate probably represents a similar part of the frond, but down lower, where the pinnules show incipient toothing. Fig. 5 of this plate shows pinuules wider than usual, with slightly undulate margins. Fig. 6, same plate, probably comes from the uppermost part of the frond, where the ultimate pimn are reduced to lobed pinnules.

The ultimate pinnæ of the lower part of the frond, as shown in Pl. XL, Fig. 3, must have been very long. Fig. 6 of the same plate may possibly belong to a different species, but more probably represents a somewhit abnormal form coming from high up on the frond. Pl. XIX, Fig. 7, gives opposite ultimate pinnæ, a rare occurrence. The sori in this fern are proportionally very large.

The plant has no close affinity with any described fossil known to me. It is nearer Aspidium Oersted $i^{1} \mathrm{Heer}$, than any other.

\section{Aspidium ellipticui, sp. nov.}

Plate XIII, Figs. 9, 10.

Frond bipinnate or tripinnate, arborescent; rachis of the principal pinna stout and rigid; ultimate pinnæ alternate, short, oblong-lanceolate, terminating in an elliptical obtuse pinnule or lobe, which is similar to the pinnules lower down on the pinna; lower pinuules distant, elliptical in sliape, obtuse, attached by the middle of the much narrowed base, or by the midnerve alone; "pper pinnules attached by the entire widened base; uppermost ones united towards the tip of the pinna; all very thick and leathery in texture; lateral nerves not distinct, but apparently simple, and bearing the sori on their summits; sori pear-shaped or truncate-elliptical, in two rows, one on each side of the midnerve; sterile forms not seen.

Localities: Hill-side near Potomac Run; bank near Brooke: rare. 
Only the fructified form of this fern was seen. The dehiscence of the sori seems to be marginal, and there are indieations of the escaping sporangia, as shown in Pl. XIII, Fig. 9, which represents a greatly enlarged sorus. The plant seems to be a distinet new species.

\section{AsPidium HeTEROPHYLLUM, sp. nov.}

Plate XIV, Figs. 1-5; Plate XV, Figs. 1-5.

Frond tripinnate, arborescent; rachises of the pinnæ of various orders, strong and rigid; principal pinnæ very large, spreading widely; penultimate pinnæe alternate, in ontline elougate-oblong or elliptical, acuminate, abruptly and greatly narrowed towards the summit, slightly so towards the base; ultimate pinnæ linear, acute, quite short, being longest towards the middle of the penultimate pinna, at first rapidly shortened towards the npper part and then gradually giving the actminate terminations of the penultimate pinne. The basal ultimate pinna on the lower side of the penultimate pinne is usually abnormally short and broad, being inserted in the angle made by the junction of the penultimate pinna with the principal rachis.

Towards the summit of the penultimate pinne the ultimate ones pass tinough pinna rednced to toothed pinnules into those which finally become simple pinnules; pinnules varying according to position on the frond, usually alternate, short, acute to obtuse, slightly falcate-ovate, attached by a widened base; those from the lower part of the frond with dentate or undulate margins, those from the middle portions with entire margins, those from the summit of the pinnæ of the varions orders united to form teeth. The basal pinnule on the lower side of the ultimate pinna, inserted in the angle between the ultimate and penultimate rachises and partly on the latter, differs from the normal pinnules in shape and size, being heteromorphous and larger thai the normal one. It is furnished with a lobe or tooth on the lower side. In the sterile forms the character of the pinnules and of the nervation is that of Cladophlebis. The pimnules have each a midnerve sending off alternately on each side slender but distinct lateral nerves, simple or once forked. Fructified forms have the pinnules mostly obtuse, while those in the sterile portions are acute; the sori are 
placed on the lower portion of the pinnules in a row on each side of the midnerve, and extend nearly to the summits of the pinnules. They are reniform, proportionally large, and inserted in the end of the upper branch of a forking nerve.

Locality: Fredericksburg.

This beautiful fern is not very rare at Fredericksburg. It has afforded the most perfect specimens found of the ferns of the Potomac flora, and a sufficient number of them has been obtained to give a pretty good idea of the character of the plant. From the size of some of the specimens we may conclude that it attained the dimensions of a tree, for all the specimens seem to be fragments of compound pinnæ, which were probably not of primary rank. Pl. XIV, Fig. 1, seems to show a portion of the upper part of a compound pimna, and Fig. 2 to represent a portion of a penultimate pinna coming from a part of the frond lower than Fig. 1, and luence larger. Fig. 3 seems to show the summit of a compound pinna like Fig. 1, and the same may be said of Pl. XV, Fig. 2. Portions like Pl. XIV, Fig. 5, and Pl. XV, Fig. 4, appear to belong to the lower part of the frond, where the pinnules begin to show division into teeth.

This plant is not very near any described fern. The sterile portion reminds one of Cladophletis parva for this part of the fern belongs to the type of Cladophlebis. The plant is a little like Aspidium Oerstedi Heer, but ean not be identified with that species.

\section{Aspidium Virginicum, sp. nov.}

Plate XV, Fig. 7 ; Plate XXI, Fig. 14.

Frond bipinnate or tripinnate; arborescent?; rachis of the principal pinna stout and rigid; pimæ of ultimate order reduced to pinnules in the terminal portions of the penultimate pinnæ, alternate, linear lanceolate, passing through pinnately lobed pimme into pinnules with entire margins; leaf-substance thick and leathery; nerves slender, immersed in the leatsubstance, and seen with difficulty; pinnules of the lower pinnæ opposite, separate to the base; attached by the entire base, elongate oblong, subacute, with denticulate margins; sterile form of the frond not seen; sori comparatively small, reniform, in two rows, one on each side of the midMON $\mathrm{xV} \longrightarrow 7$ 
nerve of the pinnules, and placed at the summit of the upper branch of a forking nerve.

Localities: Road-side near Potomac Run; 72d mile-post, near Brooke ; rare.

This ferm is son:athing like the living species Nepluodium acutum Hook, and has no near affinity with any described fossil. As its sterile form has not been found, its full character can not be made out.

Aspidium angustipinnatum, sp. nov.

Plate XVI, Figs. 1,3,8; Plate XVII, Fig. 1; Plate XIX, Fig. 10.

Frond bipinnate or tripinnate, arborescent; in the sterile forms the principal rachis is stont, straight, and rigid; the ultimate pinne alternate, with a strong stiff rachis, linear-lanceolate, comparatively short; pinnules in sterile and fertile forms Pecopteris-like, closely*placed, separate to the base, opposite, rarely subopposite, linear, slightly falcate; leaf-substance thick; sterile leaves in the lower part of the frond denticulate, towards the summit of the compound ultimate pinnæe united and passing into lobes; midnerve of sterile and fertile pinnules continning to the sumnit of the pinnules; lateral nerves of the sterile pinnules of the lower and middle portions of the penultimate pinnæe furcate towards the base of the pinnules and simple towards their tips; in the upper pinnules mostly simple, in the fertile pinnules furcate, and bearing the sori on the end of the upper branches.

In the fertile forms the principal rachis is comparatively slender, the ultimate pinnæ are opposite and widest towards their middle, and quite long; the sori are placed on the margin of the pinnules, unlike those of the preceding species, which have them within the margin. The sori are comparatively large, reniform in shape, placed in a row on each side of the midnerve, and in no case extend to the tips of the pinnules. They diminish in numbers in passing from the pinnules of the lower part of the ultimate pinnæ to those of the upper portion, and disappear a little beyond the middle portion of the pinnæ.

Localities: Entrance to Trent's Reach; fishing hut above Dutch Gap Canal; Fredericksburg; hill-side near Potomac Run. 
The fine specimens depicted in Pl. XVII, Fig. 1, and Pl. XVI, Fig. 3, come from the entrance to Trent's Reach. The latter seems to be the upper part of a compound pinna. The sori are comparatively large. Nerves occur on all of the pinnules. They are most numerous on the pimnules near the base of the ultimate pinnæ, and are not present at all on the pinmules towards the end of these pinnæ. A noteworthy feature of the fructified pinnules is the fact that the basal ones are shorter and smaller than those towards the middle of the ultimate pinnæ. In this feature, and in the opposition of the ultimate pinnæ, the fertile form differs from the sterile one. The plant seems to be not near any described form. It is more like Aspidium Jenseni Heer, than any other.

\section{Aspidium cystopteroides, sp. nov.}

Plate XVI, Fig. 2.

Sterile fronds not seen; rachis of ultimate pinmæ slender; pinnules alternate, attached by the middle portion of the base, crenately toothed, obtuse; sori rather large, in two rows, one on each side of the midrib, placed near the margin, on the summit of the uppermost branch of the nerves; subglobose in shape, similar to those of Cystopteris, with an inflated indusium at base; nerves branching palmately in each tooth.

Locality: Fredericksburg.

This pretty fern is very rare at Fredericksburg. It is much like the genus Cystopteris of the Aspidece. It does not seem to be nearly allied to any described fossil.

\section{Aspidium Oerstedi? Heer.}

Plate XIX, Fig. 4.

(See Heer, Flor. Foss. Arctiea, vol. 6, Part 2, Foss. Flor. Grönlands, p. 30; vol. 7, p. 2.)

Pinnules narrowly linear, acute, with minute teeth directed forwards; nerves simple, parallel and ending in the teeth.

Locality: Near. Telegraph Station.

This plant, although found in only one small fragment, is quite distinct from all others of the Potomac flora. I mite it with Heer's plant provisionally and with doubt, as the fraghent is too small to give the full character 
of the fern. It may be compared with that shown in Vol. VII of Heer's work just cited, PI. XLTIII, Fig. 11.

\section{Aspidium obLONGIFOLIUM, sp. nov.?}

Plate XX1, Fig. 5.

Pinuules oblong, slightly falcate, acute, dentate; sori in a row on each side of the midnerve, on the summits of the single lateral nerves, round to broadly elliptical in shape, comparatively large.

Locality: Road side near Potomac Run; very rare.

This is an Aspidium of the Didymochlœna type. It may belong to some of the elsewhere described Potomac forms.

\section{AsPidium PARVIFolium, sp. nov.}

Plate XXI, Fig. 6; Plate XXIV, Fig. 8; Plate XXV, Fig. 10; Plate XXVI, Figs. I, I4, I6, I7.

Frond bipinnate to tripinnate; ultimate pinnæ alternate; pinnules, or reduced pinnæ alternate to opposite, in the sterile portions small, oblonglanceolate, acute, with winged rachises, pinnules or reduced pinne of the lower pinne cut into ovate small lobes, the lowest ones being minutely toothed, the upper pinnules also minutely toothed; nerves of the lowest lobes or teeth composed of a midrib, which sends off on each side, alternately, simple nerves; in the upper lobes and teeth they are furcate; leafsubstance thin, and usually decurrent; in the fertile portions the pinnules or reduced pinnæ are ovate-oblong, obtuse, witl ovate-acnte lobes, the two lower being slightly dentate; nerves in the lower lobes simple, and alternately given off on each side of a slender midrib, these in the middle and upper lobes several times or simply forked; in the sterile forms the basal upper lobe of the pinnules or reduced pinnæ usually larger than the others and directed upwards parallel with the penultimate rachis; sori subglobose in the two basal lobes and situated on the summit of the midrib and of all the lateral nerves, but in the ligher lobes mostly single in each lobe, and placed on the summit of the upper branch of the lateral nerves.

Localities: Fredericksburg; red elay ball in the banks of the Dutch Gap Canal; fishing hut above this canal; rather rare at all places.

This is an Aspidinn of the Polystichum type. It does not seem to be near any described plant. 


\section{Aspidium pinNatifidum, sp. nov.}

Plate XXI, Fig. 15.

Frond unknown; probably bipinnatifid; reduced pinnæ or pinnules, linear, cut pinnately nearly to the rachis into ovate-falcate obtuse lobes or pinnules; leaf-substance thick and leathery; sori in a row on each side of the midrib, elliptical in shape and small, placed on the simple lateral nerves within the margin of the lobes.

Locality: Bank near Brooke; very rare.

This is another of the Aspidiex of the Didymochlona type. It is not nearly like any described fossil.

\section{Aspidium Dunkeri Schimper; sp.}

Plate XXII, Fig. 9; Plate XXV, Figs. 11, 12; Plate XXV1, Figs. 2, 8, 9, 18; Plate LIV, Figs. 3, 9.

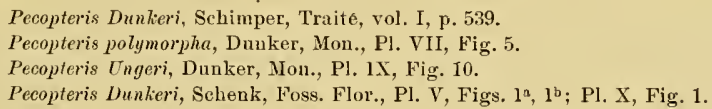

Frond bipinnate or tripinnate, arborescent; principal rachis stout and rigid; ultimate pinnæ alternate, slort, linear-lanceolate; pinnules alternate or subopposite, short, closely placed, narrowed at the base, cut more or less deeply into lobes or teeth which are ovate or oblong, obtuse or subacute, very small, those of the fertile portions of the frond standing nearly perpendicular to the rachis and laving in each lobe or pimule a simple lateral nerve which bears a sorus on its summit, those of the sterile and more common portions more obliquely placed, mostly subacute, with nerves in each lobe that fork simply in the upper ones, and in the lower ones are composed of a midnerve with alternate simple branches; leafsubstance thick; sori very nimute, club-shaped or elliptical, visible distinctly only with the leelp of a lens, and present only in the pinnules of the lower part of the pinnæ, and mostly found on the lobes towards the base of these.

Localities: Near Telegrapl Station; red clay ball in the banks of Dutch Gap Canal; Fredericksburg; entrance to Trent's Reach; fishing hut above Dutch Gap Canal; rather rare at all localities. 
This very finely cut fern is found most abundantly at the fishing hnt above Dutch Gap Canal, but is not very common even there. The sori are so small and the fertile pinnules so leathery that they can be seen only when the lower surface is uppermost. In Pl. XXII, Fig. $9^{a}$, is given a magnified pimnule with its lower surface uppernost; in Fig. ? ? a similar pinnule with its upper surface uppermost, and showing no sign of sori. This latter is the common aspect of the plant. This may explain why the sori were not seen by Dunker and Schenk. It seems to be certainly Dunker's species. The lobes in most of the specimens seem to be more closely placed than in Dunker's plant. It is one of the most widely diffused ferns of the Potomac flora.

\section{Aspidium DENTATUM, sp. nov.}

Plate XXV, Figs. 6, 7, 14, 15.

Frond tripimate; principal rachis comparatively stont and rigid; ultimate pinnæ alternate, very short, linear-lanceolate; pinnules membranaceous, alternate, lower ones separate to the base, npper ones united and reduced to lobes; lower pinnules broadly ovate, acute, narrowed to the base, and subpetiolate, ent nearly to the midnerve into ovate, acute teeth, reduced in the upper part of the compound pinnæ to ovate, obtuse lobes and teeth; sori very small, subreniform or globose, placed within the margin on the summit of the alternate simple lateral nerves; nerves in each of the pinuules and lobes, composed of a midnerve, with simple alternate lateral ones on each side; in the uppermost lobes the nerves become one or more times forked, without a midnerve.

Localities: Red clay ball in banks of Đutch Gap Canal; hill-side near Potomac Run; near Telegraph Station; rare in most of the localities.

This pretty little plant is rather abundant at the locality on the hillside near Potomac Run. Forms such as Fig. 15 are quite common here, but as a rule show no fructification. The fructified specimen, Fig. 1t, was found in the red clay ball in the banks of Dutch Gap Canal. Fig. 15 is a good deal like the smaller forms of Thyrsopteris Mirrayana (Brongn. sp.) Heer, but is no doubt a distinct species. 


\section{AsPIDIUM MACROCARPUM, sp. nov.}

Plate XVII, Fig. . .

Sterile frond not seen; fertile frond showing only a skeleton imprint; principal rachis stout and rigid; plant most probably arborescent; rachis of the nltimate pinne stont and rigid; shape and dimensions of the pinnules not disclosed; apparently large, elongate-oblong, attached by the entire base, alternate; midnerve rather slender, straight; lateral nerves simple, and bearing at their summits the sori arranged in a row on each side of the midrib. The sori are very large, reniform in shape, and seem to have been situated near the margin of the pinnules. Under a good lens the sporangia may be seen arranged often in a band near the margin of the sori.

Locality: Red clay ball in the banks of Dutch Gap Canal; rare.

This plant seems to have been a fine large fern. It is seen only as an imprint on the surface of the fine clay, giving a skeleton of the more durable parts. The imprints of the sori are very distinct. The sterile form was not seen. This seems to be a species distinct from all described ones.

\section{AsPidium microcarpum, sp. nov.}

Plate LIX, Figs. 2, 12; Plate LX, Figs. 6,7.

Frond tripinnate; sterile forms have the pinnæ of ultimate order short, subopposite, with pinnules towards the base separate and rather remote, slightly decurrent, obtuse, oblong and subopposite, but towards the tips graduating into lobes and teeth which are ovate-obtuse; leaf-substance thick; lateral nerves in each pinnule or lobe composed of a micnerve, which.on each side sends off alternately branches which fork or are simple. Fertile portions of the frond have sometimes sterile and fructified pinnules on the same pinna, but usually the fructified pinnules are on distinct parts of the frond, and then the specimens found show only the skeletons of the sori and nerves, the sori by their arrangement giving the outlines of the pinnules; sori very minute, visible distinctly only with the help of a strong lens; rounded in shape, and arranged in a row on each side of the midnerve, placed at the summit of a simple lateral nerve. 
They extend from the base to the summit of the pinmules. The arrangement of the sori indicates that the fructified pinnules in the lower pinnæ are toothed or lobed, and that towards the summit of the compound pinne they gractuate into lobes and teeth.

Locality: Hill-side near Potomac Run; very abundant.

The fructified forms are the common ones, sterile forms are very rare. Numerous specimens, such as are depicted in Pl. LIX, Fig. 12, and Pl. LX, Fig. 7, and smaller ones, may be found bere, the pinnules being reduced to imprints of the sori and principal nerves. The plant seems to be a very well marked new species.

\section{POLTPODIUM, L.}

The genus Polypodium, if it exists in the Potomac flora, is not represented by many species. The imperfect preservation of the specimens does not permit the certain determination of the genus, but there are two species which agree better with this genus than any other, and for this reason I place them provisionally in it.

Polypodium fadyeniolde, sp. nov.

Piate XVI, Figs. $4,5$.

Pinnules narrow and linear, obtuse; fragments of the fertile ones alone were seen; leaf-substance very thick and leathery; sori very large, globose in shape, placed on the ends of strong simple lateral nerves, which are at their summits expanded into club-shaped receptacles arranged in a row on each side of the midnerve of the pinnules, a little within the margin, and extending nearly from the midnerve to the margin.

Locality: Road-side near Potomac Run; very rare.

The pinnules of this plant seem to have heen narrow and long, very thick and leathery. The club-shaped summits of the nerves which supported the sori appear, when the upper surface of the pinnules is presented upwards, showing through the leaf-substance as elliptical elevations, looking like sori, as shown in Fig. 5. Figure 4 represents, slightly enlarged, a fragment of a much longer pinnule with the lower side uppermost, showing the character of the very large sori. A granulation is seen with the help 
of a lens over the surface of the sori, as if caused by the sporangia. No indusinm appears.

This fossil is a good deal like the living Ferlyenia proliferc, and the specific name is chosen from this resemblance. It is a little like Nathorstia angustifolia Heer, ${ }^{1}$ but is distinct from that plant.

Polypodium dentatum, sp. nov.

Plate XXII, Figs. 4, 5.

Frond bipinnatifid; pinnæe in the sterile forms of ultimate order, or pinnules linear-elongate, cut more or less deeply into broad, ovate, sliglitly falcate, acute lobes or pinnules; midnerve of the pinnæ strong and rigid; nerves of the lobes or pinnæ composed of a nerve-bundle formed by a parent nerve which goes off obliquely and curves outward towards the outer edge of the lobes, sending off branches only from the upper side; the branches curved strongly outward, and each twice forked, except the upper one, which is once forked; fertile pinnæ or pinnules serrate, narrowly linear; nerve-bundles in each tooth branching and diverging flabellately from the insertion, the lower branch forking several times, the upper one simple and directed obliquely upwards, bearing on its summit in each tootl an obovate sorus.

Locality: Fredericksburg; very rare.

This seems to be a very distinet species. The lens shows a granulation over the surface of the club-shaped sori which seems to be caused by tho sporangia.

\section{ACROSTICHUM, L.}

The genus Acrostichum seems to be represented in the Potomac flora by the small fragment described below. It also has near allies in the new gentus Acrostichopteris, so abundant at Baltimore.

Acrostichum Crassifolium, sp. nov.

Plate XVI, Fig. 7.

Frond and pinnæ not seen; pinnules very obtuse, thick and leathery in texture; nerves not seen distinctly; sori small, in three double rows, each row separated from its fellow by a pretty distinct line, which is

${ }^{3}$ Flor. Foss. Arc., vol. 6, part 1, No. 2, Pl. I, Figs. 1-6. 
apparently a nerve. The entire under surface of the pinnule is covered by the sori.

Locality: Fredericksburg.

Only a small fragment of this curious fern was found, and consequently little can be made out as to its true nature. It seems to be quite different from all previously described fossils.

\section{ACROSTICHOPTERIS, gen. nov.}

Fronds probably creeping, with very long, often flexuous rachises, which seem to have been more or less succulent; pinnæe going off obliquely, long and apparently slender; ultimate pinne or pinnules subopposite to alternate, comparatively short, and cut down nearly to the rachis into more or less cuneate-flabellate pinnules or primary segments. These are divided generally into cuneate-flabellate segments, which in turn are separated into oblong segments ending in oblong, or ovate-obtuse, or acute teeth; pinnules decurrent and forming a wing; nerves slender but distinct, flabellately diverging, forking dichotomonsly, and ending in the teeth; fructification occurring on the basal segments of the pinnules, in the upper portions of the frond on the upper one alone, in the lower portions on the upper and lower ones, the fructified segments close appressed to the principal rachis. The fructified segments are so morlified as to take the form of leathery, rounded, or elliptical segments, which on the lower side are covered by the naked sori, and seen from the upper side, especially when compressed on the clay, look like pods.

This curious genus of ferns seems to be of a composite character The sterile forms look so much like Baieropsis that before the fructified forms were found, which occur only at Baltimore, they were taken to be small forms of that genus.

The genus in the naked sori is like Polyporlium, but in most features stands nearest to Acrostichum, much resembling the section Rhipirlopteris. In this latter, however, the fructification is borne on separate pinnnles. If we place the fructified pinnules of Rhipidopteris as basal segments on the sterile ones, we have a form strikingly like Acrostichopteris. This genus has also some resemblance to Marsilea. 


\section{ACROSTICHOPTERIS LONGIPENNIS, sp. nov.}

Plate CLXX, Fig. 10 ; Plate CLXXI, Figs. 1, 5, 7.

Fronds with very long, more or less flexuous pinnæ, apparently creeping; ultimate pinne or pinnules subopposite to alternate, going off at a large angle and arching slightly away from the principal rachis, ending in one or two oblong lobes which have oblong blunt teeth. At base they are cut into pinnules or segments which are cuneate, fan-shaped, and these in turn are cut into oblong segments, which end in oblong or ovate-subacute teeth; the pimules or segments, in ascending from the base of the ultimate pinnæ towards their summits, diminish in the number of segments; nerves slender but distinct, fabellately diverging and forking dichotomously, the ultimate branches ending in the teeth; fructification as in the genus, and occurring on the basal upper lobe in the upper part of the frond. In the lower parts of the same they are found on the upper and lower basal lobes; the fructified lobes rounded or elliptical, and close appressed to the principal rachis.

Localities: Abundant at Belt and Covington streets, Baltimore; most common at the first-named locality.

Pl. CLXXI, Fig. 1, seems to represent a sterile form. This comes from Belt street. Figure 7 of the same plate has both of the basal lobes fructified. This comes from Covington street. Figure 5 of the same plate has only the fructified lobes retained on the principal rachis.

Acrostichopteris denstFolia, sp. nov.

Plate XCIV, Fig. 4; Plate CLXX, Fig. 11; Plite CLXXI, Figs. 2, 6; Plate CLXXII, Fig. 13.

Principal rachis slender; ultimate pinne or pinnules densely crowded, often overlapping, very broad in proportion to their length, lower ones sometimes abnormally short and wide as compared with those higher up, being broad, fan-shaped in ontline; primary segments or pinnules diminishing towards the ends of the nltimate pinne in the number of segments: lower pinnules or segments cnt into two or three main lobes, narrowly oblong or ovate, ending in minute teeth; nerves as in generic description; fructification on the lower basal lobe or on both; fructified lobes elliptical in shape and proportionally very large. 
Localities: It is common on both Belt and Covington streets, Baltimore, and is rare at the fishing hut above Dutch Gap Canal.

Only the sterile form, Pl. XCIV, Fig. 4, was found at the last-named locality. Fructified forms are the most common ones at Baltimore, and the same is true of the preceding species, A. longipennis.

Acrostichopteris parvifolia, sp. nov.

Plate XCIV, Figs. 5, 9, 10, 12 ; Plate CLXXI, Figs. 3, 4; Plate CLXXII, Fig. 14.

Principal rachis comparatively very stout and rigid; ultimate pinnæ or pinnules short, remote, small; pinmules or seginents of the first order cut normally into two lateral lobes and one terminal one, the latter largest, minute; the principal lobes diverge flabellately, each being cut normally into two oblong lobes, which end either in very short acute triangular teeth, or in oblong or ovate-obtuse to acute ones; nerves forking dichotomously, flabellately diverging, the ultimate branches ending in the teeth.

Localities: Belt and Covington streets, Baltimore; although rare there, the most abundant species of the genus at the fishing lut above Dutch Gap Canal; rare at the entrance to Trent's Reach.

Acrostichopteris parcelobata, sp. nov.

Plate XCIV, Figs. 6, 7,11, 14 .

Ultimate pinne or pinnules very short, terminating in a three-lobed segment or pinuule; principal segments or pinnules rapidly diminishing in ascending in the number of segments or lobes; the lowest pinnules or principal segments narrow and cuneate at base, as are all, mostly cut deeply into two unequal lobes, the upper ones being the snaller, both subdivided one or more times into strap-shaped lacinix, which end in narrowly oblong obtuse teeth; nerves forking repeatedly in a dichotomous manner, so that the ultimate branches end in the teeth; fructified forms not seen.

Localities: Fishing hut above Dutch Gap Canal; road-side near Potomac Run; rare.

The one shown in Fig. 11 from the Dutch Gap locality differs somewhat from that in Fig. 6 from the same locality and from that in Fig. 7 
from near Potomac Run, but the difference is not sufficient to separate them. Figure 14 gives, magnified, a complete leaf corresponding to those of Fig. 7, but more complete than any found on that specinen.

\section{ACROSTICHOPTERIS CYCLOPTEROIDES, sp. nov. \\ Plate XCIV, Fig. 8.}

Pinuules rounded, fan-shaped, cyclopteris-like in form, divided to the base into three principal lacinix, which in turn are subdivided at different distances from the base into subordinate lobes; laciniæ all oblong, diverging flabellately, the principal ones cuneate at base; they end in obtuse oblong teeth, which are quite narrow; nerves obscure, but, as in the generic description, dividing repeatedly in a dichotomous manner from the base and diverging flabellately, so that the ultimate branches end in the teeth; fertile forms not seen.

Locality: Fishing hut above Dutch Gap Canal; rare.

Several specimens of this plant were found, but they appear only in the form of detached pinnules, one of the lirgest of which I have figured. It has a small bit of the rachis still attached. This plant shows a number of detached pinnules lying as if they had fallen from the same plant. It is more like Baieropsis than any of the species of Acrostichopteris, and in its fragmentary state, with fructification not shown, it may belong to that genus of conifers.

\section{ASPLENIUM L:}

The genus Asplenium found by Heer so abundant in the Jurassic flora of Siberia is not determined positively in the Potomac flora. The species described below-A. dubium-quite possibly may belong to the tribe of the Aspidiece, being found in the section with oblong sori as in Fadyenia.

\section{Asplenium nubium, sp. nov.}

Plate X, Fig. 9.

Frond bipinnate or tripinnate; pinnules oblong, subacute, separate to the base, alternate, nearly at right angles with the rachis; nerves fureate, bearing the sori on the end of the upper branch, sori elliptical, in a row 
on each side of the midnerve, and not extending to the tips of the pin. nules.

Locality: Fredericksburg; only one specimen found.

This plant is in too fragmentary a condition to make out its true character. The shape of the pimnules is something like that of those of Dunker's Neuropteris Albertsii. The plant is quite near to Asplenizm argutulum Heer. ${ }^{1}$

\section{THINNFELDIA Ett. (ex parte).}

Fronds bipinnate or tripinnate; pimmules varying much in size and shape, mostly oblong, ovate-lanceolate, or oblong-obovate, decurrent and mostly confluent at base, coriaceous; primary nerve of the pimmles dissolved before attaining the apex into many dichotomous nerves; secondary nerves going off at a very acute angle, diverging in ascending, several times dichotomous.

The description given above for the geuus is very nearly that given by Schimper. There are several species of ferns in the Potomac flora which would come under the group laving these characters. The plants, however, are not common, except at the 72d mile-post, near Brooke, where Thimfeldia variubilis is the most common fern.

\section{Thinnfeldia Variabilis, sp. nov. \\ Plate XVII, Figs. 3-7; Plate XVIII, Figs. 1-6.}

Frond bipinnate or tripinnate; rachises of the pinne stout, arborescent; pinnules lobed or toothed, with mostly ovate-obtuse lobes or teeth, short, varying much in size and nature according to position on the frond, passing in ascending, in the upper part of the pima, through toothed and undulate pinnules into entire ones; lower pinnules attached by the rachis alone, and deeply cut into broadly ovate-obtuse lobes; up higher in the pinnse and on the frond they have ovate teeth and are attached by the middle of the much-narrowed base, and are slightly decurrent; towards the top the ultimate pinnæe pass into crenately lobed segments and these into lobed and toothed pinnules, like those lower down; all are acute;

\footnotetext{
${ }^{1}$ Flor. Foss, Are, vol. 4 , pt. '2, Beitrïge zur Flor. Ostsib., Pl. III, Fig. 7 ; Pl. XIX, Figs. I-4.
} 
leaf-substance thick and leathery; midnerve neuropteris-like, and vanishing before attaining the apex of the pinnules; lateral nerves occur in the lower portions of the pinnules mostly in nerve groups; all go off very obliquely and fork usnally several times, very fine and closely placed, but distinct.

Localities: 72d mile-post, near Brooke, common, and the most abundant fern; road-side near Potomac Run; rare.

All the specimens figured, except that in Pl. XVIII, Fig. 6, cone from the 72d mile-post, near Brooke. Strange to say, while the plant is abundant at the 72d mile-post, not a trace of it can be seen at the "bank" near by. This is a striking illnstration of the localization of the species in this flora.

Taken as a whole this Thinnfeldia is mnlike any described fossil. Some of the pinnules in shape remind one of T. rhomboidalis Ett, given by Schenk. ${ }^{1}$

Thinnfeldia granulata, sp. nov.

Plate XXVI, Figs. 10-12; Plate XXVII, Figs. 1-5, 8; Plate CLXIX, Fig. 1.

Frond bipinnate or tripinnate; rachises comparatively stout; leafsubstance thick; pimules varying in size and shape with their position on the pinne and frond; in shape they are ovate-elliptical to subrhombic, the lower ones irregularly cut into oblong to elliptical lobes; the lower surface of the pinnules has a very fine granulation between the nerves, which can be seen distinctly only by the help of a lens; nerves elosely placed, very fine but distinct on the under surface of the pinnules, repeatedly branching: and diverging flabellately.

Localities: Fishing liut above Dutch Gap Canal, and road-side near Potomac Run; rare.

The plant occurs more commonly at the former locality, where several specimens were found. It is very rare at the locality near Potomac Run.

\section{Thinnfeldia rotundiloba, sp. nov.}

Plate XXVII, Figs. 6, 7.

Frond bipinnate or tripinnate; principal rachis rather stont; pinnules with thick texture, alternate, broadly ovate in ontline, obtuse, cut more or 
less deeply into subrhombic or broadly elliptical and rounded lobes; nerves numerons, closely placed, slender but distinct, repeatedly branching in the lower lobes, and diverging flabellately; midnerve in the terminal lobe dissolving in branches some distance below the summit, and in its lower portion sending off very obliquely nerve bundles or branches which fork one or more times.

Localities: Fredericksburg; road-side near Potomac Run; very rare.

This plant in some of its forms is something like T. granulata, but it shows none of the granulations and the pinnules are more obtuse.

\section{Stenopteris SAPORTa.}

Frond large, bipinnatifid; rachis slender and narrowly winged; pinnæ subopposite; segments of the pinnæ long, linear, bluntly terminated, showing the same width and structure as the parts to which they are attached; that is, a slender, narrowly winged milnerve, segments sometimes forkerl at their tips. This descriptim given by Schimper ${ }^{1}$ agrees well with one of the Potomac species, and for this reason I place it provisionally in Saporta's genus.

\section{Stenopteris Virginica, sp. nov.}

Plate XXI, Fig. 8.

Frond unknown; lobes of the pinnules or pinnæ of ultimate order, forking at the ends or simple; pinnules and lobes coriaceous, strap-shaped, subacute, having a single slender nerve.

Locality : 72d mile-post, near Brooke; rare.

This plant agrees with Saporta's genus Stenopteris, which contains, as far as certainly made out, only the single species $S$. desmomera. The description, however, which makes the midnerve narrowly winged does not apply, as the laminæ on each side of that nerve in the Potomac plant are comparatively wide. Only a single specimen was found at the Brooke locality. 


\section{Angropteridiun, Schimper.}

Frond simply pinnate; pinnules long, linear, more or less narrowed towards their ends, rounded at the base or nearly heart-shaped, attached to the principal rachis by the midnerve alone, which sometimes forms a disarticulating short pedicel; nidnerve strong, lateral nerves going off obliquely and abruptly, taking a horizontal position or bent somewhat obliquely upwards, simple and forked.

This description given by Schimper ${ }^{1}$ agrees exactly with a number of species found in the Potomac flora. Angiopteridium is a characteristic Jurassic type, and the number of species of this genus occurring in the Potomac flora adds decidedly to the Jurassic element otherwise so strongly represented in this flora.

\section{ANgiopteridium aUriculatum, sp. nov. \\ Plate VII, Figs. $8-11$; Plate XXVIII, Fig. 1.}

Frond pinnate; pinnules thick and leathery, long linear, subacute, remotely placed, free to the base, auricnlate at base, attached by the midrib alone; auricles of the bases of the pinnules overlapping the upper surface more or less; midrib of pinnules rather stont and rigid; lateral nerves often obscurely shown, fasciculate or bifurcate, and towards the tips simply forked.

Localities: Fredericksburg; road-side near Potomac Run; rare.

The plant is rare at each locality, but is most common at Fredericks burg. It is something like Pteris longipennis Heer, ${ }^{2}$ but there is no reason to think that it is a Pteris. It resembles Pecopteris sulicifolia, ${ }^{3}$ Oldham and Morris. The forms fignred in Figs. 8, 9, 11 ocenr at Fredericksburg; Fig. 10 occurs at the locality near Potomac Rnn. This is different from the others in the great length of the pinnules and in the fasciculate nerves, which are bifurcate, with the branches again forking near their tips. The nerves are obscure on the upper surface of the pinnules. The main rachis is stout and keeled on the under surface, as is shown in Fig. 9. On the

'Zittel's Hand-book, vol. 2, p. 134.

${ }^{2}$ Foss. Flor. Arc, vol. 6, pt. 2, Pl. X, Figs. 5-13.

${ }^{3}$ Foss. Flora of the Rajmahal series, Pl. XXVII, Fig. 2. IION $\mathrm{xV} \longrightarrow \mathrm{S}$ 
upper surface the auricles at the base of the pinnules overlap more or less the surface of the main rachis.

\section{Angiopteridium nervosum, sp. nov.}

Plate Xxix, Fig. 2.

Frond unknown; pinnules seen only in fragments, but apparently long, $3.5^{\mathrm{cm}}$ wide; midnerve comparatively very slender; leaf-substance comparatively thin; lateral nerves slender but distinct, going off at an angle of over $45^{\circ}$, arched backwards slightly for a short distance from the midrib, and then inclined forward towards the tip of the pinnules; simple or forking at various distances between the midrib and margin.

Locality: Fredericksburg; rare.

This plant was found in only a few small fragments. The nerves on the right-hand half of the figure are distorted by pressure. They are shown in their normal position in the left-hand half. It is something like Tceniopteris Stenoneura Schenk, ${ }^{1}$ and also Toniopteris tenuinervis Brauns, as given in Figs. 3, 4, of the same plate, but it is larger than either, and has the nerves more dichotomous than the last. It is also a little like Tceniopteris vittatu Brongn. It has nearly the nervation of Angiopteridium $M c$ Clellandi of the Indian flora.

Anglopteridium ellipticum, sp. nov.

Plate XxIx, Fig. 3.

Frond unknown; pinnules elliptical, length, $37^{\mathrm{mm}}$, maximum width $15^{\mathrm{mm}}$; leaf-substance membranaceous; midnerve comparatively very stont ; lateral nerves slender but very distinct, going off at an acnte angle and then obliquely ascending to the margin, mostly forked at or near the base, branches simple and nearly parallel.

Locality: Fredericksburg; only one specimen found.

This is a very distinct but unusually small plant. It seems to be nearer to Stangerites ensis Oldham and Morris, than any other. This has been made an Angiopteridium by Schimper. Possibly this may be a young leaf of some of the species described under another name in the Potomac flora.

\footnotetext{
${ }^{1}$ Foss, Flor, der Grenzschichten, Pl. XXV, Fig. 5.
} 
Angiopteridium densinerve, sp. nov.

Plate XXIX, Fig. 4.

Only a small fragment. of a pinnule seen; midnerve slender; lateral nerves slender, closely placed, going off at an acute angle and maintaining the same direction to the margin, nearly parallel, forked at the base or above.

Locality: Fredericksburg.

Only one fragment was found, but this seems to indicate a wellmarked species.

\section{ANGiOPTERIDIUM PACHYPHyLlUM, sp. nov.}

Plate XXIX, Fig. 5.

Frond unknown; pinnules apparently long and proportionally quite narrow; midrib stout and prominent; leaf-substance thick, shining, and leathery, hiding the lateral nerves on the upper side.

Locality: Fredericksburg.

Only a fragment of a pinnule was found, so that its length could not be made ont. The specimen probably presents the npper surface of the leaf uppermost.

\section{Angiopteridium ovatum, sp. nov.}

Plate XxIX, Figs. 6, 7.

Frond unknown; pinnules ovate, broad and rounded at base, truncate and serrately toothed at the tip; maximum width, $36^{\mathrm{mn}}$; length, $8^{\mathrm{cm}}$; midnerve stout at base and split up into branches at the summit; leafsubstance membranaceous; lateral nerves slender but very sharply defined, remote, going off at an acute angle, arched backward near the base and forward higher up, forked near the base or above, branches slightly diverging, mostly simple, very rarely forked near the margin.

Locality: Fredericksburg.

This is a very rare plant, but a distinctly defined one. The two specimens figured were so placed as to indicate that they belonged to the same pinnule, Fig. 7, representing the tip, corresponding to Fig. 6. 
This plant is more like Macrotceniopteris ovata Schimper, Taniopteris ovalis Oldham and Morris, from Bindrabun, India, than any other described fossil. The apparent stipe in the plant of Oldham and Morris seems to be simply a portion of the midnerve stripped of the lamina of the pinnule.

ANGIOPTERIDiUM STRICTINERVE, sp. nov.

Plate XXIX, Figs. $8,9$.

Frond pinnate; principal rachis stout and rigid; pinnules elongatelanceolate; midnerves strong, rounded, and prominent; leaf-substance thick; lateral nerves closely placed, forked mostly at their insertion, rarely higher up, sometimes simple, branches simple and parallel, arched near the base strongly backward and above curved slightly forward, thin but distinct.

Locality: Fredericksburg; rare.

Although rare, this is the most common species of the genus at Fredericksburg. In the shape of the pinnules and in the course of the lateral nerves it is something like Oleandridium tenuinerve Schimper, Tceniopteris tenuinervis Brauns, as figured by Schenk, ${ }^{1}$ but that is a simple frond.

ANGIOPTERIDIUM STRICTINERVE, var: LATIFOLIUN. sp. nov.

Plate Xxx, Figs. I, 5.

Frond unknown; pinnules larger than in the normal A. strictinerve, in some cases, as in Fig. 5, attaining the width of $44^{\mathrm{mm}}$; midrib comparatively stout; lateral nerves fine but distinct and sharply defined, often simple, forking at the base or higher up, branches simple and parallel, arched backwarcl in the lower portion of the lateral nerves and then inclined forward.

Locality: Fredericksburg; rare.

This plant is in some points similar to Angiopteridium nervosum, described elsewhere, but the nerves are finer and more closely placed. In Fig. 1 there are two fragments of pinnules so placed as to indicate that they belong to the same frond, coming off pinnately from a common rachis. 


\section{Angiopteridiun dentatua, sp. nov.}

Plate XXX, Figs. 6, 7.

Frond pinnate; leaf-substance thin; pinnules oblong-ovate, abruptly narrowed at their tips, nargins finely serrate, sometimes with double teeth; midnerves strong towards their bases and attenuate towards their summits, and near the apex splitting up into branches; lateral nerves going off at a very oblique angle and curving out to meet the margin, simply forked or several times forking, slender but distinct.

Locality: Fredericksburg; rare.

This plant in the general shape of the pinnnles and the nervation is much like the Nemropterids of the Carboniferons era, and is peculiar in the fine toothing of the margin. I place it provisionally in the genus Angiopteridium, bit possibly this and A. oratum should be made a new genus. This plant seems to be a type between Thimnfeldia and Angiopteridium.

\section{ASPLENIOPTERIS, gen. nov.}

Frond bipinnate or tripinnatifid; pinnules linear-lanceolate, or oblong, acute to obtuse, lobed or toothed, sori proportionally very large, elongate to narrowly elliptical, in a row on each side of the midrib, one in each lobe or tooth, inserted on thick supports or segments, which represent the transformed segments or lobes, placed on the anterior margin of these, and running down nearly their entire length. Type, Aspleniopteris pimatifida.

This curious type of fern differs in some respects from all described fossils. The most noteworthy feature is the contraction of the lobes or teeth of the pinnules into thick leathery supports which bear the long narrow sori on their anterior margins, the general shape and position of the sori resembling those features in Asplenium. Aspleniopteris pinnatifida may be taken as the type, that being pretty fully represented in the parts found. The genus may be compared with Dicksoniu clavipes, Heer, ${ }^{1}$ but, unlike that plant, the sori are long, narrow, and not borne always on the summit of the modified lobes. The genus seems to be a composite type, uniting the features of Pteris, Asplenium, and Osmunda, resembling the latter in

\footnotetext{
${ }^{1}$ Flor. Foss. Are., vol. 4, pt. 2, Pl. II, Fig. 7.
} 
the reduction of the lobes to mere supports for the sori. The singleness of the sori in the lobes, their great size, and anterior position form peculiar features.

\section{Aspleniopteris PINNATIFid, sp. not.}

Plate XXII, Figs. 1-3, 6,7 .

Frond tripinnatifid; rachis of the primary pinna or of the frond very stont, rigid, and straight; pinne or pinnules alternate, varying much in length according to position, with strong rigid rachises; sterile pimnules linear-lanceolate, subacnte, lower ones very long, much diminished in length in ascending, cut more or less deeply into crenate and rounded teeth and lobes; lateral nerves in each lobe flabellate diverging, with the branches forked or simple, nerves very strong and distinct; fertile pimm or pinnules very long, with strong rigid rachises, linear, subacnte; lobes or teeth reduced to thick leathery supports, which bear the narrowly elliptical sori on the anterior face; the sori very lnng, almost as long as the lobes, standing one in each lobe, apparently included between the two branches of a nerve that forks at the insertion.

Locality: Fredericksburg.

This remarkable plant is rare. I can not feel sure. that the sterile forms, Figs. 1-3, with rounded lobes belong to the same species with the form depicted in Figs. 6, 7, possessing narrow subacnte fructified lobes, but the nervation and general character of the segments of the pinna indicate that they belong to the same species. The partially fructified form Pl. XXII, Fig. 7, has the lobes on the upper side mostly sterile, indicating how they are modified in the development of the sori.

Aspleniopteris adiantifolia, sp. nov.

Plate XVI, Fig. 6.

Sterile frond not seen; fertile frond bipinnate or bipinnatifid; pinnules or lobes reduced to leathery thick pedicels or supports, which bear on their anterior or upper margin narrowly elliptical or oblong sori; sori proportionally very large.

Locality: Fredericksburg; very rare. 
This small plant was found in too fragmentary a condition to permit its full character to be made out. It has some features that resemble those of Adiantum, especially the terminal position of the elongate sori on the basal upper lobes and the two terminal segments. The basal upper segment is much larger than the others, and, unlike then, is subdivided into several segments, which bear the sori on the tips of the lobes.

\section{GLEICHENIA Swartz.}

The genus Gleichenia seems, if present at all in the Potomac flora, to be very feebly represented. In this respect the Potomac flora differs greatly from that of nearly the same age described by Heer as coming from Kome, Greenland.

\section{Gleichenia NordenskiöLdi? Heer. \\ Plate XXI, Fig. 11.}

Frond unknown; pinnæ linear, narrow; pinnules in the lower part of the pinnæ separate to the base, in the upper portion united at base, oblongobtuse, minute; nerves of the pinnules distinct, consisting of a midnerve which sends off alternately lateral nerves, which in the lower part of the pinnules are forked, but in the upper portion are simple.

Locality :-Fishing hut above Dutch Gap Canal; very rare.

This plant is found only in small fragments. In the absence of fructification its identification with Gleichenia is not certain. It is very much like G. Nordenskiöldi Heer. ${ }^{1}$

\section{UNDETERMINED FERN, sp. nov.}

Plate XXI, Fig. 12.

This small fragment is too incomplete to justify a description. It reminds one of Aspleninm Dicksonianum Heer. ${ }^{2}$

Occurs very rarely at the fishing het above Dutch Gap Canal.

\section{THYRSOPTERIS Kunze.}

Sterile and fertile pinnules dimorphous; sterile frond decompound; pinnules constricted at base, cut into lobes or teeth; nerves, lateral ones, 
going off obliquely or under an acute angle; fertile pinna contracted; sori globose, paniculate or racemose, inserted on a pediceled involucre.

This description, given by Heer ${ }^{1}$ for the genus Thyrsopteris, so far as the portion pertaining to the sterile frond is concerned, agrees well with a large number of species in the Potomac flora. These I place provisionally in the genus Thyrsopteris, on account of the great resemblance that the shape of the pinnules, the lobing, and the nervation show to the sterile forms of varions species determined to be Thyrsopteris by their fructification. As, however, no fructification is found in the Potomac species, the placing of these plants in the gents must be regarded as provisional. It is quite possible that sone of them belong to Aspidium and Dicksonia. The genus Thyrsopteris seems to be eminently a Jurassic type of fern. However it may prove to be with the fructification of the various species assigned in this memoir to this genus, it is probable that they are at least distinct and true species. The great variety and comparative abundance of these forms show that this type was developed in the Potomac flora to an unusual degree. They surpass all other types, even that of Cladophlebis, and give a decided Jurassic facies to the assemblage of ferns found in this flora. Even if we can not by frnctification determine the affinities of fossils with living plants, the large development of sterile forms of wellmarked types is of importance in fixing the character of a flora.

It should be noted that a number of the species of Thyrsopteris described in the following pages show a good many features similar to those of Sphenopteris Mantelli, as described by Schenk and Heer.

\section{Thyrsopteris Virginica, sp nov.}

Plate XXIV, Fig. 1.

Frond not seen; pinnæ of ultimate order, linear-lanceolate, acute, narrowed to a petioled base, and cut very obliquely into oblong lobes, the lower of which are obtusely dentate; rachis of ultimate pimnules very slender; lateral nerves in each lobe flabellate, sending off branches which in the lower lobes are once or twice divided, in the upper ones forked or simple, rather remote, very distinct and strong. 
Locality: Hill-side near Potomac Run; very rare.

This plant is not unlike the undetermined plant Pl. XXI, Fig. 12, and may be the same. The fragments found are ton small and rare to permit its true nature to be made out. It is a little like Heer's plants, Adiantites Nympharum, and Dicksonia (Asplenium) Jolnstrupi.

Thyrsopteris BRevifolia, sp. nov.

Plate XxIV, Figs. 5, 10.

Frond bipinnate or tripimnate; rachises slender; ultimate pinnæ long, going off at a large angle and slightly curved upwards, linear, alternate; pimnules all very short in proportion to their width, lower ones separate to the base, upper ones united to form a narrow wing; pinnules much narrowed at base, cut obliquely more or less deeply into lobes or teeth according to position on the frond; lobes of the lower pinmules cuneiform or narrowed at base, very obtuse, fan-shaped and emarginate; of the upper ones, oblong or ovate, very obtuse, towards the ends of the pinnæe reduced to oblong or ovate blunt teeth or lobes; nerves in the lower lobes of the lower pinnules flabellate, remote, forking once or twice in the upper lobes of the lower pinnules, and in the upper pimules single, all quite distinct.

Locality: Red clay ball in the banks of Dutch Gap Canal; rare.

This well characterized and elegant little plant is near to Sphenopteris dissocialis Phillips. It reminds one also of Sphenopteris hymenophylloides Brongn.

Thyrsopteris nentata, sp. nov.

Plate XXIV, Figs. 4, 6, 7, 9; Plate XXV, Figs. 1, 2.

Frond bipinnate or tripimnate, arborescent?; leaf-substance thick; rachises narrowly winged; compound pimne terminating in a lobed acute segnient; ultimate pinnæ or pinnnles opposite or subopposite, reduced towards the ends of the compound pinnæ to dentate pimnules, and at the summit to united lobes; united at base to form a narrow wing, those of the lower part of the frond ent deeply into oblong or subquadrate spinytoothed lobes or pinnules; those higher up lave obliquely cut lobes and 
teeth of varying depth, the basal ones subquadrate or ovate and spinytoothed; the ultimate pinnæ or pinnules gradnally diminish towards the ends of the compound pinna; the nervation in the pimules and lobes rather variable according to the position of the part, remote, very distinct and strong; the lower pinnules and lobes have a midnerve sending off on each side alternate branches either forked or simple, in the upper ones either once forked or simple.

Localities: Fredericksburg; hill-side near Potomac Run; red clay ball in banks of Dutch Gap Canal; rare.

This handsome plant is characterized by its subquadrate, acutely dentate lobes and pinnules, and by the remoteness and strength of the nerves in them. It is not common at the localities where it is found. It is near to Phillips's Sphenopteris affinis.

\section{Thyrsopteris nervosa, sp. nov.}

Plate XXV, Figs. 4, 5, 16; Plate XXXV1I, Figs. 2, 4; Plate XxxIX, Fig. 5 ; Plate XL, Fig. 6.

Frond bipinnate or tripinnate, arborescent; principal rachis flexuous, rather slender; ultimate pinne alternate, remote; pinnules alternate ; leafsubstance thick, very obliquely inserted on the rachis, in shape oblongacute, in the lower ones cut rather deeply into subrhombic basal lobes, which toward the tips of the pinnnles pass into ovate or elliptical lobes and teeth, in the upper ones cut into elliptical acute lobes and teeth; the pinnules narrowed at base nearly or quite into a petiole; nerves very distinct, slender, closely placed, going off from the midnerve very obliquely, diverging flabellately into each lobe and tooth, deeply forked, forking repeatedly, the branches subparallel.

Localities: Fredericksburg; hill-side near Potomac Run; not very rare.

This is a very fine fern, and although the fragments fonnd are not large, they evidently belong to plants that must have attained very considerable dimensions. It has some similarity to Thyrsopteris prisca Heer. The fragment shown in Pl. XXV, Fig. 16, has longer and narrower lobes than the normal forms and may be different. 
Thyrsopteris rarinervis, sp. nov.

Plate XXVI, Figs. 6, 7; Plate XLIII, Figs. 4-6; Plate XLIV, Figs. 1, 2, 5; Plate XLIX, Fig. 2; Plate CLXIX, Figs. 6, 7 .

Frond tripinnate, arborescent; principal rachis and that of the penultimate pinnæ strong, rigid, straight; that of the ultimate pinnæe rather slender; penultinate and nltimate pinnæe alternate; ultimate pinne more or less distinctly petioled, linear-lanceolate, acnte; pinnules diminishing in size from the base to the tips of the nltimate pinnæ, passing from toothed pinnules separate nearly to the base, through entire pinnules more fully united, to lobes at the summit of the pinna; pinnnles linear to narrowly elliptical, acnte, obliquely placed, decnrrent, and united at base to form a wing of varying width, thick and leathery, narrowed at base, those of the lower portion of the frond and of the pinnæ minutely dentate; towards the summit of the componnd pinnæ the ultimate pinnæ reduced to lobed and toothed pinnules; nerves of the pinnules of the normal kind, composed of a distinct midnerve, which sends off alternately into each lobe or tooth a single nerve.

Localities: Fredericksburg; 72d mile-post, near Brooke; White House Bluff; entrance to Trent's Reach.

This fine plant is pretty widely distributed, and at White Honse Bluff it is by far the most common fern. The forms depicted in Pl. CLXIX, Figs. 6, 7, come from this place, and are plainly but small portions of what were once large fragments. The plant is not common at the entrance to Trent's Reach. Pl. XLIV, Fig. 2, gives, slightly restored, a fine specimen found here. Fig. 1 of the same plate, and PI. XLIX, Fig. 2, give two very good specimens which come from Fredericksburg. The first named seems to be the upper part of the compound pinna depicted in the last-named figure. The principal rachis seems to have been keeled or ridged on the under side.

This plant is one of the Sphenopteris Mantelli type, and perhaps by some wonld be united with that species, but it is more robust, and the pinnules are more like those of the Thyrsopteris type. It looks in some points a good deal like Sphenopteris longifolia, Dunker (Mon. Weald., Pl VIII, Fig. 4), which Schenk unites with S. Gopperti. It however differs from $S$. 
Gopperti in the leathery texture of the pinnules and in other points. In the cutting of some of the pinnules there is a good deal of likeness to T. elegans, Kunze, the living species and the sole survivor. It may also be compared with Aspienium Dicksonianum Heer. ${ }^{1}$ It resembles more than any other described fossil Thyrsopteris elongata Geyler: ${ }^{2}$

\section{Thyrsopteris BREvipennis, sp. nov.}

Plate XXXIV, Fig. 3; Plate Xxxvi, Fig. 2; PIate XxxviI, Figs. 3, 9; Plate XxxvII, Fig. 1; Plate XLI, Fig. 4.

Frond tripinnate; leaf-substance thin; penultimate pinnæ mostly opposite, short; rachises slender, terminated by an obtusely lobed segment; lower ultimate pimnæ pinnate, with basal pinnnles three lobed, passing towards their tips abruptly throngh entire pinunles into lobes more or less united, short; towards the upper part of the frond and compound pinnæ the ultimate pinnæ pass rapidly into pinnules and lobes that are more or less united; nerves departing in gronps or nerve-bundles into each lobe or tooth, flabellately diverging, and branching several times, slender but rather distinet.

Localities: Red clay ball in banks of Dutch Gap Canal; fishing hut above Dutch Gap Canal; Baltimore, collected by Meek; Deep Bottom.

This plant in facies is more like a Sphenopteris than any of the species united under Thyrsopteris, and this feature is dependent in part on the shortness of the ultimate pimnæ and the abrupt passage from lobed pinmules to united lobes. It is comparatively abundant among the plants collected by Neek at Baltimore, but is rare at the other localities. There are a number of these speciẹs with Sphenopteris facies found in the Potomac flora which differ sufficiently to forbid their union in one species. They may be noted as Thyrsopterids with a Sphenopteris facies.

Thyrsopteris alata, sp. nov.

Plate XxXVI, Fig. 3.

Frond unknown, probably tripinnate; principal rachis narrowly winged, very slender, somewhat flexuous; ultimate pinnæ alternate, short,

${ }^{1}$ Flor. Foss. Are., vol. 3, No. 2, Pl. I, Figs. 1-5.

¿Foss. Pfl. Juraform. Japaus Palæontographica, vol. 24, 1s77, Pl. XXX, Fig. 5 ; Pl. XXXI, Figs. 4, 5. 
with a winged rachis; lower pinnules with oblong lobes rounded at the ends, cut very obliquely and more or less deeply, passing torvards the tips of the ultimate pinnæ into oblong-obtuse lobes all minutely toothed on the summits or terminal margins; nerves distinct, diverging flabellately in each lobe and forking several times; the midnerve of the pinnules splitting up towards its stummit.

Locality: Hill-side near Potomac Run; rare.

This plant in the position of the toothing resembles Sphenopteris acrodentata, but the lobes are narrower and the rachises winged, characters not found in that species.

Thyrsopteris Divaricata, sp. nov.

Plate XXXVII, Figs. 5-8; Plate CLXX, Fig. 1.

Frond tripinnate; prineipal rachis slender, slightly flexuons; ultimate pinnæ remote, alternate, short; penultimate pinna terminating usuaily in a three-lobed segment; pinnules of the lower part of the frond and compound pinnæ cut more or less deeply and quite obliquely into oblong or ovate lobes, the two basal lobes being cut down nearly to the midnerve, often with three teeth, diverging more or less widely. Towards the tip of the ultimate pinnæ and the summit of the frond the pinnules pass through toothed elliptical pinnules into simple pinnules and lobes; midnerve of the pinnules splits up at the tip into branches; nerves go off obliquely into each lobe or tooth, composed in the lower ones of a midnerve, which sends off alternately on each side branches forked or simple, composed in the upper ones of forking and simple nerves.

Localities: Fishing hut above Dutch Gap Canal; Fredericksburg; red clay ball in banks of Dutch Gap Canal; rather rare.

This plant is noteworthy for the peculiar divergence of the two lowest lobes in the pinnules and the extreme slenderness of the primary rachis. It is not common, and appear's not to be nearly allied to any described fossil.

Thyrsopteris Meekiana, sp. nov.

Plate XxxvIII, Figs. 2-4, 8; Plate L, Figs. 7, 8; Plate LI, Fig. 3.

Frond tripinnate, arborescent; pinnæ and pinnules much crowded; rachises, especially the principal ones, as a rule, very stout; ultimate 
pimne alternate or subopposite, short, and in the lower portion of the frond spreading; pimmules in the basal portion of the ultimate pimne, in the lower part of the frond, ent deeply and obliquely into subacute, elliptical, or subrhombic lobes, passing in the upper part of the ultimate pimme and of the frond through round-lober pimnules into entire elliptical and acute ones, and finally into lobes of the same shape; nerves in each lobe flabellately diverging, composed of a midnerve which sends off alternately on each side branches either forked or simple.

Localities: Baltimore, collected by Professor Meek; Fredericksburg; fishing hut above Dutch Gilp Canal; one small fragment from Covington street, Baltimore; rare at most localities, but one of the most common ferns in Meek's collection made at Baltimore.

This is a Potomac Thyrsopterid of the Sphonopteris type. In some features it is like certain Potomae plants described under other names. In lobing it is somewhat like Thyrsopteris brevipennis, but the facies is quite different, the rachis is stonter, the lobes and pimne are more acute, elongate, and crowded.

Thyrsopteris Meekiana, var. angustiloba, sp. nov.

Plate XxxvIn, Figs. 5-7, 9; Plate XLIII, Fig. 8; Plate XLIV, Fig. 3; Plate XLVII, Fig. 4; Plate XLVIII, Fig. 1; Plate LIV, Figs. 2, 21; Plate LV, Fig. 1; Plato LVI, Figs. 1, 3.

Frond tripimnatifid, arborescent?; rachises comparatively slender; pinna and pinnules subopposite to alternate; pinnules of the lower parts of the compound pinne eut deeply and very obliquely into narrowly elliptical acute lobes or teeth; pinnules of the upper portions passing through those with elliptical or ovate teeth into entire ones; nerves as in T. ALeekiana, but less spreading and not so copiously branched.

Localities: Baltimore, common in the plants collected by Meek, necurring on the same pieces of shale with $T$. Mceliana, and almost as abundant as that species; fishing lut above Dutch Gap Canal; Fredericksburg; 72d mile-post, near Brooke.

This plant has the same general character as T. Meeliana, but is more slender than that and has the pinnules and pinnæ less crowded. As these features appear to be constant, this form seems entitled to be considered as a variety. 


\section{Thyrsopteris crenata, sp. nov.}

Plate Xxxrx, Figs. 1, 2.

Frond tripinnate, arborescent; pinnæ and pinnules opposite; lower penultimate pinnæ without pinnules or pinnæ near the insertion on the main rachis; leaf-substance of the pinmules thick and leathery; pinnæ of the lower portion of the compound pinnæ passing towards the summit of the compoumd pime into crenately toothed and finally into entire pinnules; lower and basal pinnules crenately toothed, oblong to subquadrate in form, separate to the much narrowed base; upper pinnules entire, elliptical to subrhombic, slightly decurrent, united more and more in ascending; nerves of the crenately toothed pinnules composed of a midnerve which dissolves into branches towards its smmnit, sending off very obliquely and alternately on each side nerve-bundles eurving strongly outwards to enter the teeth, and several times subdivided, in the upper entire pinnules composed of a midnerve sending off obliquely and alternately lateral branches curved ontwards and forked one or mone times, or simple towards the tips of the pinnules; all lateral nerves strong.

Locality: Fredericksburg; rather rare.

This fine plant seems to have no near affinity with any described fossil. The rachises are strong, rounded, and prominent.

\section{Thyrsopteris insignis, sp. nov.}

Plate XXXIX, Fig. 4; Plate XL, Fig. 1; PIate XLI, Fig. 6; Plate XLII, Figs. 1, 2, 4; Plate XLIII, Figs. 1,3 .

Frond tripinnate, very large, arborescent; leaf-substance of the pinnules thick and coriaceous; rachises strongly winged, sometimes a little flexuons; pinnæe of the first order very long and spreading; ultimate pinne in the lower part of the frond very remote, subopposite to alternate; pinnules quite variable, according to position on the frond and compound pinne, and always rather remotely and very obliquely placed, alternate to opposite, and decurrent; in the lower part of the frond as in Pl. XXXIX, Fig. 4, and PI. XL, Fig. 1, oblong-lanceolate to narrowly elliptical, acute, cut more or less deeply in the basal pinnules and very obliquely into oblong or ovate acute lobes, those towards the tips of the 
ultimate pinne becoming entire and narrowly elliptical. In this portion of the frond there is a distinct midnerve in each pinnule, which at its summit splits into branches, while it sends off alternately and obliquely on each side lateral nerves into the lobes. These in the basal lobes liave a midnerve which sends off alternately on each side simple nerves, and in those up higher they fork once or twice; pinnules of the midlle portion of the frond and compound pinne (see Pl. XLII, Fig. 2) are remote, linear, acute, and decurrent to form a wing, cut into acute short teeth; midnerve and lateral nerres of these rather slender but distinct; lateral nerves of each tooth forking deeply, one branch ending in the tip of the teetli; pinmules of the upper part of the frond and compound pinnæ (see Pl. XLII, Figs. 1, 4) reduced to narrowly oblong lobes and teeth. The ultimate pimme also, in passing to the upper portions or tips of the compound pinne, pass into lobed and toothed pinnules similar to those down lower. The compound pinne most probably end abruptly with a terminal pinnule like those lower down. (See Pl. XLIII, Fig. 1.)

Localities: Fredericksburg; road-side near Potomac Run; rather abundant at the former place, rare at the latter.

The variability of this splendid plant causes it in one or another of its forms to approach several that are described under other names. It belongs to the Sphenopteris Mantelli type of Thyrsopteris, but the thick leaf-substance, remoteness of the pinnæ and pinnules, the strong wing, and the once forking lateral nerves distinguish it. In Pl. XLIII, Fig. 1, the tip of a compound pinna is shown, and it has abruptly terminating it a pinnule similar to those lower down. It is a good deal like T. insignis, var. angustipemis, as shown in Pl. XLIII, Fig. 3, but this latter does not have the rachises winged. Among described fossils we find Aspidium Jolnstrupi, Heer, ${ }^{1}$ something like the plant now in question.

Thyrsopteris insignis, var. Angustipennis, sp. nov.

Plate XLII, Fig. 3; Plate XLIII, Fig. 2.

Frond bipinnate or tripinnate, arborescent; rachises stout and prominent; leaf-substance thick and leathery; ultimate pinnæ alternate; pinnules 
alternate, linear, acute, narrowed to a long, slender, wedge-shaped base, and attached by the midnerve alone; pinnules cut more or less deeply and obliquely into oblong or narrowly ovate, acute, diverging teeth; midnerve slender; lateral nerves simple, one in each lobe or tooth, slender.

Locality: Fredericksburg; rare.

This plant belongs to the Sphenopteris Mantelli type, and is strikingly like T. insignis. The rachis, however, is not winged, and the pinnules are narrowed to a longer and more slender base. This plant is not uncommon at Fredericksburg, and is sometimes found with pinnules even more slender than those depicted. They cover with a confused heap some fragments of the rock.

Thyrsopteris Densifolia, sp. nov.

Plate XxxIX, Fig. 3 ; Plate XL, Figg. 2-5; Plate LI, Fig. 5.

Frond tripinnate, arborescent; leaf-substance thick and coriaceous; principal rachis strong, keeled on the under side; pinnæ of ultimate order alternate, short, linear-lanceolate, acute; pinnules crowded, obliquely placed, short, subacute to obtuse, much narrowed at base, and decurrent in the basal ones to form a partial wing, those higher up united more and more, and passing through entire pinnules into more or less united lobes: lower or basal pinnules cut very obliquely more or less deeply into subacute to obtuse teeth; nerves very slender and seen with difficulty, composed in the pinnules of a midnerve which sends off obliquely and alternately into the teeth lateral nerves, which are once or twice forked and enrve outward.

Localities: Fredericksburg; 72d mile-post, near Brooke; not uncommon.

This plant is near Thyrsopteris insignis, but the pinnules do not form a continuous wing, and they are, as a rule, shorter and broader than those of the latter. The pinnules are more crowded, and the nerves differ much. This plant has some resemblance to the Wealden fossil Sphenopteris Gapperti Dunker.

MON $\mathrm{xV}-\mathrm{9}$ 
Thyrsopteris CRASSINervis, sp. nov.

Plate XLI, Figs. 1-3.

Frond bipinnate or tripinnate; rachises all slender; nltimate pinnæ opposite or subopposite, short, subacute; penultimate pinnæ very long; upper basal pinnule of the ultimate pinnæ heteromorphous, much larger than the others, cut more or less deeply into three obtuse lobes or teeth; pinnules mostly elliptical or subrhombic, lower ones separate to the base, upper ones more and more united and passing into ovate lobes; leafsubstance thick; nerves very strong, standing ont like threads; midnerve of the pinnules splitting up into branches at the summit, sending off alternately on each side lateral nerves which branch once or twice, and in the lobes of the heteromorphous pinnule sending off a flabellately diverging nerve-bundle, the branches of which mostly fork near their ends.

Locality: Fredericksburg; rather rare.

This belongs to the Sphenopteris type of Thyrsopteris, and resembles in some respects several of that type, but. it is distinguished by its strong nerves and heteromorphous upper basal pinnule.

\section{Thyrsopteris DeCURRens, sp. nov.}

Plate XLIII, Fig. 7; Plate XLVI, Figs. 2, 4; Plate XLIX, Figs. 5-7.

Frond tripinnate, arborescent, of large size?; principal rachis somewhat flexuous; rachises of all orders winged; pinnules decurrent, rather remote, varying in shape according to position and consequent lobing from oblong to linear-acute, diminishing much in size and depth of lobing in ascending towards the summits of the compound pinnæ, much narrowed at base and going off obliquely; the lower pinnules deeply and obliquely cut into narrow, oblong, obtuse lobes, upper ones narrowly oblong to linear, with acute, elliptical, shallow teeth; nerves in each lobe or tooth distinct, in those of the lower parts of the pinnæ deeply forked, in those of the upper parts simple, all very oblique and approximately parallel.

Localities: Red clay ball in banks of Dutch Gap Canal; Fredericksburg; 72d mile-post, near Brooke; hill-side near Potomac Run; fishinghut ahove Dutch Gap Canal; in all places rather rare. 
This is one of the most widely diffused of the Potomac ferns. In that respect it differs from most of the ferns of this formation, for they are usually much isolated in occurrence. It does not seem to be nearly allied to any known fossil.

Thyrsopteris angustifolia, sp. nov.

Plate XLIV, Fig. 4; Plate XLV, Fig. 3; Plate XLVIII, Fig. 2; Plate XLIX, Figs. 3, 4; Plate LV, Fig. 2; Plate LVIII, Fig. 8.

Frond tripinnate, arborescent; pinnules and lobes narrowly oblong to acute; pinnæ and pinuules usually much crowded; ultimate pinnæ and pinnules alternate, diminishing in passing towards the ends of the compound pinnæ into pinnules and lobes; pinnules and lobes narrow, obliquely cut, in shape narrowly oblong to linear, lower pinnules separate to base, and furnished with narrowly elliptical acuie lobes and acute teeth, passing in ascending into more and more fully united narrowly elliptical teeth; nerves in each lobe of the upper pinnules forked, with the upper branch forking again or single in some cases. In the lower pinnules the lobes have a midrib with alternate simple branches going off on each side; midrib and lateral nerves of the pinnules all slender.

Localities: Entrance to Trent's Reach ; fishing-hut above Dutch Gap Canal; 72d mile-post, near Brooke; hill-side near Potomac Run; not common anywhere.

This is a widely diffused fern. It is distinguished by the narrowness of its lobes and pinnules and the absence of a wing on the rachises. It belongs to the Sphenopteris Gapperti type of Thyrsopteris. Some of the specimens sent from Professor Uhler's collection, gotten at Baltimore, to New Orleans, and thus lost, were similar to this plant, and hence it probably occurs at Baltimore.

\section{Thyrsopteris Microphylla, sp. nov. \\ Plate XLV, Figs. 1, 2, 4, 5 .}

Frond tripinnate, large, arborescent; principal rachis strong; penultimate pinnæ alternate, with strong rigid rachises comparatively short, terminated abruptly by an ultimate pinna similar to those lower down on the 
compound pinna ; ultimate pinnæ of the upper part of the frond (see Fig. 2) reduced to acute, elongate, elliptical lobes and teeth; the ultimate pinnee subopposite to alternate, obliquely placed, linear-lanceolate, subacute, with slender midribs terminated by an elliptical subacute lobe, attached to the principal rachis by a much narrowed base, composed of the midnerve with a narrow wing; pinnules small, linear-oblong to elongate-elliptical, acute to obtuse, basal ones separate nearly to the midnerve, those of the ultimate pinme slightly notched into acute teeth; pinnules towards the tip of the ultimate pinne and higher on the frond without the teeth and more united at base; nerres in the basal pinnules composed each of a slender midnerve, which sends off on each side alternate simple nerves which go one to each tooth: in the lobes and simple pinnules higher on the frond, the nerves once or twice forked or simple; usually the second forking occurs in the upper branch of the forking nerves and is found in the lower pimnules of the frond on the ultimate pinnæ.

Localities: Fredericksburg, not uncommon; hill-side near Potomac Run; rare.

This fine plant belongs to the Sphenopteris Mantelli type of Thyrsopteris, and is in some of its forms like T. rarinervis and T. angustifolia. It is not winged, however. All the specimens figured except the small one (Fig. 5) come from Fredericksburg.

Thyrsopteris pachyrachis, sp. nov.

Plate XLVI, Figs. 3, 5; Plate XLVIt, Figs. 1, 2 ; Plate XLIX, Fig. 1.

Frond tripinnate, large, arborescent; pinnæ and pinnules usually crowded; rachises very stout, round, and prominent; ultimate pinnæ opposite to alternate, lanceolate in outline, rather short; pinnules passing rapidly into lobes and teeth towards the upper part of the frond and compound pinne; lower pinnules narrowed to the base, oblong or subquadrate, acute, cut more or less deeply and very obliquely into narrowly elliptic acnte teeth. In the upper parts the pinnules become narrowly elliptic, toothed, and united by decurrent bases, or pass into very obliquely placed teeth of the same shape. The altimate pinnæ pass into pinnules 
in the upper part of the compound pinnæ. The nerves are fine but distinct, closely placed, deeply forked, flabellately diverging in each lobe and tooth, consisting of a slender midnerve, which sends off very obliquely deeply forked or simple branches.

Localities: Fredericksburg; road-side near Potomac Run; near Telegraph Station; fishing-hut above Dutch Gap Canal; rare everywhere.

This fine plant-belongs to the Sphenopteris longifolia type of Wealden ferns. Its facies is one highly characteristic of the Potomac ferns, including more forms than any other. It is not closely allied to any described fossil known to me.

\section{Thyrsopteris elliptica, sp. nov.}

Plate XXIV, Fig. 3; Plate XLVI, Fig. 1; Plate L, Figs. 6, 9; Plate LI, Figs. 4, 6, 7; Plate LIV, Fig. 6; Plate LV, Fig. 4 ; Plate LVI, Figs. 6, 7 ; Plate LVII, Fig. 6 ; Plate LVIII, Fig. 2.

Frond quadripinnate, large, spreading, and arborescent; rachises strongly winged, keeled on the under side; principal rachis very stont, and often more or less flexnous; loaf-subtance of the pinnules thick; arrangement of the ultimate pinnæ varions. The plant slows a tendency to a palmate mode of subdivision of the principal rachis (see Pl. LVI, Fig. 6); compound pinnæ abruptly terminated by penultimate pinnæ like those down lower (see Pl. LI, Fig. 6); ultimate pinnæe crowded, quite short; lower pinnules of the ultimate pinnæ, in the lower part of the frond cut more or less deeply and obliquely into narrowly oblong to elliptical obtuse lobes or rounded teeth, separate to the wing of the rachis, obliqnely placed, much narrowed at the base, elliptical or ovate in shape ; pinutules in ascending towards the summit of the frond and ends of the componnd pinnæ pass into entire elliptical piunnles, and these, united more and more, pass into lobes and teeth; midnerve of the lobed pinnules splitting at the summit and sending off down lower alternately into the lobes branches which fork once or twice; branches in the upper pinunles either once forked or simple.

Localities: Fredericksburg, not uncommon; red clay ball in banks of Dutch Gap Canal; rare.

This plant is not very close to any previously described fossil. 
Thyrsopteris distans, sp. nov.

Plate XLVII, Fig. 3 ; Plate LIV, Fig. 8.

Frond tripinnate, large, arborescent; rachises strong, narrowly winged; pinne and pinnules very remotely placed; penultimate pinnæ subopposite, with ultimate pinne abruptly and irregularly diminished in length and size; ultimate pinne linear-lanceolate, passing above into lobed, toothed, or entire pimnules; basal pinnules of the lowermost ultimate pinna narrowly oblong, acute, denticulate, passing towards the tips of the ultimate pimmæ rapidly into narrowly oblong, acute lobes and teetli; nerves in the pinnules and lobes, composed of a midnerve which sends off obliquely and alternately on each side branches, which are forked in the lower ones, simple above, fine, closely placed, but distinct.

Locality: $72 \mathrm{~d}$ mile-post, near Brooke; not uncommon.

This plant belongs to the Sphenopteris Gcepperti type. The principal rachis is very strong. It is probable that in this and all the specimens of Thyrsopteris, Cladophlebis, Pecopteris, etc., the principal rachises are portions simply of compound pinnæ. In the descriptions, when plants are given as bipinnate, tripinnate, etc., it is meant that the frond is probably at least divided to the extent named. This plant seems to be not very near any other described fossil.

\section{Thyrsopteris angustiloba, sp. nov.}

Plate XLVIII, Figs. 3-5; Plate LV, Fig. 3.

Frond tripinnate; rachises distinctly winged; pinnules and lobes, especially the latter, very narrow; penultimate pinnæ alternate, rapidly diminished in ascending towards the summit of the compound pinnæ into ultimate pinnæ and pinnules, and finally into lobes; ultimate piunæ subopposite, closely placed, decurrent to form a wing, the lower ones cut obliquely and more or less deeply into narrowly oblong or elliptical pinnules towards their bases, but towards their ends these pass into lobes and teeth of the same form, narrowed to a subpetiolate base; higher on the compound pinna they change rapidly through toothed pinnules into 
entire ones, and finally into lobes and teeth; nerves in the pinnules and lobes, forked deeply in the basal ones, in the upper ones simple, all very oblique, fine, but distinct.

Localities: Fredericksburg; fishing-hut above Dutch Gap Canal; entrance to Trent's Reach; White House Bluff.

This plant is quite widely diffused. It is comparatively abundant at White House Bluff, where a number of poorly preserved specimens occur, evidently in some cases being fragments of large portions of the frond. It is also not very rare at the entrance to Trent's Reach. In other places it is very uncommon. The general aspect of this plant is much like that of Thyrsopteris angustifolia, but the distinctly winged rachis compels me to separate them. It belongs to the Sphenopteris Mantelli type.

Thyrsopteris PACHyphylla, sp. nov.

Plate L, Fig. 3.

Frond and pinnæ unknown; ultimate pinnæ terminated by a broadly fan-shaped pinnule, which is toothed on the terminal margin; pinnules not fully shown, only those near the tip of the ultimate pinne seen, alternate, elliptical, acnte, furnished with ovate teeth; leaf-substance thick; nerves not seen.

Locality: Road-side near Potomac Run.

Only one small specimen was found, but the plant seems to be a distinct new species, not near to any described fossil.

\section{Thyrsopteris pecopteroides, sp. nov.}

Plate LI, Fig. 1.

Rachis of the penultimate pinnæ stont; ultimate pinnæ closely placed, opposite or subopposite, short, linear-acute; pinnules minute, passing to lobes towards the ends of the ultimate pinnæ, subrhombic to ovate, decurrent to form a wing, lower ones slightly toothed; leaf-substance thick; nerves in the pinnules composed of a midnerve, which goes off obliquely and is turned strongly outward, and sends off alternately on each side branches which are forked or simple.

Locality: Fredericksburg; rare. 
This, althongh found only in one or two small fragments, seems to be quite a distinct new species. It looks more like some of the Gleichenice from the Lower Cretaceons of Greenland than any other plant.

Thyrsopteris pinNatifida, sp. nov.

Plate LI, Fiı. 2; Plate L1V, Figs. 4, 5, 7; Plate LV1I, Fig. 7.

Frond tripinnatifid, arborescent; rachises slender; ultimate pinnæ alternate; primary pinne towards the summit suddenly clianging from penultimate pinne to ultimate ones (see Pl. LVII, Fig. 7); ultimate pinne short, closely placed, terminating in acute oval lobes, obliquely inserted, alternate, changing in passing to the summits of the principal pimne and of the penultimate ones into lobed pinnules and finally into entire pinnules, much narrowed at base, and attached by the narrowly winged nidnerve, cut down nearly to the midnerve in their basal portions into narrowly oblong or elliptic-acute pinnules; towards their ends and higher on the compound pinne the pimnules graduate into lobes and teetl ; pinnules and lobes minute; nerves in the pimnules of the lower parts forked deeply, with the upper branch forking again; in the lobes higher simply forked.

Locality: Fredericksburg.

This elegant little plant is not very rare at Fredericksburg. It is noteworthy for the very regular and elegant shape of the pinnules and lobes and for their minute size.

\section{THYRSOPTERIS HETEROMORPHA, s]. nov.}

Plate LII, Fig. 1.

Frond apparently palmately branching, with the primary pinnæe radiating from the top of the common stipe; ultimate pinne of the central compound piunæ passing abruptly in ascending into obtusely lobed pinnules, and at the top changing into entire elliptical pinnules; ultimate pinnæ closely crowded, short, and obliquely inserted, passing in ascending into lobed and finally into entire pinnules, those of the upper side of the penultimate pinnæ larger and more deeply eut than those of the lower side, those towards the base of the penultimate pinnæ cut into elliptical subacute pinnules and lobes, which are narrowed at base and obliquely placed, the pimules of the upper side being sometimes crenately toothed; leaf-sub- 
stance leathery and thick; nerves very strong, causing the leaflets sometimes to look as if they were corded. In the erenate pinnules (Fig. $1^{\mathrm{a}}$ ) the nerves consist of a midnerve which splits up towards the summit and sends off at base two nerve-bundles; these diverge flabellately into the teeth, with the branches simple and forked; higher the lateral nerves fork deeply, with the upper branch forking again; the entire pinnules (Fig. $1^{\text {b) have }}$ branches diverging alternately from a midnerve, curving outward and once or twice forked.

Locality: Fredericksburg; rather rare.

This plant belongs to the Splenopteris Gepperti type. It seems to be a well-characterized new species of a strongly defined Wealden type.

Thyrsopteris varians, sp. nov.

Plate LII, Figs. 2-4 ; Plate LIII, Figs. 1-3; Plate LIV, Fig. 10; Plate LVII, Fig. 2.

Frond tripinnate or quadripinnate, large and spreading; leaf-substance thick and leathery; rachises of the penultimate pinnæ often partially or fully winged; ultimate pinne varying in size and shape with their position on the frond, tending to pass in ascending towards the ends of the penultimate pinnæe rapidly through lobed into entire pinnules. Principal rachis generally stout and prominent, often flexuons; ultimate pinne on the upper side of the penultimate pima sometimes much larger than those on the lower side, especially the basal upper one; ultimate pinnæ of the lower part of the frond and componnd pinne furnished with remote, elliptical, oblong, or subrhombic pinnules, which pass in ascending into lobes and teeth of the same nature. In the pinnules of the lowest portions the nerves are composed of a midnerve which sends off flabellately diverging branches, which are forked or simple; in the lobes and teeth of the upper portions they consist of a midnerve which branches-several times, beginning near the base, the branches diverging flabellately, or of a lateral nerve in each lobe which forks once or twice.

Locality: Fredericksburg; not rare.

A number of good specimens of this plant were obtained. I have, with a good deal of hesitation, united under this species a number of forms which differ somewhat in aspect, but there seems to be such a transition 
from one to the other as to forbid their separation. Plate LII, Fig. 2, shows no wing on the rachis of the ultimate pinna, but shows a feature conmon in this species, viz: the ultimate pinme on the upper side of the penultimate rachis are larger than those on the lower side. In Fig. 3, of the same plate, the rachis is not winged, and the ultimate pinnæ do not slow the marked disparity in size often seen: Fig. $4^{a}$, of the same plate, shows the nltimate pinne or pinnules decurrent, and forming a partial wing to the rachis. The nerves in the lobes or pinnules of this form are more numerous and cleeply forked than in Fig. 2. In Pl. LIII, Fig. 1, the penultimate rachis is winged, and the pinnules, here reduced to lobes, have remote, sparingly branched, strong nerves. The ultimate pinnæ do not differ much in size. In Fig: 2 , of the same plate, we have a surprising difference in the size of the ultimate pinnæ on opposite sides of the penultimate rachis. In Fig. 3, of this plate, the usual disparity of the ultimate pinnæ is seen, and the pinnules differ from the normal ones markedly in the nerves, which are fine, closely placed, deeply forked, and comparatively numerous. In Pl. LIV, Fig. 10, the basal upper pinnule is decidedly longer than the rest, and directed upwards parallel with the penultimate rachis, which is strongly winged. This is probably the upper portion of a compound pinna. This fern seems to be not closely allied to any described fossil, and to have been a large plant.

\section{Thyrsopteris RHOMbiFolia, sp. nov.}

Plate LII, Fig. 5; Plate LIV, Fig. 1.

Frond apparently palmately divided; plant slender; principal rachises slender, rounded, and prominent; ultimate pinnæ short, distant, opposite, pinnules remote; leaf-substance thick, upper basal pinnule larger than the rest, more copiously and deeply lobed; pinnules subrhombic to rhombic in shape, slightly curved forward, acute, rarely obtuse; nerves very distinct, composed in the pinnules of a midnerre which sends off altemately and very obliquely on each side forked or simple nerves, and which at its summit dissolves into branches. In the heteromorphous basal upper pinnule a nerve-bundle goes off flabellately diverging into the basal lobes, the branches of which are simple. 
Localities: Fredericksburg; fishing-hut above Dutch Gap Canal; rare.

Plate LIV, Fig. 1, depicting a specimen from the last-mentioned locality, differs from the more common Fredericksburg forms in having the penultimate rachis keeled, perhaps because the under side is shown. It gives the summit of a primary pinna.

This pretty little fern seems to form a well-marked new species.

Thyrsopteris heteroloba, sp. nov.

Plate LIII, Fig. 4.

Frond tripinnate; rachises strongly winged; principal rachis flexuous; penultimate pinnæ alternate, with a strong rigid rachis; ultimate pinnæ alternate, short, attaclied by the narrowly winged rachis which forms a sort of petiole, cut obliquely into oblong, obtuse, or spatulate pinnules or lobes to varying depth, according to the position on the pinnæ; upper basal pinnules always larger than the lower pinnules, furnished with three shallow, very obtuse lobes; towards the summit of the ultimate pinna and of the frond the pinuules pass to obtuse lobes; nerves in each pinnule and lobe fine, closely placed, flabellately diverging, with simple or forking branches.

Locality: Fredericksburg; rare.

This seems to be a very distinct new species, and it is very rare. It is somewhat like $T$. varians.

Thyrsopteris bella, sp. nov.

Plate LIII, Fig. 5; Plate LV, Figs. 6, 7; Plate LVI, Figs. 2, 5; Plate LVII, Figs. 1, 5; Plate LVIII, rig. 4.

Frond quadripinnate, spreading, arborescent ?; rachises comparatively very slender; primary rachis somewhat flexuous; penultiuate pinnæ alternate or opposite, long, closely placed, passing towards the summit of the principal pinnæ into ultimate pinnæ; ultimate pinnæ short, opposite to alternate, terminating in a three-lobed segment, usually closely placed, oblong-lanceolate in form, passing above into lobed and simple pinnules; pinnules passing in ascending into simple ones, and finally into lobes, 
lower ones cut obliquely into oblong or elliptical lobes or teeth, basal ones sometimes blunt-lobed, greatly narrowed at base, all minute; leaf-substance thin; nerves in the lobes or teeth slender but distinct, composed in the pinnules of a midnerve with obliquely placed, alternate forking or simple branches on each side, and in the lobes and teeth of lateral nerves, which fork once or twice and go off rery obliquely.

Localities: Fredericksburg; entrance to Trent's Reach; White Honse Bluff; fishing-hut above Dutch Gap Canal; rare.

This elegant little plant is one of the more widely diffused ferns. It is noteworthy for the minuteness of the pimnules and lobes. It seems to be a well-marked new species.

Thyrsopteris Microloba, sp. nov.

Plate LVII, Fig. 4.

Frond arborescent, tripinnate; principal rachis proportionally very stont, rigicl, and prominent; penultimate pinnæ alternate, closely placed, much narrowed at the base, decmrrent; lower pinnules of the ultimate pinnæe elliptical, narrowed at base, slightly and obtusely toothed, minute, the upper basal pinnule larger than the rest and more deeply toothed; pinnules on the upper side generally larger than those on the lower, and showing a toothing up higher towards the tips of the ultimate pinna; pinnules towards the ends of the ultimate pinnæ passing into lobes and teeth; leaf-substance rather thick; nerves in the lower pinnules pinnate from a midnerve, with branches forked and simple, those of the lobes up higher forked or simple.

Locality: Fishing-hut above Dutch Gap Canal; rare.

This is a plant with very minute pinnules and lobes, which has the penultimate rachises not winged, and which thus differs from the variety alata.

Thyrsopterts microloba, var. alata, sp. nov.

Plate LV, Fig. 5; Plate LVIII, Fig. 1.

This differs from T. microloba mainly in the presence of a wing on the rachises of the penultimate pinnæ, the smaller size of the principal 
rachis, and in the proportionally larger size of the pinnules and lobes. Pl. LV, Fig. 5, appears to represent the upper portion of a compound pinna, corresponding to the upper portion of the fragment represented in Pl. LVII, Fig. 4, where the pinmules are reduced to lobes and the ultimate pinne to pinnules.

Localities: Fredericksburg; above Dutch Gap Canal, near the fishing-hut.

The plant is not common anywhere, but is most abundant in thin shale partings in the bank a little above the spot at the fishing-hut, where so many plants were collected. It does not occur, strange to say, at this last-named spot, which is only a few yards distant. The fine specimen, Pl. LV, Fig. 5, was found at the Dutch Gap locality.

\section{Thyropopteris Nana, sp. nov.}

Plate LVI, Figs. 4, 8 .

Frond very small, tripinnate; rachises slender; ultimate lower pinne or pinnules very minute, short, rather remotely placed, much narrowed at the base, subrhombic in shape, eut very obliquely nearly to the midnerve into very suall elliptical or oblong pinnules or lobes, which are mostly obtusely rounded at the ends, rarely subacute, the lower ones diverging considerably; the ultimate pinnæ terminate in a three-lobed segment; the ultimate pinnæ pass towards the ends of the penultimate pinnæ and of the principal pinne into pinnules, which have a wedge-shaped base, and are cut deeply into three lobes, the lower pair diverging strongly; nerves of the pinnules and lobes fine but distinct, closely placed, those of the pimnules in the lower portion of the pinmæ flabellately diverging from a short basal nerve, mostly simple in the lobes, once or twice forking, and without the basal nerve.

Localities: Fredericksburg; fishing-hut above Dutch Gap Canal; quite rare.

This is a very small plant, which seems quite distinct from all other described fossils. 


\section{Thyrsopteris IN equipinnata, sp. nov.}

Plate LVII, Figs. 3, 8.

Frond tripinnatifid : rachises slender ; ultimate pinnæ opposite or subopposite, of unequal length on opposite sides of the penultimate rachis, rather remote, graduating above through lobed and dentate into entire pinnules, the latter being at the summit of the compound rachis and becoming more remote in the upper part; pinnules opposite, elliptical, much narrowed at the base, passing towards the summit of the ultimate and primary pinnx into entire ones, the lower ones eut into shallow, elliptical, subacute teeth; nerves fine, in the pinmules composed of a midnerve which in the toothed lower pimnules sends off very obliquely and alternately flabellate nerve-bundles with forking or simple branches, and splits up into branches at its summit; in the entire pinnules it gives off in like manner lateral nerves that are forked or simple.

Locality : Fishing-hut above Dutclı Gap Canal; rare.

The marked inequality in the length of the ultimate pinnæe on opposite sides of the principal rachis is the most noteworthy feature of this small plant. It seems to be unique.

\section{TIIYRSOPTERIS HETEROPHYLLA, sp. nov.}

Plate LVIII, Fig. 3.

Frond probably tripinnate; rachises slender; penultimate pinnæ alternate, short, closely placed, terminating in a three-lobed segment, with broadly winged rachis; pinnules remote, those on the upper side larger and less obliquely placed than those on the lower side, much narrowed at base, and decurrent to form a broad wing, cut more or less deeply into ovate teeth, elliptical to subrhombic in shape; leaf-substance thick; nerves distinct, pinnately departing from a slender midnerve, simple, one in each tooth.

Locality: Fredericksburg; very rare.

Although only a small fragment was found, this plant seems to be a distinct species. It is much like Thyrsopteris Maaliana ${ }^{1}$ Heer. 
Thyrsopteris OBTUSILOBA, sp. nov

Plate LVIII, Figs. 7, 10.

Frond tripinnatifid; pinnæ of ultimate order and pinnules subopposite, remotely placed, short; pinnules narrowly oblong, obtuse, passing above into entire ones, lower ones cut to varying depths into oblong, very obtuse lobes; lateral nerves very strong, in the lower lobes given off pinnately on each side of a midnerve which splits up at the summit; the lateral nerves forked or simple, in the upper lobes flabellate and forking once or twice.

Localities: Red clay ball in the banks of Dutch Gap Canal; hill-side near Potomac Run ; rare.

This plant has the facies of a Cladophlebis. It seems to be a distinct new species.

\section{Thyrsopteris SPHENOPTEROIDES, sp. nov.}

Plate LVIII, Fig. 6.

Frond bipinnate or tripinnate; ultimate pinnæ winged; leaf-substance thick; pinnules small, much narrowed at base, almost petioled, distant, elliptical or subrhombic in shape, acute; lower ones cut into diverging ovate-acute lobes, upper ones entire; nerves strong, composed in each pinnule of a midnerve which splits up towards the summit and sends off pinnately into the lobes and teeth lateral nerves which fork usually once.

Locality: Hill-side near Potomac Run; very rare.

This seems to be nearly allied to no previonsly described species.

Thyrsopteris squarRosa, sp. nov.

Plate LIX, Fig. 3.

Frond tripinnatifid; primary rachis stout, somewhat flexuous; ultimate pinnæ alternate, winged, closely placed; pinnules crowded, much narrowed at base, short in outline, triangular, cut more or less deeply into lobes which spread widely from the midnerve, standing almost at right angles with it, the lobes more or less club-shaped or spatulate in form, the basal ones being obtusely three-lobed; the pinnules are broadest at base, and stand nearly at right angles with the midrib: nerves strong, com- 
pused in the lower lobes of a flabellately diverging nerve-bundle, the branches of which are forked or simple; in the upper ones composed of forking nerves

Localities: Hill-side near Potomac Run; near Telegraph Station; quite rare.

This seems to be a well-marked distinct species witl a Sphenopteris facies.

$$
\begin{gathered}
\text { Thyrsopteris rhonbiloba, sp. nov. } \\
\text { Plate Lix, Figs. 6, ; ; Plate LX, Fig. ๖. }
\end{gathered}
$$

Frond tripinnate, arborescent; principal rachis stout; ultimate pinnæ alternate, linear-lanceolate in outline, terminating in an acute lobed segment: pinnules closely placed, alternate, oblong or subrhombic, acute, passing above into united lobes, cnt more or less deeply into subrhombic lobes, much narrowed at base, decurrent to form a wing on the penultimate rachis; nerves of the pinnules composed of a midnerve which. splits up at the top and sends off pinnately into the lower lobes nerve-bundles which diverge flabellately in the lobes, the branches being simple, or forked in the lower lobes; in the upper lobes the lateral nerves fork once or twice.

Locality: Hill-side near Potomac Run; not uncommon.

The penultimate pinne of this plant in the upper parts of the compound pinnæe are reduced to pinnules, as is shown in Pl. LX, Fig. 8, and in the lower portions of the frond, as in Pl. LIX, Fig. 6, they seem to pass into nltimate pinnæ. These do not have the rachis to which they are attached winged. The plant seems to be a distinct new species.

\section{THYrsopteris RETUSA, sp. nov.}

Plate LIX, Fig. 10.

Frond tripinnate; principal rachis stout; pinnæ alternate; ultimate pinnæe short, lanceolate in shape, rachis winged, terminating in a lobed segment formed of united and reduced pinnules; pinnules towards the ends of the ultimate pinnæ passing into lobes and teeth; those of the lower portion of the ultimate pinnæ much narrowed at base, united by decurrence to form a wing, oblong, terminating in three acute teetl, cut into retuse 
lobes; lateral nerves of the pinuules few and remote, going pinnately on each side of the midrib into the lobes, and forking once or twice, all strong.

Locality: Hill-side near Potomac Run; rare.

This small plant reminds one of Thyrsopteris squarrosa, but appears to be a well-marked distinct species, not nearly allied to any described fossil.

Undetermined Fern in circinate vernation. sp.?

Plate LIX, Fig. 5.

Small, circinate fern fronds, similar to the form depicted in Fig. 5, are quite common in the shale on the hill-side near Potomac Run. They occur mostly in the form of small fragments. This locality is noteworthy for the great number of specimens of a comparatively small number of species of ferns that it affords. It is eminently a fern locality, being the only place where the specimens of that family surpass in numbers all others put together.

\section{OSMUUNDA, L.}

The genns Osmunda is not represented in the Potomac by many species, but the number of individuals, of at least one of the species, is considerable.

OsMunda SPHENOPTERoIdes, sp. nov.

Plate XXV, Fig. 13.

Frond most probably bipimnatifid, spreading; rachises slender; sterile and fertile pimules on the same pinna; lower pinnules of the ultimate pinne fertile, the upper ones sterile, occasionally some of the basal lobes of the upper pinnules fructified; pinnules alternate, remote, especially the fertile ones; fertile pinnules much reduced in size, oblong in form, with bluntly rounded lobes, which are covered with sori ; sterile pinnules short, cut more or less deeply into oblong, elliptical, subacute lobes, obliquely placed, narrowed at base to a sort of petiole; nerves fine, but distinct, branching flabellately in each lobe or tooth, departing from a more or less pronounced midnerve, the branches sometimes forked, but more commonly simple.

MON XV- 10 
Locality: Red clay ball in the banks of Dutch Gap Canal; rare.

This is a well marked species. Its rarity may be ouly apparent. The plants found in the red clay ball form a peculiar assemblage, a number of them, as in this case, being found nowhere else. The amount of material in this ball was small, and owing to this, we can not say whether or not the plants found in it were actually rare in the stratun represented by this ball, and from which it was torn. It would seem that this ball belonged to a fossiliferous layer, not now to be seen in place in the exposures about Dutch Gap. No doubt many originally rich fossiliferous layers lave been destroyed in the local erosions to which the formation was from time to time in the course of its deposition subjected.

The plant is possibly composite in nature, and not a sharply differentiated Osmunde, but as it contains more of the features of this genus than any other, I have placed it there. The sori are very small, being fine dots. The exact details of their structure could not be made out.

\section{Osmunda Dicksonioides, sp. nov.}

Plate XLI, Fig. 5; Plate LVIII, Fig. 9; Plate LIX, Figs. 1, 4, 8, 9, 11; Plate LX, Figs. 2, 4, 5, 9; Plate LXI, Figs. $1,2$.

Sterile frond large, arborescent, tripinnate; rachises stout, especially the principal ones; ultimate pinne subopposite to alternate, closely placed, linear-lanceolate, acute, ending with pinnules reduced to united teeth and passing towards the summits of the compound pinnæ into pinnules; pinnules or reduced pinnæ alternate, closely placed, oblong to ovate, passing above towards the tips of the compound and ultimate pinnæ through oblong or ovate lobed or toothed pinnules into entire ones, and finally into united teeth, ovate-acute in form. The lower pinnnles or reduced pinnæ are much narrowed at base, cut more or less deeply into ovate, elliptical, subquadrate, acute lobes and teeth, the lobes, especially the basal ones, being often toothed; the nerves in each lobe composed of a midnerve sending off obliquely and alternately branches either forked or simple; reduced in the teeth of the upper pinnules and of the terminal portions of the lower ones to forked or simple lateral nerves in each lobe or tooth; the fertile frond distinct from the sterile one; the pinnules of the former much reduced in 
size, very thick and leathery, apparently consisting of a midrib, which has on each side a narrow thickened lamina, bearing on the margins large fruitmasses rounded in form.

Locality : Hill-side near Potomac Run.

The fertile forms are very rare at this locality, but the sterile ones are very abundant, and much the most common of the specimens found here. The form depicted in PI. LX, Fig. 5, I regard as the fructified form of the fern which is described above, and which shows so many well-preserved sterile specimens. As, however, the sterile and the fructified forms were not found connected together, the union can not be taken as certainly authorized. Unfortunately the fructification is not well enough preserved to render its details clear. Fig. 5 gives the appearance as seen in natural size with the unaided eye. Fig. $5^{2}$ gives the appearance under a lens. The apparent fruit-masses look like rounded masses of naked sori or sporangia. The entire fructified pinnules are so much thickened and so poorly preserved, that nothing but the rounded shape and granular appearance of the fruit-masses can be made out. Each mass of fruit seems to represent a contracted and modified pinnule or lobe. The metamorphosis of the pinnules reminds one of Osmundt more than of any other living genus, and I place the plant provisionally in this genus. Possibly this may be a new genus, composite in character, which has some of the features of Thyrsopteris and Osmunda, for there is an indication of a cupshaped grouping in the fruit dots. It is strange that no specimen of this plant was found on the road-side near by.

\section{Osmunda Dicksoniomes, var. Latipennis, sp. nov.}

Plate LX, Figs. 1, 3; Plate LXI, Fig. 3.

Frond tripinnatifid, large, arborescent; rachises proportionally slender; pinnæ and pinnules alternate; rachises of the ultimate pimm narrowly winged; pinnules with membranaceous leaf-substance, short, oblong in shape, and acute, attached by the middle point of the narrowed base, cut more or less deeply into rounded, subquadrate, or broadly oval lobes, the lower ones of which have shallow, subacute teeth; fructified form not seen. Nerves in each lobe remote, strong, composed of a nerve-bundle 
which diverges flabellately from a more or less prononnced midnerve, the branches usually once forked, rarely bifurcate.

Locality: Hill-sicle near Potomac Run ; comparatively rare.

This plant is much nore rare than the type species, and, although evidently nearly allied to it, has the nerves more widely diverging and remote, a more regular dentation, a winged rachis in the ultimate pinnæ, and wider, more rounded lobes. The pinnules also are decidedly broader in proportion to their length.

\section{SAGENOPTERIS, Pr.}

The Jurassic genus Sagenopteris is represented in the Potomac flora by several well-characterized species. None of these, however, seem to be very-abundant, and the genus furnishes a very small element to the flora.

\section{Sagenopteris latifolia, sp. nov.}

Plate XIVIII, Fig. 10.

Frond unknown; pinnules apparently subquadrilateral, narrowed gradually to the base and rapidly to the sumnit; midnerve in the lower part of the pimnule strong, in the upper part dissolving into branches; lateral nerves going off very obliquely, branching near the midrib, turning outward, and then by repeated branching and anastomosis forming long, rather regular, elliptical to rhombic meshes, which fill the lamina.

Locality: Near Telegraph Station.

Only two fragments of this plant were found. As, however, no detailed exhaustive search was made at this locality, and the amount of material was small, the rarity may be apparent rather than real. The shape of the pinnules is nearer that of S. rhoifolic of the Rletic than that of any other species of the genus known, but the anastomosis is more copious than that of the Rhetic species. In copionsness of anastomosis and in the shape of the meshes it is nearer S. Mantelli Schenk, of the Wealden. It seems to lie between these two species. In the figure the margin on the right-hand side appears to represent the original border of the leaf, but the other parts have been torn away. 


\section{SAgenopteris Elliptica, sp. nov.}

Plate XXVI1, Figs. ?, 11-17.

Frond with five pinnules at the summit of a strong stipe, the right and left outermost pinnules smaller than the inner ones; pinnules narrowed gradually to a slender wedge-shaped base, and attached by a short petiole, elongate-elliptical in outline and acute to acuminate at the tips, rarely subquadrate in outline; midnerve strong at base, dissolving towards the summit into branches; lateral nerves leaving at an acute angle, curving out to meet the margin, repeatedly branching and anastomosing, so as to for'm meshes, which are quite irregular in size and shape; meshes elougateoblong or irregular subrhombic, some much larger than the others; between the nerves on the lower side of most of the pinnules numerous rounded or oblong minute elevations or dots oceur, which can be seen distinctly ouly with the help of a lens; these appear to be the fructification.

Localities: Road-sicle near Potomac Run; Kankey's; Covington street, Baltimore.

At each of the two last-named localities a small fragment only was found. It is most abundant at the Potomac Run locality, from which all the specimens figured come, but it is not very common even here. No specimen was found at the other or lill-side locality, only a few hundred feet away. The dots look much like fructification, and I have no doubt that this is their character. This would place the plant in the Dictyopteris group of Polypodium. It would seem from this that Sagenopteris is a feru and not a rhizocarp, as Schimper finally held it to be. Although this species has five pinnules at the summit of the stipe, it seems to be elearly a Sagenopteris.

This plant, in the general shape of the pinnules and the character of the midnerve, reninds one strongly of the Neuropterids of the Coal Measures. The shape of some of the pinnules, as in Fig. 16, is strikingly like that given by Brongniart in his Histoire for Glossopteris Phillipsii (Pl. LXI bis, Fig. 5), which he makes a Sagenopteris. The pinnules in some specimens are much like those of Sagenopteris rhoifolia. ${ }^{1}$ The plant is decidedly 
Jurassic in type. In Fig. 14, the lowest pinnule on the right-hand side belongs to the left hand, and forms the outermost one on that side. It has, by displacement and pressure, been turned to one side and doubled back under the summit of the stipe, so as to lie alongside of the outermost one of the right-hand side of that frond.

Sagenopteris Virginiensis, sp. nov.

Plate CxxxviII, Fig. 13; Plate CxxxIx, Fig. 1.

Frond unknown; shape of pinnules not seen, probably broadly elliptical or oval; stipe or petiole of pimnules apparently long; midnerve toward the base very strong, dissolving in branches towards the apex; areolation very distinct, formed by lateral nerves which go off obliquely and curve outwards to meet the margin, forking repeaterlly, and anastomosing to form meshes that are irregular in size and shape, being mostly elongate, oblong, or subrhombic.

Locality: Fredericksburg; very rare.

Plate CXXXVIII, Fig. 13, seems to represent the upper part of the specimen figured in Pl. CXXXIX, Fig. 1. The lamina of the leaf in the lower part of this specimen has been torn away, leaving the midrib bare. This appears to be a very large species of the genus.

\section{SCLEROPTERIS, Saporta.}

Frond bipinnate or tripinnate, coriaceous; pinnæ pinnately parted, pinnules or segments more or less constricted at base, decurrent on the lower side, and forming a narrow wing to the rachis, entire, or incised and lobed on the anterior margin; nervation immersed, formed of a few nerves branching flabellately from a common nerve at the base, diverging flabellately by repeated branching to fill the limb.

The above is very nearly Saporta's diagnosis of the genus Scleropteris established by him. I modify the nervation only so as to include the forms described in the next following pages, which clearly belong to this genus. As to the nervation, Saporta says, in Paléontologie Française, Plantes Jurassiques, vol. 1, page 365, that the nerves come out obliquely from the back side of the pinnules. This is not the case in all specimens, 
even of those placed by him in the genns, as in Pl. XLV, Fig. 2, given by him of Phillips's Sphenopteris lanceolata, which he makes Scleropteris Phillipsii. Saporta shows quite satisfactorily that Brongniart's genns Pachypteris, which has for its type $P$. ovata, was established under the mistaken idea that the specimen furnishing the type bad in the pinnules only a miduerve. It is identical with Phillips's Neuropteris lcevigata. This Saporta makes a Scleropteris with the name S. lcevigata.

Zigno, however, takes this plant as belonging to his genus Dichopteris, because it appears to have the nerves, several in number and parallel, proceeding obliquely from the rachis. But an inspection of Zigno's figure shows that this idea of the nervation arises from the fact that he bas not drawn the true point of insertion of the lateral nerves, which is farther within the apparent rachis, and at this point the nerves most probably unite. Zigno has taken the margin of the wing for that of the rachis. According to this, I'achypteris onght not to be considered as a genus. Brongniart's Pachypteris ovate would be Scleropteris levigata Sap., while Saporta makes Bronguiart's Pachypteris lanceolata, and Phillips's Sphenopteris lanccolata, Scleropteris Phillipsii.

SCLEROPTERIS ELLIPTICA, sp. nov.

Plate XXVIII, Figs. 2, 4, 6; Plate XxIx, Fig. 1.

Frond bipinnate or tripinnate, arboreseent; principal rachis stout and woody; nltimate rachises rather slender, straight, and winged; nltimate pinna alternate, linear, terminating abruptly in a pinuule like those lower on the pinux; pinnules or segments thick and leathery, narrowly eliptical, acute, opposite, narrowed at base into a sort of petiole, decurrent to form a narrow wing; nerves immersed in the thick leaf-substance, inconspicnous, diverging flabellately from a short common or mother nerve which does not extend beyond the base of the pinnules, branches once or twice forked or simple.

Localities: Fredericksburg; lignite deposit near Potomac Run; fishing-hut above Dutch Gap Canal; Kankey's; near Telegraph Station.

The plant is not very rare at Fredericksburg. The two fine specimens figured in PI. XXIX, Fig. 1, and Pl. XXVIII, Fig. 6, come from that 
locality. The leaf-substance of this plant is so thick and the epidermis so well preserved that on drying the leaves curl up and peel off from the stone like paper, so that it is difficult to preserve the specimens. The nerves are seen with difficulty, but still they were clearly made out. Plate XXVIII, Fig. 6, gives a portion lower on the frond than the part figured in PI. XXIX, Fig. 1. Plate XXVIII, Fig. 2, gives a small form from Fredericksburg with unusually remote pinnules.

All the features of this plant, except the nerves, agree exactly with those given by Brongniart for Pachypteris lanceolata, and the resemblance to Phillips's Sphenopteris lanceolata is striking.

This Potomac plant was evidently a large one. In this and the other species of the grenus found in the Potomac beds there is no tendency to the lobing of the pinnules given by Saporta as existing on the anterior margin of some species.

Scleropteris elliptica, var. LOxGifolia, sp. nov.

Plate XxviIJ, Fig. 7.

Frond and pinnæ not seen; pinnules linear-elliptical, alternate or opposite, oblong-subacute, gradually narrowed towards the base, very long, decurrent, forming a narrow wing; leaf-substance leathery; nerves comparatively fine, closely placed, forking from a common nerve at the base, diverging slightly, branches deeply once or twice forked, with the ultimate branches parallel.

Locality: Fredericksburg; very rare.

This is probably only a variety of Scleropteris elliptica, but the differences are considerable. The figure gives the summit of an ultimate pinna, which ends in a pinnule larger than those immediately below it on the pinna. It is noteworthy that the pinnules diminish very rapidly in passing towards the tip of the pinna.

Scleropteris Virginica, sp. nov.

Plate XXVIII, Figs. 3,5 .

Frond bipinnate or tripinnate; rachises comparatively stout; primary pinnæ or those of the frond terminated by an ultimate pinnule like those 
immearately below it on the principal rachis; viltimate pinnæ opposite, terminated by a lobed tip, the pinnules of the lower portion having here passed into more or less united lobes; pinnules small, opposite, thick, and leathery, elongate-elliptical, acute, narrowed gradually to the base and inserted by a sort of petiole, decurrent to form a narrow wing; nerves inconspicuous from immersion, branching from a common point or a very short nerve at the base of the petiole, diverging slightly, the secondary branches forking once or twice.

Locality: Red clay ball in banks of Dutch Gap Canal; rare.

This is a much smaller form than S. elliptica, and more like S. Pomeli Saporta, being, however, somewhat larger than that.

Scleropteris dentata, sp. nov.

Plate LXIII, Figs. $3,4$.

Frond bipinnate?; rachises slender, those of the ultimate pinnæ winged; pinnules with leathery leaf-snbstance, oblong to elliptical, acute, greatly narrowed at base, and decurrent to form a wing; lower pinnules cut very obliquely into ovate-acute lobes, which pass in the pinnules higher on the frond and towards the tips of the ultimate pinnæ into triangular and shallow acute teeth; the ultimate pinnx (Fig. 3) terminate with an oblong pinnule, which has at its summit three teeth; nerves of the pinnules composed of a slender midnerve, which sends off alternately into each lobe or tooth a deeply forked lateral nerve, sometimes having one of the branches forking again.

Locality: Fredericksburg; quite rare.

This fern shows a curious blending of the features of Scleropteris and Ctenopteris, standing midway between them. Perlaps it would be better to make it a new genus.

\section{CTENOPTERIS, Brong.}

Frond bipinnate or tripinnate; pinnæ broadly linear lanceolate, pinnate, and pinnatifid; pinnules attached by the entire base, slightly decnrrent, lower ones separate, upper ones slightly united at base, slightly curved 
forward; leaf-substance thick, margins entire or with spinons teeth; nerves several, arising from the rachis either separately, or from a common point, or from a short parent nerve, branching one or more times, branches turned slightly outward, or with a central nerve that sends off on each side branches that diverge flabellately.

The forms from the Potomac flora that I have placed in the genus Ctenopteris, with the amended description given above, differ somewhat from the typical form on which Brongniart founded the genus, viz, Ctenopteris cycatea Brong., and the species of Saporta, C. grandis, but stand very near to the latter.

These Potomac species apparently are composite in type and unite some of the features proper to several generir of ferns. They have, however, so many of the characters of Ctenopteris that it seems proper to place them in that genus.

Perhaps the differences shown when they are compared with the typical ctenopterids are due to modifications produced in the genus as time passed, for we must remember that Ctenopteris cycuden and C.grandis are Liassic fossils, while the Potomac forms are much younger. The divergences are of such a nature as to suggest this relationship, for the chief ones consist of a greater complexity produced by the differentiation of the nerves, which tends to produce a midnerve, and by the development of teeth on the margins of the pinnules or segments

Althongh from the general character of these plants I regard them as ferns, still, so long as they show no fructification, it is quite possible that they may be cycads. Schimper ${ }^{-1}$ well says that the tripinnate character of the leaf of the genus does not necessarily exclude it from the cycads, for the cycad genus Bowenia has bipinnate leaves. Bowenia resembles the Potomac plants more strongly than the forms on which Brongniart founded the genus, for this cycad has leaflets cut away obliquely in front and nerves which diverge from a common point at the base of the pinnules, features fonnd in the Potomac plants; and, what is more significant, some of the pinnules of Bowenia have at least one spinous tooth, much like those of the Potomac plants.

${ }^{1}$ Zittel's Handbuch der Palieontol., vol. 2, Liferung I, p. 123. 
Saporta calls attention to the resemblance of the Jurassic ctenopterids to the odontopterids of the Carboniferous, and says that there is much difficulty in giving any good distinction betrveen Ctenopteris and Zigno's genus Dichopteris from the Oolite. He thinks it possible that Dichopteris may represent Ctenopteris in the Oolite, the main difference being that Dichopteris has its pinnules narrowed at base. Saporta also remarks that Scleropteris is near to Ctenopteris. The Potomac plants bring these genera still nearer, supplying connecting links, for we find some with the characters of each of these genera predominating, and they graduate into one another. They show that the features relied upon to distinguish Scleropteris, Ctenopteris, and Dichopteris have in the main but little value. Scleropteris may remain a distinet genus, but, as has been suggested, there seems to be no good reason why Dichopteris should not be united to Ctenopteris; for, as Saporta says, the bifurcation of the frond of the former may have been accidental. If we omit the slight union of the pinnules at base and the absence of teeth, the resemblance between the nervation of Dichopteris Visinica, ${ }^{1}$ its shape, and the attachment of the pinnules, and these features in some of the Potomac etenopterids is most striking. We have the same slight forward curvature of the pinnules, the oblique cutting arva in front, the slight decurrence below, and the same mode of insertion of the nerves. The nerves differ only in the more copious branching of the central ones of the Potomac plants.

Heer $^{2}$ gives figures of plants which he places in his cycadean genus Clenidium. These, and more especially the species $C$. dentatum, resemble in some points the Potomac plants; but in Heer's plants the cycadean features predominate, and they certainly belong to a genus distinet from that of the Potomac fossils. Phillips's Odontopteris Leclienbyi Zigno (Geol. of Yorkshire, p. 218) may also be compared with these plants. The species Ctenopteris Itier $i^{3}$ Sap. seems to belong to a type quite different from $C$. grandis and $C$. cycadea, having the nervation only in common. C. Itieri is much more fern-like than the two latter.

\footnotetext{
${ }^{1}$ Zigno: Flor. Foss. Form. Oolitice, Pl. XII.

${ }^{2}$ Flor. Foss. du Portugal, Pl. XV1.

${ }^{3}$ Pal. Française, Plantes Jur., vol. 1, Atlas, Pl. XLIV, Figs. 1, 3.
} 
The Potomac fossils give more of the frond than the species hitherto known, and thus add a good deal to our knowledge of this curious genus. Unfortunately no trace of finctification was seen.

Ctenopteris insignis, sp. nov.

Plate LXI, Figs. 4, 5; Plate LXII, Fig. 1 ; Plate LXIII, Figs. 1, 2.

Frond large, arborescent, bipinnate or tripinnate; principal rachis very strong, striate; ultimate pimne with strong rigid rachises, alternate, terminating in a lobed segment, the pinnules passing into lobes more or less united towards the ends of the ultinate pinne; pinnules thick and leathery, those of the lower and mildle portions of the pinne attached by the entire base, slightly decurrent, separate, cut away obliquely above, alternate to subopposite, gradually diminishing towards the summit of the pinne in size and depth of toothing, not sensibly narrowed at base, oblongacute, curved slightly forward, terminating in a large ovate to subtriangnlar acute tootl. The pimules usually show two acute or spinons teeth on each side, a comple near the base, and a second couple near or at the summit of the pinunle, the associated members of the conples being opposite or subopposite. Sometimes there is an additional tooth on the posterior margin below the upper one, and sometimes the terminal tooth is enlarged to an oblong lobe (see Pl. LXI, Fig. 4), which is slightly notched; nerves several, departing separately from the principal rachis along the entire width of the base of the pinnule, the outermost ones once forking and curving outwards, the inner ones forking deeply several times and slightly diverging flabellately, the ultimate branches nearly or quite parallel, long, and slender.

Localities: Fredericksburg; road-side near Potomac Run.

This splendid plant is not uncommon at the first-named locality, and . is found in small bits only at Potomac Rum. All the specimens figured come from Fredericksburg. The specimens show a black, glossy plantmatter, which peels off like paper from the stone, and inclicates that the epidermis was dense and durable. A thick coriaceous epidermis covered the main rachis and all parts of the plant. The nerves are not usually distinctly seen, being obscured by the thick epidermis. The form given in 
Pl. LXI, Fig. 4, differs from the typical forms in having the termination of the pinnules an oblong lobe, which is slightly notehed or toothed. Figure 5 of the same plate appears to be the summit of an ultimate pinna, differing in the trilobate terminal pinnule from the normal termination, as slown in Pl. LXIII, Fig. 1, where the lobes gradually diminish in size towards the sumnit.

Ctenopteris virginiensis, sp. nov.

Plate LxII, Fig. 4 ; Plate LXV, Fig. 1 ; Plate LXVI, Fig. 4.

Frond bipinnate or tripinnate, probably. arborescent; rachises stout, strongly ridged or keeled; ultimate pinnæ subopposite; leaf-substance thick; pinnules comparatively short and broad in proportion to their length, opposite or alternate, slightly decurrent, distinct to the base or slightly united, attached by the entire base, rounded obliquely on the upper side at base, slightly curved forwards, posterior margin nearly always free from teeth, terminating in a triangular tooth, with an acute tooth on each side of this at the summit of the pinnnle, and with an acute or spinous tooth about midway on the anterior margin; nerves proceeding from a common point on the rachis of the ultimate pinnæ, branching several times and diverging slightly, the ultimate branches long and nearly parallel.

Locality: Fredericksburg; rather rare.

This plant has a very stout principal rachis, but the species is decidedly smaller than C. insignis, and shows some important points of difference from it. On nearly all the pinnules there are no teeth on the posterior margin of the pinnules, and only one on the anterior margin. The most important difference is in the nerves. They form two principal nerve-bundles, which depart from a common point and not from the entire base of the pinnule. Thus they show a tendeney to form a midnerve withont aetually developing one. In this feature there is an approach to the Scleropteris type.

Cteinopteris Minor, sp. nov.

Plate LxVII, Fig. 3.

Fronds small, arborescent, bipinnate or tripinnate; principal rachis strong, rigid; ultimate pinnæ with rachises strong towards the base and 
much attenuated towards the summit, alternate to subopposite, and terminating in a slender toothed or lobed segment; pinnules small, separate in the lower part of the ultimate pinne, but united at base in the upper part of the same, attached by a base slightly narrowed and decurrent, cut away obliquely on the upper side of the base, inclined forwards, alternate to opposite. Towards the summit of the ultimate pinne the pinnules diminish in size and in the number and depth of the teeth, the uppermost ones being entire and elongate-oblong in shape. The lower and middle pinnules of the ultimate pinne are generally subrhombic in form and vary somewhat in the number and form of the teeth; they terminate in a comparatively large triangular or ovate tooth or lobe, which is generally entire and rarely slightly dentate, and generally show two more or less acute teeth on each side and in pairs, a pair near the base and one near the summit, the members of the pairs being opposite or subopposite. Sometimes additional teeth appear, generally on the posterior margin of the pinnules; principal nerves several, departing separately from the rachis of the ultimate pinne so as to fill the central portion of the base of the pinnules. The outermost ones fork once and curve outwards, the inner ones fork several times and diverge slightly in a flabellate manner; the ultimate branches are short and diverge strongly; all the nerves strong.

\section{Locality: Fredericksburg; rare.}

This plant is in many features like Ctenopteris insignis. It differs firom this mainly in the small size of the pinnules, the greater variability of the teeth, and in the character of the ultimate forking of the nerves. In $C$. insignis the ultimate branches of the nerves are long, slender, and nearly parallel. Perhaps this is merely a small variety of that plant.

\section{Ctenopteris integrifolia, s]. nov.}

Plate LXII, Fig. 2; Plate LXV, Fig. 3.

Frond unknown; pinnules oblong to subelliptical, slightly curved forwards, subacute, obliquely cut away on the anterior margin at base, decurrent on the lower side, separate to the base in the lower portions of the ultimate pinnæ, united slightly in the upper ones, which are much diminished in size; nerves several and distinct, departing from the rachis 
at several points, the onter ones once or twice forking and turned ontwards, the central nerve branching several times, branches flabellately diverging; all the ultimate branches from deep forking are long.

Localities: Road-side near Potomac Run; Fredericksburg; very rare.

This plant makes a close approach to Zigno's Dichopteris Tisianica, the main difference being the more copious branching of the central nerve, as shown in the pinnules of PI. LXV, Fig. 3, magnified in Fig. 3. In that shown in PI. LXII, Fig. 2, from Fredericksburg, the pinnules are somewhat falcate, and are united at base. It is apparently a fragment of the terminal portion of a pinna.

\section{Ctenopteris angustifolia, sp. nov.}

Plate LxV, Fig. 2; Plate Lxvi, Fig. 4.

Frond unknown; ultimate pinnæe long, with rather stont rachises, pinnules linear or narrowly oblong, in proportion to wilth quite long, slightly curved forwards, separate to the base, or united to form a wing on the rachis of the pinnæ, cut away obliquely on the upper side at base, and slightly decurrent on the lower side, attached by the entire base, terminated by from one to three acute or spinous teeth, and having a varying number of the same placed irregularly on both margins. The nerves proceed from the rachis at different points along the entire base of the pinunles; the outer ones simple or forking once, the central ones forking several times, the nltimate branches being long, slender, and slightly diverging.

Locality: Road-side near Potomac Run; rare.

There is some difference in the two specimens figured, which, however, may be due to different positions on the frond.

Ctenopteris longifolia, sp. nov.

Plate LxVII, Fig. 5.

Frond unknown; rachis of the ultimate pinne very broad but not apparently very woody; pinuules placed very remotely, opposite, going off obliquely, very long, linear, narrowed gradually and slightly towards the base and slightly decurrent, tips not seen; nerves not well made ont, but apparently as shown in Fig. $5^{\text {a }}$; that is, several, departing independ- 
ently from the rachis and forking near the base; the hranches, so far as seen, simple, and nearly parallel.

Locality : Fredericksburg; only one specimen found.

This is another of those curio us forms which, as they stand nearest to Ctenopteris, are placed provisionally in this genus. The obscurity about the nerres is wholly confined to their character at the attachment of the pinnules. They were not distinctly seen at this point, and maty be not forking there but separate. The plant is very much like the genus Encephatartos, and especially resembles E. tridentatus Lelmm. It may really belong to this genus.

\section{ZAMIOPSIS, gen. nov.}

Fronds large, bipinnate to tripimatifid; leaf-substance leathery and thick, covered with a dense durable epidermis; rachises strong, rigid, and keelerd on the lower surface, often with ridged or raised margins on the upper surface; penultimate pinne very long, ultimate pinnæ or pinnules usually closely placed, narrowed to the base, mostly linear-lanceolate or oblong-lanceolate, the lower ones generally cut obliquely into pinnules which are denticulate, but pass above into denticulate cr spinous teeth and terminate in two or more spinons teetls; nerves of the pimnules and lobes mostly composed of a midnerve which goes off. very obliquely and curves strongly outwards, sending off obliquely and alternately lateral branches, which are forked or simple and curve upwards towards the smmmit of the segment; in the lobes and teeth the lateral nerves go off very obliquely and fork once or twice, having very long ultimate branches; nerves, although fine, very distinct.

This curious type of ferns, if ferns they are, reminds one of the cycadean genus Stangeria in some respects, but in the nature of the lobes and teeth they differ from Stangerita. In most species the nerves towards the upper portion of the ultimate pinne or pinnules are very oblique and have long slender branches, while in the lower or basal portions they form nerve-bundles that curve more or less strongly outwards to meet the margin of the pinnule or reduced pinna. The plants show a curious blending of the features of cycals and ferns, with a predominance of the latter. 
In the branching of the rachis we have the fern rather than cycadean character, although Bowenia shows that this is not necessarily solely a fern feature. We can hardly assume that Bowenia is the only branching cycad that ever existed. It is more natural to suppose that it is a survivor of a group of branching cycads that once possessed numerous forms. The nervation of the lower portions of the pinnules is rather that of ferns than of cycads, but Stangeria shows that similar nerves may exist in cycads. The very long, slender; deeply forking nerves in the summits of the pinnules are similar to those of cycads. The peculiar spiny teeth are decidedly like those of eycads, but the teeth pass below on the frond into lobes, and these lower down graduate into segments that we may call pinnules, and this feature is clearly fern-like. The nerves are immersed in the dense leaf-substance, so that they are often obscured.

The singular plant Zamiopsis laciniata, given on Pl. LXVI, has so many features that cause it to differ from the typical forms of Zamiopsis, that it may well be questioned whether or not it should be made a new genus; but as it has some features allying it to the typical Zamiopsis, I place it with a good deal of hesitation in that genus. So long as no fructification is found with these plants their true position ean not be positively determined; meantime they may be placed provisionally among the ferns. This type forms quite an important element in the Potomac flora.

Zamiopsis PINNATIFIDa, sp. nov.

Plate LXI, Fig. 7 ; Plate LXII, Fig. 5; Plate LXIV, Fig. 2; Plate LXVII, Fig. 2.

Frond large, arborescent?; principal rachis keeled on the under side, strongly ridged on the upper margins, probably tripinnate; pinnules or reduced pinne alternate, attached by the middle of the narrowed base, oblong, terminated by usually two acute shallow teeth in the basal portions, eut down nearly to the midrib into ovate denticulate lobes or pinnules; up higher on the pinnules or reduced pinnæ these pass into ovate teeth, which become more and more shallow. On the basal lobes or pinnules there are on each margin two or three shallow spinous teeth; midnerve of the ultimate pinnie or pinnules strong at base, rapidly attenMoN $\mathrm{xV}-11$ 
tated towards the summit, and dissolving into branches near the tips; lateral nerves of the basal toothed pinnules or lobes composed of a nervebundle which goes off very obliquely from the lower portion of the lobe or below it, branching several times, curving strongly away from the midnerve of the pimmle or reduced pinna, slightly diverging, the ultimate branches going into the teeth, and mostly simple. In the lobes towards the upper end of the pinnules the nerves become less and less copionsly branched, being finally reduced to nerves forking only once or twice.

Locality: Fredericksburg; rather rare.

This plant must have been a very large one. Plate LXI, Fig. 7, and Pl. LXIV, Fig. 2, give probably fragments of compound pinnæ. The pinnules cut into lobes are most probably reduced ultimate pinne, the lobes representing what are, in portions lower down, pinnules separate to the base; possibly these fossils may be a variety of the next following, Zamiopsis insignis, but there seem to be no forms establishing a passage into that species.

\section{ZaMiopsis INSIGNIS, sp. nov.}

Plate LXII, Fig. 3 ; Plate LXIV, Figs. 1, 3; Plate LXV, Figs. 4-6; Plate LXVI, Fig. 2; Plate LXVII, Fig, 7.

Frond very large and spreading, probably tripinnate; leaf-substance of the pinumles thick and leathery; epidermis, covering the principal rachis, as well as the other portions of the plant, thick and durable; principal pinne going off at very nearly a right angle, very long, with a very stout, rigid rachis, keeled on the lower side, with marginal ridges on the upper side. The ultimate reduced pinna or pinnules pass towards the summit of the penultimate pinnæ into much reduced toothed pinnules, united at base and decurent; ultimate pinne or pinnules oblong, much nurrowed at base in the lower ones, and attached by the middle of the base, alternate, varying in size, extent of tootling, and remoteness with their position on the frond, lower ones cut deeply and obliquely into oblong or subquadrangular lobes or pinnules, which nsually have near the tips on each side shallow spinous teeth, and end in a comparatively large ovate-acute tooth. Sometimes only one tooth is found on the lobes, and that occurs on the 
upper margin ; this varies with the position of the lobes on the pinnæ and the frond; on the lower lobes and pinnæ it is broadly triangular, rather deeply cut, and directed outwards; in the upper pinnæ and lobes it is minute, shallow, and spinous; in the upper portions of the frond the lobes end in or graduate into spine-like teeth, which are sometimes much prolonged and quite slender, these teeth directed forwards or outwards are single or double. The reduced ultimate pinnæ or pinnules end variously, either in two or more acute teeth or in an ovate-denticulate lobe; midnerve of the ultimate pinne or pimules strong towards the base, rapidly much attenuated higher, and at the summit dissolving into branches; nerres of each lobe or pinnule of the basal portions of the lower pinnæ or pinnules composed of a nerve-lundle which goes off very obliquely from the rachis below the base of the lobe or pinnule, curving strongly outrards, forking near the base, with each branch forking deeply once or twice again. Towards the summit of the ultimate pinnæ the lateral nerves become very oblique, do not curve so suddenly and strongly outwards, but continue for a long distance, more or less in the direction of the axis of the pinna, are forked several times with long branches, forming indeed the branches into which the midnerve splits up. In the upper toothed pinnæe the midnerve (see Pl. LxIV, Figs. 1a, $1^{\mathrm{b}}$ ) continues only a little more than one-tluird of the length of the pinna. It is split up into very obliquely placed, slightly diverging, and very deeply forking branches, which fork once or twice, and have very long, slender, ultimate branches. The lateral nerves from the lower portions of these pinnæ, go off very obliquely, fork once or twice, and have very long, slender, ultimate branches.

Locality: Fredericksburg; rather common.

The specimens obtained of this plant show that it must have attained a very large size. The fragment figured in Pl. LXIV, Fig. 1, is probably a portion of a componnd pinna of large dimensions. The specimen given in Pl. LXV, Fig. 4, which is a portion of probably a pennitimate piuna, shows that these must have been in some cases very long. The epidermis over the pinnules and rachises of Pl. LXIV, Fig. 1, was so thick and durable, that it could be peeled off like paper. Plate LXIV, Fig. 3, seems to show a fragment of a penultimate pinna, forming the lower portion of one 
corresponding to that depicted in Pl. LXV, Fig. 4. Plate LXIV, Fig. 3, shows some irregularity in the spacing of the penultimate pinne or pinmules, the central ones on the left-land side showing an abnormal croweling. Plate LXVII, Fig. 7, appear's to be an nltimate pinna or pinnule from still lower on the frond than any of the others, and the lobing is irregular, two of the lobes from the middle of the specimen on the righthand side being cut deeply into falcate, narrowly oblong, or ovate lobes. While the general plan of the lobes and teeth is the same thronghout, some variation is shown in the number, arrangement, and shape of the tecth. Thus we have in Pl LXV, Fig. 5, the lobes or incipient pinnules subquadrangular, curved forward, with a terminal ovate tip, and on the exterior margin near the tip a broadly triangular tooth directed outwards.

\section{ZaMiopsis LONGIPENNIS, sp. nov.}

Plate LXI, Fig. 8.

Frond unknown; ultimate pinnæ or pinnules very long, ensiform, slightly falcate, acuminate; margins of the pinumles cut into shallow, narrowly ovate single or donble teeth, midnerve strong towards the base and vanishing towards the ends of the pinnules, splitting up into branches, in the upper portion not placed centrally in the pinnules; lateral nerves distinct, going off very obliquely, curving outwards and forked once or twice, with the ultimate branches long and slender.

Locality: Fredericksburg: only one specimen found.

This may possibly be the summit of a pinnule of Zamiopsis insignis, but it has features not seen in that species, and the pimule was evidently much longer than any seen on it. The eccentric position of the midnerve and the convex expansion of the lower margin near the summit of the pinnules are peculiar features.

\section{Zamiopsis laciniata, sp. nov.}

Plate LxVI, Fig. 1, 5-8.

Frond very large and wide-spreading, probably arborescent; ultimate pinnæ alternate, the lower ones very long, rapidly diminishing in length 
and size in ascending towards the summit of the principal pinne, having a distinctly winged rachis, and terminating in a variously shaped segment formed of united pinnules or lobes, usually three in number; pinnules very variable in size and shape, mostly long, ribbon-shaped, slightly narrowed to the base and attached by the entire base, decurrent, and united to form a wing, cut very obliquely into a few lobes of varying depth, which are elongate-oblong or narrowly ovate in shape, and nearly always placed on the posterior margin of the pinnule. The lobes toward the summit of the pimnules pass sometimes into acute triangular teeth, which are turned outwards. The pinnules at the summit of the ultimate pinne pass into more or less united lobes, which vary a good deal in shape, being sometimes much narrowed and even wedge-shaped at base, and incised into a varying number of irregularly shaped teeth; nerves of the pinnules departing from a short mother nerve at the base of the pinnules, forming three branches, these diverging slightly in a flabellate manner; branches very long, slender, but distinct, onter branches simple or once or twice forked, the inner one forking several times and approaching the character of a midnerve; leafsubstance thick and leathery.

Locality: Frederickśburg; rare.

This splendid but very peculiar fossil unites some of the features of Zamiopsis with some of those of Ctenopteris. It really stands intermediate to typical forms of these two genera. It also shows some of the features of Scleropteris, and it hence belongs to quite a comprehensive type of plants. As the nervation is not essentially different from that of Zamiopsis, it seems best to place it provisionally in that genus.

The plant is a remarkable one. In its pinnules and longer lobes, so far as the shape goes, it reminds one of Saporta's Stenopteris desmomera, but the nervation is very different. Some of the pinnules towards the tips of the lower ultimate pinnæe are narrowly strap-shaped, and show a very considerable length without any lobing or toothing. But as the tips of these are wanting, it is possible that they may possess teeth up higher. Figure 6 , the upper portion of an ultimate pinna, and also Figs. 5, 7, show how irregular the toothing and shape of the pinnules, liere reduced to lobes, become in the terminal portions of the ultimate pinnæ. 


\section{ZaMiopsis PETIOLATA, sp. nov. Plate LXVI, Fig. 3.}

Frond bipinuate or tripinnate; principal rachis with a strong wing; primary pinna terminating abruptly in a large incised pinunle similar to those lower lown; pinnules petiolate, attached by the midnerve, prolonged into a stout petiole, alternate, cut obliquely into oblong or subelliptical obtnse pinnules, in the lower part of the ultimate pinna turned ontwarch. These graduate in the upper parts of the same into lobes and teeth of the same general character. The summit of the ultimate pinna is a broad oblong segment ending in several shallow subacute teeth formed by the union of the lobes at the summit; the ultimate pinne in passing towards the summit of the penultimate ones diminish much in size, the pinnules and lobes passing finally into teeth; lateral nerves in each pinnule and lobe consisting of a nerve-bundle which goes off very obliquely from a point near the lower end of the pinnule or lobe, branching near the insertion, and curving out to enter the pinnule or lobe, the branches forking again once or twice, with the ultimate nerves very long and slender, owing to their deep forking.

Locality: Fredericksburg'; very rare.

This is another of the peculiar cycad-like ferns which form such a striking feature in the Potomac flora. Possibly it is a new genus, and I place it with donbt provisionally in the genus Zamiopsis. The principal rachis has on each side a strong succulent wing or margin (see Fig. $3^{\text {a }}$ ). The nerves agree fully with those of Zamiopsis.

\section{PHANEROGAMS.}

\section{GYMNOSPERMAE.}

\section{ZAMIE $A$.}

The cycads of the Potomac flora, although presenting a considerable number of species, by no means equal the Coniferce in that respect, but it is especially in the number of individuals that this group contrasts with the Coniferce. With the exception of Dioonites the speeies, when found, are among the great rarities at the different localities. As the specimens 
are generally very fragmentary and apparently injured by transport, it is quite possible that the comparative rarity of cycads is apparent rather than real, being due to the accidents of preservation, which were not favorable to these plants. Although not equaling the ferns and conifers, the cycads are present with a development sufficient to form an important element in the flora and to add greatly to the Mesozoic aspect of the vegetation.

\section{ANOMOZAMITES Schimper.}

Leaves comparatively small, linear or ribbon shaped, sometimes (the younger?) entire, mostly cut into irregular segments; lamina of the leaf attaclied laterally, sometimes undivided or only partially divided, but most often divided into rectangular lobes unequal in size, which, especially in the lower ones, are rounded; nerves going off at right angles, simple, and parallel. The segments have sometimes a corded border.

This description, which is very nearly that given by Schimper ${ }^{1}$ for' Anomozamites proper, typified in Anomozamites inconstans Göppert, fits exactly a few of the smaller Tæniopteris-like cycads of the Potomac flora. The forms thus limited range, according to Schimper, from the Rhretic to the Wealden. From the genus proper, having the above description, certain large leaves are excluded by Schimper in the work above quoted, and placed in a subgenus, Platypterigium. These will be noticed further on. In the genus proper of Anomozamites thère are two species in the Potomac flora.

\section{Anomozamites angustrelolius, sp. nov.}

Plate XXX, Figs. 2, 3 .

Leaves comparatively narrow, $4^{\mathrm{cm}}$ wide, ribbon-shaped at the tip, narrowed rapidly; leaf-substance thin, lower portions of leaf not seen; midnerve moderately strong; lateral nerves going off nearly at riglit angles, simple, parallel, arched slightly forward, towards the tip of the leaflet going off more obliquely and arched forward more strongly, slender, but distinct.

Localities: Fredericksburg; Baltimore; in Meek's collection; rare. 
The small fiagment (Fig. 2) occurs in the plants collected by Meek at Baltimore, probably at Federal Hill. It is the smallest of the Potomac Anomozamites and may be a young form of some of those found in the Platypterigium subgenus, for it shows no tendency to subdivision of the lamina.

ANomozanites viRginicus, sp. nov.

Plate Xxx, Fig. 4 ; Plate Xxxi, Fig. 3.

Lenves proportionally very long, of medinun width, $37^{\mathrm{mm}}$ wide, no segmentation visible; the nerves are simple and go off nearly at right angles, and near the margin curve slightly forward, thin, but distinct; leafsubstance thin ; midnerve strong. .

Localities: Road-side near Potomac Run; near Telegraph Station; rare.

The leaves of this plant are considerably larger than those of $A$. angustifolius. No tendency to segmentation is shown, and it may be a young form of one of the large Platypterigia.

\section{ANOMOZAMITES, subgenus PLATYPTERIGIUM, Schimper.}

Leaves large, up to two feet and more in length, and half a foot wide; lamina of the leaf thin, divided into segments of unequal size, that are rounded or obtusely rhombic in shape; nerves parallel, simple, and forked; forms are Pterophyllum Braunsii Schenk., P. princeps Oldham and Morris, etc.

This description of Schimper for the subgenus agrees well with certain large leaves that are rather common at Fredericksburg. Schimper says that these leaves may be compared with the split leaves of Macrotconiopteris, and such I for some time took them to be, but was finally compelled to think that the segmentation was not the result of accidental fissuring. The individuals of the species of this genus are very much more abundant than those of the species of Anomozamites proper. It is peculiar that I could find no specimen showing the ends of the leaves, and the base of the leaf also was never found. Parts of the middle portions of the leaves were by far the most common. The plants collected by Professor Uhler at Fredericksburg, and which were lost in transmittal to New Orleans, contained a fine tip of one of these leaves. 
These Platypterigia must have attained a great size, rivaling that of Macrotceniopteris magnifolia of the Virginia Rhætic. For some time, when only very imperfect specimens had been found, I thought that these were fissured leaves of that or a nearly allied plant.

My recollection of the lost tip of the leaf in Professor Uhler's collection is not definite enough to enable me to describe it accurately, for I examined it only casually, expecting to be able later to critically stndy it. The leaf tapered gradually to a subacute point, much as do some of those of $M$. magnifolia.

The larger specimens of this subgenus probably formed portions of leaves that must have been over two feet long $\left(60^{\mathrm{cm}}\right)$ and a half foot wide $\left(15^{\mathrm{cm}}\right)$. The rachis is very stout and wide, with a ridge or cord rumning in the middle on the lower side. The upper side is smooth, or with a marginal ridge on each side. Fragments of leaves $25^{\mathrm{cm}}$ long, and withont sensible diminution in their width, have been obtained, and some specimens $14^{\mathrm{cm}}$ wide were seen. Midribs with a width of $9^{\mathrm{mm}}$ have been found, and a portion of a petiole showed the width of $13^{\mathrm{mm}}$. The nerves towards the base, as shown in Pl. XXXI, Fig. 2, are more oblique in their course than in the middle of the leaf. The ridge in the center of the midnerve on the under side seams to be due to the woody bundle of the true midnerve, showing by pressure through the thick epidermis. This epidermis on the midnerve is striated parallel with the length of the leaf. None of the lateral nerves are furcate even at base.

\section{Platypterigium densinerve, sp. nov.}

Plate Xxx, Fig. 8; Plate XxxI, Figs. 1, 4; Plate Xxxı, Figs. 1, 2; Plate xxxIII, Fig. 1; Plate XXxIV, Fig. 1; Plate XxxV, Figs. 1, 2.

Leaves very large, probably $60^{\mathrm{cm}}$ and more in length, and as much as $20^{\mathrm{cm}}$ in width; leaf-substance very thick and membranaceous; midnerve moderately strong, covered with a thick, dense epidermis, which is striated parallel with the length of the leaf, and which makes the midnerve appear wider than it really is, on the lower surface sometimes appearing ridgecl in the middle, on the upper side smooth or corded on each margin at the attachment of the lamina of the leaf; laminx entire, or more commonly cut 
into segments of varying width, that are rectangnlar, irregularly quadrilateral, or subrhombic in shape, and have often the posterior or onter margins obliqnely rounded off; nerves very fine and placed very closely trgether, so that two or three occur in the space of $1^{\text {min }}$, going off nearly at right angles, curving very slightly forward, parallel.

Locality: Fredericksburg; not uncommon.

This splendid plant has yielded a number of specimens, but all of them, no donbt owing to the great size and to the fragility of the leaf, show only small portions of the plant. The base and tip of the leaf were in no case found, although carefully songht for. The specimen mentioned as $25^{\mathrm{cm}} \mathrm{long}$, with no sensible diminution in width, belonged to this plant. One specimen showing only half the lamina of the leaf was $9^{\mathrm{cm}}$ wide (see Pl. XXXV, Fig. 2). This indicates a leaf $20^{\mathrm{em}}$ wide. The tip seen in Professor Uhler's collection seems to have belonged to this species. This plant has the same kind of vaguely defined midnerve that was described in Contributions to the Knowledge of the Older Mesozoic Flora of Virginia, Mon. U. S. Geol. Survey, vol. 6, as belonging to Mucrotaniopteris magnifolia Rogers, of the Older Mesozoic or Rhætic flora of Virginia. It is dne to the dense epidermis and leaf-substance at the junction of the lamina of the leaf and the midnerve, which hides the insertion of the rerves and widens the apparent midnerve.

The nerves, although exceedingly slender and closely placed, are sharply defined and have only one woody bundle, differing in this point from those of the Rhætic fern. They are usually one-half millimeter apart, although sometimes only one-third of this. Fragments of the petiole were very rarely seen.

This plant may be compared with Nilssomia Johnstrupi, Heer ${ }^{1}$. It is very much like Pterophyllum princeps Oldham and Morris, ${ }^{2}$ and also strongly resembles Pterophyllum Braunsii Schenk. Both of these are Rhrtic plants, and both are placed by Schimper in his subgenus Platypterigium. Nitsonia Johnstrupi seems to be a Platypterigium surviving into the Middle Cretaceous.

1 Flor. Foss. Are., vol. 6, Part II, Pl. VI, Figs. 1-ij.

${ }^{2}$ Pal. Indica, Foss. Flor. Rajmahal, Series II, vol. 1, Pl. XII., Fig. 1. 
Platypterigiem Rogersianum, sp. nov.

Plate XXXI, Fig. 2; Plate XxxIII, Fig. 2; Plate XxxIV, Fig. 2.

Leaf large, rivaling. the dimensions of $P$. densinerve; leaf-substance thicker and more coriaceous than that of $P$. densinerve. It is comparatively strong and coriaceous; midrib well defined, rounded, and prominent, rigid, and withont apparẹnt dense epidermis ; nerves comparatively strong, towards the base of the leaf going off more obliquely, higher and towards the middle of the leaf going off at a right angle, simple, straight, and parallel, more remote than those of $P$. densinerve, being $1^{\mathrm{mm}}$ apart.

Locality : Fredericksburg; rare.

This fine plant is much rarer than $P$. densinerve. It is a more robust species than the latter. It is not so prone to segmentation as that species, possibly from its denser and stronger leaf-substance. One specimen was seen $11^{\mathrm{cm}}$ wide, and in a length of $12^{\mathrm{cm}}$ showed no division into segments. I have named the plant in honor of Prof. William B. Rogers, who first studied the geology of the Potomac formation and called attention to its plants.

ZAMITES, Brong., emend.

Leaves small or of medium size, in growing old becoming detached ; leaflets attached to the upper side of the rachis by a callosity, somewhat contracted or rounded at base, almost cordate there, linear or ovatelanceolate, acute or obtuse, margins entire, of firm consistency; nerves simple or forked, the middle ones parallel, diverging only towards the summit, the lateral ones ending in the margin.

This description, which is essentially that given by Schimper, ${ }^{1}$ applies to some detached leaflets found in the Potomac flora. They are always among the rarest of fossils in this flora, appearing only in sparingly dispersed fragments. They form a very inconsiderable element in the Potomac flora, being found mostly at Fredericksburg.

\section{Zamites tenuinervis, sp. nov.}

Plate LxVII, Fig. 1; Plate LxIX, Fig. 2; Plate LXX, Fig. 1; Plate LxxV, Fig. 3; Plate LXXVI, Fig. 7; Plate LxxVIII, Fig. 6; Plate LXxxIV, Fig. 7.

Leaflets very long, attaining the length of $20.5^{\mathrm{cm}}$ and a width of $24^{\mathrm{mm}}$, at base abruptly subcordate, in shape ensiform, sometimes curved,

${ }^{1}$ Zittel's Handbuch der Palaeont., vol. 2, Lief. 2, p. 218. 
acute; nerves very numerous and closely placed, fine but distinct, forked at base or simple, occasionally forked a little higher, parallel after forking.

Localities: Fredericksburg; Kankey's ; banks of Dutch Gap Canal; fishing-hut above the canal; near Telegraph Station.

This fine plant is the most common cycad at Fredericksburg, where it is not very rare. PI. LXX, Fig. 1, is the most complete specimen seen, but in this the nerves unfortmnately were obscure. It is almost always found in the form of detached fragments of the basal portions of leaves, showing that they were very deciduous and disarticulated, so as to leave the detached base more or less heart-shaped. They were apparently attached by a callosity. In PI. LXXVI, Fig. 7, a small bit of the rachis may still be seen attached to the base of the leaf. When the leaves have been detached from the callosity by which they were attached, their bases have a cordate simus. The plant does not seem to be nearly allied to any described fossil.

\section{Zamites CRassinervis, sp. nov. \\ Plate Lxix, Fig. 4; Plate LxxxiII, Fig. 3.}

Leaves broadly elliptical, short, acute, abruptly narrowed at base and attached by a callosity; nerves simple or forking at the very base, very strong, distant, parallel to near the apex, where they are more crowded.

Locality: Fredlericksburg; rare.

This is a well-marked form of a type a good deal like some of the species of Nageiopsis, to be described later, but the leaves seem to have been very decidnous, unlike Nageiopsis, and are at base, when detached, somewhat heart-shaped.

\section{Zamites distantinervis, sp. nov.}

Plate LxxxIII, Fig. 4.

Leaves long, slender, slightly narrowed towards the base, which was not seen, and gradually so towards the tip, which is lancet-shaped and subacute, almost acuminate, slightly curved and subfalcate; nerves strong, proportionally very remote, parallel, not forking in the parts seen.

Locality: Fredericksburg; very rare. 
The base of this leaf was not seen, and the nerves towards the tip were too obscure to be made out. The plant may be Nageiopsis or Podozomites, but the flexuous character of the leaf indicates that it is a Zamites, and here I place it provisionally.

\section{ZaMites ovalis, sp. nov. \\ Plate LXXXV, Fig. 4; Plate CLXX, Fig. 3.}

Leaves short, oval, acute, abruptly rounded off at base, and showing, when detached, a heart-shaped sinus, almost as broad at base as elserwhere; nerves not seen.

Localities: Banks of Dutch Gap Canal; fishing-hut above the canal; road-side near Potomac Run; near Telegraph Station; rare.

This plant can be placed among the Zamites only witl doubt.

\section{Zamites subFalcatus, sp. nov. \\ Plate LXXXIV, Fig. 13; Plate LXXXV, Fig. 3.}

Leaves long, proportionally narrow, subfalcate, acute, widest near the base, abruptly rounded off at base, attachment not seen; nerves not seen.

Locality: Kankey's; very rare.

This is another of the doubtful species of Zamites. The epidermis was so thick that the nerves could not be made ont. Only a slight striation can be seen. The plant specimen given in Pl. LXXXIV, Fig. 13, seems to be a tip of a leaf whose base is probably the specimen figured in Pl. LXXXV, Fig. 3. The amount of material obtained from Kankey's place is so small and the impressions are so poorly preserved, that the number of specimens of any given plant obtained there can not be taken as indicating its actual abundance or scarcity.

$$
\text { Zamites, sp.? }
$$

Plate LXXXIY, Fig. 1:.

A single fragment of a thick leaf was found at Kinkey's place. The nerves were not seen. It is apparently a portion of a leaf of Zamites too imperfectly preserved to permit the species to be determined. 
ENCEPHALARTOPSIS, gen. nov.

Leaves pinnate, leaflets oblong, linear-elliptical, obtuse, terminated by several spinous teeth, margins having irregularly placed, shallow, spinons teeth; nerves numerous, closely placed, forking one or more times and at varying intervals, slightly diverging, and mostly ending in the teeth, anastomosing oceasionally by branches sent off abruptly from one nerve to another.

This curions genus has been found as yet with only one species. It combines the features of Encephalartos with the anastomosing nerves of Ctenis. It is so close to Encephlalartos that, were it not for the occasional anastomosis of the nerves, one would have $n o$ hesitation in placing it in that genus. It probably should be regarded as the prototype of that genus.

\section{ENCephalartopsis Nervosa, sp. nov.}

Plate LXX, Fig. 4; Plate LXXI, Figs. 3, 4; Plate LXXII, Figs. 3, 4.

Leaves and leaflets with the character given for the genus; the shallow, spinous teeth on the margins vary in shape, and tend to pass to rectangular notches; the teeth do not appear on the basal portions of the leaflets; the base or attachment of the leaflets was not seen; the nerves are numerous, closely placed, fine but distinct; they slightly diverge, fork at long intervals and at varying heights throughout the length of the leaf, and are approximately parallel; they anastomose rarely by abruptly sending off branches to unite with the adjacent nerve; the anastomosing branches make comparatively large angles with the parent nerve.

Locality: Fredericksburg; rare.

This plant evidently varied a good deal in the size of its leaves, for the fragment Pl. LXXII, Fig. 4, is much larger than that given in Pl. LXX, Fig. 4. In Pl. LXXI, Fig. 3, the position of the two leaflets indieates that they were disposed in a pinnate manner.

\section{CTENOPHYLLUM, Schimper.}

Leaflets rariable in size, mostly small, long, linear, comparatively narrow and ribbon-shaped, gradually narrowed towards the ends, attached 
to the rachis on the upper side and tonching each other, or united at base, attached by the entire base, nerves in part forking.

This genus is represented in the Potomac flora doubtfully by one species, which has in some respects a different character from the typical forms, such as Ctenophyllum Braunianum Schimper.

Ctenophyluum latifolium, sp. nov.

Plate LXVIII, Figs. 2, 3.

'Leaf very large and wide-spreading; length of leaflets not disclosed, width in the same portion of the leaf variable, ranging from $27^{\mathrm{mm}}$ to $35^{\mathrm{mm}}$; leaflets alternate, going off in the lower part of the leaf at a large angle, in the upper portion much more oblique, attached by the entire width of the widened base, which is decurrent and meets the expanded base of the adjacent ones, forming a broad rounded sinus, those of the upper portion of the leaf united more and more, all curved slightly upwards towards the summit of the leaf; tips of the leaflets not seen; nerves very strong, going off obliquely at their insertion in the lower and middle portions of the lower leaflets, but nearly at right angles in the upper portions, and all turning strongly outwards to enter the leaflets; nerves of the uppermost leaflets all oblique; the nerves fork at the insertion or are simple and parallel; nccasionally but rarely those simple at base fork somew here higher; under a strong lens the nerves are seen to be composed of two closely placed nerve-strands which form a flat nerve-bundle.

Locality: Fredericksburg.

This splendid plant is very rare; only one specimen was seen. As found in the rock, it was as is depicted in Fig. 2, and probably the specimen clepicted in Fig. 3 was attached to the top of it, for it is clearly the smmmit of the specimen given in Fig: 2. But in loosening the imprint in the quarry it was much broken up. The leaf originally must lave been of huge dimensions, for the parts seen are clearly but a small portion of it. The plant shows an irregularity in the size of the leaflets, for in Fig. 2 the right-hand lower leaflet is much wider than the adjacent ones. The nidnerve is stout and rounded. The leaf must have been over a meter in length. This species is strikingly like the large Ctenoplylla of the Rhrtic 
flora of Virginia (see Contributions to the Knowledge of the Older Mesozoic Flora of Virginia, Mon. U. S. Geol. Survey, vol. 6, Pl. XXXIX, Figs. 1-3, to Pl. XLII, Fig. 1). It may possibly be a descendant of some such plant as $C$. grenclifolium. Its extreme rarity indicates that this form of eycad was nearly extinct in this region.

\section{GLOSSOZAMITES, Schimper.}

Leaves pinnate, with leaflets lingulate or elliptical in shape, obtuse at the summit, inserted on the upper face of the midrib by a contracted base, equilateral; nerves fine, branching dichotomously, liverging slightly from the point of attachment towards the borders of the leaflets, which are always entire.

This description of the genus given by Saporta coincides exactly with the character of a fossil found in the Potomac flora. Only one species of the genus was found. The genns is characteristic of the Lower Cretaceous, and seems to play a very unimportant part in the Potomac flora.

Glossozanites distans, sp. nov.

Plate LxVIII, Fig. 5.

Leaf pinnate, midrib slender; leaflets alternate, diminishing in size in ascending, distant, oblong, linguiform, slightly curved upwards, attached to the npper surface of the midrib by a rounded, abruptly narrowed base, which in the lower ones is slightly amricnlate, obtuse; nerves fine, numerous, elosely placed, diverging slightly from the point of attachment, and ending, except the central ones, in the entire margin; onter nerves simple or deeply fureate; inner ones repeatedly forked, with the ultimate branches of all very long and approximately parallel.

Locality: Fredericksburg; very rare.

Ouly one specimen of this very fine plant was found, and that in a fragmentary condition. The leaflets of the lower portion have a base which indicates that they were attached by a callosity. The nerves when forked have very long branches, owing to the distance from their ends at which the forking takes place. It is very much like Schenk's Podozamites 
Zitteli (Glossozamites Zitteli Schimper), ${ }^{1}$ but the leaflets are not so obtuse and are farther apart, while the nerves are more branched.

\section{CTENIS (Lindley and Hutton), Zigno emend.²}

Leaf profonndly pinnatifid; rachis thick, striated, and furrowed; leaflets or lacinix approximate, linear-elongate, entire, enlarged at base, separated by an acute sinus; nerves equal, thick, arising from the rachis, diverging towards the base, then approximate, parallel, forked, branches uniting to form areolie that are obliquely elongate, rhomboidal in shape.

The above is Zigno's description of Ctenis, being an amendment of that of Lindley and Hutton. If we alter this so as to read "leaves pinnate," and omit the items "enlarged at base, separated by an acnte sinus," it will apply to a very noteworthy form found in the Potomac flora. This is without doubt either a trne Ctenis, or so closely allied to it that, in the absence of more definite characters, it may be placed in that genus.

Ctenis imbricata, sp. nov.

Plate CxxxyIII, Figs. 10-12.

Leaf very large, pinnate; leaflets attached by the entire base, which is narrowed and rounded off on both sides, to the upper face of the midrib or stem, obtuse at their, tips and rounded, with broad, shallow, seeming lobes on the under side, imbricated some distance above the base, each leaflet expanding at that point and partly overlapping the next one; nerves strong and distinet, wide apart, forking at or near the base or a short distance ligher up; branches, so far as seen, parallel, anastomosing at long intervals by a few inosculating branches, so as to form long irregular or subrhombic meshes, nppermost leaflets united; leaf terminating in a leaflet in which the midnerve seems to split up into two branches; at the tips of the leaflets the anastomosis is more copious and the nerves are finer and more closely placed.

Locality: Fredericksburg; very rare.

This remarkable plant agrees quite well with the subgenus Ctenis, and in some points it is like the fignres of Ctenis falcata, ${ }^{2}$ Lindley and Hutton,

${ }^{1}$ Schenk, Foss. Phanz, der Wernsdorf. Schichten, 1sil, Pl. J, Fig. 8.

${ }^{2}$ Ziguo, Flor, Foss. Form. Oolitic, rol. 1, 1856-'68, Pl. XX]V, Figs. I-3. HION $\mathrm{XV}-12$ 
given by Zigno. It has the same mode of insertion of the nerves, which are irregular, forking, and anastomosing, but in Ctenis falcato the leaflets are decurrent, and become much widened at their insertions. The Potoma plant is more like Nathorst's plant from the Rhætic of Sweden, which he first named Anthrophyopsis Nilssoni, and afterwards called Ctenis fallax The termination, especially of the leaflets in the two plants, shows a resemblance. Pl. CXXXVIII, Fig. 12, gives what seems to be the middle of a leaf of large size. Fig. 11 gives the upper portion of a leaf that seems to linve been much larger than that depicted in Fig. 12, as is shown in the much greater width of the midrib. This specimen is a good deal distorted by pressure, so that its true character may be disguised. The wide midrib seems to be split into two branches, which are connected by sualler nerves. The fragment of a leaflet visible on its left-hand side seems to have harl its base pressed over upon the upper surface of the midrib, while the lower half of that on the right hand seems to have been torn away by the splitting off and detaching of a portion of the midrib. The specimen given in Fig. 10 seems to be the tip of a leatlet, perhaps corresponding to the basal portions shown in Fig. 12.

\section{PODOZAMITES Fr. Braun (emend.).}

Leaves small, with a slender rachis, pinnate; leaflets alternate, remote. directed more or less upward, with a gradually narrowed base, often furnished with a short petiole, ovate-elliptical, elongate, lancet-shaped, or linear, sometimes somewhat curved, detaching themselves from the rachis, and nsually found isolated; nerves forked at the base, often very fine and closely placed, parallel with the margin to near the tips of the leaflets, where they converge.

The genus Podozamites is represented in the Potomae flora apparently by a considerable number of species; but as the specimens appear usually in the form of fragmentary and detached leaves, they do not generally admit of a full characterization and positive determination. The leaflets having the character of Po?ozamites are quite rare, and the genus contributes no important element to the flora. They give one the impression of a type in decadence Most of them are in form strikingly like the 
leaves of Nageiopsis, a genus of conifers described in this work, but they differ from this in the very deciduous nature of the leaflets, and above all in the convergence of the nerves at their summit.

Podozamites subfalcatus, sp. nov.

Plate Lxvili, Fig. 6; Piate CLXx, Fig. 9.

Leaves unknown; leaflets subfalcate, narrowly elliptical to strap-shaped, obtuse or subacute, gradually narrowed to the base sn as to form a broad, short pedicel, thick and leathery; nerres slender, and not well disclosed, forking near the base, then nearly parallel to near the tips, where they converge.

Locality: $72 \mathrm{~d}$ mile-post near Brooke; rare.

Only detached fragments of leafets were found. The leaflets must have varied a good deal in size, as Pl. LXVIII, F.ig. 6, represents a nearly complete leaf, which is much smaller than that of which Pl. CLXX, Fig. 9, represents a fragment. The shorter form, Pl. LXVIII, Fig. 6, is a good deal like Zamites ovatus, and $Z$ affinis Schenk, ${ }^{1}$ forms which Schimper makes Podnamites. The longer leaflet on the other hand is somewhat like $Z$. nervosus Schenk, same plate, Fig. 10.

\section{Podozamites distantinervis, sp. nov.}

Plate LXxIX, Fig. 5; Plate LxxXII, Fig. 4 ; Plite LXXXIII, Figs. 1, 2, 6, 7; Plate LXXXIV, Figs. 1, 2, 8, 10, 14, 15; Plate LXXXY, Figs. 12, 16.

Leaves comparatively large, pinnate; leaflets large, elongate-elliptical in form, varying a good deal in size, maximum width varying from $27^{\mathrm{mm}}$ to $40^{\mathrm{mm}}$, nsually comparatively broad, full length not seen, but ranging from $11^{\mathrm{mm}}$ to over $14^{\mathrm{em}}$, obtuse or subacute at tip, usually somewhat narrowed toward the base, and at the base rather abruptly rounded off into a short pedicel; nerves strong, quite remote, forking at or near the base, and then parallel to near the tip, where they converge and connive more or less.

Localities: Road-side near Potomac Run; Fredericksburg: near'Telegraph Station ; rare.

This is the most common Podozamites, but still it is not abundant. More specimens were found at Fredericksburg than anywhere else, prob-

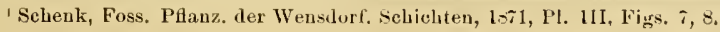


ably because more material was obtained there than at most places. Pl. LXXXIII, Fig. 1, gives the upper portion of an unusually large leaflet, in which the nerves are obscure, but may be seen to converge at the summit. Fig. 2 of the same plate shows two leaves of medinm size in a position as if coming off from a common stem. Pl. LXXXIV, Fig. 10, gives three leaflets detached, and from displacements overlapping one another. Figs. 14 and 15 of the same plate give the base and the tip of the leaf fragments slightly enlarged, to show the nervation. The base given in Fig. 14 is more abruptly rounded off than usual, but little narrowing toward the base having taken place; possibly such leaflets, with those such as given in Fig. 8 of the same plate, may belong to a different species.

This Podozamites does not seem to be near any of the heretofore deseribed species.

Podozamites pedicellatus, sp. nov.

Plate LXXVI, Fig. I ; Plate LXXVIII, Fig. 7; Plate LXXxII, Fig. 5.

Leares not seen; leaflets large and long, length not fully disclosed maximum width varying from $26^{\mathrm{mm}}$ to $35^{\mathrm{mm}}$; slape probably oblong to elongate-elliptical, gradually narrowed to the base, and elliptically shaped there, furnished with a long, broad pedicel, curved to one side, decidnous; nerves, forking near the base, then nearly parallel, tips of leaflets not seen.

Locality: Fredericksburg; rare.

This possibly may be a Nageiopsis, as the nerves at the tips of the leaflets were not seen, but the deciduous nature of the leaflets indicates that they belong to Podozamites.

Podozamites grandifolius, sp. nov.

Plate LXXXII, Fig. 2; Plate LXXXII, Fig. 5.

Leaflets very large, $4.5^{\mathrm{cm}}$ wide and over $20^{\mathrm{cm}}$ long; shape not seen, probably elongate-elliptical, with stout pedicel at base; nerves where seen strong, parallel, remote, composed of two nerve-strands which are closely placed, and form a flat nerve-bundle.

Localities: Fredericksburg; road-side near Potomac Run ; rare.

This plant is quite rare, and, owing to their great size, the leaflets were found only in a fragmentary condition; hence their shape could not be made 
out exactly. Pl. LXXXIII, Fig. 5, from the Potomac Run locality, indieates that it had at the base of the leaflets a stout pedicel. Pl. LXXXII, Fig. 2, from Fredericksburg, is a fragment of what must have been a very large leaf. The lower or posterior margin of this leaf is nowhere shown.

\section{Podozamites acutifolius, sp. nov.}

Plate LXXX, Fig. 6 ; Plate LXXXV, Figs. 10, 15; Plate LXXXVII, Fig. 1; Plate CLXX, Fig. 2.

Leaves very deciduous, varying in length, oblong, subacuminate, maintaining the maximum width to near the base, and then suddenly rounded off and attached by a short pedicel; nerves branching near the base, and one branch sometimes forking again higher up; at the tips of the leaflets the nerves converge to a common point, quite distinct.

Localities: Fishing-hut above Dutch Gap Canal; Deep Bottom; near Telegraph Station; road-side near Potomac Run; bank near Brooke; rare.

The leaves of this plant are much like those of Podozamites lanceolatus Schimper, and the larger leaves resemble Podozamites Emmonsi Newberry. The smaller ones resemble $P$. temuinervis:

I take this opportunity to correct an oversight made in Contributions to the Knowledge of the Older Mesozoic Flora of Virginia (Mon. U. S. Geol. Survey, vol. 6) with reference to the employment of the name Podozamites Emmonsi. This name I used for a Podozamites found by Emmons in the Rhretic of North Carolina, overlooking the fact that Professor Newberry had already used this name for the same plant in his article on the Chinese Mesozoic plants in Smithsonian Contributions to Knowledge.

\section{DIOONITES Bornemann.}

Leaves quite large, with strong rachis; leaflets attached on the upper side of this by the whole width of the base, sometimes expanded at base so as to extend up and down the rachis, linear-lanceolate or elongate-linear, acute at tips, of firm leathery consistency; nerves simple and parallel.

This description of Schimper given to the gents agrees exactly with certain forms that are very common in the Potomac flora. The plants placed in the genus Dioonites are by far the most abundant cycads in the 
Potomac strata, and these alone give to this group of plants the considerable importance that they possess in this flora.

\section{Droonites Buchianus Schimper.}

I'terophyllum Buchianum, Ettingshansen, Beitraige z. Fl. der Wealdenperiode, p. 21, Pl. I, Fig. 1. Plerophyllum Saxonicum, Reich., Ettingshausen, Kreidedora ron Niederschœna, Pl. I, Figs. 11, 12. Dioonites Saxonicus, Schimper, Traité de Paléont., vol. 2, p. 211.

Plate LxviII, Fig. 1; Plate Lxlx, Figs. 1, 3; Plate LXX, Figs. 2, 3; Plate Lxx1, Fig. 1; Plate LxxII, Figs. 1, 2; Plate LxxIII, Figs. 1-3; Plate LXXIV, Figs. 1-3.

Leaves very large, attaining probably the length of a meter and over; maximum width, $30^{\mathrm{cm}}$ and over; rachis stout, showing a keel on the under side; epidernis over the rachis and leaflets thick and durable; leaves thick and leathery; leaflets varying much in dimensions, distance, shape, and termination; leaflets linear-acute, sometimes closely placed, sometimes remote, those in the mirldle part of the leaf the most commonly found, these going off at an angle of $45^{\circ}$, those of the upper part more and more oblique, until at the summit they occur in the prolongation of the midrib, and the leaf is terminated by a leaflet, the terminal leaflets much shorter and narrower than those lower down; length varying, attaining in some cases $25^{\mathrm{em}}$; the leaflets slightly narrowed to the base and attached by the whole width of the base, obliquely set on and decurrent; epidermis sometimes showing a granulation or a line of dots between the nerves; nerves fine, very closely placed, forking at the base, parallel, and terminating without convergence in the summits of the leaflets, some of the onter ones ending in the margins a little below the summit.

Localities: All points on James River that yield plants, except Deep Bottom; especially abundant at entrance to Trent's Reach, in banks of Dutch Gap Caual, and at fishing-hut above the canal; very abundant at Kankey's; found also at all plant localities north of Kankey's to Fort Washington, but not abundant beyond Telegraph Station.

This splendid plant is one of the most widely diffused and characteristic fossils of the Potomac flora. At the entrance to Trent's Reach, in the thin plant-bearing layer near the top of the bluff, the imprints are in places very numerous, and much of the plant-substance is still retained, the relies being matted together. Here it is found in company with Baieropsis 
pluripartita, Brachyphyllum, Frenelopsis parceramosa, etc. In the right bank of Dutch Gap Canal, in the thin partings of dark gray clay, interstratified with sandy layers, very large impressions occur and the fossils are very numerons. They seem to occur irregularly distributed and in pockets. Some of the imprints seen lying in the clay were 12 to 18 inches long and as wide, but owing to the brittleness of the rock they were much broken in taking them out. At a spot about 200 yards above the fishing-hut at Dutch Gap, where hardly any other fossil occurs, the leaves of this plant are so abundant as to fill the clay for the thickness of a foot or more. It is a curious fact that at this point, and at several localities north of Fredericksburg, if the remains of this plant occur in great numbers in the clay, they seem to exclude others. The distribution is apparently somewhat peculiar. On leaving James River not a trace of the plant is to be seen until Kankey's place is reached. Here immense numbers of the leaves occur in the dark clay with hardly any other plants. None were found at Fredericksburg, and as the amount of material obtained there was large, we may safely assume that it did not exist at that locality. It occurs as the principal fossil in the cut where the railroad crosses the Occoquan. It is abundant near Telegraph Station, but only fragments occur at White House and at Fort Washington. It has not been certainly identified north of Fort Washington. Some small bits of leaves found at Baltimore, on Belt and Covington streets, seem to belong to this species, but they can not be certainly identified. It was indicated by fragments found in the excavation for the reservoir at Washington.

Ettingshausen, in his Beitrag zur Flora der Wealden Periode, described this plant under the name Pterophyllum Buchianum, as occurring in the Wernsdorf strata of the northern Carpathians, considering these as of Wealden age. He gives a figure of a fragment belonging, as he thought, to a cycad leaf three or four feet loug. Schenk (Die foss. Pflanzen der Wernsdorf-Schichten) shows that these strata, according to the investigations of Hohenegger and Zittel, are not Wealden but Urgonian in age, younger than the oldest Neocomian, and older than the Gault. It is very fortunate that the Potomac formation has yielded so many fine specimens of this plant, as they add a good deal to our knowledge of it. 
All the parts are shown except the base of the leaves. Among the hundreds of specimens seen, it is singular that in no case was any portion of the base found.

The leaves appear to have been thick and durable, for in a number of eases the leaf-substance may be stripped from the stone, retaining the shape of the leaflets. The epidermis seems to be especially thick over the midrib. The nerves are immersed in the leaf-substance and are usually obscured.

In Ettingshausen's figure the specimen is somewhat distorted by pressure. The leaflets on the right-liand side have been crushed over at base so as to appear to be attached to the upper face of the midrib and partly within its margin, whereas they are really attached to the margin and lie usually in one plane.

This plant seems not to have been confined strictly to the Urgonian, but to have survived to a later period, while its narrower form at least began in the Wealden. Ettingshausen ${ }^{1}$ gives figures of Pterophyllum Saxonicum Reich., which certainly represent portions of $D$. Buclianus. In these figures some of the leaflets go off at a more open angle than is usual in D. Buchianus, but this is due to distortion from pressure, for this mode of departure can be duplicated in many of the Potomac plants. Ettingshausen says that the surface of the Niederschuena plant is covered with fine dots arranged in rows between the nerves. In the Potomac plants they are eloser than Ettingshansen's figure represents then to be. Hosius and Von der Marek ${ }^{2}$ represent a fragment which they identify correctly with Pterophyllum Saxonicum, coming from the Neocomian sandstone of the Teuterburger Wald. This is evidently a portion of the midrib and the bases of two leaflets of Dioonites Buchianus. The leaflets are by distortion from pressure made to go off nearly at right angles.

Dioonites Buchianus, var. obtusifolius.

Plate CLXVIII, Fig. 3.

Leaves long and wide, with a stout midrib; leaflets subopposite, inserted on the upper face of the midrib and considerably within its mar-

1 Kreidetiora von Niederschœua in Sachsen, Pl. I, Figs. 11, 12.

${ }^{2}$ Flor. der Westfäl. Kreideformation, Pl, XLIV, Fig. 19 б. 
gin, ver'y remote, obtusely rounded off at the tips, comparatively short, bases of the leaflets thickened and callous when tom off, and when the midrib is compressed, leaving a depressed scar:

Locality: Left bank of Dutch Gap Canal; rare.

The figure gives a portion only of the large specimen found. The specimen is $20^{\mathrm{em}}$ long, and shows no decided diminution in the size of the midrib or in the lengths of the leaflets; but the leaflets at the summit of the stem are ouly half as far apart as those at bottom; seventeen leaflets occurred on the portion found.

\section{Dioonites Buchianus, var. angustifolius.}

Pterophyllum abietinum Göpp., Dunker. Mon. der norddentsch. Wealdenbild., Pl. VII, Fig. 2. Dioönites abietimus Miquel, Schenk. Flor. der nordwestdeutsch. Wealdenform., PI. XVI, Fig. 1.

Plate LXVII, Fig. 6; Plate LXVIII, Fig. 4; Plate LXXI, Fig. 2.

Leaflets and nerves as in the normal form $D$. Buchianus, except that they are much narrower in the lower parts of the leaves.

Localities: Dutch Gap, especially at the fishing-hut above the canal; Kankey's; crossing of the Occoquan; near 'Telegraph Station.

These leaflets, as those of the normal species, vary a good deal in the distances apart at which they are placed. In Pl. LXVII, Fig. 6, they are very remote; in Pl. LXXI, Fig. 2, they are very close together. The forms that are placed in this variety show throughout the leaf narrow leaflets, and they do not seem to be mere accidentally narrow forms of the typical plant. They never graduate into the wider leaf forms.

This narrow leaf variety seems to be the same with the Wealden plant figured by Schenk as Dioonites abietinus Miquel, in his Wealden flora, Pl. XVI, Fig. 1. It appears also to be identical with the fossil given by Dunker as Pterophyllum abietinum Göpp. Hosins and Von der Marck ${ }^{1}$ give a figure of what they call $D$. abietinus, which is exactly like some of the specimens of this Potomac fossil. The figure of the Westphalian fossil represents a plant distorted by pressure. It comes from the Neocomian sandstone of the Teuterburger Wald.

${ }^{1}$ Flor. der Westfäl. Kreideformation, P1. XLIV, Fig. 199. 
The specimens of this variety are much rarer than those of the normal species D. Buchianus.

This form, if identical with the European fossils named above, begins in the Wealden and survives into the Neocomian.

TYSONIA, gen. nov.

Trunks varying considerably in shape and in dimensions, petrified with silica, mire or less flattened, seen with the broader side in front, they are oblong-ovate and truncate; in cross-section they are broadly subelliptical; medulla proportionally small; woody cylinder comparatively thick; cortical exterior layer, with the permanent bases of the petioles very thick; bases of the petioles in cross-section nornally subrhombic or subtriangular, with the lower angle very obtuse, the onter angles acute and prolonged, the superior side forming a curved line bent upwards or forming an obtuse angle, but often from pressure distorted into irregular, rhombic, or triangular forms; trunks each with a large eccentric terninal leaf-bud or growing bud; some of the trunks, probably of female plants, have numerous lateral buds; others, probably male plants, are without lateral buds; bases of the potioles of the leaves represented by open casts of the petioles, which from the points of insertion of the petioles pass upwards and outwards, so that their direction at their exit from the cortical investment is nearly horizontal.

These trunks have some of the characters of Carruthers's genus Bennettites and of Mantellia Brongn., being apparently an intermediate type. I have named the genus in honor of $M[$. Tyson, who first called attention to these plants. Carruthers ${ }^{1}$ says: "Through the kindness of Principal Dawson I have seen a photograph of one of the cycadean stems found by P. Tyson, esq., in Maryland. *** It is obviously a species of Bennettites, with smaller leaf-scar's than those in B. Saxbyanus."

It seems from his description of the plant that Carruthers saw a photograph of trunk No. 1. He does not seem to have had a photograph of trunk No. 2, which differs in important points from No. 1. Carruther's thinks that the apparent buds on his Bennettites are not leaf-buds, but organs of reproduction. There is nothing in the Potomac plants to show

' Fossil cycadean stems from the secondary rocks of Britain, Trans. Linn. Soc. London, vol. $26,1: 9$, postseript, p. 708 . 
what the nature of the buds was. Carruthers's description of the crosssection of the bases of the petiole of Bennettites agrees well with the crosssections in Tysonia. He explains the exterior aspect of the trunks, which shows a series of hollow imprints left by the bases of the petioles separated by plates, as caused by certain processes which seem to have taken place in the Potomac plant also. He says the trunk, when living, was surrounded by the permanent bases of the petioles, and the base of each petiole was clothed with a dense ramentun, which was developed to such an extent as to separate very considerably each petiole from its neighbor. The silica forming the petrifying material laving found speedy access to the delicate scales of the ramentum has preserved them in a remarkably perfect mannel" In some of the English specimens the petrified ramentum stands out as a net-wurk of ridges, while the originally more durable petioles have decayed and left rhomboidal cavities representing their original form. Carruthers states also that the leaf disarticulated at a point some distance from the cortex, leaving a considerable portion of the bases of the petioles permanently surrounding the stem. This explanation given for the English Bennetites no doubt applies to the similar features seen in the Potomac Tysonia. In this latter, now thoroughly silicified in all the specimens seen, it is clear that the material surrounding the bases of the petioles was silicified before the bases, and that thése subsequently decayed, learing perfect hollow casts of their form.

No microscopic examination of the trunks of Tysonia has been made, and I am compelled to confine the description to macroscopic characters.

There are two kinds of trunks, differing mainly in the presence or absence of axillary buds There are two kinds of axillary buds on the same trunk, a feature which, according to Carruthers, appears in Mantellia but not in Bennettites. In would seem that in the buds on Tysonia, which resemble those of Bennettites, there was a woody axis of varying size, surrounded by scars of leaves much smaller than the normal ones, or of bracts. This woody axis certainly protruded beyond the bases of the petioles. Some of them are larger than others and some are hollow, the hollows being no donbt due to decay before silification. No indication of fructification has been seen in connection with the Potomac stems. 
These stems have a number of features in common with Bennettites, but do not fully agree with that genus. Compared with Mantellia Brongn., Cycadeoidea, Buckland, they show some points of resemblance. Carruthers says of Mantellia trunks that they are cylindrical, covered with the long permanent bases of the petioles, and have the fruits borne on secondary axes which generally protrude beyond the bases of the petioles. In this feature these secondary axes resemble Tysonia, and not, according to Carruthers, Bennettites. The axillary branches in Mantellia, like those of Tysonia, are broken off at the point where they leave the bases of the petioles. Carruthers says that some of the branches in Mantcllia are undeveloped and still exist as mexpanded leaf-buds; and this seems to be the case with some of those of Tysonia, those that have little or no woody axis. Some of the stems of Mantellia have no lateral buds, and they may, as Carruthers says, be male stems, their staminal flowers being on cones borne on the termination of the main axis. The Potomac stem No. 2 has no axillary buds, and shows indications of having borne a terminal appendage (bud?) by the side of the terminal growing leaf-bud. Carruthers says that the Mantellia trunks were cylindrical, their flattened condition being due to pressure.

From this it will be seen that the stems of Tysonia have a number of points in common with Mantellia. They stand nearer to this than to Bennettites. The shape of the trunk is more that of Bennettites, but in the shape of the bases of the petioles and in other features Tysonia more closely resembles Mantellia.

In describing the new species Tysonia Marylandica, it is best to notice the two nearly complete stems separately, as they are typical and show some important points of difference. I will describe them as trumk No. 1 and trunk No. 2. One of these was found, as stated before, near Contee's station, in an iron-ore pit near the base of the Variegated Clay formation, and one was found on a farm near Beltsville, a locality a few miles south of Contee's. A fragment like trunk No. 1 was found with this trunk, and another fragment like trunk No. 2 was found on the surface of the Variegated Clay group at a locality (Spring Garden) in the outskirts of Baltimore. It is impossuble now to tell which of the trunks was found near 
Contee's. The fragments in all respects resemble the trunks. This would indicate that the differences seen in the trunks are constant and not merely accidental, and hence have an important meaning.

\section{TRUNK No. 1.}

Plates CLXXIV to CLXXVIIr.

This trunk is silicified, of an ash-gray color, and is free from ferruginous matter. It is oblong-elliptical in shape, with a cross-section roughly elliptical in form, as shown in Pl. CLXXVIII, which gives a photograph of its top. The flattening may be due to compression. From one side near the base a considerable portion has been broken off, as is shown in Pl. CLXXVI. The maximum height of the trunk, measured on the the perfect side, seen in Pl. CLXXIV, is $34^{\mathrm{cm}}$, and the greatest dimension at base is $30^{\mathrm{cm}}$. Its thickness there is $26^{\mathrm{em}}$. The length of the longest dimension at top is $19^{\mathrm{cm}}$, and the maximum width there is $12^{\mathrm{cm}}$

At the top a portion is broken away so as to produce a depression slanting downwards, well shown in Pl. CLXXVI. This looks a good deal like the sear that would be left by the tearing away of a terminal stem-like appendage. This depression occurs on one side of the summit of the trunk. What was probably the terminal bud of growth is distinct from this, and is seen in the center of the top on Pl. CLXXVIII as a rather faintly marked depression. On the summit, and to the left of the central bud, is another large depression, which appears to correspond to a terminal growth or bud of some kind. Plate CLXXV gives a photograph view of the perfect narrow side of the trunk in question, giving an idea of its thickness. Plate CLXXVII gives a view of the base of the stem, showing the small central medulla surrounded by a comparatively thick woody zone, a vaguely defined cortical layer, and outside of all the very thick mass, composed of the bases of the petioles and the material which enveloped them This last portion makes up much the larger part of the trunk.

On the surface of the trunk, well shown on Pl CLXXIV, are several large, diep, irregnlarly shaped pits, due no doubt to the decay of several adjacent bases of petioles before the silicification took place. 
The bud-scars are of two kinds, which are well shown on the plate last mentioned. The large scars stand ont somewhat from the surface of the trimk, and have a woody axis of rarying thickness, surrounded by one or more concentric circles of small leaf-scars. These leaf-scars are abont one-third the size of the imprints left by the bases of the petioles. The woody axis within these encircling small leaf-scars varies a good deal in size, and some of them, as Carruthers pointed out, are more or less hollow, no doubt being caused by the decay of the axis before silicification took place. These axes probably bore some kind of fructification.

The small leaf scars surrounding these axes were probably caused by leaves of small size or bracts, whose bases, like those of the larger leaves, persisted untilafter the silicification of the material which surrounded them tonk place and then decayed The smaller bud-scars are quite different from those just described. These too may be seen on Pl. CLXXIV. They are considerably smaller than those with the woody axes, and consist simply of concentric circles of small leaf-scars like those around the woody cores of the larger scars. They have no woody axis, and appear to be undeveloped buds composed of small leaves or bracts. There is nothing to show what is the functional meaning of these numerous scars of buds, but it is quite possible that the larger ones may have bome the female inflorescence, and hence trunks such as No. 1 would belong to the female plants. The open pits left by the decay of the bases of the petioles of the principal leaves of the trunks are exact casts of these bases. They seem to have had normally in cross-section a shape that is accurately represented by a bow with the string bent into an acute angle caused by drawing an arrow to its head, the curving bow representing the upper side of the hollow cast. Owing to distortion they assume sometimes rhombic or elongated triangular shapes. They are smaller towards the top of the stem than towards the bottom, and have an average size towards the bottom of the trunks of $18^{\mathrm{mm}}$ by $8^{\mathrm{mm}}$, towards the top of $10^{\mathrm{mm}}$ by $5^{\mathrm{mm}}$.

FRAGMENT No. 1.

Between Washington and Baltimore was found a large fragment exactly resembling trunk No. 1, but not broken off from that. This resem- 
blance may indicate that trunk No. 1 came from the same locality. It is silicified in the same way and has the same kinds of scars. The casts of the petioles in this fragment are rather larger than those of trunk No. 1, being $22^{\mathrm{mm}}$ by $12^{\mathrm{mm}}$ in cross-section. This fragment is shaped like an irregular disk or quoit, having the dimensions $26^{\mathrm{mm}}$ by $19^{\mathrm{cm}}$.

TRUnK No. 2.

Plates CLXXIX, CLXXX.

This was probably obtained from near Beltsville, being picked up on the surface of the ground on Mr. Emack's farm. It is exactly like the fragment found at Spring Garden, Baltimore, being even silicified in the same way. The silica, replacing the vegetable matter of this trunk, contains a large amount of iron, so that in proportion to bulk it is much heavier than trunk No. 1. Curiously enongh, both this trunk and the ferruginons fragment found at Spring Garden show a projecting seam of ferruginons silica. This is slown on the narrower side of the trunk on Pl. CLXXX, and less distinctly on the front left-hand side, on Pl. CLXXIX. This seam appears to be due to a crack in the trunk, which was filled with infiltrated silica in the form of a vein. This silica in the projecting plate or vein seems to be in part at least due to a partial filling of the crack by sand, for grains of sand are mixed with the silica deposited from solution. On one side of the trunk near the top and close to the projecting silicious plate, soldered to it and the trunk, are a number of small pebbles coated with iron. The sand and pebbles indicate that the original place of the trunk was in sandstone, not clay, and this would canse us to infer that the trunk was silicified in the lower Potomac sand. It would then come into the upper Potomac or clay member only after the destruction of the sandstone or sand originally holding it. Trunk No. 2 is ovate in shape, and decidedly narrowed towards the top. It is not so much flattened as No. 1 , as is indicated in the view of the narrow side given in Pl. CLXXX. A small piece is broken away from one side at the top, but still this trunk is more complete than No. 1. On the broader side, Pl. CLXXIX, the maximum height is $41^{\mathrm{cm}}$, the greatest dimensions at base $35^{\mathrm{cm}}$, the shorter dimension there $3 t^{\mathrm{cm}}$. The dimensions at the top before the breaking off of 
the fragment were $14^{\mathrm{cm}}$ by $12^{\mathrm{cm}}$. The tapering to the top is caused mainly by a slope of one face of the trunk, viz, that shown on the right-hand side on Pl. CLXXIX, and hence the terminal bud, or that of growth, is thrown much to onte side of the axis of the trunk. A large terminal bud may be seen on the lighest part of the trunk, and on one side of this is the break spoken of, which slopes down the trunk just as if the base of a stem had been torn off. It is quite possible that this may have been a stalk bearing the male inflorescence. If so, the trunk would be that of the male plant, and the structural differences from those of No. 1 would be accounted for by the sexual distinction.

In both No. 1 and No. 2 the growth seems to have been maintained by the development of successive circles of leaves at the summit of the trunk which unfolded from a bud composed of undeveloped leaves, and not from a terminal bud inclosed by bud scales, as Saporta holds to be the case with his genus Clathropodium. The fracture may be seen on Pl. CLXXIX, near the top of the trunk on the left hand, and very distinctly on PI. CLXXX in front near the top. Trunk No. 2 shows none of the larger lateral or axillary growths or buds such as are so common in No. 1. Near the top are faint indications of what may have been two small undeveloped leaf-buds without woody axis, but they are too obscure for us to conclude positively that they are buds of any kind. They are composed of circles of very minute apparent leaf-scars, which are much smaller than those similarly placed in No. 1 and not near so distinct as these.

The hollow casts left by the bases of the petioles indicate that these had normally, in cross-section, the same shape as those of trunk No. 1. But there is a greater tendency than in No. 1 for the upper side to be bent in the form of an angle and thus give the cross-section a rhombic shape. Some of the imprints are a good deal larger than the others, but the variations are due to distortions from pressure. The average dimensions of the cross-sections are $22^{\mathrm{mm}}$ by $12^{\mathrm{mm}}$.

\section{FrLGMent No. 2.}

This specimen, found at Spring Garden, measures in its greatest length $27^{\mathrm{cm}}$, and in its greatest width $23^{\mathrm{cm}}$, being in the shape of an irregular prism 
It seems to have been split off longitudinally from a trunk so as not to show any portion of the terminal bud. It has no axillary buds. The cross-sections of the bases of the petioles resemble those of No. 2, but are somewhat higher proportionally, being $14^{\mathrm{mm}}$ in height, against only $20^{\mathrm{mm}}$ in length.

We may from the above detailed account sum up the description of the species as follows:

\section{Tysonia Marylandica, sp. nov. \\ Plates CLXXIV-CLXXX.}

Stems ovate or oblong, more or less flattened, medulla comparatively small; woody zone large, external integument, with the bases of the petioles, very thick; male inflorescence probably borne on a stalk on the summit of the trunk by the side of the bud of growth of the trunk, and carried on a trunk without axillary buds; female inflorescence on axillary growths; growth of the trunk maintained by a terminal bud, which unfolded successive circles of leaves.

Localities all in Maryland, viz: Spring Garden, at Baltimore; near Contee's station; near Beltsville.

\section{CONIFER E.}

The conifers form the most important element in the Potomac flora. Taken as a whole they lend a decidedly ancient aspect to this flora A number of the most important of these conifers have passed entirely away, leaving no living species. The genera still surviving and most nearly allied to these more important Potomac forms appear now very locally distributed and contain few species. Indeed we may regard them as in process of extinction. Such of them as lave hitherto been found in other parts of the world are here much more abundantly represented.

The conifers are largely developed in variety of types and in the number of individuals belonging to the different types, as well as in the very general diffusion of the forms. In the number of different species the conifers are inferior to the ferns, but they far surpass the ferns in the number of individuals belonging to each species. They are much more IION $\mathrm{XV}-13$ 
generally diffused than are most of the species of ferns. When a species of fern is found it is always, except on Potomac Run, among the rarest of the plants. At the same time the different species of ferns are usually very restricted in occurrence. The conifers form the most widely diffinsed of the Potomac plants, and when they occur they are generally the most abundant plants at the locality. One or two examples may be given to illustrate the abundance of individuals. At the entrance of 'Trent's Reach, in one layer six to eight inches thick, fragments of the branchlets of Fenelopsis parceramosa were so abundant, that they formed a considerable portion of the mass of the stratum. With these immense number's of fragments of Baieropsis pleuripartita were found. Fenelopsis ramosissima is by far the most common plant at Fredericksburg.

The abmulance of imprints of the leaves of conifers is not the only evidence of the great development of conifers in the Potomac. It is shown in the immense amount of lignite formed from coniferous wood. This lignite occurs both in the form of isolated logs and fragments, and in tiers of $\log$ s piled one over the other, as if caused by prostrate forests, indicating that some, at least, of the conifers of that day grew massed in forests as now.

Certain peculiar genera, now extinct, seem to have been very largely developed in the Potomac vegetation, and if we are to judge from their predominance in the fossils of localities where they occur, they must have formed the leading and most characteristic types. These will be noticed further on under proper heads. The archaic character of many conifers as well as ferns does not prepare us to expect to find angiosperms associated with these two elements.

\section{NAGEIOPSIS, gen. nov.}

Trees or shrubs with leaves and branches spreading in one plane; leaves varying much in size and shape, those towards the base of the twigs sometimes smaller than those higher up, distichous mostly, or rarely subdistichons, opposite and persistent, attached by a short slightly twisted footstalk, usually to the side of the twig, more rarely slightly within the 
margin on the upper or under surface of the stem, either attenuated towards the base or abruptly rounded off there, at their ends acute or subacute; nerves several, coalescing at base to form a footstalk, forking immediately at the base or a short distance above, then approximately parallel to near the tips of the leaves, where they are somewhat crowded together, but do not converge to a union, ending in or near the extremity.

This fine genus is one of the most largely developed and characteristic forms of the Potomac flora, furnishing a very important and widely diffused type. The single leaves and unbranched leafy twigs are so much like the cycad genus Podozamites, that when they were first found I took them to be forms of that genus, but later so many specimens were found showing unquestionable coniferous characters, that I found myself, contrary to my preconceived notions, compelled to regard the plants as coniferous.

This genus is so much like the Nageia section of Podocarpus, that I have felt considerable hesitation in making it a distinct genus. It may be a question whether or not some of the species hitherto described as Podozamites in other formations besides the Potomac should be regarded as belonging to Nageiopsis. In the absence of branching twigs it is not always easy to distinguish these plants from Podozamites. In the leares of this plant, however, the nerves do not converge and unite in the tips as in Podozamites. This is the only feature which will distinguish detached leaves of the two genera.

I am strongly inclined to think that Podozamites Emmonsi, Newberry, from the Rhrtic of North Carolina and Virginia, as well as Podozamites tenuistriatus, from the same formation, belong to Nageiopsis.

Nageiopsis longifolia, sp. nov.

Plate LXXV, Fig. 1; Plate LXXVI, Figs. 2-6; Plate LXXVII, Figs. 1, 2 ; Plate LXXVIII, Figs. 1-5; Plate LxxIX, Fig. 7; Plate Lxxxy, Figs. 1, 2, 8, 9.

Leafy twigs very large, with stout woody stems sometimes $1^{\mathrm{cm}}$ and over thick; leaves strap-shaped, narrowed at the base, attached by a short, slightly twisted petiole most commonly to the margin of the stem, rarely within it on the upper and lower face, acute or subacute, and gradually narrowed towards the tips, varying in width and length; maximum length 
seen $18^{\mathrm{cm}}$ and over, maximum width $1^{\mathrm{cm}}$ and over, usually remotely placed, generally opposite, rarely subopposite, going off normally at an angle of about $45^{\circ}$, but often from pressure distorted in position; nerves comparatively few, forking at or near the base, parallel to near the apex, where they are slightly crowded.

Localities: Fredericksburg; Kankey's; near Telegraph Station; 72d mile-post, near Brooke; Deep Bottom; red-clay ball in banks of Dutch Gap Canal; fishing hut above Dutch Gap Canal.

This splendid plant is quite widely diffused, but it is rare at all points except Fredericksburg, where it is not uncommon ; all the larger specimens figured come from this latter locality. Pl. LXXV, Fig. 1, slightly restored, shows that the leafy twigs must have attained great dimensions, for this is eridently but a small portion of the twig. Pl. LXXVIII, Figs. 1, 4, must form portions of still larger twigs. Fig. 3 of this plate shows a sort of keel on the stem, probably dne to shrinking. On this the leaves are not strictly distichous Pl. LXXVII, Fig. 1, shows leaves of the greatest width. In Fig. 2 of the same plate the position of the leaves is dne to distortion from pressure acting downwards. PI. LXXVI, Fig. 4, gives leaves of unnsual width On Fig. 5 of the same plate we see the scars left by the bud-scales of a terminal bud. Pl. LXXVI, Fig. 3, shows at the top of the stem the bases of two lateral branches. It seems that this plant often continued the growth of its leafy branches by means of a terminal bud flanked by two lateral buds. On Fig. 5 there are indications at the place marked by the scars of the bud-scales that two lateral branches had been torn away. Before I saw the specimen depicted in Fig. 3 I supposed that the plant was a Podozamites close to Zamites Gicepperti Schenk. ${ }^{1}$ In the character of the leaves it is much like this plant; Sclienk's plant is evidently much mutilated.

Nageiopsis zamioldes, sp. nov.

Plate LxxIx, Figs. 1, 3; Plate Lxxx, Figs. 1, 2, 4; Plate LxxxI, Figs. 1-6.

Leafy twigs wide-spreading, copiously branching; leaflets varying a good deal in length and width according to position, those at the base of the branches sometimes unequal and much smaller than those up higher. 
The leaflets attain a maximum width of $2^{\mathrm{cm}}$ and a length of $7^{\mathrm{cm}}$. They are widest near the base, and taper gradually to an acute tip, are abruptly narrowed at base and rounded off, attached by a very short, slightly twisted foot-stalk mostly to the sides of the stem, usually distichous, varying in shape from narrowly ovate to linear-lanceolate, opposite nearly always; nerves remote and distinct, forking at or near the insertion of the leaves, diverging strongly on entering the leaf, and almost parallel to near the summit, where they are more crowded together, the outer ones terminating in the margins below.

Localities: Fredericksburg; banks of Dutch Gap Canal; fishing hut above Dutch Gap Canal.

This fine plant is abundant at Fredericksburg, but it is quite rare at other localities, only a few imperfect specimens being found, as, for example, at Dutch Gap. As will be seen from the figures, the leaves vary a good deal in size, shape, and distance apart; the smaller are often more crowded than the larger ones. The fine specimen given in Pl. LXXIX, Fig. 1, apparently branched several times. In Pl. LXXX, Fig. 1, a thick strong stem is shown, and the leafy twig had evidently considerable length, the leaves being comparatively remote from each other. Fig. 4 of the same plate gives fragments of a copiously branching stem, the junction of one terminal and two lateral twigs being shown radiating from a common point, which seems to be a usual mode of branching in the plants of this genus. The two lower left-hand twigs seem to come off in a similar manner from down lower on the stem. The leaves on this specimen are much crowded. In Pl. LXXXI, Fig. 1, we have apparently the same mode of branching.

This plant, in the nerves and shape of the leaflets, is so much like a Zamites, ihat for some time I held it to be a cycad. It is the most abundant species of Nageiopsis found at Fredericksburg. Unlike the leaves of Zamites and Podozamites, those of this and the other species of Nageiopsis seem to be quite persistent, for they are usually found attached to the stem.

Nageiopsis Recurvata, sp nov.

Plate Lxxy, Fig. 2; Plate Lxxix, Fig. 4; Plate Lxxx, Fig. 3.

Stems stout, leaves remote, recurved, subacute to obtuse, gradually narrowed to the base, and attached to the margin of the stem, or slightly 
within it, by a comparatively broad flat pedicel, in shape elongate-elliptical to oblong, length reaching $S^{\mathrm{cm}}$ and width $15^{\mathrm{mm}}$. Nerves five, numerous, closely placed, forking near the base, and parallel to near the summit, where they are a little more crowded; the outer nerves on the upper margin end in the margin of the leaves some distance below the summit.

Localities: Fredericksburg; banks of Dutch Gap Canal; fishing-hut above Dutch Gap Canal. It is most common at Fredericksburg, but is rare everywhere.

\section{Nagieopsis crassicaullis, sp. nov.}

PIate LxxIx, Figs. 2, 6; Plate LxxxiI, Fig. 1; Plate LxxxIV, Figs. 3, 9, 11.

Leaves with very thick stems even at the summits of the leafy twigs; leaflets attaining very considerable dimensions; length not made out, width up to $27^{\mathrm{mm}}$ and over, gradually narrowed to the base and tip; elongateelliptical in shape, attached by a short slightly twisted pedicel to the margin of the stem, or slightly within it; nerves at the base and summit of the leaves, so far as seen, indistinct and not well made out, fine and rather remote.

Localities: Road-side near Potomac Run ; Fredericksburg; Kankey's; 72d mile-post, near Brooke; banks of Dutch Gap Canal; fishing-hut above the canal.

The plant is rare, and having long narrow leaves, with a thin leaf-substance, the leaves are usually found detached and in fragments; in this respect it is more like Zamites than most of the species of Nageiopsis. The nerves are usually so fine and the leaf-substance so thick, that they can not be clearly made out. It is not certain that some of the specimens placed in this species are not Zamites.

NAGEIOPSIS Latifolia, sp. nov.

Plate Lxxxil, Fig. 3.

Leaves very broad and short, base and apex not seen; leaf-substance thin; shape of leaves probably broadly elliptical; nerves not fully disclosed, but probably branching near the base; they are then approximately parallel to near the apex, following the margins, and parallel. 
Localities: Fishing-hut above Dutch Gap Canal ; road-side near Potomac Run; very rare.

Several detached leaves of this plant were found at the fishing-hut above Dutch Gap Canal. They occurred together, as if coming from the same plant, but were detached so as to give no intimation of the mode of attachment, kind of stem, etc. The most complete of these leaves is given in the figure. Fragments indicating even greater width than that of the one figured were seen. The maximum dimensions indicated were $12^{\mathrm{em}}$ by $5^{\mathrm{cm}}$. It is possible that this plant is a broad-leaved Podozamites, similar to the broad-leaved forms such as Podozamites Reinii Geyler, described by Geyler from the Jurassic formation of Japan. (Ueber Foss. Pflanzen aus der Juraform. Japans, Pl. XXXIV, Fig. 2.)

\section{Nageiopsis Decrescens, sp. nov.}

Plate LXxviI, Fig. 3.

Leaves, so far as seen, small, elosely placed, narrowed at the base and apex, diminished greatly and abruptly in ascending on the leafy twigs, in shape narrowly oblong to linear; nerves forking at base, parallel to near the apex, the outer ones ending in the margins just below the apex.

Locality: Road-side near Potomac Run.

Only one specimen of this plant was found. It shows the peculiarity of a sudden diminution of the leaves in ascending. As a rule the leaves of the species of this genus diminish towards the lower portions of the leafy branches if there is any inequality in them.

\section{Nageiopsis ovata, sp. nov.}

Plate LXXv1I, Fig. 4; Plate LXXX, Fig. 5.

Stems comparatively very stout; leaves opposite, going off nearly at right angles from the stem, closely placed, lower ones smaller but gradually increasing in ascending, broadest near the base and abruptly rounded off there, attached by an extremely short slightly twisted pedicel, narrowing to an acute tip, oblong to elongate-elliptical in shape; nerves indistinct, but forking at base, diverging on entering the base of the leaf, then nearly 
parallel to the tip, where they are sonewhat crowded, the outer ones ending in the margin below the apex.

Locality: Fredericksburg.

The specimens of this pretty plant are quite rare. The lower leaflets are markedly smaller than those higher on the leafy twigs, but this is a feature not nncommon in plants of this genus.

NAgeiopsis obtusifolia, sp. nov.

Plate LxxXr, Fig. 7.

Leaves short in proportion to width, very obtuse, attached by a short slightly twisted pedicel, broadly elliptical or oblong in shape, broadest near the base, slightly inequilateral at base; nerves forking once or twice near the base and then parallel to near the summit, where they are a little crowded together, the outer ones ending in the margins a little below the apex.

Locality: Road-side near Potomac Run.

This plant was evidently very rare. It shows the unusual feature of having the margin of the base on the lower side more convex and broader than on the upper side, which latter is cut arvay in a concave manner. The nerves also tend to go off in bundles, branching more than once at the base of the leaves. It is very rare.

NAgeiopsis inequilateralis, sp. nov.

Plate $\operatorname{Lxxx} \nabla$, Fig. 6.

Leaves snort and broad in proportion to length, slightly inequilateral at base, obtuse, elliptical, broadest near base, abruptly narrowed on the lower side at base, and more gradually rounded off on the upper side; leaf-substance very thick, epidermis dense and shining; nerves not distinctly seen, but parallel towards the upper part, and slightly crowded at the summit of the leaflets.

Locality: Kankey's.

Only one specimen of this plant was found. The thick epidermis obscures the nerves. 


\section{NAGeiopsis aCUMinata, sp. nov. \\ Plate LXXxY, Fig. 11.}

Leaves narrowly ovate, widest at base and slightly acuminate, abruptly rounded off at base and attached by a short strong pedicel, gradually narrowed torvards tips; nerves not seen.

- Locality: Near Telegraph Station; very rare.

Only one good specimen seen. It shows a small bit of the stem still attaclied. As no large amount of material was obtained at this place the rarity of the plant may be apparent rather than real. It is possible that the plant may be a Zamites.

\section{NAGEIOPSIS HETEROPHYLLA, sp. nov.}

Plate Lxxxıv, Fig. 1; Plate Lxxxvı, Figs. 6, 7; Plate Lxxxvili, Figs. 2, 5.

Stems large, branching freely; leaves suall, narrowly ovate to oblonglinear, widest near the base and usually rather abruptly rounded off there, attached by a very short slightly twisted pedicel, gradually narrowed to acute tips; leaves sometimes varying irregularly in size, larger and smaller ones being intermingled or placed on opposite sides of the stem; leafy branches terminating in a leaf similar to the lower ones; nerves forking once or twice near the base of the leaves, then parallel to near the summit, where they are more approximate, the outer ones ending in the margins below the summit.

Localities: Fredericksburg; fishing hut above Dutch Gap Canal.

This pretty little plant is not uncommon at Fredericksburg. It shows the peculiar feature (as in Pl. LXXXVI, Fig. 7, and Pl. LXXXVIII, Fig. 2) of having the leaves at the bases of the twigs very unequal on opposite sides, and also, as in the first-named figure, the peculiarity of having small leaves intermingled with large ones. In Pl. LXXXIV, Fig. 4, the tips of the leaves have been removed by accidents of preservation.

\section{Nageiopsis MicrophylLa, sp. nov.}

Plate LxxxIV, Fig. 6; Plate Lxxxy, Fig. 14; Plate LxxxyI, Figs. 1-3, 5.

Leafy twigs pinnately arranged, terminating in a leaf larger than those lower down; leaves very small, narrowed to the base and apex, ellip- 
tical or oblong, acute to acnminate, attached by a very short pedicel; nerves forking near the base, then parallel to near the tips, where they are more crowded.

Localities: Fredericksburg; road-side near Potomac Run; fishing hnt above Dutch Gap Canal.

The plant is not uncommon at the Dutch Gap locality, but is comparatively rare elsewhere. The best specimens (as Pl. LXXXVI, Fig. 5) come from Fredericksburg. Fig. 3 of the same plate, having its leaves widest at base and abruptly rounded off there, comes from the Potonac Run locality, and is possibly a different species. Pl. LXXXV, Fig. 14, shows a stem of unusual thickness.

Nageiopsis angustifolia, sp. nov.

Plate Lxxxy , Figs. 8, 9; Plate LxxxvII, Figs. 2-6; Plate LxxxvilI, Figs. 1, 3, 4, 6-8; Plate LXXXIX, Fig. 2.

Leafy stems large, branching copiously and wide-spreading; branches often opposite, swollen at their attachments to the main stem, and marked with scars left by the bud-scales; the leafy stems often subdivided towards their ends into smaller branches on which the leaves are much diminished; leaves varying much in size, very long in proportion to width, narrowly linear-acute to acuminate, generally very remotely placed, narrowed gradnally to apex and base, attached by a short twisted pedicel generally to the sides, sometimes to the upper and lower surfaces of the stems slightly within the margin; nerves forking near the base and then parallel to the summit, the onter ones terminating in the margin below the summit of the leaves, quite strong.

Localities: Fishing hut above Dutch Gap Canal; road-side near Potomac Run; 72d mile-post; bank near Brooke; Fredericksburg; near Telegraph Station; Fort Washington.

This fine species is one of the most widely diffused of the Potomac plants, and is the most generally distributed species of Nageiopsis. It is not very rare at the Dutch Gap locality, but is most common at Fredericksburg, where the plants given in Pl. LXXXVI, Figs. 8, 9, and Pl. LXXXVII, Fig. 2, occur. It is one of the most notewortly connecting 
links between the plants of the various localities which, as has been stated, show so much tendency to isolation and local distribution. It is found with the numerous Angiosperms of the two localities near Brooke, and connects these with the plants of Dutch Gap and of Fredericksburg. Some of the leafy stems must have been very large and wide-spreading.

On some of the branches at their bases there are very distinct scars left by the scales which invested the terminal buds. The branches seem commonly to have formed at their extremities a terminal and two opposite lateral buds with which to continue the growth in the next season. The formation of such buds on these plants and on Cephalotaxopsis indicates that there were well-defined pauses in the growth of the branches. The leaves seem to have been very persistent, as they are usually attached to the stems.

The specimen given in Pl. LXXXVI, Fig. 9, indicates well the copionsness of the branching of this plant. It shows on the left hand at base what seems to be a portion split off from a large stem, and attached to this is a lateral twig, which has at base the marks of bud-scales. Near its summit this in turn sends off two opposite lateral twigs. This specimen and also that of Pl. LXXXVIII, Fig. 8, show that the leaves tend to diminish in size when the tivigs split up into subordinate branches. This plant in its mode of branching and in the shape of its leaves, as well as in the arrangement of the scars of the bud-scales, is much iike Cephalotaxopsis, but it has several nerves in the leavas.

\section{Nageiopsis sUbfalcata, sp. nov. \\ Plate CLXYIII, Fig. 4.}

Stems comparatively very stont; leaves narrowed gradually to the base and apex, subacnte, subfalcate, attached by a short slightly twisted foot-stalk; leaf-substance thick and leathery; nerves not seen, but apparently several, and as in Nageiopsis.

Locality: Fishing hut above Dutch Gap Canal.

Only one specinen of this plant was found. Its position is doubtful, and it may be a Sequoia, for the foot-stalks seem to be decurrent. They leave imprints on the stem resembling those of Sequoia. 
PHYLLOCLADOPSIS, gen. nor.

Leafy stems branching copionsly and irregularly; leaves small, opposite, very thick, of varying sizes on the same branch, varying a good deal in shape, broadly ovate, broadly elliptical or orbicular, broadest at base, abruptly narrowed into a short slightly twisted pedicel, obtuse to subacute, terminal leaflet of the twigs like those lower down; nerves usually not distinct, being inmersed in the thick leaf-substance, radiating palmatel-from a common point at base, and forking once or twice.

This genus is quite rare in the Potomac flora, and as yet shows only one species. Its character and place can not be fixed positively from the suall amount of material found. It is strikingly like Phyllocladus in many respects. In some features it resembles Nageiopsis, but the nerves have a different character. The genus is provisionally formed and named from the resemblance to Phyllocladus.

\section{Phyllocladopsis iteterophylla, sp. nov. Plate LxxxIV, Fig. 5 ; Plate CLXVII, Fig. 4.}

Plant with the generic character, having the terminal leaflet of the twigs much larger than those next below, and in shape ovate-obtuse; leafy branches keeled.

Locality: Fishing hut above Dutch Gap Canal; rare.

\section{FEILDENIOPSIS, gen. nov.}

Leaves linear-oblong, subspatulate, tapering gradually below to a broad petiole-like base, mode of attachment not seen; leaf-substance thick and glossy, at summit rounded and very obtuse; nerves distinct and prominent, single and parallel for a short distance above the lowest visible portion of base, then forking all nearly at the same height, with branches parallel to near the summit; at snmmit curving round to meet one another, with a strong nerve uniting the abutting nerves. This peculiar plant is much like Heer's genus Feildenia, from the Miocene of Greenland. 


\section{Feildeniopsis crassinervis, sp. nov.}

Plate Lxxxy, Fig. 5.

Plant with the generic character, having very strong broad nerves, which are sharply defined like threads in the dense leaves, the latter having a glossy look, and seening to narrow so as to form a sheathing or clasping base. The nerves of this species are quite like those of Heer's species Feildenia MIossiana, ${ }^{1}$ curving around to abut at the sumnits of the leaves, and the points of meeting are comnected by a strong nerve, which descends and seems to split up to form the central pair of nerves.

Locality: The olant occurs only at Kankey's and is very rare.

\section{BAIEROPSIS, gen. nov.}

Leaves borne towards the ends of the branches?; leafy branches pinnately arranged, opposite or subopposite, in the same plane with the leaves, diminishing in ascending in the size and number of the leaves; towards the summit of the leafy stem the leafy branches reduced to simple leaves; the leafy stem terminated by a simple leaf similar to those of the branches and stem lower down ; leaves on the lower branches pinnately arranged, subopposite or alternate; lower leafy branches terminating, as does the main stem, by a single leaf; leaves attached pinnately to the branches by short pedicels, in shape like a fan, with wedge-shaped bases, divided nearly to the base into several principal segments or laciniæ, usually two or three in number, these in turn divided into a varying number of subordinate segments, and the latter divided into a number of nltimate laciniæ, which are strap-shaped, of varying width and length, and end in teeth; the lacinize of various orders subdivided dichotomously, diverging slightly; the nerves branch repeatedly in a dichotomous manner, beginning in the pedicel, the branching taking place at varying heights; the nerves diverge in a flabellate manner, and one or two of the ultimate branches end in the teeth terminating the ultimate laciniæ; they are slender but distinct; fructification not positively made out, but apparently in the form of very small rounded or elliptical

\footnotetext{
${ }^{1}$ Flor. Foss, Arctica, vol. 5, Pt. I, Die Mioc. Flor. des Grinnell-Landes, Pl. III, Figs, 2-5.
} 
nut-like seed, that are borne on short pedicels on each side of slender stems, which spring from the main stem like the leaves, and appear to represent metamorphosed leaves.

This curions gronp of plants has its single leaves in shape and nervation strikingly like those of Jeampanlia, and in some cases they are much like those of Baiera. Before the more complete specimens were found, showing the mode of attachment of the leaves, I thought that the plants belonged to the genns Baiera. Heer united the plants formerly called Jeanpaulia with Baiera; but there would seem to be a very considerable difference between such a plant as Jeanpanlia Münsteriana, given by Schenk, ${ }^{1}$ and Heer's Baiera longifolia. The leaves of Schenk's plant appear to be compound, composed of pinnately arranged segments with a terminal segment. The plan of this leaf is much like that of the leafy branches of Baieropsis, and it may be a question whether or not this Rhretic stipposed leaf is really a leafy branch. There is also some resemblance between the mode of segmentation of Baieropsis and that of the plants which Heer ${ }^{2}$ called Jeanpautia borcalis, and J. lepida, and which in the fourth volume of the same work he was inclined to think might be ferns. But these two plants have mnch shorter and proportionally broader lobes than those of Baieropsis. Baieropsis in some points is like Saporta's genus Ginkgophyllum. In this latter, however, the leaves are flabellately divided only towards their summits and very sparingly segmented, while the greater portion of their length in their lower portions is strap-shaped, and these long strap shaped basal portions unite at their insertions to form a wing along the midrib. Some of the leaves of Baieropsis are in shape much like those of some forms of Adiantum. These might be regarded as Ginkgos, were it not for the pinnate arrangement of the leaves.

These forms, which I have united under tne generic name Baieropsis, seem to have more of the characters of the Ginkgo section of broad-leaved conifers. They are most probably nearly allied to Ginkigophyllum and Baiera, but still in some of the forms fern character's are to some extent present, and so long as the fructification is not clearly made ont, the true place of the group can nos be positively determined. 
The nature of the apparent fructification is obscure from the poor preservation of the specimens, and from the fact that the precise connection of the seed-like bodies with the leaves is not seen. The seeds are abont $2^{\text {mum }}$ in diameter, are sessile or attached by very short pedicels to slender naked stems, being opposite or subopposite, and on both sides of them. The stems with their seeds seem to represent metamorphosed leafy branches or leaves, taking the place of the ordinary leaves, which appear higher. The general character of these seeds and their apparent mode of attachment remind one of the supposed seed of Baiera ITinsteriana from the Rhætic of Bairenth, which represent metamorphosed leaves of that plant.

\section{Baieropsis expansa, sp. nov.}

Plate LXXX1X, Fi.gs. 1, 3; Plate XC, Fig 1.; Plate XC1, Fig. 2; Plate XCII, Fig. 5.

Leaves very large, having probably the width of $12^{\mathrm{cm}}$, and the length of over $15^{\mathrm{em}}$, attached by slender pedicels, and apparently distributed as given in the generic description-i. e., pinnately on leafy twigs, which themselves are arranged pinnately on a principal stem, the main stem and branches ending in leaves of the normal kind; leaves divided to near their bases into several principal laciniæ, which in turn are subdivided at varying heights into subordinate laminæ, and these into ultimate ones that are long and narrow, ribbon-like, with the ends not seen; all subdivide dichotomously and diverge so as to give the leaf a fan shape; the ultimate lacinix $1.5^{\mathrm{mm}}$ wide and under; the nerves distinct, although slender. They fork at the base in the primary laciniæ, and then repeatedly subdivide dichotomously in the laciniæ at varying intervals, the branches being more or less parallel.

Localities: Fredericksburg; red clay ball in the banks of Dutch Gap Canal; fishing hut above the canal; entrance to Trent's Reach.

In some specimens the apparent simple strong nerves under a good lens seem to run in pairs, the members of which are so closely placed that they seem to the unaided eye to be simple nerves. This fine plant is not very rare at Fredericksburg in pretty good specimens. At the other localities the great size of the leaves caused them to be preserved in a very fragmentary state. 
There is a strong resemblance between the fragments of some of these leaves and Baiera cretosa ${ }^{1}$ Schenk, but Schenk's figure indicates a larger and coarser leaf.

\section{Baieropsis pluripartita, sp. nov.}

Plate LXXXIX, Fig. 4; Plate XC, Figs. 2-5; Plate XCI, Figs. I, 3, 4, 7 ; Plate XCII, Figs. I, 2, 6.

Leafy branches with the character of the genus; stems slender, leaves broadly fan-shaped, opposite or subopposite, attached by short pedicels, nsually divided down to near the base into three principal segments; these by repeated dichotomous subdivision give rise finally to long, slender, ultimate segments, that are strap-shaped and about $1^{\mathrm{mm}}$ wide, their length not being made out, as their tips were not in any case seen, but in the largest leaves probably attaining the length of $4^{\mathrm{cm}}$ and more from the last point of subdivision: the nerves slender but distinct, forking at the base to enter the principal lacinire, and then forking repeatedly and dichotomously at long intervals, with the branches nearly parallel, one or two being found in the ultimate lacinix. The apparent fructification (see Pl. XC, Fig. 4) is as given in the generic description.

Localities: Entrance of Trent's Reach; banks of Dutch Gap Canal; red clay ball; fishing hut above the canal.

The plant is not uncommon at the first and last named localities. It is usually associated in its occurrence with Dioonites Buchianus. There is a considerable variation in the size of the leaves and in the number of their segmenis, apparently depeuding on the position of the leaves on the leafy twigs, those towards the summits being smaller and with fewer segments. The largest and most perfectly preserved forms were found at the entrance to Trent's Reach. The leaves were nsually found in a very fragmentary state, and in no case were their tips seen.

\section{BaIEROPSIS PLURIPARTITA, Var. MINOR, sp. nov. \\ Plate XCI, Fig. 5; Plate XCII, Figs. 3, 4.}

Twigs and leaves as in B. pluripartita, but much smaller and constantly so, without gradations into the larger form; the uitimate laciniæ very nu- 
merous and narrow, being under $1^{\text {wm }}$ in width; the leaves attain a maximum length of $4^{\mathrm{c}}$, but mostly are under that, and have a maximum width of $3.5^{\mathrm{cm}}$, but generally are narrower; nerves as in $B$. pluripartita, but more subdivided, closer, and more delicate.

Localities the same as for $B$. pluripartita.

The specimens of this plant are much more numerous than those of $B$. pluripartita, but they are mostly very fragmentary. This is the most common Baieropsis at Dutch Gap, and it is the most common plant in the red clay ball which occurs in the banks of the canal. It appears in numerons fragments poorly preserved at the entrance to Trent's Reach, being found in the same layer with Frenelopsis parceramosa, and Dioonites Buchianus. The lower right-hand leaf in Pl. XCII, Fig. 3, is nearly a complete one, wanting only the tips of the ultimate laciniæ, which no donbt, as in B. pluripartita, terminated in teeth. The above-mentioned leaf is one of the largest found in this plant.

\section{Baieropsis foliosa, sp. nov. Plate XCIII, Figs. 4-6.}

Leafy branches abruptly changed to leaves in ascending (Fig. 4); lower leafy branches of the main stems having on the upper side simple leaves, but on the lower side, towards the base, possessing leafy branches of the normal type in place of the simple leaves of the upper side; leaves and leafy branches closely placed; leaves quite small, fan-shaped, short, mostly divided nearly to the base into two principal laminæ, both of which are subdivided a little above the base into laciniæ; these in turn, by dichotomous subdivision, give short strap-shaped lobes, which end in two shallow acute or narrowly elliptical teeth, or else in two narrowly oblong subacute teeth; nerves forking at base and then repeatedly forking in a dichotomous manner, so that the branches from the last forking end in the teeth.

Localities: Bank near Brooke; White House Bluff.

At the last-named place the plant is very rare, but it is abundant at the bank near the railroad in the vicinity of Brooke. Here it is, with the exception of the angiosperm leaves, the most common fossil. There is some variation in the size of the leaves and in the number of subdivisions, some IION $\mathrm{XV}-\mathrm{-14}$ 
of the leaves, as in Figs. 5, 6, being lnrger than others, as in Fig. 4. Strange to say, these leaves, although so abundant at the bank near Brooke, show not a single specimen at the $72 \mathrm{~d}$ mile-post, only a few hundred feet distant.

Baieropsis denticulata, sp. nov.

Plate XCInl, Fig. 7.

Stems of the leafy branches proportionally stout; leafy branches and leares alternate; leaves fan-shaped and wide in proportion to length, divided to near the base into two principal laninæ, and those a little higher subdivided into two subordinate laciniæe which repeatedly subdivide until the ultimate lacinix end in two linear subacute teeth of comparatively great length; nerves repeatedly forking flabellately, so that the ultimate branches end in the teeth.

Locality : Fishing hut above Dutch Gap Canal.

This plant is quite rare, and usually occurs in small fragments.

Bateropsis dexticulata, var. angustifolia, sp. nov.

Plate XClI, Fig. 7 .

Leaves subopposite, narrowly fan-shaped to wedge-shaped, quite narrow in proportion to their width; leaves attached more obliquely than in $B$. denticulata, but with the laciniæ and nerves as in that species, the laciniæ being fewer in number.

Locality: Bank near Brooke; very rare.

The facies of this plant is different from that of Baieropsis clenticulata.

BaIEROPSIS LONGIFOLIA, sp. nov.

Plate XCI, Fig. 6.

Leaves very long in proportion to their width, deeply cut into very long and slender principal lacinix, which are two in number and diverge slightly; these are subdivided several times into long and slender lacinix, finally giving long narrowly strap-shaped ultimate laciniæ which are $1^{\mathrm{mm}}$ and under in width, the tins not seen; arrangement of the leaves as given in the generic character; nerves rather indistinct, but as in B. pluripartita; the main stem quite slender. 


\section{Locality: Near Telegraph Station.}

This plant has a decided facies of its own, dne to the slenderness and the length of the laciniæ. The subdivisions of the leaves are much ferwer. than in B. expansa and B. pluripartita, and take the form of pairs. It is quite rare.

\section{Baieropsis adiantifolia, sp. nov. \\ Plate XCII, Figs. 8, 9; Plate XCIII, Figs. 1-3; Plate XCIV, Figs. 2, 3.}

Stems moderately strong; leaves subopposite to opposite, closely placed, often imbricated, subquadrilateral to flabellate fan-shaped, narrowed to a wedge-shaped base, and attached by a short pedicel which springs from the lower corner of the leaf, so that the inner margin of the leaves runs close to the main stem, parallel with it, and often overlapping it, while the lower margin of the leaves stands nearly at right angles with the main stem; leaves cut down to near the base into two principal laciniæe, and those higher cut into two or more minor laciniæ; ultimate laciniæ very shallow and strap-shaped, ending in acute very short teeth, or rarely in narrowly elliptical and subacute ones; all the laciniæ turned outwards or upwards, the lower margins of the leaves being entire or having sometimes an acnte tooth; leaves in ascending towards the tips of the leafy branches have their lower margins directed more and more upwards, become smaller, assume more of au elliptical or a wedge shape, have the laciniæ only on the upper margin, and finally coalesce to form a terminal leaflet, which at base shows three segments, but whose terminal portions are unt seen; nerves fine but distinct, branching at base from a mother nerve and then dividing repeatedly in a dichotomous manner so as to fill the laminæ, and have the branches ending in the teeth.

Localities: Fredericksburg; road-side near Potomac Run; near Telegraph Station.

The plant is most frequent at Fredericksburg but is not abundant there, and is usually in a very fragmentary state. If we look to the shape of the leaves alone this curions plant is much like a fern of the type of Adiantum, but the gradations throngh different forms connect the specimens so closely with the flabellate leaves of Baieropsis that they can not 
be separated by any goor distinctions. The principal difference from the more common and typical forms of Baieropsis is found in the greater proportional width of the leaves and the smaller depth of the subdivision.

BaIERopsis adiantifolia, var. minor, sp. nov.

Plate XCIY, I’ig. 1.

Leaves nearly in shape as those of $B$. adiantifolia, but much smaller, alternate, with their lower margins making an angle of $45^{\circ}$, with the stems divided above the base into two lacinia, one smaller, directed upwards, and divided near the summit into short strap-shaped laciniæ that end in teeth, and one larger, directed outwards, also subdivided into strap-shaped lacinix; nerves as in B. adiantifolia.

Locality: Fredericksburg.

This may be only the upper part of a small branch of $B$. cudiantifolia. It is very rare.

BAIEROPSIS MACROPIIYLLA, sp. nov.

Plate XC, Fig. 6.

Leaves very large, dividing repeatedly into laciniæ and diverging flabellately; form and dimensions of the leaves not made out; ultimate lacinix, so far as seen, $4^{\mathrm{mm}}$ wide; nerves forking at long intervals, with the branches parallel.

Locality: Fredericksburg.

Only a few specimens were found. The leaf was probably very large, the fragments indicating a maximum length of about $20^{\mathrm{em}}$, with a nearly equal width. The great size of the leaves caused them to be preserved only in fragments. It is possibly a Baiera. The plant has on the wider basal portions of the laciniæe a number of peculiar elliptical protuberances, which seem to spring from off-shoots of the nerves. The exact nature of these could not be made out, but they seem to be ratlier a fungoid growth than fructification.

BAIERA, F. Braun, emend.

Leaves leathery, gradually narrowed into the longer or shorter pedicel, fan-shaped, with repeated dichotomous subdivision, segments linear, some- 
times ribbon-shaped, incised at the tips or entire, inserted on short branches; nerve-bundle issuing from the base of the leaf and repeatedly forking.

This description, which is that given by Schimper on page 261 of the second volume of Zittel's Handbook, applies to only one of the forms of the Potomac. The essential point is the insertion of the leaves in tufts on the summit of short branches which form annually. This is a very different arrangement of the leaves from that in Baieropsis, where they are all in one plane, arranged pinnately on the sides and at the tips of leafy twigs.

\section{Baiera foliosa, sp. nov.}

Plate XCIV, Fig. 13.

Leaves numerons, grouped in bundles or tufts at the summit of short, stout, annual growths, having their basal portions long, slender, and gradually narrowing into a pedicel; their upper portions dichotomonsly divided into a small number of strap-shaped laciniæ, the ultimate ones being a little over $1^{\mathrm{mm}}$ wide; nerves slender, forking at long intervals, with branches parallel.

Locality: Fishing hut above Dutch Gap Canal.

This plant, evidently a true Baiera, is very rare, the specimens, few in number, being, with the exception of the one figured, found in small fragments. The leaves at the summit of the short twigs seem to have been very numerous and more slender than in the Jurassic Baieras.

\section{FRENELOPSIS, Schenk.}

Trees or shrubs; stems seen in thickness up to $5^{\mathrm{em}}$ and more; stems and branches cylindrical, jointed, branches alternate or whorled, radiating from the same zone on the principal stems and curving upwards; epidermis dense and durable, cortical tissme thick, and apparently succulent; leives on the joints very short, varying somewhat in shape, normally more or less triangular in form, acute, close appressed, not decurrent, minute and scale-like, one to three in number, alternating in position on the sucessive joints; epidermis marked with minute tubercles arranged in rows, which to the unaided eye appear as fine striæ running longitudinally on the stem 
and parallel to one another; woody axis of the larger branches and stems conparatively small, in the ultimate smaller branches apparently wanting, these being composed seemingly of a succulent material, which was covered by a dense, durable epidermis; fruit not seen.

The stems and branches of this plant, originally cylindrical, are now from pressure always found flat. The stems and larger branches are generally found decorticated or deprived of their epidermis. The removal of the epidermis carries away the scale-like leaves, and on the smallest ultimate twigs they in such cases leave no scars But when the stems and largest branches are deprived of their epidermis and not decorticated, rhombic or triangular scars mark the place of the leaves on the joints. The larger twigs quite often are arranged on the main stems in an umbellate manner: In other cases the branches are arranged in the same plane and go off alternately

The genus Frenelopsis, as hitherto known, is composed of only two species, viz, F. Hoheneggeri Schenk, and F. occidentalis Heer. The former is, according to Schenk, the most abundant plant in those beds in which it occurs. He gives in Die Foss. Pflanzen der Wernsdorf Schichten, the most complete description and delineation of this species known. We may then, in our comparative study of this Potomac species, confine ourselves to Schenk's figures and description. Schenk, in his description of the leaves, says (page 13) that they occur in pairs opposite to each other, the succeeding pairs being decussate. The leaves of one of the Potomac species certainly occur in whorls of three, and, judging from the figures given by Schenk, I am inclined to think that the leaves on $F$. Hoheneggeri occur also in threes on the joints. In Pl. VI, Fig. 6, in Sclienk's work, the pair of leaves in the middle of the stem seem to present on the front aspect of the twig the greater portion of their width, and by their position strongly suggest that they are opposed behind by a single leaf, which belongs to the same whorl. The lower leaf on this twig, by its eccentric position, indicates that it is opposed behind by two leaves. The position of the pail above mentioned is quite similar to that seen in some specimens of the Potomac plant $F$. ramosissima, where the pair is opposed by a single leaf. If this be the true character of the arrangement of the leaves, then Schenk's opinion, ex- 
pressed on page 15 of the above-named work, is correct, and the plant is nearly allied to Frenela It is perhaps the ancestral form of the living Frenela, not yet fully differentiated, for the Potomac plant $F$. parceramosa has only one leaf on each joint.

Heer's F. occidentalis from Valle de Lobos, Portugal, does not afford specimens well enongh preserved to add to our knowledge of the genus. In his Contributions a la Flor: Foss. du Portugal, Pl. XII, Fig. 4, is a good deal like some of the specimens of $F$. ramosissima.

The striking resemblance of the Potomac forms, and especially of $F$. ramosissima, to Frenela confirms Schenk's original conclusions, and there seems to be little doubt that Frenelopsis is more nearly allied to that genus than to Ephedra, as Heer thought. If the leaves of $F$. Hoheneggeri are really in pairs, then the generic description must read: Leaves one to three on the joints. This would not be incompatible with a relationship to Frenela, for in that genus the leaves are not always in threes, but occur occasionally in fours, or even scattered singly, as sometimes is the case in Frenela australis Hooker. Leaves in fours occur also in $F$. subumbellata Parlatore.

Schenk ${ }^{1}$ very correctly calls attention to the resemblance between $F$. Hoheneggeri and Massalongo's Aularthrophyton, depicted in Flor. Foss. del Monte Colle, etc. There is so strong a resemblance that it is difficult to believe that they belong to different genera.

$F$. ramosissima is probably a better differentiated form in the direction of Frenela than $F$. parceramosa and $F$. Hoheneggeri.

Frenelopsis ramosissima, sp. nov.

Plates XCV-XCIX ; Plate C, Figs. 1-3 ; PIate CI, Fig. 1.

Tree or large shrub; stems seen up to a diameter of $5^{\mathrm{cm}}$; stems and branches originally cylindrical, now from pressure always flat, apparently with a large pith, often appearing to have been hollow; the larger branches sometimes scattered and alternate, but more commonly in umbel-like whorls containing three to five branches, usually in the larger branches curving upwards; stems and branches jointed, with joints usually very 
short, the jointing most conspicuous on those parts which retain the cortical layer and epidernis, especially distinct in the smallest ultimate branches, the jointing on the larger decorticated stems often not visilble; woody axis proportionally very small, apparently surrounded originally by a thick succulent cortical layer, which was covered by a firm, parchment-like, very durable epidermis; this latter marked by very fine longitudinal lines formed of rows of small tubercles or dot-like elevations; in the smallest or ultimate branches the woody matter seems to have been almost or wholly wanting, the material composing the branch being sneculent and covered with a firm epidermis; leaves in whorls of threes, leaves of successive whorls alternating; on the youngest branches the leaves are often retained uninjured in the form of minute, closely appressed scales, mostly broadly triangular in form, acute, often acuminate, sometimes mucronate, united at base; on the older branches often convex in form, and under a lens showing towards their tips a prominent line forming a sort of keel; on these branches, when deprived of epidermis, the leaves leave scars, rhomboidal in shape, and slightly elongated in the direction of the length of the stems. The shape of the older leaves varies more than that of the younger ones, being broadly triangular, with very short acute tips or mucronate, sometimes dome-sliaped to broadly conical, with tips prolonged to various lengtlis, often acuminate and sometimes mucronate; the ultimate succulent branches, seeming to have performed the work of leaves and always short, go off from the joints in the axes of the scale-like leaves, generally curve upwards, and apparently lie in the same plane. The subordinate twigs always end with a branch like those sent off lower down; ultimate branches in length, stoutness, number of branches on the penultimate twigs, and degree of crowding show considerable variation; in some cases the ultimate branches are very closely placed, three or four on a side, with a terminal one short and stout, in other cases they are remotely placed, stout and long; again, the plants have sometimes on the penultimate twigs a few remote, very short branches, hardly more than buds; buds sometimes found on short twigs, arranged as are the branches, forming club-shaped growths, in which a number of internodes with partially formed leaves are shown. 
Localities: Fredericksburg; Baltimore, at Federal Hill.

The plant is very rare at Baltimore, but abounds at Fredericksburg, where it is by far the most common fossil. The great number of specimens of this plant at the latter locality indicates that a forest of it must have grown near by. The existence of well-defined buds shows that the growth of the plant was not continnous, but that periods of repose occurred. In many cases the epidermis of the ultimate twigs is so well preserved that it shows the entire shape and dimensions of the twigs, and may be stripped off from the stone. In such cases there is no trace shown of woody fiber, and only a faint imprint is left. The entire material of the smaller twigs was evidently pulpy and succulent. Only in the older and larger stems is a small woody axis shown. In all cases the removal of the epidermis carried away the leaves, and these leave no scars except on the older twigs. It is quite common to find the shrunken remains of the twigs lying in molds which are now considerably larger than themselves, and which they evidently once filled. In twigs $\mathbf{1}^{\mathrm{wn}}$ and under in diameter we may often find the parchment like opidermis perfectly preserved, wrinkled transversely, filled with a brown dust, but showing no woody matter. When woody matter existed it has always been changed to jet, involving the total destruction of the tissue, so that its structure can not be made out. The woody axis, when present in the form of jet, is always much smaller than the tube of epidermis which incloses it. It is a peculiar fact that the woody uatter of this plant was never found preserving the structure of the tissues. This results, perhaps, from the succulent nature of the material. This destruction of tissue and softening of the material of the plant may account for some peculiar differences seen in parts which evidently once belonged to the same plant. On some of the older stems, if some of the succulent cortical zone remains, or if the epidermis is preserved, the jointing is plainly shown. (See Pl. XCIX, Figs. 2, 3; Pl. XCVI, Fig. 3, etc)

In other cases, where only the woody axis is preserved or nothing but an imprint is left, no indications of jointing can be seen, although on ultimate twigs of the same specimen which retain the epidermis the jointing is plain. In the decorticated specimens figured on Pl. XCVII, Figs 1, 2; Pl. XCVIII, Fig. 2; Plate XCVI, there is no trace of jointing, the softening 
of the tissues and the pressure to which it has been subjected, obliterating the evidences of it. In Pl. XCVI, Fig. 1, the main stem shows no jointing, while the nltimate and not fully decorticated twigs do show jointing; $\mathrm{Pl}$. XCV, Figs. 1, 2, 3, 5, retaining epidermis, show good jointing.

The specinens with bods, as in Pl. XCIX, Fig. 1, had thick fleshy stems, with a comparatively small woody axis, surrounded by a very thick succulent cortical layer. It looks as if this material was provided to sustain the growth of the buds. Pl. C, Fig. 1, gives a restoration of what was the probable appearance of one of the smaller twigs. The smaller branches seem always to have been spread out in one plane and to have gone off alternately. The tubercles seem to have been borne on the surface of the epidermis. They are never conspicuous on this species, and are seen best on the youngest ultimate twigs, requiring the help of a lens to make them out distinetly.

The most conspicuous features of this species are the copiousness with which the branching takes place and the shortness and smallness of the branches. The ultimate branches of $F$. Hoheneggeri form usually very long cylinders, which feature is never seen in this species.

Considering the great number of specimens found at Fredericksburg, it is most surprising that no trace of it has been found at any other Virginia locality. This gives us a striking instance of the localization of the Potomac plants. This fossil forms a type of Frenelopsis very near to Frenela, and different in many respects from the other known species.

Frenelopsis parceramosa, sp. nov.

Plate CXI, Figs. 1-5; Plate CXII, Figs. 1-5; Plate CLXVIII, Fig. 1.

Tree or shrub; stems and branches originally cylindrical, now found flat from pressure; primary and subordinate branches very succulent, jointed, with very short nodes, usually found in a very fragmentary condition; epidermis parchment-like and very durable, having rows of minute tubercles, which form distinctly visible longitudinal lines on the stem; ultimate branches very long with, in the visible portions, but little diminution in the width, from pressure appearing as very narrow, strap-shaped twigs, arranged either in an umbellate manner or alternately in one plane, 
remote or closely placed, varying much in width, viz, from $1^{\mathrm{mm}}$ to $12^{\mathrm{mm}}$; the naximum length of the largest ultimate branches seen, $13^{\mathrm{cm}}$; very prone to break into fragments at the joints and very deciduous; leaves very short and closely appressed, very broadly triangular generally, and but little prolonged above the joint, often seemingly entirely undeveloped, one on each joint, those of the adjacent joints alternating in position; branches originally succulent and containing but little woody matter; in the ultimate twigs no woody matter is visible, and they appear to have been composed of a durable epidermis surrounding a fleshy internal portion; the ultimate twigs umbranched, and seeming to have been very long and comparatively thick.

Locality: Found only at the entrance of Trent's Reach, and there almost wholly in a layer 6 to 9 inches thick near the top of the Potomac beds.

This remarkable plant is more like Frenelopsis Hoheneggeri Schenk, than is $F$. ramosissima. It has larger epidermal tubercles than this latter fossil, and they make lines in the direction of the length of the stems that are plainly visible to the unassisted eye. This plant has the same long, cylindrical, jointed, nltimate twigs as those of Schenk's plant, but the internodes are much shorter. The leaves when seen are always very slightly prolonged above the joints, one being on each joint. But in some twigs on many of the joints no leaves appear, as on the main stem in $\mathrm{Pl}$. CXI, Fig. 2, and on many of the joints of Pl. CXII, Fig. 5; when present they are often barely visible. The joints are generally marked by strong constrictions, and many of them simply show a deeply sunken line, which runs across the stem more or less obliquely, generally with a downward bend towards the middle. It is evident that the ultimate twigs played the part of leaves. Only in the older and larger stems do we see any woody axis, and this is always proportionally very small considering the diameter of the twigs. The joints are placed very close together, differing in this point markedly from $F$. Hoheneggeri. The epidermis is very dense and strong, and it is owing to it that the twigs are often found well preserved.

The ultimate twigs were deciduous, and it is a rare thing to find any of them attached to stems. They usually appear as detached fragments. 
Yultitudes of these fragments occur in the layer mentioned before, and they formed a considerable portion originally of the stratum They occur here with Dioonites Buchianus, Brachyphyllum crassicaule, Williamsonia Virginicnsis, Baieropsis pluripartita, etc. Here again we find a remarkable case of isolation.

\section{BRACHYPHYLLUM (Brongniart, ex parte), Schimper.}

Trees or shrubs, with limbs and trigs branching in an irregularly pinnate manner; leaves very short, spirally arranged, densely crowded, and tonching by their broadened bases; when living probably fleshy and pyramidal, curred upwards, or by mutual pressure acquiring a pentagonal or hexagonal form, and projecting in the form of a very short nippleshaped boss, persisting for a long time; when old and on thickened branches dilated into a shield-shaped form; scars left by the fall of the leaves erect, rhombic in form, contignous, and marked in the middle by a vaseular cicatrix.

The above is the description of the genus given by Schimper, excluding the form of Pachyphyllum Saporta, Pagioplygllum Heer, formerly included in the genus by Brongniart. He goes on to say that the leaves are very short, fleshy, and shaped like a nipple, which may be either straight or curred upwards, being enlarged and touching the adjacent ones at base. With age, and in consequence of its dilation, the nipple-shaped projection disappears almost wholly, and the leaves resemble pentagonal or hexagonal cushions, which surround the branch like a cuirass. After the fall of these singular leaves the branches are covered with rhomboidal scars like those of Lepidodendron.

This description in its essential points agrees better with certain of the Potomac plants than that of any other known fossils. The Potomac fossils show mostly only the scars left after the fall of the leaves, and they do not have the vascular cicatrix in their center, but in all other respects these scars are exactly like those of Brachyphyllum. The peculiar mode of branching of this gents is well shown in the fossils now in question. In the shape of the leaf-scars and in the arrangement of the branches, as well as in their form, some of the Potomac fossils are much like Schimper's 
genus Echinostrobus. Again, in many points they are a good deal like Saporta's genus Palcocyparis, but in this latter the leaves are decussate, while in the Potomac plants they are more numerous and spirally arranged. It is possible that the Potomac fossils belong to a generalized type allied to Echinostrobus and Palcoocyparis, hut standing nearest to Brachyphyllum It seems best to place them provisionally in this last genus.

Brachyphyllum CrassicaUle, sp. nov.

Plate C, Fig. 4; Plate CIX, Figs. 1-7; Plate CX, Figs. 1-3; Plate CXI, Figs. 6, 7; Plate CXII, Figs. 6-8; Plate CLXVIII, Fig. 9.

Trees with large branches, irregularly pinnate; on the penultimate twigs the ultimate branches lower and next to the main branch subdivide pinnately into branches; those higher are unbranched and simple; nltimate branches vary in numbers and closeness, sometimes few and remote, and again crowded, contiguons, almost touching; towards the summit of the penultimate branches the ultimate ones become much crowded and grow gradnally shorter, are cylindrical, and taper gradually to an obtuse point; leaf-scars of young leaves elliptical in shape, slightly prolonged in the direction of the axes of the stems, and such leaves seem to have been fleshy, slightly convex, and with a free tip slightly keeled in the upper half; with age the leaves become broader and more convex, being broadly elliptical, almost circular, and they leave similar scars after their fall; when crowded and dilated with age the leaves and leaf-scars are subrhombic or rhombic in shape; the surface of the leaves, which is very rarely preserved, shows fine tubercles or dots, arranged in curving lines parallel to their margins and converging towards their tips; cones small, globular, or subelliptical in shape, attrehed laterally to the penultimate twigs, taking the place of ultimate branches; scales numerous, spirally arranged, touching, shape not made out, but probably with age rhombic and polygonal.

Localities: Entrance to Trent's Reach; 72d mile-post, near Brooke; fishing hut above Dutch Gap Canal.

Fragments of this plant are abundant at the first-named locality in the same stratum with Frenelopsis parceramosa, etc., and are rather rare at the other localities. Most of the specimens showing scars of leaves occur here. 
Pl. CX gives a large imprint of a decorticated branch found at the fishing hut above the canal. The specimen appears to have been much macerated before entombment, so that the stone shows only the ontline of the twigs, all traces of leaves and their scars having been removed. The imprint of the comparatively small woody axes and of the apparently succulent matter surrounding them is all that is shown. The most common specimens found at the entrance to Trent's Reach are the terminal portions of the penultimate twigs. Several good specimens were obtained at the $72 \mathrm{~d}$ milepost. The specimens given in Pl. CXII, Figs. 6-8, occur here. This is another of the connecting links between the floras of the $72 \mathrm{~d}$ mile-post and Dutch Gap.

The views of Heer and Saporta differ muen as to the character of the cones of Brachyphyllum. Heer ${ }^{1}$ depicts a twig of what he calls Bruchyphyllum insigne. This bears two cones. These he describes as subglobose, with numerous spirally arranged, approximate, woody hexagonal peltate scales, with a round depression in the center. This description applies partly to the macerated cone of $B$. crassicaule, given in Pl CIX, Fig. 6, but the obscure rounded markings on this appear to be not scales but the scars left by them. This, the only cone found attached to twigs with the character of Brachyphyllam, is unfortunately too poorly preserved to throw any light on the character of the cones of this group. This cone seems to be attached by a short branch to the under side of the twig, and hence it is partly overlapped by this.

Saporta ${ }^{2}$ gives figures and descriptions of numerous specimens of Brachyphyllum found in France. On page 319, after noticing Heer's conclusions, he says that the forms of Brachyphyllum presented at the upper extremities of their branchlets small or medium-sized ovoid or oblong cones, that were, according to the species, persistent or caducous. The cones were composed of numerous scales, arranged spirally, closely imbricated and appressed, terminated by an apophysial prolongation, lanceolate in shape, thickened, keeled on the back, and more rarely by means of an apophysis dilated into a thomboidal more or less developed cushion. He thinks that

1 l'lor. Foss. Arctica, vol. 4, pt. 2, Beiträge zur Jura-Flora Ostsib., etc., Pl. XIII, Fig. 9.

2Paléont. Française, ze Sér. Végétaux, vol. 3, 1878, pp. 313-321. 
Heer's plant was not Brachyphyllum, but one resembling it, and that the specimen was too imperfect to decide the matter. At the entrance of Trent's Reach a number of specimens of well-preserved cones are found with the twigs of Brachyphyllum. These agree closely with those assigned. by Saporta to Brachyphyllum, and will be described further on. On the whole, the evidence seems to indicate that Saporta's description of the cones of this genus is the more nearly correct one.

Brachyphyllum crassicaule is a good deal like $B$. Moreauanum, Brongn., at least in some of its forms. (See Pal. Française, Végétanx, vol. 3, PI. CLXVI, Fig. 1; Pl. CLXVII, Fig. 1.)

BRACHYPHYLLUM PARCERAMOSUM, sp. nov.

Plate CX, Fig. 4.

Twigs branching sparingly and dichotomously; leaves and leaf-scars elliptical to subrhombic, with the longer dimensions in the direction of the length of the twigs; leaves convex, spirally arranged, showing a keel in their upper portions, closely appressed, contiguous, prolonged very slightly at the tips, branches cylindrical, of the same thickness throughout; so far as can be seen about $4^{\mathrm{mm}}$ in diameter.

Locality: Near Telegraph Station.

This plant, found sparingly near Telegraph Station. differs from $B$. crassicande in the comparatively slender, strictly eylindrical branches, which show no tapering, subdivide very rarely, and then in a dichotomons manner, and also in the regular shape of the leaves. In its general aspect this fossil is a good deal like Cyparissidium. It is also a good deal like some of the forms of Brachyphyllum gracile. (See Pal. Française, Végétanx, vol. 3, Pl. CLXVIII, Fig. 2 ; Pl. CLXX, Figs. 4, 5.)

\section{Brachyphyllum, sp. ? (Cone.)}

Plate Cxxxy, Fig. 8.

Cone broadly oblong, widest near the top, length $20^{\mathrm{mm}}$, maximum width $15^{\mathrm{mm}}$, attached to the summit of a short branch, narrowed slightly and gradually toward the base, showing at the summit a slight nipple or boss-like projection ; scales numerous, spirally arranged, closely appressed, 
and partly imbricated, convex, broadly elliptical to subrhombic, and slightly prolonged at their summits into acute tips.

Locality: Entrance to Trent's Reach; rare.

These cones are found associated with the branches of Brachyphyllum crassicaule. They may belong to this species, or to some other conifer. They agree pretty well in shape with the macerated cone given in $\mathrm{Pl}$. CIX, Fig. 6. It is obviously a cone of the same type with those described by Saporta as associated with the French specimens of Brachyphyllum. It agrees best with the cones of B. gracile Brongniart, but does not seem to be identical with them.

\section{Brachyphyluum, sp.? (Cone.) \\ Plate Cxxy, Fig. 9.}

Cone small, broadly oblong?, length not made out, as the basal portion is wanting, width $10^{\mathrm{mm}}$; scales numerous, closely appressed, partly imbricated, spirally arranged, thick and convex, in shape broadly elliptical to subrhombic, acute at the tips.

Locality: Entrance to Trent's Reach.

These cones occur with those of the preceding species and are more common than the latter. They seem to belong to a distinct species. In the rounded shape and in the size they come nearer than any of the previously described ones to what Saporta thought was the male ament of $B$. gracile Brong. It resembles in some points that shown in Pal. Française, Tégétanx, vol. 3, Pl. CLXXI, Fig. 9. It may be the male ament of B. crassicaule, although apparently rather large for that.

\section{Brachyphyllum, sp.? (Cone.)}

Plate CLxVIII, Fig. 2.

This is a small fragment of a cone found at the entrance to Trent's Reach with the two last-described species. It is too imperfect to admit of description, the margins being in no place preserved, and the surface showing only subrhombic scars with depressed points in the center. These scars seem to be those left by the scales of the cones. 
A number of aments of conifers were found at the $72 \mathrm{~d}$ mile-post, near Brooke, and elsewhere, whose species can not be determined. They appear to be male aments, possibly in some cases of Brachyphyllum, but certainly of some conifer. They usually occur together in large numbers, as if coming from plants near by. These will be designated as $(a),(b)$, $(c)$, etc. These aments resemble somerwhat Heer's genus Elatides.

AMENT OF CONIFER (a), sp.?

Plate CXXXVI, Fig. 2.

Male (?) aments ovate to oblong in shape, small, subacute at their tips; scales numerous, broadly elliptical, prolonged slightly into an acute tip, spirally arranged, thin, close appressed, slightly imbricated, forming a thin flat ament that leaves only a slight imprint; length of ament about $9^{\mathrm{mm}}$, and width about $4^{\mathrm{mm}}$.

Locality: Near Brooke, at $72 \mathrm{~d}$ mile-post.

Some fragments of shale for the space of several inches are covered more or less thickly with these aments, which evidently fell from plants not far distant. The shape and size of the scales and aments of this species agree pretty well with some of the strobiles supposed by Saporta to be male aments of species of Brachyphyllum. ${ }^{1}$

AMENT OF CONIFER (b), sp.?

Plate CXXXVI, Fig. 3.

Aments very small, broadly ovate, obtuse or acute at summit, sometimes attached to short pedicels; size about three by six millimeters; scales very thin, close appressed, slightly imbricated, numerons, spirally arranged, in shape broadly elliptical to subrhombic, with a slight prolongation into acute tips.

Locality: 72d mile-post, near Brooke.

The imprints are quite thickly scattered on some few fragments of shale, but are not so numerons as those of species $(a)$. The cones are smaller than those of $(a)$. Brongn.

${ }^{1}$ Compare Pal. Franęaise, Végétaux, vol. 3, Pl. CLגVII, Fig. 3, of the strobile of B. Moreauanum MON $\mathrm{xV}-15$ 
AMENT OF CONIFER (c), sp.?

Plate CxxxvI, Fig. 4.

Aments globose or broadly oblong, very small and varying in size, the largest being five by three millimeters ; scales arranged as in species $(a)$ and $(b)$, thin, subacute at their tips, closely appressed, minute, narrowly elliptical in shape, numerous, and spirally arranged, somewhat imbricated.

Locality : 72d mile-post, near Brooke.

They occur on a few pieces of shale in considerable numbers crowded together; seem to be different from species $(a)$ and $(b)$ in the smaller and more variable size and the more rounded form and in the narrowly elliptic shape of the scales.

AMENT OF CONIFER $(d)$, sp.?

Plate Cxxxvi, Fig. 5.

Aments mostly ovate, sometimes elliptical, varying somewhat in size, averaging five by three millimeters, broadest at base and narrowed above to an acute tip; scales in number and arrangement as in the preceding species, in shape broadly elliptical to ovate, prolonged at the sunımit to a very short acute tip.

Locality: On the railroad near Cherry Hill Station.

This station is on the Alexandria and Fredericksburg portion of the Atlantic Coast Line Railroad, midway between Quantico and Powell's Creeks. 'The aments are found in the shale in a cut a little north of the station. They occur crowded in considerable numbers on the surface of a few specimens of the rock. No prolonged search was made here, as there did not seem to be any prospect of finding good material. With these were found a few obscure imprints of some conifer with acicular leaves.

\section{AMent of CONIFER (e), sp.?}

Plate CXXXV, Fig. 7.

An ament, elongate-oblong in form, very narrow in proportion to its length, with numerous chaffy scales imbricated on a slender axis, incurved and spoon-shaped. 
Locality: $72 \mathrm{~d}$ mile-post, near Brooke.

Only one specimen of this fossil was found. It seens to be the male ament of some conifer, possibly of some one described under another name. Fig. $7^{\mathrm{b}}$ represents one of the scales flattened out by pressure on the surface of the clay. Fig. $7^{\mathrm{a}}$ represents the shape of the enlarged scales as they were attached to the axis.

\section{AMent of CONIFER, $(f)$ sp. ? \\ Plate CXXXVI, Fig. 8.}

Fig. 8 represents small catkins, that occur rarely, grouped together in large numbers on the surface of some portions of the clay at the $72 \mathrm{~d}$ milepost. Where found they cover the surface confusedly, as if they had floated in numbers on the surface of the water. They occur only in small bits, none showing the entire length. They were linear in shape. No conjecture can be made as to the species of tree from which they come.

\section{LEPTOSTROBUS Heer.}

"Strobile stipitate, very long, with scales that are loosely imbricated, narrowed at base, and have the upper margin crenulate $; * * *$ leaves needle-shaped, fasciculated on shortened branches." This is Heer's description of the genus formed to contain peculiar Jurassic plants from eastern Siberia. He says of Leptostrobus rigida ${ }^{1}$ that the leaves are $2^{\mathrm{mm}}$ wide, very long, with two very distinct nerves, which sometimes show between themselves some very fine strix (see Pl. VII, Fig. 11 ${ }^{\mathrm{c}}$ ). Some of the fragments of leaves that he saw were $10.5^{\mathrm{cm}} \mathrm{long}$ with the ends not present. If we modify Heer's description so as to make it read: leaves needle-shaped, very long, $2^{\mathrm{mm}}$ and under in width, seattered on the larger or principal stems and grouped in bundles on the ends of short twigs, attached directly to the stems, nerves slender and parallel, we shall be able to include in this genus certain remarkable conifers found in the Potomac strata. These Potomac fossils are a good deal like Schizolepis Fr. Braun, but the leaf of this latter had only one nerve. 


\section{Leptostrobus LONGIFolius, sp. nov.}

Plate CI, Figs. 2, 3; Plate CII, Figs.1-4; Plate CIII, Figs.6-12; Plate CIV, Fig. 6.

Trees or shrubs with stont and long primary leafy branches, which contain the leaves attached singly and scattered along the stem, as now seen attached to the under surface or to the sides of the stems, but most probably originally found spirally arranged and attached to the stems on all sides. The primary leafy branches have lateral and terminal short shoots, on the ends of which the leaves are arranged in tufts; leaves very long and narrowly linear or needle-shaped, with their extremities in no case seen, attached by the entire bases, not narrowed; nerves several, parallel, slender, and obscure.

Localities: Fishing hut above Dutch Gap Canal; Fredericksburg; 72d mile-post and bank near Brooke; hill-side near Potomac Run.

The plant is not uncommon at any of the localities. It is most abundant at the fishing hut above Dutch Gap Canal, where all the forms depicted on Pl. CII occur. The leaves oecur, as elsewhere, most commonly detached. They seem to be quite deciduous, especially on the older and larger stems. All the specimens found have suffered from maceration and transportation in water, and hence the present mode of arrangement of the leaves in the comparatively few cases where they are found attached does not give an accurate picture of their original condition. The leaves in tufts at the ends of the short shoots may represent all that were originally present, or they may be only the younger last-formed ones, the older ones lower on the twigs having fallen off.

This latter is probably the true state of the case. At any rate, these short shoots seem to be growths from lateral buds, perhaps annually formed. Neither on these nor on the longer main stems are any scars left by fallen leaves to be seen, but this does not prove that they were not present, for in all cases the naked portions have lost their epidermis and suffered a good deal from maceration. They are decorticated and reduced to the woody fiber, or show only imprints of this. The leaves as now seen on the older and larger stems seem to be all attached laterally, or to the ends of the stems or to the under surface. This is probably due to the accidents 
of preservation. The leaves on the upper surface, after the settling of the twig on the bottom, were most exposed to the action of the water and were removed, while those that were attached to the under surface, being held in place by the pressure of the superincumbent stem, were retained. Most of the leaves that appear to be attached to the sides of the stems no doubt are really attached to their under surface. This seems to be the case in Pl. CI, Fig. 2, and Pl. CII, Fig. 3. The ends of the large stems in these figures are broken off. It is, then, most probable that the leaves were scattered spirally around the larger stems. The leaves seem to have been attached by their entire unnarrowed bases and to have been directed upwards towards the summits of the stems. Hence we find them sometimes curved at base as Heer ${ }^{1}$ has depicted, but I have seen none so much bent or so regularly, as those of Heer.

The nerves are very obscure, and the leaves, even the best preserved, rarely show any traces of them, for they seem to have been slender and immersed in the leaf-substance. Generally only fine striæ are visible on them, even with the help of a lens. They seem to be about four in number and parallel. No difference in strength was noted, as Heer intimated. The length of some of the leaves must have been very considerable, for some fragments, with both the base and summit missing, were as much as $15^{\mathrm{cm}}$ long. In Pl. CIII, Figs. 6, 8, 9, are given some fragments of leaves from the $72 \mathrm{~d}$ mile-post near Brooke, where detached leaves occur on some portions of the shale in considerable numbers, crowded together or overlying one another. In some cases, as in $8^{a}$ and $6^{\text {a }}$, they show four vely fine nerves. In others, as $6^{\mathrm{d}}$, no nerves are seen, but the leaves appear smooth and convex from pressure. Again, in some cases, as in $6^{\circ}$, only one nerve is visible. Sometimes, as in $6^{\mathrm{b}}$ and $6^{\mathrm{c}}$, the nerves vary in strength and are vaguely shown. These differences are no doubt due to the accidents of preservation. Sometimes it seems that apparent nerves are longitudinal wrinkles or folds in the leaves caused by pressure. This seems to be the case in $6^{\mathrm{a}}$ and $6^{\mathrm{e}}$.

On the hill-side near Potomac Run a good many detached fragments of long and very narrow leaves with four very fine nerves occur scattered 
on some portions of the shale. They are shown partly in Pl CIII, Figs. 10-12, and Pl. CIV, Fig. 6. These were never seen certainly attached to any stem, but their bases are sometimes well shown, looking as if they had been attached in a clasping manner by a widened base, and in Pl. CIV, Fig. 6, the base may be seen attached to what seems to be a portion of the stem. In Pl. CIII, Fig. 12, two bases seem to be put together, possibly by accident. These leaves may belong to a different species, but I place them provisionally in the species now being described.

Leptostrobus foliosus, sp. nov.

Plate CI, Fig. 4 ; Plate CIII, Fig. 5 ; Plate CIV, Fig. 1.

Leaves long and very slender, about $1^{\mathrm{mm}}$ in width, length not made out, densely crowded on the principal and longer shoots throughout their lengtl, grouped in bundles at the ends of the shorter lateral shoots: nerves very slender, not well made out, apparently three in number.

Localities: Fishing hut above Dutch Gap Canal; red clay ball in the banks of Dutch Gap Canal.

This is clearly a different species from the preceding, and it is not so common. The nerves could be seen on only one specimen and that vaguely, so that their number is not positively determined. They appear to be three, but this may be due to the state of preservation, and the number visible may vary according to the condition of the fossil. It is quite possible that the true number may be four. The leaves are almost always seen detached and crowded together, as if derived from the same specimen.

\section{Leptostrobus? MULTiflorus, sp. nov. \\ Plate CLXV, Fig. 6.}

Strobile stipitate, with a very thick axis of inflorescence, covered by numerous small spatulate-shaped scales, that are loosely imbricated and arranged in a spiral manner.

Locality: 72d mile-post, near Brooke.

Only one specimen of this curious inflorescence was found, and it was too imperfect to make out clearly its character, since the rock on which the imprint was made is a rather coarse sandstone. The specimen was evi- 
dently much injured by maceratiou before it was entombed. The lower portion of the axis lias lost most of its scales, while the upper portion still retains them. These scales, although smaller than those given by Heer for the species examined by him, appear to more nearly resemble those of Leptostrobus than those of any other plant. I place it with doubt in this genus. The cone somewhat resembles those of Heer, ${ }^{1}$ but the scales are smaller, more numerous, and more closely placed.

The following seed have the character of the seeds described by Heer as Samaropsis, from the Jurassic of Ust-Balei, in eastern Siberia. ${ }^{2}$ These seeds Heer, ${ }^{3}$ in subsequent remarks on Leptostrobus, takes to be those of that plant. The Potomac seed throw no additional light on the subject. It is at least significant that they occur with leafy branches that have the character of Leptostrobus. It will perhaps be best to distinguish these Potomac fossil seed as Leptostrobus (a), (b), etc.

\section{Seed of Leptostrobus? (a), sp.?}

Plate CXXXV, Fig. 6.

Seed smooth, obovate in shape, obtusely rounded at one end, and narrowed at the other into a sort of neck; winged, with wings of the same width, except towards the neck, where it is slightly narrowed.

Locality: Fishing hut above Dutch Gap Canal.

Seeds of this nature are sparingly found at this locality. They may be seed of one of the species of Leptostrobus found at Dutch Gap.

Seed of Leptostrobus ? (b), sp.?

Plate CXxxvI, Fig. 10.

Seed broadly elliptical, winged; wing proportionally small and prolonged at one end into a slight point, widest in the middle, and narrowed slightly towards the extremities of the seed.

Locality: Fishing lut above Dutch Gap Canal.

Winged seed of this nature are found sparingly here. They may be seed of Leptostrobus.

${ }^{1}$ Flor. Foss. Arctica, vol. 6, pt. 1, Pl. VII, Fig. 7 ; Pl. VIII, Figs. 1-3.

${ }^{2}$ Flor. Foss. Arctica, vol. 4, pt. 2, Beitrïge zur Jura-Flora Ostsib. etc., p. 80, et seq.

${ }^{3}$ Ibid., Nachtrag zur Jura-Flora Sibirieus, vol. 6, pt I, p. 23. 


\section{Seed of LEptostrobus? (c), sp.?}

Plate CxxxvI, Fig. 11.

Seed oblong-elliptical, with a slight acute tip at one end and a very short stem-like prolongation at the other. Smooth, winged; wing very large in proportion to the seed, widest in the middle and flared out there, narrowed towards the apex and base, prolonged to a short subacute point, and ending below in what seems to be a point of attachment to a pedicel.

Locality: Kankey's; only one specimen found.

This seed differs from the others in its greater size as well as that of the wing, and in the greater proportional size of the wing as compared with the seed, also in the flaring out of the wing in its middle portion. It is a little like Heer's Samaropsis rotundata. It is possible that these seed do not belong to Leptostrobus, but to the genus next to be described, viz, Laricopsis, for Larix has samara-like seed.

\section{LARICOPSIS, gen. nov.}

Trees or shrubs, with the penultimate trvigs sending off alternately in the same plane ultimate branches; leaves thin, narrow, and thread-like, attached by the entire base either in bundles at the same point on the stem or scattered singly on its surface, both on the same stem, very deciduous, the leaf-bundles leaving small scars Nerves not made out with certainty, but apparently one for each leaf.

This genus is nearer to Larix than to any other known plant, and the resemblance is sufficiently great to render it possible that it may be the ancestor of this genus. It should be noted that the young shoots of Larix often have the leaves scattered singly as they occur in this genus, and it is probable that the immature portions of Larix approach the ancestral forms more nearly than the mature portions do. In these specimens also the leaves appear most often to be attached laterally to the stems as now preserved, while no doubt they were originally scattered around the stem. This appearance, as in the case of Leptostrobus, is doubtless due to the accidents of preservation. No nerves could be made out with certainty. The leaves are very narrow, being sometimes like hairs. 
LARICOPSIS LONGIFOLIA, sp. nov.

Plate CII, Figs. 7, 8; Plate CrII, Figs. 2, 3; Plate CLXV, Fig. 4; Plate CLXVIII, Figs. 5,6.

Leafy stems comparatively very stout, branching rarely, with the ultimate branches in the same plane and alternate; leaves narrow, about $.5^{\mathrm{mm}}$ or under in width, very long in proportion; portions seen are over $3^{\mathrm{om}}$ long and not entire, grouped occasionally in bundles as in Larix, more commonly scattered singly and attached by the unnarrowed bases, flat and thin, deciduous on the older branches; nerves not certainly made ont, apparently one for each leaf.

Locality: Fishing hut above Dutch Gap Canal.

The plant is rather rare, and is generally found in a very fragmentary state or in the form of detached leaves. The removal of the leaf-bundles leaves sometimes quite distinct dot-like scars on the upper surface of the stems. Considering the narrowness of the leaves the stems are remarkably thick. Owing to the crossing of the leaves in superposition they often look as if they split into branches, and then they remind one strongly of Heer's genus Phoenicopsis, but they certainly never fork.

\section{LARICOPSIS ANGUSTIFOLIA, sp. nov. \\ Plate CrI, Figs. 9, 10; Plate CrrI, Figs. 1, 4.}

Twigs slender, branching sparingly; leaves exceedingly narrow and hair-like, entire length not seen, but certainly equaling $3^{\mathrm{cm}}$, thin, flat, scattered over the surface of the stems or grouped in bundles; nerves not seen.

Localities: Fishing hut above Dutch Gap Canal; entrance to Trent's Reach; rare.

These leaves often do not surpass $.2^{\mathrm{mm}}$ in width. As in the case of the preceding species, they are always broken off towards the tips, so that their true length can not be made ont. The leaves as now seen are all attached to the sides of the stems apparently, but this is no doubt due to the fact that they, in many cases at least, come from the under sides of the stems, being held in place by the superposition of the latter. The grouping of the leaves in bundles occurs irregularly and rather rarely. 
Possibly these specimens may be the narrower leaves on forms of the preceding species, but this is hardly probable. It is rare, but more common than the preceding species.

\section{LARICOPSIS BREVIFOLIA, sp. nov.}

Plate CII, Figs. 5, 6.

Twigs slender, branching freely; leaves distributed and attached as in the preceding two species, thin, flat, wide in proportion to their length, short, acute at the tips; nerves not seen; length of leaves $1^{\mathrm{cm}}$ and little more, width $8^{\mathrm{mm}}$, crowded on the younger branches, deciduous when old.

Localities: Fishing hut above Dutch Gap Canal ; entrance to Trent's Reach.

This plant is quite rare. The leaves are, in proportion to their length, much wider than those of the two preceding species. Fig. 5 presents two lower branches on the right-hand side that are entirely deprived of their leaves. The leaves of this species look something like those of Heer's genus Inolepis.

\section{TORREYA Arnott.}

Small trees, with leaves linear or lanceolate, in two rows, either opposite or alternate, flat, decurrent at base, without a midrib, but marked longitudinally on the lower side, on each side of the central line of the leaf, by a narrow sunken band.

This genus has not furnished to the Potomac flora any considerable element, since the two species found are quite rare.

\section{Torreya Virginica, sp. nov.}

Plate CIX, Fig. 8.

Stems slender; leaves subopposite, linear, narrowed gradually to the base and apex, at the apex prolonged into a short spinous tip, attached by a short slightly twisted footstalk to the margins of the stems or slightly within them, slightly decurrent; midnerve not apparent. 'The leaves have on each side of their axial line a strong cord-like line running through the leaf nearly parallel, converging at the base and apex, and seeming to be 
imprints made by the two medial depressed lines of the leaf; leaves rather remote, flat, coriaceous, and persistent.

Locality: 72d mile-post, near Brooke; only one specimen found.

This plant is quite different from the species of Cephalotaxopsis and Nageiopsis fonnd in the Potomac flora. The leaves were leathery and durable, and marked by two prominent cord-like ridges in the center, which do not seen to have been nerves.

Torreya falcata, sp. nov.

Plate CXIII, Fig. 4.

Stems of ultimate twigs slender; leaves coriaceons, distichous, approximate, spreading, attached by a broad base to the margins of the twigs, or somewhat within the margins, slightly decurrent, linear, falcate, acute, prolonged at the summit into a short spinous tip. Marked in the medial line with two strong parallel lines.

Locality: Hill-side near Potomac Run; rare.

This plant is a good deal like T. parvifolia, Heer, as given in Flor. Foss. Arctica, vol. 3, pt. 2, Pl. XVII, Figs. 1, 2.

\section{CEPHALOTAXOPSIS, gen. nov.}

Trees or shrubs, with fruit probably in the form of drupaceous and nut-like seed, branching copiously, with branches umbellately arranged or alternate in the same plane, often opposite from paired terninal buds; stems comparatively very stout, rigid, and woody; leaves distichous, varying a good deal in size, flat, linear, thick and leathery, persistent, attached by very short slightly twisted footstalks to the sides of the stems or slightly within the margins, prolonged at the apex into a short spinous tip, with a single flat broad midnerve, which on the lower side of the leaf is bordered on each side like Torreya by a sunken line.

This is a very important genus in the Potomac flora, on account of both the number of species and the great number of individuals in some of the species. The genus is one of the most characteristic types of the Potomac vegetation. It is very near to Cephalotaxus, but does not appear to be 
identical with it. It rather seems to be a composite type, uniting some of the features of Cephalotaxus, Torreya, and perhaps Taxus. A common mode of growth of the branches seems to have been by a terminal bud with opposite buds, one being on each side of the terminal one, all being covered with scales, which, as in Cephalotaxus, leave sometimes distinct scars at the base of the shoots of annual growth.

No fruit has been found attached to the leafy twigs of these plants, hence its nature has not with certainty been determined, but certain nutlike fruits have been found in company with the leaves which most probably belong to this genus.

\section{Cephalotaxopsis magnifolia, sp. nov.}

Plate CIV, Figs. 4, 5 ; Plate CV, Figs. 1, 2, 4 ; Plate CVI, Figs. 1, 3 ; Plate CVII, Figs. 1, 2, 4 ; Plate CVIII, Figs. 1, 3, 4 .

A tree or large shrub, with stout limbs, so far as seen, branching sparingly, the branches being in the same plane and remote, opposite or alternate, the ultimate twigs showing sometimes at their bases scars of the budscales; leaves variable in size, attaining a maximum length of $6^{\mathrm{em}}$ and a maximum width of $5^{\mathrm{mm}}$; subspirally arranged, that is, attached mostly to the sides of the twigs, but sometimes somerwhat within the margins and slightly on the upper and lower surfaces; attached by short slightly twisted footstalks in two rows in the same plane, subopposite or alternate, rather remote, with the ultimate twigs terminated abruptly by a leaf; the leaves very thick and leathery, persistent, and very durable, widest near the base and generally abruptly rounded off there, more rarely tapering gradually to the base, gradually narrowing towards the apex, where they terminate in a spinons or mucronate point; the leaves (see Pl. CV, Fig. 1) below and near the shoots of annual growth sometimes unusually small; midrib broad, flat, distinet, with a narrow sunken line on each side.

Localities: Fishing hut above Dutch Gap Canal, rare; Fredericksburg, very common.

This is one of the most abundant plants at Fredericksburg, where many well-preserved specimens occurred. The growth of the twigs seems often to have been made by a terminal bud flanked by two opposite lat- 
eral ones, and these seem to have had persistent bud-scales, which have sometimes left quite distinct scars, as in PI. CV, Fig. 1.

Owing to the leathery character and great durability of the leaves, they may often be found as perfectly preserved as if they had been pressed in a herbarium, even sometimes having a greenish color. They then show the minutest details of their structure. The spiny tip at the ends of the leaves seems to be the prolongation of the midrib beyond the leaf. This tip, however, is not generally preserved. The thick character of the leaves has caused them in drying to wrinkle transversely, as in Pl. CVI, Fig. $1^{\text {a }}$. The leaves are notably thick and prominent. As shown in Pl. CV, Fig. 2, the ultimate twigs are terminated by a leaf in a manner similar to cycads. The midrib has two depressed lines running very close to it that leave in some cases two imprints looking like two parallel nerves, as in Pl. CVIII, Fig. 4, and Pl. CIV, Fig 5. These remind one of the two imprints seen in Torreyg. The variation in the size of the leaves does not surpass that seen in Cephalotaxus drupacea, which this plant closely resembles. The bud-scales seem to have been persistent for some time.

Cephalotaxopsis ramosa, sp. nov.

Plate CIV, Figs. 2, 3 ; Plate CVI, Figs. 2, 4; Plate CVII, Fig. 3 ; Plate CVIII, Fig. 2.

Tree or shrub, with stout branches in whorls or scattered alternately, and in the same plane; bud-scales persistent at the bases of the shoots of annual growth; leaves comparatively thin, narrow, tapering gradually to the base and apex, insertion and arrangement of the leaves as in C.magnifolia; the leaves have a maximmm length of $4^{\mathrm{cm}}$ and a maximum width of $4^{\mathrm{mm}}$.

Localities: Fredericksburg, common; road-side near Potomac Rum.

This plant is much like C. magnifolia, but it is much more copiously branched, the leaves are narrower in proportion to their length, have a thinner texture, and a proportionally narrower midrib. It is rather more abundant at Fredericksburg than C. magnifolia. It may possibly be a form of $C$ magnifolia, but the facies is constant and different from that of this species. The tendency to a whorled grouping of the branches is marked. A common mode of arrangement is that given in PI. CVII, Fig. 3, Pl. CIV, 
Fig. 2. The branches are now by pressure brought into one plane: In Pl. CVIII, Fig. 2, the right-hand lateral branch has been torn off. In Pl. CVI, Fig. 2, they appear to have been pinnately arranged, a mode not so common as the umbellate one. In PI. CIV, Fig. 2, all the fragments seem originally to have belonged to the same branch.

\section{Cephalotaxopsis brevifolia, sp. nov.}

Plate CV, Fig. 3 ; Plate CVI, Fig. 5 ; Plate CVII, Fig. 5.

Trees or shrubs, with ultimate branches, so far as seen, alternate and strictly in one plane; leaves thick and leathery, attached and arranged as in the preceding species, narrowly oblong to narrowly elliptical, mostly narrowed gradually at the base and apex, maximum dimensions $21^{\mathrm{mm}}$ by $3^{\mathrm{mm}}$, average dimensions $13^{\mathrm{mm}}$ by $2^{\mathrm{mm}}$, short in proportion to the width; midnerve slender.

Localities: Fishing hut above Dutch Gap Canal; Fredericksburg; road-side near Potomac Run; rare.

Pl. CV, Fig. 3, a specimen from Fredericksburg, gives the largest leaves seen. Only small fragments of ultimate branches were found. The leaves in proportion to their size are remarkably thick and leathery.

Cephalotaxopsis microphiylla, sp. nov.

Plate CVIII, Fig. 5 ; Plate CIX, Fig. 9.

Tree or shrub, copiously branching, with branches alternate, slender, all in one plane; leaves arranged and attached as in the preceding species, very small, average dimensions $1^{\mathrm{mm}}$ by $7^{\mathrm{mm}}$, leaf-substance thin, in slape narrowly oblong to narrowly elliptical, tapering gradually to the base and apex; midnerve slender.

Localities: Fredericksburg; fishing hut above Dutch Gap Canal.

This plant is quite rare, and is the smallest of the gents. The leaves on the ultimate twigs towards the summit of the branches are very minute, as on the uppermost branch on the left hand in PI. CIX, Fig. 9, from the Dutch Gap locality. The midnerve, owing to its slenderness, is generally not visible. 


\section{ATHROTAXOPSIS, gen. nov.}

Trees or shrubs, copiously branching, with principal stems or branches proportionally strong, cylindrical, rigid, sending off thickly placed, long, slender, cord-like, ultimate twigs, all in the same plane and spreading widely; the ultimate twigs leave the penultimate ones under a very acute angle and show a tendency to a fastigiate grouping; cones mostly broadly oblong, rarely globular, obtuse and rounded at base and apex, average dimensions $10^{\mathrm{mm}}$ by $14^{\mathrm{mm}}$, attached singly on the summit of short lateral branches and placed on the lower portions of the leafy stems and branches, the twig with its cone representing the branching leafy twigs which occur higher up; scales of the cones woody, thick, wedge-shaped in the basal portions, expanded at the free ends, and probably shield-shaped, numerous, spirally placed, attached at a large angle, the middle ones being nearly or quite at a right angle with the axis, close appressed, opening with age; seed under each scale one, elliptical in shape, smooth and bony in texture, average dimensions $1^{\mathrm{mm}}$ by $2.5^{\mathrm{mm}}$; leafy branches ending abruptly in an ultimate twig similar to those sent off pinnately and altemately lower down; leaves very thin and scale-like, elliptical, rhombic, or oblong, with varying age changing their shape, the rhombic forms representing the oldest and most crowded leaves, slightly keeled on the back, spirally arranged.

As now found, owing to maceration, the leaves are rarely visible or appear very indistinct. The upper or free surface of the scales of the cones was in no case seen sufficiently well preserved and so presented as to show clearly its original character. This surface seems to have been expanded something like the similarly placed part in the scales of Sequoia. The shape of the cone also is a good deal like that of the cone of that genus, but the leaves and the number of seed under the scales differ. The scales of Attrotaxopsis are wedge-shaped, thick, and woody. In a number of cases they were found sufficiently well preserved to permit one to separate them from the cone, and to pick out the comparatively large seed, which were very well preserved. The cones are comparatively quite small in size, and are found on the lower portions of leafy principal twigs. In some cases, where the cones are numerous, the branch seems to have borne 
no leafy twigs, as in the specimens given in Pl. CXVI, Figs. 1, 2. The cones when unripe are compact, with close-appressed scales, but with age the scales diverge.

Heer ${ }^{1}$ describes his genus Cyparissidium as having an oval strobile, furnished with numerous scales, which are spirally arranged on the axis, imbricated, coriaceous, and rounded, loosely spreading at the apex, mucronate, etc.; seed one under each scale and rounded? ; leaves alternate, imbricated, and appressed. Heer bases his conchisions as to the character of the seed on the imprint of a rounded object under a scale similar to those that he attributes to Cyparissidium (See Pl. XIX, Fig. 11.)

While Athrotaxopsis has a number of the characters of Cyparissidium, the differences are too important to allow its being united with the latter genus; the character of the cone is essentially different. Athrotaxopsis in many features, both of the foliage and the cones, is strikingly like the living genus Athrotaxis, and perhaps may be regarded as an ancestral form of this genus. The main distinction is in the single seed under each scale. It has also, in the character of the leaves and branches, points in common with Echinostrobus and Saporta's genus Palceocyparis. It is evidently a comprehensive type. The great length and slenderness of the ultimate twigs make it probable that they were pendulons.

Athrotaxopsis grandis, sp. nov.

Plate CXIV, Figs. 1-3; Plate CXVI, Figs. 1-4; Plate CXXXV, Fig. 10.

Trees or shrubs, with strong principal branches, bearing cones on the lower portions, and in the upper portions leafy branchlets alone; stems seen $1^{\mathrm{cm}}$ thick, with a length of $30^{\mathrm{cm}}$ and an expanse of over $25^{\mathrm{cm}}$, the terminal portions not being preserved. Cones as given in the generic description, leafy stems copiously branched in an alternate manner, the branches being crowded and all in the same plane. The ultimate twigs are long, comparatively strong, and cord-like, and were probably pendulous, mostly unbranched, or sometimes dividing dichotomously; leaves close appressed, elliptical when young and acute at their tips; rhombic when old, and crowded, thin, slightly keeled on the summit. 
Localities: Fredericksburg; 72d mile-post, near Brooke.

At the latter place the plant is rare, but at the former it is quite common, being in one layer one of the most common plants. It occurs here sometimes in very large specimens. The fine form figured in Pl. CXIV, Fig. 1, is a part of a specimen which, although still only a fragment of a branch, was considerably larger than the part figured. Most of the large specimens liave suffered so much from the action of water before entombment that they are decorticated and have lost their leaves.

Atmrotaxopsis tenuicaulis, sp. nov.

Plate CXIV, Figs. 4, 5; Plate CXV, Fig. 4 ; Plate CXVI, Fig. 6 ; Plate CXVII, Fig. 2.

Small trees or shrubs, with comparatively very slender stems, branching copiously and mostly at short intervals; branches alternate and in the same plane, ultimate branches short, slender, thread-like, with an ultimate branch terminating the penultimate branches, the ultimate twigs simple or rarely dichotomous; leaves arranged spirally, close appressed, keeled slightly at the tips, elliptical to rhombic in shape, acute.

Localities: Fishing hut above Dutch Gap Canal; Fredericksburg.

At the latter place the plant is rare, while it is not uncommon at the former. This form is characterized by the narrowness and the shortness of the ultimate branches. They are usually numerous and closely placed. The leaves are rarely preserved, and they sometimes show a faint keel at their tips, as in Pl. CXVII, Fig. $2^{2}$.

\section{Athrotaxopsis expansa, sp. nov.}

Plate CXIII, Figs. 5, 6 ; Plate CXV, Fig. 2 ; Plate CXVI, Fig. 5 ; Plate CXVII, Fig. 6 ; Plate CXXXV Figs. 15, 18, 22 (cones).

Trees or shrubs, the leafy branches being very long and with slender woody axes, spreading widely, sparingly branched, branches in one plane; the ultimate twigs alternate, remote, very long and cord-like, probably pendulous, unbranched or rarely dichotomons; leaves quite thick (comparatively), keeled, elliptical to subrhombic, acute to obtuse, the lateral ones often rather obtuse and divergent from the stem, cones, oblong, sometimes from distortion made more or less globular in form, comparatively MON $\mathrm{xV}-16$ 
large, being $14^{\mathrm{mm}}$ by $11^{\mathrm{mm}}$ on an average, scales and other parts as in the generic description.

Localities: Hill-side near Potomac Run; entrance to Trent's Reach; banks of Dutch Gap Canal; fishing lut above the canal.

This plant is very common in large specimens at the first and last named localities. At the Potomac Run locality, on the hill-side in the woods, it is, next to the ferns, the most common plant, but it is not found on the road-side only a few hundred feet away. The fine specimen, Pl. CXV, Fig. 2, comes from the fishing hut. The lower detached fragments were once no doubt attached to the same stem with the upper portion. This figure shows well the characteristic mode of branching of the species and the wide spread of the twigs. This species shows a mode of preservation of the twigs common in this but rare in the others. In it the leaves or: the upper face of the older stems have fallen off, exposing the slender woody axis, whereas on the ultimate youngest twigs all the leaves are preserved. The cone, Pl. CXVII, Fig. 6, from Potomac Run, is no doubt globular in form on account of distortion, being compressed in the direction of its length. These cones are larger than those of $A$. grandis. Plate CXXXV, Fig. 15, gives one of the largest size.

\section{Athrotaxopsis PACHYPHYLLa, sp. nov. \\ Plate CXV, Figs. 1, 3; Plate CXVII, Figs. 1, 3-5.}

Small trees or shrubs, copionsly branching, with branches all in one plane, comparatively stout, rigid, and mostly long, cylindrical in shape; ultimate twigs mostly simple; leaves very thick, prominent, horny in texture, with strong keel, arranged as in the preceding species, elliptical to rhombic in shape, very durable, dropping off with increasing age; cones not seen.

Localities: In the banks of Dutch Gap Canal; fishing hut above Dutch Gap Canal.

This plant is one of the most common ones in the banks of Dutch Gap Canal. It occurs, however, in a very fragmentary condition. It is characterized by the thickness of the leaves. 


\author{
SEQUOIA Torrey. \\ Sequola cycadorsis, sp. nov. \\ Plate CXII, Figs. 9-11; Plate CXIII, Figs. 1-3.
}

Leafy branches, with keeled stems which were apparently succulent, branching dichotomously; leaves remotely placed, alternate to subopposite, widest near the base, decurrent, narrowly linear, acute, varying in length considerably, attaining the maximum dimensions of $3.5^{\mathrm{cm}}$ in length and $2^{\mathrm{mm}}$ in width, margins of the leaves apparently thickened from being rolled slightly, obliquely inserted, the longer leaves straight or slightly curved upwards, shorter leaves (on younger branches ?) strongly falcate, all thick, leathery, and rigid, with a midnerve that is prominent on the lower side of the leaves and forms a sort of keel in the longer leaves, showing a sunken central line on the upper side of the leaves.

Locality: $72 \mathrm{~d}$ mile-post, near Brooke.

This plant is very rare. It is in some respects unlike the ordinary forms of Sequoia, and so strongly resembles Cycalites that for some time I thought that it should be placed in that genus, but the finding of branching stems, such as are shown in Pl. CXII, Fig. 9, shows that it can not be Cycadites. Perhaps it should be regarded as a new genus, but as it stands apparently nearest to Sequoic I have placed it provisionally in that genus. It seems to be a comprehensive form, combining the characters of Cycudites with those of some of the species of Podocarpus, such as P. Meyeriana Endlicher, and $P$. elongata E. Neyer. It is also a good deal like Taxites falcatus Nathorst (see Floran vid Bjuf, Pl. XXII, Fig. 11). In the decurrent leaves lying strictly in one plane it resembles Sequoia. It is a good deal like Dawson's Cycadites unjiga (see Cretaceons and Tertiary Flora of British Columbia, Pl. I, Figs. 2, $\left.2^{a}\right)$.

\title{
Sequoia Reichenbachi (Geinitz) Heer.
}

Plate CXVIII, Figs. 1, 4; Plate CXIX, Figs. 1-5; Plate CXX, Figs. 7, 8; Plate CXXII, Fig. 2; Plate CLXVII, Fig. 5.

Branches elongate, leaves decurrent at base, spreading, linear-lanceolate, falcate, incurved, acuminate, widest at base; one-nerved. 
Localities: Fredericksburg: fishing lut above Dutch Gap Canal; banks of Dutch Gap Canal.

This plant is quite abundant at the fishing hut in the forms with narrow leaves, such as are figured in Pl. CLXVII, Fig. 5. It is also common in such forms as Pl. CXVIII, Fig. 4, etc. It is comparatively rare at the other localities.

The type of Sequoia illustrated in S. Reichenbuchi is much the most common one in the Potonac flora. It is illustrated in such plants as S. ambigua and $S$. subulata. Those with scale-shaped leaves are very rare.

S. Reichenbachi is the most common conifer at the fishing hut. Nearly all the specimens have the leaves closely placed on the twigs. The twigs branch copiously, and by their size indicate that the growth was vigorous All the leaves are widest at base, strongly falcate and acute, decurrent at base, with a distinct midrib, the larger leaves being acuminate. Pl. CXX, Fig. 7, shows an unusual mode of insertion of the leaves, they being at right angles with the stem. This position seems to be assumed by the older leaves. As a rule the younger leaves are obliquely placed and strongly curved upwards. The scars left by the leaves after falling' off from the older twigs are obovate, rounded at the top, with a round vascular scar at the top and a furrow ruming down from it (see PI. CXIX, Figs. 4, 5). Fig. 4 gives the natural size, and Fig. 5 gives the scars from another stem enlarged. The forms, Pl. CXVIII, Fig. 1, and Pl. CXIX, Fig. 1, show some differences from the Dutch Gap specimens in having the leaves more remote and obtuse. They look something like Heer's species S. Smithiana. The first-naned specimen shows that some of the forms attained very considerable dimensions. In Pl. CXVIII, Fig. 4, and PI. CXIX, Fig. 3, at the points marked $(a)$, we have the tips of twigs showing a growing bud with undeveloped leaves.

Sequola Reichenbachi (Gein.) Heer, var. longifolia, il. v.

Plate CXVII, Fig. 8.

Stems comparatively very stout, branching freely; leaves rather remotely placed, strongly falcate, narrowly linear, widest at base, decurrent, and united to form a narrow wing, very long and acuminate; midnerve slender. 
Localities: Fredericksburg; fishing hut above Dutch Gap Canal; rare.

This plant differs from the normal S. Reichenbachi in the very long and slender leaves.

\section{Sequora subulata Heer. \\ Plate CXVII, Fig. 7 ; Plate CXVIII, Figs. 5, 6.}

Branches comparatively slender, pinnately arranged in one plane; the ultimate branches are nearly at right angles with the penultimate stems; leaves obliquely inserted, widest at base, acuminate, very narrow, sometimes acieular, very long in proportion to their width, nsually closely placed on the ultimate twigs, more remote on the older ones, united at base.

Localities: Fishing hut above Dutch Gap CanaI; Fredericksburg; near Telegraph Station.

The plant is rather common at the Dutch Gap locality, but is very rare elsewhere. Pl. CXVII, Fig. 7, gives a portion of an older twig with unusually remote and very narrow leaves. Pl. CXVIII, Fig. 6, has on the ultimate twigs closely placed leaves that are very long in proportion to their width.

\section{Sequola ambigua Heer.}

Plate CxviII, Fig. 2; Plate CXx, Figs. 1-6; Plate CxxvII, Fig. 5; Plate CXXXII, Fig. 3.

Branches elongate, fully leaved throughout, branchlets alternately grouped; leaves decurrent, short, rather thick, falcate, incurved, acuminate, one-nerved; strobiles globose in form; scales peltate, rather flat.

This description which Heer gives ${ }^{1}$ for his Sequoia ambigua, from the Kome beds of Greenland, and his figures agree so closely with certain of the Potomac conifers, that there seems to be no doubt that this plant is found in the Potomac flora also. It may be added, for the Potomac forms, that the leaves are wiclest at base, narrowly oblong to subtriangular.

Localities: Fishing hut above Dutch Gap Canal; river bank a few yards above the fishing hut; near Telegraph Station.

The plant is rather common at the first and second localities, and rare at the third. There are a fer points of difference in the Kome and Potomac forms, but no greater than might be expected in the same species when 
grown so far apart. The leaves of the Potomac plant are apparently not quite so thick as those from Kome and not so constantly incurved, and they are usually more closely placed. The cones of the Potomae plant have the free surface not so much elongated transversely, and the transverse depression on their summit is greater.

\section{Sequota Rigida Heer.}

Plate CxviII, Fig. 3; Plate CXXI, Fig. 2; Plate CXxv I, Fig. 2; Plate Cxxx, Fig. 3.

Leaves coriaceons, rigid, linear, acuminate at apex, patent, straight, one-nerved, transversely very finely rugulose, not narrowed at base, adnately long decurrent.

This description of $S$. rigida, given by Heer, ${ }^{1}$ agrees very well with some of the Potomac conifers, the transverse rugosity alone being absent. This, however, is accidental, and due to the accidents of preservation. The localities for the Potomac fossils are near Telegraph Station; hill-side near Potomac Run. The form Pl. CXXI, Fig. 2, is one of the most common plants near Telegraph Station. Heer says that this species is more common in the Atane than in the Kome beds. Pl CXXX, Fig. 3, is a good deal like Glyptostrobus Gronlandicus, as given by Heer. ${ }^{2}$ He speaks of the leaves of $S$. rigida as prolonged into a fine point. This feature may be seen on a number of the specimens of the Potomac fossil. It is not, however, a character that would in most cases bo preserved. It is noteworthy that so far as seen this species does not occur at Fredericksburg and Dutch Gap.

\section{SEquoia DENSIFolia, sp. nov.}

Plate CXXI, Fig. 4.

Stems slender; leaves narrowly linear, acute and actuminate, strongly falcate, widest at base, decurrent and adnate, showing a tendency of the leaves to crowding and aggregation into groups, in which the members have their bases overlapping in some cases, or adnate; midnerve slender but distinct.

Locality: Fishing hut above Dutch Gap Canal; very rare. 
This plant differs from all the other Sequoias in the peculiar crowding of the leaves at their bases, which seems to arise from a grouping in whorls, the groups being separated by a comparatively considerable interval.

\section{Sequola gracilis Heer. \\ Plate Cxxy I, Figs. 3, 4.}

Heer ${ }^{1}$ describes $S$ gracilis as Sequoia, with alternate branches, approximate; leaves scale-shaped, imbricated, subfalcate, decurrent at base, and without a midnerve.

This description and the figures given in Pl. XXII, Figs. 1-10, Pl. XVIII, Fig $\mathbf{1}^{\mathrm{e}}$, agree closely with some of the Potomac plants.

Localities: 72d mile-post, near Brooke, common; bank near Brooke, rare.

The specimens are found in small bits and fragments of twigs, and these are among the most abundant fossils at the first-named locality. Such bits as those given in Fig. 3 are the most common.

Sequola delicatula, sp. nov.

Plate CXXI, Fig. 3.

Principal twigs slender, penultimate and ultimate ones all in one plane, minute, short, closely placed, alternate and pimnate in arrangement; leaves very small, narrowly linear, acute or acuminate, widest at base, decurrent, and mostly crowded; midnerve slender but distinct.

Locality: Fishing hut above Dutch Gap Canal; very rare.

This plant is a good deal like $S$. subulata, but the leaves are proportionally wider and not so falcate, while the ultimate branches are placed at more uniform intervals.

\section{SEquola, species?}

Plate CXX, Fig. 9.

Sten with very broad elliptical to nearly circular leaf-scars, which are spirally arranged.

Locality: Found very rarely at Fredericksburg.

This may possibly be one of the older twigs of S. Reichenbachi. 


\author{
SEQUOIA, species? \\ Plate CXVI, Fig. 7; Plate CXXX1I, Figs. 2, 5, 6 .
}

Leafy twigs unknown; cones rather large; scales deciduons with age, large, wedge-shaped at base, with the free summits shield-shaped, and furnished with an umbo; apper portions marked with several furrows, which run longitudinally on the scale and resemble those of the scales of Glyptostrobus.

Localities: $72 \mathrm{~d}$ mile-post, near Brooke, not rare; Fredericksburg, very rare.

These scales, found mostly at the $72 \mathrm{~d}$ mile-post, are not uncommon there. They have a marked character, which makes it easy to recognize them. They are always found in a fragmentary state, only a few scales adhering to the axis and widely diverging, indicating that the scales were quite decidnons and diverged widely on the ripening of the cones. A marked feature is the occurrence of deep furrows on the upper expanded ends of the scales, which possibly indicates some affinity with Glyptostrobus. The shape, too, of the scales resembles that of Sphenolepidium, so that the type may be a comprehensive one. Plate CXVI, Fig. 7, from Fredericksburg, shows a portion of a cone compressed logitudinally.

SEquora, species?

Plate CXXXII, Fig. 10.

Leafy stems unknown; cones large; scales wedge-shaped at base and expanded towards the free ends, surface of the free ends of the scales not made ont; the upper expanded portions of the scales are marked with longitudinal furrows as in the preceding species, and the scales appear to have been deciduous.

Locality: Fredericksburg.

Only one cone of this kind was found. It shows the same longitudinal plications or furrows on the upper portions of the scales as the preceding species, but not to such a marked extent, and the cone is considerably larger than any of those found at the $72 \mathrm{~d}$ mile-post. It evidently forms a distinct species. 


\section{ARAUCARIA Jilss.}

Leaves sometimes thickened or coriaceons, four-sided, falcate, incurved, keeled on the back and sometimes flattened, possessing several nerves, acute at the apex or mucronate, inserted by a narrowed and twisted base and decurrent; spirally inserted, or generally distichous on the lateral branches and branchlets.

The above description by Saporta ${ }^{1}$ gives the character of the two types of the leaves of Arancaria. The kind of leaves given in the latter part of the description is that of certain forms found in the Potomac flora, and I have placed these provisionally in this genus.

\section{Araucaria podocarpoives, sp. nov.}

Plate LXXXVI, Fig. 4.

Stems comparatively stout; leaves small, oblong, elliptical, subacute, narrowed to the base and apex, alternate, distichous, inserted by short slightly twisted footstalks spirally on the stems, placed near the margins and arranged in two rows in the same plane by the twisting of the footstalks; nerves slender, indistinct, several in number, diverging at their entrance into the leaf, then parallel to the summit, where they were not distinctly seen.

Locality: $72 \mathrm{~d}$ mile-post, near Brooke, where it was found in only one specimen.

This plant has the appearance or Podozamites, but the leaves are spi. rally arranged, and the nerves are not converging apparently at the summit. It is also like Nageiopsis, but the insertion of the leaves is different. It is very much like Gardner's Podocarpus incerta, from the Eocene of Bournemouth. $^{2}$

\section{Araucaria obtusifolia, sp. nov.}

Plate Lxxxy, Fig. 13.

Leaves spirally disposed, arranged in four (?) rows, flat, obtuse, widest near the base, falcately curved upwards, decurrent and imbricated at base; nerves thin, parallel, several in number. 
Locality: Entrance to Trent's Reach; only one specimen found.

This peculiar plant differs from most Araucarias in several features. On the npper face of the stems scars appear, as if formed by the removal of leaves, indicating that they were arranged in four rows. It is possible that the leaves on the upper and lower faces of the twigs were different from the lateral ones and smaller. The top of the twig shows what seems to be a growing bud of undeveloped leaves, and it indicates that the leaves were really spirally arranged, but by twisting of the bases or footstalks were brought into the same plane, grouping themselves in four rows. The nerves were obscure.

Araucaria zamioldes, sp. nov.

Plate CXXI, Fig. 1.

Leafy ultimate twigs terminating with a leaflet like those lower on the twig; stem slender; leaves closely placed, alternate, pinnately arranged in the same plane, flat, thin, slightly falcate, widest near the base and narrowing gradually to the tips, which are acute, attached by a slightly twisted base; nerves several, parallel, and ending as in Zamia, partly on the margins near the tips, quite slender and inconspicnous.

Locality: Hill-side near Potomac Run; very rare.

This plant is a good deal like a cycad of the Pterophyllum type.

\section{TAXODIUM Richard (GLYPTOSTROBUS Endl.)}

The fossils of the Potomac flora belonging to Taxodium are found in the group of plants united by Endlicher in the genus Glyptostrobus, which genus is now by Bentham and Hooker placed with Taxodium. Schenk ${ }^{1}$ says of Glyptostrobus, that the leaves are attached spirally and are of various shapes; "they are either upright, short, appressed, oval, acute, scale-shaped, the tips on the older stems not seldom divergent, or else on the horizontal twigs arranged distichously, linear acute. On upright stems these also are directed upwards. Both kinds of leaves have decurrent bases. * * Ripened cones, woody, oboval in shape, with scales wedge- 
shaped and widened at the tips, which are imbricated, and have on their ends a ronnded rim marked with from three to seven furrows."

This description agrees well with the appearance of a number of leafy twigs found in the Potomac strata.

Taxodium (Glyptostrobus) ramosum, sp. nov.

Plate CXXIII, Figs. 2, 3; Plate CXxIV, Fig.2; Plate CXxvII, Fig.1; Plate CXXXII, Fig.1; Plate CLXVI, Fig. 1.

Stems profusely branching at short intervals; branches short and rigid, often showing a tendency to a fastigiate arrangement; leaves on the older twigs proportionally long, narrowly elliptical, mostly appressed, especially on the upper and lower faces of the twigs, the lateral ones sometimes slightly divergent at the tips and incurved; the leaves on the younger stems short, narrowly elliptical, thick, and close appressed, strongly convex, and keeled on the back; male aments on the tips of short branches not seen; nerves single and thread like.

Locality: 72d mile-post, near Brooke; very common.

This plant is one of the most common conifer's at the $72 \mathrm{~d}$ mile-post. The ultimate twigs often show at their tips a whorl of short, scale-like, divergent leaves, that seem to have surrounded the base of the male aments. These in all cases had fallen off, and hence their character could not be made out. There is little doubt, however, that some of the numerous aments of conifers from this locality, described as aments of conifers $(a)$, (b), $(c),(d)$, come from this plant. Some of the forms of this plant are a good deal like Widdringtonia Reichii, as figured by Velenovsky, ${ }^{1}$ and they also resemble the branches of Taxodium (Glyptostrobus) expansum, but diifers from both of these in the strong convexity of the leaves on the young twigs and their short, elliptical shape, as well as in being more rigid, stouter, and much shorter in the twigs. The chief resemblance is in the nerves, which in both Widdringtonia and in the Potomac plant are single in each leaf, slender and thread-like, running along the middle of the leaves throughout their whole lengtlı. The ultimate twigs of the Potomac plant are sometimes more delicate than in any of the forms

${ }_{1}^{1}$ Die Gymnospermen der böhm. Kreideformation, Pl. X, et seq. 
figured, but are short and rigid. Some of the ultimate twigs, as those marked $3^{a}$ and $3^{b}$, on Pl. CXXIII, are so short and minute that a good lens is needed to make out their details, but the leaves are seen to be sharply defined and very convex. PI. CXXIII, Fig. 3, shows a much-branched twig with very minute and short ultimate branches. Pl. CXXII, Fig. 1, shows a tendency to fastigiate grouping of the branches.

\section{Taxodi um (Glyptostrobus) Virginicum, sp. nov.}

Plate CXXI, Fig. 6.

Branches slender, going off at an acute angle; leaves very small, with the arerage dimensions, $1^{\mathrm{mm}}$ by $4^{\mathrm{mm}}$, narrowly oblong in shape, narrowed to the base and summit, acute, remotely placed; nerves not seen, but apparently single.

Locality: Hill-side near Potomac Run; very rare.

This plant is nearest to Glyptostrobus Gronlandicus Heer, among described fossils, but the leaves are much smaller. It is also somewhat like Sequoia fastigiata Heer, but the twigs are not fastigiate. The leaves seem to have been somewhat deciduous, and to have had a mucronate tip.

Taxodium (Glyptostrobus) expansum, sp. nov.

Plate CXXIII, Fig. I.

Twigs alternate and pinnately arranged, going off at an angle of $45^{\circ}$, spreading widely, directed slightly upwards, very long and cylindrical in form; leaves thick and convex, narrowly elliptical or narrowly oblong, proportionally very long and narrow, decurrent, usually close appressed, the lateral ones with their tips sometimes diverging; nerves not seen.

Locality: Near Telegraph Station.

This plant is not uncommon at the locality near Telegraph Station, and is one of the most abundant conifers at that place. To judge from the specimen figured, the plant must have been wide-spreading, for this is a mere fragnent of what must have been a large branch, the basal portion of the nltimate twigs being all that is preserved. The rigid character of the species is well shown in this specimen. The specimen figured is one of those with the stoutest ultimate twigs. Many are more delicate and thread- 
like. The plant is a good deal like Velenorsky's Sequoia heterophylla, in those forms with the shortest and most appressed leaves (see Die Gymnosperm. der böhmisch. Kreideformation, Pl. XIII, Figs 6,8). It is also like some of the forms of Cyparissidium Heer, but the leaves are longer and narrower than those of this genus.

\section{Tazodium (Glyptostrobus) fastigiatum, sp. nov.}

Plate Cxxy, Figs. 1, 3.

Stems branching eopiously; twigs long, cylindrical, branching at long intervals in a dichotomous manner and very irregularly, the branches assuming a fastigiate grouping; lateral leaves on the older twigs oblong to ovate, acute, decurrent, diverging slightly, and incurved; facial leaves close appressed, elongate-oblong, towards the summit of the stem elliptical to ovate-acute; leaves on the younger twigs elongate-oblong to narrowly elliptical, close appressed, or with the lateral ones sometimes slightly diverging; midnerve distinct, but slender and thread-like.

Localities: $72 \mathrm{~d}$ mile-post, near Brooke; hill-side near Potomac Run.

This plant is rare at the $72 \mathrm{~d}$ mile-post, but is one of the most common conifers at the Potomac Run locality. The specimen figured in Pl. CXXV, Fig. 1, must have been originally very large, for the lower and detached branch is plainly a part of the upper portion. This plant is, in the form of the leaves, like Glyptostrolus Europceus, and may possibly be an ancestral form of this species. The leaves and twigs remind one of Biota pendula Endlicher, one of the varieties of $B$. orientalis.

\section{Taxodium (Glyptostrobus) denticulatum, sp. nov. Plate CXXIV, Fig. 1.}

Branches comparatively stont and rigid, rather copionsly piunately and altemately subdivided; leaves thick, convex, very elongate-oblong to elongate and narrowly elliptical, close appressed, with ends lancet-shaped and prolonged into an acute spinous tip, midnerve strong and prominent.

Locality: Kankey's.

Only one specimen was found, but as the material accessible was very limited in amount and unfavorable for the preservation of specimens, no 
idea can be gotten from the apparent rarity of the forms found here of their real abundance. Dioonites Buchianus, in great abundance, formed nearly all the specimens obtained here.

\section{Taxodiun (Glyptostrobus) Brookense, sp. nov.}

Plate CXxII, Fig. 1; Plate CxxIV, Figs, 3-9: Plate CxxxI, Fig. 5; Plate CLXV, Figs. 1-3; Plate CLXVI, Figs. 4; 7 ; Plate CLXVII, Fig. 3.

The principal stems seen are moderately stout and very rigid, the secondary ones mostly slender and rigid, the ultimate ones usually very long, slender, and unbranched, wide-spreading, often very delicate and thread-like, going off at an angle of about $45^{\circ}$, but from distortion due to pressure frequently appearing fastigiate and irregularly grouped; leaves on the oldest stems elongate-linear, acute, elose appressed, on the younger stems all very narrowly oblong, or narrowly elliptical, acute to obtuse, very closely appressed, not distinctly visible without the leelp of a lens in many cases, all spirally arranged; the facial leaves usually acute, the lateral ones usually more obtuse and sometimes slightly divergent at the tips and incurved; midnerves slender and thread-like.

Locality: 72d mile-post, near Brooke; abundant and in fine specimens.

This beautiful plant is found in abundance.in an interrupted and thin layer of fine clay along with the best preserved of the Angiosperms which occur at the 72d mile-post, such as Menispermites, Sassafias, etc. Strange to say, it is not found at the bank on the railroad near by. It evidently had twigs that spread widely in one plane, and some of the twigs indicated an expanse of more than a foot. The shale or clay was very unfavorable for the extrication of the specimens, and many of them were much broken up in taking them ont.

This was the case with all of the largest imprints. Plate CXXII, Fig. 1, gives a form with the ultimate twigs of the maximum thickness. It gives well the original mode of attachment and the expansion of the branches. In most cases distortion from pressure has crowded the twigs together and much disguised their true arrangement. This may be seen in Pl. CLXV, Figs. 2, 3, and these figures show also the minuteness of some of the ultimate twigs. They often look like slender threads, the 
facial leaves are often much elongated, the sides forming parallel lines and the top being an acute triangle. This elongation of the leaves on the front aspect, and the presence of the thread-like miduerves, make some of the twigs to appear striated. The male inflorescence shown in Pl. CLXVI, Fig. 7, occurs at the locality near Brooke, associated with T. Brookense in such a way as to make it probable that it belongs to this plant.

The varying forms of the leaves on the younger trigs and the character of the midnerres are well shown in Pl. CXXII, Figs. $1^{\mathrm{a}}, 1^{\mathrm{b}}$. The leaves on the upper face of the older trig's are not usually preserved, being perhaps sooner destroyed on account of their greater exposure. The lateral leaves are usually so closely appressed that in most cases, if seen without the help of a lens, they seem to be consolidated with the stem, and the ultimate twigs look like cords. On many of the ultimate twigs the lateral leaves arch slightly away from the stems in the center, the tips curving in and being closely united to it. The lateral leaves are most commonly rather obtusely rounded at the tips. The facial ones, when much drawn out, often end in a lancet-shaped point. The thread-like nerves run throughout the entire length of the leaves withont change in their thickness, and this gives them their peculiar cord-like character, which can be seen only with the help of a lens.

Most of the plant-bearing material at the 72d mile-post is a confused mixture of sand and clay, composed of torn up and redeposited matter. In this occur the various forms of Sphenolepidium found at this locality and some of the Angiosperms, but these plants are always in small fragments. No specimens of Taxodiun Brookense occur in this material, but they are found in the layer of clay above mentioned. As all the well-preserved and most renarkable Angiosperms of this locality occur in this layer, and a number of them nowhere else, it is proper to describe it more particularly. This clay layer does not seem to be a deposit of an age different from that of the confused matter, but it is simply a more uniform material, the result perhaps of pauses in the movement of the agitated waters in which fine clay in small irregular patches was somewhat uniformly laid down. It is only one or two inches thick, and does not continue unbroken, but is cut out here and there by the confused material, and 
runs with an undulating dip beneath the railroad track, exposing some five or six feet of length. The clay is very fine, unmixed with sand, and fairly well laminated. In this the leaf imprints occur beantifully preserved. Unfortunately but a few feet in length of this substance was found.

Taxodium Brookense is in many features a good deal like the plant which Velenorsky calls Widdringtonia ${ }^{1}$ Reichii, and of which he gives figures representing an enlarged twig closely resembling some of the forms of the Potonac fossil, especially in the shape of the leaves and in the lancet-shaped tips of the facial ones. His description in many points will apply to the Potomac plant. The older stems, such as the one given in Pl. VIII, Fig. 6, depart more widely from the Potonae forms.

On the whole the twigs of the Potomac plant are stouter and more rigid than those of $W$. Reichii. Possibly the Potomac fossil is an ancestral form of the Bohemian plant. Heer describes a fossil from the Atane beds of Greenland similar to the Bohemian fossil, but says its leaves have no midrib. As stated, it is not easy in all eases in T. Brooliense to detect the midnerve, and Heer may have had specimens in which it was not preserved, although originally present. Velenovsky does not show that the Widdringtonia like cone which he assigns to lis plant is certainly connected with it. The shape and the arrangement of the leaves of $T$. Brookense are strikingly like what may be seen in the young leaves of Glyptostrobus pendulus Endlicher.

Taxodium (Glyptostrobus) Brookense, var. angustifolium, sp. nov.

PIate CLXVII, Fig. 1.

Copiously branched, with very slender twigs; leaves very narrow, linear, closely appressed, obtuse to subacute; ultimate twigs cord-like, and going off irregularly from the penultimate ones; nerves very slender and thread-like.

Locality: White House Bluff.

This plant in essentials is the same as the normal $T$. Brookense, but it is uniformly more slender, the leaves are narrower and always close appressed, and it has a more irregular mode of branching, with more

' Die Grnumospermen der böhmisch. Kreideformation, Pl. VIII, Figs. 4-6, 16 ; PI. X, Figs. 1, 11, 12 ; PI. VIII, Fig. 16. 
crowded twigs. It is much the most common conifer at White House, where it seems to have been abundant. Owing, however, to the friable nature of the clay which contains the imprints and its admixture with sand the specimens are poorly preserved. The specimen figured was evidently a very large form originally. When found it extended over five or six inches of area, but was broken in taking it up.

\section{SPHENOLEPIDIUM, Heer (SPHENOLEPIS Schenk).}

Branches and twigs alternate, with spirally placed, short, imbricated leaves that are decurrent at base, acute or acuminate on the younger twigs, appressed on the older ones, divergent and somewhat curved inwards; cones placed on axillary lateral branchlets which have close appressed leaves and form a raceme, persistent, rounded, or oblong; scales of the cones persistent, leathery, wedge-shaped, with the upper margin truncate, when mature, divergent.

This description of the genus by Schenk applies very nearly to a number of coniferous plants from the Potomac flora, which, with the species of Taxodium, form very important elements in this flora. These two genera ustially are to be found associated together at the same localities and in the same layers, and with them we usually find some of the species of Sequoia. The constant association of the forms of these three genera is no doubt due to the accidents of preservation, the conditions favoring the preservation of one promoting likewise that of the others. It is possible that some of these plants may really belong to that group of Sequoias that possesses imbricated scale-shaped leaves, such as S. concinna, etc. In the absence of fructification the question can not be positively decided. Certainly these plants possess in the forms of the leaves and twigs many features seen in that section of the Sequoias.

Sphenolepidium Parceramosum, sp. nov.

Plate CXXIX, Fig. 7 ; Plate CXXX, Fig. 8; Plate CXXXI, Fig. 2.

Branches long and slender, dividing at long intervals in a dichotomous manner, giving a few rather stout, long, cylindrical branches, showing a tendency to fastigiate grouping; lateral leaves short, acute, with a distinct MON $\mathrm{xV}-17$ 
slender midnerve, subfalcate, narrowly oblong to narrowly elliptical, decurrent, with the tips slightly divergent and incurved, those on the upper and lower surfaces of the stems (facial ones) close appressed, with no visible midrib, oblong to elliptical, obtuse to subacute, remote.

Localities: Fredericksburg; 72d mile-post, near Brooke.

This plant is not very rare at Fredericksburg, and is very common at the $72 \mathrm{~d}$ mile-post, where it occurs in numerous fragments in the confusedly mixed sand and clay. The peculiar mode of branching reminds one of Heer's Sequoia concinna from the Atane beds of Greenland, but the leaves, although of the same general character as those of S. concinna, are more closely placed and not so long and slender.

\section{Sphenolepidium dentifolium, sp. nov.}

Plate CXXVII, Figs. 3, 4; Plate CXXVIII, Figs. 2-6; Plate CXXIX, Fig. 5 ; Plate CXXx, Figs. 4-6, 10

Stems branching freely, with long, slender, rigid, alternate twigs, that are obliquely attached; leaves ovate, oblong, or elliptical, thick, short, acutely dentate in form, obliquely placed, decurrent, and united at base in the same plane, with no leaves apparently on the upper and lower faces of the twigs ; midnerve distinct and often strong.

Locality: Fredericksburg.

This plant is one of the most common conifers at Fredericksburg. It is much like Sequoia Couttsice, but the thick, short, tooth-shaped leaves differ from those of this Sequia. Pl. CXXX, Fig. 6, and Pl. CXXVII, Fig. 4, give two twigs which show on their tips two lateral undeveloped leaf-buds and a terminal partially developed one. The ultimate twigs on most of the specimens are placed rather remotely and irregularly, showing a tendency to a fastigiate grouping, but in Pl. CXXVIII, Fig 5, they are closely placed at regular intervals and in a pinnate manner. The plant reminds one of some forms of Sphenopteris Mantelli.

\section{SPhenolepidium ReCURVIFolium, sp. nov.}

Plate CxxvII, Fig. 2; Plate Cxxx, Figs. 2, 7.

Branches and branchlets slender and very long, ultimate branches inserted very obliquely and at irregular intervals, strongly turned upwards; 
leaves, so far as seen, inserted only laterally, strongly decurrent, and adnate or united, thick and leathery, strongly recurved, oblong to ovate, acute or acuminate, much wider at base than elsewhere, cut away on the upper side; midnerve very strong and rigid.

Localities: Fishing hut above Dutch Gap Canal; hill-side near Potomac Run; near Telegraph Station; rare at each locality.

This well-marked plant is in some respects like some of the species of Pagiophyllum (Pachyphyllum). The shape and the great thickness of the leaves are the main points of resemblance. The fine specimen given in Pl. CXXVII, Fig. 2, shows towards the tips of the ultimate twigs a recurvation stronger than usual, so that the leaves stand nearly at right angles to the stem. The plant belongs to the type of Sequoia Couttsice.

\section{Sphenolepidium pachyphyllum, sp. nov.}

Plate CxxxI, Figs. 6, 7.

Branches long, rigid, and slender, sending off at irregular intervals alternate subordinate twigs ; leaves, so far as seen, strictly distichous, with no facial ones, crowded, adnate at base or overlapping, much wider at base than elsewhere, gradually tapering to an acute tip so as to give them a triangular or ovate form; acute or acuminate, straight or slightly falcate, attached nearly at right angles to the stems, very thick and dense in texture, with an unusually large midnerve.

Locality: Near Telegraph Station.

This strongly marked plant is very rare. It is very much like Pagiophyllum Heer (Pachyphyllum Saporta), in the great thickness of the leaves. It is almost exactly like the form of Sequoia Reichenbachi given by Schenk. ${ }^{1}$

\section{Sphenolepidium Virginicum, sp. nov. \\ Plate CXXV, Fig. 4 ; Plate CLXVI, Fig. 6.}

Branches comparatively stout, alternate; facial leaves elliptical and close appressed, lateral ones ovate, acute, slightly divergent and incurved at the tips, strongly decurrent, all with distinct midnerves, on the youngest twigs they are elliptical and closely appressed; female strobile terminal on 
stout short twigs, oblong in form, with woody or leathery scales wedge-shaped and truncate on the free surface, strongly divergent when mature; male aments? narrowly oblong-elongate, persistent, composed of thin, ovate, imbricated scales, terminal at the ends of short slender lateral twigs.

Locality: $72 \mathrm{~d}$ mile-post, near Brooke.

This plant is rather common at the above-named locality. In the character of the cones it is somewhat like Athrotaxopsis, but mnlike that gents the scales opened widely on ripening. The leaves also are unlike those of Athrotaxopsis. The male aments given at (a) seem to be persistent, for they remain on branches that show the ripened cones. They show open chaffy scales. The plant is not uncommon at the $72 \mathrm{~d}$ milepost, but very rarely shows cones, and is a good deal like Sphenolepidium Kurvianum Heer (Sphenolepis Kurriana Schenk), but the cones are not globose.

\section{Sphenolepidium Kurrianum, Heer.}

Plate CXXVI, Figs. 1, 5, 6; Plate CXXviII, Figs. 1, 7; Plate CXXIX, Figs. 1, 4, 6, 8; Plate CXXX, Fig. 11 ; Plate CXXXI, Fig. 4 ; Plate CLXVII, Fig. 2.

Twigs branching copiously, often much crowded, ultimate twigs rather short and rigid, going off very obliquely and tending to assume a fastigiate grouping; leaves imbricated, scale-shaped, the facial ones close appressed, elliptical or oblong, subacute, lateral ones oblong or ovate-acute, often with the tips spreading and incurved, decurrent, lateral and facial, leaves keeled on the back, all usually thick and sometimes deciduous; cones not seen.

Localities: All the Dutch Gap localities, especially at the entrance to Trent's Reach and the fishing hut above the canal; Freciericksburg; 72 mile-post; bank near Brooke; near Telegraph Station.

It is more common at the $72 \mathrm{~d}$ mile-post than at any other place. It is very abundant here in the form of small fragments. Some of the specimens show a very copious branching and crowding of the twigs, covering the shale with an intricate mass of them. Of such a character is the specimen Pl. CXXVIII, Fig. 1 from near Telegraph Station, and Pl. CXXVI, Fig. 1 from the $72 d$ mile-post. This latter is a form with leaves thinner and more slender than usual. In some of the other specimens, such as $\mathrm{Pl}$. 
CXXVI, Fig. 6, Pl. CXXVIII, Fig. 1, and PI. CLXVII, Fig. 2, the leaves are shorter, more convex, and more closely appressed than in others. Indeed, there is a considerable degree of variation in the leaves. In such forms as Pl. CLXVII, Fig. 2, the leaves are thick, horny, and exceedingly durable. They can be detached from the shale in the form of small black shining scales.

In this and other forms of Sphenolepidium the facial leaves often appear of somewhat different shape from the lateral oues, being more obtuse, probably from their close appression to the stem. The forms, such as PI. CXXVIII, Fig. 1, resemble Ettingshausen's IViddringtonites Haidingeri from the Wealden of Hanover (see Beiträge zur Flor. der Wealdenperiode, Pl. XI, Fig. 1).

This plant is the most common conifer at the $72 \mathrm{~d}$ mile-post, a place where conifers form the predominant fossils. It is a widely diffused species.

\section{Sphenolepidium Sternbergianum (Dunk. sp.) Heer.}

Plate CXXI, Figs. 8, 10, 11 ; Plate CXXX, Fig. 9.

Branches slender, long, remote, going off very obliquely ; leaves linear, falcate, acute to acuminate, sometimes acicular, patent, decurrent, much wider at base, with slender but distinct midnerve, apparently distichous, and attached only laterally; cones not seen.

Localities: Hill-side near Potomac Run; Fredericksburg.

This, the normal form of S. Sternbergianum, is comparatively rare, being much less common than the variety densifolium. It differs from Heer's forms only in not showing leaves on the upper surfaces of the twigs, but this is no doubt due to the removal of these leaves from their more exposed position.

Sphenolepidium Sternbergianum, var. densifolium Heer, sp.

Plate CXVIII, Fig. 7; Plate CXXI, Figs. 5, 7, 9; Plate CXXV, Fig. 2; Plate CXXIX, Fig. 3; Plate CXXX, Fig. 1; Plate CXXXI, Figs. 1, 3 ; Plate CXXXII, Fig. 4.

Branches slender, ultimate twigs going off very obliquely so as to appear dichotomous, tending to a fastigiate arrangement, subdividing irregularly; leaves short, lateral ones acute, linear to narrowly ovate, diverg- 
ing, falcate or subfalcate, comparatively closely placed, strongly decurrent; midnerve distinct; facial leaves ovate to elliptical, apparently obtuse and smaller than the lateral ones, closely appressed, with often no midnerve visible, sometimes removed by maceration; cones not seen.

Localities: Near Telegraph Station; hill-side near Potomac Run; 72d mile-post; Fredericksburg.

This plant is rare at all the localities except the $72 \mathrm{~d}$ mile-post, where it is quite common. Plate CXXXI, Fig. 1, shows a number of undeveloped branches and buds. This plant is a good deal like Sequoia fastigiata. It has the leaves more crowded, straighter, and less diverging than the normal $S$. Stembergianum, and the facial leaves, probably owing to compression, seem to be blunt and elliptical in form.

\section{GIMNOSPERHOUS FRUITS.}

The following fruits of Gymnosperms, not being connected with leafy twigs, probably in some cases belong to plants described from their leaf branches under other names. In some cases, owing to their imperfect preservation, it is not possible to place them with certainty in their true position.

\section{ABIETITES Mantell.}

Under this head I group certain cones that have in the main the character of some forms of Abies.

ABIETITES Macrocarpus, sp. nov. ?

Piate Cxxil, Figs. 7.

Axis thick; scales long, thin, and closely appressed, imbricated, numerous.

Locality: Fishing hut above Dutch Gap Canal; very rare.

This cone, although very imperfect and wanting the base and the apex, was evidently very long. Only the bases of the scales are preserved, and those on the upper face have been stripped off. It seems to be more like that of Alvies than that of any other conifer. It resembles Cunninghamites Oxycedrus Ettingshausen, from the Cretaceous flora of Niederschöna. 
Abietites ellipticus, sp. nov. ?

Plate CXxxI, Figs. 8, 9; Plate CXxxIII, Figs. 2-4; Plate ClXvilI, Fig. 8.

Cones of medium size, elliptical in outline; scales thiu, long, imbrieated, and closely appressed; axis thick.

Locality: Fredericksburg.

This cone is not uncommon at Fredericksburg. It is very much like that of Abies. In Pl. CXXXII, Fig. 9, the upper surface of the cone has been accidentally removed so as to expose the axis. 'This, towards its base, is very thick. The species seems to be of the same general character as $A$. macrocarpus, but the cones are smaller and much shorter.

Abietites angusticarpus, sp. nov. ?

Plate CxxxIII, Fig. I.

Cone oblong, very narrow in proportion to its length; axis proportionally very thick and short; scales short, comparatively thick at base, thin towards the summit, imbricated, closely appressed.

Locality: Fredericksburg.

This was found in only one specimen, which, although imperfectly preserved, is clearly different from the two previously described species. It was evidently very narrow in proportion to its length, for the base and summit are not preserved. The scales appear unusually thick at base as if still inclosing the seed, and they are proportionally very short. They have been removed from the upper surface of the axis so as to show the scars of insertion.

\section{ARAUCARITES Sternb. emend.}

Under this head I place certain fragments of cones that appear to be more nearly allied to Arancaria than any other conifer, but whose true place is doubtful.

Araucarites Virginicus, sp. nov.

Plate CXXXIV, Fig. 7 .

Cone obovate, rounded at the summit; scales large, numerous, thick, transversely subrhomboidal to nearly round, shield-shaped, umbouate.

Locality: Entrance to Trent's Reach. 
Only one specimen was found. The cone, whose form is pretty well preserved, is in shape and in the character of the scales a good deal like Sequoia. It resembles more than any other cone that of Araucaria Cretaceu Brongniart, as given by Schimper, ${ }^{1}$ but it is much smaller.

Araucarites Aquiensis, sp. nov.

Plate CXXXIII, Figs. 8-12.

Scales of the cones varying considerably in size and shape, attaining the maximum dimensions in length of $5^{\mathrm{cm}}$ and in width across the top of $3^{\mathrm{cm}}$, with the minimum of $3.5^{\mathrm{cm}}$ by $1.5^{\mathrm{cm}}$; scales probably closely appressed and imbricated, wedge-shaped, and narrowed at base into a sort of footstalk, thickened at the summit, and rounded on the upper margin, with a depressed transverse furrow, very decidnous, and always found scattered singly and sparingly in the clay.

Locality: Bank near Brooke.

These scales are not uncommon. No cone was found from which they could come. In their shape and deciduous character they resemble some of the forms of Abies. The scales are like those of Dammara also. Near their summits they all show on one face a distinct curving imprint, as if made by the pressure of the terminal edges of the overlapping next lower scales. I have taken its specific name from Aquia Creek, near which the locality yielding them occurs.

\section{CARPOLITHUS St.}

Under the head of Carpolithus I place a number of nut-like seed of conifers which have not been found in connection with leafy branches, and whose proper place can not be made out with any certainty. No doubt some of them belong to some of the conifers described with other names, the characters being taken from leafy branches. These fruits form an important element in the Potomac flora, and they are the most abundant gymnospermous fruits found. 
Carpolithus fasciculatus, sp. nov.

Plate CxxxIV, Fig. 1.

Seed nut-like, witli a hard smooth surface, broadly elliptical in shape, sessile, on a short stout stem, crowded into a fascicle, comparatively large.

Locality: Fredericksburg.

Only one specimen was found. As this fruit has not been found attached to any leafy twigs, its place can not be fixed. It occurs at Fredericksburg with numerous leafy twigs of Cephalotaxopsis, and as the fruit of Cephalotaxus has a nut-like bony seed, it is probable that these fossils belong to some species of the first-named genus. The twig to which the nut-like seeds are still attached is more like the twigs of Cephalotaxopsis than any of the other coniferous wood found at the locality.

This fruit and those next to be described have suffered a good deal from maceration; hence, as now presented, they must be more or less disguised.

\section{Carpolithus ternatus, sp. nov.}

Plate CXXXYY, Figs. 2-4, 6, 8.

Seeds oblong, obttuse, smooth, grouped in threes, the individuals more or less united and sessile, attached to the sides and summits of short stout stems, which are attached to thick, woody, principal branches: texture of the nut-like seed lard and woody.

Locality: Fredericksburg; rather common.

This is the most abundant Carpolithus at Fredericksburg. The seeds have a peculiar character of union at the bases, forming a palmately three-lobed cluster. Possibly this union, real or apparent, may be due to the immaturity of the seed if it is real, for they show gradations in separation which seem to be connected with age, the oldest and largest being most distinct. Thus in Fig. 6 the lowest group on the right-hand side shows seed separated nearly to the base, while in some groups, as in the upper part of Fig. 4, the individuals are united nearly to their summits. These seed also are probably those of Cephalotaxopsis. They remind one of Lesquereux's Equisetum yloullosum. (See Cretaceous and Tertiary Floras, Pl. XI.VIII, Fig. 3.) 


\section{Carpolithus Virginiensis, sp. nov.}

Plate CxxxIy, Figs. 11-14; Plato Cxxxy, Figs. 1, 5; Plate CLxvIIL, Fig. 7.

Seeds hard, smootl, and nut-like, small, obovate or broadly elliptical, sometimes globular, often more or less strongly ridged, ridges seen for the most part three in number; borne singly on short pedicels, arranged alternately on the principal branches, and tending to assume a fasciculate grouping.

Localities: Near Telegraph Station; fishing hut above Dutch Gap Canal.

These fruits are rare at the first-11amed locality, but are not uncommon at Dutch Gap. The ridges seen do not seem to show themselves unless maceration has removed some of the exterior tissue of the seed. The seed seem originally to have had smooth, firm exteriors. Like the preceding species of Carpolithus, they were probably inclosed in some sort of fleshy matter, possibly having been plum-like. These seeds occur with abundant impressions of the leaves of Baieropsis, and the pedicels with the principal stems resemble the woody matter of Baieropsis more than that of any other plant. It is probable that these are the seeds of some species of that genus, perhaps of B. pluripartita, the one with which they are most commonly associated. The fact that almost exactly similar seed are found constantly with Baiera Mïnsteriana makes this all the more probable, since that plant seems to be nearer to Baieropsis than to the true Baieras. These latter, according to the figures of Heer and Nathorst, lave their leaves sparingly subdivided into lobes of equal importance, are very narrowly wedge-shaped, and are grouped on the summits of short shoots. These features are not found in some of the forms of Baiera Münsteriana. 'These seed resemble Lesquereux's Cinchonidiun ovale, but these latter are smaller, They may be compared also with the seed of Heer's ${ }^{1}$ Czelianowskia. They are strikingly like Lesquereux's Carpites gemmaceus. ${ }^{2}$ Pl. CLXVIII, Fig. 7. is peculiar in showing only one strong rib, instead of three.

1 Flor. Foss. Aretica, vol, 6, Part I, Pl. VI, Fig. 15.

${ }^{2}$ Cretaceous and Tertiary Floras, Pl. XL, Fig. 19. 
Carpolithus agglomeratus, sp. nov.

Plate Cxxxiv, Fig. 5 .

Seed small, globular in form, smooth, mut-like, crowded together closely into a species of head, which is sessile, or borne on very short pedicels, and carried on short lateral branches.

Locality: Fredericksburg.

These seeds are very rare. They probably belong to some species of Baieropsis, and, as the most abundant and indeed almost the only species of this genus occurring at that place is B. expansa, these seed may belong to it. They are a good deal smaller than those of the preceding species. Owing to the close crowding and the very short pedicels, some of these forms appear united at base, as in C. ternatus.

\section{Carpolithus conjugatus, sp. nov.}

Plate CXXXIV, Fig. 9.

Fruit apparently composed of a whorl made of three pairs of nutlike seeds united near their bases and of a single one radiating from a central point, probably the summit of a pedicel; the component nut-like seed are obovate, obtuse, and rounded at the free ends, narrowed to a sort of neck at the place of union, marked by transverse striæ or wrinkles, which run around the bodies.

Locality: Fredericksburg.

Only one specimen was found. As it is quite possible that this is distorted by pressure, it may be much disguised, at least in the grouping of the seed-like bodies. I am unable to offer even a conjecture as to the true place of this group of bodies.

Carpolithus geminatus, sp. nov.

Plate Cxxivi, Fig. 10.

Seed of medium size, elliptical or obovate, smooth, nut-like, and firm, in pairs at the summit of a very short pedicel, almost sessile.

Locality: Fishing hut above Dutch Gap Canal.

Only one specimen was found. The left-hand nutlet of the pair has had its summit removed by accident, and hence does not present the true 
shape of the seed. It is under these circumstances impossible to say anything positive about the affinity of the fossil. It is, however, in the pairing of the seeds, their shape and position, most like the seeds of Ginkigo.

Carpolithus Brookensis, sp. nov.

Plate Cxxxv, Figs. 2, 4 ; Plate CxxxvI, Fig. 6; Plate CLXVII, Fig. 6.

Seed elliptical, prolonged above into an acute beak of considerable length, which is usually bent to one side, below narrowed into a pedicel for attachment to the stem; on the upper surface usually three strong ridges shown, which run longitudinally the entire length of the firuit.

Localities: Bank near Brooke; fishing hut above Dutch Gap Canal.

This form of seed is not uncommon at the bank near Brooke, where they are never found attached, but occur scattered through the clay. The unusual form shown in Pl. CLXVII, Fig. 6, was found in a single specimen at the fishing hut above Dutch Gap Canal. It shows no ridges, but a kernel-like nucleus within the mass of the seed. It may be a different species. At the bank near Brooke, where these seed are most common, no plant occurs to which these seeds could probably belong besides Baieropsis foliosa and Nageiopsis angustifolia. The former is quite common, and it is probable that the fossil now in question forms the fruit of it.

Saporta ${ }^{1}$ calls attention to the fact that the seeds of the older conifers are usually angled, and says that the young ovnle of Salisburia is slightly compressed, showing two or three angles. This two or three sided structure, showing more or less pronounced keels or wings, is found, as he says, in the most primitive conifers. It may then be questioned whether or not the angled or keeled surface of the ovule of Salisburia is an embryonic feature. It will be noted also that the young ovule of Salisburio shows a tendency to form a beak on its free extremity. The possession of a beak may also be an embryonic feature. If so, it is interesting to note so many embryonic characters in these seeds, which probably belong to Baieropsis, an old member of the Salisburia family.

These seed show a considerable amount of variation, and possibly they do not all belong to the same species. 


\section{Carpolithus latus, sp. nov.}

Plate CXXXV, Fig. 3.

Seed of medium size, broadly pear-shaped, with a very short acnte projection or mucro on the summit as wide as long, narrowed below into a comparatively very stout pedicel, showing on the upper surface two strong flat ribs, which are placed on each side of the medial line and rum nearly parallel with the margins.

Locality: Fishing hut above Dutch Gap Canal.

Only one specimen of this plant was found, and hence its character is imperfectly shown. It is clearly different from all the other Potomac forms of Carpolithus. It shows a peculiar flaring out in width in the middle. It is probably a seed of some Baieropsis.

\section{Carpolithus curvatus, sp. nov.}

Plate CXXXV, Fig. 17.

Seed large, elongate, broader at one end than at the other, curved on one margin and nearly straight on the other, convex, covered with a thick, smcoth, and shining epidermis.

Locality: Fredericksburg; found in only one specimen.

This curious form casually inspected looks something like the imprint of a shell. It is in slape and size unlike all the forms of Carpolitlus foind in the Potomac beds. It may be a Cycadeospermum.

\section{CARPolithus SESSILIS, sp. nov.}

Plate CXxXVI, Fig. 9.

Seed small, subrhombic to elliptical in form, acute, much narrowed at each end, upper surface marked with three lines denoting ridges, sessile; principal stem comparatively stout.

Locality: Fishing hut above Dutch Gap Canal.

This and the form next to be described are very rare. They are both much like the nut-like seed of Cephalotaxus, and probably belong to some species of Cephalotaxopsis. 


\section{Carpolithus mucronatus, sp. nov. \\ Plate CxxxyI, Fig. 15.}

Seed of medium size, elliptical, widest towards the summit, ending in a short rigid tip (mucro), narrowed gradually towards the base into a very short stout pedicel, by which it is attached to the principal stem, marked on the upper surface with three strong lines or ridges.

Localities: $72 \mathrm{~d}$ mile-post; bank near Brooke; very rare.

This is probably a seed of Cephalotaxopsis.

\section{CICADEOSPERMUM Saporta.}

In the genus Cycadeospermum I place various smooth horny seeds, which resemble those of cycadaceous plants more than those of conifers, but which are always found detached and isolated. This fact, and the additional one that they are usually imperfectly preserved, render the correct placing of these plants impossible. They are always few in number, and for'm a very insignificant element in the Potomac flora.

Cycadeosperium acutum, sp. nov.

Plate Cxxxy, Fig. 12.

Seed oval, acute, small, with a smooth, firm surface, obtusely rounded at base.

Locality : Hill-side near Potomac Run.

This small seed is very rare. It was found only isolated and not in connection with any leafy twigs. The seed figured by Heer ${ }^{1}$ as the seed of Ginkigo sibivica are a good deal like this one.

\section{Cycadeospermum obovatum, sp. nov. \\ Plate CXxxV, Fig. I3.}

Seed of medium size, obovate in form, narrowed towards the base, where a trace of the pedicel is seen ; smooth and firm.

Locality: Hill-side near Potomac Run; rare.

This seed is something like Carpolithus Virginiensis, but it is larger, and besides is smooth and glossy on the surface. 


\section{Cycadeospermum spatulatum, sp. nov.}

Plate CXXXV, Figs. 11, 21.

Seed of considerable size, smooth and glossy on the surface, spatulate in form, truncate and abruptly rounded off at the base, narrowed towards the upper end; the sides nearly straight.

Locality: Hill-side near Potomac Run; rare.

These seed, found always detached, are covered by a smooth, glossy, parchment-like epidermis, which peels off from the stone. It is the most common seed at the Potomac Run locality, but still is not abundant.

Crcadeospermum ellipticum, sp. nov.

-Plate CXXXV, Fig. 19.

Seed broadly elliptical, nearly orbicular, smooth and firm, covered with a smooth, shining epidermis, that is very durable.

Localities: Fishing lut above Dutch Gap Canal; Fredericksburg; rare.

This seed must have had a considerable amount of woody matter in its composition, as it leaves a deep depression in the clay. It is the most common cycad seed at Dutch Gap.

Cycadeospermum Rotundatum, sp. nov.

Plate CXxxvi, Fig. 12.

Seed small, suborbicular; surface smooth and firm, with a leathery, durable epidermis.

Locality : Kankey's.

This small seed, found in only one specimen, is in shape similar to the preceding, but is much smaller.

Cycadeospermum angustum, sp. nov.

Plate CXXXY, Fig. 20.

Seed narrowly elliptical, elongate, smooth, and firm.

Locality: Hill-side near Potomac Run.

This seed, found in only one specimen, is very long in proportion to its width. It seems to be a distinct species. 


\section{AMent of ANgIOSPERM ?, sp. ? \\ Plate Cxxxv, Fig. 16.}

This may have been the pollen-bearing catkin of some unknown Angiosperm. As only one specimen was found, and it was very imperfectly preserved, nothing definite can be said as to its true place.

Locality: Fishing hut above Dutch Gap Canal.

\section{Fruit capsules, sp.?}

Plate CXxxV, Fig. 14.

This figure shows two capsules of some fruit apparently united at base and borne on a short pedicel. They are elongate-elliptical in shape, having at the summit tooth-like projections, as if due to incipient dehiscence.

Locality: Occurs in only one species, at the fishing liut above Dutch Gap Canal

\section{CONE OF CALLitRIS ? sp.? \\ Plate CLXIX, Fig. 8.}

This fossil, which appears to be nearer Callitris than any other, seems to be a broadly oblong cone, truncate at the summit. It is attached by a very stont pedicel to a thick twig, and appears to be split into several portions, which are narrowly oblong.

Locality: It was found in only one specimen, at the fishing hut above Dutch Gap Canal.

\section{SEED OF PINUS ?, sp. ? \\ Plate CLXX, Fig. 4.}

The figure represents what seems to be a seed of Pinus. It is of small size, elliptical in form, and has attached to it a large scale.

Locality: One specimen only found at Covington street, Baltimore.

\section{Pollen sacs ?.}

Plate CXXXVI, Fig. 7.

Fig. 7 gives a number of small capsules, natural size, grouped in a radiate manner, that resemble the pollen sacs of Taxus. They may belong to Athrotaxopsis.

Locality: A single specimen found at the $72 \mathrm{~d}$ mile-post. 


\section{WILLIAMSONIA Carr. \\ Willianisonia Virginiensis, sp. nov. \\ Plate CXXXIII, Figs. 5-7; Plate CLXV, Fig. 5.}

Axis stout, with a broad, deep depression at its summit, surrounded by an elevated ridge which has been left by the fruit. Bracts in at least two whorls, which alternate with each other, and are situated beneath and around the scar left by the detachment of the fruit, oblong to narrowly ovate in shape, apparently originally covered with numerous extremely fine hair-like appendages, which, however, owing to the accidents of preservation, are now often absent.

Localities: Entrance to Trent's Réach; fishing hut above Dutch Gap Caual.

This fossil is rare at the latter locality, and is not uncommon at the former in the layer with Dioonites Buchianus, Frenelopsis parceramosa, etc. Some of the bracts are smooth and show no traces of the hair-like appendages. The best preserved specimens, however, show them very distinctly under a lens, and to the unaided eye they appear as fine striæ. The bracts were evidently thick and fleshy, for in many cases they appear convex on the surface.

Von Otto ${ }^{1}$ gives illustrations of large star-shaped bodies, which he calls Asterosoma rudiciformc. These resemble the Potomac fossils now in question, but they are much larger, and have fewer bracts than W. Virginiensis. Von Otto says of these fossils, that in nearly all four specimens found there occur near the star-shaped bodies thread-like little cylinders which wind about and occasionally lie upon the star-shaped bodies. This description would seem to indicate the existence on these bodies o threadlike appendages like those on the Potomac fossils. These Williamsonialike fossils of Von Otto come from the upper Quader of the vicinity of Königstein in Saxony.

${ }^{1}$ Additamente zur Flora des Quadergebirges, pt. 2, Pl. II, Fig. 4; Pl. III, Figs. I, 2. MON $\mathrm{XV} \longrightarrow 18$ 


\section{UNDETERMINED PLANTS.}

The plants next following do not possess characters that place them definitely in any particular group of vegetable forms. I give figures of them, as they seem to be worthy of notice, and, so far as can be made out, they are different from any of the fossils described under other heads in this memoir.

$$
\begin{aligned}
& \text { Macrospores ?, sp. } \\
& \text { Plate Cxxxy, Mir. } 1 .
\end{aligned}
$$

At the fishing hut above Dutch Gap Canal we occasionally, but rarely, find, on certain thin layers of fissile, very fine-grained clay, a number of minute circular markings confusedly associated together. As seen under a lens, they are in the form of a circular raised ring, in the center of which is a minute knob. They occur also in the red clay ball in the banks of Dutch Gap Canal.

\section{UNDETERMINED PLANT $(a)$. \\ Plate CxxxyI, Fig. 13.}

This peculiar stem is more like an Ephedra than any other plant known to me. It has a number of long, slender, woody cylindrical stems, which radiate from a conmon point. In several places they seem to be jointed, but the jointing does not appear to be generally present. In several there are scars, as if left by the detaching of twigs. The stems are decorticated.

Locality: Fredericksburg; only one specimen.

$$
\begin{aligned}
& \text { UndeTERMined Plant (b). } \\
& \text { Plate CXxxyi, Fig. } 14 .
\end{aligned}
$$

This plant is composed of a number of woody cylindrical twigs, that branch in a dichotomous manner, and pursue an irregular, flexuous course. In the irregular branching and flexuous character of the twigs it looks more like a root than an aerial growth.

Locality: Occurs in one specimen at Fredericksburg. 


\section{Undetermined plant $(c)$.}

Plate CXXxvir, Fig. 1.

This singular fossil comes from Fredericksburg in only one specimen. The main stem seems to have been rather succulent. It has attached laterally towards the top a number of flat leathery appendages that seem to have had a slight woody axis or midnerve. They remind one of the ribbon-like subterranean leaves of Stigmaria. The fossil is apparently a root.

\section{UndETERMINED PLANT $(d)$. \\ Plate CxxxvII, Figs. 2, 3.}

This fossil appears in the form of large main stems, that are strongly striated and send off irregularly large striated branches. They seem to have been somewhat succulent in character, and probably were roots.

Locality: The plant occurs rarely at Fredericksburg.

\section{UndETERMined PLANT $(e)$.}

Plate CXXXVII, Fig. 4.

This fossil, found in only one specimen at Fredericksburg, is very imperfect. It shows the curious feature of having a number of stems radiating from the same zone on a common stem. The bases only of these are preserred. They appear swollen and even bulbons, and are marked by transverse stria. They look something like the singuiar stems found at Baltimore, and figured on Pl. CLIX, Figs. 4, 5.

\section{Undetermined plant $(f)$.}

Plate CxxxvII, Fig. 5.

tuis is a woody branching stem, found in only one specimen at Fredericksburg. It is without significant character, being decorticated. It may belong to Athrotaxopsis.

\section{UNDETERMINED PLANT $(g)$. \\ Plate ClXIX, Figs. 4, 5.}

The specimens of this plant show very long and slender cylindrical stems, with a comparatively small wondy axis, surrounded by a suceulent 
cortical layer. The branches, which are like the main stems, go off at long intervals from the same zone, apparently in whorls. They go off ustally at right angles from the main stem and then bend upwards at a right angle, so as to be parallel to the main stem. The branches are often as thick as the main stem.

Localities: Quite common at Belt and Covington streets, Baltimore.

UNDETERMined PLANT $(h)$.

Plate CLXIX, Fig. 9.

This fossil is composed of long cylindrical stems, which send off very obliquely, and apparently in whorls, branches which are similar to the principal stems. The stems and branches had a stout woody axis, which was surrounded by a cortical layer, succulent in nature, and of considerable thickness. This latter sometimes leaves a wrinkled and puckered margin to the woody axis, but it is not always preserved. The bases of the branches seem to be swollen, and they are marked by transverse scars, which may be dne to the fall of bud-scales, or may be simply wrinkles from shrinking in the cortical layer. The plant may be the stem of Cephalotaxopsis or Baieropsis.

Locality: It occurs rarely at Covington street, Baltimore.

\section{UNDETERMINED PLANT $(i)$.}

Plate CLxxmI, Fig. 11.

This fossil occurs in the form mostly of detached, circular, sheath-like impressions, having a small circnlar orifice in the center. The imprints show a number of moderately strong nerves or ribs, that radiate from the central orifice and end in spike-like teeth around the margin. Usually a number of these imprints are found near one another, and sometimes vague indications of a stem occur, but too mnch disguised by maceration to give any idea of the mode of attachment. The imprints look more like sheaths of some Equisetum than anything else.

Locality: They are not uncommon at Covington street, Baltimore. 


\section{ANGIOSPERMAE.}

The angiosperms of the Potonac flora form an important element in it. In number of species, however, they are far inferior to the conifers and ferns, and do not equal these in the extent of their diffusion. The localities at which angiosperms ocenr in notable amounts, in the strata in place, are the 72d mile-post; bank near Brooke; White Honse Bluff; the two localities at Baltimore and at Fredericksburg. The plants at Fredericksburg are much more arehaic in type than those of the other localities.

It is, then, only from Fredericksburg northwards that we find this modern element playing an important part in the flora of the beds in place. All of the localities in this more northern portion of the Potomac area do not contain any considerable proportion of these plants. None occur at the lill-side near Potomac Run, and only a few fragments are found on the road-side near by, as well as near Telegraph Station. The two localities at Baltimore show the Variegated Clay or upper member of the Potomac in place over the plant-bearing beds. At Brooke the Eocene caps the fossiliferous strata. Unly a few imperfect fragments of angiosperms occur in the strata in place in the immediate vicinity of Dutch Gap Canal; but at Deep Bottom, where the Eocene caps the Potomac, angiosperms predominate in the fossils found in the disturbed bowlders of sandy clay and clay which come from the destruction of beds that once lay upon the sand of the lower Potomac These are of more recent type, as are those of the Brooke localities, White House Bluff, and the two Baltimore localities. But, as has been stated before, these beds can not be separated in age. The Lower Potomac era seems to have had a flora that was rapidly changing. In the lower and middle strata, ferns, cycads, equiseta, and conifers predominated, giving the flora a Jurassic facies, but with these were mingled a considerable number of angiosperms, mostly of archaic type. The strata of Dutch Gap Canal and at Fredericksburg give us a good type of this portion of the formation. Towards the upper part of the formation 
angiosperms abounded and predominated, several having living genera, but with them many of the plants found lower down in the formation still existed. The beds at Brooke, White House Bluff, and Baltimore are types of this portion of the formation

It is a noteworthy fact that many of the fossils that are nearly. allied to living genera are comprehensive types, showing perhaps ancestral forms of living types. The same may be said of the conifers that are associated with these angiosperms, and which show affinities with living genera of conifers. They are not, then, either the conifers or the associated angiosperms, so recent in type as a hasty inspection might indicate. When in any series of beds at a given locality the fossils are of the character of those found at Fredericksburg and at Dutch Gap, we may conclude that the absence of angiosperms is explainable by the removal by erosion of the upper strata, which contain them in large numbers.

Another fact that should be noted as probably indicating the really great antiquity of the most modern-looking angiosperns is the great rarity of individnals in most of these, and it is the most recent types that show the fewest individuals. This probably means that the type is of recent introduction. This feature should, however, be accepted with caution as a basis for reasoning concerning the scarcity or abundance of forms, since we know nothing concerning the conditions which favored or opposed the preservation of given plants. Apparent relative abundance or rarity may be determined solely by the conditions controlling fossilization. Then, too, the amount of material obtained from a given locality lias, of course, much influence in fixing the apparent abundance of the plants found only at that spot. These remarks apply with special force to the Potomac fora, which shows such a remarkable localization of the plants. It will be, perhaps, proper to state in this connection that a very large amount of material was obtained at the entrance to Trent's Reach; fishing hut above Dutch Gap Canal; Fredericksburg; the trvo Bronke localities; a smaller amount, but still large, at White House Bluff, the two Baltinore localities, and the two Potomac Run localities, and very little from the others. 


\section{CONOSPERMITES Ett.}

Conospermites ellipticus, sp. nov.

Plate CXxxvII, Fig. 14.

Leaves very thick and leathery, with entire margins, elliptical in snape; nerves three in number, slender but distinct, one medial and two marginal, the latter parallel to the margins of the leaf, all running from the base to the apex, and apparently uniting at the apex; no other nerves seen.

Locality: Road-side near Potomac Run.

Only one specimen was found. The thick leathery texture of the 'eaves concealed all the nervation except the three main nerves. They continne without much diminution from base to apex. $14^{3}$ is a reproduction of the leaf.

\section{ACACIEPHYLLUM, gen. nov.}

Leaves in outline elliptical or spatulate, in texture quite thick, narrowed gradually below into a long petiole; leaves inserted very obliquely on comparatively stont stems, arranged spirally; petiole, on entering the lamina of the leaf, splitting up into a comparatively stout middle nerve and two lateral ones, the latter varying in stoutness; each main nerve sends off very obliquely subordinate nerves, which anastomose with the adjacent ones to form long and irregular meshes; ultimate nerves not seen; the midnerve splits up towarls the apex by sending off lateral nerves. These leaves are more like those of some of the acacias of New Holland than any other plants. We may compare them with the phyllodes of Acacia salicina Lind., and A. longifolia Willd.

\section{ACACLefHyllum LONGIFOLIUN, sp. nov.}

Plate Cxxxv11, Fig. 6 ; Plate CxxxyIII, Figs. 1-3.

Entire leaves not seen, but long elliptical in form, gradually narrowing below into a long petiole; midnerve persistent to near the summit of the leaf, comparatively strong, sending off very obliquely slender secondary 
nerves, and these in turn sending off subordinate ones which are very slender, and anastomose at very long intervals to form very long and large meshes; ultimate nervation not seen.

Localities: Fishing hut above Dutch Gap Canal; red clay ball in the banks of Dutch Cap Canal; very rare.

This leaf differs from the other species of the genus in its large size, in the great proportional size of the midrib, and in the very slender lateral nerves which are sent off from the basal portion of the leaf, and for some distance diverge very slightly from the midrib. The lateral primary nerves hardly surpass in stoutness the secondary ones.

\section{Acaciephyllum spatulatum, sp. nov.}

Plate CxxxvıII, Figs. 4, 6-9.

Leaves elliptical or spatulate in shape, mostly of the latter form, inserted spirally and very obliquely on stout stems by means of long petioles, into which the leaves gradually narrow, forming wedge-sliaped bases; petiole at the base of the leaf lamina splits up into three nerves of nearly equal importance, but with the middle slightly predominating; each of these sends off very oblique branches, which are quite slender and anastomose at long intervals, forming very long and large irregularly shaped meshes; ultimate nervation not seen.

Localities: Fishing hut above Dutch Gap Canal; the red clay ball in the banks of Dutch Gap Canal; rare.

The plant is most common at the first-named locality, but is not abundant anywhere. The leaves of this plant may be compared with those of Leucospermum conocarpum R. Brown.

ACACIÆPHYLLUM MICROPHYLLUM, sp. nov.

Plate CXxxVIII, Fig. 5.

Main stem proportionally very stout; leaves spirally placed and very obliquely on the stems, small, elliptical in shape, narrowed gradually with a wedge-shaped base into a petiole of varying length, subacute, nerves as in the preceding species.

Locality : Fishing hut above Dutch Gap Canal. 
Only one specimen was found. On the branch preserved on the left side of the figure only two leaves are to be seen borne on the summit; but this is no doubt due to the fact that the lower leaves have been accidentally removed.

Açaclaperyllum variabile, sp. nov.

Plate CLXX, Fig. 7.

Leaves small, variable in shape, ranging from narrowly elliptical to subspatulate and broadly elliptical, often inequilateral, placed spirally and very obliquely on the stem, with long petioles; leaf-substance comparatively thick and hiding the nerves; nervation as given in the generic description, but not distinct; primary nerves slender; nltimate nerves not seen.

Locality: Covington street, Baltimore; rare.

\section{PROTEÆPHYLLUM, gen. nov.}

I group under this head a number of leaves with a very archaic type of nervation that occur in the Potomac flora. In their nervation, and in many cases in the form of the leaves, they bear a greater resemblance to species of Protec than any other plants. The main points that characterize them are the absence of any pronounced difference in the size of the primary nerves, the great slenderness of these, the lax and irregular reticulation formed, and the uniformly strong nltimate nerves, which give a reticulation that reminds one of ferns. Indeed, I was for some time in donbt whether some of these leaves were really angiosperms and not ferns. There are two types of these leaves, that differ only in the presence or the absence of a distinct midrib; when the midrib is present the leaves assume an elliptical form; when it is absent, they tend to take an orbicular shape. We might perhaps divide the genus into two subgenera according to this distinction, giving one the name rotundatum. and the other the appellation elongatum.

The genus may be described as follows: Leaves orbicular or elongate in form; in the case of the former, no midrib present; in the case of the latter, a thick, vaguely defined, and apparently somewhat snceulent midrib 
exists; petioles proportionally very thick and apparently succulent; nervation of the primary order very slender, and with little or no difference in the strength of the primary nerves; reticulation of all orders lax, irregular in shape, and varying in the size of the meshes; ultimate nerves strong, all of equal strength and fern-like. These leaves form an important portion of the angiosperms that oceur with a predominant flora of Jurassic type, as at Fredericksburg, and they give a very ancient look to the angiospermous element of the flora.

Protexphyllum Reniforie, sp. nov.

Plate CXXxIX, Fig. 3; Plate CLVI, Fig. 4; Plate CLX, Figs. 1, 2.

Leaves small, reniform, inequilateral ; leaf-substance quite thick; petiole proportionally very thick and apparently succulent, splitting up on entering the leaf into a number of nearly equal primary nerves, which, repeatedly subdividing in a palmate manner and anastomosing, fill the leaf with a very irregular lax reticulation, the branches being nearly of equal strength with the primary nerres; ultimate reticulation not seen. The smallest reticulation seen is formed by comparatively strong branches, that generally make large, nearly right angles with their parent nerves. The branches of the primary nerves go off very obliquely.

Localities: Fredericksburg; $72 \mathrm{~d}$ mile-post; fishing hut above Dutch Gap Canal ; rare.

The imprint given in Pl. CXXXIX, Fig. 3, represents the entire leaf. On the right-hand lower side it has been pressed upwards from below so as to roll over the lower margin of the leaf upon the nerves, making the outermost of them appear to issue from a marginal nerve. This pressure has probably produced also a distortion of the primary nerves in the left-hand half of the leaf, crowding them together abnormally. The thick substance makes it difficult to follow the ultimate nervation. Plate CLX, Fig. 1, gives a large fragment of a leaf much mutilated and wrinkled transversely. This specimen, presenting its lower surface uppermost shows the nerves much more distinctly. It shows that the penultiuate meshes seen are subrhombic in shape, being made by nerves meeting mostly under acnte angles, but the ultimate or smallest meshes are irregular, subrotund, or 
polygonal in form, quite different from those next above them in size. This figure does not show any of the original margin of the leaf or of the petiole, although the outline and dimensions of the leaf are evidently retained nearly unchanged.

This curious leaf, in shape and nervation, reminds one of the leaves called Protorhipis by various authors, under the supposition that they are the prothalli of ferns. It may well be questioned, however; whether some of these are not ancient forms of dicotyledons. The nervation of the Potomac plant is something like that of a fern, and is decidedly archaic in type. The form is similar to that of some Hedera, as H. primordialis Saporta, but in Hedera the midrib and primary nerves are much stronger than the secondary ones. In the midrib splitting up into numerons primary nerves of nearly equal size, in the dichotomous forking of the latter, and in the very thick petiole we have a strong resemblance to some of the Proteacece, as Protea cordata Thunb. In shape it is a good deal like Begonia hydrocotylifolic. It is also similar in shape to Populus arctica Heer. ${ }^{1}$ This species may be taken as the type of the subgenus Rotundutum of the forms of Protecepthyllum.

\section{Ppotefephyllum orbiculare, sp. nov.}

Plate CXXXIX, Fig. 4.

Leaf small, orbicular in shape, slightly hent-shaped at base; primary nerves all nearly of equal thickness, diverging slowly, and radiating from the base of the leaf, sending off obliquely very slender branches, which anastomose to form irregular comparatively large meshes; ultimate nerves forming oblong pentagonal or hexagonal meshes.

Locality: "Fredericksburg; only one specimen found.

This plant also belongs to the rotundate section of Proterephyllum. It more than the preceding species resembles Hedera, but the radiate arrangement of the slender primary nerves does not agree with that genus. It may also be compared with Protea cordata Thunb. The nervation of this plant is much like that of Banksites Saportanus, Velenovsky (see Die 
Flora der böhm. Kreideform., Pl. I, Fig. 18). Conospermites hakeafolius (Fig. 11 of the same plate) has a nervation similar to that of the Potomac plant.

\section{Protedefhylum, sp.?}

Plate CXXXIX, Fig. 2.

This fossil is too fragmentary to justify an attempt to determine its species. It forms the upper part of an elliptical leaf, most probably has a midnerve which towards the summit splits up into branches. These are slender and are sent off obliquely; they subdivide irregularly into secondary branches, which anastomose irregularly to form large lax meshes. It may be compared with Protea glabru Thunb. It belongs to the elongate section of Protecepliyllum.

Locality: Fishing hut above Duteh Gap Canal.

Protedphyllum oblongifolium, sp. nov.

Plate Cxxxix, Fig. 5; Plate CXL, Figs. 1, 2.

Leaf rather large, spatnlate, oblong or oblong-elliptical, narrowerl very gradnally below into the petiole; summit not seen; midnerve stont, and continning to near the tip of the leaf; secondary nerves very slender, leaving the midrib at a more or less acute angle, and arching around in an irregularly flexnous manner to unite with those of the same order next above, sending off branches obliquely, mainly on the outer side, which pursue a flexuons course parallel to the margin of the leaf, finally dissolving into smaller branches; the lateral nerves anastomose into large, irregular meshes, made up of subordinate meshes, the minor branches of the lateral nerves, which meet under large angles, forming a net-work that is very irregular; leaf-substance moderately thick; the ultimate reticulation strong and fern-like.

Locality: Fredericksburg.

Leaves of this character are not uncommon at Fredericksburg. 'The nervation is very lax, irregular, and archaic in type. The leaves are always quite fragmentary, but so many specimens are found giving all parts of the leaf, that a quite reliable restoration can be indicated. In Pl. CXL, Fig. 2, I give a full-size restoration of the leaf of the largest dimen- 
sions. The nervation is something like that of Ficus protogca, Ettingshausen, from the Cretaceous strata of Niederschöna. ${ }^{1}$ The irregularity of the areolation, the slenderness of the primary nerves, and the proportionally very strong ultimate reticulation make the leaf more like some Proteas than any other living forms.

\section{Protedephyllum ovatum, sp. nov.}

Plate CXLI, Fig. 1.

Leaves of medium size, ovate-acute, with the tip bent, to one side, abruptly rounded at base, and subcordate; midnerve very thick and apparently somewhat succulent; primary nerves very slender, going off nearly opposite in pairs, basal pair leaving at a very large angle and curving strongly around approximately parallel to margin, those higher up leaving at more and more acnte angles, curving gently until near the margin of the leaf, and then bending strongly upwards, gradually approaching the margin, sending off slender branches, which anastomose to form large, lax, and mostly irregular quadrangular primary meshes; ultimate meshes variable in size, distinctly defined, and formed chiefly by the meeting of the nerves under large angles.

Locality: Fredericksburg; only one specimen found.

This leaf of moderate size is noteworthy for the great thickness of its midrib, the unusual slenderness of its primary nerves, and the irregulurity of its nervation. This, like the preceding, belongs to the elongate section of I'rotecephyllum. The leaf seems to have been somewhat inequilateral. The nervation has some of the characters of the Celastrinece, as shown in $C$. Scandens.

\section{l'rote.epityllum ellipticum, sp. nov.}

Plato CXLII, Figs. 1, 2.

Leaves rather lange, oval-elliptical in form, subacnte at summit, rapidly rounded at base, and then narrowed gradually into the petiole; midnerve very thick, and apparently somewhat succulent; primary lateral nerves very slender, going off at an oblique angle, arching upwards ap- 
proximately parallel to the margin for some distance, not meeting one another; the primary nerves sending off branches in a dichotomous manner, and these anastomosing to form large, irregular, lax primary meshes; the ultimate meshes, elongate and mostly quadrangular. rather indistinctly defined, owing to the thick leaf-substance.

Locality: Fredericksburg; rare.

The nervation of this plant is more like that of Protecephyllum ovatum than any other in the size and loose texture of the midnerve, the slender primary nerves, and the irregular lax nervation; it is proteaceous, but combines with the characters of the Proteacece some of those of the Celastinece. Indeed, we may say generally of the leaves of Protecphyllum with a midrib, that they combine features of the nervation of both these genera. This species may be compared with Persoonia daphnoides. It belongs to the elongate section of Proteceplyyllum. Fig. 2 is a restoration from several specimens.

\section{Protemphillum tenuinerve, sp. nov.}

Plate CL, Fig. 13 ; Plate CLVI, Fig. 2.

Shape of leaf unknown; leaves apparently of large size and elongate; leaf-substance thick; midnerve extremely thick, loose-textured, and apparently somewhat succulent; primary nerves extremely slender, going off at a more or less acute angle, then arching backwards and splitting up into branches that are nearly as strong as the primary nerves. These branches meet obliquely to form oblong or elliptical irregular primary meshes of large size; ultimate nervation not visible.

Localities: Fishing hut above Dutch Gap Canal ; road-side near Potomac Run; rare.

These leaves are remarkable for the striking contrast in the size of the midnerve and the primary nerves. They really possess no distinct primary nerves. The nervation is a good deal like that of some Persoonias. The leaf must lave been very large.

Proteжphyllum dentatum, sp. nov.

Plate CLVI, Fig. 7 ; Plate CLXXII, Figs. 1, 4 ; Plate CLXXIII, Figs. 12, 14.

Leaves small, orbicular in outline; leaf substance thin, margins cut into acnte or subacute ovate teeth, which are directed forwards, and are of vary- 
ing but always small depth; no midrib seen; the base and summit of the leaves not found; the nerves very slender and seen with difficulty, they are several in number, of about the same strength, and appear to diverge from the base of the leaf with a flexuons conrse; they unite to form a series of large, elongate, subrhombic meshes; slender branches appear to enter each tooth.

Localities: Belt and Covington streets, Baltimore.

This species is one of the abundant plants at these localities. The leaffragment, Pl. CLXXII, Fig. 4, is very imperfect, since the margins have all been removed. The shape of these leaves is more like that of some of the species of Protea, while the nervation resembles that of some of the species of Persoonia.

\section{ROGERSIA, gen. nov.}

Leaves long, narrow, and willow-like, wedge-shaped at base, acute, with a very strong midnerve and very slender primary nerves; these go off very obliquely and diverge very slowly from the midrib, running for a long distance nearly parallel with the margins of the leaves; they anastomose with branches sent off from other nerves of like grade higher up to form very long, irregularly shaped, and lax meshes; ultimate reticulation oblong, subrhombic, of quite uniform dimensions This genus is named for Prof. W. B. Rogers, who first called attention to the plants of the Potomac formation and studied its geology.

Rogersia longifolia, sp. nov.

Plate CXxxIX, Fig. 6; Plate CXLiv, Fig. 2; Plate CL, Fig. 1; Plate CLIX, Figs. 1, 2.

Leaves narrowly elliptical, gradually narrowed to the base and apex, with werlge-shaped base, acute, very long in proportion to width; midrib comparatively very stout; primary nerves very slender, going off very obliquely, proceeding upwards for some distance nearly parallel with the uargin, but gradually approaching it; prinrary nerves sending off very obliquely secondary nerves, which anastomose with their neighbors to form elongate, subrhombic, and irregular meshes, which have their maximum dimensions turned upwards and slightly outwards; primary meshes filled 
with pretty sharply defined ultimate meshes, polygonal in shape, and varying in the number of sides from four to six.

Localities: Fishing hut above Dutch Gap Canal; Fredericksburg; Kankey's ; rare.

The shape of these leaves is a good deal like that of Salix. The midnerve is in size out of all proportion to the primary nerves sent off from it. In its primary nerves and in the shape of the leaf the plant is a good deal like Glossochlamys transmutans Ettingshansen and Gardiner. ${ }^{1}$ The resemblance in leaf-form and nervation to Persoonia mollis R. Brown is strong. The affinities of the plants of this genus seem to be with the Proteacece.

Rogersia ANGUSTIFolia, sp. nov.

Plate CXL111, Fig. 2; Plate CXLIX, Figs. 4, ४; Plate CL, Figs. 2-7.

Leaves narrow, small, very elongate-oblong, narrowed gradually to the base and apex, subacute, sometimes curved ensiform; midnerve proportionally very strong, with a thick petiole; lateral or primary nerves very slender, going off at an acute angle and arching up towards the summit, forming more or less persistent nerves approximately parallel with the margin, and having a flexuous course. They send off very obliquely slender lateral nerres, which anastomose with the adjacent ones, and form irregular, elongate, polygonal meshes, with their longer dimensions directed upwards. The latter, by splitting up into ultimate nerves, form an irregular, lax, ultimate net-work.

Locality: Fredericksburg.

This is the most common angiosperm at Fredericksburg, and it is rather abundant there. It has leaves shaped much like some forms of Sulix, but the nervation is different. The midnerve is remarkable for its great proportional strength. The nervation is usually so fine that even the primary nerves are seen with difficulty. The leaf-substance seems to lave been thick and the epidermis firm and durable, so that the leaves are generally well preserved.

In the shape and nervation of the leaves tris plant may be compared with Persoonia mollis R. Brown. 


\section{SASSAFRAS Nees.}

The genus Sassafras seems to have been certainly present in the Potomac flora in forms that differ little from the living species, and in at least one species the fossil leaves can be matched by the living plants which abound in the vicinity. The genus, however, is sparingly represented both in species and individuals. Remarkably few specimens of undoubted Sassafras were found.

\section{Sassafras PaRvifolium, sp. nov.}

Plate CXXXIX, Fig. 7.

Leaf very small, shape not seen. At the summit there is an obtusely rounded short lobe, and on each side of this occur two oval subacute lobes which are imperfectly shown, owing to mutilation.

Locality: Covington street, Baltimore, very rare.

Sassafras cretaceum, Newb., var. heterolobum. Plate CLII, Fig. 5; Plate CLIX, Fig. 8; Plate CLXIV, Fig. 5. .

Leaves small, but varying somewhat in size, wedge-shaped at base, expanding rapidly above so as to assume a fan-shape, having at the summit three lobes, which extend nearly to the same height, but are very shallow. The middle one has its margins parallel with the midrib for the greater portion of its length, but at its summit it is abruptly rounded and very obtuse, or else narrows to a subacute point; the lateral ones are separated from this by a rather broad, rounded sinus, and have their tips more or less divergent, subacute, pretty broad, with the outer margin curving gently and the inner nearly straight. The petiole seems to have been strong, and soon after entering the leaf it splits into three nerves, one medial and two lateral; lateral nerves going off obliquely at nearly the same point and running nearly straight into the lateral lobes, each sending off on the outer side, near the base and at the same height, two strong branches, that curve upwards; lateral nerves at higher points and the midnerve throughout, sending off obliquely lateral nerves that are much smaller than the two lower outer ones. Subordinate nerves and reticulaMON $\mathrm{xV}-\longrightarrow 19$ 
tion not seen; leaves thick, and the lamina of the leaf decurrent for a short distance on the petiole, forming a narrowing wing.

Locality : $72 \mathrm{~d}$ mile-post, near Brooke; rare.

This plant seems to be a variety of Sassafras cretaceum Newb., from the Cretaceous of Dakota, but the nerves are more slender and the terminal lobes different from the normal species. It is a good deal like $S$. parvifolium, from Covington street, Baltimore, but is much larger.

\section{. Sassafras bilobatum, sp. nov. \\ Plate CLVI, Fig. 12; Plate CLXIV, Fig. 4.}

Leaf-substance moderately thick; leaf rather large, elliptical-shaped at base, eut into a rather long lateral lobe, ovate in shape, which is turned away from the midrib, having the opposite side of the leaf gently rounded off; terminal lobe much larger, ovate in shape; midnerve strong, sending off on the right-hand side from near the base and into the lateral lobe a strong nerve, and on the left-band side from a little ligher a smaller one, which curves upwards, following the margin of the leaf for some distance; the midnerve above the base at different points sends off minor nerves, which curve upwards and fork; ultimate nervation not seen.

Localities: Deep Bottom; 72d mile-post, near Brooke; very rare.

This plant is strikingly like some leaves of the living species of Sassafras, in which we occasionally find leaves with a single lateral lobe, just like that in the fossil. Among fossils it is nearest to S. recurvatum, Lesq., from the Cretaceous of the Dakota group. ${ }^{1}$ The fine form, Pl. CLXIV, Fig. 4, was found at the 72d mile-post. Only one specimen was discovered here. It is quite possible that if more had been found some of them would have sliown two lateral lobes, for the size of the lowest lateral nerve, on the left-hand side of the leaf, although inferior to the corresponding one on the right hand, indicates that the plan of the leaf calls for two lateral lobes.

\section{FICOPHYLLUM, gen. nov.}

Leaves elliptical in outline, subacute, gradually narrowed at base, with the lamina of the leaf more or less decurrent along the petiole; midnerve 
and petiole extremely thick proportionally: lateral or primary nerves proportionally and in most of the forms absolutely slender, extremely irregular in arrangement, forming a lax reticulation of very archaic type. Ultimate reticulation strongly marked and fern-like.

This genus is an important one in the Potomac flora, and has contributed a considerable number of individuals to the vegetation of that epoch. It is largely developed in association with Jurassic types of plants, as at Fredericksburg, where it is most abundant, and is almost wanting in the strata where more modern elements abound, as at Brooke, White IIouse, and Baltimore. As illustrating the archaic and pecnliar features of these leaves and those of Protecephyllum, I may state that for some time no other leaves but these were found at Fredericksburg, and finding them associated only with plants of Jurussic facies I found it difficult to give any. good characters distingnishing them from ferns. There is a general and strong resemblance between these plants and some species of Ficus, and for this reason it seems best to place them in a new genus, indicating by its name the apparent affinity with that genus. It is quite possible that these are ancestral forms of Ficus.

Ficophiyllum crassinerve, sp. nov.

Plate CXLIV, Fig. 3 ; Plate CXLV, Fig. 3 ; Plate CXLVI, Fig. 1 ; Plate CXLVII, Fig. 4 ; Plate CXLVIII, Figs. 1, 2, 4; Plate CLVII, Fig. 4; Plate CLXXIII, Fig. 10.

Leaves large, of varying size, sometimes attaining very large dimensions, elliptical in outline, subacute, with tips often broadly wedge-shaped, rounded off gradually at base, and narrowed slowly into the petiole. Midrib) very stout, woody, and strong nearly to the tip of the leaf, rather vagnely defined, and apparently somewhat succulent; primary nerves in proportion to the mid-rib slender, but compared with those of the other species of the genus thick; they go off on each side of the midrib, mostly very obliquely, subopposite or alternate, arch backwards and then strongly forwards, curving around so as to connect with the next nerves of the same rank; they send off on the outer side branches which continue for some distance cnrving towards the summit and gradually approaching the margin; between the main lateral nerves, which are nsually thick and strongly marked, subordinate lateral ones are commonly shown, as in Pl. 
CXLIV, Fig. 3, Pl. CXLVII, Fig. 4. These unite with the main lateral nerves or the larger branches from them, and form very large, irregularlyshaped, lax meshes. Sometimes the principal net-work in the interspaces of the main lateral nerves is formed by large branches from these; the mion of the principal lateral nerves, or of their main branches, makes a row of well-defined arches near the margin of the leaf; the ultimate meshes are quite uniform in size, mostly subrhombic in form, and not so sharply defined as in most of the types with archaic forms of nervation from Fredericksburg.

Localities: Fredericksburg, quite common; Deep Bottom; fishing hut above Duteh Gap Canal, rare.

This singular plant must have had in some of its leaves a very great size. This is indicated by such fragments of leaves as are shown in Pl. CXLIV, Fig. 3, and Pl. CXLVII, Fig. 4, both of natural size. The midrib especially is conspicuous for its great thickness. It, and especially its extension as the petiole, seem to have been somewhat succulent. This was much the largest species of leaf found at Fredericksburg. As these archaiclooking leaves were the first ones found, and as I found it diffienlt to give any characters which would distinguish them from ferns, I have given the details of their nervation more fully than I would have done if the presence of angiosperms had then been fully established in the Potomac flora. $U_{p}$ to this time these strata have been held by most persons to be Triassic.

The leaf, Pl. CXL, Fig. 3, shows what might at first sight seem to be a petiole, but it is really a portion of the midrib from which the lamina of the leaf has been stripped, and the basal portion of the lamina, still shown, is doubled back and contorted. Plate CXLVIII, Figs. 1, 2, shows leaves of the smallest size.

The nervation of these leaves is a good deal like that of Dawson's Ficus maxima, Cretaceous and 'Tertiary Floras of British Columbia.

Ficophyllum tenuinerve, sp. nov.

Plate CXL, Fig. 3; Plate CXLI, Fig. 2; Plate CXLV, Figs. 1, 4; Plate CXLVII, Fig. 2; Plate CXLIX, Figs. 1, 3, 5; Plate CLVI, Fig. 1.

Leaves varying in size, sometimes attaining very considerable dimensions, oval in outline, rapidly rounded off towards the base, where it is 
widest, and then gradually narrowed to the petiole, subacute at the tip, where the margins for some distance down are generally straight; midrib comparatively very thick, and apparently somewhat succulent; petiole somewhat succulent and very thick; the leaves probably pinnately arranged; primary nerves very slender in proportion to the size of the midrib, departing at an angle of about $45^{\circ}$, arching around to connect with those next above, and sending off branches mostly on the outer side, forming by their union several series of arches between the midrib and the margin; between the main primaries subordinate ones spring from the midrib, sending off branches to unite with the main primaries; primary net-work of nerves formed of the principal branches of the primaries meeting nearly at a right angle, composed of large, lax, obtuse-angled meshes, four to six sided; ultimate net-work composed of nerves of uniformly equal strength, meshes nearly of the same size, obtuse-angled, and generally four-sided.

Localities: Road-side near Potomac Run, very rare; Fredericksburg; common.

The petiole of this plant is, in proportion to the primary nervation, even more massive than that of $F$. crassinerve. The primary nerves are notably slender, and their branches meet more nearly at a right angle, while the series of arches running parallel with the margin are more numerous than in F. crassinerve. Plate CXLl, Fig. 2, indicates that some of the leaves must have attained dimensions rivaling those of $F$. crassinerve. This shows well also the straight margins towards the tips of the leaves, which are caused here to have a triangular outline. On the other hand, the small leaf, Pl. CXLIX, Fig. 3 , gives a degree of smallness never found in F. crassinerve. The leaves in Fig. 5 of the same plate occur in such a position as to suggest they were attached in pairs or pinnately. The upper leaf, on its left-hand basal margin, has the lamina torn loose and pressed over on the midrib, while the similarly situated portion of the lower leaf is crushed back and donbled over upon itself. This figure shows a great thickness of petiole, but it was evidently somewhat succulent, as it is wrinkled and slightly puckered. Plate CXLV, Fig. 4, gives a restoration made out from a large number of specimens which give all parts of the leaf, so that it may be relied upon as giving a pretty accurate idea of it. 
Ficophyllum serratum, sp. nov.

Plate CXLV, Fig. 2; Plate CXLIX, 1ig. 9.

Leaves of medium size, strongly serrate-toothed, teeth often irregular in size, sometimes double, acute, and directed forwards; shape of the leaf not fully disclosed, but apparently elliptical; midnerve proportionally very strong, lateral or primary nerves very slender, not fully disclosed, but apparently forming by the union of the branches of the primary nerves irregular large meshes; ultimate nervation not seen.

Locality: Fredericksburg; very rare.

With the exception of the toothing this leaf is very much like $F$. tenuinerve. It is somewhat similar to Quercus Johnstrupi ${ }^{1}$ Heer, from the Patoot beds of Greenland, but the Potomac plant is larger and has a differeut nervation.

Ficophyllum eucalyptoides, sp. nov. Plate CLXIY, Figs. 1, 2.

Leaves of medium size, narrowed towards the base and summit, rapidly rounded towards the base, prolonged at the summit into an acute or mucronate point; leaf-substance very thick, with a dense glossy epidermis; midnerve proportionally strong and continuing strong to near the snmmit; lateral or primary nerves extremely slender, closely placed, going off at nearly equal intervals, subparallel, curving forwards, sending off obliquely delicate branches, which split up dichotomously and anastomose to form elongate, subrhombic, irregular meshes, ending near the margin in a fine nerve, which runs for some distance nearly parallel to the margin.

Locality: $72 \mathrm{~d}$ mile-post, near Brooke; very rare.

The leaves seem to have been attached in a pinnate mamer. In the marginal nerve and the slender primaries it resembles Eucalyptus. It is a good deal like Ficus magnolicefolia Lesq., Cretaceous and Tertiary Floras, Pl. XVII, Figs. 5,6 .

\section{FICUS Tournef.}

The genus Ficus is represented in the Potomac flora doubtfully by only two species, and these have, so far as found, very few individuals. If present, it seems to be newly introduced. 
Ficus Virginiensis, sp. nov.

Plate CXLIII, Figs. 1, 3; Plate CXLIV, Fig. 1.

Leaves small, elongate-oblong, obtuse, gradually narrowed towards the base into the petiole, so as to form a long, narrow wing along the petiole; midrib distinct to the summit; lateral nerves slender, but very sharply defined, making a large angle with the petiole and going off at regular and equal intervals, opposite or subopposite, arching over in a flexuous manner to unite with those next above, forming a series of well-defined arches not far from the margin; branches on the outer side from the arches form a flexuons nerve, which runs parallel with and near to the margin, and which, by sending branches to the principal arches, forms a series of subordinate ones; branches sent off from the primaries and from the midrib unite under large angles to make a series of meshes irregular in size and polygonal in form; these are filled by the ultimate reticulation, which is. as are all the nerves, sharply defined.

Locality: Fredericksburg; rare.

This plant, in shape of leaf and nervation, is like some forms of Sapindus. It is much like Lesquereux's Ficus laurophylla, ${ }^{1}$ but the primary nerves are not so strong and the arches are more pronounced.

Ficus Fredericksburgensis, sp. nov.

Plate CXLVIII, Figs, 3, 5.

Leaves of medium size, oblong or elliptical, subacute; midnerve very strong; primary nerves rather strong, leaving the midnerve alternately at an angle of about $45^{\circ}$, at regular and nearly equal intervals, arching backwards and then forwards until near the margin, where they bend abruptly forwards, forming arches by union with the primaries next above; reticulation not seen.

Locality: Fredericksburg; rare.

The plant is a good deal like Sapindopsis elliptica, but the nervation is stronger, and the leaves are larger.

\footnotetext{
${ }^{1}$ Cretaceous and Tertiary Floras, Pl. I, Figs, 12, 13.
} 


\section{SAPINDOPSIS, gen. nov.}

Leaves pinnate, both odd pinnate and abruptly pinnate; terminal leaves usually more or less united at base ; upper pairs of leaves lecurrent, forming a wing on the common stem, the wing lessening in width on the pairs in descending; leaves mostly opposite in pairs, sometimes subopposite; the lowest pairs lack the wing, and are sometimes short-petioled; leaves thick, with dense and often glossy epidermis, elliptical or lancet-shaped, with a strong prominent midrib, which extends with slight diminution to the tip of the leaf; lateral nerves going off at a large angle, and uniting more or less completely near the margin to for'm a series of arches; the lateral or primary nerves, as seen on the lower side of the leaves, strong and prominent, but on the upper side, owing to the thickness of the leaves, generally indistinct; the ultimate reticulation is strong, and forms a series of rather large, irregular, polygonal meshes.

This genus is a very important one in the strata containing the more recent types of plants, especially as seen at the two Brooke localities and at White House. It has furnished an immense number of individuals, forming at these places the predominant fossils. The upper leaves, perhaps owing to the presence of the wings, seem to have been very persistent. It is probable that, normally in all cases, the lowest leaflets on the compound leaf were petioled, but, perhaps owing to this fact, they are by no means so commonly found attached to the stems as the upper ones. The leaves are so much like those of Sapindus that perhaps they might with propriety be placed in that genus. They seem to bé at least ancestral forms of Sapindus. The leaves of some species seem to be very variable within certain limits.

\section{SAPINDOPSIS CORDATA, sp. nov. \\ Plate CXLVII, Fig. 1.}

Leaf small, oblong with a subcordate base of thick consistency; midnerve and petiole strong, nervation mostly concealed by the thickness of the leaves; primary nerves as seen very slender, going off at an angle of about $45^{\circ}$, and half-way to the margin bending suddenly forward to connect with the next primaries, sending off at the point of sudden bending a branch which connects with the next lower primary. 
Locality: Fredericksburg; very rare.

The thick leaf-substance and the dense glossy epidermis obscure the nerves. The leaf figured seems to be one of the lower petioled ones, and apparently presents its lower face uppermost.

\section{Sapindopsis elliptica, sp. nov.}

Plate CXLVII, Fig. 3.

Leaves elongate, elliptical, narrowed gradually towards the base and apex; midnerve strong and prominent; primary lateral nerves slender but distinct, going off at an angle of about $45^{\circ}$, arching backwards slightly and then forwards, and then at three-fourths of the distance to the margin abruptly turned forwards to unite with the next primaries to form a series of arches which run parallel with the margin and near to it intervening ninor nerves leave the midnerve, as do the primaries, and unite mostly with the middle points of the arches; ultimate reticulation distinct, composed of proportionally large, irregular; polygonal meshes.

Locality: Fredericksburg; very rare.

The plant is much like Sapindus in the form of the leaf and in the nervation. It has some of the features of Ficus laurophylla Lesq.

All the nervation of this plant is slender, but very distinct.

\section{Sapindopsis magnifolia, sp. nov.}

Plate CL1, Figs. 2, 3; Plate CLII, Figs. 2, 3; Plate CLIII, Fig. 2; Plate CLIV, Figs. 1, 5 ; Plate CLV, Fig. 6.

Leaves odd-pinnate, leaf-substance thick and leathery, epidermis thick and glossy; leaflets comparatively large, lancet-shaped to elongate-elliptical, subacute, upper pair and terminal leaflet sometimes united for some distance; uppermost pair of leaflets mostly decurrent on the lower side by a broad wing, on the upper side cut away nearly or quite to the midrib, wings diminishing in width on the leaflets in descending, lowest pairs of leaflets short-petioled; leaflets placed opposite or subopposite in pairs; midnerve very stont, rounded, and prominent, continuing strong to the tip of the leaflets; primary nerves comparatively slender, conspicuous only on the under sides of the leaflets; the primary nerves go off pinnately at about 
an angle of $45^{\circ}$, arch at first slightly forwaids, and then bend strongly forwards to form arching nerves, which run for some distance approximately parallel to the margin, gradually approaching it; these communicate with one another by one strong nerve each to form large spaces approximately pentagonal in form, and by a series of minor nerves, which meet at a large angle, connect with the midrib and primary nerves to form quadrangular or subrlombie primary meshes; the ultimate meshes quadrangular or subrhombic and comparatively distinct.

Localities: 72d mile-post; bank neär Brooke; White House Bluff.

This plant is very common at all these localities. It, with S. variabilis, makes up the greater part of the fossils at these places. The plant is much like S. variabilis, and may possibly be a large variety of it. The leaves, however, are uniformly thicker in substance than those of that species. They show a greater tendency to short, broad forms, and the midnerve continues remarkably strong to the tips of the leaves. The chief cause of separation is the nervation, which is quite different from that of S. variabilis, lacking the distinct commecting marginal and arching nerve seen in that species. Fragments found indicate leaflets larger than any of those figured. Plate CLIV, Fig. 5, shows an abnormally short thick leaf. It may possibly be the terminal one, for this is sometimes different from those lower down. Plate CLII, Fig. 3, gives a pair of large leaves which remind one of Hymencea, but they are the terminal leaflet of the compound leaf, and one (the right-hand) lateral leaflet; the other lateral leaflet on the left-hand side has been accidentally torn away.

Sapindopsis Variabilis, sp. nov.

Plate CLI, Fig. 1; Plate CLII, Figs. 1, 4 ; Plate CLIII, Fig. 3 ; Plate CLIV, Figs. 2-4; Plate CLV, Figs. 2-5.

Leaves and leaflets small ; leaflets, especially the upper ones, varying much in size, shape, and mode of arrangement; leaves odd or abruptly pinnate; leaflets narrowly elliptical to lancet-shaped; leaf-substance leathery and thick, epidermis dense and glossy; leaflets normally opposite or subopposite, upper leaflets decurrent normally by a narrow wing, but often losing these features; the wing diminishes in width on the pairs descending, 
until the lowest pairs are short-petioled; midrib and nerves as seen on the under side prominent and sharply defined; midrib stout at base, but towards the summit rapidly attenuated; lateral primary nerves going off pinnately at uniform and nearly equal intervals, proportionally very strong, at first inclining slightly forwards, and then three-fourths of the distance to the margin bending abruptly forwards at nearly a right angle, to form a bow-shaped, strong nerve, which connects with the next primary at the angle made by it, thus forming a series of arches; this marginal nerve and the primaries send off nearly at right angles a series of branches which are proportionally very strong and distinet, forming the primary reticulation. They unite nearly at right angles, and form four to six sided primary meshes; the ultimate meshes are of the same general character, but smaller.

Localities: 72d mile-post; bank near Brooke; White House Bluff.

This is the most abundant angiosperm at the last-named locality. It is very common at the two Brooke localities, but is not so abundant there as $S$. magnifolia. This plant is very variable, and shows a curious fuctuation between odd and abruptly pimnate leaves and an alternate or opposite arrangement of the leaflets, as if the habit of the plant was not yet fixed. Plate CLII, Figs. 1, 4, seems to give the normal mode of arrangenent of the leaves; i. e, they are odd-pinnate, with the lower leaves in pairs. In none of the species, however, does the odd or abruptly pinnate mode of arrangement of the terminal leaves seem to mean anything or to be fixed.

I have given a number of figures of abnormal forms of this plant to illustrate its variability. Pl. CLIV, Fig. 2, shows union of the three terminal leaves and the decurrence of the two outer or lower ones by means of a very wide wing. The next lower pair of leaves are narrowly decurrent and normally paired. Fig. 4 of the same plate shows the decurrence of the uppermost leaves, but the leaves next below are not paired, and are unequally winged. The next lower leaf stands alone and the stem is quite flexuous. Fig. 3 of the same plate shows two terminal leaves united and decurrent to the next lower one on the left-hand side, which is single, and uniting with it at base. On the right-hand side the terminal leaf on that side is decurrent to the paired leaves below, with which, however, it does not unite. Pl. CLV, Fig. 4, shows a terminal 
decurrent pair, and the following ones lower down, widely separated, and alternate. Pl. CLIII, Fig. 3, shows what seems to be the base of the common petiole, and it looks as if it were clasping. This figure, however, has the abnormal character of possessing ouly three leaves and all of them terminal, the only case of the kind seen.

\section{SAPINDOPSIS PARVIFOLIA, sp. nov. \\ Plate CLIV, Fig. 6.}

Leaves and leaflets very small, leaves odd-pinnate; terminal leaflet much larger than the others, united with the right-liand next lower leaflet; uppermost leaflets subopposite, long-decurrent, united by a narrow wing with the pair next below; second pair from the top subopposite, slightly decurrent, not reaching to the next pair; last or third pair subpetioled; midnerves comparatively strong, other nervation not seen; leaves elliptical in shape, subacute, with the lamina of the leaf cut away obliquely on the upper side; leaf-substance thick and leathery.

Localities: 72d mile-post; bank hear Brooke; White House Bluff; rare.

This may be only a small form of $S$. vuriabilis.

\section{SAPINDOPSIS BREVIFOLIA, sp. nov. \\ Plate CLIII, Y'ig. 4 ; Plate CLV, Figs. 1, 7; Plate CLXIII, Fig. 3.}

Leaves odd-pinnate, terminal leaflet usually the largest; leaf-substance thick and leathery, obscuring the nerves; terminal leaflet oval or elliptical, sometimes slightly inequilateral, very wide in proportion to leugth; lower paired leaflets elliptical in shape, very short in proportion to the width, sometimes slightly falcate, subacute or obtuse; upper pair cut away obliquely on the upper side nearly or quite to the midrib, decurrent on the lower side, or subpetioled; midnerve strong, lateral nerves not fully shown; the primaries are pinnately arranged, go off at equal intervals, and arch slightly forward, the lower portions alone being seen.

Localities: $72 \mathrm{~d}$ mile-post; bank near Brooke; rare.

This plant shows some variation, but not enough to eause a separation into distinct species. In Pl. CLXIII, Fig. 3, the terminal leaflets, all that 
were seen, are closely crowded, so that the lateral ones overlap the terminal one; the leaves are elliptical, and the nerves are stronger than in any of the other specimens. In Pl. CLIII, Fig. 4, and Pl. CLV, Fig. 7, the terminal leaflet is distinctly petioled and comparatively remote from the lower ones, which also are furnished with petioles. This seems to be quite a distinct species from the preceding.

\section{Sapindopsis tenuinervis, sp. nov.}

Plate CLIII, Fig. 1.

Leaves odd-pinnate, summits of the leaflets not seen, but they are apparently of considerable size; leaflets narrowed gradually at their bases, more so in the lower ones, which are wedge-shaped at base, and the lowest pair petioled; uppermost pair of leaflets slightly united to the terminal one, and this latter larger than the others and less narrowed at base; uppermost leaflets cut away obliquely at base on the upper side nearly to the midrib, decurrent on the lower side, with a narrowing wing to the next pair, but not uniting with it; next lower pair very slightly decurrent, and wedgeshaped at base; leaflets quite remote, the leaf-substance thick and leathery; epidermis firm and glossy ; midnerves comparatively slender; lateral primary nerves slender; the lowest primary nerves go off very obliquely and run approximately parallel with the margin for some distance; succeeding primaries go off at more obtuse angles until towards the middle of the leaflet they go off at right angles; towards the margins of the leaflet they bend abruptly forwards and connect with the next higher primaries, forming a series of arches; intermediate subordinate nerves go off from the midnerve, and send off branches which anastomose with branches from the primaries, forming finally an ultimate reticulation mostly subrhombic in shape; nervation all quite slender and the reticulation lax.

Localities: 72d mile-post; bank near Brooke; not uncommon.

This plant seems to be quite a distinct species.

Sapindopsis obtusifolia, sp. nov.

Plate CLVI, Fig. 13; Plate CLIX, Figs.3-6.

Leaf-substance very thick; leaflets glossy, oblong, rounded, and very obtuse at the tips, often slightly inequilateral, that is, the midnerve does 
not divide the leaves exactly in half; midnerve stont, rigid, and rounded; lateral primary nerves very slender, not fully disclosed, going off at small intervals from the midrib at an angle of about $45^{\circ}$, arching slightly forward to near the margin, and then abruptly bending forwards to connect with the next prinary at its sudden bend, the connecting nerves forming a marginal one; ultimate reticulation not made out.

Localities: Deep Bottom; 72d mile-post, near Brooke; not very rare at the latter place.

\section{SALICIPHYLLUM, gen. nov.}

I group nnder this head a number of leaves imperfectly preserved and of donbtful affinity owing to the poor preservation of the nerves. In the nervation, so far as it could be made out, and in the shape of the leaves, they appear to be nearer Salix than any other genus. The leaves may be described as elongate-elliptical in outline, with midnerves strong at base and much attenuated towards the summit; lateral nerves slender, the primaries going off very obliquely and curving strongly towards the summit of the leaf, continuing approximately parallel with the margin, but gradually approaching it.

This genus has furnished a considerable element to the Potomac flora, the plants being chiefly found in the strata showing the flora with more recent aspects.

\section{Saliciphyllum Longifolium, sp. nov.}

Plate CL, Fig. 12.

Leaves small, oblong elliptical, very long in proportion to their width, summit not seen, gradually narrowed towards the base; midnerve towards the base very strong, attenuated above; lateral nerves slender; primary nerves going off at an acnte angle, inclining forward to near the margin, then abruptly bent forward to form an arch which is approximately parallel with the margin, this connecting with the next primary above at the point where it suddenly bends; the successive arches make a continuous sinuous marginal nerve, which is as strong as the primaries connected by it; intercalated subordinate nerves from the midrib send off branches which unite 
with those of the primaries, and finally form the ultimate meshes, which are irregular in form and size, quite large, and mostly subrliombic in form.

Locality: Road-side near Potomac Run; very rare.

The shape and nervation of this leaf remind one strongly of Salix. It has also a good deal of likeness to Persoonia daphinoides.

Saliciphyllum ellipticum, sp. nov.

Plate CXLvi, Figs. 2, 4; Plate CL, Fig. 8; Plate ClXIII, Fig. 5; Plate CLXVI, Fig. 2.

Leaves elliptical in outline, small, broad in proportion to their length, narrowed gradually at the base and summit, acute; midnerve strong at base and attenuated at the summit; primary lateral nerves going off at a very acute angle, arching strongly forwards; ultimate nervation not seen.

Localities: Fishing liut above Dutch Gap Canal; Fredericksburg; $72 \mathrm{~d}$ mile-post, near Brooke; rare.

Angiosperms are very rare at the fishing hut above Dutch Gap Canal. This fossil is the most common of those at this place. The leaf-substance appears to have been quite thick, and so was the epidermis, so that this latter was quite durable. It was owing to this character of the leaf that the finer nervation was concealed.

\section{SAliciphyllum PaRvifolium, sp. nov. Plate CLXXII, Fig. 5.}

Leaf very small, broadly elliptical, acute, narrowed at base and apex; petiole proportionally very strong, expanded below with a wing as if due to stipules or to a clasping mode of attachment; midnerve very slender, lateral nerves going off very obliquely and curving upwards, only partially seen; ultimate reticulation not seen.

Locality: Covington street, Baltimore; found in only one specimen.

\section{CELASTROPHYLLUM (Etting sp.).}

Leaves small, elliptical in shape, margins toothed or entire; midnerves slender; primary nerves very slender, going off obliquely and pinnately, curving up towards the apex, connected by comparatively strong nerves, 
which run nearly at right angles with the connected nerves, forming an irregular, slender, lax reticulation; ultimate reticulation not seen; leaf-substance mostly thin.

Under the head of Celastropliyllum I group a number of small leaves, which mostly have the nervation too slender and poorly preserved to enable one to fix the character with any definiteness. The placing of these in a group based on affinities with the Celastrinece is of course, under such circunstances, only provisional. On the whole, the general character of these leaves is nearer to Celastrus than to any other living plant. They form a consilerable element in the Potomac flora, although no species furnishes, so far as found, any great number of individuals.

\section{Celastrophyllum arcinerve, sp. nov.}

Plate CXLVI, Fig. 3.

Shape of leaf not seen, probably oval or elliptical ; midnerve comparatively strong; leaf-substance thin; primary nerves very slender but comparatively distinet, going off at an acute angle and curving strongly upwards towards the tip of the leaf, running for a long distance parallel to one another, and gradually nearing the margin, bent into a series of bowshaped arches, which are commected by a regular series of cross-bars or nerves, going off nearly at right angles and forming a series of large pentagonal meshes filled by small nearly rectangular meshes; the ultimate reticulation formed of mainly pentagonal or hexagonal meshes.

Locality: Fredericksburg; very rare.

This plant differs in some points of the nervation from the others grouped under the head of Celastrophyllum, except perhaps C. latifolium, to be described later. It is on the whole considerably like Celastrus trigynus, and also resembles $C$. ruber.

Celastrophyllum proteoides, sp. nov.

Plate CXLVI, Fig. 5.

Leaf small, elongate-elliptical, narrowed gradually to the base into the petiole; leaf-substance thin; no nerves seen; they must be very slender.

Locality : Fishing lut above Dutch Gap Canal. 
Only one specimen was found. The leaf is too imperfectly shown to enable its character to be made out. It may be compared with Celastrus Senegalensis.

\section{Celastrophyllum acutidens.}

Plate CLVI, Fig. 8.

Leaves small, narrowly-elliptical; leaf-substance comparatively thick; margins with acute, shallow, and small teeth, that are curved forwards; midnerve proportionally quite strong; lateral nerves very slender, going off at an angle of about $45^{\circ}$, curving forwards and forking dichotomously, very poorly disclosed; reticulation not seen.

Locality: $72 \mathrm{~d}$ mile-post, near Brooke; very rare.

This plant looks something like a Bankia in its toothing and in the shape of the leaf.

\section{Celastrophyllum obtusidens, sp. nov.}

Plate CLVI, Fig. 5.

Leaves rather large, with a comparatively thick and firm leaf-substance, apparently elliptical in shape, having on the margins of the leaves shallow, obtusely-rounded teeth, turned outwards and very closely placed; midnerve proportionally quite thick; primary nerves very slencler, going off obliquely and curving forwards, the bases only being seen; ultimate norvation not visible.

Locality: $72 \mathrm{~d}$ mile-post, near Brooke; quite rare.

This plant also resembles Banksia in the peculiar teeth and the very slender primary nervation. The teeth have been accidentally removed, except at the summit of the leaf. It is close to $C$. acutidens, and may be a variety of it.

\section{Celastrophyllum Brookense, sp. nov.}

Plate CLVIII, Fig. 8; Plate CLIX, Fig. 7.

Leaves of medium size, varying considerably in dimensions, narrowed towards the base, so as to give them a wedge-shaped form, swelling rapidly out in the middle to a broad elliptical shape; towards the summit narrowed rapidiy and prolonged to a point probably; midnerve very distinct, lateral MON $\mathrm{xV}-20$ 
primaries going off at equal intervals, very strongly curved upwards; minor nerves not seen; leaf-substance thick.

Locality : $72 \mathrm{~d}$ mile post; not very rare.

This plant is a good deal like Euonymus glaber.

\section{Celastrophyllum denticulatum, sp. nov.}

Plate CLXIX, Fig. 10; Plate CLXXII, Fig. 7.

Leaf very small, elliptical to ovate in shape, acute; margins minutely . dentate; midnerve slender, lateral nerves going off obliquely and curving up, very slender, lower ones more oblique and arching more strongly than the upper ones; ultimate nervation not seen.

Locality: Covington street, Baltimore; very rare.

$$
\begin{aligned}
& \text { Celastrophyllum latifolium, sp. nov. } \\
& \text { Plate ClixiI, Figs. 3, } 6 \text {; Plaio ClXxiII, Fig. } 13 .
\end{aligned}
$$

Leaves very small, broadly elliptical to nearly orbicular, obtuse at summit, flared out in the middle, narrowed to the base; leaf-substance very thin; midnerve slender, attenuated to wards the summit; lateral nerves very slender, going off very obliquely, and curving in a circular manner towards the tip of the leaf, opposite, connected by transverse nerves, that go off nearly at right angles and make quadrangular subrhombic meshes; ultimate reticulation not seen.

Localities: Belt and Covington streets, Baltimore.

These leaves are quite common at the Baltimore localities. In shape and nervation they are much like the living plant Celastrus nutans. The leaf given in Pl. CLXXIII, Fig. 13, is a good deal like C. arcinerve in the peculiar nervation, but it is smaller and more delicate.

Celastrophyllum tenuinerve, sp. nov.

Plate CLXXII, Fig. 2.

Leaf very small, probably orbicular in shape, rounded abruptly at base; midnerve comparatively strong; primary nerves imperfectly shown, very slender, going off at rather a large angle, tending outwards and then up- 
wards, branching apparently in a dichotomons manner; ultimate reticulation not seen; leaf-substance very thin.

Locality: Covington street, Baltimore; very rare.

Celastrophyllum obovatum, sp. nov.

Plate CLXXII, Figs. 9, 10.

Leaf-substance very thin; leaves small, rounded, and very obtuse at summit, narrowed gradually to the base, obovate in shape ; midnerve strong at base, much attenuated towards the stummit; lateral nerves very slender, going off very obliquely and curving around towards the summit, flextous in their course and sending off obliquely branches which connect either with other branches or with the primaries, forming large, elongate, subrhombic meshes; ultimate nervation not seen.

Localities: Belt and Covington streets, Baltimore; not uncommon.

This leaf is much like that of Euonymus frigidus. It is also like that of Celastrus obovatus, but the nervation is different.

\section{QUERCOPHYLLUM, gen. nov.}

Leaves small, wedge-shaped at base; leaf-substance thick, with strong ovate teeth directed forwards; midnerve strong at base, rapidly attentuated above; lateral or primary nerves sometimes slender, going off very obliquely and curving forwards, forking dichotomously; ultimate nervation not seen.

The leaves placed in this genus, from their affinity with Quercus, are rare and nnimportant, since they play but a very small part in the Potonrac flora. The amount of material found is too small, and the degree of preservation too poor, to permit their character to be definitely fixed.

\section{QUERCOPHYLLUM GROSSEDENTATUM, sp. nov.}

Plate CLVI, Fig. 9.

Leaf small, entire shape not shown; margin furnished witl very large ovate, acute, unequal teeth, that are turned upwards ; midnerve quite strong towards the base, much attentated above, and splitting up into the primary nerves; primary nerves subopposite, strong at base, forking dichotomonsly.

Locality: $72 \mathrm{~d}$ mile post, near Brooke; found in only one specimen. 
QUercophyllum tenuinerve, sp. nov.

Plate CALIX, Nigs. 6, 7 .

Leaves elliptical, narrowed towards the apex and base, wedge-shaped at base; margins beginning some distance from the base, serrate-toothed, with the teeth directed forwards; midnerve strong towards the base; primary nerves very slender, going off at a very acute angle, and arching forwards to end in the teeth, sending off obliquely on each side alternate, very slender, subordinate nerres; ultimate reticulation not seen.

Locality: Fredericksburg; quite rare.

\section{VITIPHYLLUM (Cissites?), gen. nov.}

Leaves small, approximately fan-shaped, cut to different depths into obtuse, flabellately arranged lobes of varying shapes and size; nerves mostly radiating from the top of the petiole, the main ones generally three in number, the middle one being the strongest; petioles very long and comparatively stout. The leaves, which I group under this head from their general resemblance to Vitis, form a very considerable element in the Potomac flora as found in the beds at Baltimore. They are abundant there and are the most common plants at that locality. They have most affinity with some of the fossils described by authors under the name Cissites.

\section{VITIPHYLLUM CRASSIFOLIUM, sp. nov.}

Plate CL, Figs. 9, 10.

Form of leaves not made out, as only segments were seen; principal segments of comparatirely large size, incised obliquely into oblong-obtuse lobes, which in turn are notched at the summit to form two or three shallow obtuse lobes; nerves going off obliquely one into each main lobe, slender and imperfectly shown, only one branch seen in each lobe; leafsubstance very thick; ultimate nervation not seen.

Locality: Road-side near Potomac Run; very rare.

The specimens shown in Figs. 9, 10, seem to be fragments of principal or primary segments of the leaf, probably the middle one. 


\section{Vitiphyllum PARVIFol.Jum, sp. nov.}

Plate CLXXII, Figs. 11, 12.

Leaves very small, arranged alternately and rather remotely on very Iong and proportionally stout petioles, more or less fan-shaped, quite variable in form and size, cut down to near the base into three main lobes, and these subdivided again towards the summit into lobes or teeth, which diverge slightly; primary nerves three, radiating from the summit of the petiole, the middle one being the strongest, each going into a main lobe : the primary nerves send off obliquely branches which go into the subordinate lobes or teeth.

Localities: Belt and Corington streets, Baltimore; rare.

This is a very peculiar Cissus-like leaf, which in some of its forms is not unlike Synaphaca polymorpha R. Br.

\section{Vitiphyllum multifidum, sp. nov.}

Plate CLXXIII, Figs. 1-9.

Leaves small, varying a good deal in size and shape, broadly fanshaped to subrotundate, more or less heart-shaped at base, cut generally pretty deeply into three principal lobes separated by sinuses that turn slightly outwards; these in turn are subdivided rarionsly; in the larger leaves they are cut into subordinate lobes that are like the principal ones, but are cut less deeply; the larger lobes terminate in shallow lobes or teeth that are mostly bluntly rounded off or emarginate; primary nerves normally radiating flabellately from near the base of the leaf and going into the principal lobes, the lowest ones being smallest and increasing inwards to the central one, which is the largest; the primaries sending off obliquely branches on each side which go into the ultimate lobes and teeth; reticulation not seen; leaf-substance quite thick; petiole very long and proportionally quite stout.

Localities: Belt and Covington streets, Baltimore; very common.

This plant is the most common angiosperm at the two Baltimore localities. Some of the leaves must have attained proportionally a considerable 
size, as indicated by Pl. CLXXIII, Fig. 2. That shown in Fig. 5 of the same plate seems in lobing and nervation somewhat different from the others.

\section{MYRICA L.}

The genus Myrica is represented in the Potomac flora by only one donbtful species, and this is exceedingly rare.

\section{Mrrica Brookensis, sp. nov. \\ Plate CL, Fig. 11 ; Plate CLVI, Fig. 10.}

Leaves quite small, elliptical in outline, acute, narrowed to the base, pinnate, margins beginning a little above the base, serrated with small acute teeth directed forwards; petiole quite short; midrib rather stont at base, much and rapidly attennated above; primary nerves slender, leaving the midrib obliqnely curving upwards and following the margins for some distance, connected with one another by nerves that go off nearly at right angles: ultimate nerres not seen.

Locality: 72d mile-post, near Brooke; very rare.

\section{BOMBAX L.}

This genus also has one donbtful and very sparingly developed species. The leaf placed in this genus occurs very rarely.

\section{Bombax Virginiensis, sp. nov.}

Plate CLI, Fig. 4.

Leaf small, oblong, tip not seen, elliptically rounded at base; midnerve slender; petiole long, slender, and curved to one side, both distinet and prominent; leaf-substance thick and leathery; lateral primary nerves going off nearly at right angles, forking about midway in the leaf, sending nerves backwards and forwards, which unite to form pentagonal spaces, from the angles of which branches go off nearly perpendicularly towards the margins. 
Locality: $72 \mathrm{~d}$ mile-post, near Brooke; very rare.

This plant resembles Velenovsky's Bombax argillaceum. ${ }^{1}$ It also resembles in some points Sapindopsis.

\section{POPULOPHYLLUM, gen. nov. .}

Leaves rotundate; petiole thick and apparently somewhat succulent; nerves tending to a radiate grouping from the summit of the petiole; midnerve not much surpassing in strength the nerves which go off on each side of it.

The leaves, which I place in this genus from their resemblance to Populus, are too fragmentary to permit their precise determination. They are always rare, and form no important element of the flora.

Populophyllum reniforme, sp. nov.

Plate CLV, Fig. 9 ; Plate CLVI, Fig. 3.

Leaves small, reniform, margins crenate; petiole thick and apparently succulent; midnerve hardly stronger than the lateral nerves; primary nerves radiating from the base of the leaf, forking freely, and anastomosing to form irregular, elongate, subrhombic, or pentagonal meshes; leaf-substance rather thick.

Locality: 72d mile-post, near Brooke; quite rare.

This plant is like Protecphlyllum reniforme, but the margins are slightly crenate, and it has a more pronounced midnerve. It is a good deal like Populus retusa, ${ }^{2}$ Heer, from Cape Lyell.

Populophyllum hedereforme, sp. nov.

Plate CLXVI, Fig. 3.

Leaf angular and polygonal in outline, small, entire shape not seen; leaf-substance thick and glossy; petiole thick and long, apparently somewhat succulent; no midnerve seen; primary nerves of nearly equal strength, radiating from the base of the leaf and forking higher up; ultimate nervation not seen.

Locality: $72 \mathrm{~d}$ mile-post; very rare.

' Die Flor. der böhm. Kreideform., pt. 2, Pl. IV, Figs, 6-9.

${ }^{2}$ Flor. Foss. Arctica, vol. 4, pt. 1, Beitrïge zur foss. Flor. Spitzbergens, Pl. XIV, Figs, 6, 7. 
This plant is very much like some species of Populus, especially in its petiole, which indicates a tremulons leaf.

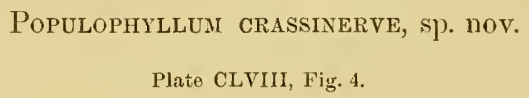

Leaf too fragmentary to make out its shape, but apparently very large; midnerve not much surpassing the size of the lowest primary nerves that go off on each side of it, and which, apparently with the midrib, radiate from the base of the leaf; the lowest lateral primaries and the midnerve in its upper portion send off very obliquely strong subordinate nerres, which in turn branch, but the further subdivision could not be followed; the minor nervation not seen.

Locality: Deep Bottom; very rare.

This leaf differs in the pronounced midnerve and the strong nervation from the other species of the genus. Possibly it may be a different genus, but in general character it is most like Populus.

\section{ULMIPHYLLUM, gen. nov.}

Leaves too imperfectly shown in most cases for the shape to be made out; midnerve comparatively strong. and prominent; lateral or primary nerves opposite or subopposite, strong, and prominent, proceeding straight and parallel to near the margin.

The leaves placed under this head belong to only a few species and furnish but few specimens. They have some of the features of Quercus, but are on the whole nearer to Ulmus.

Ulmiphyllum Brookense, sp. nov.

Plate CLV, Fig. 8; Plate CLXIII, Fig. 7.

Leaves small, oval in shape, subacute; margins cut into subacute shallow teeth that are mostly donble; midnerve very strong; lateral primary nerves going off very obliquely, subopposite, directed upwards, nearly straight and parallel in their course to the margin, the basal pair being considerably the strongest and most branched; the primary nerves 
send off obliquely on both sides branches, the largest on the lower side; ultimate branches sent off nearly at right angles from these and from the midnerve, which meet under a large angle to form the ultimate reticulation; this composed of irregular, three to five sided, distinctly marked meshes; from the base of the lowest primaries on the lower side two strong lateral nerves go off.

Locality : 72d mile-post, near Brooke; rare.

ULMiPHYLLUM TENUINERVE, sp. nov.

Plate CLVIII, Fig. 1.

The leaf is too fragmentary to make out its shape; midnerve distinct but small; lateral primary nerves going off at equal and regular intervals, opposite, and oblique, proceeding straight and parallel towards the margin; branches going off at angles varying from $45^{\circ}$ to $90^{\circ}$ from the primaries meet and sometimes form a pretty continuons intermediate comecting ultimate nerve; ultimate reticulation slender, and composed of meshes that vary much in size and shape, being angular and four to six sided.

Locality: 72d mile-post, near Brooke; very rare.

The arrangement of the primaries in this species. is much like that in $U$. crassinerve, but the ultimate nervation is quite different.

\section{ULMIPHYLLUM CRASSINERVE, sp. nov.}

Plate CLVIII, Figs. 6, 7.

Leaf apparently large, form not made ont; midnerve moderately strong but very distinct; lateral primary nerves comparatively thick and very distinct, leaving at an angle of $45^{\circ}$, opposite, going straight and parallel to the margin; the primary nerves send off at right angles branches that fork, with the branches diverging widely and anastomosing to form a very irregular net-work that varies much in size and shape; the meshes are mostly elongate, with their largest dimensions perpendicular to the primaries.

Locality: Deep Bottom; not very rare.

This leaf is much like Quercus of the Q. faginea type. 


\section{STERCULIA L.}

A good many of the leaves found in the Potomac flora appear to have some affinity with Sterculia, but only one species seems to be near enough to the genus to justify its being placed in it.

\section{Sterculia elegans, sp. nov.}

Plate CLVII, Fig. 2; Plate CLVIII, Figs. 2, 3.

Leaves palmately tripartite, the middle lobe largest, subrhombic in shape and acute; lateral lobes elliptical, acute, slightly curved upwards, with the lower margin towards the base more convex than the upper, so as to give the basal outline of the leaf a subcordate shape; a strong midnerve runs throngh the middle of each lobe, the three radiating from the base of the leaf; subordinate nervation not seen.

Locality: Deep Bottom; not very rare.

These leaves vary a good deal in size. The base of the leaf has the outline of some Sussufius. Pl. CLVII, Fig. 2, is a restonation of the leaf.

\section{ARALTA L.}

The genus Aralia, like Stcreulia, play's a very unimportant part in the Potomac flora, having, if present at all, only one very doubtful species.

Aralia dubia, sp. nov.

Plate CLVII, Figs. 1, 7.

Leaf-substance thick; shape of leaf not made ont; leaf divided for some distance down into oblong-elliptical lobes, which at tip are subacute and sometimes prolonged into a mucronate point, each lobe having one or two midnerves, and from these lateral nerves go off obliquely and remotely that arch strongly up towards the tips of the lobes, following the margin in their npper course; ultimate nervation not seen.

Locality: Deep Bottom; rare.

Pl. CLVII, Fig. 1, seems to represent the upper part of a lobe. In Fig. 7 the leaf seems to have been divided into four or five lobes. The right-hand segment, containing two midnerves, seems to be the central lobe, 
probably dividing higher up. The fragment on the left, partly covered by the main leaf, appears to be a detached lobe, which is wrinkled from pressure. The plant on the whole seems to be nearer to Aralia than to any other genus, but it is too poorly preserved to permit its character to be definitely fixed.

\section{JUGLANDIPHYLLUM, gen. nov.}

I place under this head a leaf that occurs rarely in the Potomac flora. Its affinities are doubtful, but it seems to be nearer to Juglans than to any other genus. The specific description gives the generic description also.

\section{JUGLANDIPHYLLUM INTEGRIFOLIUM, sp. nov.}

Plate CLVII, Figs. 3, 5, 6 .

Leaves of medinm size, bases not seen, tips oval in outline, prolonged into a tooth-like tip that is turned to one side; leaf-substance thin ; midnerve strong; primary lateral nerves strong and very distinct, going off at regular and equal distances alternately, parallel, arching forward to near the margin, where they are bent abruptly upwards, gradually approaching the margin, branches going off at a large angle from these and the midnerve and forking, making by their meeting a set of strong meshes, that are elongate, subrhombic, varying nuch in shape and size, and standing mostly at right angles to the main nerves with their longer dimensions; these meshes having sharp angles and very distinct; the ultimate reticulation (Fig. $6^{\text {a }}$ ) strong, being made by nerves which meet nearly at a right angle, the meshes four to six sided and rotundate.

Localities: Deep Bottom, comparatively common; White House Bluff; very rare.

This plant has some of the features of Persea, and in some respects it resembles some forms of Quercus.

\section{MYRICEPHYLLUM, gen. nov.}

This genus includes plants that stand nearer to Myyrica than to any other, yet are not near enough to be placed in that genus. Generic description same as the specific description given below. 


\section{MYricephyllum dentatum, sp. nov.}

Plate CLVI, Fig, 6.

Leaves small, linear-oblong, base and summit not seen; margins cut deeply into acute teeth that are turned forwards and often donble; leafsubstance thick, leaves quite narrow; midnerve strong; primary nervation not seen.

Locality: $72 \mathrm{~d}$ mile-post, near Brooke; very rare.

PLATANOPHYLLUM, gen. nov.

In this genus I place leaves that in general resemble Platanus, but which can not be certainly placed in that genus. The generic description, as there is only one species, is essentially the same as that of the species.

\section{Platanophyllum crassinerve, sp. nov.}

Plate CLVIII, Fig. 5.

Shape of leaf not seen, leaf apparently quite large; margins not preserved on any specimen; midnerve very strong, especially toward the base; basal pair of primaries much stronger than those higher, sending off on the lower side near the base a strong nerve; the primaries are arched strongly upwards and send off branches mainly on the lower side; branches going off vearly at right angles connect the primaries, and by forking freely and anastomosing they form subrhombic elongate meshes that stand with their longer dimensions nearly at right angles with the primaries.

Locality: Deep Bottom; very rare.

This plant, in the strong lower basal branches sent off from the lower primaries, resembles Aralicephyllum, but they are not so strong as in this genus. It also resembles Hedera platanoides Lesq.

\section{ARALI EPHYLLUM, gen. nov.}

Leaves more or less fan-shaped, divided more or less deeply into three principal lobes, the middle or terminal one subrhombic or elliptical in ontline, rapidly narrowed to an acute tip, and separated from the lateral lobes by broad sinuses rounded at the bottom; the lateral lobes divided into two 
minor lobes, one being larger than the other; the larger one ovate, sometimes inequilateral, and turned upwards; the outer or smaller one is ovate, and turned outwards; the primary nerves three, radiately diverging from the same or nearly the same point at the base of the leaf, going to the summit of each primary lobe; from the two lateral primaries a strong branch goes off a short distance above the base on the lower side and extends to the summit of the outer smaller lobes; all the primaries are strong, and send off on each side branches which curve up and anastomose; ultimate reticulation not seen.

These leaves are comprehensive in type and unite some of the characters of Liquidamber, Aralia, and Sassafras. In their primary nervation they resemble Sassafras recurvatum, ${ }^{1}$ Lesq. The lobing is a good deal like that of S. platanoides, Lesq. ${ }^{2}$ The mode of nervation resembles that of Liquidamber integrifolium, Lesq.

Araliephyllum obtusilobum, sp. nov.

Plate CLXIII, Figs. 1, 4; Plate CLXIV, Fig. 3.

Leaf-substance thick; leaves rather small, broad fan-shaped in outline, narrowed lapilly at base into the petiole, with a slight decurrence of the lamina on the petiole; petiole comparatively very stout, on entering the leaf split up into three strong primary nerves, which diverge palmately to go one into each principal lobe; some distance above the point of divergence a strong branch is sent out on the lower side of each lateral primary to go into the ontermost and smallest lobes; middle lobes broadly elliptical, separated from the lateral ones by sinuses that are rounded at base, obtuse or subacute; lateral principal lobes ovate, or oblong-obtuse, or subacute; sometimes inequilateral and curved slightly upwards; minor lateral lobes separated from the main ones by wedge-shaped sinuses turned ontwards, broadly ovate, obtuse, or subacute; branches of small size go off from the primaries ligher in the leaf in an oblique manner, and curve upwards towards the ends of the lobes.

Locality: $72 \mathrm{~d}$ mile-post, near Brooke; quite rare.

${ }^{1}$ Cretaceons aud Tertiary Floras, p. 57 ; Cretaceous Flora, Pl. X, Fig. 3.

${ }^{2}$ Cretaceous and Tertiary Floras, PI. VII, Fig.1. 
Pl. CLXIII, Fig. 1, differs in several points from Pl. CLXIV, Fig. 3, being more like Ar: acutilobum.

\section{Araliephyllum aCUTilobum, sp. nov.}

Plate CLXIII, Fig. 2.

Leaves small, broad fan-shaped, rounded off rapidly at base; leaf-substance thick; primary nerves comparatively strong and distinct, the middle one the strongest, three in number, radiating from the base of the leaf; leaves cut into three principal lobes; the middle lobe narrowed at the base, flared out in the middle, and narrowed again towards the tip so as to be broadly elliptical in outline, considerably larger than the lateral ones, separaterl from the latter by a sinus that is directed outwards and widest at the base; main lateral lobes turned at first outwards and then curved slightly upwards, inequilateral, with a very convex outer margin furmished with a short acute tip, almost mucronate; these main lateral lobes towards the base of the leaf incised into an ovate, subacnte, short lobe that is turned outwards and slightly downwards; the outer primary nerves, near their base, send off a strong branch on the lower side that goes into the outermost small lobe or tooth; reticulation not seen.

Locality: $72 \mathrm{~d}$ mile-post, near Brooke; very rare.

This plant is a good deal like the preceding species, but seems to be distinct from it.

Aralitephyllum magnifolium, sp. nov.

Plate CLIX, Figs. 9, 10.

Leaf very large, but the specimens found are too fragmentary to make out the shape; nerves seen, especially the primaries, very strong: the primaries, three in number, radiating from the same point at the base of the leaf, the middle one being the strongest; the lateral or ontermost primaries send off some distance above their base a strong nerve on the lower side; the branches sent off by them higher are not so strong; the arrangement of these principal nerves indicates that the lobing of the leaf is similar to that of the preceding species. 
Locality: $72 \mathrm{~d}$ mile-post, near Brooke; very rare.

In Fig. 9, in the right-hand upper portion of the fragment, at (a), we have apparently a portion of the original sinus and margins of the lobes preserved, as well as a part of the right lateral main lobe. This shows that the leaf must have been quite large. In Fig. 10, at (a), in the righthand basal portion of the leaf, we have apparently a portion of the original basal margin, indicating that the lower part of the leaves was shaped like that portion of the preceding species.

\section{Aralitephyllum aCeroides, sp. nov.}

Plate CLVI, Fig. 11 ; Plate CLXII, Fig. ..

Leaf large, approximately fan-shaped, ent pretty deeply into three large lobes, the lateral ones about half-way down to the base cut on the outer margin into a slallow, acnte, tooth-like lobe, simlar to those of Liriodendion; the middle and largest lobe not preserved, but apparently shaped like that of the other species of the genus-that is, it was broadly elliptical and flared out in the middle, being narrowed to the base and summit; separated from the main lateral lobes by a sinus that is turned slightly outwards and is broadest at the bottom; the main lateral lobes above the tooth-like lobe inequilateral, slightly convex on the upper margin, with the lower one very convex, turned upwards, and ending in a subacute tip; three principal strong nerves diverge from the base of the leaf, one going into each principal lobe, the middle one being the strongest; the two onter lateral primaries send off on their lower side, some distance from and at the same height above their divergence, a strong branch that curves upwards to enter the lateral tooth-like lobe; the primaries send off at points higher smaller branches nearly at right angles, which curve upwards and branch. The lateral primaries send off on the outer side the largest branches.

Locality: 72d mile-post, near Brooke; very rare.

This splendid leaf differs in some respects from the previonsly described species of Aralicophyllum, more especially in the peculiar shape and smaller size of the subordinate lateral lobe, but it is so close to them - in essential points that it cannot be separated and placed in a distinct 
genus. This, more than any other species of the genns, shows a markedly comprehensive character. The general shape of the leaf and the position of the lobes remind one strongly of Sassafiras. It is also a good deal like some species of Acer. The small outermost lobes are strikingly like those of Liriodendron. Its generic affinities are with Aralia.

\section{HYIENÆA L.}

The genus Hymenca appears to be represented by one well-characterized species, which, lowever, so far as seen, shows very few individuals. It should, however, be stated that most of the well-preserved species of angiosperms from the 72d mile-post, near Brooke, such as those of Sassafras, Aralicephyllum, Hymencea, Menispermites, Hederephlyllum, etc., are obtained from the thin layer of well laminated clay before deseribed. As nearly all these plants are found nowhere but in this layer, and as the amount of material obtained from it was very small, the apparent rarity of these fossils may result solely from this fact, and statements concerning the abundance of the specimens should be made with this qualification.

\section{Hyuenea Virginiensis, sp. nov.}

Plate CLXIII, Fig. 6.

Upper part of the leaves not seen; towards the base they are narrowed into an elliptical shape; leaves in pairs at the summit of the petiole; petiole very strong; midnerves of the leaves strong and prominent; lateral nerves not seen; leaf-substance thick; epidermis thick and glossy; the right-hand leaf is considerably larger than the left-hand one; the midnerves of the leaves do not run through the centers of the leaves, the outer portion of the lamina being wider:

Locality: $72 d$ mile-post, near Brooke; rare.

This planit is a good deal like Hymencea primigenia ${ }^{1}$ Saporta, as figmred by Velenorsky, but the leaves are wider at base.

ACERIPHILLUII, gen. nov.

This genus is formed to contain a species of comprehensive type which stands nearer to Acer than to any other, but still differs too much to permit

${ }^{1}$ Flor. đer böhm. Kreideform., pt. 2, Pl. VI, Fig. 4. 
its being united with it. The generic character is the same with that of the species.

$$
\begin{aligned}
& \text { ACERIPH yllum ARALIOIDES, sp. nov. } \\
& \text { Plate CLXIII, Fig. } 8 .
\end{aligned}
$$

Leaves of medium size, in outline fan-shaped, at base subcordate, lamina of the leaf slightly decurrent, cut deeply into three lobes, the lateral ones slightly overlapping the middle one; the middle lobe the largest and prolonged considerably beyond the lateral ones, broadly elliptical, much narrowed at the base, flared out in the middle and rounded off to a subacute end, separated from the lateral ones by a sinus which is widest at bottom and directed outwards; lateral lobes ovate-subacute, turned upwards and slightly outwards; the upper margin of the lateral lobes convex and directed outward; the outer margin, in its upper portion, nearly straight and directed towards the summit of the leaf; the primary nerves, three in number, the middle one considerably the largest, radiating from the base of the leaf and going one into each lobe; they send off alternately and obliquely branches which curve upwards; the lateral primaries send off much stronger branches on the lower than on the upper side, and the basal one on each side, as in Aralicephyllum, much surpasses the others: ultimate reticulation not seen.

Locality: $72 \mathrm{~d}$ mile-post; very rare.

This elegant leaf is a remarkably comprehensive type, combining features of Acer, Sterculia, Sassafras, and Aralia. It reminds one strongly of Aralicephyllum, but lacks the subordinate lateral lobes.

\section{MENISPERMITES Lesq.}

This genus, like most of the angiosperms of modern type, has but few specimens in the Potomac beds; possibly, as before stated, because the strata that contain them chiefly have yielded very little material.

\section{Menispermites Virginiensis, sp. nov.}

Plate CLXI, Figs. 1, 2.

Leaves large, orbicular in shape, with margins undulate or obscurely crenulate; leaf-substance moderately thick; nerves (primary) numerous, MON $\mathrm{XV}-21$ 
radiating from a point considerably above the base, principal ones turned upwards, lesser ones turned outwards, and the smallest turned downwards ; primary nerves send off branches very obliquely, so that they appear almost dichotomons; the primary reticulation, formed by branches from these sent off nearly at right angles, is composed of large, irregularly shaped meshes, mostly four or five sided, made by the meeting of branches nearly at a right angle; the ultimate reticulation is similar but smaller.

Locality: $72 \mathrm{~d}$ mile-post, near Brooke; very rare.

This fine leaf is a good deal like the living Menispermum Canadense, but wants the acute summit of that leaf. The base of the fossil is not shown with sufficient distinctness to make it perfectly clear whether the leaf is peltate or not. It seems to be deeply auriculate, the auricles overlapping largely. It occurs in the same stratum with the fine specimens of Taxodium, Brookense, Aralicephylhum, Aceriphyllum, Sassaficas, etc.

\section{Menispermites tenUinervis, sp. nov.}

Plate CLXXII, Fig. 8.

Leaf small, orbicular in shape, subpeltate; leaf substance very thick; nerves very obscure and slender, only three seen, radiating from a point some distance above the base of the leaf.

Locality: Covington street, Baltimore; very rare.

This plant looks something like a Lemna. The leaf is much smaller than that of $M$. Virginiensis.

\section{ARISTOLOCHIÆPHYLLUM, gen. nov.}

I place in this genus certain fragments which apparently belonged to a large, rather coarse leaf, which has a strong likeness in its nervation to Aristolochia. The fragments are too imperfect to permit the shape of the leaf to be made out, but it was apparently similar to that of some species of this genus.

Aristolochieferyllum CRASSINERve, sp. nov.

Plate CLX, Figs. 3-6.

Shape of leaf not seen; the leaves were apparently large and rather coarse; leaf-substance thick; petiole and primary nerves very strong and 
woody; subordinate nerves strong and cord-like, ultimate reticulation strong, with the nerves prominent and thread-like; primary nerves go off from the midnerve at an angle of about $45^{\circ}$, sweeping around to form bow-shaped curves; they send off branches nearly at right angles, which anastomose to form irregularly shaped, strongly defined meshes filled by an ultimate reticulation which is very distinct and prominent, formed by nerves meeting nearly at right angles.

Locality: 72d mile-post, near Brooke; rather common.

This plant has a nervation so prominent and well characterized that a small bit of it may be readily recognized. The fragments are so much broken that little idea can be gotten from them of the shape of the leaf. They occur in the redeposited sand and clay. The fragmentary condition of the fossils is perhaps partly due to the large size of the leaf. That shown in Fig. 3 seems to be a fragment from the central portion of the leaf. It may show a part of the midrib. That shown in Fig. 6 seems to come from the lower left-hand portion of the leaf, apparently being a portion of a basal auricle which is pressed against what seems to be a part of the petiole. This part of the leaf seems to have been crushed against the petiole so as to cause the leaf to donble over on itself. The great size of the petiole and that of the primary nerve in this figure indicate that the leaf must have been very large. Fig. 5 seems to represent a fragment of the midrib, or of a large primary nerve; Fig. 4 gives a fragment apparently from a basal auricle, magnified three diameters to show the nervation.

\section{HEDERAPHYLLUM, gen. nov.}

The two species placed in this genus have the general character of Hedera, but do not agree with it closely enough to unite them with this genus. They apparently were but slightly developed, if we may judge from the few specimens found.

The genus may be characterized as containing leaves of rather small size, rotundate in form, with nerves radiating from the base of the leaf, the middle one being the strongest; petioles long and moderately strong; leaf-substance thick. 
Heder fipyllum crenulatum, sp. nov.

Plate CLXII, Fig. 3.

Leaf rather small, probably rotundate, with subcordate base, shape not fully shown; margins undnlate to crenate; leaf-substance thick; petiole and lower portion of the midrib comparatively strong; midnerve rapidly diminishing above: primary nerves radiating from the top of the petiole, the middle one the strongest; on each side of the midnerve, at its base, a strong lateral nerve goes off and proceeds obliquely upwards to near the margin ; this sends off from its base a strong, much divided branch, which turus outwards and downwards; both this and the main lateral nerve from which it proceeds forked often, the branches flabellately diverging; reticulation not seen.

Locality: $72 \mathrm{~d}$ mile-post, near Brooke; very rare.

This plant is a good deal like some forms of Populophyllum, but the nervation, although different in some details from the species next to be described, is essentially the same. In this the branches go off much more obliquely, and the basal outermost branch is proportionally much larger. The leaf is much like some of those of Hedera Helix.

\section{Heder a PHyllum angulatum, sp. nov.}

Plate CLXII, Fig. 1.

Leaf-substance thick and glossy; leaf small, with margins straight, and at intervals bending abruptly, forming right angles or larger angles with the former direction, the lower margin nearly at right angles with the petiole and turning slightly downwards; shape of the lower part of the leaf polygonal; terminal lobe incomplete, so that its shape can not be made out; on each side of it a broad tooth or lobe like the lateral one of Liriodendron occurs, separated from the terminal one by a broad sinus, so that the upper margin of the lateral lobe has a direction nearly at right angles with the midrib; petiole long, rather slender, but distinct; primary nerves radiating from the top of the petiole at the base of the leaf, in type similar to that of Aralicephyllum. There are three primaries; the middle and principal one proceeds to the tip of the leaf, and the two lateral ones to the lateral 
lobes; these latter sending off from near their base on the outer side two strong branches, and these and the primaries higher up sending off slender branches nearly at right angles that anastomose; reticulation not seen.

Locality: $72 \mathrm{~d}$ mile-post, near Brooke; only one specimen seen.

This leaf also belongs to a comprehensive type, but does not combine the features of so many different leaves as the preceding. It unites the features of Aralicephyllum, Hedera, and Liriodendron.

\title{
EUCALYPTOPHYLLUM, gen. nov.
}

This genus contains only one species, whose character, owing to the scantiness of material and the imperfection of the specimens, cannot be further characterized than as having a near affinity with Eucalyptus.

EuCALYPTOPHyLlum obloNgifolium, sp. nov.

Plate CLXII, Fig. 4.

Leaves small, oblong, base and summit not seen; midnerve comparatively strong; lateral nerves very slender, crowded, going off obliquely, flexuous, and branching copiously; the ultimate branches form a closely crowded reticulation, composed of elongate, subrhombic meshes, that stand nearly at right angles with the midrib; all the nerves are very slender.

Locality: 72d mile-post, near Brooke; very rare.

This leaf is something like Tristania laurina, R. Brown.

\author{
PHYLLITES Brongn. \\ Phyllites pachyphyllus, sp. nov. \\ Plate CXLIX, Fig. 2.
}

Leaf small, apparently spatulate in shape, flared out a little below the middle, broad, and rounded at the summit, and gradually narrowed towards the base; leaf-substance very thick; midnerve quite strong; nervation not seen.

Locality: Fredericksburg; only one specimen found.

This leaf shows no characters that can serve to place it in any particular genus. 


\section{GENERAL REMARKS AND CONCLUSIONS.}

The following list gives all the different fossil plants found in the Potomac formation of which figures and descriptions are given in this work :

\section{LIST OF POTOYAC FOSSIL PLANTS.}

\section{CRYPTOGAMS. EQUISETER.}

Equisetuar L.

1. E. Virginienm, sp. nov ..............

2. E. Lyelli Mantell ..................

3. E. Marylandicum, sp. nor..........

3a. Equisetum, sp ....................

3b. Equisetum, sp ....................

\section{Filices.}

Cladolphlebis Brongu., ex parte.

4. C. constricta, sp. nov ...............

5. C. latifolia, sp. nov .................

6. C. Virginiensis, sp. nov..............

7. C. denticulata, sp. nov ...............

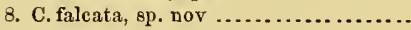

9. C. parva, sp. nov .....................

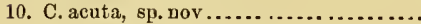

11. C. oblongifolia, sp. nov ...............

12. C. crenata, sp. nov.................

13. C. species ? , sp. nov ..................

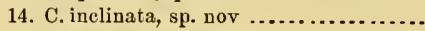

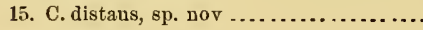

16. C. species ? , sp, nov ..................

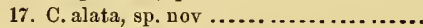

18. C. species ?, sp. nov ..................

19. C. rotundata, sp. nov ..................

20. C. sphenopteroides, sp. nov ...........

21. C. petiolata, sp. nov ................

22. C. inæquiloba, sp. nov ................

23. C. pachyphylla, sp. nov ..............

24. C. brevipennis, sp. nov..............

25. C. species ?, sp. nov.

\section{Pecopteris Brong.}

26. P. Virginiensis, sp. nov

27. P. strictinervis, sp. nov

28. P. ovatodentata, sp. nor ..............

29. P. microdonta, sp. nov .............

30. P. constricta, sp. nov .................

31. P. brevipennis, sp. nov ...............

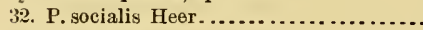

33. P. angustipennis, sp. nov ............

34. P. Browniana Dunker....................

35. P. pachyphylla, sp. nov
SPHENOPTERIS Brong. Page.

36. S. thyrsopteroides, sp. nov .......... 89

37. S. acrodentata, sp. nov.............. 90

38. S. latiloba, sp. nov................. 90

39. S. Mantelli Brongn .................. 91

40. S. spatulata, sp. nov .............. 93

41. S. pachyphylla, sp. nov ............ 93

Aspidium Sw.

42. A. Fredericksburgense, sp. nov ........ 94

43. A. ellipticum, sp. nov .............. 95

44. A. heterophyllum, sp. nov........... 96

45. A. Virginieum, sp. nov.............. 97

46. A. angustipinnatum, sp. nov ......... 98

47. A. cystopteroides, sp. nov ............ 99

48. A. Oerstedi Heer.................... 99

49. A. olslongifolium, sp. nov........... 100

50. A. parvifolium, sp. nov ............... 100

51. A. pinnatifidum, sp. nov............ 101

52. A. Dunkeri Schimper, sp............ 101

53. A. deutatum, sp. nov.............. 102

54. A. macrocarpim, sp. nov ............ 103

55. A. microcarpum, sp. nov ............ 103

\section{Poly Podium L.}

56. P. fadyenioides, sp. nov............ 104 57. P. dentatnm, sp. nor ............. 105

\section{Achostichum L.}

58. A. crassifolium,sp. nov ............. 105

ACROSTICHOPTERIS gen. nov.

59. A. longipennis, sp. nov ............. 107 60. A. densifolia, sp. nov .............. 107

61. A. parvifolia, sp. nov .............. 108

62. A. parcelobata, sp. nov............... 108

63. A. cyclopteroides, sp. nov............ 109

\section{Asplenium $\mathrm{L}$.}

64. A. dubium, sp. nov............... 109

Thinnfeldia Ett. ex parte.

65. T. variabilis, sp. nov............. 110

66. T. granulata, sp. nov ............... 111

67. T. rotnndiloba, sp. nov............ 111 


\section{STENOPTERIS Saporta.}

68. S. Virginica, sp. nov

\section{Angiopteridiun Schimper.}

69. A. auricnlatum, sp. nov ..............

70. A. nervosum, sp. nor.

71. A. ellipticum, sp. nov.

1. A. ellipticime sp. nov. ................

nsinerve, sp. nov ................

73. A. pachyphyllum, sp. nov............

74. A. ovatum, sp. nov ................

75. A. strictinerve, sp. nov..............

76. A. strictinerve, var. latifolium, sp. nov.

77. A. dentatum, sp. nov

AsPLENIOPTERIS, gen. not.

78. A. pinnatifida, sp. nov

79. A. adiantifolia, sp. nov .............

\section{Gleichenia Sw.}

80. G. Nordenskiol,li, Heer.

81. Undeterwined fern, sp. nov ...........

\section{THYRsopteris Kunze.}

82. T. Virgiuica, sp.nov

83. T. brevifolia, sp nov.

84. T. dentata, sp, nov.................

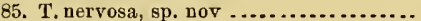

86. T. rarinervis, sp. nov ...............

87. T. brevipennis, sp. nov..............

88. 'T'. alata, sp. nov ....................

89. T. divaricata, sp. nov ................

90. T. Meekiana, sp. nov ................

91. T. Meekiana, var, angustiloba, sp. nov..

92. T. crenata, sp. nov ................

93. T. insignis, sp. nov ................

94. T. insignis, var. angustipennis, sp. nov..

95. T. densifolia, sp. nov ................

96. T. erassinervis, sp. nov..............

97. T. decurrens, sp. nov...............

98. T. angustifolia, sp. nov ..............

99. T. microphylla, sp. nov..............

100. T. pachyrachis, sp. nov .............

101. T. elliptica, sp. nov .................

102. T. distans, sp. nov .................

103. T. angustiloba, sp. nov ...............

104. T. pachsphylla, sp. nov ..............

105. T. pecopteroides, sp. nor .............

106. T. pinnatifida, sp. vov ...............

107. T. heteronorpha, sp. nov .............

108. T. varians, sp. nov ..................

109. T. rhombifolia, sp. nov ...............

110. T. heteroloba, sp. nov ...............

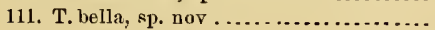

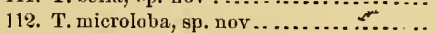

ThYrsopteris Kunze-Continued.

Page. 114. T. nana, sp. nov ..... 140

115. T. inæquipinnata, sp. nov........... 142

116. T. beterophylla, sp. nov............ 142

117. T. obtusiloba, sp. nov .............. 143

118. T. sphenopteroides, sp, nov ......... 143

119. T. squarrosa, sp. nov............... 143

120. T. rhombiloba, sp. nov............. 144

121. T. retusa, sp. nov .................. 144

$121 b$. Undetermined fern.............. 145

\section{Osuunda L.}

122. O. sphenopteroides, sp. nov .......... 145 123. O. Dicksonioides, sp. nov ............. 146 124. O. Dicksonioides, var. latipennıs, sp. nov 147

\section{Sagenopteris Pr.}

125. S. latifolia, sp. nov................. 148 126. S. elliptica, sp. nov ................ 149 127. S. Virginiensis, sp. nov............. 150

\section{SCLEROPTERIS Saporta.}

128. S. elliptica, sp. nov ................. 151

129. S. elliptica, var. longifolia, sp. nov .... 152

130. S. Virginica, sp. nov ............... 152

131. S. dentata, sp. nov............... 153

\section{Ctenopteris Brongn.}

132. C. iusignis, sp. nov ............... 156

133. C. Virginiensis, sp. nov ............. 157

134. C. minor, sp. nov .................. 157

135. C. integrifolia, sp. nov ............... 158

136. C. angustifolia, sp. nov .............. 159

137. C. löngifolia, sp. nov ............... 159

ZAMIOPSIs, gen. nov.

138. Z. pinnatifida, sp. nov .............. 161

139. Z. insignis, sp. nov .................. 162

140. Z. longipennis, sp. nov .............. 164

141. Z. laciniata, sp, nov ................. 164

142. Z. petiolata, sp. nov ............... 166

\section{PHANEROGAMS.}

GYMNOSPERMA.

ZAMIEA.

ANOMOZAMITES Schimper.

143. A. angustifolius, sp. nov ............ 167

144. A. Virginicus, sp. nov .............. 168 
Anomozanites (subgenus PlatypteriGIUs2) Schimper.

145. P. densinerve, sp. nov

146. P. Rogersianum, sp. nov .............

Zanites Brougn., emend.

147. Z. tenuinervis, sp. nov

148. Z. erassinervis, sp. nov ................

149. Z. distantinervis, sp. nov .............

150. Z. oralis, sp. nov ....................

151. Z. subfalcatus, sp. nov ................

151a. Z. species?

ENCEPHALARTOPSIs, gen, nov.

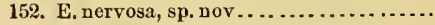

Ctenophyllum Schimper.

153. C. latifolinm, sp. nov ...............

GLossozanites Schimper.

154. G. distaus, sp. nov

Ctexis (Lind. \& Hut.) Zigno emend.

155. C. imbricata, sp. nov

Podozamites Fr. Braun., emend.

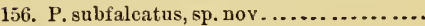

157. P. distantinervis, sp. nov .............

158. P. pedicellatus, sp. nov ..............

159. P. graudifolins, sp. nov ..............

160. P. acutifolius, sp. nov ................

\section{Dioonites Bornem.}

161. D. Buchianus Schimper.

162. D. Buchianus, var. obtusifolins, Sehimper, sp ........................

163. D. Buchianus, var. angustifolius, Schimper, sp .........................

Trsonia, gen. nov.

164. T. Marylandica, sp. nov

\section{CONIFERÆ.}

\section{NAGEIOPSIS, gen. nov.}

165. N. longifolia, sp. nov .................

166. N. zamioides, sp. nov .................

167. N. recurvata, sp, nov ................

168. N. crassicaulis, sp. nov ...............

169. N. latifolia, sp. nov
NAGEIOPSIs, gen. nov.-Continued.

Page.

170. N. decrescens, sp. nor .............. 199

171. N. ovata, sp. nov ................. 199

172. N. obtusifolia, sp. nov .............. 200

173. N. inæquilateralis, sp. nov ............ 200

174. N. acumiuata, sp. nov .............. 201

175. N. heterophrlla, sp. nov ............. 201

176. N. microphylla, sp. nov.............. 201

177. N. angustifolia, sp. nov............. 20.

178. N. subfalcata, sp. nov ............... 203

Phyllocladofsis, gen, nov.

179. P. heterophylla, sp. nov ........... 204

Feildeniopsis, gen. nov.

180. F. classinervis, sp. nov.............

BAIERopsis, gen. nov.

181. B. expansa, sp. nov ............... 207

182. B. pluripartita, sp. nov ............. 208

183. B. pluripartita, var. minor, sp. nov .... 208

184. B. foliosa, sp. nov ................. 209

185. B. denticulata, sp. nov .............. 210

186. B. denticulata, var. angustifolia, sp. nov. 210

187. B. longifolia, sp. nov .............. 210

188. B. adiautifolia, sp. nov............. 211

189. B. adiantifolia, var, minor, sp. nov.... 212

190. B. macrophylla, sp. nor ........... 212

BaIERA F. Braun, emend.

191. B. foliosa, sp. nov ................ 213

\section{Frenelopsis Schenk.}

192. F. ramosissina, sp, nov .

193. F parcerausosa, sp. nov ............

BRachyphyllum Brongn. ex parte, Schimper.

194. B. crassicaule, sp. nov ............. 221

195. B. parceramosum, sp. nov ........... 223

196. B. species ? (cone) ................. 2223

197. B. species ? (cone) ................. 224

198. B. species? (cone) ............... 224

\section{LeptostronUs Heer.}

199. L. longifolius, sp. nov .............. 228 200. L. foliosus, sp. nov ............... 230

201. L. ? multiflorus, sp. nov ............ 230

202. L. ? seed $(a)$ species $? . . . . . . . . . . . . \quad 231$

203. L. ? seed $(b)$ species ?................ 231

204. L. ? seed (c) species?.............. 232 
LARICOPSIS, gen. nov.

205. L. longifolia, sp. nov .

206. L angustifolia, sp. nov

207. L. brevifolia, sp. nov

TORREYA Arnott.

208. T. Virgiuica, sp. nov

209. T. ralcata, sp. nor

Cephalotaxopsis, gen. not.

210. C. magnifolia, sp. nov .............

211. C. ramosa, sp. nor ..................

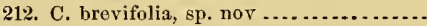

213. C. microphylla, sp. nov

Atir Rotaxopsis, gen. nov.

214. A. grandis, sp. nov ...

215. A tenuicaulis, sp. nov

216. A. expansa, sp. nov..

217. A. pachyphylla, sp. nov ............

\section{SEquora Torrey.}

218. S. eycadopsis, sp. nov

219. S. Reicbenbachi (Geinitz, sp.) Heer

220. S. Reicheubachi, var. longifolia, Heer, sp............................

221. S. subulata Heer ...................

2श2. S. ambigua Heer .... . . . . . . . . . . . . .

223. S. rigida Heer. ... . . . . . . . . . . . . . . .

224. S, densifolia, sp. nov ................

225. S. gracilis Heer . . . . . . . . . . . . . . . . .

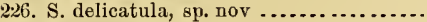

$22 \pi$. S. species?

228. S. species? ....... . . . . . . . . . . . .

229. S. species? .....................

\section{ARAUCARIA Juss.}

230. A. podocarpoides, sp. nov............

231. A. obtusifolia, sp. nov...............

232. A. zamioides, sp. nov ..............

Taxopium Rich. (GLyptostrobUs Endl.)

233. T. ramosum, sp. nov .

234. T. Virginicum, sp. nov

235. T. expansum, sp. nov

236. T. fastigiatum, sp. nov.............

237. T. denticulatum, sp. nov ............

238. Т. Brookense, sp. nov ................

239. T. Brookense, var. angustifolium, sp.

$$
\text { nov .......................... }
$$

Sphenolepidrux Heer (Sphenolepsis Schenk).

240. S. parceramosum, sp. nov

241. S. dentifolium, sp. nov
Page.
Sphenoleprduri Heer (Sphenolepsis Schenk)-Continued.

Page.

242. S. recurvifolium, sp. nor ............ 258

243. S. pachyphyllum, sp. nov .......... 259

244. S. virginicum. sp. nov .............. 259

245. S. Kurrianum (Dunk.) Heer..... . . . . . 260

246. S. Sterubergianum (Dunk. s[..) Heer... 261

247. S. Sternbergianum, var. densifclium,

Heer, sp.......................... 261

ABIETites.

248. A. macrocarpus, sp. nov........... 262 249. A. ellipticus, sp. nov ............... 263 250. A. angusticarpus, sp. nov ........... 263

Araucarites Sternb., emend.

251. A. Virginicus, sp, nov ............ 263 252. A. Aquiensis, sp. nov................ 264

\section{Carpolithus Sternb.}

253. C. fasciculatus, sp. not ............ 265

251. C. ternatus, sp. nov ............... 265

255. C. Virginiensis, sp. nov ............ 266

256. C. agglomeratus, sp. nov........... 267

257. C. conjugatus, sp. nov ............. 267

258. C. geminatus, sp. nov.............. 267

259. C. Brookeusis, sp. nov.............. 263

260. C. latus, sp. nov ................... 269

261. C. curvatus, sp.nor.............. 269

262. C. sessilis, sp. nov .................. 269

263. C. mucronatus, sp.nov............. 270

CrCadeospermun Saporta.

264. C. acutum, sp. nov ................. 270

265. C. obovatum, sp. nov.............. 270

266. C. spatulatum, sp. nov............. 271

267. C. ellipticum, sp. nov ............. 271

268. C. rotundatrim, sp. nov ............. 271

269. C. angustum, sp. nov ............... 271

AMENTS OF CONIFERS, etc., SPECIES UNDETERMINED.

270. Male (?) ament (a), species ? ......... $2: 25$

271. Male ament $(b)$, species ? ............

272. Male ament $(c)$, species ? ............ 226

273. Male ament $(d)$, species ?........... 22ti

274. Male ament $(e)$, species ?........... 226

275. Male ament $(f)$, Rpecies? .......... 227

276. Ament of angiosperm, species? ........ 272

277. Fruit capsules, species ?............ 272

278. Cone of Callitris?, sp. nor......... 272

279. Seed of Pinus ?, вp, nov ............. 272

280. Pollen sacs?, species ?.............. 272 


\section{Williamsonia Carr.}

281. Williamsonia Virginiensis, sp. nov....

\section{UNDETERMINED PLANTS.}

281a. Macrospores sp

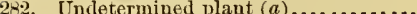

283. Undetermined plant $(b) \ldots \ldots \ldots \ldots$.

284. Undetermined plant (c).............

285. Undetermined plant $(d) \ldots \ldots \ldots \ldots$

286. Uudetermined plant $(c) \ldots \ldots \ldots \ldots \ldots$

28\%. Undetermined plant $(f) \ldots \ldots \ldots \ldots$.

238. Undetermined plant $(g) \ldots \ldots \ldots \ldots \ldots$.

289. Undetermined plant $(h) \ldots \ldots \ldots \ldots \ldots$

290. Undetermined plant (i) ..............

\section{ANGIOSPERMA.}

Conospermites Ett.

291. C. ellipticus, sp. nov

ACACI.EPHYLLUM, gen, nov.

292. A. longifolium, sp. nov ..............

:93. A. spatulatum, sp. nov...............

294. A, microphyllum, sp. nov.............

295. A. variabile, sp. nov ................

Proteephyllua, gen. nov.

296. P. reniforme, sp. nov

297. P. orbiculare, sp. nov ...............

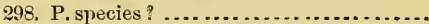

299. P. oblongifolinm, sp. nov ..............

300. P. ofatum, sp. nov ..................

301. P. ellipticum, sp. nov ................

302. P. tenuinerve, sp. nov..............

303. P. dentatum, $\mathrm{sp}$. nov ...............

\section{ROGERsia, gen. nov.}

304. R. longifolia, sp. nov ................

305. R. angustifolia, sp. nov..............

\section{Sassafras Nees.}

306. S. parvifolinm, sp. nov .

307. S. cretaceum Newb.,sp.var.heterolobum 308. S. bilobatum, sp. nov ...............

FicophyLlui, gen. nov.

309. F. crassinerve, sp. nov ................

310. F. tenuinerve, sp. nov ...............

311. F. serratum, sp. nov................

312. F. eucalyptoides, sp. nov.............

\section{Ficus Tournef.}

313. F. Virginiensis, sp. nov

314. F. Fredericksburcrensis, sp, nov
SAPINDOPSIS, gen. nov.

Page. 296

\section{SALICIPHYLLUM, gen. nov.}

323. S. Iongifolinm, sp. nov ............. 302

324. S. ellipticum, sp. nov ............... 303

325 . S. parvifolium, sp. nov ............. 303

\section{Celastrophyllum Ett.}

326. C. arcinerve, sp. nov ............... 304

327. C. proteoides, sp. nov................. 304

328. C. acutidens, sp. nov .............. 305

329. C. obtusidens, sp. nov ............... 305

330. C. Brookense, sp. nov ................ 305

331. C. dentienlatum, sp. nov ........... 306

332. C. latifolium, sp. nov ................ 306

333. C. tenuinerve, sp. now ............... 306

334. C. obovatum, sp. nov ............... 307

Quercophyllua, gen. nov.

335. Q. grossedentatum, sp. nov .......... 307

3336. Q. tenuinerve, sp. nov............... 308

VITIPHYLLUM (Cissites), gen. nov.

337. V. crassifolium, sp. nov ............. 308

338. V. parvifolium, sp. nov .............. 309

339. V. multifidum, sp. nov .............. $\quad 309$

\section{MYrica L.}

340. M. Brookensis, sp. nov ............... 310

\section{Bombax L.}

341, B. Virginiensis, sp. nov ..............

Populophyllum, gen. nov.

342. P. reniforme, sp. nov............... 311

343. P. hederaforme, sp. nov ............. 311

344. P. crassincrve, sp. nov.............. 312

UlarpHyLum, gen. nov.

345. U. Brookeuse, sp. nov ............... 312

346. U. teuninerve, sp. nov .............. 313

347. U. crassinerve, sp. nov ............. 313 


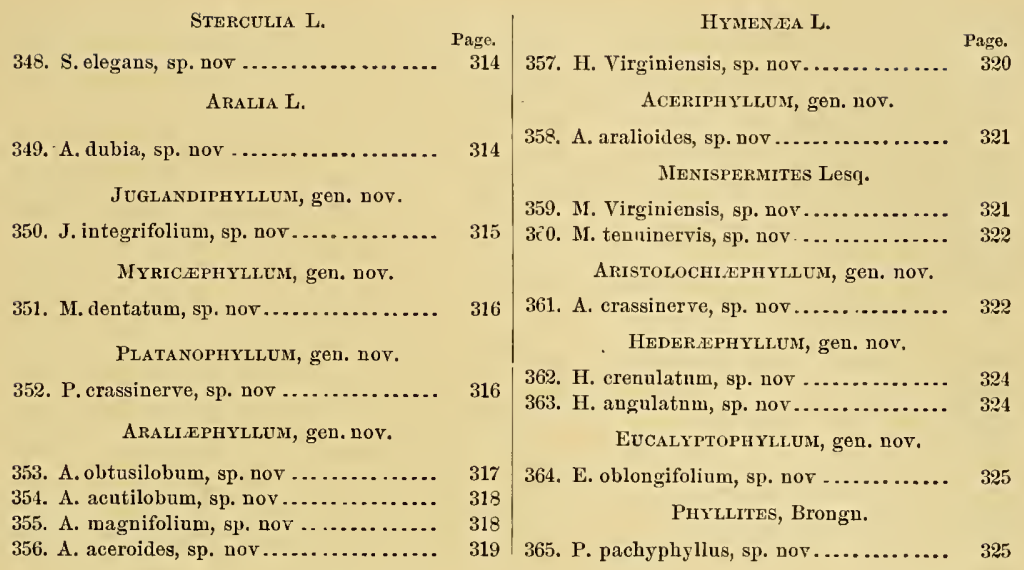

Of these plants a considerable number may be omitted in any comparison with other floras, since they do not present any features that can aid in identification. When, however, these have been omitted, there still remain many that are well characterized, and that are largely represented and widely diffused. These may be taken as characteristic of the flora, and they should have more weight than any others in determining the age of the strata which contain them.

Before the examination of the geological relations of the Potomac flora is undertaken it will be well to define in what sense the names of certain geological formations, to which frequent reference must be made, will be taken in this memoir. The two formations which are capable of misconception are the Wealden and Neocomian. By some the Wealden formation is regarded as an independent group forming the uppermost member of the Jurassic. Others regard it as a series of beds contemporaneous with a portion of the lower Neocomian, formed in estuaries and marshes at the time when a portion of the typical lower Neocomian, which is marine, was being deposited in the sea. The latter view is the one assumed in this memoir.

In this work the Neocomian period is taken as including the Urgonian and Aptian of D'Orbigny, the former being, when present, the middle 
member and the latter the npper member of the formation. When, then, reference is made to Neocomian plants, fossils of the Wealden, Urgonian, and Aptian groups are included and not distinguished.

In the regions containing Potomac areas the older flora which comes next to that of the Potomac beds is that described by me in Contributions to the Knowledge of the older Mesozoic of Virginia (Mon. U. S. Geol. Survey No.6). This is Rhætic in age.

In Virginia, and as far north as the Potomac beds have been traced and identified, if we except the doubtful location of the trunks of Tysonict Marylandica, no plants of any value in determining age have been found in any Mesozoic strata above the lower Potomac.

But in New Jersey a large number of well-preserved fossil plants have been collected from the sands and clays that form the lowest member of the Cretaceous of that State, and which are so largely worked at some localities for the manufacture of fire-brick and pottery. These plants form the flora which comes next above that of the lower Potomac beds, and possesses importance in determining geological relations.

The New Jersey fossils are being studied and described by Dr. Newberry. Until his conclusions are published we must wait for a final determination of their age. It may, however, be stated here that these fossils have been generally taken to be of nearly the age of those from the Dakota group of the United States, or of the Cenomanian of Europe.

The geological relations of the plant-bearing beds of New Jersey and the upper Potomac, or mottled clay group of Maryland, have not been determined, but, as has been stated before, these two groups will probably prove to be of the same age. The two floras then with which that of the lower Potomac may be compared as next preceding and following it, in the areas where it is found, are the Rhætic plants of Virginia and North Carolina, and the probably upper Cretaceous New Jersey flora. The comparison with these is important, as showing on the one hand survivors from the older flora, and on the other hand precursors for the younger.

By the kindness of Dr: Newberry I have been enabled to see a large. number of drawings of the New Jersey plants. They show that the flora of this formation is totally different from that of the lower Potomac. The 
difference is much greater than one would expect in the fossils of two formations so near each other in geological age.

All of the numerous remarkable types so characteristic of the Potomac strata are wanting in the New Jersey Cretaceons. But besides this, in the New Jersey beds angiosperms constitute much the greater part of the plants. In the Potomac formation the ferns, cycads, and conifers form much the greater element in the flora. One is induced to think that in producing such an entire change in the vegetation some other cause besides the mere lapse of time must have acted. The alteration is mainly caused by the very general extinction of the Jurassic types which still survived in the Potomac flora, and of the warmth-loving plants which existed in it. The question might be asked, Was this change hastened by the coming on of a cold period in this region in the interval between the lower Potomac and the New Jersey Cretaceous?

\section{GEOLOGICAL AFFinities OF THE POTOMAC PLANTS.}

In the description of the different species of Potomac plants attention was called in each case to the known fossils that are identical with or most nearly allied to the plant being described. It will perhaps be useful to repeat in this place these statements, in part at least, and to add such details as may suggest themselves, in order that we may get a connected view of the geological relations of the flora. For this purpose I will take up in succession the different groups of plants, and try to give what may be deduced from their character.

It might cause error to attempt to determine the age of the flora by giving percentages of the elements common to the Potomac and known floras. In many cases particular species are represented by few individuals, and these are not well characterized. In other cases, much fewer in number perhaps, the species may be represented by numerous individuals which are well characterized and widely diffused. Species of the kind last mentioned, although m uch inferior in numbers to the kind first named, ought to have more weight than these in fixing the character and determining the age of a flora. Then, again, some species may be merely survivors of an older flora, or newly introduced precursors or prototypes of forms that attain their typical character later. These are not of so much ralue in 
fixing age as species attaining their maximum development in the age in question.

One of the most noteworthy features of the Potomac flora is the overwhelming predoninance of new species and the proportionally very large number of peculiar types. It is true that, owing to the absence of the flowers and fruit, we may in many cases fail to place with accuracy the forms in still hiving groups: but still, in a very large number of cases, enough is shown in the foliage to indicate that it differs in type from that of the plants of other formations, and in a considerable number of instances the character is so remarkable and well defined as not to require any other evidence to prove the uniqueness of the plants possessing it.

We might explain the remarkable abundance of new forms in the Potomac by assuming, for the region and period possessing this flora, unusual topographical or climatal features, but this is rendered improbable by the fact that the flora of the formation possesses a uumber of species known from other parts of the world. When we consider the distance that separates the countries in which these common species grew their similarity is surprising.

It is more probable that the peculiarity of the Potomac flora is to be explained by the fact that it belongs to a period whose land plants have not been found elsewhere, or if found are poorly represented. As will be seen later, this conclusion tallies with the deductions to be drawn from an examination of the individual elements composing the flora. If, as we are led to think from a study of the plants composing this flora, its age is Neocomian, then we should expect to find in any large collection of its fossils a great proportion of new forms ; for the Neocomian, taken the world over, is predominantly marine, and its land flora is one of the least known.

Taking up now the different groups composing the Potomac flora, we find the Equiseta first in order.

\section{EQUISETA.}

In passing from the flora of the Rhætic beds of North Carolina and Virginia to that of the Potomac, we find a very marked change in the Equisetacece. There is in the Potomac no trace of Schizoneura, a group meagerly represented in the Rhætic flora in foliage at least. 
The Equiseta have undergone a significant change, assuming decidedly more recent features. The Rhrtic equiseta, although few in species, seem to have attained a very large size and to have lived in vast numbers in certain conditions of the marshes, hardly any other fossils being found with them. They were also apparently unbranched. In the Potomac era the species were small in size, copiously branched, like some living kinds, and they seemingly no longer, as in the Rhrtic, lived in such immense colonies. It can hardly be doubted that the mode of occurrence of the specimens of E. Virginicum, at the fishing hut above Dutch Gap Canal, fairly represents its distribution in life. It seems to have grown sparingly, scattered here and there in the midst of a vegetation consisting mainly of ferns, cycads, and conifers, with now and then an angiosperm. At Baltimore E. Marylandicum grew rather abundantly with similar elements, but with a predominant angiospernous flora. These two, from their comparative abundance, appear to be the most characteristic equiseta of the era. E. Lyelli is almost wholly confined to Fredericksburg, and from its rarity there seems to be a survivor from Jurassic times. This is indicated also by its comparatively large size. While the general character and distribution of the Potomac equiseta indicate an age decidedly younger than the Rhrtic and even the Jurassic, the same result would be deduced from an examination of the two more characteristic species.

Equisetum Virginicum is so near to E. Burchardti Dunk., that it is not entirely clear that it should be made a distinct species. At least it may be regarded as a representative of E. Burchardti in America. E. Marylandicum belongs to the same type of small equiseta as $E$. Virginicum and $E$. Burchardti, which, in its copious branching and small size, stands near to the living species of the genus.

So far, then, as the meager evidence of the Equiseta goes, we would infer that the age of the Potomac beds is Wealden (i. e., older Neocomian) or younger.

FERNS.

The evidence of the ferns, if we look to the species alone, is not clear and positive for any conclusion. A typical Mesozoic or pre-Cretaceous flora consists almost wholly of four elements. These are ferns, cycads, 
conifers, and equiseta. In such a flora generally the ferns and conifers stand first in the number of kinds and of individuals, the cycads usually coming next, and the equiseta last. Were it not for the considerable angiosperm element in the Potomac flora it would be typical Mesozoic, and this would be largely due to the great variety and the universal diffusion of the ferns. While the number of different kinds of ferns is proportionally very large, the number of individuals of each kind is, comparatively speaking, very small. There is also a curious mingling of older and more recent types, and a remarkable localization of many of the species. The species identified with those of other floras seem to be mainly a few worldwide and long-lived forms. Many of the older types seem to be survivors from the Jurassic. The flora of the Cenomanian is quite well known from a number of widely separated regions. The fact that nearly all of the ferns of the Potomac are absent from the different Cenomanian floras is strong evidence that the Potomac flora is older than Cenomanian.

Let us now rapidly examine the evidence to be deduced from the different groups of ferns. Cladophlebis: The ferns placed in the genus Cladophlebis do not, it is true, show fructification, but the plan of their foliage and nervation is a well-marked one, which is, the world over, very characteristic of Jurassic floras. The great number of species of this type found in the Potomac flora is certainly significant. In no flora which does not have strong Jurassic affinities could such a large proportion of the ferns be of this type. It would seem that the conditions prevailing in Jurassic times favored the development of this particular kind of foliage, and we may assume that in the Potomac era these conditions had not wholly passed away.

The presence of such a large element, having the facies of Cladophlebis, is entitled to more weight in fixing the geological relations of a flora than the establishing of the identity or near relationship of a few species in two widely separated floras. But we are not without confirmatory evidence derived from this source. The species of this genus in the Potomac flora are probably all new, but some of them differ so little from some of those occurring in the Rhætic and Jurassic floras, that they may fairly be taken as survivors and representatives of the older species. For example, 
C. constricta is very near to Alethopteris cycalina Schenk, from the Wealden. C. Virginiensis is perhaps not to be distinguished from Brongniart's Pecopteris Whithicnsis of the Oolite of England, and is very near to Acrostichides linncecefolins, from the Rhætic of Virginia. C.denticulata is much like Neuropteris ligata, Lindley and Hutton, from the Oolite of England. C. falcuta is very similar to a large number of Jurassic ferns grouped by some under the general name Whitbiensis, being in its smaller forms especially like C. nelbensis Nathorst, from the Rhatic of Sweden. C. purva is very close to C. pseudowhitbiensis, from the Rhetic of Virginia. It is hardly worth while, however, to trace further the resemblance of the species of Potomac Cladophlebids to those of other floras.

Pecopteris: The genus Pecopteris, taken simply as a type of foliage and nervation, has but little value in fixing age, for this group does not seem to be characteristic of any particular geological period. The genus is but little developed in the Potomac, and its comparative rarity may perhaps be taken as evidence, such as it is, of the comparatively recent age of the beds. But in this genus we are enabled to detect two species as common to the Potomac and known floras, while several are very close to previonsly described plants. The identification of the Potomac fragments with Heer's P. Socialis, from the Atane beds or Middle Cretaceous of Greenland, does not have much weight, as the Potomac fossils are quite rare and imperfect. The case is different with $P$. Brownianu. This is an important and characteristic plant in the Wealden of Europe. It is widespread in the Potomas beds, and is largely represented by identical or nearly allied forms, such as Pecopteris strictincrvis and $P$. constrictu, giving, indeel, a type form. Besides these we have $P$. Virginiensis, much like $P$. denticulata Brong., an Oolitic fossil.

Sphenopteris: The genus Sphenopteris, like Pecopteris, taken simply as a type of foliage and nervation, does not characterize any particular era. But in the Wealden everywhere there is one particular type of Sphenopteris which is highly characteristic of that formatiou. This is the so-called species Sphenopteris MIantelli. The adjective so-called is used becanse in my opinion too many probably different plants have been united under this name, as las been done in the case of Pecopteris Whittiensis. As MON XV-2? 
matters now stand, Sphenopteris Muntelli is the name of a particular. type of foliage and nervation very conmon in Wealden ferns rather than the name of a single species. But however this may be, the evidence given by the presence of this type of fern is not affected. The existence in a flora of a large element in the ferns which has the type of $S$. Mantelli may be taken as indicating affinities with the Wealden flora.

Now in the Potomac flora not only is S. Mantelli present in beds which show plants of the most recent facies existing in the formation, but there is a very important group of ferus which, althongh placed in the genus Thyrsoptcris, have nearly the nervation and foliage typified in $S$. Mantelli. The great development in the Potomac of ferms of the general type of S. Mantelli gives strong evidence of Wealden or somewhat later age. A somewhat later age than Wealden is indicated, perhaps, as most of the species are somewhat modified, so as to depart more or less from the typical S. Mantelli, and to assume the facies of Thyrsopteris. The other species of Sphenopteris give little lielp in fixing the age of the Potomac strata.

Aspidium: The gemus Aspidium would seem to be, when largely developed in a flora, a decidedly recent element. The finding of as many as fourteen species of true Aspidium in the Potomac flora, and the comparatively large number of individuals shown by some of these, would, if taken alone, indicate a very recent age for this flora. There is nothing in the foliation or in the fructification to make ns think that these plants conld not be still living. Aspidium Ocrstenti is determined as present, but the identification is doubtful, as the amount of material found is too small to permit any sure conchusion. With the exception of $A$. Dunkeri Schimper, the other species are peculiar to the Potomac formation. Pecopteris Dunkeri Schimper, of the TTealden of Europe, seems to be quite characteristic of that formation. It is pretty certainly an Aspidium, as shown by the Potomac forms. It is a plant of considerable importance in establishing the existence of Wealden elements in the Potomac flora.

Polypodium and Acrostichum: These two living genera are probably sparingly represented in the Potomac flora. Of course, as far as their evidence goes in this flora, they establish relations with living plants rather than 
with the older pre-Cretaceous floras. But their presence is not certainly established, and, if present, their species are too. few and feebly dereloped to indicate anything more than a recent introduction.

Acrostichopteris seems to be an extinct genns, peculiar to the Potomac formation. It can then give but little aid in fixing geological age. The fact, however, that it is extinct probably denotes a comparatively great age for the formation to which it is confined.

Asplenium: This genus also, if present, is probably to be considered as a recent element, but nemly introduced.

Thimfeldia: This genus shows three species; one of them, Thinnfeldia variabilis, being quite common at the 72d mile-post, near Brooke. The genus is an old one, characterizing the Rhætic, and Infra-Lias. The continuance of this type into the Potomac formation makes an important addition to the older elements of the flora. The species, although not capable of identification with any of those of the older floras, must be regarded as survivors.

Stenopteris: This genus is doubtfully present. It is too rare and too imperfectly preserved to be of use if presant. It is one of the still lingering Jurassic types, now almost extinct.

Angiopteridium: This is a more valuable genus in throwing light on the age of the flora containing it. The absence of fructification in the Potomac plants, however, renders it impossible to say positively whether or not these forms are really Angiopteridium; but it is at least clear that large ferns with this type of foliage are more cliaracteristic of the older Mesozoic formations than of the later ones. While the number of individuals of any particular species is very small, yet the number of species is surprisingly large, and the genus adds much to the archaic facies of the flora. This is one of the groups which does not appear to go up into the Cenomanian flora, and hence, like Cladophtebis, it nust be regarded as a still surviving older element.

Gleichenia: This genus, which, as Heer has shown, is so largely represented in the older Cretaceous of the northern part of the American continent, shows a surprising deficiency in forms in the Potomac flora.

Aspleniopteris: This is an extinct form peculiar to the Potomac beds, and for that reason it can give us little help in determining the age of the 
Potomac by a comparison of its plauts with known floras. Its extinction indicates a considerable antiquity for the Potomac strata.

Thyrsopteris: What was said of Cladophlelis may in the main be repeated for this genus. It is true that, as no fructification has been found on these ferms, they may be incorrectly placed in the genus Thyrsopteris. Still, the very great development in the Potomac flora of ferns with a foliage and nervation so characteristic of the later Jurassic and Lower Cretaceous can not be without significance. This type of fern is much the most common in the Potomac strata. The species, most of them well characterized, number forty. They are distributed over the whole of the Potomac area, and a number of them are among the most common ferns at the localities yielding thent. This group, more than any other, tends to give a Mesozoic facies to the Potomac flora. They have almost or quite passed away in the interval between the time of the deposition of the lower. Potomac and that of the oldest Cretaceous of New Jersey. Their absence in the flora of the latter group greatly adds to the comparatively recent aspect of this latter.

A number of these Thyrsopterids have the same type of foliage as the Wealden ferns, Sphenopteris Mantelli Brongn.; S. Gapperti Dunker; S. cortui Schenk; S. plurinerviu Heer; and S. Gomesiana Heer, as well as the Urgonian plants Asplenium Dicksonianum Heer; A. Nanchifoffanum Heer, and various Dicksonias, such as D. Johnstrupi Heer. It is a significant fact that this type of foliage, so common towards the close of the Jurassic and in the oldest Cretaceous, is the most abundant single type in the Potomac strata also. Such a general prevalence of a type is more significant of geological relationship than the identification of a few species common to two formations. It is not worth while to examine in detail the affinities of the different species. Most of them are new and unique. One or two have some resemblance to Oolitic species, while a greater number may be grouped as belonging to the two Wealden types $S$. Mantelli and $S$ Gapperti.

Osmunda: The plants placed in the genus Osmunda, although not numerons in species, are very common at the Potomac Run locality. They quite possibly differ somewhat from true Osmundas, the genus not 
being fully differentiated. If so, this genus can not be used in determining the age of the strata. It wonld simply indicate for them a very considerable antiquity.

Sagenopteris: This is a well-marked genus, not easily mistaken for any other, and hence it is valuable in determining age. It has such a wide range in time, however, that it will not enable us to fix within narrow linits the horizon of the beds containing it. It appears to extend from the Rhrtic into the lower Cretaceous or Neocomian, surviving in the Neocomian of Westphalia.

Scleropteris: This genus is well characterized, so that it is readily detected. It has a considerable number of species in the Potomac beds, although none of them are anywhere common. This group of plants gives to the Potomac flora one of its most important Jurassic elements, for this type is eminently characteristic of the later Jurassic. It must be regarded as a survivor in the Potomac, coming down from an older flora.

Ctenopteris: This genus has, so far as the question of age is concerned, very nearly the same significance as Scleropteris, being Jurassic. But the Ctenopterids of the Potomac appear to be modified descendants of the forms found in the older floras. They do not necessarily imply an age as great as even that of the Oolite, and it should be noted that some of them much resemble Heer's genus Ctenirlium, found in the Wealden of Purtugal. There is nothing in the general character of these Potomac plants that would make it improbable that they occur in the older Neocomian.

Zamiopsis: This is a remarkable type, peculiar, so far as known, to the Potomac. It can not help us in determining the question of age. This genus appears in some points to be allied with Ctenopteris, for it has the same curious union of the characters of ferns and cycads.

CYCADS.

The comparatively large number of cycads in the Potomac strata does much to separate the flora of this formation from that of the Cenomanian, and to increase in it the resemblance to the typical Mesozoic or Jurassic flora. They indicate that in the Potomac tropical conditions still prevailed to a considerable extent. Cycads are rare after the Neocomian 
in the fossil floras of countries now possessing a cool temperate climate. We are, then, from a consideration of the family as a whole, entitled to hold that the Potomac flora can not be later than Neocomian in age. The character and the degree of development of the particular genera and species point unmistakably to the Neocomian as the age of this formation.

Anomozamites: This is an old type, belonging to the Rhrtic and older Jurassic. Anomozamites proper is but slightly developed in the flora, and at the same time, not being clearly established by the few and imperfect specimens found, may be passed by. The case is different, lowever, with the subgenus Platypterigium. This is a well-characterized form, and the comparatively large number of fairly well preserved specimens found at Fredericksburg give it considerable weight. The genus seems to be most characteristic of the Rhretic and older Jurassic, but it almost certainly survives intil the middle Cretaceous in Heer's Nilssonia Johnstrupi, from the Atane beds of Greenland. There is, then, nothing strange in finding this genus in Neocomian strata.

Zamites: This is eminently a later Jurassic genus, but the Potomac specimens are too imperfect and uncertain to be used.

Encephalartopsis: This genus, from its nearness to the living Encephalartos, is a recent element in the flora. From its great rarity, however, it is not entitled to much weight, and must be regarded as a newly introduced form.

Ctenophyllum: This is an old type. As it is exceedingly rare and differs a good deal from the most common Rhætic form, it must be regarded as a survivor.

Ctenis: The same may be said of this as of Ctenophyllum. It is a considerably modified survivor from the Rlıetic and Jurassic floras.

Podozamites: This has no value in fixing definitely the age of a flora, for, as the name has been used, it ringes throughout the Mesozoic. In addition to this, the Potomac yields ouly detached and sparingly dispersed leaves.

Dioonites: This grenus, known from the Neocomian (Urgonian) of the Wernsdorf strata, is entitled to great weight in fixing the age of the Potomac. It is well characterized, widely distributed, and very abundant in 
the Potomac, being one of the most characteristic plants in it. It is smrprising to find such a close resemblance between the most common forms of the Potomac plant and the Wernsdorf fossil. This species is more important than a large number of raguely defined plants.

Tysonia: The trunks of Tysonia have their nearest relations in later Jurassic and Wealden forms, and hence may well exist in a Neocomian flora.

CONIFERS.

The conifers form much the most important and abundant element in the Potomac flora. In development they surpass all other groups. The proportion of conifers in the flora, taken alone, is a feature that strongly indicates that it is Neoconian in age, for it seems that in this period the conifers, in proportion to the other elements of the flora, are more abundant than they are at any other time. The Neocomian age of these plants is indicated also by the near affinity of many of the types to present forms, and by the existence in it of very important and well-characterized genera that distinguish the Neocomian strata of various parts of the world. At the same time, horvever, there are in this flora a number of unique types, that indicate that the Potomac was a period of rapid development for the conifers, in which many genera became extinct. The existence of these and a number of groups which might be regarded as prototypes or ancestral forms of living genera shows that, notwithstanding the existence in it of a number of angiosperms, this is a very old flora.

Nageiopsis: This renarkable genus is greatly developed in the Potomac and highly characteristic of it. It is so much like the Nageia section of Podocarpus living in the East Indies, Java, and Japan, that it is difficult to resist the idea that there is a genetic connection between them; Nageia being a survivor and descendant of Nageiopsis. This is confirmed by the remarkable isolation and limited development of Nageia. It is interesting to note the fact that so many of the characteristic coniferous types of the Potomac flora have their nearest living representatives in certain genera of very limited development and restricted distribution confined to the eastern coast of Asia and to Australia. Among these may be mentioned, in addition to Nagreiopsis, Athrotaxopsis, now represented by Athrotaxis in Tas- 
mania; Frenelopsis, represented by Frenelu in New Holland; Cephalotaxopis by Cephelalotaxus, in China and Japan; and Baieropsis, by Ginkigo in Japan. The same is true of a number of the ferns, cycads, and protealike angiosperms.

While Nageiopsis has not been recognized outside of the Potomac formation, yet some of the species are much like fossils previously known and described under other names. There are a number of species of Podlozamites that resemble some of the forms of Nageiopsis, which it is not worth while to mention. Zamites Gapperti Schenk, however, from the Wernsdorf beds, is so mneh like Nagciopsis longifolia that it is difficult to think that it is a different plant, while $N$. latifolia seems to belong to the same broad-leaverl coniferous type as the Porlozamites Reinio of Geyler.

Feildeniopsis: This is a decidedly recent element, being near Heer's Miocene Feildenia.

Phyllocladopsis: This might be placed with Nageiopsis, ete., among the types which are represented most nearly among living plants by restricted genera in the Chino-Australian region, as it finds its nearest kin in Plyglloclctus of New Zealand, Borneo, and Tasmania. But both Feildeniopsis and Phylloclatopsis are too rare in the Potomac flora to have much importance. So far as they go, they indicate a more recent age for the formation.

Baieropsis: This is a very important genus in the Potomac, but owing to the fact that it is a peculiar type, confined to the flora of that formotion, it can be of little help in determining age. This is one of the most widely diffused and characteristic types found in the formation. The fanshaped and split-leaved Gingkos form a group eminently characteristic of the later Jurassic and Wealden. Possibly Buieropsis is a descendant of Ginkgoplygllum, and if so, its presence is quite compatible with the Neocomian age of the flora which contains it.

Baiera: This is most characteristic of the Jurassic, but it is too sparingly present to have any importance.

Frenelopsis: This genus has all the characters that would give a fossil plant weight in a flora. It is well characterized, well distributed, and very abundant at some localities. Frenelopsis parceramosa is very near to the Neocomian F. Hoheneggeri, and the genus is confined to the Wealden and 
Urgonian groups. Frenelopsis ramosissima is so much like Frenela that a genetic connection can hardly be denied, and this latter would seem to be a younger form than $F$. parceramosa.

Brachyphyllum: The Potomac forms of Brachyphyllum are most like Heer's Brachyphyllum obesum from the Wealden of Portugal.

Leptostrobus: This is Jurassic, and lends additional weight to the older elements of the flora.

Laricopsis: This must be regarded as a recent element, but it differs from Larix enough to render it doubtful whether it could be regarded as indicating any particular post-Jurassic time.

Torreya: This belongs to the more recent forms, but it is ton slightly developed in the flora to have much weight.

Cephalotaxopsis: This is a very important and highly characteristic plant. It is unnistakable in character, widely diffused, and represented by several species, some of which seem to have been abundant. It is so much like Cephlalotaxus that possibly it should not be separated from it. It adds much weight to the more recent elements of the flora.

Athrotaxopsis: This is very near the living genus Athrotaxis, and the same may be said of its significance that was said of Cephalotaxopsis.

Sequoin: This is the most important genus of conifers in the Potomac formation, on account of both its large development and the number of species that it shows common to the Potomac and to the lower Cretaceons floras of other parts of the world. Thus we find in the Potomas and in the Urgonian strata of Kome, Greenland, the species S. Reichenbachi, S. ambigua, S. rigida, S. gracilis; and, in addition, the species $S$. subulata is found in both the Potomac and the Atane, or middle Cretaceons, beds of Greenland. Considering the number of species, this is proportionally a large number of common ones. Sequoia gives more previously known species than any other genus of plants.

Araucaria: This genus begins in the Jurassic and comes down to the present time, so that the Potomac species, being peculiar to it, can not indicate any particular post-Jurassic era.

Tcuodium (Glyptostrolus): The Glyptostrobus type of Taxodium is most characteristic of the middle and upper Cretaceons; and the Potomac 
species, although new, have most affinity with species from formations of those ages.

Sphenolepidium: This is one of the most important coniferons genera in the Potomac. It gives two characteristic genera of the Wealden abundant in the Potomac, viz, S. Kurianum and S. Stemberyjanum. The large development of this type adds much to the weight of evidence for the Neocomian age of the Potomac.

Abictites: The type of cones placed in Abietites is too poorly preserved and too rare to have much value; but, so far as their evidence goes, it indicates an age more recent than the lower Cretaceous.

We may pass over the various forms of fruits and inflorescence, and of course the undetermined plants, as too poorly characterized to throw light on the question of age, and take up the angiosperms.

\section{ANGIOSPERMS.}

The angiosperms, in the number of kinds and in the degree of devolopment of some of the species, are pretty well represented. Hitherto it has proved so uniformly true that, with the single exception of Heer's Populus primceva from Kone, angiosperms are totally absent from all Neocomian floras, that Saporta is inclined to think that this Populus was erroneonsly ascribed to Kome. Any considerable number of angiosperms in a flora would, perhaps by most if not all paleobotanists, be taken by itself as almost, if not quite, proving the post-Neocomian age of the flora which contains them.

Now, for the first time, we have presented in a flora which possesses an overwhelmingly large proportion of Jurassic or typical Mesozoic elements a very considerable number of angiosperms. The presence of these plants, taken by itself, should not induce any one to assume that the Potomac flora is post-Neocomian. It simply confirms the assumption made by more than one writer, that the apparently sudden advent of this type of plants in predominating numbers in the Cenomanian is not to be taken as indicating their true mode of appearance. Perhaps all paleobotanists will admit that angiosperms really made their appearance gradually, and that their first advent must be looked for far back in the Mesozoic, in the midst of a flora essentially Jurassic or Mesozoic in type. 
The character of the Potonac angiosperms shows that the first advent of this class must be looked for still further back in time, but the Potomac flora gives ns the first appearance of this high type in any notable amounts, and shows that these plants, at least as early as the oldest Cretaceous, were present in considerable numbers, thus pushing back by at least one epoch the date of their considerable development. It should be noted that we do not find in them, althongh many of them are quite archaic in type, any forms establishing a transition between angiosperms and the ferns or gymnosperms.

The examination of most of the genera in this group will give us but little help in making out the precise age of the Potomac flora. Most of them are too poorly characterized or too remote from living genera to make a comparative study worth much. The fact, however, that a number of the most peculiar forms seem to be generalized types, indicates a very considerable antiquity for the flora.

As, however, all or very nearly all of the species of these angiosperms passed away before the advent of the flora of the New Jersey Cretaceous, we are entitled to conchde even from this group that the Potoniac flora is older than the Cenomanian. Such genera as Acacicephyllum, Proteceplyyllum, and Rogersia seem to be very archaic. The same may be said, perhaps, of Celastrophyllum, and certainly of Ficophyllum. Populophyllum, Quercophylhem, Ulmiphyllum, Saliciphyllum, Juglandiphylhum, and Eucalyptophylhem, etc., are too imperfectly characterized to be of use.

Such genera as Sassafras, Vitiphyllum, Sapindopsis, Myrica, Sterculia, Hymenca, and Menispermites are found in the Cenomanian or have closely allied forms in it. Vitipluyllum is very near Cissites, and Sapindopsis is very close to Stpintus, both being genera occurring in the Cenomanian. All these, however, are represented in that formation by species different from those of the Potomac.

The remarkable leaves shown in Aralicphlygllum, Aceriphyllum, and Iledercuplyllum, as illustrated in $H$. angulatum, seem to be comprehensive types, and hence are probably old forms

Taken as a whole, then, and compared with the Cenomanian flora of the Dakota and New Jersey Cretaceous strata, the angiosperms of 
the Potomac decidedly point to the Neocomian as the age of the Potomac beds.

From this brief review of the flora, we see that there is in it a very large and inportant element that belongs to the Jurassic or typical Mesozoic flora; a less important, but still large element, that has near relations in Cenomanian and even living forms; while the largest, nost fully developed, and characteristic element is most nearly allied to forms distinguishing the Neocomian.

All the important species common to the Potomac and the floras of known formations are found in the Neoconian, including under this name both the Wealden and Urgonian.

If any additional evidence were needed of the Neocomian age of the Potomac, it may be found in the peculiar union of old and new types, whose evidence, if we consider them by themselves, is contradictory.

Schenk, in Die Foss. Pflanz. der Werns. Schichten, page 29, in speaking of the character of the Neocomian flora of the Wernsdorf beds, well says that the flora of the older Cretaceous occupies in the development of the plant kingdom a position similar to that of the Trias, for the forns characteristic of two great periods of development meet in it; that is, the survivors of the past period (Mesozoic) and the new forms of the approaching one (Tertiary).

This being true, we should expect to find in any large collection of Neocomian plants a great mingling of types. We would find the survivors of the old floras and the newly arrived precursors of the more recent ones mingled with a number that attain their development in and are peculiar to the Neocomian. This is exactly what we find to be true of the Potomac flora. That so many of these plants are new is perhaps to be explained, in part at least, by the fact already mentioned, that the flora of this epoch is very poorly represented and comparatively but little known. It is not possible to say positively to what precise epoch of the Neocomian the Potomac belongs. Its flora ranges from the Wealden through the Urgonian, and probably ineludes some Cenomanian forms. 
TABLES. 
TABLE I. - List of specirs of the Potomuc formution, with the localitics at which they were collected.

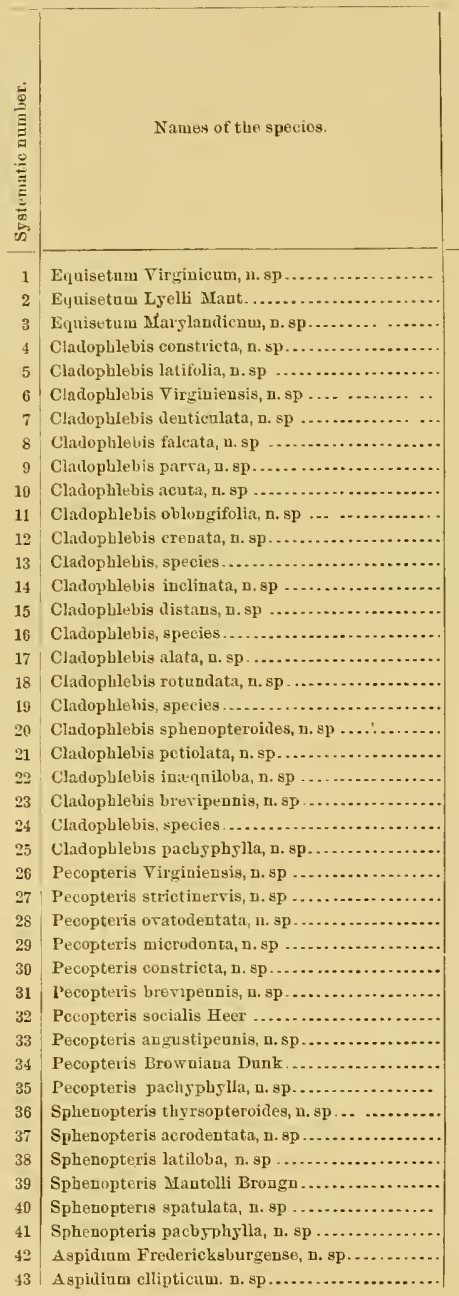

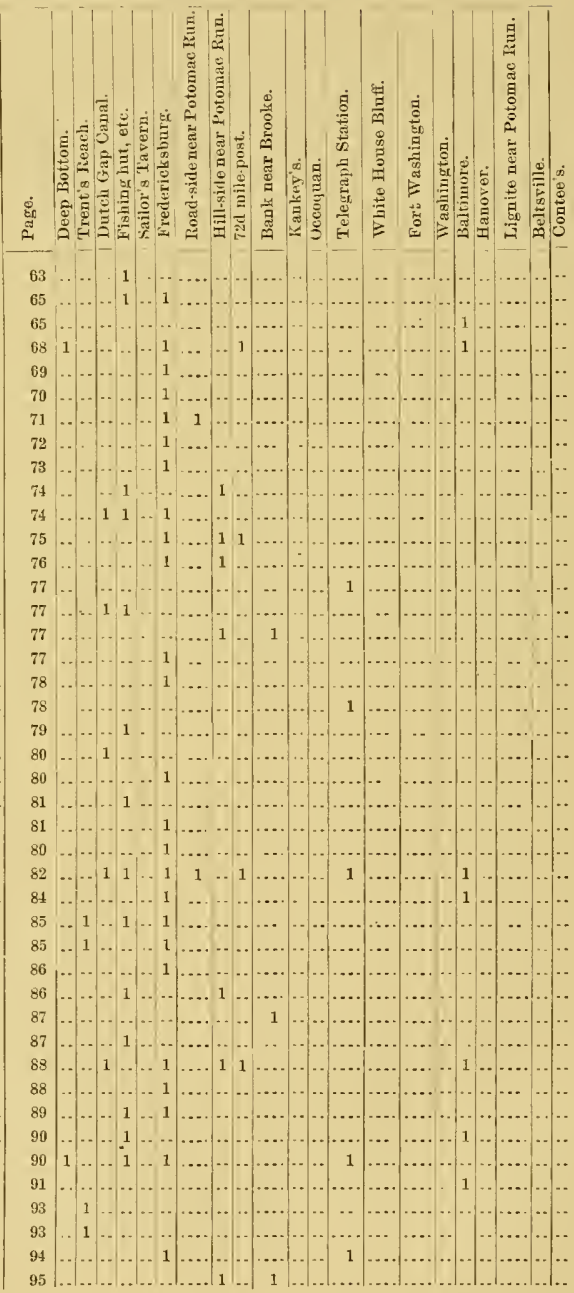


TABLES.

TABLE I.-List of species of the Potomae formution, with the loealities at which they were eollceted-Cout'd.
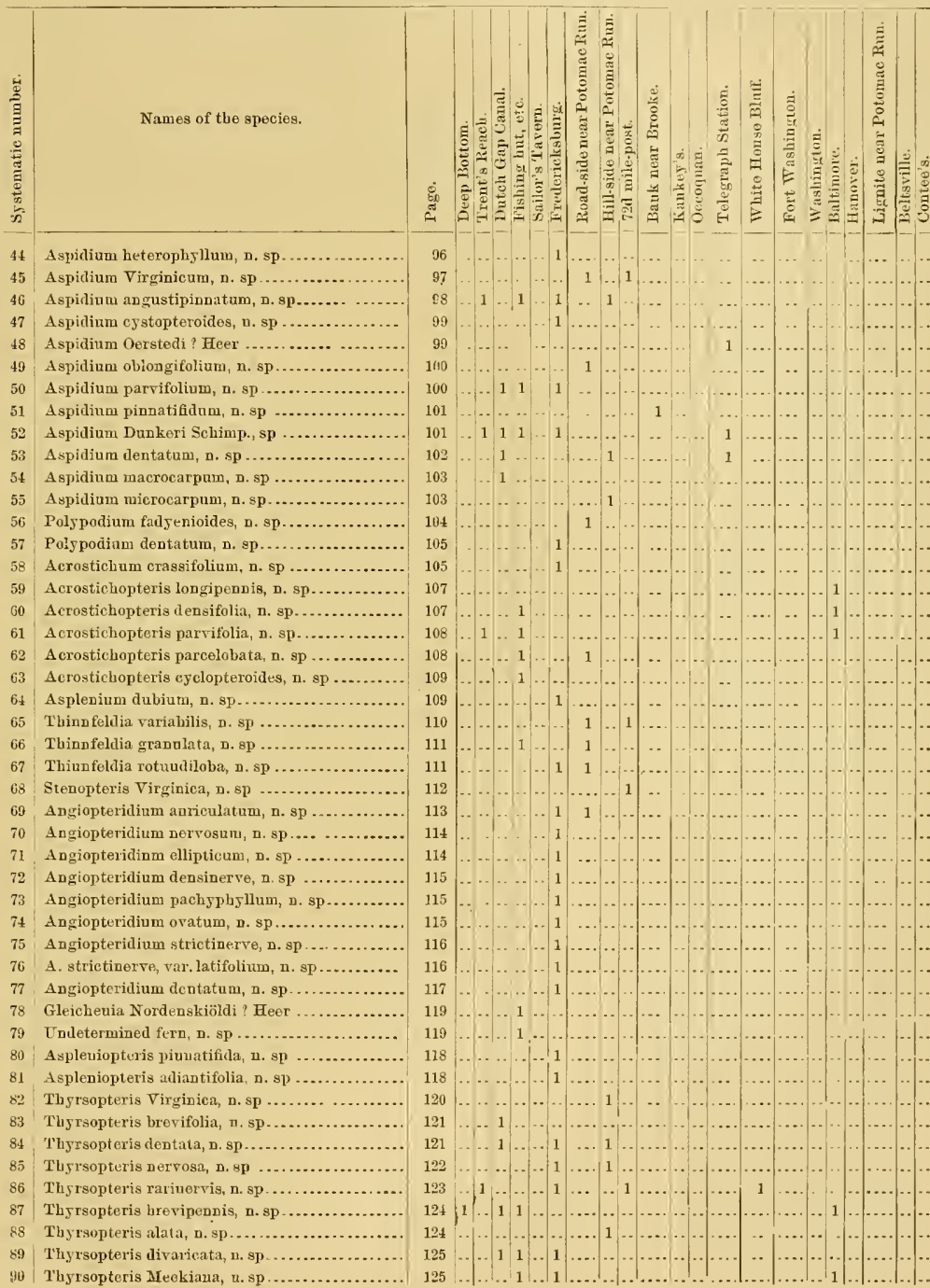

1 Aspidium heterophsllum, $\mathrm{n} . \mathrm{sp} \ldots \ldots \ldots \ldots . . .$.

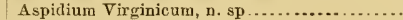

\section{6}

97

98

99

1140

100

101

101

102

103

103

104

105

105

107

107

108

108

109

109

110

110
111

111

112

113

114

114

115

115

115

116

116

117

117
119

119

128

118

120

121

121

122

123

124
124

124

125
125

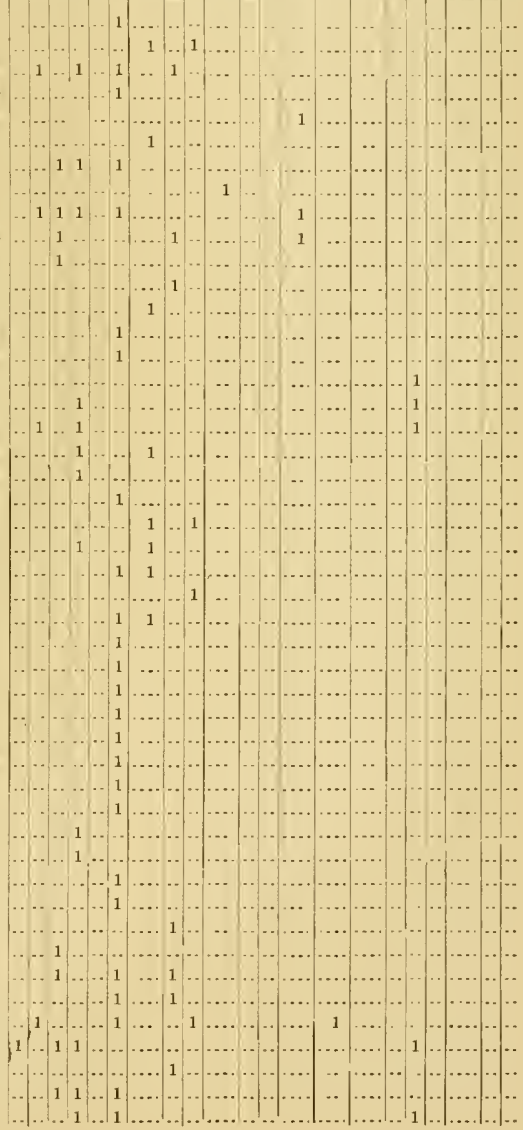


TABLE I.-List of speeies of the Potoma formation, with the localities at which they were collected-Cont'd.

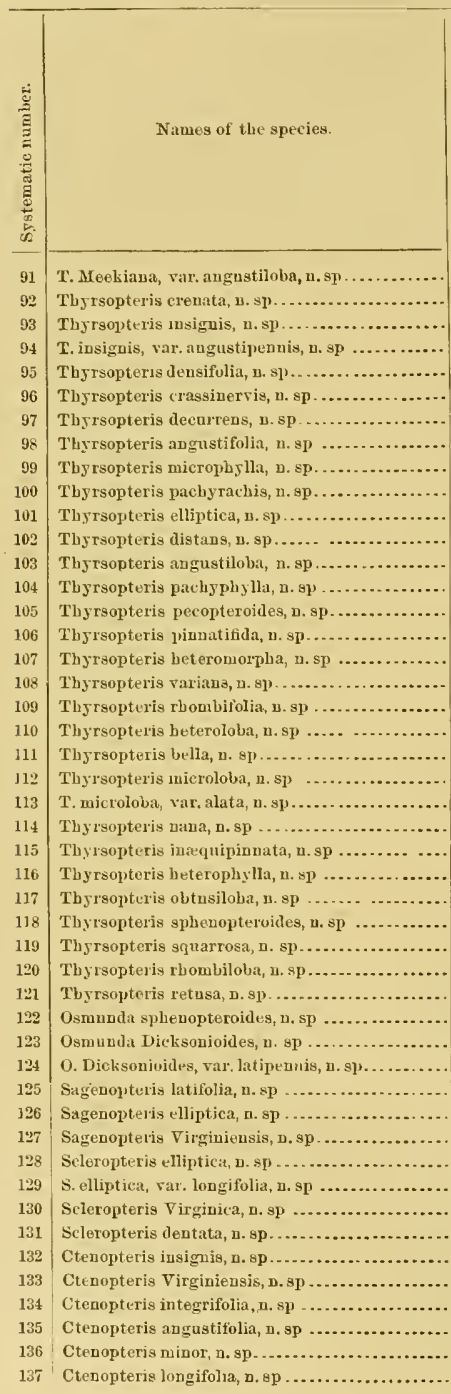

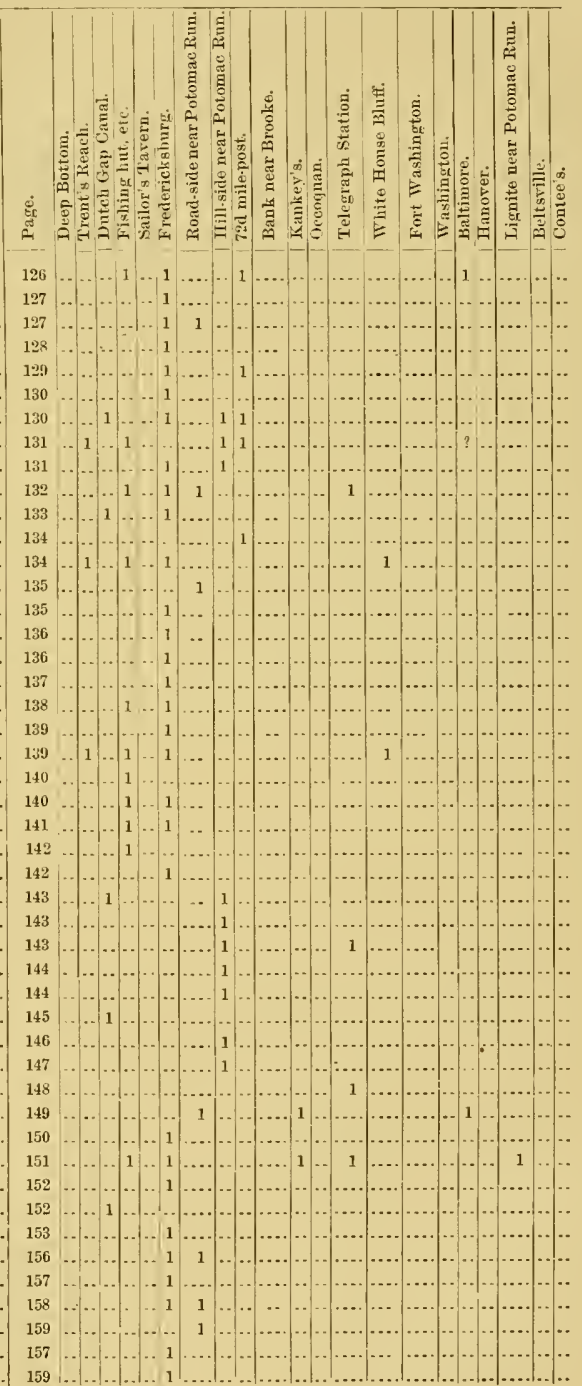


TABLES.

TABLE I.-List of specics of the Potomac formation, with the localities at which they were collected-Cont'd.

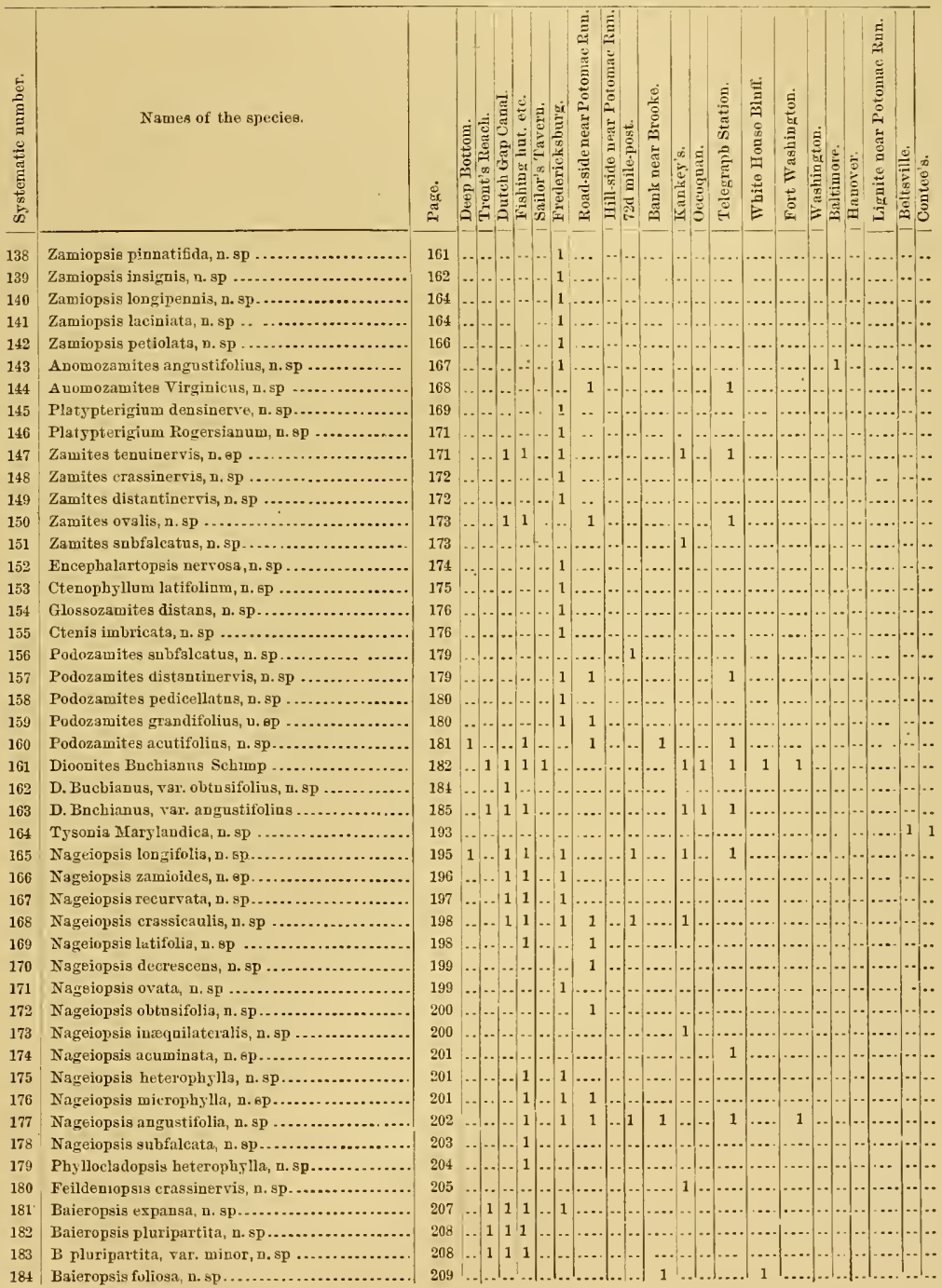
MON $\mathrm{xV}-23$ 
TABLE I. - List of species of the Potonae formation, with the localities at which they were collected-Cont'd.

\begin{tabular}{|c|c|}
\hline 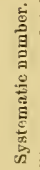 & Names of the species. \\
\hline 185 & Baieropsis denticulata, n. sp .......... \\
\hline 186 & B. denticulata, rar. augustifolia, $\mathbf{n}$. sp....... \\
\hline 187 & Baieropsis longifolia, n. sp .................. \\
\hline 188 & Baieropsis adiantifulia, n. sp........... \\
\hline 189 & 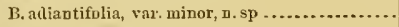 \\
\hline 190 & Baieropsis macrophylla, n.sp................ \\
\hline 191 & Baiera foliosa, $\mathrm{n}, \mathrm{sp} \ldots \ldots \ldots \ldots \ldots \ldots$ \\
\hline 192 & Frentopsis ramosissima, n. sp $\ldots . . . .$. \\
\hline 193 & Frenelopsis parceramosa, n. sp............. \\
\hline 194 & 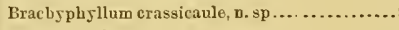 \\
\hline 195 & Brachsphyllum pareeramosum, n. sp........... \\
\hline 196 & Brachyphyllum, species? (cone) ............... \\
\hline 197 & Brachsphyllaw, species? $(\operatorname{con} \theta) . . . \ldots \ldots . .$. \\
\hline 198 & Brachyphyllum, species? (cone) .............. \\
\hline 199 & Leptostrobus longifolius, n. sp ............... \\
\hline 200 & Leptostrobus foliosus, n. sp. ................ \\
\hline 201 & Leptostrobns multiflorus, n.sp .............. \\
\hline 202 & Leptostrobus, (a) species ?, seed............. \\
\hline 203 & Leptostrobus, $(b)$ species ?, seed ............. \\
\hline 204 & Leptostrobus, (c) species?, seod .............. \\
\hline 205 & Laricopsis longifobia, n. sp ..................... \\
\hline 206 & Laricopsis angustifolia, n. sp.............. \\
\hline 207 & Laricopsis brevifolia, n. sp .................... \\
\hline 208 & 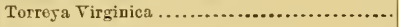 \\
\hline 209 & 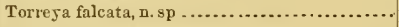 \\
\hline 210 & Cephalotaxopsis maguifolia, $\mathrm{n}, \mathrm{sp} . \ldots . . . .$. \\
\hline 211 & Cephalotaxopsis ramosa, o. sp ............. \\
\hline 212 & 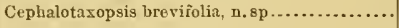 \\
\hline 213 & Cephalotaxopsis microphylla, n. sp............. \\
\hline 214 & A throtaxopsis grandis, n. sp ................ \\
\hline 215 & Athrotaxopsis tenuicaniis, n. sp....... \\
\hline 216 & Athrotaxopsis expansa, n. sp .................. \\
\hline 217 & Athrotaxopsis pachyphylla, D. sp ........... \\
\hline 218 & 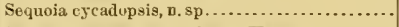 \\
\hline 219 & Sequoia Reichenbachi (Gein.) Heer. ........... \\
\hline 220 & 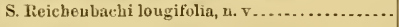 \\
\hline 221 & Sequoia smbulatia Hoer. ....................... \\
\hline 222 & 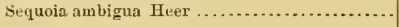 \\
\hline 223 & Sequoia rigida ffeer ...................... \\
\hline 224 & 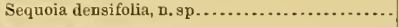 \\
\hline 225 & Sequoia gracilis Heer $\ldots . . . . . . . . . . . . . . .$. \\
\hline 226 & Sequoia delicatnla, n. sp .................. \\
\hline 227 & 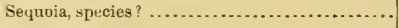 \\
\hline 228 & 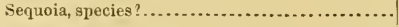 \\
\hline 229 & Sequoia, species? ..................... \\
\hline 230 & A raucaria polocarpoides, n. sp ............. \\
\hline 231 & 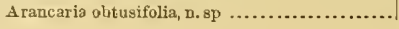 \\
\hline
\end{tabular}

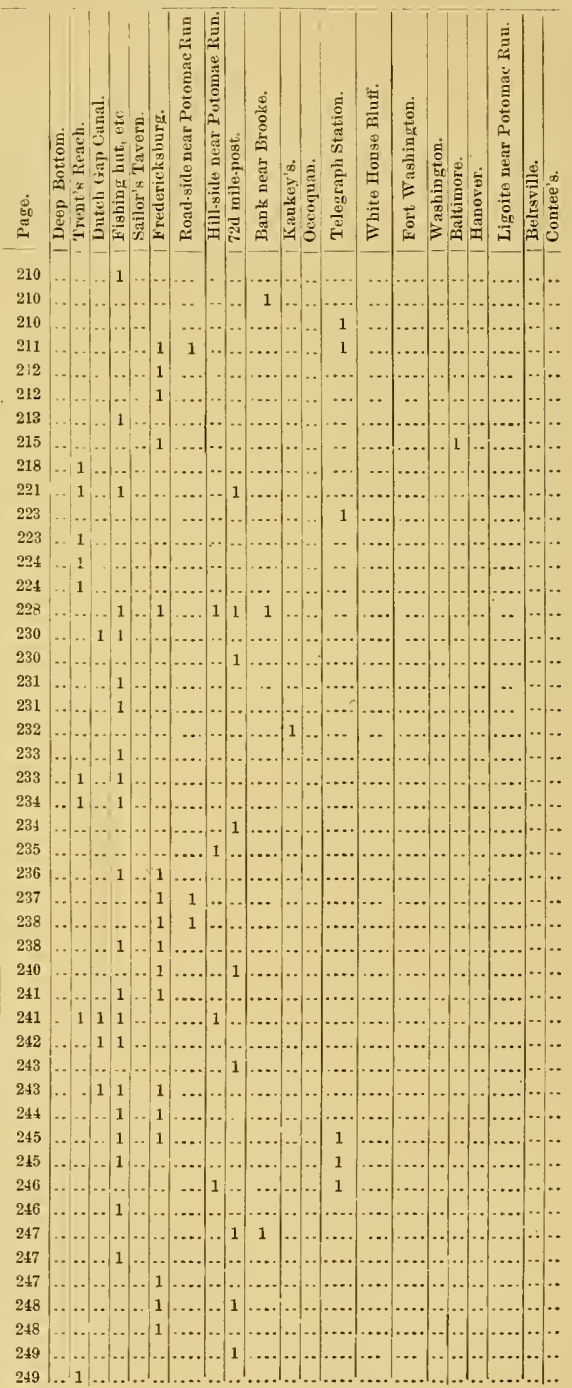


TABLE I.-List of specics of the Potomac formation, with the localities at which they were collected-Cont'd.

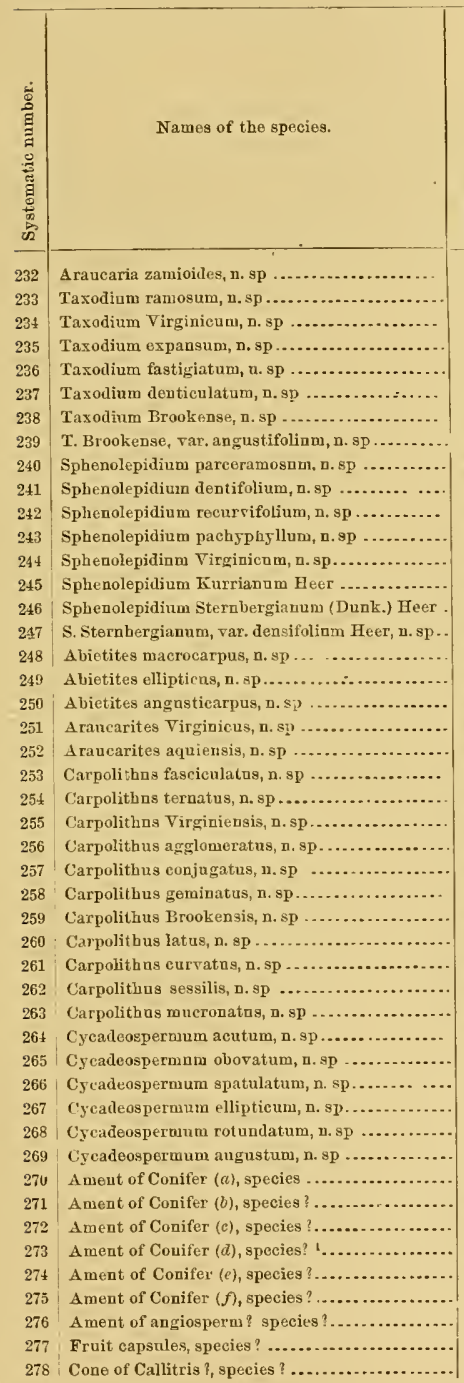

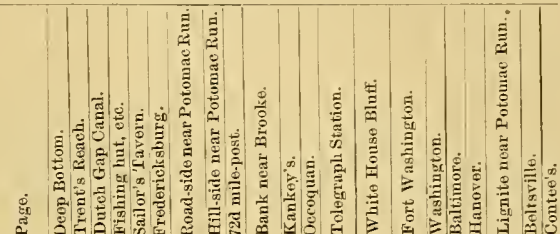

250

251

252

252

253

253

254

256

257

258

258

259

259 
TABLe I. - List of speeies of the Potomao formation, with the loealities at which they were collectcd-Cont'd.
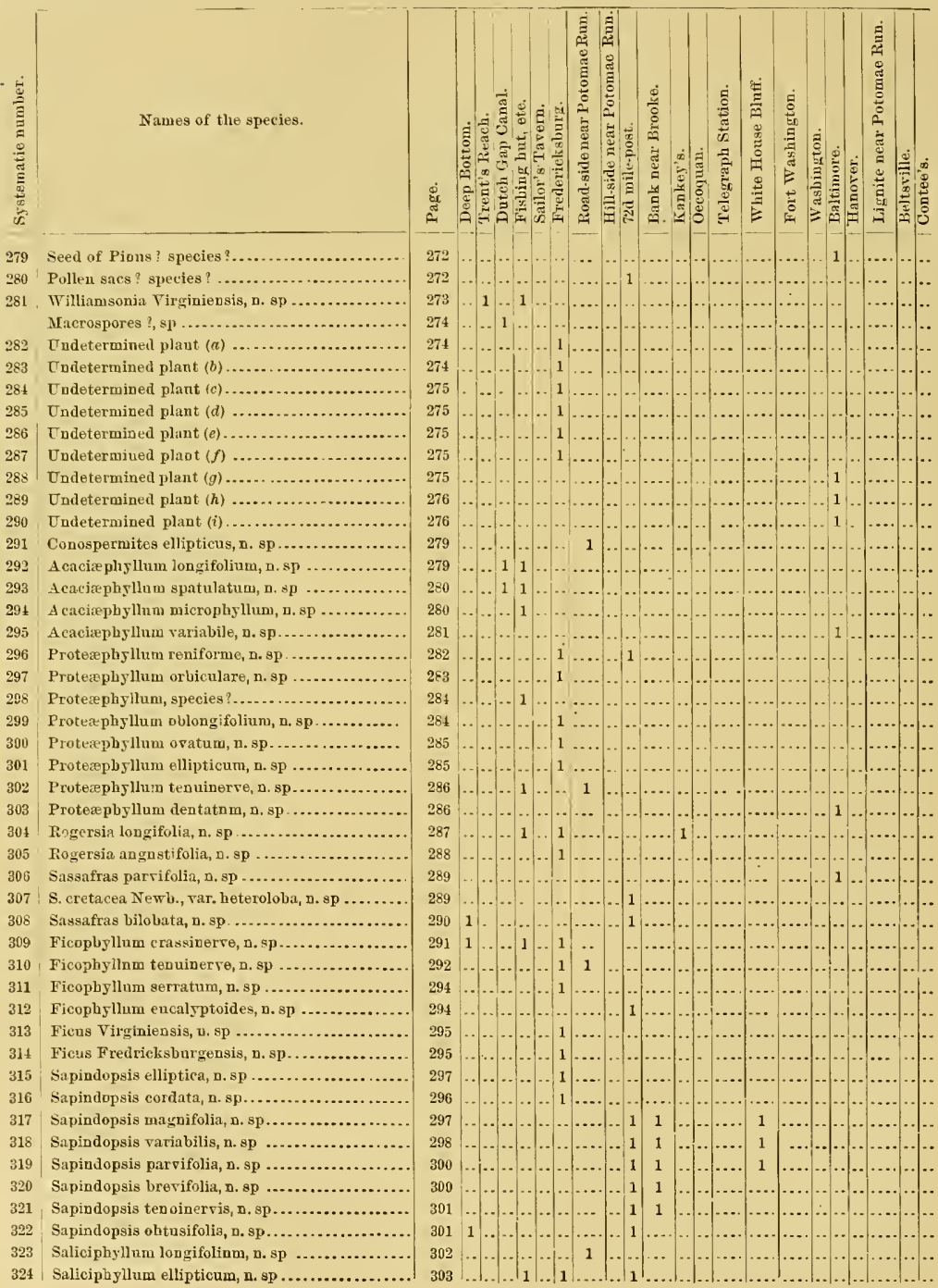

29

$$
31
$$

313

Salicina ne 
TABLE I.--List of species of the Potomac formation, with the localities at which they were collected-Cont'd.

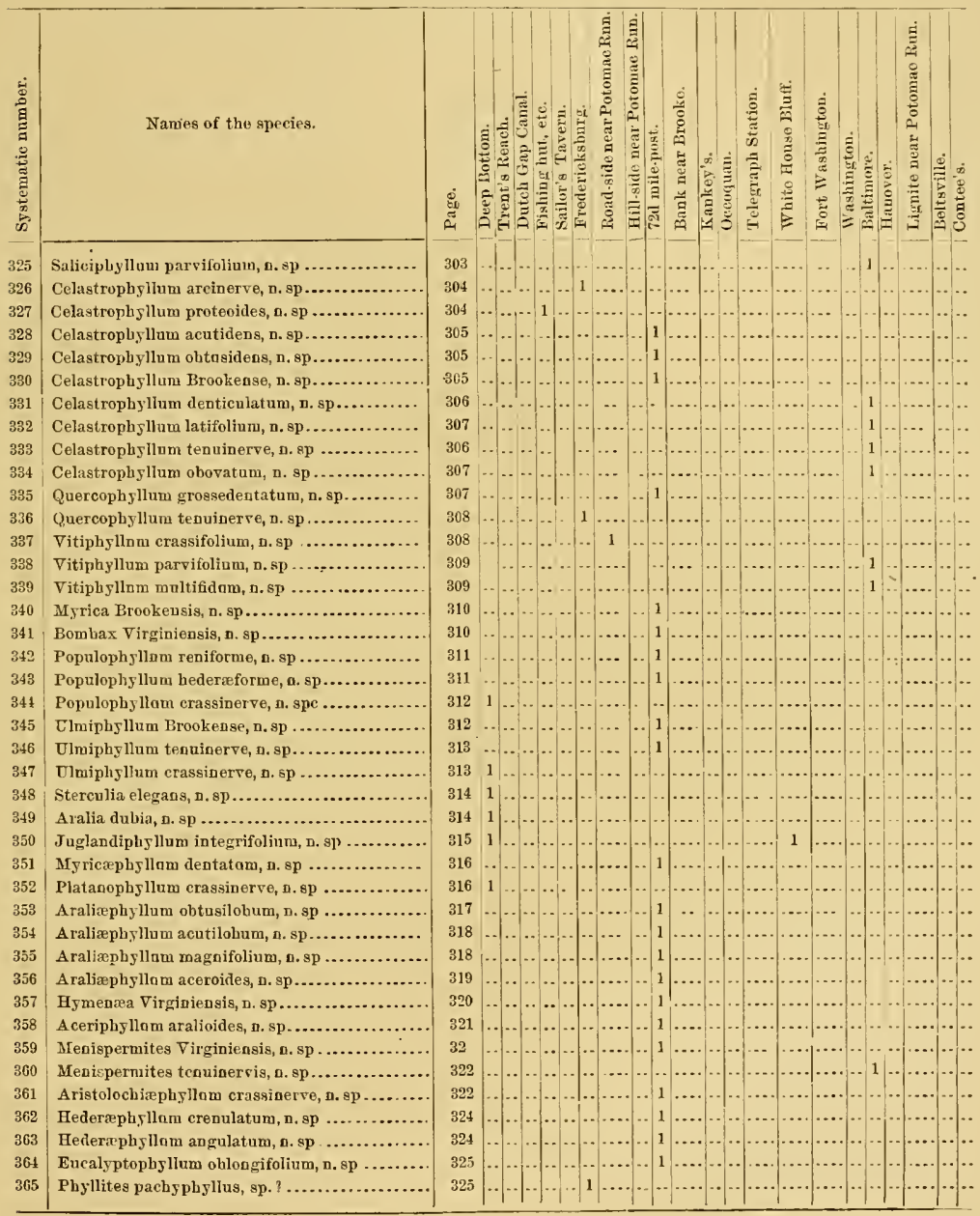


TABLE II.-List of species of plants of the Potomac formation identical

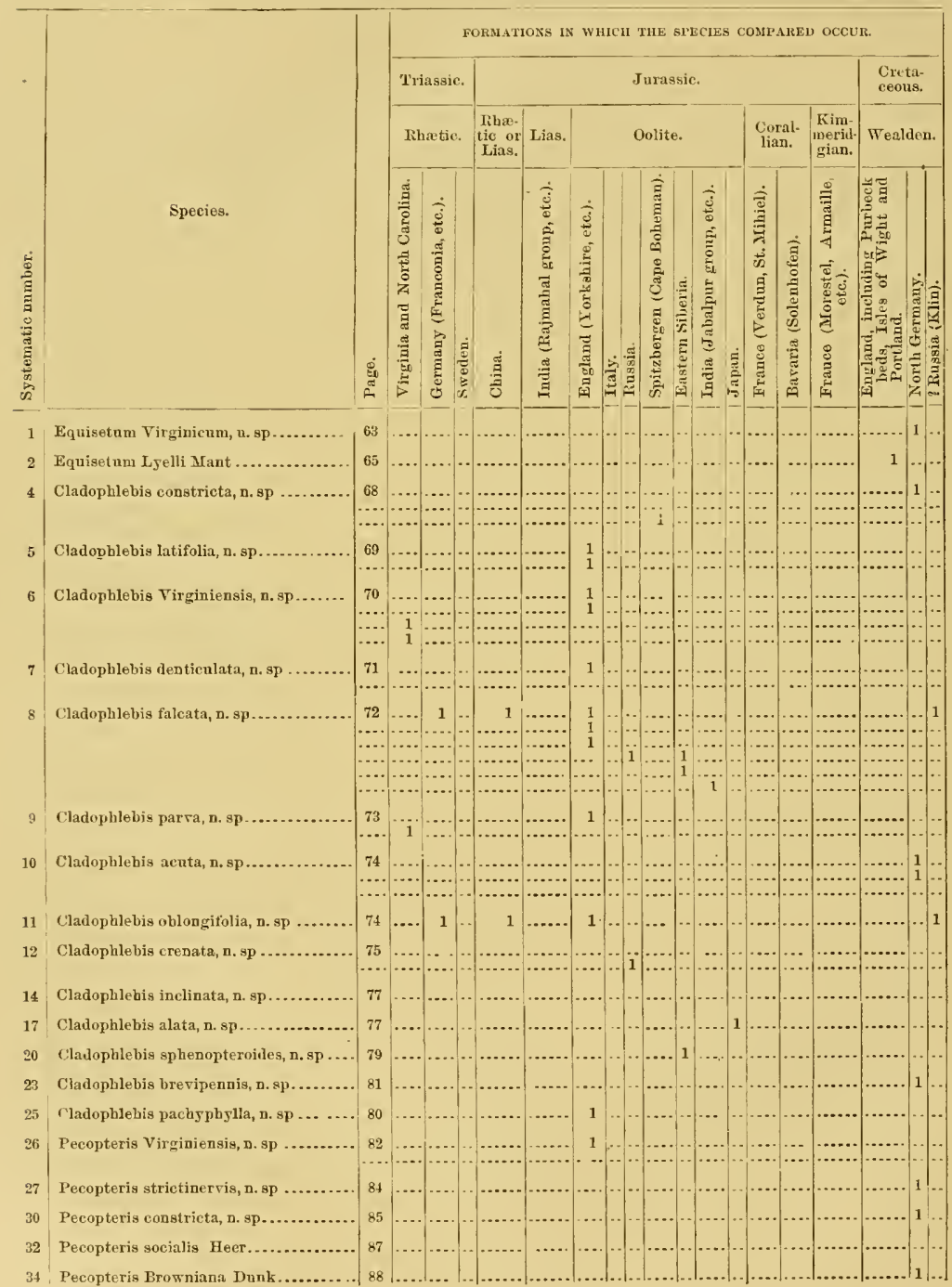


TABLES.

with or allied to species described from other localities and formations.

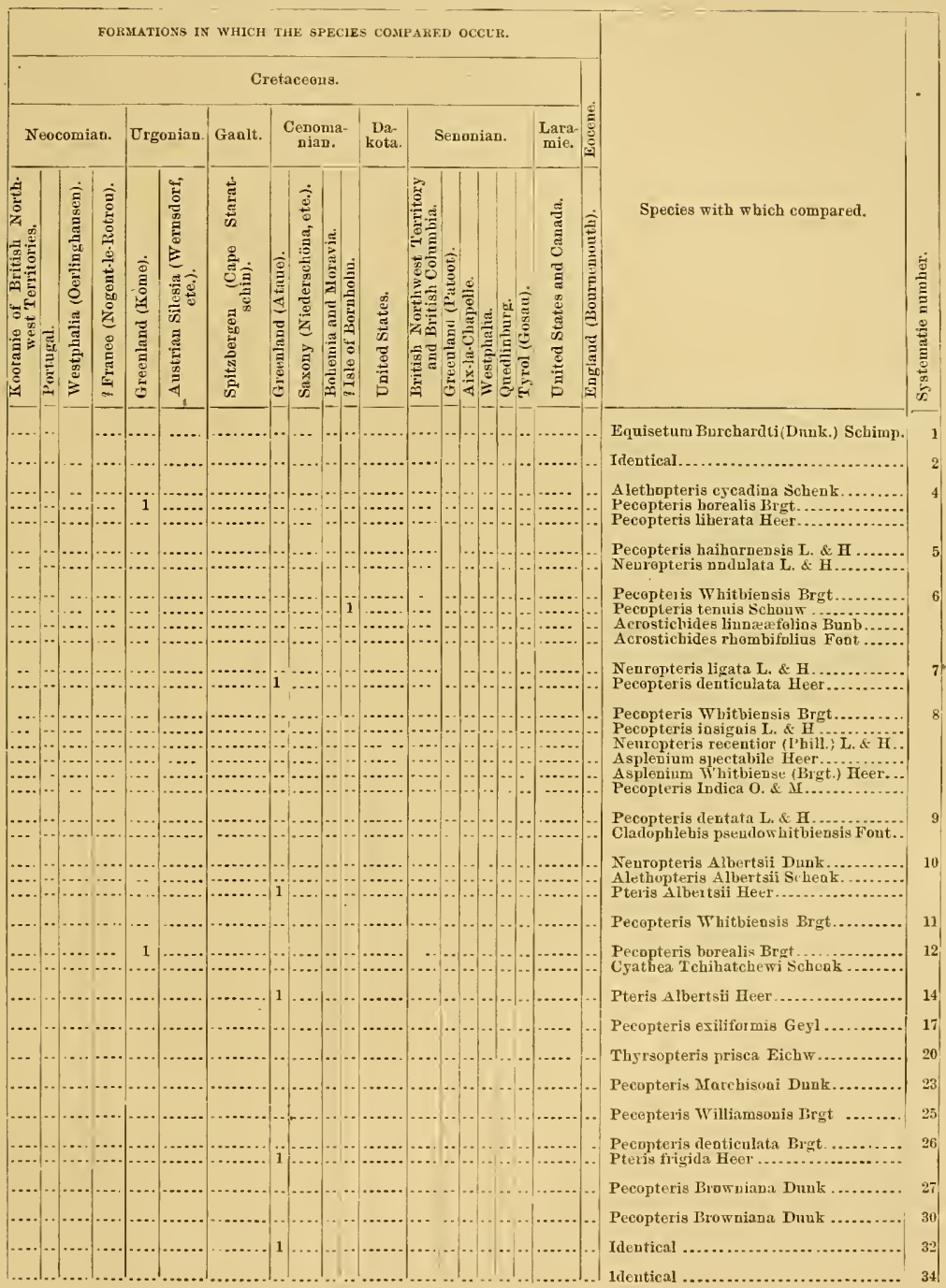


TABLE II.-List of species of plants of the Potomac formation identical

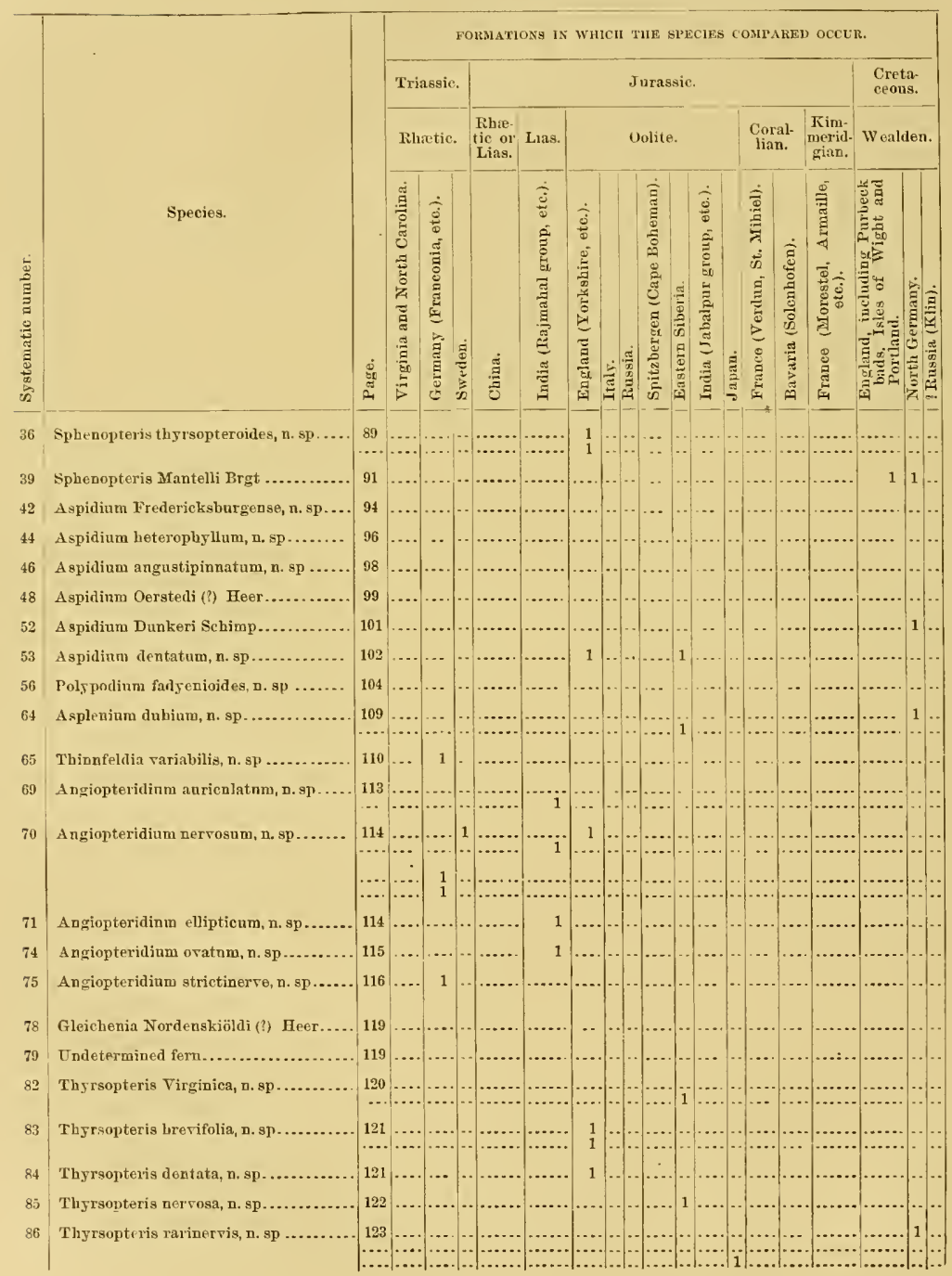


TABLES.

with or allied to species described from other localities and formations-Continned.

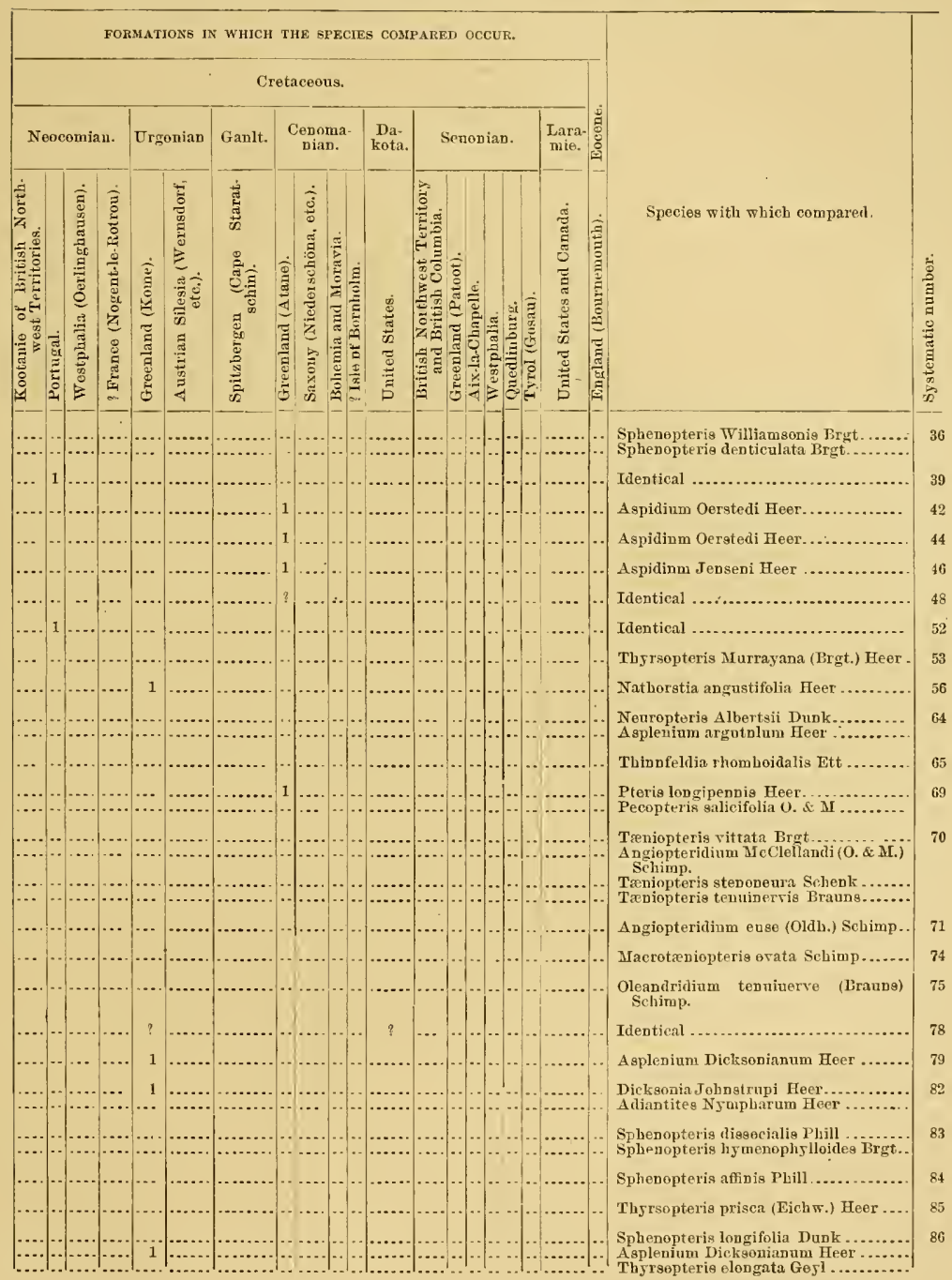


TABLE II.-List of species of plants of the Potomac formation identical

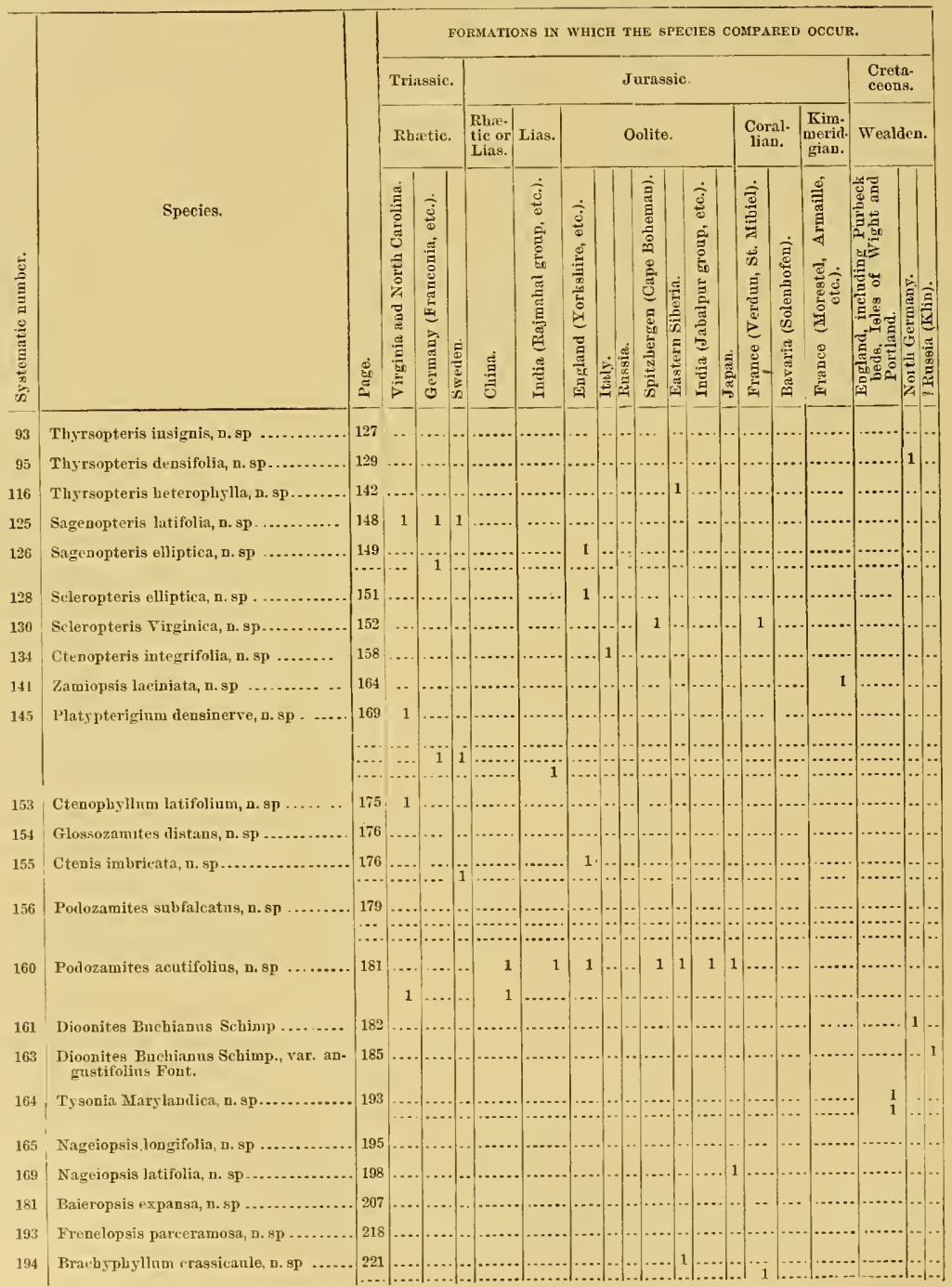


TABLES.

with or allied to species described from other localities and formations-Continued.

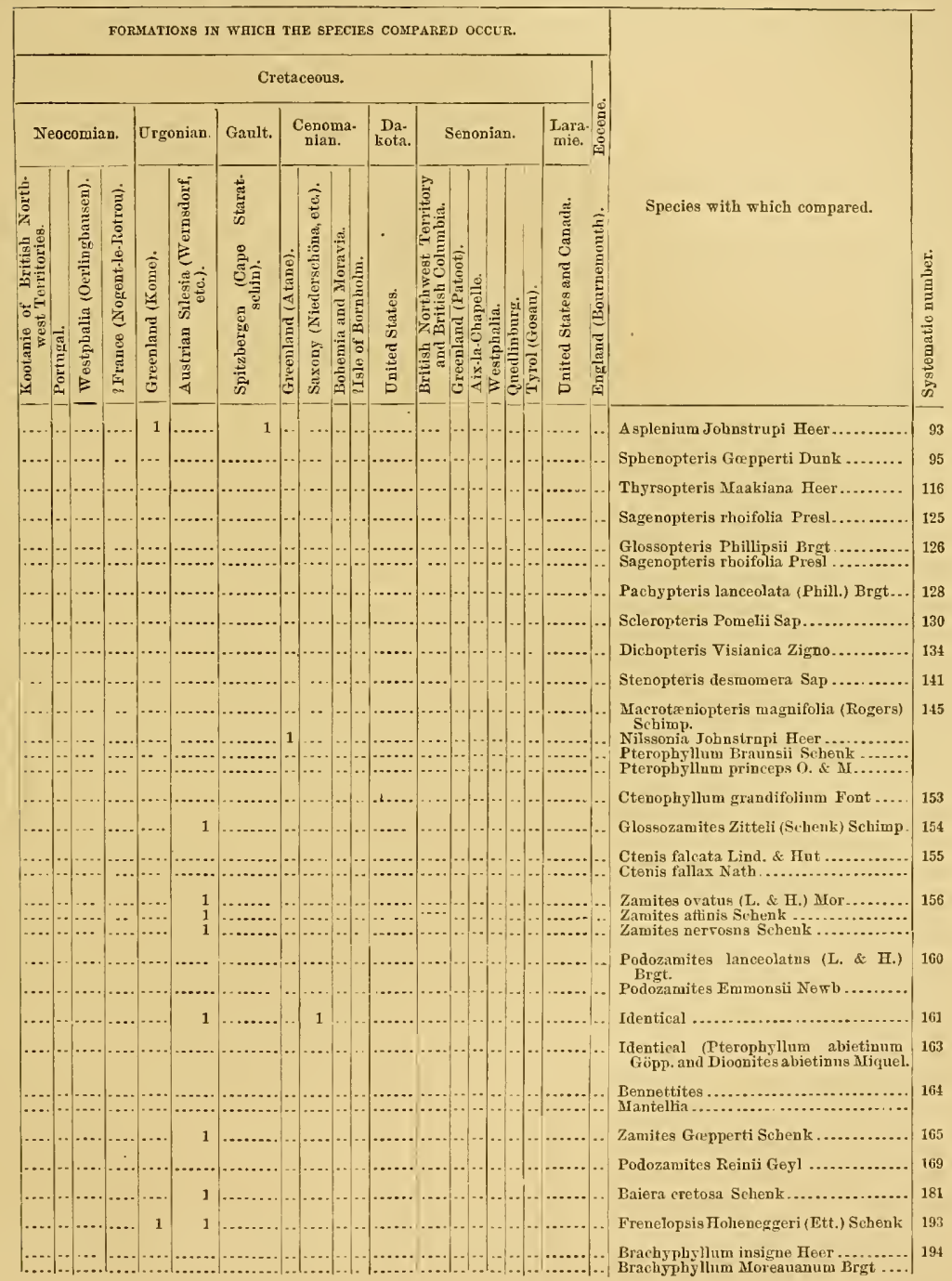


Table II.-List of species of plants of the Potomac formation identical

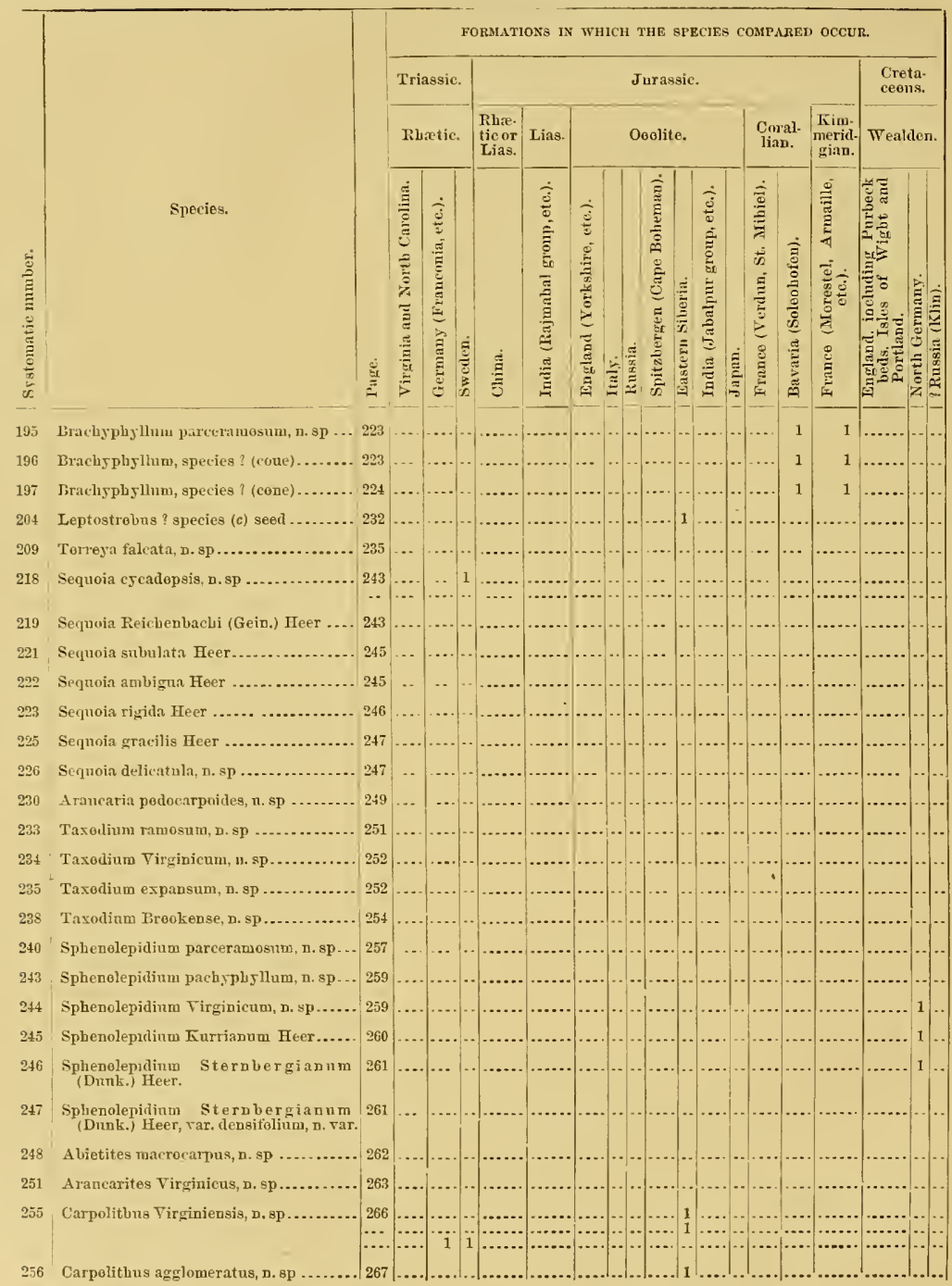


TABLES.

with or allied to species described from other localities and formations-Continued.

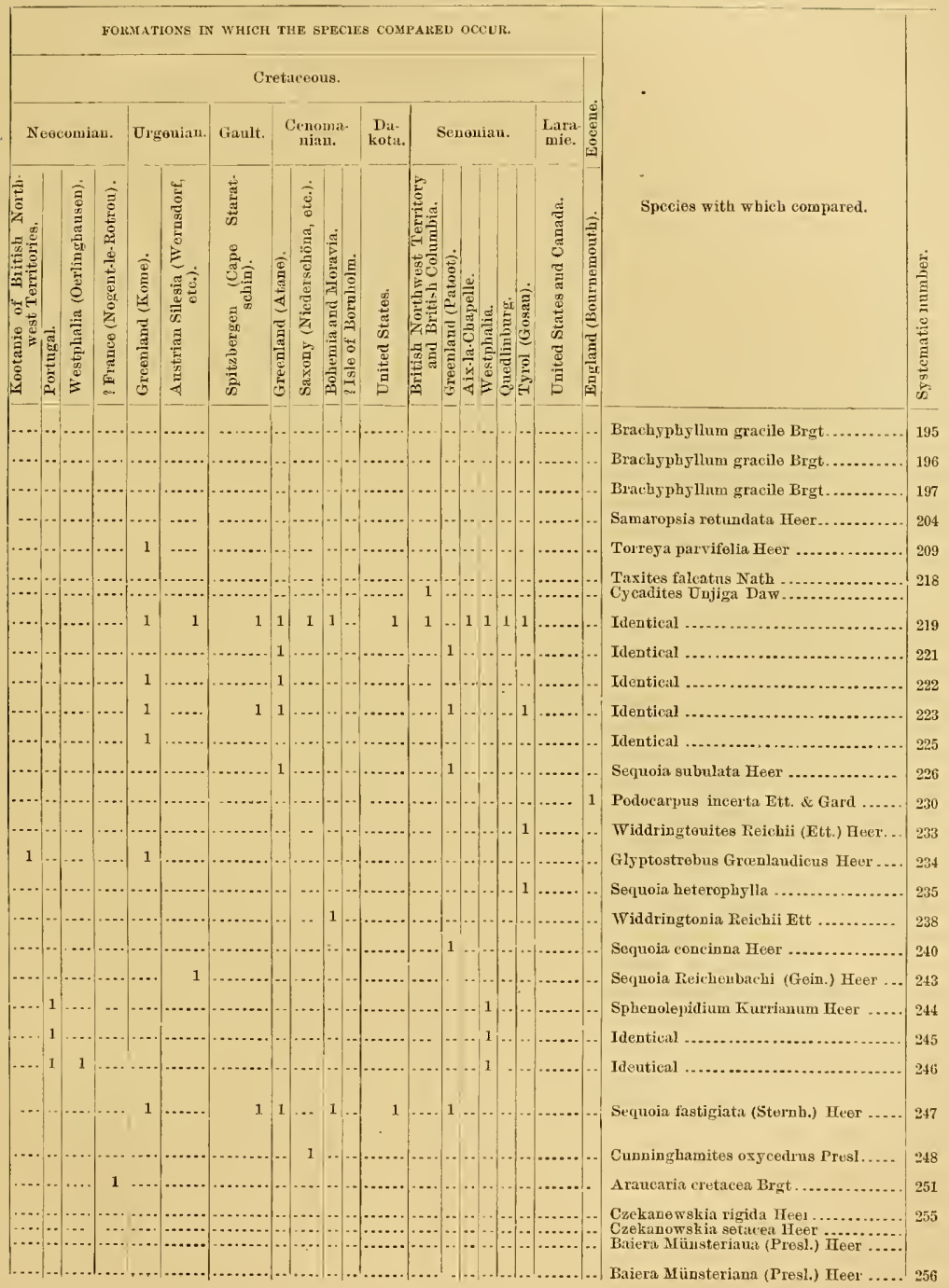


TABLE II.-List of spccies of plants of the Potonac formation identical

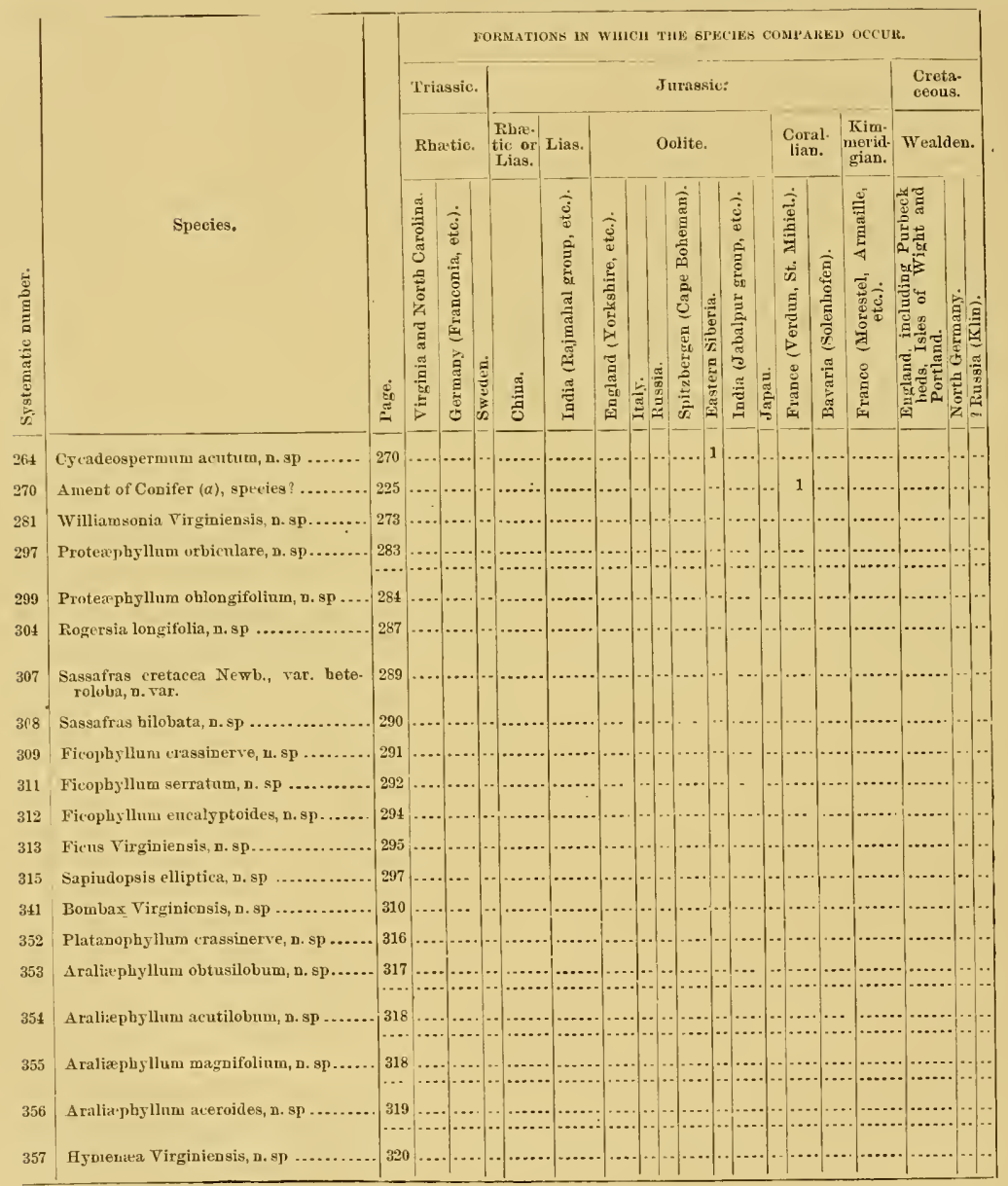


TABLES.

with or allied to species described from other localities and formations-Continued.

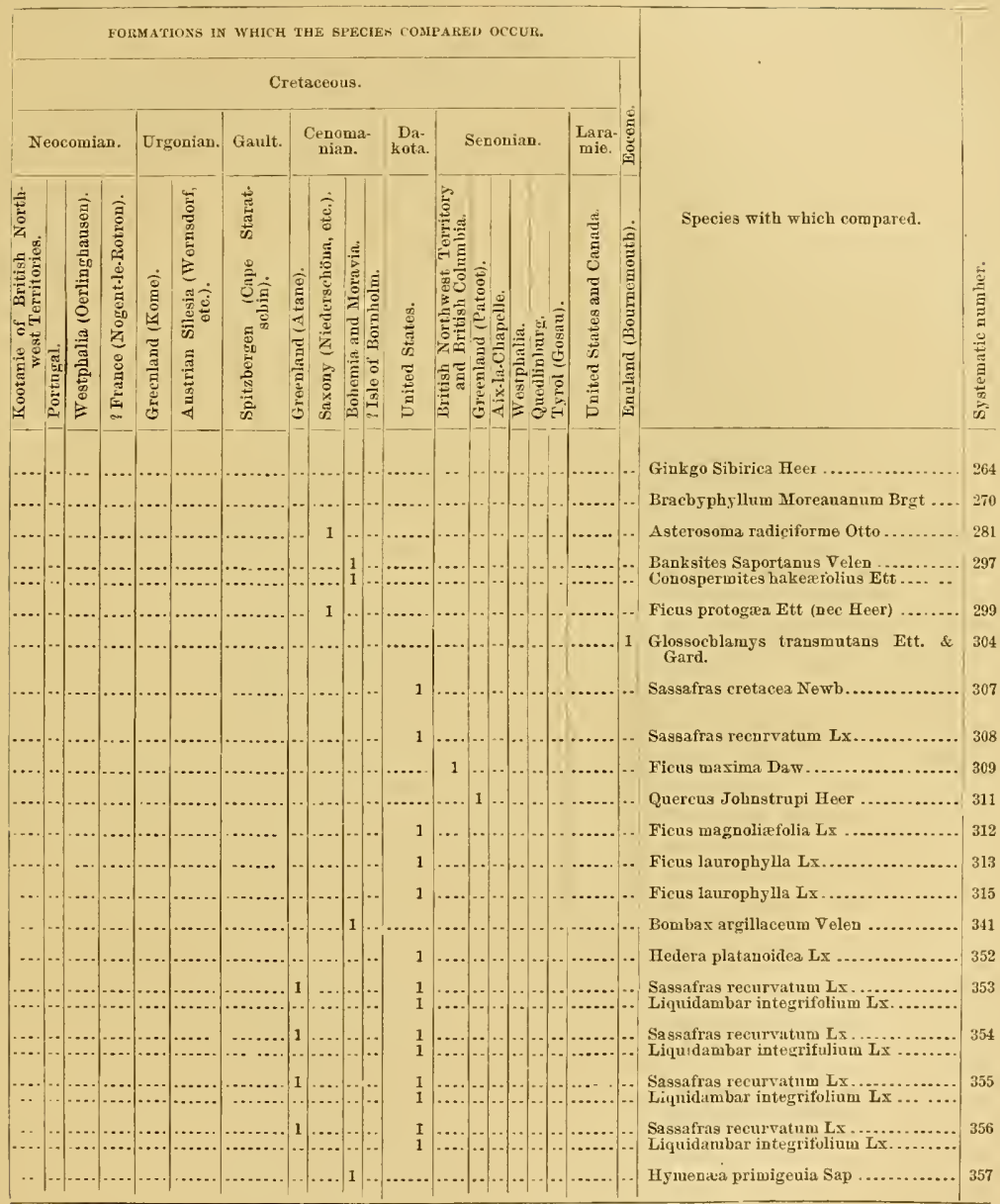


TABLE III.-Localities other than those of the Potomao formation at which Po'omae species or their allies have been found, arranged primarily in the ascending orter of their geologio age.

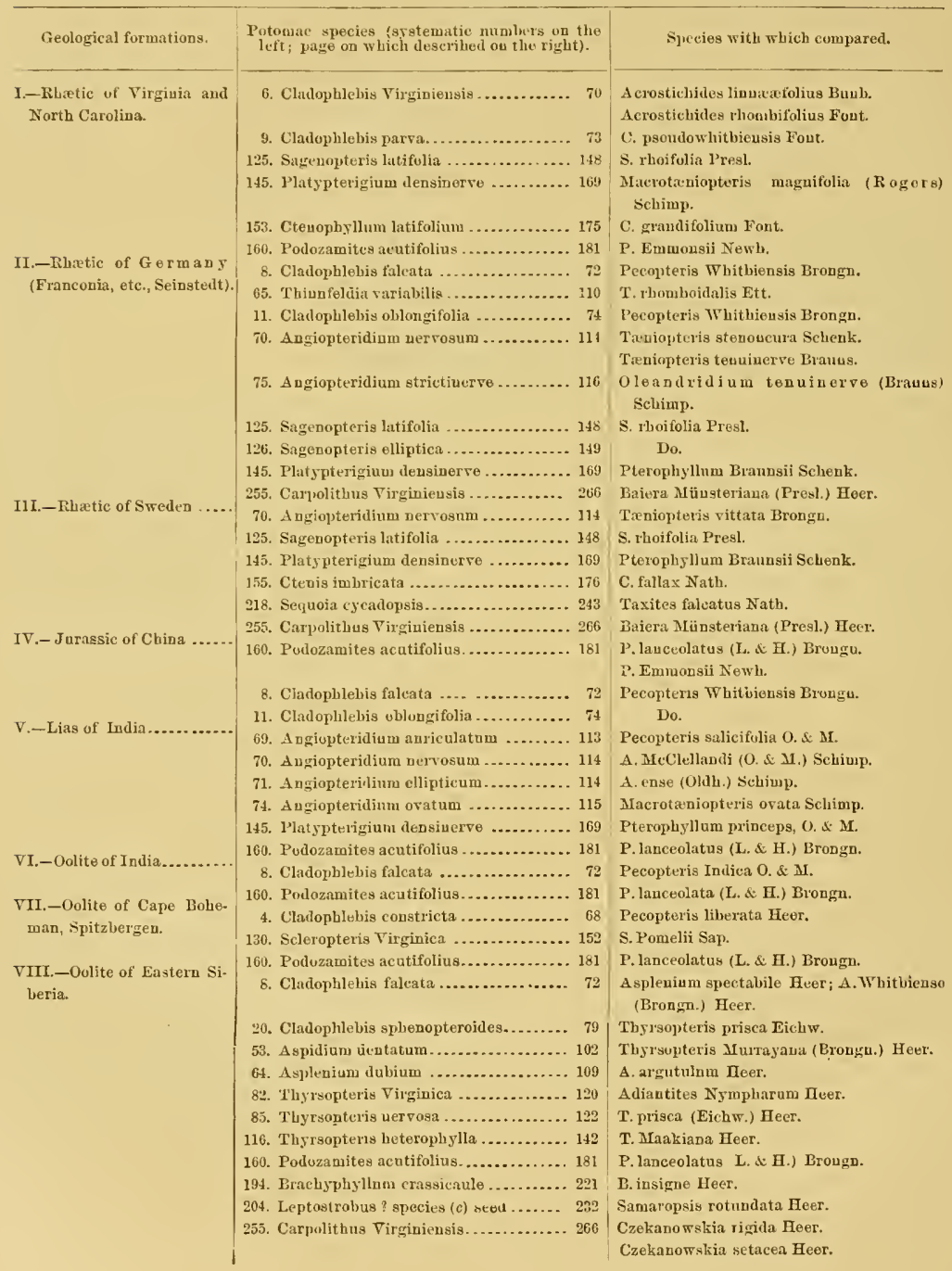


TABLE III.-Localities other than those of the Potomac formation at which Potomac species or their allies have been found, etc.-Continued.

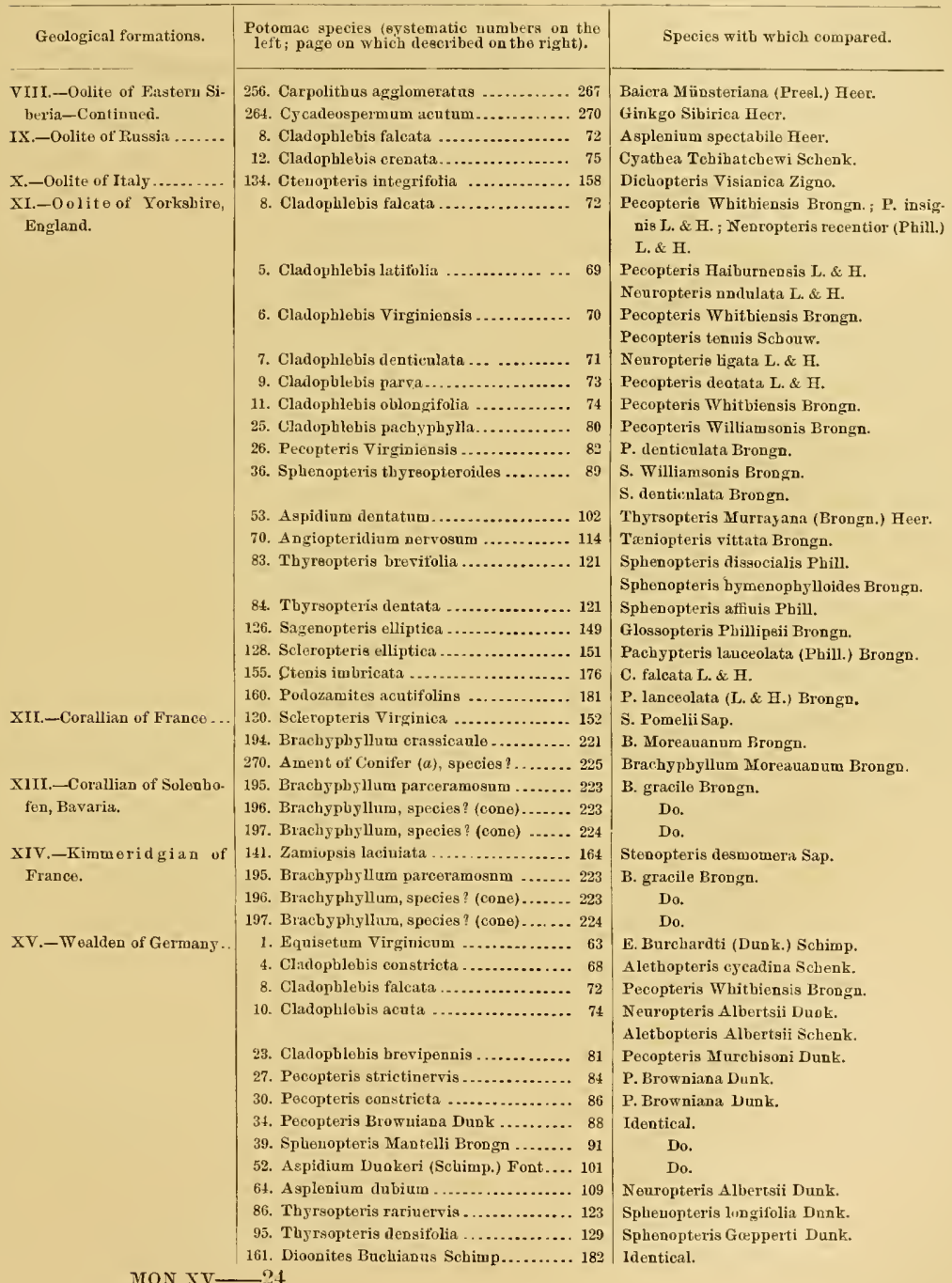


TABLE III.-Localitics other than those of the Potomac formation at which Potomac specics or their allies have bcen found, cte.-Continued.

\begin{tabular}{|c|c|c|}
\hline Geological formations, & $\begin{array}{l}\text { Potomac species (systematic numbers on the } \\
\text { left; page on which described on the right). }\end{array}$ & Species with which compared. \\
\hline $\begin{array}{l}\text { XV. W Walden of Germany- } 1 \\
\text { Continued. }\end{array}$ & $\begin{array}{l}\text { 168. D. Bnchiauns anguetifolius Font ...... } 185 \\
\text { 244. Sphenolepidium Virginicnm ......... } 259 \\
\text { 245. Sphenolepidum Kurrianum Heer .... } 260 \\
\text { 246. Sphenolepidium Stern ber g i a n n m } 261 \\
\text { (Dunk.) Heer. }\end{array}$ & $\begin{array}{l}\text { Ideutical (= Pterophyllumabietinum Göpp } \\
\text { and D. abietinus Miquel). } \\
\text { S. Kurrianum Heer. } \\
\text { Identical. } \\
\text { Do. }\end{array}$ \\
\hline XVI.-Wealden of England.. & $\begin{array}{r}\text { 2. Equisetum Lyelli Mant .............. } 65 \\
\text { 39. Sphenopteris Mantelli Brongn ....... } 91 \\
\text { 164. Ty } 90 \text { ia Mary landica .............. } 193\end{array}$ & $\begin{array}{l}\text { Do. } \\
\text { Do. } \\
\text { Benuottites. } \\
\text { Mantellia. }\end{array}$ \\
\hline $\begin{array}{l}\text { XVII. - Wealden ? (Neoca. } \\
\text { mian?) of Klin, Kussia. }\end{array}$ & 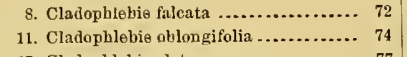 & $\begin{array}{l}\text { Pecopteris W bitbiensis Brongn. } \\
\text { Do. }\end{array}$ \\
\hline $\begin{array}{l}\text { XVI1L.Jurassic? (W eal. } \\
\text { den? Neocomian?) of Ja- } \\
\text { pan. }\end{array}$ & 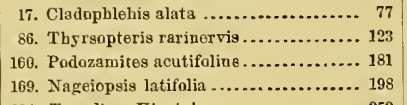 & $\begin{array}{l}\text { Pecopteris exibformis Geyl. } \\
\text { T. elongata Geyl. } \\
\text { P. lanceolatus (L. \& H.) Brongn. } \\
\text { Podozamites Reinii Geyl. }\end{array}$ \\
\hline $\begin{array}{l}\text { XIX.-Nencomian (Koota. } \\
\text { nie) of Brit. NW. T. }\end{array}$ & 234. Taxadium Virginicum ............... 252 & Glyptostrobus Grönlandicns Heer. \\
\hline $\begin{array}{l}\text { XX.-Neocomian of Portu- } \\
\text { gal. }\end{array}$ & $\begin{array}{l}\text { 39. Spbenopteris Mantelli Brongn ....... } 91 \\
\text { 52. Aspidium Dunkeri (Schimp.) Font .... } 101 \\
\text { 244. Sphenolepidium Virginieum ......... } 259 \\
\text { 245. Sphenolepidium Kurriannm Heer .... } 260 \\
\text { 246. Sphenolepidium Sternher gi a n u m } 261 \\
\text { (Dunk.) Heer. }\end{array}$ & $\begin{array}{l}\text { Identical. } \\
\text { Do. } \\
\text { S. Kurrianum Heer. } \\
\text { Identical. } \\
\text { Do. }\end{array}$ \\
\hline $\begin{array}{l}\text { XXI-Neocomian of West. } \\
\text { phalia. }\end{array}$ & $\begin{array}{l}\text { 246. Sphenolepidium Sternbergianum } 261 \\
\text { (Dnnk.)He日r. }\end{array}$ & Do. \\
\hline $\begin{array}{l}\text { Xxil.-Noocomian? of } \\
\text { France. }\end{array}$ & 251. Araucarites Virginicus .............. 263 & Arancaria cretacea Brongn. \\
\hline $\begin{array}{l}\text { XXrII.-Urganian of Green. } \\
\text { land. }\end{array}$ & 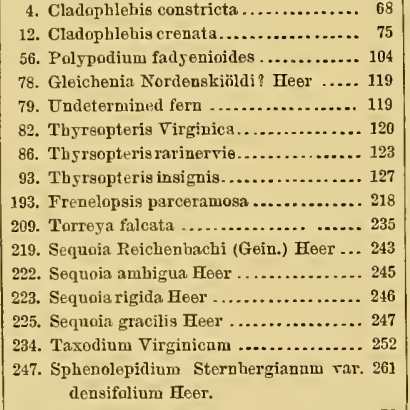 & $\begin{array}{l}\text { Pecopteris horealis Brongn. } \\
\text { Pecopterjs borealie Brongn. } \\
\text { Nathorstia anguatifolia Heer. } \\
\text { Identical. } \\
\text { Asplenium Dicksonianam Heer. } \\
\text { Dicksonia Johnstrupi Heer. } \\
\text { Asplenium Dicksonianum Heer. } \\
\text { Asplenium Johnstrupi Heer. } \\
\text { F. Hobeneggeri (Ett.) Schenk. } \\
\text { T. parvifolis Heer. } \\
\text { Identical. } \\
\quad \text { Do. } \\
\quad \text { Do. } \\
\text { Do. } \\
\text { T. (Glyptostrobus) Grönlandicum Heer. } \\
\text { Sequoia fastigiata (Sternb.) Heer. }\end{array}$ \\
\hline $\begin{array}{l}\text { XXIV.-Urgonian of } \Delta \text { ns. } \\
\text { trian Silesia. }\end{array}$ & 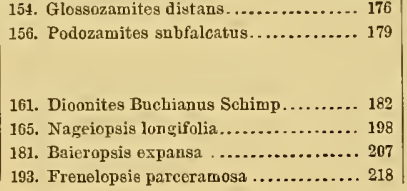 & $\begin{array}{l}\text { G. Zitteli (Schenk) Schimp. } \\
\text { Zamites avatns (L. \& H.) Morr. } \\
\text { Z. affinis Schenl. } \\
\text { Z. nervosus Schenk. } \\
\text { Identical. } \\
\text { Zamites Gopperti Schenk? } \\
\text { Baiera cretosa Scbenk. } \\
\text { F. Holieneggeri (Ett.) Schenk. }\end{array}$ \\
\hline
\end{tabular}


TABLE III.-Localities other than those of the Potomac formation at which Potomac species or their allies have been found, cte.-Continned.

\begin{tabular}{|c|c|c|}
\hline Geological formations. & $\begin{array}{l}\text { Potomac species (systematic nnmbers on the } \\
\text { left; page on which descriled on the right). }\end{array}$ & Species with which compared. \\
\hline $\begin{array}{l}\text { XXIV.-Urgonian of Aug- } \\
\text { trian Silesia-Continued. } \\
\text { XXV.-Ganlt of Spitzber. } \\
\text { gen. }\end{array}$ & $\begin{array}{l}\text { 219. Sequoia Reichen lachi (Gein.) Hetr... } 243 \\
\text { 243. Sphenole pidium pachyphyllum ....... } 259 \\
\text { 93. Thyrsopteris insignis ............... } 127 \\
\text { 219. Sequoia Reichenbachi (Gein.) Heer... } 243 \\
\text { 223. Sequoia rigida Heer ................ } 246 \\
\text { 247. Sphenolepidinm Sternhergianum, var. } 261 \\
\text { densifolium Heer. } \\
\text { 6. Cladophlebis Virginiensis............. } 70\end{array}$ & $\begin{array}{l}\text { Identical. } \\
\text { Sequoia Reichenhachi (Gein.) Heer. } \\
\text { Asplenium Johnstrupi Heer. } \\
\text { Identical. } \\
\quad \text { Do. } \\
\text { Sequoia fastigiata (Stornb.) Hecr. } \\
\text { Pecopteris tenuis Schouw. }\end{array}$ \\
\hline $\begin{array}{l}\text { Bornholn. } \\
\text { XXVII-C enomanian of } \\
\text { Greenland. }\end{array}$ & 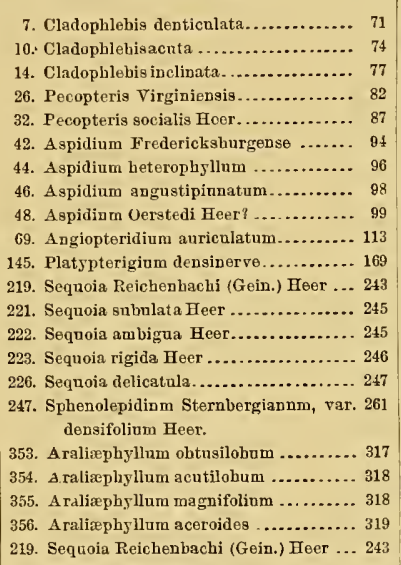 & $\begin{array}{l}\text { Pecopters denticnlata Heer. } \\
\text { Pteris Albertsii Heer. } \\
\text { Pteris Alhertsii Heer. } \\
\text { Pteris frigida Heer. } \\
\text { Identical. } \\
\text { A. Oerstedi Heer. } \\
\text { A. Oerstedi Heer. } \\
\text { A. Jenseni Heer. } \\
\text { Identical. } \\
\text { Pteris longipennis Heer. } \\
\text { Nilssonia Jobnstrupi Heer. } \\
\text { Identical. } \\
\quad \text { Do. } \\
\text { Do. } \\
\text { Do. } \\
\text { S. enbulata Heer. } \\
\text { Seguoia fastigiata (Sternb.) Heer. } \\
\end{array}$ \\
\hline $\begin{array}{l}\text { XXVIII.-Cenowanian of } \\
\text { Bohemia and Moravia. }\end{array}$ & 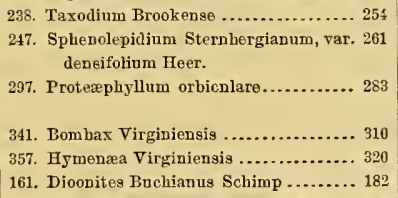 & $\begin{array}{l}\text { Widdringtonia Reichii Ett. } \\
\text { Sequoia fastigiata (Sternb.) Heer. } \\
\text { Banksites Saportanns Velen. } \\
\text { Conospermites hakerefolius Ett. } \\
\text { B. argillaceno Velen. } \\
\text { H. primigenia Sap. } \\
\text { Identical. }\end{array}$ \\
\hline $\begin{array}{l}\text { XXIX.-Cenomanian of } \\
\text { Saxony. }\end{array}$ & $\begin{array}{l}\text { 219. Sequoia Reichenbachi (Gein.) Heer... } 243 \\
\text { 248. A bietites macrocarpus................. } 262 \\
\text { 281. Williamsonia Virginiensis ............. } 273 \\
\text { 299. Proteephyllim oblongifalium ........ } 284 \\
\text { 78. Gleichenia Nordenskiöldi ? Heer ...... } 119\end{array}$ & $\begin{array}{l}\text { Do. } \\
\text { Cnnuinghamites oxjcedrus Presl. } \\
\text { Asterosona radiciforme Otto. } \\
\text { Ficus protogxa Ett. (nec Heer). } \\
\text { Identical?. }\end{array}$ \\
\hline $\begin{array}{l}\text { XXX.-Dak ot a Group, } \\
\text { United States. }\end{array}$ & 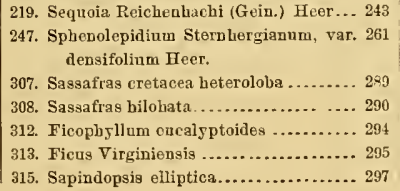 & $\begin{array}{l}\text { Identical. } \\
\text { Sequoia fastigiata (Sternb.) Heer. } \\
\text { S. cretacea Newb. } \\
\text { S. recurvata Lx. } \\
\text { Ficus magnoliafolia Lx. } \\
\text { F. laurophylla Lx. } \\
\text { Ficus laurophylla Lx. }\end{array}$ \\
\hline
\end{tabular}


TABLE III.-Localities other than those of the Potomac formation at which Potomac species or their allies have been found, etc.-Continued.

\begin{tabular}{|c|c|c|}
\hline Geological formations. & $\begin{array}{l}\text { Potonac species (srstematic uurubers on the } \\
\text { left; page ou which described ou tho right). }\end{array}$ & Species with which compared. \\
\hline $\begin{array}{l}\text { Xxx-Dakofa G r o u p, } \\
\text { United States-Continued. }\end{array}$ & 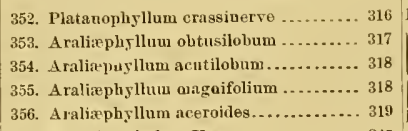 & $\begin{array}{l}\text { Hedera platanoidea Lx. } \\
\text { Sassafras recurvatum Lx. } \\
\text { Liq̨uidambar integrifolium Lx. }\end{array}$ \\
\hline $\begin{array}{l}\boldsymbol{x} \times x \mathrm{I}-\text { Senonian of Patoot, } \\
\text { Greenlaud. }\end{array}$ & 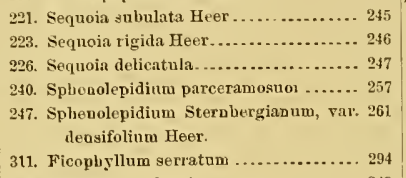 & $\begin{array}{l}\text { Tdeutical. } \\
\quad \text { Do. } \\
\text { S. subulata Heer. } \\
\text { Sequoia coucioaa Heer. } \\
\text { Sequoia fastigiata (Sternb.) Heor. } \\
\text { Quereus Joluatrupi Heer. }\end{array}$ \\
\hline $\begin{array}{l}\text { XxxII. }-S e \text { novian of } \\
\text { British America. }\end{array}$ & $\begin{array}{l}\text { 218. Sequoia cyeadopsis.................. } 243 \\
\text { 219. Sequoia Reichenbachi (Gein.) Heer ... } 243 \\
\text { 309. Ficophy llum crassinerve.............. } 291\end{array}$ & $\begin{array}{l}\text { Cscadites Unjiga Daw. } \\
\text { Ilıntical. } \\
\text { Ficuч uasima Daw. }\end{array}$ \\
\hline $\begin{array}{l}\text { XXXIII.-Senodiaa of Qued- } \\
\text { livburg. }\end{array}$ & 219. Sequoia Reichenbachi (Gein.) Heer ... 243 & Ideutical. \\
\hline $\begin{array}{l}\text { XXXIV.-Senonian (Gosan) } \\
\text { of Tyrol. }\end{array}$ & 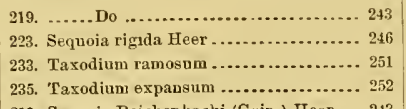 & $\begin{array}{l}\text { Do. } \\
\text { Do. } \\
\text { Widdringtonites Reichii (Ett.) Heer. } \\
\text { Sequoia hettrophylla. }\end{array}$ \\
\hline $\begin{array}{l}\text { XxरV.-Senonian of West- } \\
\text { phalia. }\end{array}$ & $\begin{array}{l}\text { 219. Sequoia Reichenbachi (Gein.) Heer ... } 243 \\
\text { 244. Sphenolepidium Virginicum. ........ } 259 \\
\text { 245. Sphenolepidium Kurriauum Heer ..... } 260 \\
\text { 246. Sphenolepidium Ster u bergian u m } 261 \\
\text { (Dunk) Пeer }\end{array}$ & $\begin{array}{l}\text { Identical. } \\
\text { Sphenolepidiom Kurrianum Foer. } \\
\text { Identical. } \\
\text { Do. }\end{array}$ \\
\hline $\begin{array}{l}\text { XXXVI. SEDODian of } \\
\text { Aachen. }\end{array}$ & 219. Sequoia Reichenbachi (Gein.) Heer ... 243 & 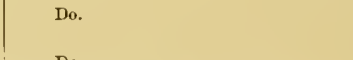 \\
\hline XXXVI1,-Laramie group.. & 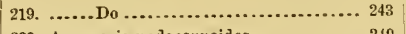 & $\begin{array}{l}\text { Do. } \\
\text { Podocarnus incerta Ett. \& Gard. }\end{array}$ \\
\hline $\begin{array}{l}\text { XXxVIII.-Eocene of Eng- } \\
\text { land. }\end{array}$ & $\begin{array}{l}\text { 230. Araucaria podocarpoides ................ } 249 \\
\text { 304. Rogersia lougifolia .................... } 287\end{array}$ & $\begin{array}{l}\text { Podocarpus incerta Ett. \& Gard. } \\
\text { Glossochlamys transmutao \& Ett. \& Gard. }\end{array}$ \\
\hline
\end{tabular}




\section{INDEX.}

\begin{tabular}{|c|c|c|c|}
\hline & Page. & n.................... & Page. \\
\hline A & & (2) & 249,250 \\
\hline Abietites Mantell . ...................................... & 262 & utusifolia & $\begin{array}{l}249 \\
249\end{array}$ \\
\hline 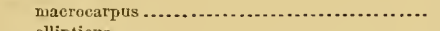 & 262 & zamioides . .................................. & 250 \\
\hline ellipticus...................... & 263 & Araucarites Sterub, emend......................... & 263 \\
\hline Angusticarpus ................... & 263 & 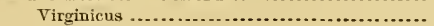 & 263 \\
\hline 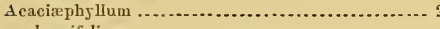 & $279-281$ & 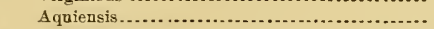 & 264 \\
\hline 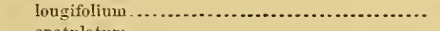 & 279 & Aristolochixphyllum............... & 322,323 \\
\hline (n) & 280 & erassinerve ........... & 322 \\
\hline (n) & 280 & 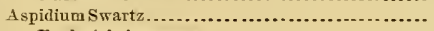 & $93-104$ \\
\hline (n).................. & 281 & isbnrgense.............................. & 94 \\
\hline (n) & 32 & ( & 95 \\
\hline ris & & 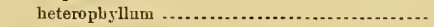 & 96 \\
\hline isis & -109 & Virginicum & 97 \\
\hline ( & 107 & tatum ............................................ & 98 \\
\hline . & 108 & 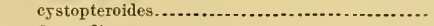 & \\
\hline n.................. & 10 & (1). & \\
\hline (8. & 30 & lium & .100 \\
\hline ( & 105,106 & m & 100 \\
\hline . & 105 & fidum & 101 \\
\hline erm? & 272 & (1) & 101 \\
\hline sp. ? & $225-227$ & m $\ldots \ldots \ldots \ldots \ldots \ldots \ldots \ldots \ldots \ldots \ldots$ & 102 \\
\hline m Sehimper.......................... & $113-117$ & carpum .................................... & 163 \\
\hline (n...................... & 113 & pum $\ldots \ldots \ldots \ldots \ldots \ldots \ldots \ldots \ldots \ldots \ldots \ldots$ & 103 \\
\hline & 114 & (n) & $117-119$ \\
\hline (2) & 11 & a & 118 \\
\hline (n) & 115 & (n) & 118 \\
\hline ( & 115 & 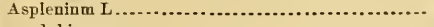 & 109,110 \\
\hline 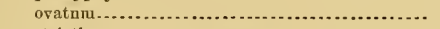 & 115 & , & 109 \\
\hline strictiuerre. . . . . & 116 & 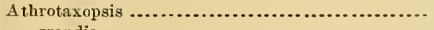 & $239-2+2$ \\
\hline rar. latifolium ...................... & 11 & 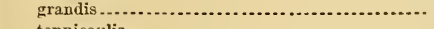 & 240 \\
\hline ( & 117 & lis ............... & 241 \\
\hline (n) & $277-325$ & 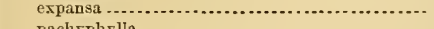 & 241 \\
\hline tes Sehimper.. & $167-171$ & 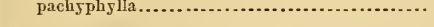 & 242 \\
\hline ( & 16 & B. & \\
\hline (nen & 168 & 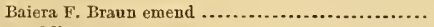 & 212 \\
\hline genus Platypterigium Schimper............. & $168-171$ & 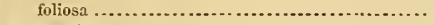 & 213 \\
\hline 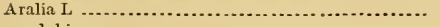 & 314 & Baieropsis & $205-212$ \\
\hline & 314 & (n) & 207 \\
\hline n............ & $316-320$ & pluripartita...$\ldots \ldots \ldots \ldots \ldots \ldots \ldots \ldots \ldots \ldots \ldots \ldots \ldots \ldots$ & 208 \\
\hline obrim........... & 317 & 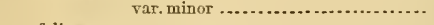 & 208 \\
\hline acutilobum ........... & 318 & 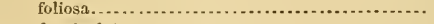 & 209 \\
\hline & $3: 8$ & 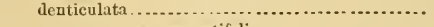 & 210 \\
\hline 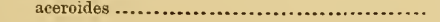 & 319 & var. angustifolia ....................... & 210 \\
\hline
\end{tabular}


Baieropsis longifolia ............................ adiantifolla.

var. min macrophylla

Bombax

Brachyphyllum (Brougniart) Schimper .............

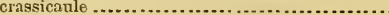

parceramosum.................................

sp. ?.......

Brooke station (plaut locality) described.

\section{C.}

Callitris, cone of ?............................. 272

Carpolithus St ............................ 20t-270

fascienlatus ............................... 265

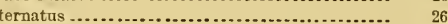

Firginiensis ....................................... 260

agglomeratus............................... 267

conjagatns ..................................... 267

geminatus ...................... 267

Brookensis .............................. 268

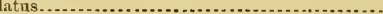

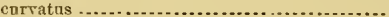

mucronatns

Celastroply

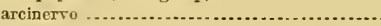

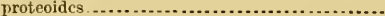

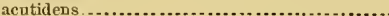

(n)

(l)

denticulatnm

latifolium

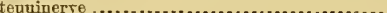

oboratnm ....................................

Cephalotaxopsis........................... 235-238

magnifolia . ................................ 236

ramosa .................................. 23

hrevifolia . . ............................. 238

Cephalotaxopsis microphylla.................... 238

Cladophlebis Brongu......................... $67-81$

latifolia

$\nabla$ irginiensis

(1)

falcata ....

parra

(1)

ohlougifolia .......................................

crenata.

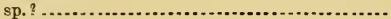

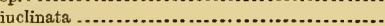

distans.

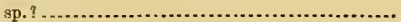

roturdatio

ephenopteroides.

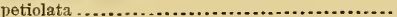

inæquiloba

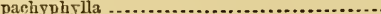

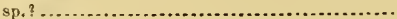

brevipennis

Coniferæ

Conospermites Ett ellipticus.

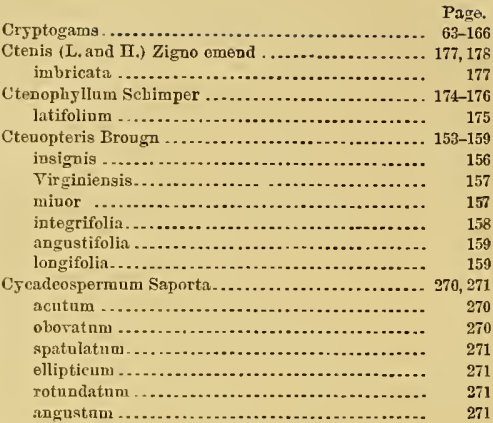

D.

Deen Bottom (plant loeality) described ........... 10,11

Dinouites Bornemand ........................... 181-180 Bucbianns Selimper . . ........................ 182

rar. obtusifolins.......... 184

rar, augustifolius.......... $\quad \mathbf{1 8 5}$

Dutch Gap Caoal (plant locality) described ......... 12-14

E.

Encephalartopsis ............................ 174

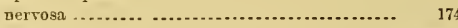

Equisetere.................................. $63-66$

Equisetum L................................ $68-66$

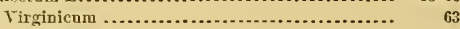

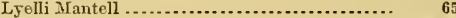

Rhizome of . . . . .

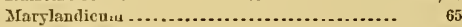

Eucalsptophyllum ............................ 325 oblongifolium .......................... 325

F.

Fieldeuiopsis.................................. 204, 205

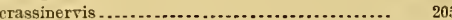

Ficophyllum ................................... 290-294

crassinerve................................. 291

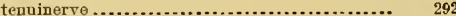

serratum ............................................ 294

fucalyptoides .............................. 294

Ficus Tournef ................................ 294, 295

Virginiensis............................ 295

Fredericksburgeusis ......................... 295

Filices . $66-166$

Fredericksburg (plant locality) deseribed.......... 15,16

Frenelopsis Sebenk . . . . . . . . . . . . . . . . . . . . . . .

ramosissima................................ 215

parceranosa ............................. 218

Fruit capsnles sp.?............................ 272

G.

Gleichedia Swartz.............................. 119

Tordeuskiöldi ? Heer........................ 11

Glossozamitee Schimper......................... $\quad 176$

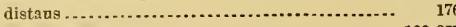

Gрmоровретпæ................................ 166-277

Grmnospermons fruits. ........................ 262-273 
H.

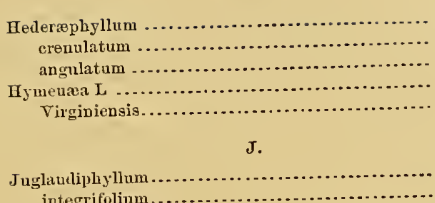

ז.

Kankey's (plant localits) descrihed .................

L.

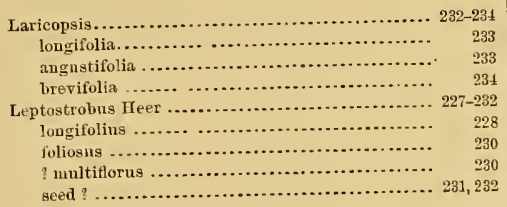

I.

Macrospores? \&p

McGee, W J, proposed Potomac as the name of a geological group .................. traced Potomac formation to bead of Chesapeake Bay ......................................

Meek, F. B., fossil plants fonvd at Baltimore by .....

Hudispermites Lesq ........................... Virginiensis . . . . . . . . . . . teuninervis

Irriea L.

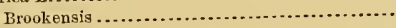

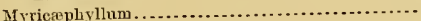
deutatum ..

\section{N.}

Nageiopsis ................................... longifolia..................................

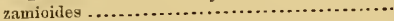

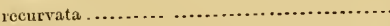

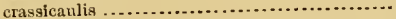
latifolia . . . . . . . . . . . . . . .

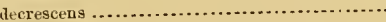

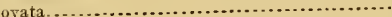

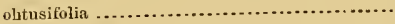

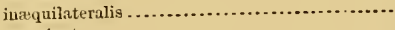

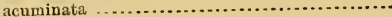

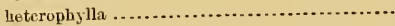
mic ropliylla.

angustifolia .

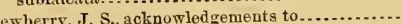

\section{o.}

Osmunda L ...........

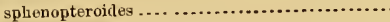
Dicksonioides

Page.

23-225

324

324

320

320

315

315

21,22

22

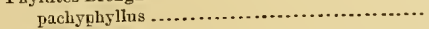

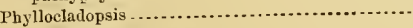

beterophy

Plant localities deseribed . . .....................

Platanophyllua ............................... 316

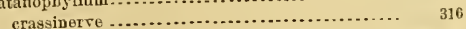

Platypterigian ................................. 168-171

densinerve ................................. 169

Rogersianum .............................. 171

Podozawites Fr. Braun emend. ................... 178-181

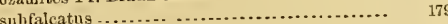
distantinervis........................... 179 pedicellatus................................ 180

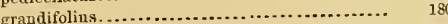
graudifolins.

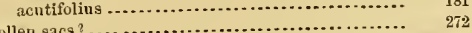

Pollen sacs ? . .................................. $\begin{array}{r}272 \\ 105\end{array}$

Polypodium L ................................ 104, 105 fadyenoides ............................... 104 dentatum ................................. 105

Populophyllum .............................. 311, 312

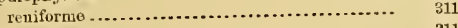

hederaforme............................. 311

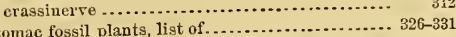

Potomac fossil plants, list of . .................... 326-331

Potomac proposed by W J McGee as name of a geo-

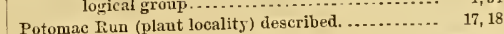

Proterphyllum ................................ 231-287

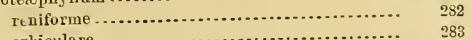

orbiculare................................ $\quad 283$

s1. ? . . . . .

oblongifolinm ............................. $\quad 284$

ovatum .................................... 28

ellipticum.................................

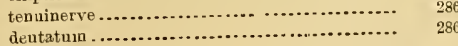

\section{Q.}

Quercophyllum .............................. 307, 308 grossedentatum ............................. 307

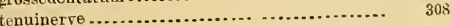

\section{R.}

Rogers, William B., cited on geological relations, 1,4,6,33, 34, $35,49,52$

Rogersia . lougifolin . angustifolia................................. 288 
Sagenopteris Pr................................

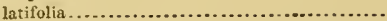

olliptica..

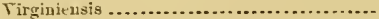

Salicipbyllum...................................

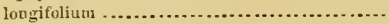

ellipticum....................................

parrifolinw . . . . . . . . . .

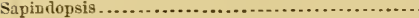

cordata ....................................

olliptica . . . . . . .

magnifolia ..................................

rariabilis . ...................................

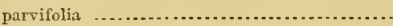

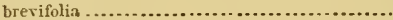

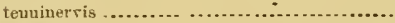

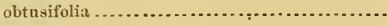

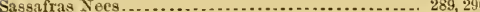
parvifolium ............................ $\quad 280$

cretaceum Хerb., var. lieterolvbum ........... \$ $\$ 90$

bilobatum ............................... 290

Scleropteris Saporta .......................... 150-153

elliptica

var. longifolia ...................... 15

Tirginica ................................. 152

dentata ..... . . .

Seed of Piuus ! sp. ? $\ldots \ldots \ldots \ldots \ldots \ldots \ldots \ldots \ldots \ldots \ldots \ldots$
Sequoia Torrey $\ldots \ldots \ldots \ldots \ldots \ldots \ldots \ldots \ldots \ldots \ldots \ldots \ldots \ldots$

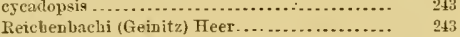

$\begin{array}{rr}\text { Reicbenbachi (Geinitz) Heer.................. } & 243 \\ \text { rar. longifolia.... } & 244\end{array}$

sublata ... ............................. 245

ambigu: Heer . . . . . . . . . . .

rigida Heer . ............................... 246

deusifolia ................................. 246

gracilis Heer . . . . . . . . . .

delicatulata ................................ 247

sp. ?.................................. 247,248

Sphenolepidium Heer (Spbenolepis Sehenk) . . . . . ... 257-262

pareeranosum ............................ $\quad 257$

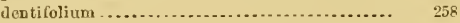

recnrvifolium - . . . . . .

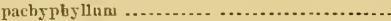

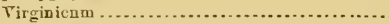

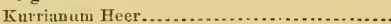

Sternbergianum (1)unk. sp.) Heer.............. var. densifolium Heer.........

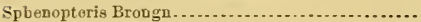

thyrsupteroides ............................

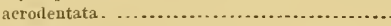

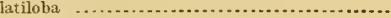

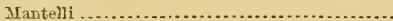
spatulata

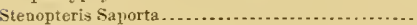

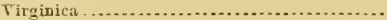

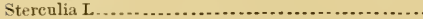

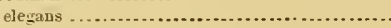

T.

Tasodiun Fichard (Glyptostrobas Eudl.)......... 250-257

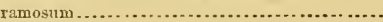

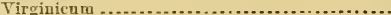

expansum

Taxodium denticulatum

Brookeuso ................................ rar, angustifolium $\ldots \ldots \ldots \ldots \ldots \ldots$..........

Page.

253

254

256

Taylor, I. C., citet on fossil plants at Fredericksburg

Telegralu Stition (plant locality) described.......

Thiusfeldia Ett.

variabilis $\ldots . . . .$.

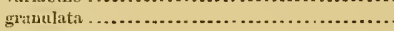

rotutudiloba

$110-112$

110

111

Thurysouteris Kumzos.

Tirginica................................ 120

brevifülia . . . . . . . . . . . . 121

dentata ..................................... 121

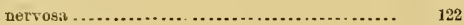

rarinervis ................................ 123

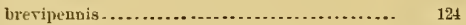

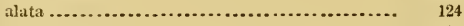

divaricata.............................. 125

Meekiana ................................ 125 rar, angustiloba.................. $\quad 126$

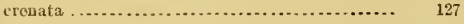

insiguis .............................. 127 Yar. anmustipeunis ................... 128

densifolia . . . . . . . . . . . . . . . . 129

crassinervis .................................... 130

decurreus .............................. 130

angustifolia ............................... 131

microphylla ................................. 13i

pacluyruchis .............................. 132

elliptica ................................. 133

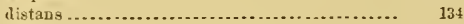

augustiluba ................................. 134

pacluspluylla............................. 135

pecoptroides ............................ 135

piunatifita ................................ 136

heteromorpha ........................... 136

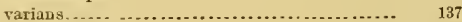

rhonbifolia .................................... 138

beteroloba.................................... 139

bella ..................................... 139

microluba ................ 140 var.alatik.......................... 140

vana ...................................... 141

iorequipinoata .......................... 112

heterojibylla .............................. 142

obtrasilolia.............................. 143

spbeLopteroides......................... 143

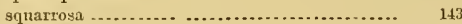

rhombiloba ............................... 144

retasa . . . . . .

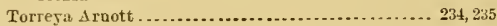

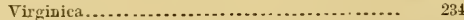

falcata .................................. 235

Trent's Reaeh (plant locality) described ........... 11, 12

Trson, P., fossil escaus found by ................. 5, 30,31

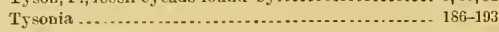

Mrarylandica .............................. 193

U.

Uhler, P. R., discovered fossil plants ........... $5,6,15,33$ acknowledgments to ......................... 33

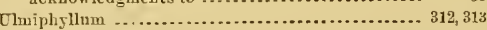

Broukense................................... 312

tenuinerre ................................ 313

crassinerve .............................. 313 
Undetermined fern............................
Undetermined fern in eircinate vernation.........
Undeterwiued plants...........................

\section{$\nabla$.}

Vitiphyllum (Cissites ?) crassifolium

.............................

W.

Ward, Lester F., made the tables comparing Potomac Ilauts and other fossil floras

Pagre.

119

145

$274-276$

Zamiem

Vilumia Car

Page

$08-310$

308

309

309

coll.eted fossil plants at Baltimore.............

acknorledgments to

bite House Bluff (plant locality) described ......

33

22,23 pinnatifida ........................... 161

lıngipennis.................................. 164

laciniata ................................. 164

petiulita ............................... 166

Zamites Brougn............................. 171-173

tenuinervis............................ 171

crassinervis . . . . . . . . . . . . . .

distnntinervis .............................. 172

ovalis ................................ 173

subituleatus .............................. 173

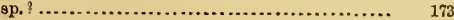

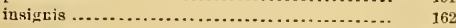








